\title{
MEMBERS AND SUBSCRIBERS
}

The INSTITUTO INTERNACIONAL DE LITERATURA IBEROAMERICANA was organized in 1938 in order to advance the study of Iberoamerican Literature and to promote cultural relations among the peoples of the Americas.

To this end, the Institute publishes the Revista Iberoamericana quarterly and sponsors the publication of noteworthy books by Iberoamerican authors -in their original language and in English translation-, and of learned works and textbooks.

Members of the Institute meet in Congresses every two years and are of two types: regular members who pay $\$ 25.00$ a year, except in Iberoamérica where the fee is $\$ 10.00$, and Patron Members who pay $\$ 30.00$ or more a year.

Institutions such as universities, colleges, and libraries may become subscribers (at $\$ 20.00$ a year or $\$ 10.00$ a year in Iberoamérica), or Subscribing Patrons (at a minimum of $\$ 30.00$ a year) without holding membership in the Institute.

Regular members and subscribers receive the forthcoming issues of the Revista Iberoamericana free, but Patrons (whether Members or Subscribers) receive, in addition, the forthcoming issues of all the publications of the Institute, and the Proceeding of the Congress, etc., and their names will appear in the Revista Iberoamericana at the end of the year.

\section{SUBSCRIPTION APPLICATION}

I would like to become a subscriber to the Revista Iberoamericana. Would you please send my subscription to the address indicated below. I understand that I may become a member by following the steps indicated in the statutes of the Institute, which may be obtained upon request.

I am enclosing:

$\begin{array}{ll}\$ 20.00(\quad) & \text { Regular subscription } \\ \$ 25.00(\quad) & \text { Regular Member* } \\ \$ 10.00(\quad) & \text { Latin American Countries } \\ \$ 30.00(\quad) & \text { Patron subscription (all publications) }\end{array}$

Name

Address

City State Zip

Please make your checks payable to the Instituto Internacional de Literatura Iberoamericana and mail your dues to: WILLIAM J. STRAUB, 1312 C.L., University of Pittsburgh, Pittsburgh, Pennsylvania, 15260, U.S.A. All communications regarding the circulation and distribution of the publications of the Institute should also be addressed to Mr. Straub.

* In order to become a member, please send your curriculum vitae and the names of two members of the Institute who may recommend you. 


\section{SOCIOS Y SUSCRIPTORES}

EL INSTITUTO INTERNACIONAL DE LITERATURA IBEROAMERICANA se organizó en 1938 con el fin de incrementar el estudio de la Literatura Iberoamericana e intensificar las relaciones culturales entre todos los pueblos de América.

Con este fin el Instituto publica la Revista Iberoamericana, por los menos tres veces al año, y patrocina la publicación de obras notables de autores iberoamericanos -en el idioma original y en traducción inglesa-, y la de obras de erudición y textos de enseñanza.

Los socios del Instituto se reúnen en Congreso cada dos años, y son de dos categorias: el socio de número, cuya cuota anual es de veinticinco dólares, excepto en Iberoamérica, donde es de sólo diez dólares, y el Socio Protector, cuya cuota es de treinta dólares o más al año.

Las bibliotecas, colegios, universidades y demás instituciones que, sin ser socios, sí favorecen al Instituto, son de dos categorias: el suscriptor corriente, cuya cuota anual es de veinte dólares y de sólo diez dólares en los países de Iberoamérica, y el Suscriptor Protector, cuya cuota es de treinta dólares al año.

La Revista Iberoamericana se envía a los socios de número y a los suscriptores corrientes del Instituto, y tanto los Socios Protectores como los Suscriptores Protectores reciben, además de la Revista, las obras publicaciones que vayan saliendo, y Memorias. Los nombres de los Protectores se publican en la Revista Iberoamericana al fin de cada año.

\section{INVITACION}

El Instituto invita cordialmente a quienes simpaticen con los fines que persigue, a que se hagan ora socios, ora PROTECTORES de é1. Quienes así lo apoyen deben enviar su cuota anual, por adelantado, en forma de giro postal o bancario pagadero al Instituto Internacional de Literatura Iberoamericana y por conducto del Sr. WILLIAM J. STRAUB-1312 C.L., University of Pittsburgh, Pittsburgh, Pennsylvania, 15260, U.S.A., que es la única persona encargada de la circulación y la distribución de las publicaciones del Instituto.

\section{CUATRO NUMEROS POR AÑO}

A partir de 1970 la Revista Iberoamericana se publica cuatro veces al año, en vez de dos y tres, como se había hecho hasta entonces.

Los manuscritos deberán ser enviados al Director, en original y una copia, antes de las siguientes fechas: $1^{0}$ de noviembre, para el primer número (enero-marzo); $1^{0}$ de enero, para el segundo número (abril-junio), $1^{0}$ de abril, para el tercer número (julioseptiembre) y $1^{0}$ de septiembre, para el cuarto número (octubre-diciembre). 


\section{REVISTA IBEROAMERICANA}

\section{PROPOSITOS}

Esta REVISTA aspira a constituir, gradualmente, una vital representación de los valores espirituales de la creciente cultura iberoamericana.

Su director y asesores quieren hacer vivo el lema que cifra el ideal adoptado por nuestro Instituto: A LA FRATERNIDAD POR LA CULTURA.

Reflejara en sus páginas una clara imagen de la literatura y del pensamiento de Iberoamérica.

\section{NORMAS EDITORIALES}

La REVISTA IBEROAMERICANA sólo publicará artículos aceptados por su Director, quien será asesorado por la Comisión Editorial “Ad-hoc”. Las ideas contenidas en los artículos que se publiquen pertenecen al autor, quien será único responsable de las mismas. Se recomienda que en los manuscritos de artículos, notas y reseñas presentados para su publicación se sigan las normas de “The MLA Style Sheet”, publicado en PMLA, lxvi (1951). Desde el momento en que los artículos han sido entregados a la imprenta, no se aceptarán cambios en el texto.

Los manuscritos deben ser enviados al Director, en original y copia, y sólo serán considerados cuando la Tesorería informe que el autor es miembro o suscriptor de la RI. En caso de no ser aceptados para su publicación, sólo se devolverá el original si el autor envía el sobre con el correspondiente importe en estampillas o sellos de correos de U.S.A. La Dirección de la RI no se considera obligada a acusar recibo ni a contestar cartas a los autores que han enviado trabajos sin ser solicitados, y no son miembros del Instituto o suscriptores de la RI.

La reproducción de cualquier trabajo publicado en la RI debera ser autorizada por el Director.

\section{CANJE Y SUSCRIPCIONES}

Todo to referente a CANJE y demás intercambio de publicaciones con casas editoras, instituciones o autores debera hacerse par intermedio del Jefe de Canje, y a tal efecto se ruega dirigirse a: LILLIAN S. DE LOZANO, 1312 C.L., University of Pittsburgh, Pittsburgh, Pennsylvania, 15260, U.S.A. Todo to referente a SUSCRIPCIONES, compras, órdenes de pago, etc., en que sea menester la intervención de la Tesorería, deberá hacerse por intermedio de la Secretaría-Tesorería, 1312 C.L., y a tal efecto se ruega escribir a: WILLIAM J. STRAUB, University of Pittsburgh, Pittsburgh, Pennsylvania, 15260, U.S.A. 


\section{INSTITUTO INTERNACIONAL de LITERATURA IBEROAMERICANA}

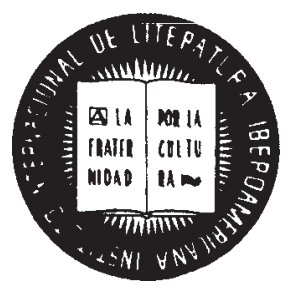

MESA DIRECTIVA

(1977-1979)

PRESIDENTE

Keith A. McDuffie, University of Pittsburgh

\section{VICEPRESIDENTES}

Ivan A. Schulman, University of Florida, Gainesville José Emilio Pacheco, Universidad Nacional Autónoma de México

\section{VOCALES}

David Lagmanovich, Catholic University of America Raquel Chang-Rodríguez, City College, CUNY

SECRETARIO-TESORERO

William J. Straub, University of Pittsburgh

DIRECTOR DE PUBLICACIONES

Alfredo Roggiano, University of Pittsburgh 


\title{
גhevista $\mathfrak{J}$ beroamericana
}

\author{
Organo del \\ Instituto Internacional \\ de Literatura Iberoamericana
}

Vol. XLIII

Julio-Diciembre de 1977

Nos. $100-101$

PATROCINADA POR LA UNIVERSIDAD DE PITTSBURGH

DIRECTOR

Alfredo A. Roggiano, 1317 C.L., Universidad de Pittsburgh

Pittsburgh, Pennsylvania, 15260, U.S.A.

\section{ASISTENTE DEL DIRECTOR}

William J. Straub

COMITE EDITORIAL (1975-1977)

Jaime Alazraki, University of California, San Diego, La Jolla

João Alexandre Barbosa, Universidade de São Paulo

Bella Jozef, Universidade Federal do Rio de Janeiro

Klaus Meyer-Minneman, Universitäts Hamburg

SECRETARIO-TESORERO

William J. Straub, 1312 C.L., University of Pittsburgh

Pittsburgh, Pennsylvania, 15260, U.S.A.

JEFF DE CANJE

Lillian S. de Lozano, 1312 C.L., University of Pittsburgh

Pittsburgh, Pennsylvania, 15260, U.S.A. 



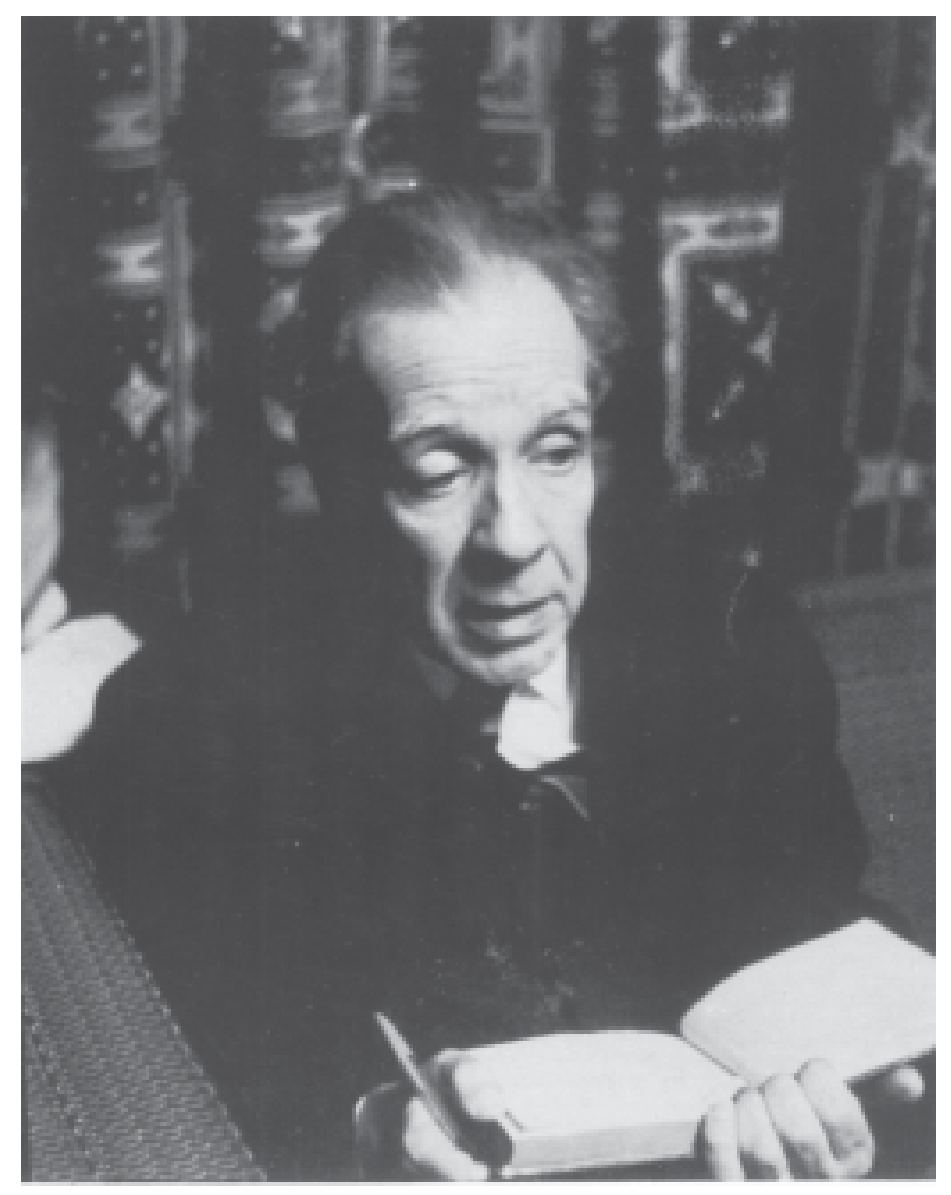




\title{
REVISTA IBEROAMERICANA
}

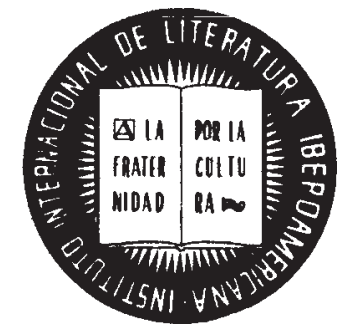

\section{INQUISICIONES SOBRE BORGES}

Número Especial dedicado a

\author{
JORGE LUIS BORGES
}

\author{
Dirigido por \\ ALFREDO A. ROGGIANO, University of Pittsburgh \\ EMIR RODRIGUEZ MONEGAL, Yale University
}

La fotografía reproducida en la tapa fue tomada durante una visita de Jorge Luis Borges a Pittsburgh en 1967 por A. F. Supervielle y es propiedad de Alfredo Roggiano. 


\title{
40 INQUISICIONES SOBRE BORGES
}

\section{SUMARIO}

\author{
ESTUDIOS
}

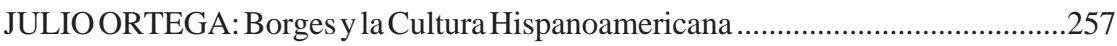

EMIR RODRIGUEZ MONEGAL: Borges y la Política ...........................................269

EMIL VOLEK: Aquiles y la Tortuga: Arte, Imaginación y la Realidad Según Borges ..................................................................................................293

LUIZ COSTA LIMA: A Antiphysis em Jorge Luis Borges ........................................311

DAVID W. FOSTER: Para una Caracterización de la Escritura en los Relatos de Borges... .337

WALTER MIGNOLO: Emergencia, Espacio, "Mundos Posibles”: Las Propuestas Epistemológicas de Jorge L. Borges ....

SYLVIA MOLLOY: “Dios Acecha en los Intervalos”: Simulacro y Causalidad Textual en la Ficción de Borges.....

ARTURO ECHAVARRIA FERRARI: “Tlön, Uqbar, Orbis Tertius”:

Creación de un Lenguaje y Crítica del Lenguaje

SUZANNE JILL LEVINE: Adolfo Bioy Casares y Jorge Luis Borges: La Utopía como Texto ....

ZUNILDA GERTEL: La Imagen Metafísica en la Poesía de Borges.....

JAIME ALAZRAKI: Borges o el Difícil Oficio de la Intimidad:

Reflexiones Sobre su Poesía más Reciente 449

OSWALDO E. ROMERO: Dios en la Obra de Jorge L. Borges:

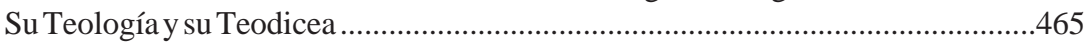

RODOLFO A. BORELLO: El Evangelio Según Borges ............................................503

ROSLYN M. FRANK y NANCY VOSBURG: Textos y Contra-Textos en "El jardin de senderos que se bifurcan" 517

MARIA LUISA BASTOS: Literalidad y Trasposición: "Las Repercusiones Incalculables de lo Verbal” .535

NICOLAS BRATOSEVICH: El Desplazamiento como Metáfora en Tres Textos de Jorge Luis Borges . .549

E. CARACCIOLO TREJO: Poesía Amorosa de Borges ..............................................561

GERARDO MARIO GOLOBOFF: “Ser Hombre” (Exploración del

Tema del “Otro” en un Soneto de Jorge Luis Borges) .575

HUMBERTO RASI: Borges Ante Lugones: Divergencias y Convergencias

\section{NOTAS}

ANA MARIA BARRENECHEA: Borges y los Símbolos 601

ALICIA BORINSKY: Borges en Nuestra Biblioteca 
JOSE MUNOZ MILLANES: Borges y la “Palabra” del Universo ...............................615

JAMES E. HOLLOWAY: “Everness”: Una Clave para el Mundo Borgiano ...............627

ALFRED MAC ADAM: Lenguaje y Estética en Inquisiciones .................................637

EILEEN M. ZEITZ: “La Escritura del Dios”: Laberinto Literario de Jorge Luis Borges ......................................................................................645

EDELWEIS SERRA: La Estrategia del Lenguaje en Historia Universal

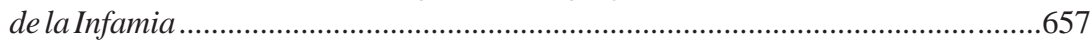

JOHN INCLEDON: La Obra Invisible de Pierre Menard ..........................................665

TAMARA HOLZAPFEL y ALFRED RODRIGUEZ: Apuntes para una

Lectura del Quijote de Pierre Menard .................................................................671

MONIQUE LEMAITRE: Borges...Derrida...Sollers...Borges .................................679

MARTA GALLO: Asterión, o el Divino Narciso .........................................................683

OSCAR A. HAHN: Borges y el Arte de la Dedicatoria .............................................691

ROBERTO GONZALEZ ECHEVARRIA: Borges, Carpentier y Ortega ...................697

EDUARDO GONZALEZ: Borges Marginal ...........................................................705

JOSE MIGUEL OVIEDO: Borges Sobre los Pasos de Borges ...................................713

JORGE SCHWARTZ: Borges y la Primera Hoja de Ulysses/La Ultima

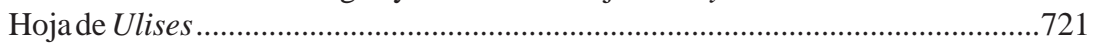

DONALD YATES: Publicaciones Recientes Sobre Borges .......................................729

MARIA BONATTI: Dante en la Lectura de Borges .................................................737

\section{RESEÑAS}

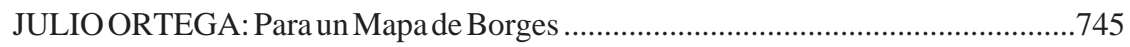

MARIA LUISA BASTOS: De Borges, Sobre Borges ................................................750

SAUL SOSNOWSKI: Sobre Roberto Paoli, Borges. Percorsi di significato .............. 755 


\title{
ESTUDIOS
}

\author{
Borges y la Cultura \\ Hispanoamericana
}

Aun cuando el propósito de una lectura de la obra de Borges en el sistema de la cultura hispanoamericana parecería ir, en estos momentos, en contra de la corriente -pues una parte de nuestra critica prefiere estudiarla dentro del cosmopolitismo que le hace eco, mientras que otra parte parece resignada a perderla-; creo que es oportuno empezar a interrogarnos por la naturaleza americana de esta escritura, y por sus funciones en el interior del discurso cultural nuestro.

Es evidente que como toda obra mayor la de Borges actúa en un ámbito literario universal. Pero igualmente ella actúa en la dinámica creativa de una cultura hispanoamericana, a cuya estructuración sin duda responde y en cuyas aperturas así mismo se constituye. No se trata, por cierto, de plantear una disyunción de supuestos niveles específicamente americanos y europeos en esta obra, to que nos llevaría a una mera tematizacibn; sino, más bien, de interrogar la escritura borgiana en sus mecanismos productivos, los cuales responden -se trate de unos u otras temas- a una práctica de textualización característica de las elaboraciones de la escritura hispanoamericana, cuya realización a su vez proyecta un discurso diferencial. Esta lectura inicial no busca cuestionar los esfuerzos críticos por entender la obra de Borges en el museo de sus referencias; ni se propone discutir la argumentación sancionadora que ella conoce especialmente en la Argentina. Sólo busca ensayar otras convergencias. Primero, porque una escritura se exterioriza como tal en el ámbito productivo de su horizonte cultural; segundo porque sería un derroche resignarse a perder -en nuestro mejor conocimiento del discurso americano- una obra mayor. Especialmente si estamos persuadidos de que una zona de esta escritura se produce también en la dinámica de ese discurso cultural.

La permanente polémica acerca de la supuesta extrañeza cultural de la obra de Borges ha oscurecido, en lugar de favorecerla, una mejor discusión de su estatuto americano. Algunos críticos, como Néstor Ibarra, no han dudado en proclamar que “personne n'a moins de patrie que Jorge Luis Borges"; ${ }^{1}$ lo cual debe haber ratificado la sanción de “extranjerizante” que en Argentina es usual para separar, y perder, a esta 
obra. ${ }^{2}$ No obstante, algunos críticos han intentado ya plantear la lectura de Borges fuera de esta polarización. Humberto M. Rasi, tiene razón cuando afirma que: “The general direction of the studies devoted to Borges' writings, as well as the preferences of certain of his translators, has contributed, for various reasons, to create the image of a countryless writer, one foreign to the literature and realities of his homeland". ${ }^{3}$ Es claro que desde Fervor de Buenos Aires (1923) se han reiterado y desarrollado en esta obra no pocos temas y problemas específicos de una percepción particular de la historia y la realidad argentinas; los que van de la presencia elegíaca de la ciudad a la constitución de un ámbito histórico a partir de los ancestros y de figuras como Sarmiento, Quiroga y Rosas, enjuiciados y valorados de un modo en la obra juvenil y de otro en la obra de la madurez. Y no es menos cierto que la necesidad de precisar la experiencia literaria dentro de la cultura podía ser analizada desde el polémico criollismo inicial hasta las disquisiciones sobre el escritor latinoamericano y la tradición europea, y los deslindes y opciones en sus prólogos a obras argentinas. Pero la división temática no nos daría una visión integral de su escritura, cuyos mecanismos identifican, mas bien, los temas aparentemente dispares desde su tratamiento.

Emir Rodríguez Monegal había adelantado en 1952 que la obra de Borges sólo podía ser argentina, por su misma avidez cultural cosmopolita, por la nostalgia de la violencia, por su percepción de un paisaje urbano particular. ${ }^{4}$ En el sentido de esta observación, Carlos Fuentes escribe: ”¿puede haber algo más argentino que esa necesidad de llenar verbalmente los vacíos, de acudir a todas las bibliotecas del mundo para llenar el libro en blanco de la Argentina?”5 Y explicita así su percepción americana de esta obra:

Pues el sentido final de la prosa de Borges - sin la cual no habría simplemente novela hispanoamericana- es atestiguar, primero, que Latinoamérica carece de lenguaje y, por ende, que debe constituirlo. Para hacerlo, Borges confunde todos los géneros, rescata todas las tradiciones, mata todos los malos hábitos, crea un orden nuevo de exigencia y rigor sobre el cual pueden levantarse la ironía, el humor, el juego, si, pero también una profunda revolución que equipara la libertad con la imaginación y con ambas construye un nuevo lenguaje latinoamericano que, por puro contraste, revela la mentira, la sumisión y la falsedad de lo que tradicionalmente pasaba por "lenguaje” entre nosotros. La gran ausencia en la prosa de Borges, lo sabemos, es de índole crítica. Pero el paso del documento de denuncia a la síntesis crítica de la sociedad y la imaginación no hubiese sido posible sin este hecho central, constitutivo, de la prosa borgiana. ${ }^{6}$

A pesar de que esta postulación es indudable, la generalización que plantea Fuentes como diferencial confirma, a la larga, la insularidad y, finalmente, la extrañeza de esa prosa. Es evidente que en la escritura borgiana hay una crítica permanente al uso indistinto o indulgente del lenguaje literario -y una sátira a ciertos 
énfasis de estilo, que las crónicas de Bustos Domecq ilustran-, pero los mecanismos que producen esa escritura atestiguan, más bien, una tradición creativa hispanoamericana. En este sentido, la novedad de la prosa borgiana no es una negación de los previos lenguajes hispanoamericanos, sino, por el contrario, su realización privilegiada.

Veamos, así, la interacción de los géneros. Por lo menos desde los Comentarios reales del Inca Garcilaso de la Vega, la escritura americana se constituye en la polivalencia de su formalización. La escritura dramatiza su realización en un espacio textual, que se sustenta en la historia entendida como política (la utopía incaica como horizonte realizado del orden neo-platónico); que se formaliza en una suma crítica de textos (las crónicas que se refutan o que se insertan como un intertexto probatorio); que se autorefiere para producirse (el relato que se desdobla y reconduce); que colinda con el tratado novelesco y filosófico, con la literatura y con la crítica; y, en fin, que revela la trama de historia y ficción, allí donde se genera el discurso cultural de una América cuya existencia y conciencia son el drama de un texto.

Estos rasgos desconstruyen el estatuto verosímil y ortodoxo de la escritura clásica -aquélla que postula un orden del sentido en un discurso suficiente-, para producir, en cambio, una escritura cuyo modelo será virtual -aquella que postula un sentido por resolverse en el nuevo orden de su heterodoxia formal. Son, por ello, rasgos característicos de una elaboración americana de la escritura; y aluden a las mismas formas productoras de un imaginar y conocer la realidad desde nuestra experiencia histórica y social. Si bien es cierto que estas formas -la conjunción inter-textual, el montaje de distintos niveles culturales, la autogeneración de la escritura, la plurivalencia de un género- son, en último término, universales, no es menos cierto que en una semiótica de la cultura darían razón de su topología americana. Así como, desde una “arqueología del lenguaje”, veríamos la recurrencia de una actividad descodificadora, que dialécticamente responde a sus modelos de la cultura hegemónica, estatuyendo su propio código: el discurso por el cual, en el seno de la cultura occidental, somos otra cultura. Como en la escritura del Inca Garcilaso, en la de Martí, en la de Rubén Darío, en la de Vallejo -pero también en movimientos de escritura como los de la crónica de Indias, el barroco americano, el Modernismo y nuestras vanguardias-, podemos reconocer los rasgos y los mecanismos tanto de esta confluencia de géneros, en un espacio textual descodificado, como las distintos aperturas, incorporaciones y respuestas que configuran esta escritura americana diferencial.

Distintas tradiciones alimentan la obra de Borges, como observa Fuentes, pero asimismo recorren los estratos de la escritura americana; y nuestra tradición, siendo una tradición de la ruptura, como ha dicho Octavio Paz, es también incorporatriz: y no porque deba simplemente llenar un espacio cultural en blanco, que la obligaría a sucesivas dependencias, sino porque los mecanismos de la escritura nuestra suponen una dinámica expansiva (como ha visto bien José Lezama Lima); la cual no es necesariamente acumulativa, pues actúa por desplazamientos y formalizaciones, tal 
como se ilustra en la misma obra de Borges. Precisamente, en Lezama Lima y en Paz este mismo mecanismo es constitutivo: distintas tradiciones convergen no como repertorios pasivos sino como modelos críticos o diseños míticos, sin su espesor cultural originario; en su nueva trama imaginaria, en el espacio de un debate. Desde Borges -como desde Paz y Lezama-, nuestra lectura de la tradición -nuestra lectura de Garcilaso, Martí o Darío-, revela la dinámica de esa escritura hispanoamericana, su proceso histórico y su horizonte cultural.

La manera americana de la producción de la escritura borgiana parece, pues, patente en el hecho de que sus mecanismos de formalización textual actúan desde la desconstruccion de los repertorios de la cultura. De allí que el recuento de sus referencias culturales solo nos daría la suma de sus fuentes, o sea el espacio indeterminado de su obra; los mecanismos que trabajan sobre esas fuentes, en cambio, dan cuenta de la productividad misma de su escritura. No hay que perder de vista el hecho de que la totalización de la literatura, la analogía de la biblioteca y el universo, la equivalencia de un libro y todos los libros, y otras figuras o ideas paralelas, características de Borges, se realizan en un proceso de textualizacion que las convierte en un repertorio formal y especulativo, extraído del espesor de significación totalizadora de sus orígenes culturales. Es un espacio de ficción -alimentado por la especulación de su doblaje crítico- lo que descodifica el estatuto probatorio y finalista de la cultura que, además, en Borges son varias culturas, situadas en el mismo espacio plano de su conversión textual. Esa descodificación, que fractura la gramática de la cultura, que introduce en ella la discontinuidad, actúa también por reducciones paródicas, por inducciones analógicas, por equivalencias y paradojas, desde una interrogación radical por la naturaleza imaginaria del conocimiento mismo. Así se produce la conversión en literatura de los repertorios de la cultura: la ficcionalización de su voluntad de verdad y de significación. Al final, este radicalismo descodifica la postulación del sentido que sustenta a las mediaciones y disciplinas de la cultura, introduciendo en ella la actividad crítica de la imaginación.

Así, "Nueva refutación del tiempo", ${ }^{7}$ no sólo es una especulación sobre la experiencia mística de la intemporalidad -más un análisis de la tradición textual del tema, del repertorio filosófico y literario que lo refiere-, sino que es además uno de los textos en que la escritura borgiana lleva a las últimas consecuencias su pasión desconstructora.

En efecto, su propósito radical es también paradójico: negar la materia y el espíritu, negar el espacio, lleva a la negación del tiempo. La inducción es especulativa, pero asimismo irónica: o sea, una argumentación, que evoca las conjeturas intelectuales del barroco. Pero Borges va mas allá: a la afirmación parabólica de lo imaginario; dice: "Si las razones que he indicado son válidas, a ese orbe nebuloso (de lo imaginario) pertenecen también la materia, el yo, el mundo externo, la historia universal, nuestras vidas”. Esto es, los objetos por excelencia de la cultura, aquellos que fundan y sostienen a los repertorios del conocimiento y de la conciencia. Más que una 
postulación, sin embargo, más que otra filosofía, esta conclusión de Borges -que se reproduce en su ficción en la negación del yo, en las recurrencias de la historia, en los anacronismos e interferencias del tiempo, en las duplicaciones del espacio, en los espejismos del sueño...-, delata la práctica reductora de su escritura. Esta descodificación implica, pues, que la realidad se percibe como cultura. Y en su radicalismo, esta escritura produce el trastrocamiento de las correlaciones establecidas por el lenguaje, que la cultura ha fijado como lugar del conocimiento. Así, la imaginación trasciende a la cultura, y la literatura equivale a la conciencia pura del mundo; o sea, a una conciencia sin postulaciones ni convocaciones. La naturaleza humana es, tal vez, lacónicamente trágica, pero su elaboración cultural parece ser imaginaria: el sentido está en la imaginación; en el poder con que ella provee la coherencia de sistemas paralelos al mundo y, ocasionalmente, la mediación de una experiencia que nos trasciende -mística, estética o ética, nombres que, a su vez, se equivalen. ${ }^{8}$

En ese ámbito de codificaciones la experiencia individual no vence la discordia o la errancia de un destino, que en la historia o en la cultura -y tal vez en la obra literaria- a veces logra, sin embargo, la percepción de un sentido, si no total al menos justificativo, suficiente al estoicismo que reconoce la ausencia de explicaciones finales. Entre la imaginación y el escepticismo, esta escritura delata, pues, en su propia ocurrencia los dilemas y los enigmas de su indagación sin respuestas. Por ello, las últimas líneas de la "Nueva refutación del tiempo" ("El mundo, desgraciadamente, es real; yo, desgraciadamente, soy Borges”), no solamente responden con el escepticismo del destino humano frente a las especulaciones y virtualidades de lo imaginario; también aluden, en su retorno a los nombres elementales (el tiempo, el río, el fuego, el yo, que equivalen a los otros nombres de la experiencia mística descrita), a un primer día del lenguaje en un primer día del mundo; sólo que, en ese mismo movimiento, su implicación crítica alude al último día de la cultura, allí donde prevalece un mundo sin explicación. ${ }^{9}$

Otra vez, sólo nos quedan las palabras -y su dinámica crítica en la ficción de la escritura. Al final, pues, de la refutación del tiempo- al final de las categorías de la cultura- retorna el tiempo en el habla de sus nombres. Un habla que ya no es adánica ni apocalíptica, como lo fue en Neruda y en Vallejo; que tampoco es sensorial como en Darío, ni constitutiva de la conciencia como en Octavio Paz. Es un habla del despojamiento: la voz de la utopía al final de las utopías. O sea: la imaginación que da razón de su inteligencia constructora en el ámbito de una cultura cuya razón sólo puede ser imaginaria. Así, Borges lleva a sus consecuencias últimas la desconstrucción cultural que moviliza a la escritura americana, revelando en ella su polarización productiva de lo imaginario. Porque si nuestra cultura construye una respuesta que universalize a la imaginación como actividad analítica y como realización de una práctica descodificadora, en Borges esta respuesta encuentra su radical horizonte crítico. Allí donde se disuelve la cultura occidental y donde el lenguaje que nos dice 
retorna con la lucidez y el riesgo de una aventura extremada por su naturaleza cuestionadora y por su poder creador.

Se ha dicho -y es una manera de decirlo- que Borges sólo pudo ser hispanoamericano. De hecho, el radicalismo de su obra no es menos heterodoxo que la aventura de Joyce, un irlandés; o la de Kafka, un judío checo; y, tal vez, la de Pound, un norteamericano que a diferencia de Eliot no tuvo necesidad del fetichismo del Este. El propio Borges se ha referido al papel de los escritores irlandeses en la literatura inglesa -y también en la historia de Inglaterra- y a la actitud paralela que reivindica para el escritor nuestro: "Creo que los argentinos, los sudamericanos en general, estamos en una situación análoga; podemos manejar todos los temas europeos, manejarlos sin supersticiones, con una irreverencia que puede tener, y ya tiene, consecuencias afortunadas". ${ }^{10}$ Esa "irreverencia” es central a nuestros mecanismos de incorporación y disyunción: supone el proceso descodificador y la dinámica de una escritura disolvente y diferenciadora. Por lo demás, resulta revelador que la crítica francesa o norteamericana, ${ }^{11}$ al testimoniar su lectura de Borges, no haya dejado de expresar también su extrañeza por la heterodoxia cultural que ella promueve. Y ello porque a pesar de su evidente modernidad, esta obra no reconoce una historia orgánica detrás de su museo cultural; sino que actúa sobre el paisaje cultural como en un campo levantado por familias de imágenes, de tramas y de ideas; esto es, en un espacio eminentemente textual. De allí que esta obra no suponga en el lector europeo el redescubrimiento de sus fuentes literarias, y sí, por el contrario, el libre uso, a veces anacrónico, a veces extravagante, de las mismas. Quizá no sea casual la modestia literaria de Borges (que concede al interlocutor inglés la bondad expresiva del inglés; al francés, la eficacia del francés; y al italiano, que la ignora, la inexistencia de la literatura argentina), pues su relación con las culturas centrales que exaltan su obra es, más bien, una relación que parte de la glosa y la parodia-de los procesos mistificadores, lúdicos y críticos de una vasta descodificación. Modestia que es también, en el ajedrez borgiano, una figura defensiva: el éxito de mis libros prueba la decadencia de la literatura, ha dicho. Cuando Nabokov - cuyas novelas son otro vaciado de la significación desde el brillante predominio de la argumentación y la trama como aventura formal- expresó que la literatura de Borges era como un umbral detrás del cual no había nada, se equivocó al no seguir su intuición: detrás de ese umbral hay otro umbral; o sea, un laberinto de formas, que desconstruye la morada tradicional de una literatura situada por las culturas.

Esta escritura transforma, pues, a los significados de la cultura que recorre en significantes del signo cultural en que ella se realiza. Las nociones del tiempo y del infinito, del libro y el universo, del panteismo y del idealismo, antes que sentidos plenos de una ideología, son instancias formales de la especulación en un orden especular. No hay que olvidar que se producen en una secuencia que al mismo tiempo las promueve y disuelve, como elaboraciones fantásticas de una verdad no menos imaginaria. Son nociones que, como Tlön, se plasman en nombre del sentido, 
construyendo su equivalencia del mundo, y que se disuelven como ilusión última; porque en la utopía borgiana -el espacio suficiente de lo imaginario-, se genera su propia anti-utopía: las evidencias de lo ilusorio, el agnóstico final que revela la ficción del laberinto edificado. Una postulación reconoce su contradicción, y en estas tensiones la cultura se convierte en significante. De este modo, emerge un nuevo signo: la significación crítica de lo imaginario. Una escritura rehace el camino y recomienza en su nueva práctica constructora, liberando su propio espacio, realizándose en su dinámica cuestionadora. Es esta práctica la que da razón del discurso cultural, de la topología que caracteriza a la producción de conciencia y al trabajo de una tradición que nos elabora y constituye.

Por tanto, si la empresa de Borges, en su centro descodificador, evoca otras no menos radicales -y ya desde el Quijote, pero quizá sobre todo las empresas modernas de Joyce o Pound-; es claro que la distingue su dinámica interiorizada en el discurso hispanoamericano. Porque esta escritura extrema su manejo de las tradiciones, más allá de la instancia formalizadora del texto; y en su reducción analítica rehúsa los sistemas de la ilusión verosímil del relato al revelar los mecanismos de su desarrollo, convirtiendo al texto del relato en el comentario de ese mismo proceso. Es de este modo como esta escritura prolonga los procesos inter-textuales que ya estaban en Garcilaso, las incorporaciones heterodoxas que verbalizaba Darío, las reducciones mito-poéticas de José María Eguren, las aperturas polares que manejaba Huidobro...Una empresa desconstructora paralela a la suya es visible en la ruptura del referente nominal que lleva a cabo la escritura de Vallejo; cuya práctica cuestiona el estatuto del lenguaje para generar su materialidad, su moderna naturaleza de conciencia impugnadora. Otras aventuras, asimismo paralelas, son las de Pedro Páramo (donde la cultura religiosa es desconstruida de su orden natural); de Cien años de soledad (donde la historia es descodificada por la ficción); y, particularmente, de Rayuela. En este texto la cultura es desconstruida en sus elementos de significación, y en su sentido mismo, desde una indagación deliberativa. Los significados que la cultura propone ya no son formas especulativas, como en Borges, sino alternativas agotadas o parciales, que la experiencia americana cuestiona desde su búsqueda de un lenguaje -y de una escritura y un texto diferenciales-, capaz de rehacer el sistema mismo de la cultura; capaz de responder con el habla de los primeros días. Así, en el espesor de la cultura, una conciencia hispanoamericana se modula como un discurso cuestionador y, a la vez, virtualizador. Desde sus aperturas y disyunciones, esta escritura probablemente responde $-\mathrm{y}$ corrige- a las operaciones y a las disoluciones borgianas. ${ }^{12}$

Un excelente análisis de James E. Irby ${ }^{13}$ ha demostrado la continuidad de la idea utópica en la obra de Borges. Esta idea es reveladora de su descodificación cultural, pero también de cómo esa actividad produce las íntimas equivalencias que reconstruyen su naturaleza americana. De hecho, el impulso utópico es otro de los radicalismos de esta escritura. La biblioteca que es el universo más su infinitud, las sectas y organizaciones que resumen de otro modo a los hombres, las empresas 
intelectuales que forjan versiones coherentes y totales, así como el instante de la mirada que vence a la condición sucesiva del lenguaje, aluden a esa dinámica interna en las formas vaciadas de una utopía cuyo recinto, por sus materiales, es cultural, pero cuyo espacio mayor es el ámbito de la imaginación fundadora.

En "El idioma analítico de John Wilkins", ${ }^{14}$ podemos analizar la raíz de esta actividad utópica: la descodificación del lenguaje mismo, como alternativa para otro orden referencial, que trascienda la arbitrariedad del signo y reformule la significación. La plasmación de esta idea, su realización y también su crítica, esta en el universo doble de Tlön.

Sobre este aspecto central conviene discutir aquí las observaciones de Michel Foucault en torno a Borges. ${ }^{15}$ Las palabras y las cosas, nos dice Foucault, nace de una Erase de Borges que esta en "El idioma analítico de John Wilkins". Citando a una supuesta enciclopedia china, Borges escribe allí que: "los animales se dividen en $a$ ) pertenecientes al Emperador, $b$ ) embalsamados, $c$ ) amaestrados, $d$ ) lechones, $e$ ) sirenas, $f$ ) fabulosos, $g$ ) perros sueltos, $h$ ) incluidos en esta clasificación, $i$ ) que se agitan como locos, $j$ ) innumerables, $k$ ) dibujados con un pincel finísimo de camello, $l$ ) etcétera, $m$ ) que acaban de romper el jarrón, $n$ ) que de lejos parecen moscas”. El comentario de Foucault es el siguiente:

Este texto de Borges me ha hecho reír durante mucho tiempo, no sin un malestar cierto y difícil de vencer. Quizá porque entre sus surcos nació la sospecha de que hay un desorden peor que el de lo incongruente y el acercamiento de to que no se conviene; sería el desorden que hace centellear los fragmentos de un gran número de posibles órdenes en la dimensión, sin ley ni geometría, de lo heteróclito; y es necesario entender este término lo más cerca de su etimología: las cosas están ahí “acostadas”, “puestas”, “dispuestas” en sitios a tal punto diferentes que es imposible encontrarles un lugar de acogimiento, definir más allá de unas y de otras un lugar común. Las utopías consuelan: pues si no tienen un lugar real, se desarrollan en un espacio maravilloso y liso; despliegan ciudades de amplias avenidas, jardines bien dispuestos, comarcas fáciles, aun si su acceso es quimérico. Las heterotopías inquietan, sin duda porque minan secretamente el lenguaje, porque impiden nombrar esto y aquello, porque rompen los nombres comunes o los enmarañan, porque arruman de antemano la "sintaxis” y no sólo la que construye las frases -aquella menos evidente que hace "mantenerse juntas” (unas al otro lado o frente de otras) a las palabras y a las cosas. Por ello, las utopías permiten fábulas y los discursos: se encuentran en el filo recto del lenguaje, en la dimensión fundamental de la fábula; las heterotopías (como las que con tanta frecuencia se encuentran en Borges) secan el propósito, detienen las palabras en sí mismas, desafían, desde su raíz, toda posibilidad de gramática; desatan los mitos y envuelven en esterilidad el lirismo de las frases.

Y, mas adelante, añade: 
Sin embargo, el texto de Borges lleva otra dirección; a esta distorsión de la clasificación que nos impide pensarla, a esta tabla sin espacio coherente, Borges les da como patria mítica una región precisa cuyo solo nombre constituye para el Occidente una gran reserva de utopías. ¿Acaso en nuestro sueño no es la China justo el lugar privilegiado del espacio?

Pues bien, en primer término hay que recordar que la clasificación planteada por Borges es calificada por él mismo en el plano “de las arbitrariedades”; porque "notoriamente no hay clasificación del universo que no sea arbitraria y conjetural. La razón es muy simple: no sabemos que cosa es el universo". ${ }^{16} \mathrm{Y}$ añade Borges: "La imposibilidad de penetrar el esquema divino del universo no puede, sin embargo, disuadirnos de planear esquemas humanos, aunque nos conste que éstos son provisorios”. Su propósito al anotar estas “esperanzas y utopías” del orden del lenguaje, es característico, por cierto, de su especulación central en torno a los nombres primigenios, a un lenguaje simultáneo y a una escritura, por tanto, utópica, previa a la cultura: "Teóricamente -escribe-, no es inconcebible un idioma donde el nombre de cada ser indicara todos los pormenores de su destino, pasado y venidero”.

Esa arbitrariedad, pues, es para Borges un indicio de la cultura misma -y de aquí parte la compleja intuición de Foucault-, si bien las consecuencias que Borges extrae de ello, y el mecanismo que supone en una clasificación arbitraria la certeza, siguen otra dirección. Lo heteróclito no pertenece en la escritura borgiana al orden de las significaciones sino al de las formalizaciones: lo arbitrario no implica al sentido, que se hace conjetural, que se reduce al modelo insólito o irónico gracias a su misma precisión. De allí que lo heteróclito forme parte de una secuencia analítica que lo integra -como el mismo idioma utópico de John Wilkins-; y así se equivalen la clasificación de los animales, el ordenamiento de una biblioteca, y la conjetura de Wilkins. El "lugar común” que reclama Foucault, y que implica también al sentido, no ocurre en estas clasificaciones porque en tanto códigos funcionan como metáforas a su vez textualizadas en el recuento borgiano, donde sí, en cambio, dan razón de sus equivalencias en sus mecanismos. Allí funciona la parodia borgiana de la cultura: rehacer sus mecanismos arbitrarios para volver al punto de partida: el nombre, no menos utópico, que equivale a todos los nombres. Así, en la cultura, esta práctica borgiana establece una actividad de vaciado -el del sentido estable-; y otra de recuperación -la de sus formas y modelos. Se desplaza, por lo mismo, hacia la construcción de un origen, no menos dramatizado, del lenguaje y sus funciones primordiales, analógicas y reveladoras.

Lo cual nos lleva a revisar el punto central del análisis de Foucault: su crítica de las utopías, y su disyunción utopía-heterotopía. Pienso, sin ironía, que dos años tarde -después de mayo de 1968- esta página opinaría distinto acerca de las utopías, pues el libro fue escrito en 1966. Porque, precisamente, las utopías no consuelan sino todo lo contrario: establecen una actividad crítica y disolutiva en el orden de la significación 
que el lenguaje proyecta. Suponen no un lugar y un tiempo improbables sino un lenguaje virtual: aquel que rehace las pautas y subvierte los códigos. Sus ciudades son un mapa que pone en entredicho a las nuestras, y sus jardines y comarcas funden el orden natural y el cultural. Basta pensar en Fourier, pero también en la recurrencia utópica en Borges y en las formaciones utopistas propias de nuestra cultura.

De allí justamente que las utopías sean, por excelencia, heterotopías: su gramática es un escándalo de la inteligencia porque supone el diseño de la contradicción; o sea, el radicalismo que refine a las palabras y las cosas en la desconstrucción de la cultura y la historia, abriendo el espacio de otras construcciones, que nos cuestionan. Por último, la "patria mítica” a que Foucault remite el texto borgiano, la China como "lugar privilegiado", no es sino un lugar puramente textual: una enciclopedia conjetural recortada de su propósito por un mecanismo, más bien, típicamente hispanoamericano. Lo cual no discute, ni mucho menos, la intuición y el notable propósito de Foucault -su rica arqueología del conocimiento en los órdenes de la cultura-; sino que simplemente sitiúa los mecanismos borgianos en la arqueología de una cultura hispanoamericana, la cual, sin duda, responde también a algunos desplazamientos que Foucault observa en la constitución de una modernidad -y ya Octavio Paz había reclamado la necesidad de situar la lectura crítica de Borges en ese espacio $^{17}$-; si bien no es menos cierto que la historia de la semejanza y de las equivalencias -que fundamentan las relaciones estables de la cultura clásica-es, en nuestra cultura, un temprano proceso de descodificación. ${ }^{18}$

Tanto Julio Cortázar como Carlos Fuentes se han referido a la ausencia de una dimensión crítica, histórica y social, en la obra de Jorge Luis Borges; y Mario Benedetti ha hablado del "singular caso Borges, un escritor excepcionalmente dotado para la especulación intelectual y definitivamente malogrado para la captación de la realidad”. ${ }^{19} \mathrm{Y}$, sin embargo, la producción de su escritura revela mecanismos que son centrales a la misma elaboración de nuestra realidad cultural. Es obvio que hay otras zonas, más evidentes, temáticas y declarativas, en las cuales el intelectual y el cuidadano Jorge Luis Borges tributan la ideología de una sub-cultura bonaerense específica, cuya caricatura emerge en las boutades antidemocráticas de un Borges paradójicamente locuaz. Es probable también que, al final, su obra disuelve su propia dinámica descodificadora en una tierra de nadie que ella misma señala para extinguirse; tal como parece sugerir su última utopía, la “utopía de un hombre que esta cansado”, ${ }^{20}$ donde la perfección ya sólo puede ser del olvido y de la muerte. De cualquier modo, la complejidad de su obra -no las simplificaciones de Borges- nos descubren en el ámbito universalizado de nuestra propia invención cultural. Allí donde recuperamos el sentido de la imaginación que nos configura y de la conciencia contemporáneaa que nos constituye.

University of Maryland

JULIO ORTEGA 
NOTAS

1 Néstor Ibarra: “Jorge Luís Borges”, Lettres Franvaises, Buenos Aires, IV, 14, 1944, p. 9.

2 María Luisa Bastos ilustra bien la respuesta argentina a la obra de Borges en su libro Borges ante la crítica argentina. 1923-1960 (Buenos Aires: Ediciones Hispamérica, 1974). Emir Rodríguez Monegal dedicó un libro a la fase más polémica de este debate: El juicio de los parricidas; la nueva generación argentina y sus maestros (Buenos Aires: Ed. Decaulión, 1956).

3 Humberto M. Rasi: “The final creole: Borges’ view of Argentine history”, TriQuarterly 25, Fall 1972, p. 149.

4 En ensayo recogido por Emir Rodríguez Monegal, en su Narradores de esta América (Montevideo: Alfa, 1962), p. 20.

5 Carlos Fuentes, La nueva novela hispanoamericana (México: Joaquín Mortiz, 1969), p. 26.

6 Carlos Fuentes, Ibid.

7 Jorge Luís Borges, Otras Inquisiciones (Buenos Aires: Emece, 1971, 6ta. ed.), pp. 235-257.

8 En una penetrante lectura de la escritura borgiana, Walter Mignolo y Jorge Aguilar Mora señalan que la escritura "no es representación del mundo sino que es ella misma mundo (como práctica textual) y no puede sino producirse en el constante movimiento de decodificación (lectura) y recodificación (escritura)”, en "Borges, el libro y la escritura”, Caravelle, Universidad de Toulouse, No. 17, 1971, pp. 187-194.

9 Carter Wheelock llega a la siguiente conclusión, a propósito del debate implícito en Borges entre el agnosticismo y la percepción literaria: "What we find in Borges - what fills his essays and is implicit, often patent in his fiction- is the esthetic equivalent and symbol of his philosophical position. As is well known, his philosophy consists largely in an agnostic affirmation that truth, although it may be known, is not recognizable ... Borges does not deny that literature should express truth; he denies that truth is available through expression. So he rejects expression in favor of suggestion, which he calls allusion"; en "The Committed Side of Borges”, Modern Fiction Studies, vol. 19, No. 3, pp. 373-379.

${ }^{10}$ Jorge Luis Borges, Discusion (Buenos Aires: Emec6, 1957), p. 161.

${ }^{11}$ Jaime Alazraki ha reunido las principales lecturas francesas y norteamericanas de Borges en su compilación crítica Jorge Luis Borges, (Madrid: Taurus, Serie El escritor y la critica, 1976).

12 Julio Cortázar se ha referido en estos términos a la lección de Borges: "Vivíamos en la Argentina de esa época, sometidos a una cantidad de escritores que continuaban ese estilo pesado y farragoso del romanticismo español y francés. De pronto aparecía un hombre joven, un argentino joven, que escribía yo diría lapidariamente, como si cada palabra fuese un cristal facetado y tallado, cuidadosamente pensado, antes de insertarse en la frase, como quien monta una joya muy complicada con muchos elementos. Eso que era sobre todo una lección formal, una lección de economía de medios, de precisión de medios, de rigor de medios, creo que ha sido la gran lección que Borges me ha dado a mí. Borges me enseñó a eliminar todos los floripondios, las repeticiones, los puntos suspensivos, los signos de exclamación inútiles, y eso que todavía existe en mucha mala literatura que consiste en decir en una página lo que tan bien se puede decir en una línea”. “Julio Cortazar en la Universidad Central de Venezuela”, Escritura, Caracas, enero/junio 1976, No. 1, p. 162.

${ }^{13}$ James E. Irby: “Borges and the Idea of Utopia”, Books Abroad, Oklahoma, vol. 45, No. 3, 1971, pp. 411-419. 
${ }^{14}$ Jorge Luis Borges, Otras inquisiciones, pp. 139-144.

${ }^{15}$ Michel Foucault, Las palabras y las cosas, "Prefacio”, (M6xico: Siglo XXI, 1969). Cito per esta traducción de Elsa Cecilia Frost.

16 Jorge Luis Borges, Op. cit., pp. 142-143.

17 Octavio Paz: "Sobre la crítica”, en Corriente alterna (México: Siglo XXI,1967), pp. 42-43.

18 Jaime Alazraki propone esta conclusión: “Martínez Estrada veía en Kafka y en el mito, el empleo de la magia para percibir un mundo que es mágico. Borges ha renunciado a esa posibilidad respecto al mundo, pero no respecto a la cultura; ha renunciado al laberinto de los dioses, pero no al laberinto de los hombres. Su modo de percibirlo se nutre de las ideas de todos los tiempos: el tiempo ciclico, el panteismo, la ley de causalidad, el mundo como sueño o idea y otras, pero ahora han dejado de ser verdades absolutas -como ilusamente pretendían-para convertirse en mitos ... A pesar de su naturaleza racional, son mitos, porque ... a la par de constituir un desafío al orden tradicional, posibilitan una nueva comprensión del material al cual se aplican”. "Estructura oximorónica en los ensayos de Borges”, en J. Alazraki, op. cit., p. 264.

${ }^{19}$ Mario Benedetti: "Dos testimonies sobre Borges”, en Letras del continente mestizo (Montevideo: Area, 1967, 2da. ed.), p. 73.

20 Jorge Luis Borges, El libro de arena (Buenos Aires: Emecé, 1975), pp. 121-133. 


\section{Borges y la Política}

I.

La obra política de Borges casi no ha merecido la consideración de la crítica. En cambio, sus opiniones políticas -esas que transcribe ávidamente la prensa de por lo menos tres continentes- han merecido una consideración excesiva. La confusión ha llegado al punto de que se ha podido establecer públicamente la siguiente dicotomía: el escritor Borges es un genio; el opinante político Borges, un imbécil. El propio Borges ha fomentado esta fácil categorización al declarar, mil y una vez, que no sabe nada de política (lo que no le impide, acto seguido, emitir toda clase de opiniones); que nunca ha leído un diario (pero sus opiniones aparecen en todos los periódicos del mundo occidental); que su escepticismo en materia política es tan radical que cree que cuanto menos Gobierno haya mejor (lo que no le ha impedido, recientemente, elogiar tres Gobiernos particularmente notorios: los de Franco, Pinochet y Videla). Sus amigos se han cansado de advertirle que no opine más de política, que se niegue a ser entrevistado sobre esos temas, que la mayor parte de los que le hacen preguntas políticas sólo quieren tenderle trampas. El lo sabe, asiente y se ríe.

Que Borges, a los setenta y tantos años haya decidido tomar el papel de vieillard terrible es comprensible aunque no justificable. Hay que respetar el derecho de los demás a tener opiniones impopulares. Lo que no significa compartirlas, es claro. Pero lo que no se debe aceptar es que los críticos, apoyados en aquella dicotomía, juzguen a Borges sólo por sus opiniones políticas. Tomar estas opiniones como si fueran juicios críticos y estuvieran en el mismo nivel intelectual de sus ensayos literarios o estéticos; leer sus declaraciones a la prensa y basar en ellas un análisis de su política, y (lo que es aún peor) de la ideología de su obra; reiterar la dicotomía (Dr. Jekyll y Mr. Hyde) entre un genio literario y un imbécil político, es caer precisamente en el juego suicida del vieillard terrible. Las razones que Borges puede tener para jugar ese juego, o el placer que extrae de enfurecer a sus interlocutores, es un asunto estrictamente privado. Esas razones no funcionan (no deben funcionar) si lo que se quiere juzgar es la obra política de Borges, más abundante e inesperada de lo que se piensa. 
Esa obra política (como todas) esta íntimamente ligada a un contexto específico $\mathrm{y}$, por to tanto, requiere en quien la considere un conocimiento de lo que realmente ocurría en Argentina, y en el mundo occidental, cuando Borges escribió esos textos. Como el estudio de su biografía y de su contexto histórico está recién empezando a hacerse, es natural que éste sea el aspecto más descuidado por los eruditos borgianos. Si hay, ahora, un nivel satisfactorio de estudio de sus textos literarios, no pasa lo mismo con el estudio ideológico de los mismos. Leídos, por lo general, fuera de contexto, o examinados a la luz de teorías que no ayudan a definir a Borges sino al crítico (informan más sobre el partido al que pertenece el crítico que al que pertenece Borges), esos textos deben ser inscritos en las circunstancias en que fueron publicados para poder ser leídos con provecho y sin escándalo. A manera de anticipo de un trabajo más minucioso que he realizado para un libro en preparación, ofrezco ahora estas observaciones. ${ }^{1}$

II.

La primera guerra mundial es el contexto en que hay que situar el despertar de Borges a la realidad política. Ese despertar se produce no en la Argentina sino en Suiza, país neutral que esta situado precisamente en el corazón de la Europa en guerra. Borges tiene unos quince años cuando la familia se instala en Ginebra en el verano europeo de 1914. allí pasara una larga temporada que más tarde él definiría como época de "garuas". ${ }^{2}$ La circunstancia de estar en Suiza y de ser argentino aseguraba una doble neutralidad. Sin embargo, Borges (o Georgie, como entonces era llamado por todo el mundo) no deja de ser afectado por la guerra. El impacto mayor lo produce la obra literaria de los poetas expresionistas alemanes que él descubre hacia 1917 junto con la de Walt Whitman. En sus versos, la furia casi erótica de la guerra y su violencia criminal aparecen expresadas en imágenes ardientes, dislocadas, de fuego. Algunos de los poetas que Georgie lee habrán de ser sacrificados en la guerra: Ernst Stadler en el frente occidental; August Stramm en el ruso. A través de sus poemas, el muchacho vivirá vicariamente la experiencia de la guerra. Es un bautismo de fuego, es también un holocausto. $\mathrm{O}$ como ahora se dice, un genocidio.

En artículos que Georgie publicó en España poco más tarde y en antologías que preparó para revistas del ultraísmo, no sólo presentó y analizó la poesía expresionista (como han documentado estudios hechos por Guillermo de Torre, Gloria Videla y Cesar Fernández Moreno, entre otros) ${ }^{3}$ sino que se identificó con lo que él llama una "hermandad de poetas." Tanto su obra crítica de entonces, como su poesía de la primera época, esta influída por este generoso concepto. Esos eran los años en que la juventud de Europa tenía el Jean Christophe, de Romain Rolland, como libro de cabecera y en que la visión de un pan-europeísmo servía de espejismo a los más jóvenes. ${ }^{4}$ Georgie no sólo escribió entonces poesía expresionista en español: también compartió el credo del movimiento y, sobre todo, su ideología juvenil. En unas 
declaraciones hechas a James E. Irby, en 1962, y que han sido muy citadas, ${ }^{5}$ Borges ha definido su preferencia juvenil por el expresionismo sobre otros movimientos de vanguardia en estos términos inequívocos:

En Ginebra, donde pasé los años de la Primera Guerra (...) conocí el expresionismo alemán, que para mí contiene ya todo lo esencial de la literatura posterior. Me gusta mucho más que el surrealismo o el dadaísmo, que me parecen frívolos. El expresionismo es más serio y refleja toda una serie de preocupaciones profundas: la magia, los sueños, las religiones y las filosofías orientales, el anhelo de hermandad universal... (p. 6)

Es precisamente este anhelo el que habrá de determinar, al nivel más profundo, la adhesión de Georgie al expresionismo. La experiencia de la guerra convirtió a los mejores poetas en pacifistas. Los millones de muertos en ambos frentes -en esa tierra de nadie que las novelas de Henri Barbusse (El fuego, 1916) y de Erich Maria Remarque (Sin novedad en el frente, 1929) habrían de popularizar ${ }^{6}$-convertirían, paradójicamente, estos poetas guerreros en campeones de la hermandad de los hombres. Ellos descubrieron de la manera más terrible que la guerra es siempre pagada por los inocentes, que son los hijos y no los padres los que son sacrificados en los campos de batalla. Si al discutir el expresionismo (y los demás movimientos de vanguardia) se insiste siempre en la rebelión de los jóvenes contra el oficialismo y la tendencia radical de la mayoría de sus poetas, menos se insiste en lo que realmente originó esta rebelión. El parricidio, como lo revela trágicamente el mito de Edipo, es sólo la segunda etapa de un conflicto que se inicia realmente con un filicidio. Fue Layo el que atentó primero contra la vida de su hijo. Los poetas expresionistas debieron luchar en una guerra que se convirtió (como la de Viet Nam) en uno de los más catastróficos filicidios de la historia. (Cuando hablo de la guerra de Viet Nam no me olvido que empezó en 1946 siendo una aventura colonial francesa en Indochina.)

Súbitamente, y ante los ojos de una sociedad que se consideraba muy culta, la sociedad europea de la Belle Epoque, toda una generación fue masacrada de una manera tan gigantesca que hizo de los sacrificios rituales de los aztecas un espectáculo suburbano. Europa mostró entonces obscenamente al mundo entero lo que ocultaba el desfile de elegantes uniformes, vistosas maniobras navales y viriles cargas de caballería. Por primera vez, los jóvenes de Europa no eran sacrificados (para mayor gloria del Imperio alemán, francés o inglés) en remotas áreas coloniales. En 1914 fueron inmolados en mataderos, llamados trincheras, a las mismas puertas de sus hogares. El parricidio, pues, vino como reacción inevitable a esta hecatombe de hijos. Los poetas expresionistas fueron los primeros en llamar la atención (en esos días de prensa altamente censurada) sobre el genocidio que se estaba practicando en los gloriosos campos de Francia, Austria, Polonia y Rusia. 
Estas revelaciones deben haber sido terribles para Georgie ya que él no sólo estaba protegido de semejante carnicería por ser argentino y vivir en la neutral Suiza sino que estaba permanentemente protegido de toda esta aventura militar por su mala vista. Además, la rebelión parricida le estaba vedada por una razón muy personal: su padre era el más generoso y tolerante de los padres. Amigo de su hijo y practicante convencido de la teoría de que son los hijos los que educan a los padres, don Jorge era no sólo tan modesto que le hubiera gustado ser invisible (como ha contado Borges en su “Autobiographical Essay”) ${ }^{7}$, sino que jamás interfería en las decisiones de su hijo por creer que es mejor que se equivoquen, y aprendan de sus errores, a que sigan dócilmente la autoridad paterna. Es claro que un padre tan discreto no podía sino suscitar la más completa devoción. Georgie, en vez de rebelarse, lo imitó fielmente.

Esto no impidió que, en su poesía, la rebelión que estaba enmascarada debajo de la devoción filial, se manifestase simbólicamente. Por eso, cuando estalla la revolución rusa, Georgie habrá de escribir un poema que nunca recogió Borges en sus obras pero que esta ahí, en las revistas de la época para documentar su entusiasmo de los dieciocho o diecinueve años. Su titulo, "Rusia”, es bastante explícito:

Mediodías estallan en los ojos

Bajo estandartes de silencio pasan las muchedumbres

Y el sol crucificado en los ponientes

se pluraliza en las vocinglerías

de las torres del Kremlin

En el cuerno salvaje de un arco iris

clamaremos su gesta

como bayonetas

que portan en la punta las mañanas. ${ }^{8}$

Otro poema, “Gesta maximalista”, también ilustra la adhesión de Georgie a un socialismo que todavía no se llamaba comunista:

Desde los hombros curvos

se arrojaron los rifles como viaductos

El cielo se ha crinado de gritos y disparos

Solsticios interiores han quemado los cráneos

Uncida por el largo aterrizaje

la catedral avión de multitudes

quiere romper las amarras 
Pájaro rojo vuela un estandarte

sobre la hirsuta muchedumbre. ${ }^{9}$

Hay un tercer poema que aunque no refleja tan directamente una ideología socialista, coincide en utilizar una imaginaria que ya habían explotado los expresionistas. Se titula, “Trinchera.”

\author{
Angustia. \\ En to altísimo una montaña camina \\ Hombres color de tierra naufragan en la grieta más baja \\ El fatalismo unce las almas de aquéllos \\ que bañaron su pequeña esperanza en las piletas de la noche. \\ Las bayonetas sueñan con los entreveros nupciales. \\ El mundo se ha perdido y los ojos de los muertos to buscan \\ El silencio aúlla en los horizontes hundidos. ${ }^{10}$
}

La alusión fálica del sexto verso da perspectiva al poema, y al período. Estos son los años en que Georgie descubre (en el ardor de la adolescencia) la violencia de la guerra y la violencia del sexo, la hermandad de los poetas y la fraternidad de la carne. Perdido en un mundo que se estaba deshaciendo ante sus ojos neutrales, Georgie encontró en la experiencia imaginaria de la guerra y en la exaltación de los ritmos rojos, una metáfora para sus propios intensos y confusos sentimientos de lealtad filial y amor incestuoso, el oscuro ímpetu parricida que la poesía de ese tiempo apenas enmascara. Uno de los primeros, si no el primero, de los artículos que Georgie escribió en su vida es una reseña de tres libros españoles que envié desde la península a su amigo Maurice Abramowicz y que este publicó en el periódico ginebrino, La Feuille, después de haber corregido discretamente el francés de Georgie. ${ }^{11}$ Uno de los libros reseñados era de Pío Baroja y tenía el llamativo título, Momentum catastrophicum. Escrito en la época en que Don Pío estaba más anarquista que nunca, el libro ataca sin piedad la hipocresía de las naciones poderosas que sin dejar de ser imperialistas fuera de fronteras, practican una política doméstica del más cauteloso liberalismo. Escrito después de la victoria aliada y cuando el Tratado de Versalles permitió a Francia, Inglaterra y los Estados Unidos perpetuar por algunos años más su imperio sobre el mundo, Baroja se manifiesta a favor de la paz y dedica un ambiguo elogio a Wilson: "Marco Aurelio de la gran república de los trusts y las máquinas de coser, el único apóstol y árbitro de los asuntos internacionales, la flor de los arribistas...” Georgie aplaude a Baroja explícitamente. Sin duda que la elección de este libro fue determinada por la coincidencia ideológica. Ambos (el joven argentino, el irascible vasco) creían en la paz y desconfiaban de los gobiernos. Georgie había heredado de su padre una suerte de anarquismo filosófico que estaba fundado en Spencer, no en Bakunin. El descubrimiento de la fraternidad expresionista y el impacto de la revolución soviética no habían sino acentuar ese anarquismo. 
No es extraño, pues, que los dos libros que Georgie preparó, pero nunca publicó, en ese período estuvieran fuertemente impregnados por la ideología anarquista. Al evocar esta época en su “Autobiographical Essay,” Borges resumira de esta manera sus temas y su perspectiva:

In Spain, I wrote two books. One was a series of essays called, I now wonder why, Los naipes del tahur (The Sharper's Cards). They were literary and political essays (I was still an anarchist and a freethinker and in favor of pacifism), written under the influence of Pío Baroja. Their aim was to be bitter and relentless, but they were, as a matter of fact, quite tame. I went in for using such words as “fools," "harlots," "liars.” Failing to find a publisher, I destroyed the manuscript on my return to Buenos Aires. The second book was titled either The Red Psalms or The Red Rhythms. It was a collection of poems -perhaps some twenty in all- in free verse and in praise of the Russian Revolution, the brotherhood of man, and pacifism. Three or four of them found their way into magazines -“Bolshevik Epic,” "Trenches,” "Russia.” This book I destroyed in Spain on the eve of our departure. I was then ready to go home. (p. 223)

Lo que Borges no cuenta en su “Autobiographical Essay,” es que por lo menos uno de los artículos que pensaba recoger en Los naipes del tahur tenía un tema erótico: “Casa Elena (hacia una estética del lupanar en España).” A ese trabajo pertenece esta frase memorable:

Y la Estatuaria -esa cosa gesticulada y mayúscula- la comprendemos, al deliciarnos con las combas fáciles de una moza, esencial y esculpida como una frase de Quevedo. ${ }^{12}$

En el contexto de este artículo, se comprenden mejor las alusiones (tan oblicuas) de Borges en el “Autobiographical Essay,” a ciertas palabras fuertes, como "harlots," que le gustaba usar en sus trabajos de Los naipes del tahur. Pero la discreción de Borges no impide reconocer la indiscreción de Georgie. Para el adolescente, una vez más, la fraternidad humana y la violencia de la guerra estaban indisolublemente ligadas a la violencia erótica. Marte y Venus se le revelaron conjuntamente al tímido, ojeroso, moreno adolescente de lentes tan gruesos.

III

La política habrá de solicitar masivamente la atención de Borges una vez más a fines de los años veinte. Ya instalado en la Argentina y dedicado a la difusión del ultraísmo (primero) y a su demolición (casi de inmediato), Borges hace sus primeras armas en la política doméstica hacia 1927. Con un grupo de amigos poetas que, como él, eran asiduos colaboradores del periódico Martín Fierro, Borges funda un Comité 
de Jóvenes Intelectuales para apoyar la candidatura de Hipólito Irigoyen a la presidencia de la República. De acuerdo con una crónica olvidada que escribió Ulises Petit de Murat en 1944, lo que movió a los jóvenes a apoyarlo fue la convicción de que el Peludo (como llamaban cariñosamente al candidato) no tenía la menor posibilidad de ser reelecto ya que sus enemigos habrían de hacer fraude en las urnas. ${ }^{13}$ Para ellos, lo atractivo de tal candidatura es que era una causa perdida. Los iniciadores del movimiento fueron Borges, Petit de Murat y un joven poeta, Francisco López Merino, que habría de suicidarse al año siguiente y al que Borges dedicaría un par de poemas muy personales. Pronto otros jóvenes se sumarían al Comité: Francisco Luis Bernárdez, Leopoldo Marechal (ambos católicos), Enrique y Raúl González Tuñón (izquierdistas). En su crónica, Petit de Murat cuenta una anécdota que permite reconocer la actitud básica de Borges frente a esa campaña. Yendo a visitar un día el comité central de la campaña irigoyenista, fueron recibidos por el Director que los aburrió con sus discursos. En un melodramático aparte e imitando el acento lunfardo, Borges se volvió a Petit y le preguntó: “Che, ¿cuándo vienen las empanadas envueltas en nombramientos?"

No todos los intelectuales jóvenes estaban dispuestos, como estos, a apoyar causas perdidas. La dirección de Martín Fierro, que se enorgullecía de su neutralidad política, publicó una declaración en el número 44-45 (agosto 31-noviembre 15, 1927) desvinculándose por completo del Comité y subrayando su neutralidad. Tal reacción no le gustó a Borges y a Petit; pronto mandaron la renuncia como colaboradores de Martín Fierro. Mas drásticos en su reacción contra el Comité fueron los redactores de otra revista, Claridad, que tenía una orientación izquierdista. En el número correspondiente a abril, 1928, publicaron un poema atribuido a los miembros del Comité y que incluía la siguiente plegaria a Irigoyen:

Desfacedor de viejos y caducos regímenes, cuando al cabo traspongas los anhelados límites del gran salón presidencial, escucha nuestros ruegos, comprende nuestros gestos y dános consulados, cátedras y otros puestos, Hombre genial y sin igual! ${ }^{14}$

El poemita aparecía firmado por Borges, Marechal, Nicolás Olivari, Pablo Rojas Paz, los hermanos González Tuñón, Francisco Luis Bernárdez, Francisco López Merino y otros. Naturalmente que nadie creyó que fuera auténtico. Era demasiado obvia la intención del periódico de denunciar la venalidad de los jóvenes intelectuales. Lo curioso es que la perspectiva de casi cincuenta años, ha invertido la situación. Porque son los burladores los que han resultado burlados. Al oponerse al Comité, el periódico se oponía también a la reelección de Irigoyen; es decir: se oponía al único caudillo realmente popular que había producido entonces la Argentina. En tanto que 
los supuestamente alienados intelectuales burgueses que formaban el Comité salían a defender un jefe populista, los socialistas de Claridad aparecían alineados con la peor reacción derechista que veía en Irigoyen una amenaza a sus privilegios de clase y a su feliz acuerdo con los intereses internacionales.

Borges, en cambio, que no necesitaba y no quería ningún puesto público (su Mecenas era Don Jorge Borges), había descubierto en Irigoyen un caudillo que podía admirar. Unos tres años antes de este incidente, en un artículo que recogió en Inquisiciones (1925), había tenido oportunidad de expresar su opinión, a la vez política y alegórica, de lo que representaba Irigoyen para la Argentina. Debe subrayarse el hecho de que cuando Borges publicó este artículo, el Peludo no estaba en el poder, y que no era, naturalmente, la esperanza de un nombramiento (con o sin empanadas) lo que lo movía a elogiarlo.

El criollo, a mi entender, es burlón, suspicaz, desengafiado de antemano de todo y tan mal sufridor de la grandiosidad verbal que en poquísimos la perdona y en ninguno la ensalza. El silencio arrimado al fatalismo tiene eficaz encarnación en los dos caudillos mayores que abrazaron el alma de Buenos Aires: en Rosas e Irigoyen. Don Juan Manuel, pese a sus fechorías e inútil sangre derramada, fue queridísimo del pueblo. Irigoyen, pese a las mojigangas oficiales, nos está siempre gobernando. La significación que el pueblo siempre apreció en Rosas, entendió en Roca y admira en Irigoyen, es el escarnio de la teatralidad, o el ejercerla con sentido burlesco. En pueblos de mayor avidez en el vivir, los caudillos famosos se muestran botarates y gesteros, mientras aquí son taciturnos y casi desganados. Les restaría fama provechosa el impudor verbal. ${ }^{15}$

Toda una teoría del criollismo se encuentra sintetizada aquí. Para Borges, ese criollismo esencial (que él buscó en los versos de sus tres primeros libros de poemas y en los ensayos de sus tres primeros libros de crítica) nada tiene que ver con el criollismo de la letra de tango, ya contaminado por la sentimentalidad gallega o italiana. Por eso, le gusta el taciturno Irigoyen, y en su entusiasmo por los criollos viejos, hasta llega a encontrar virtudes en Rosas, el archi-enemigo de sus antepasados. En un momento en que todos se complacían en comparar a Irigoyen con Rosas para subrayar la arbitrariedad de ambos, su autoritarismo, su falta de respeto por los derechos políticos de sus adversarios, este artículo de Borges muestra como se manifiesta en ambos la raíz de un criollismo que desdeña la ostentación y se apoya en el silencio.

El entusiasmo de Borges por Irigoyen desapareció apenas el Peludo ganó (contra todas las expectaciones) la Presidencia. En vez de ir a reclamar un puestito al sol, Borges se convirtió en crítico del Gobierno. No le faltaban razones. Si en su primera presidencia, el Peludo había sabido aprovechar la prosperidad económica traída por el boom de la carne y la lana durante la Primera Guerra Mundial para realizar 
importantes reformas políticas y financieras, en su segunda presidencia Irigoyen no sólo estaba viejo y cansado sino que se encontraba frente a una situación económica que se había deteriorado notablemente, tanto en la Argentina como en el mundo entero. Apenas tomado el poder, Irigoyen tuvo que enfrentar el crack de la bolsa neoyorkina del año 29. Rodeado por un elenco mediocre, exacerbada su natural desconfianza por la edad, Irigoyen termina por alienar a sus mejores amigos. En 1930, hasta sus más cercanos colaboradores estaban dispuestos a aceptar cualquier solución de fuerza. Una gripe fue el pretexto que permitió forzarlo a deponer temporariamente el poder. El General Uriburu inmediatamente se hizo cargo del Gobierno.

La reacción de Borges al golpe militar se encuentra documentada en una carta que escribió por esa fecha a Alfonso Reyes, de quien se había hecho muy amigo durante la temporada en que el escritor mexicano estuvo de Embajador en Buenos Aires. La carta es muy irónica y literaria, pero revela no sólo la desilusión de Borges con respecto al Peludo sino su desilusión con respecto a los militares. Aunque él estaba (como tantos entonces) mal informado con respecto a los militares -creía, por ejemplo, que todos eran honestos-, su simpatía por Irigoyen no había desaparecido del todo. La perdida de la mitología que había generado el Peludo es lo que más le duele en su caída. También le duele (y con que lucidez) el hecho de que el nuevo régimen esté empeñado en uniformar la opinión y sólo permitir la Independencia bajo la Ley Marcial, como observa irónicamente Borges. Una intuición del régimen fascista que pronto se implantaría en la Argentina se puede encontrar en estas líneas irónicas. ${ }^{16}$ En un artículo posterior, que habría de recoger en Discusión (Buenos Aires, Gleizer, 1932), Borges completaría su juicio. Al hablar de “Nuestras imposibilidades”, y hacer el balance de las limitaciones de los argentinos, Borges elige terminar su diatriba con estas palabras:

Penuria imaginativa y rencor definen nuestra parte de muerte. Abona lo primero un muy generizable artículo de Unamuno sobre La imaginación en Cochabamba; lo segundo, el incomparable espectáculo de un gobierno conservador, que está forzando a toda la república a ingresar en el socialismo, sólo por fastidiar y entristecer a un partido medio.

Hace muchas generaciones que soy argentino; formulo sin alegría estas quejas. (p. 17)

El moralista político en que se ha convertido al fin Borges aparece claramente definido en este texto.

IV

La segunda guerra mundial, y sus largos prolegómenos europeos, darían oportunidad a Borges a aumentar considerablemente su obra política. Las primeras 
señales de que estas preocupaciones empezaban a dominar su conciencia se pueden advertir en ciertas observaciones que aparecen, cada vez más frecuentemente, en los textos críticos de los años treinta. En esa época, Borges empezó a hacer periodismo profesional para aumentar un poco sus casi invisibles ingresos. Es verdad que mientras Padre viviera no habrían de faltarle casa y comida pero la jubilación de éste no había sobrevivido intacta la crisis del año 1929. Por eso, el joven escritor aumenta cada vez más su colaboración en periódicos que pagan, aunque no sea mucho: $L a$ Nación y La Prensa, en primer lugar; Crítica (cuya sección literaria dirige por un par de años) y Síntesis. A partir de 1936, y por espacio de unos dos años y medio, habrá de encargarse de la sección, “Libros y Autores Extranjeros,” del semanario femenino, El Hogar. Es precisamente en este inesperado lugar donde Borges practicará, lapidariamente, una propaganda política anti-fascists.

Es imposible reseñar aquí los numerosos textos de esa campaña. Bastard indicar algunos de los aspectos más salientes. El ataque central está dirigido al fascismo, en sus dos vertientes de entonces: la italiana (que a Borges, como a tantos otros en Europa, le parecía sobre todo ridícula), la alemana (que él correctamente veía como siniestra). Aunque hay ataques a Marinetti (que visitó Buenos Aires en 1936 como representante de la Italia fascists al Congreso del P.E.N. Club), la mayor parte de las diatribas están dirigidas contra la nazificación de la cultura germánica. Así, por ejemplo, en mayo 30, 1937, dedica una breve reseña a un libro escolar que ilustra a los niños alemanes sobre el peligro semita. Además de transcribir algunos de sus horrores, Borges informa que el libro, titulado, Trau Keinem Jud Bei Seinem Eid, fue publicado en Baviera, que se encuentra en la cuarta edición y que ya ha vendido 51,000 ejemplares. ${ }^{17} \mathrm{El}$ mismo mes de mayo, publica otra reseña del libro en la revista Sur. Allí amplía lo dicho en El Hogar, resume y traduce algunos de los pasajes antisemitas más groseros ("He aquí el judío-¿quien no lo reconoce?-, el sinvergüenza más grande de todo el reino. El se figura que es lindísimo, y es horrible.”), y llega a la conclusión:

¿Qué opinar de un libro como este? A mi personalmente me indigna, menos por Israel que por Alemania, menos por la injuriada comunidad que por la injuriosa nación. No sé si el mundo puede prescindir de la civilización alemana. Es bochornoso que la estén corrompiendo con enseñanzas de odio. ${ }^{18}$

Lo que sobre todo ofende a Borges en el antisemitismo germánico es la estupidez, la agresión contra los valores culturales que han hecho a Alemania famosa. Esa misma estupidez (denunciada reiteradamente en las páginas de El Hogar y de Sur) es la que encontrará entre sus compatriotas fascistas. Porque en tanto que Borges no sólo ha aprendido alemán y ha estudiado con devoción y amor la filosofía, la poesía, la novela producidas por Alemania, los nazis argentinos sólo admiran el terrible poder de Hitler. Para destruir este punto de vista habrá Borges de escribir dos textos importantes. Uno es muy conocido: “Deutsches Requiem,” cuento de El Aleph (1949), en que se 
transcribe el monólogo de Otto Dietrich zur Linde, subdirector del campo de concentración de Tarnowitz, en la víspera de su ejecución por las fuerzas aliadas. Menos conocido en su original español, es un artículo que Borges publicó en la primera página de El Hogar en diciembre 18, 1940, cuando ya la máquina de Hitler había destruído Polonia, había concluído la gran ofensiva en el frente occidental que en quince días arraso con el ejercito franco-inglés y se preparaba para la invasión de Inglaterra. El artículo se titula, “Definición del germanófilo,” y ya desde su primera frase sitúa nítidamente, brillantemente, la perspectiva borgiana:

Los implacables detractores de la etimología razonan que el origen de las palabras no enseña lo que estas significan ahora; los defensores pueden replicar que enseña, siempre, lo que éstas ahora no significan. Enseña, verbigracia, que los pontífices no son constructores de puentes; que las miniaturas no están pintadas al minio; que la materia del cristal no es el hielo; que el leopardo no es un mestizo de pantera y de león; que un candidato puede no haber sido blanqueado; que los sarcófagos no son lo contrario de los vegetarianos; que los aligatores no son lagartos; que las rubricas no son rojas como el rubor; que el descubridor de América no es Amerigo Vespucci y que los germanófilos no son devotos de Alemania. ${ }^{19}$

Lo que Borges esta postergando decir es que los germanófilos (los argentinos, al menos) no están interesados en Alemania. Por eso observa que en las muchas ocasiones en que ha discutido con ellos sobre Alemania, se ha sorprendido al advertir que no reconocían los nombres de Holderlin, Schopenhauer o Leibnitz, y que su interés en aquel país se reducía a una sola cosa: Alemania era enemiga de Inglaterra. Y como esta última se negaba (y sigue negándose, por ahora) a devolver las Islas Malvinas a la Argentina, Inglaterra es el enemigo. Otros aspectos paradójicos del germanófilo argentino son subrayados por el artículo:

Es, asimismo, antisemita: quiere expulsar de nuestro país a una comunidad eslavogermánica en la que predominan los apellidos de origen alemán (Rosenblatt, Gruenberg, Nierenstein, Lilienthal) y que habla un dialecto alemán: el yiddish o juedisch. (id.)

Una conversación imaginaria, pero típica, sirve a Borges para completar el retrato -que en ciertos aspectos anticipa argumentos de Sartre en su famoso, "Retrato del antisemita”-. La conversación siempre comienza con una discusión del Tratado de Versalles, 1919, que fue tan injusto con Alemania. Tanto Borges como su interlocutor están de acuerdo en que una nación victoriosa debe dejar de lado la opresión y la venganza. El desacuerdo empieza cuando el germanófilo deduce de esta premisa la conclusión de que ahora que Alemania es vencedora tiene derecho a destruir a sus enemigos. 
Mi prodigioso interlocutor ha razonado que la antigua injusticia padecida por Alemania la autoriza en 1940 a destruir no solo a Inglaterra y a Francia (¿por qué no a Italia?) sino también a Dinamarca, a Holanda, a Noruega: libres de toda culpa en esa injusticia. En 1919 Alemania fue maltratada por enemigos: esa todopoderosa razón le permite incendiar, arrasar y conquistar todas las naciones de Europa y quizá del orbe.... El razonamiento es monstruoso, como se ve. (id.)

A las objeciones de Borges, el imaginario interlocutor opone un panegírico de Hitler. Una última paradoja habrá de cerrar el diálogo:

Descubro, siempre, que mi interlocutor idolatra a Hitler, no a pesar de las bombas cenitales y de las invasiones fulmíneas, de las ametralladoras, de las delaciones y de los perjurios, sino a causa de esas costumbres y de esos instrumentos. Le alegra lo malvado, lo atroz. La victoria germánica no le importa; quiere la humillación de Inglaterra, el satisfactorio incendio de Londres. Admira a Hitler como ayer admiraba a sus precursores en el submundo criminal de Chicago.(...) El hitlerista, siempre, es un rencoroso, un adorador secreto, y a veces público, de la "viveza” forajida y de la crueldad. Es, por penuria imaginativa, un hombre que postula que el porvenir no puede diferir del presente, y que Alemania, victoriosa hasta ahora, no puede empezar a perder. Es el hombre ladino que anhela estar de parte de los que vencen.

No es imposible que Adolf Hitler tenga alguna justificación; sé que los germanófilos no la tienen. (id.)

Al publicar este artículo en la primera página de El Hogar, Borges estaba realizando un acto político que habría de tener consecuencias unos años más tarde, cuando subiera al poder un militar que (aunque sin ser nazi él mismo) estaba rodeado de nazis. Incluso en el momento en que el artículo se publica, cuando la derrota de Francis y el cerco de Inglaterra por la Lutwaffe y los submarinos parecían condenar a la estrangulación el último enemigo de Hitler (Stalin estaba protegido por el pacto nazisoviético de 1938), una actitud como la de Borges iba a contrapelo de la sociedad argentina, católica hasta el antisemitismo, y del Gobierno, fascists por sentido de clase, por vínculos económicos con la Italia de Mussolini, por resentimiento contra el imperialismo británico. Pero Borges nunca buscó ser popular. Por el contrario, ya a los 41 años empezó a cortejar la impopularidad política. En la Argentina de los años 40 esa impopularidad tenía un nombre: ser antifascists.

Una última pieza importante del dossier antinazi de Borges es el texto, “Anotación al 23 de agosto de 1944,” en que celebra la liberación de París y que se publicó en Sur ese mismo año. El texto es muy conocido porque fue recogido en Otras inquisiciones (1952). ${ }^{20}$ Además de comunicar la sorpresa ante "el grado físico de mi felicidad cuando me dijeron la liberación de París” (p. 156), Borges registra otras, la más inesperada de las cuales es advertir que muchos partidarios de Hitler también estaban 
entusiasmados con la liberación. Le parece inútil tratar de razonar con los mismos germanófilos los oscuros motivos de ese cambio. Esos “consanguineos del caos” (pp. 156-157), ignoran todo sobre los móviles profundos de su conducts, como señala apoyado en una cita de Whitman que avala (inesperadamente, para é1) nadie menos que el Dr. Freud. Al cabo, y después de recordar un pasaje de Man and Superman, de Bernard Shaw, Borges descubre la clave de esa enigmática conducta. Para él esa clave esta en un día que es "el perfecto y detestado reverso" del que esta evocando: ese 14 de junio de 1940, en que las tropas de Hitler entraron en París.

Un germanófilo, de cuyo nombre no quiero acordarme, entró ese día en mi casa; de pie, desde la puerta, anunció la vasta noticia: los ejércitos nazis habían ocupado a París. Sentí una mezcla de tristeza, de asco, de malestar. Algo que no entendí me detuvo: la insolencia del júbilo no explicaba ni la estentórea voz ni la brusca proclamación. Agregó que muy pronto esos ejércitos entraron en Londres. Toda oposición era inútil, nada podría detener su victoria. Entonces comprendí que él también estaba aterrado. (p. 157)

La conclusión a que llega Borges después de este descubrimiento es muy elegante, en el sentido en que se habla en matemáticas de la solución breve de un problema complejo:

El nazismo adolece de irrealidad, como los infiernos de Erigena. Es inhabitable; los hombres sólo pueden morir por él, mentir por él, matar y ensangrentar por él. Nadie, en la soledad central de su yo, puede anhelar que triunfe. Arriesgo esta conjetura: Hitler quiere ser derrotado. Hitler, de un modo ciego, colabora con los inevitables ejércitos que lo aniquilaran, como los buitres de metal y el dragón (que no debieron de ignorar que eran monstruos) colaboraban, misteriosamente, con Hércules. (pp. 157-158)

Al ano siguiente de publicarse en Sur esta profecía, Hitler habría de morir en las ruinas de su bunker y un oscuro y sonriente coronel tomaria las riendas del poder efectivo en Argentina. Para Borges, un nuevo ciclo de su lucha contra el nazismo habaia de iniciarse. ${ }^{21}$

\section{V.}

El ascenso al poder de Juan Domingo Perón había sido lento y secreto. Sólo en octubre 17, 1945 resultó obvio para todo el mundo en la Argentina que el que realmente gobernaba no era el Presidente Farrell sino su ministro de Guerra y Secretario del Ministerio de Trabajo. Ese día, la mayor concentración de masas que se había visto hasta la fecha en Buenos Aires, pidió y obtuvo el regreso del Coronel Perón al Gobierno del que había sido eliminado ocho días antes por intrigas de 
colegas. El Gobierno cedió, Perón salió al balcón de la Casa Rosada a saludar a sus fieles y un grito de victoria (el mayor orgasmo colectivo que había escuchado Plaza de Mayo, según insinúa un historiador metafórico) rubricó lo que ya era evidente: Argentina tenía un segundo Rosas. ${ }^{22}$ Lo que no había conseguido Irigoyen, lo lograba ahora Perón. El retorno del Coronel al poder le permitió preparar las elecciones de febrero 24, 1946. Con el ejército, la policía y los sindicatos (estos sólo parcialmente) a sus órdenes, el Coronel obtuvo una victoria escasa, sólo el 51 porcentaje de los votos, pero suficiente.

Dentro del 49 porcentaje que enfáticamente votó contra Perón se encontraba no sólo la derecha más rancia sino, también la izquierda que veía en Perón un demagogo fascista, un líder populista que se había apropiado muchas cosas del socialismo para su mayor beneficio político. Por razones propias, también Borges militaba en esa inmensa minoría.

En unas declaraciones que hizo para el diario montevideano, El Plata, en octubre 31, 1945, es posible comprender que su total oposición a Perón se basaba en la convicción de que este era nazi. Aunque Borges reconoce allí la legitimidad de muchas de las reformas sociales que Perón y los suyos proponían, al mismo tiempo condena acerbamente la ola de odio que el nuevo líder había desatado. Reconoce en esa pedagogía los síntomas que el mismo había denunciado en Alemania y en Italia. también señala que los intelectuales argentinos ya estaban combatiendo al régimen y que la única solución democrática en esta situación anómala, era ceder el poder a la Suprema Corte de Justicia, para poder llamar a elecciones realmente libres. En sus declaraciones, Borges se manifestaba, sin embargo, pesimista en cuanto al pronto retorno del país al régimen democrático.

Su pesimismo estaba justificado. Como se sabe, Perón no cedió el poder a la Suprema Corte, manipuló a los sindicatos con promesas y con beneficios, persiguió con la policía a sus enemigos políticos, concedió inmunidad a los grupos nazifascistas, y asumió formalmente el poder. Entretanto, Borges firmó cuanto manifiesto se le puso al alcance. La venganza de Perón tardó pero fue digna de su generosidad. Si Borges estaba equivocado en cuanto a que Perón fuera nazi (le faltaba el sistemático odio de Hitler, la locura sado-masoquista), no estaba equivocado en cuanto a su fascismo. Y fueron precisamente los métodos fascistas de la humillación y el manoseo -equivalentes del purgante que Mussolini usó contra sus enemigos-los que Perón usó contra Borges y su familia.

En aquella fecha, había ya unos ocho años que Borges trabaja como modesto auxiliar en la biblioteca municipal, “Miguel Cané.” Ese era su único empleo. La pensión de Padre apenas daba para los gastos de la casa. De modo que resultó fácil para Perón vengarse de los manifiestos firmados por Borges. En agosto de 1946, éste fue oficialmente informado que había sido promovido a inspector de pollos y conejos en el mercado municipal de la calle Córdoba. En su “Autobiographical Essay,” resume irónicamente el episodio: 
I went to the City Hall to find out what it was all about. "Look here,” I said, "It’s rather strange that among so many others at the library I should be singled out as worthy of this new position." "Well," the clerk answered, "you were on the side of the Allies ... what do you expect?” His statement was unanswerable; the next day, I sent in my resignation. ${ }^{23}$

En el “Essay,” y tal vez por pudor, Borges no explica en que consistia la promoción. Es obvio que había sido elegido para ese cargo por el sentido alegórico que se da precisamente a las gallinas y conejos: animales mansos y hasta cobardes, víctimas del machismo rioplatense en sus chistes más groseros. Pero si Borges era corto de vista y nada atlético, tenía un coraje moral que no era común. Renunció a su cargo y de inmediato acepto un homenaje de la SADE, en que fue leído un breve texto suyo sobre el episodio. Como es prácticamente desconocido, a pesar de haber sido publicado más de una vez entonces, lo reproduzco en su totalidad:

\section{Dele-Dele}

Hace un día o un mes o un año platónico (tan invasor es el olvido, tan insignificante el episodio que voy a referir) yo desempeñaba, aunque indigno, el cargo de auxiliar tercero en una biblioteca municipal de los arrabales del Sur. Nueve años concurrí a esa biblioteca, nueve años que serán en el recuerdo una sola tarde, una tarde monstruosa en cuyo decurso clasifique un número infinito de libros y el Reich devoró a Francia y el Reich no devoró las Islas Británicas y el nazismo, arrojado de Berlín busco nuevas regiones. En algún resquicio de esa tarde única, yo temerariamente firme alguna declaración democrática; hace un día o un mes o un año platónico, me ordenaron que prestara servicios en la policía municipal. Maravillado por ese brusco avatar administrativo, fui a la Intendencia. Me confiaron, ahí, que esa metamorfosis era un castigo por haber firmado aquellas declaraciones. Mientras yo recibía la noticia con debido interés, me distrajo un cartel que decoraba la solemne oficina. Era rectangular y lacónico, de formato considerable, y registraba el interesante epigrama DeleDele. No recuerdo la cara de mi interlocutor, no recuerdo su nombre, pero hasta el día de mi muerte recordare esa estrafalaria inscripción. Tendré que renunciar, repetí, al bajar las escaleras de la Intendencia, pero mi destino personal me importaba menos que ese cartel simbólico.

No sé hasta donde el episodio que he referido es una parábola. Sospecho, sin embargo, que la memoria y el olvido son dioses que saben bien lo que hacen. $\mathrm{Si}$ han extraviado lo demás y si retienen esa absurda leyenda, alguna justificación los asiste. La formulo así: las dictaduras fomentan la opresión, las dictaduras fomentan el servilismo, las dictaduras fomentan la crueldad; más abominable es el hecho de que fomentan la idiotez. Botones que balbucean imperativos, efigies de caudillos, vivas y mueras prefijados, muros exornados de nombres, ceremonias unánimes, la mera disciplina usurpando el lugar de la lucidez... Combatir esas tristes monotonías es uno de los muchos deberes del escritor. ¿Habré de recordar 
a lectores de Martín Fierro y de Don Segundo que el individualismo es una vieja virtud argentina? Quiero también decirles mi orgullo por esta noche numerosa y por esta activa amistad.

Entre los discursos que se pronunciaron en la misma ocasión, el más importante fue el del Presidente de la SADE, el escritor Leonidas Barletta, militante comunista y que había sido miembro del famoso grupo de Boedo. Barletta saludo a Borges por su valentía al enfrentarse a la dictadura y no aceptar el silencio. El comienzo de su discurso es suficientemente explícito:

Nos hemos congregado en torno de esta mesa para desagraviar, en la persona de Jorge Luis Borges, a los escritores argentinos, agredidos por su activa defensa de la cultura. Su obra y su conducta acreditan con exceso la representación que tácitamente le acuerda nuestro afecto y nuestra admiración. (id.)

Su largo discurso, axial como el breve texto de Borges, fueron publicados por el periódico Argentina Libre. ${ }^{24}$ Para la izquierda, que durante casi una década habría de luchar contra Perón, Borges (el exquisito, el paradójico Borges) se había convertido en símbolo de la resistencia de los intelectuales contra la dictadura. Era este un extraño papel para un hombre irónico como el, pero Borges lo representó con la mayor sencillez posible. De esta manera, resultó evidente que Perón había elegido mal, ya que hubiera podido identificar más fácilmente entre los suyos un digno inspector de gallinas y conejos.

Unos dos años después, el Gobierno peronista habría de encontrar una nueva ocasión de humillar a los Borges. En septiembre 8, 1948, un grupo de damas de la sociedad argentina decidió reunirse en la calle Florida para cantar el Himno Nacional y repartir algunos panfletos contra la dictadura. Era de tarde y pronto un numeroso grupo de gente se había formado en torno de ellas. La policía pronto llegó a disolver la manifestación y detener a las damas principales con el argumento (correcto) de que no habían pedido permiso para manifestar. (En la redada, detalle pintoresco, cayeron dos damas uruguayas que estaban comprando zapatos en una boutique de la calle Florida y salieron imprudentemente a curiosear.) El magistrado condenó a las manifestantes a un mes de prisión. Entre las damas estaban Norah Borges y Dona Leonor Acevedo de Borges. Como la última ya había cumplido los sesenta, se la autorizó a quedarse en su departamento de la calle Maipú, con un vigilante a la puerta. Borges ha comentado el episodio en sus conversaciones con Richard Burgin. Empieza hablando de Madre:

Borges:

She is a remarkable woman. She was in prison in Peron's time. My sister also. Burgin: Peron put them in prison? 
Borges:

Yes. My sister, well, of course, in the case of my mother it was different, because she was already an old lady -she's ninety-one now- and so her prison was her own home, no? But my sister was sent with some friends of hers to a jail for prostitutes in order to insult her. Then, she somehow smuggled a letter to us, I don't know how she managed it, saying that the prison was such a lovely place, that everybody was so kind, that being in prison was so restful, that it had a beautiful patio, black and white like a chessboard. In fact, she worded it so that we thought she was in some awful dungeon, no? Of course, what she really wanted was for us to feel, well, not to worry so much about her. She kept on saying what nice people there were, and how being in jail was much better than having to go out to cocktails or parties and so on. She was in prison with other ladies, and the other ladies told me that they felt awful about it. But my sister just said the Lord's Prayer. There were eleven of them in the same room, and my sister said her prayers, then she went to sleep immediately. All the time she was in jail, she didn't know how long a time might pass before she would see her husband, her children, and her mother or me. And afterwards she told me -but this was when she was out of jail-she said that, after all, my grandfather died for this country, my great-grandfather fought the Spaniards. They all did what they could for the country. And I, by the mere fact of being in prison, I was doing something also. So this is as it should be. ${ }^{25}$

Hay otro testimonio sobre el episodio. Es un libro, El grito sagrado, escrito por una de las detenidas, Adela Grondona, y publicado unos diez anos después. ${ }^{26} \mathrm{La}$ imagen de Norah que transmite, parece certificar lo que ella decía en la carta citada por Borges, de que las cosas no estaban tan mal en la cárcel, o (al menos) que no lo estaban para Norah. Ella se pasaba encontrando cosas hermosas que alabar, una balustrada aquí, un rostro allí, y mantenía a todas las presas -damas o prostitutas eran to mismo, para ella- alegres con sus cantos y dibujos. Y también, es claro, con sus rezos. La prisión duro un mes entero, pero habría podido ser mas breve si las damas hubieran consentido en humillarse y pedir la intercesión de Evita. En sus conversaciones con Burgin, Borges relata axial este aspecto del episodio:

Burgin: How long was she (Norah) in prison?

Borges:

A month. Of course they told her that if she wrote a letter she would be free at once. And the same thing happened to my mother and my sister, her friends and my mother answered the same thing. They said, "If you write a letter to the Senora you'll get out." "What senora are you talking about?" "This senora is Senora Peron.” “Well, as we don't know her, and she doesn't know us, it's quite meaningless for us to write to her.” But what they really wanted was that those ladies would write a letter and then they would publish it, no? And then people would say how merciful Peron was, and how we were free now. The whole thing 
was a kind of trick, it was a trick. But they saw throug $i$ it. That was the kind of thing they had to undergo at the time.

Burgin: It was a horrible time.

Borges:

Oh, it was. For example, when you have a toothache, when you have to go to the dentist, the first thing that you think about when you wake up is the whole ordeal, but during some ten years, of course, I had my personal grievances too, but in those ten years the first thing I thought about when I was awake was, well, "Perón is in power.” (p. 120)

Soportar a Perón, sobrevivir, ese era el problema principal para Borges en aquellos años, pero en vez de hacerlo en digno silencio (como Chaves, y su autor, Eduardo Mallea), o de rodillas, como tantos escritores y plumíferos argentinos, Borges to hizo protestando. ${ }^{27}$ En la ciudad ocupada por su propio Ejercito en que se había convertido Buenos Aires, Borges continué hablando y hablando hasta que un día pudo despertarse y saber que Perón había caído. O mejor dicho: que lo habían hecho caer. Pudo saber (aunque seguramente eso ya no le importaba) que el Macho, como lo llamaban los suyos, a última hora había renunciado a luchar $\mathrm{y}$, muy discretamente, se había refugiado en una cañonera paraguaya, seguramente para inspeccionar in situ las gallinas y conejos que llevarían en la bodega.

La Liberación (como fue llamada entonces) trajo para Borges muchas recompensas de carácter político. ${ }^{28}$ Fue nombrado Director de la Biblioteca Nacional, recibió el Gran Premio Nacional de Literatura en 1956, fue aplaudido por haber sido uno de los pocos que en los años de la dictadura no se había callado o doblegado. A partir de entonces, Borges dejó de ser un escritor marginal, independiente, de ideas filosóficas anarquistas, para convertirse en un escritor oficial, conservador, representante de una oligarquía que prefiere cualquier gobierno al juego democrático libre. En esa decisión política de Borges influyó mucho una circunstancia privada. Debido al creciente deterioro de su vista, a partir de 1956, su médico le prohibib leer y escribir. Debió apoyarse, más que nunca, en su madre para toda clase de actividad intelectual y, sobre todo, para la información política.

A los setenta años, Madre era una mujer enormemente activa, que apenas representaba cincuenta. En realidad, ya empezaba a parecer la mujer de su hijo; confusión que aunque ella no fomentaba, la halagaba extraordinariamente. A la influencia de Madre, de Norah y del circulo vehemente de sus muy conservadoras amistades, se debe la inscripción de Borges en el Partido Conservador. Aunque para disminuir la adhesión, él haya dicho que ser conservador es una forma de escepticismo, la decisión habría de comprometerlo con una causa, no sélo perdida sino indigna de encontrarse. ${ }^{29}$ A partir de 1956, las opiniones políticas de Borges dejan de tener algo que ver con la realidad argentina, o mundial. Son expresión de la falta de contacto con una realidad compleja y mudable de un hombre al que la ceguera ha terminado por aislar del mundo cotidiano: el mundo de la política. 
VI.

Ahora resulta obvio que Borges (como la mayoría de sus compatriotas) se equivoco al juzgar tan negativamente muchos aspectos de la obra de Perón. No advirtió que, a pesar de su demagogia y su falta de respeto por el proceso democrático, Perón puso al día a la Argentina en materia de legislación social y en la protección de los derechos de los trabajadores. Tampoco advirtió que en su política internacional y en su oposición al capitalismo anglo-norteamericano, Perón tenía razón, aunque sus razones pudieran estar corrompidas por una concuspicencia financiera que lo hizo amasar una fortuna personal enorme. Es decir: Borges veía al fascista Perón, al demagogo Perón, al torturador Perón, al cachador Perón. No veía los otros aspectos de una personalidad, verdaderamente carismática y que, en cierto sentido, resultó como un borrador carnavalesco de Fidel Castro. Pero si Borges no podía reconocer los aspectos positivos de Perón, tampoco los advertían los liberales que lo rodeaban, ni los izquierdistas (tanto los jóvenes parricidas como los viejos aparatchiks) que militaban en otros bandos. Solo cuando su segundo asalto al poder, resultó evidente que había otro Perón. Para Borges era ya demasiado tarde. Aparte las numerosas alusiones en poemas, cuentos y ensayos, el texto principal que escribió Borges contra Perón es un cuento, redactado en colaboración con Adolfo Bioy Casares y titulado, “La fiesta del monstruo.” Fechado el 24 de noviembre de 1947, este relato circuló en manuscrito y sin nombre de autor, subterráneamente, en el Río de la Plata. Fue publicado a la caída de Perón, y aun así, sólo en Montevideo, en la sección literaria del semanario Marcha, que entonces yo dirigía. ${ }^{30}$ En un lenguaje barroco que lleva hasta sus últimos límites el lunfardo de algunos personajes de Bustos Domecq, el protagonista narra su participación en la manifestación monstruosa que para celebrar a Perón se organiza en las barriadas. El narrador es un hombre estupido y muy venal que sólo se suma a los manifestantes por el afán de sacar tajada. Su relato (ejemplo típico de la narración que Wayne Booth llama de "unreliable narrator”), ${ }^{31}$ resulta una parodia de una parodia. A través de la sordidez del relato, se ponen al descubierto los mecanismos demagógicos que utiliza Perón para crear manifestaciones espontáneas de apoyo a su régimen. El humor es salvaje, y la narración resultaría sólo grotesca si no condujera a un desenlace violento, y (lamentablemente) histórico. Antes de llegar a Plaza de Mayo, los manifestantes tropiezan con un joven intelectual judío, tratan de forzarlo a que grite los slogans peronistas y por no hacerlo a satisfacción, lo matan. Aunque no muy frecuentes, estos episodios ocurrieron en la Argentina de Perón, especialmente en la época en que el Coronel controlaba la policía y estaba ya consolidando su poder. Entre sus aliados ocasionales se encontraba un grupo, la Alianza nacionalista, que era nazi y que había convertido la persecución y exterminio de los judíos en deporte favorito. Perón condenó más de una vez en público estas prácticas pero nunca ordenó que la policía castigase a esos asesinos. Aunque no era nazi, le convenía tener esos mastines de reserva. ${ }^{32}$ 
Borges, pues, estaba técnicamente equivocado al creer que Perón era nazi pero no estaba equivocado al creer que Perón fomentaba a los nazis argentinos. Por eso, porque tenía razón en lo esencial, podía no importarle no tenerla en los detalles. Como ha dicho más de una vez en sus historias y cuentos, y sobre todo en "Emma Zunz,” las circunstancias podrían ser falsas, pero era verdadero el ultraje cometido. ${ }^{33}$ Para el moralista político que Borges es, en definitiva, la culpa de Perón, y de tantos otros, reside allí. Por eso, él no podía pactar, y hasta ahora no ha pactado, con hombres como éste: los villanos sonrientes de la historia argentina.

\section{VII.}

Si Borges se hubiera limitado a escribir sobre política, este trabajo habría terminado ao,ui. A partir de 1956, y con muy pequeñas excepciones (algunos notorios poemas sobre Israel, por ejemplo), no ha publicado nada sobre temas explícitamente políticos. ${ }^{34}$ Pero no ha cesado de conceder entrevistas sobre temas de actualidad y ha opinado sobre cuanto acontecimiento político sus interlocutores le han ofrecido. Negando su capacidad de opinar en tales materias, no ha dejado de hacerlo, con esa perversidad de vieillard terrible que se ha ido acentuando con los años. Sus declaraciones han alimentado el fuego y ahora hasta aquellos que soportaron durante años las peores dictaduras (la de Franco, por ejemplo) se creen con derecho a ofenderse porque Borges apoya a Pinochet, o aplaude a Nixon. Jesús había pedido que antes de tirar la primera piedra estuviéramos seguros de estar libres de culpa. Pero los críticos de Borges no tienen escrúpulos evangélicos. La profesión de lapidarios es, por lo demás, demasiado popular. A río revuelto (para citar otro lugar común) son los pescadores los que ganan. Todo esto sería aceptable $-\mathrm{y}$ hasta implicaría una cierta cuota de justicia poética ya que Borges, cuando muchacho, también practicó el alacranismo político y crucificó a Lugones, por ejemplo- ${ }^{35}$ si a nivel de la crítica responsable se practicase un examen cuidadoso de la política de los textos borgianos. Es decir: sería aceptable si los críticos de Borges que militan tan visiblemente en la izquierda, realmente estudiaran del punto de vista ideológico sus textos en vez de glosar monótonamente, como el cuervo de Poe, sólo sus opiniones periodísticas. Descubrirían, entonces, no sólo que Borges ha escrito más sobre política de lo que se cree (como he tratado de demostrar aquí) sino que su obra entera tiene una ideología política.

Es claro que para analizar la ideología política del texto que llamamos Borges se necesita algo más que un recuento de sus opiniones. La ideología de un texto (como ya lo sabían Marx y Engels) ${ }^{36}$ no coincide necesariamente siempre con la ideología manifestada por el autor en sus declaraciones politicas. En el prefacio de la Comedie Humaine, Balzac se declara monárquico y católico. ${ }^{37}$ Su pintura de la sociedad francesa de la primera mitad del siglo xIx está, por suerte, libre de esas piadosas ficciones. Lo mismo pasa con el fascismo de D’Annunzio (que ha analizado 
brillantemente Paolo Valesio) o con el antisemtismo de Céline (sobre el que ha escrito un trabajo fundamental Julia Kristeva). Ni la obra de D’Annunzio defiende para nada la sociedad burguesa, conservadora de la familia y del estado, de las buenas costumbres y de la propiedad privada que son la base del fascismo, ni la de Celine defiende el ideal nazi de una sociedad basada en la disciplina y el fervor de una mística política del superhombre germánico. D’Annunzio es (como texto) un apóstol de la corrupción y del decadentismo; Céline, un partidario del caos y del absurdo, atravesado por una piedad que sólo sabe expresarse en el insulto y la cólera. La obra de Borges (el texto que llamamos Borges) no pretende conservar la sociedad burguesa sino negarla, no está a favor de la familia y las buenas costumbres sino de la extinción total de la realidad, del tiempo y el espacio, del individuo y sus ilusiones de poder político: ilusorio como todo lo cotidiano. Un mundo tan negativo, una heterotopía tan radical (como ha dicho Michel Foucault) ${ }^{38}$ no puede ajustarse a ningún régimen fascista, se llame Franco, Pinochet o Videla el jefe. Son precisamente los edificantes enemigos de Borges, esos padres de familia que quieren gobiernos estables y fuertes para asegurar a sus proles un futuro mejor, los que sostienen regímenes totalitarios. Ellos son los que cuando un Perón o un Franco gobiernan, bajan la cabeza. Borges, en cambio, el enfant terrible/vieillard aún más terrible sigue escribiendo contra los espejos y la cópula porque multiplican la humanidad. ${ }^{39}$ Su mundo no es el mundo del fascio sino el horrible mundo malthusiano de la nada.

Yale University

EMIR RODRIGUEZ MONEGAL

\section{NOTAS}

1 En mi libro, Borges, A Literary Biography, de próxima publicación por E.P. Dutton (New York), se estudia detalladamente la carrera y la obra políticas del autor.

2 Cf. Nota autobiográfica en Exposición de la actual poesía argentina (1922/1927), compilada por Pedro Juan Vignale y César Tiempo (Buenos Aires, Minerva, 1927), p. 93.

3 Cf. Guillermo de Torre: Literaturas europeas de vanguardia (Madrid, Caro Raggio, 1925), y la Historia de las literaturas de vanguardia (Madrid, Guadarrama, 1925); Gloria Videla: El ultraísmo. Estudios sobre movimientos poéticos de vanguardia en España (Madrid, Gredos, 1963); César Fernández Moreno: La realidad y los papeles. Panorama y muestra de la poesía argentina (Madrid, Aguilar, 1967). En este trabajo, estos libros serán citados por el nombre del autor, la fecha y la página solamente.

4 Jorge Luis Borges: “Biografías sintéticas: Romain Rolland,” en El Hogar, Buenos Aires, julio 25, 1937, p. 30.

5 Cf. James E. Irby: “Encuentro con Borges,” en Revista de la Univensidad de México, México, junio 1962.

6 Jorge Luis Borges: “Biografías sintéticas: Henri Barbusse,” en El Hogar, marzo 19, 1937, p. 28.

7 "Autobiographical Essay," en The Aleph and Other Stories. 1939-1969, compilado y traducido por Norman Thomas di Giovanni en colaboración con el autor, (New York, E.P. Dutton, 1970), p. 206.

8 Cf. de Torre, 1925, p. 62.

9 Cf. de Torre, 1925, p. 63.

${ }^{10}$ Cf. Videla, 1963, pp. 100-101. 
11 Jorge Luís Borges: “Chronique des lettres espagnoles. Trois nouveaux livres,” en La Feuille, Ginebra, agosto 20,1919. En una visita a Maurice Abramowicz que realicé en Ginebra, 1975, pude ver no sólo el original manuscrito de este trabajo sino que también recogí valiosas informaciones sobre el mismo que me hizo el Dr. Abramowicz. Debo a la generosidad del Profesor Donald A. Yates la copia del texto de Borges, tal como se publicó en La Feuille.

12 Cf. Fernández Moreno, 1967, p. 141.

13 Cf. Ulyses Petit de Murat: “Jorge Luis Borges y la revolución literaria del Martín Fierro,” en Correo Literario, Buenos Aires, febrero $1^{\circ}, 1944$.

14 Cf. Luis C. Alen Lascano: La Argentina ilusionada. 1922-1930 (Buenos Aires, Ediciones La Bastilla, 1975), p. 245.

15 Jorge Luis Borges: “Queja de todo criollo,” en Inquisiciones (Buenos Aires, Proa, 1925), p. 132.

16 “Jorge Luis Borges a Alfonso Reyes,” en L’ Herne (París, 1964), p. 56.

17 “Libros y autores extranjeros,” en El Hogar, mayo 20, 1937, p. 26.

18 Jorge Luis Borges: “Una pedagogía del odio,” en Sur, no. 32 (Buenos Aires, mayo 1937), p. 81.

19 Jorge Luis Borges: “Definición del germanófilo,” en El Hogar, diciembre 13, 1940, p. 3. También en: Emir Rodríguez Monegal: Borges par lui meme (París, Du Seuil, 1970), pp. 130-133.

20 Jorge Luis Borges: Otras inquisiciones (Buenos Aires, Sur, 1952).

21 Aunque menos, Borges también escribió en esa época contra el stalinismo. Veánse, por ejemplo, las ironías contra el arte del realismo socialista contenidas en la reseña de "Un copioso manifiesto de Breton,” publicada en El Hogar, diciembre 2, 1938, p. 89. Me he referido a este texto en un trabajo leído en el Congreso sobre el Surrealismo, organizado por el Instituto Internacional de Literatura Iberoamericana en la Universidad de Pennsylvania, Philadelphia, en agosto 24, 1975, bajo la presidencia del Profesor Peter Earle, y que será publicado en la Memoria de dicho Congreso.

22 Cf. Félix Luna: El 45. Crónica de un año decisivo. (Buenos Aires, Editorial Sudamericana, 1971), p. 293.

23 “Autobiographical Essay,” p. 244.

24 Jorge Luis Borges: “Dele-Dele;” y Leonidas Barletta: “Desagravio a Borges,” en Argentina Libre, Buenos Aires, agosto 15, 1946, p. 5.

25 Cf. Richard Burgin: Conversations with Jorge Luis Borges (New York, Holt, Rinehart, Winston, 1969), pp. 118-119.

26 Cf. Adela Grondona: El grito sagrado.(Treinta días en la cárcel (Buenos Aires, 1957).

27 Cf. Emir Rodríguez Monegal: El juicio de los parricidas. La nueva generación argentina y sus maestros (Buenos Aires, Deucalión, 1956), pp. 29-98.

${ }^{28}$ Cf. Jean de Milleret: Entretiens avec Jorge Luis Borges (París, Pierre Belfond, 1967), p. 82.

29 Cf. de Milleret, 1967, pp. 220-221, en que Borges declara su “escepticismo político,” y agrega que una vez, hablando en público delante de sus nuevos correligionarios, los conservadores, los decepcionó porque “mon thème a tourné autour de mon idée: Si 1'on est conservateur, on n'est pas fanatique car on ne peut s'enthousiasmer pour le conservatisme, pas plus que n'est concevable un conservateur fanatique.” También declara que se hizo conservador para dar "plaisir à ma mêre et ma soeur.”

30 H. Bustos Domecq: “La fiesta del monstruo,” en Marcha, Montevideo, setiembre 30, 1955, pp. 20-23. Hay traducción al inglés, a cargo de Alfred MacAdam con Suzanne Jill Levine y Emir Rodríguez Monegal: “Monsterfest,” en Fiction, New York, Vol. 5, no. 1, 1977, pp. 2-5.

31 Cf. Wayne Booth: The Rhetoric of Fiction, Chicago, The University of Chicago Press, 1961.

32 Un ejemplo: El 4 de octubre de 1945, “por la noche, en los alrededores de la Facultad de Ingeniería un grupo de aliancistas tiroteó a un grupo democrático y un estudiante, Aaróm Salmún Feijóo, fue asesinado por negarse a vivar a Perón.” (Luna, 1971, p. 211) Uno de los slogans de los manifestantes del 17 de octubre, 1945, era: "Haga patria matando un estudiante.” (id., p. 308) Otro slogan era: “Haga patria, mate un judío.” (id., p. 343, n. 89) El 23 de noviembre, 1945, hubo “un pequeño 'pogrom’ en el barrio Once, por cuenta de los activistas del nacionalismo.” (id, p. 396) Toda esta información está extraída de una fuente neoperonista. El autor indica que, una vez, Perón “debió publicar un comunicado. Decía que 'sujetos irresponsables al grito de Viva Rosas, Mueran los judíos, Viva Perón, escudan su indignidad para sembrar la alarma y la confusión. Quienes así proceden viven al margen de toda norma 
democrática y no pueden integrar las filas de ninguna fuerza política argentina.’” (id., p. 354). El comentario del autor es: "Pero los muertos estaban muertos."

33 Jorge Luis Borges: “Emma Zunz,” en El Aleph (Buenos Aires, Losada, 1949), p. 68. El final del cuento dice literalmente: "La historia era increíble, en efecto, pero se impuso a todos, porque sustancialmente era cierta. Verdadero era el tono de Emma Zunz, verdadero el pudor, verdadero el odio. Verdadero era también el ultraje que había padecido; sólo eran falsas las circunstancias, la hora y uno o dos nombres propios."

${ }^{34}$ Una de las pocas excepciones, el poema, “1972,” en La rosa profunda (Buenos Aires, Emece, 1975), p. 107, donde dice:

Pero la patria, hoy profanada quiere

Que con mi oscura pluma de gramático,

Docta en las nimiedades académicas

Y ajena a los trabajos de la espada,

Congregue el gran rumor de la epopeya

Y exija mi lugar. Lo estoy haciendo.

35 Cuando Lugones publicó su Romancero (1924), Martín Fierro dedicó una parte de su "Parnaso Satírico," a la composición “Romancillo, cuasi romance del ‘Roman-cero' a la izquierda," que firmaban Mar-Bor-Vall-Men, seudónimo tras el cual eran visibles Leopoldo Marechal, Jorge Luis Borges, Antonio Vallejo y Evar Méndez. Cf. Segunda época, Año III, no. 30-31, Buenos Aires, julio 8, 1926.

${ }^{36}$ Cf. Friedrich Engels: “Letter to Margaret Harkness, Beginning of April 1888 (draft)," en Marx and Engels on Literature and Art, compilado por Lee Baxandall \& Stefan Morowski (St. Louis, Mil., Telos Press, 1973), pp. 115-116.

37 “J'ecris à la lueur de deux Vérités eternelles: la Religion, la Monarchie, deux nécessités que les évenements contemporains proclament, et vers lesquelles tout écrivain de bon sens doit essayer de ramener notres pays.” (“Avant-Propos,” en La Comedie Humaine, Paris, La Pléidade, Gallimard, 1966, I, p. 9). Paul Lafargue nos dice, en sus Reminiscences of Marx (1880), que este admiraba tanto a Balzac "that he wished to write a review of his great work La Comédie Humaine as soon as he had finished his book on economics.” (Baxandalll \& Morowski, 1973, p. 150).

${ }^{38}$ Cf. Michel Foucault: Les mots et les choses (Paris, Gallimard, 1966), p. 9.

39 Jorge Luis Borges: "El tintorero enmascarado Hákim de Merv", en Historia universal de la infamia (Buenos Aires, Megáfono, 1935), p. 92; y “Tlön, Uqbar, Orbis Tertius,” en El jardin de senderos que se bifurcan (Buenos Aires, Sur, 1941), pp. 10-11. Un comentario de estos textos, y de su contexto literario y biográfico, se encuentra en el trabajo, "El lector como escritor," que está recogido ahora en mi libro: Borges: Hacia una poética de la lectura (Madrid, Guadarrama, 1976), pp. 41-93. 


\title{
Aquiles y la Tortuga: Arte, Imaginación y la Realidad según Borges
}

\author{
La ironía del escritor es la mística \\ negativa de la época sin Dios.
}

(G. Lukács, Teoría de la novela)

"Hay un concepto que es el corruptor y el desatinador de los otros," escribe Borges en su ensayo "Avatares de la tortuga”. Todos conocemos ese viejo chiste de Zenón de Elea: el del porqué Aquiles Piesligeros no alcanza la tortuga, cuya formulación es: Aquiles corre diez veces más ligero que la tortuga y le da una ventaja de diez metros. Aquiles corre esos diez metros, la tortuga corre uno; Aquiles corre ese metro, la tortuga corre un decimetro; Aquiles corre ese decímetro, la tortuga un milímetro; Aquiles Piesligeros el milímetro, la tortuga un décimo de milimetro y así infinitamente, sin alcanzarla. La broma es originada, según el sistema de Zenón, por la vertiginosa proyección del infinito en lo finito, proyección tanto más “vertiginosa” cuanto más pequeña y fútil es esta realidad finita. Es una metáfora que lleva a parálisis - quod erat demonstrandum.

Borges resulta fascinado por esa intrigante paradoja y recurre a ella reiteradamente en Discusión (1932) y en Otras inquisiciones (1952), que flanquean su obra narrativa de mayor relieve y que estará en el centro de nuestra atención; y esta imagen se halla indudablemente en el fondo de su "sistema" metafísico. ${ }^{1}$ Borges ve en ella una irrealidad que confirma el carácter alucinatorio del mundo, un tenue y eterno intersticio de sinrazón que nos hace saber que el mundo que hemos soñado "resistente, misterioso, visible, ubicuo en el espacio y firme en el tiempo" es falso. Y de ahí emprende la transformación imaginativa de la realidad de este mundo.

Borges es la más bella "mala hierba” en las letras hispanoamericanas en lo que va del siglo. El contacto con su universo es fatídico: aceptada la minúscula fisura metafísica en el mundo real, si bien sólo como un juego de la imaginación, este mundo estalla. La obra borgeana teje un vertiginoso laberinto en torno del lector asombrado y éste, sorbido por los espejismos de los espejismos, yerra perdido en los infinitos corredores de “inútiles simetrías y ... repeticiones maniáticas”. Hasta los partidarios de la doctrina que más escándalo ha merecido entre las de Tlön, para señalar un caso extremo, no escapan a la seducción borgeana. ¿Qué díria el viejo Marx a este desvarío tlönizante sobre el concepto de la muerte expuesto por uno de sus aprendices que es al mismo tiempo un agudo crítico hispanoamericano?: 


\begin{abstract}
Mi muerte es la forma de mi realización, casi de mi perduración; la muerte es...la intersección entre la eternidad y lo temporal, momento en que la verdad se encarna en el hombre o sube de su interioridad, y debe ser acatada. Cumplir la muerte es un modo de recuperarse más allá del absurdo y fugaz mundo de los sentidos-sueños, permaneciendo en un rito casi religioso, repetible por todos los hombres. La violencia es la piedra de toque porque en ella está la llave hacia otro universo, la posibilidad de evadir esa chaqueta de fuerza, la realidad, y entrar a la definitiva roca del nirvana, es el contacto que puede establecer el hombre con las ocultas potencias que gobiernan su quehacer, sean éstas divinidades o meras y anónimas leyes cíclicas, es su sendero, a través de la acción del otro, que mata o muere, hacia sí mismo. Etc. ${ }^{2}$
\end{abstract}

Pero volvamos a la seducción borgeana. ¿En qué consiste? Es lo que intentaremos ver.

\title{
EL PROGRAMA DE UNA MAGIA NARRATIVA
}

En Discusión encontramos un ensayo titulado "El arte narrativo y la magia” en donde Borges se propone analizar el procedimiento de la novela (“...el problema central de la novelística-escribe allí-es la causalidad.”), y distingue, sorpresivamente, "dos procesos causales: el natural, que es el resultado incesante de incontrolables e infinitas operaciones; el mágico, donde profetizan los pormenores, lúcido y limitado.” Estos procesos, según Borges, no se excluyen: “...la magia es la coronación o pesadilla de lo causal, no su contradicción.” En la definición de la magia Borges parte de Frazer ("ley...de la simpatía, que postula un vínculo inevitable entre cosas distantes”) y la aplica ingeniosamente al proceso narrativo: “...una novela...debe ser un juego preciso de vigilancias, ecos y afinidades. Todo episodio, en un cuidadoso relato, es de proyección ulterior.” Como resultado puede aparecer en la narración un "secreto argumento", como en Poe, Melville, etc. De los dos procedimientos "causales", Borges opina que "en la novela...la única posible honradez está con el segundo," abandonando la causalidad "normal” a la "morosa novela de caracteres”, que “dispone una concatenación de motivos que se proponen no diferir de los del mundo real". ${ }^{3}$

En la intuición de Borges se mezclan dos aspectos: de un lado está la realidad mágica y la lógica particular de su constitución, investigada por Frazer; del otro, la organización del proceso narrativo, aquello que los formalistas rusos llamaron “motivación de composición” (Tomashevski, Teoría de la literatura, 1925) y lo que ya Chejov expresó de una manera menos “mágica” al afirmar que si al comienzo del relato se habla de un clavo inserto en la pared, al final del mismo, el héroe debe colgarse de ese clavo. Si la 1ógica “mágica” y la causalidad del mundo real entran en oposición natural, “el juego de vigilancias, ecos y afinidades” es indiferente con 
respecto a esta oposición, porque es elemento de otro orden, a saber, del proceso narrativo.

Esta imprecisión y la parcialidad por el interés en uno de tantos procedimientos novelísticos no deben inquietamos. Esto ya pertenece al nivel operacional del programa. Y, aún más, es su conditio sine qua non. Só1o esto nos aclara la paradoja de que los escritores con programas vagos y hasta contradictorios crean obras de arte, mientras que los con programas más "desarrollados" y "consistentes” ... escriben la crítica. Y un programa "perfecto" lleva hasta la parálisis creadora, crítica y eventualmente también humana (Ver los programas inventados y planificados, por ejemplo, por el realismo socialista). ${ }^{4} \mathrm{~L}$ a creación verdadera va más bien por el camino opuesto, va desde el lado del arte: cuanto más se aproxima el artista en cuanto tal a su programa, tanto más se pierde en el laberinto de las leyes artísticas.

Examinemos la complejidad estructural de las obras borgeanas en algunos casos concretos.

\section{“LA MUERTE Y LA BRUJULA"}

En “La muerte y la brújula”, sección “Artificios” de Ficciones (1944), tenemos tres estratos sobrepuestos: el universo "mágico" como opuesto implicitamente al mundo "real”; la línea "mágica" de la fábula opuesta a la "real”; y dos planos del sujet, el del resumen inicial, ambiguo, a manera de presagio y el del desarrollo explicativo. El universo "mágico", cíclico, esta regido por las leyes del eterno retorno. La acción, que tiene lugar en uno de los ciclos, sigue dos líneas: una falsa, la "mágica”, y otra efectiva, la "real". La narración se abre con un resumen-presagio: "De los muchos problemas que ejercitaron la temeraria perspicacia de Lönnrot, ninguno tan extraño -tan rigurosamente extraño, diremos-como la periódica serie de hechos de sangre que culminaron en la quinta de Triste-le-Roy... Es verdad que Erik Lönnrot no logró impedir el último crimen, pero es indiscutible que lo previó...” Aparte de la tensión y la curiosidad producidas, ¿quién intuirá que el mencionado será el último problema resuelto por el detective de "temeraria perspicacia”, y aún más, que éste lo "resolverá" de manera tal que él mismo se convertirá en víctima de los "hechos de sangre" que ocurren con "extraño rigor"...? La ironía distanciadora del narrador omnisciente ante el personaje, pero también ante el lector, es evidente.

En la disputa entre Lönnrot y el comisario Treviranus sobre la interpretación de los hechos, el lector sigue al primero por estar guiado por la tradicción del género policial -el cuarto estrato que se interpone entre el mundo narrado y el lector- en que Sherlock Holmes siempre sobrepasará al "imbécil constante” Watson (ver el primer análisis de esta oposición funcional fundamental para el género policial en $\mathrm{V}$. Shklovski, Sobre la teoría de la prosa narrativa, 1925). En un esfuerzo por prevenir el cuarto crimen, el detective lo provoca. La línea "mágica” de Lönnrot se cruza 
primero alusivamente con el universo cíclico (“un recuerdo asombrado y vertiginoso”), para revelar inmediatamente su falacia frente a la línea "real” y para abrirse luego explicitamente al universo cíclico. La expectación del lector a partir del género policial, con la que el narrador juega, está anulada: el desenlace paradójico esta en un contraste irónico con el presagio inicial, pero que, a su manera, cumple.

El "secreto argumento" del relato es sorpresivamente la línea "real” y, por supuesto, la concepción cíclica del universo. Al mismo tiempo, lo “real”, insertado en el andamiaje del eterno retorno, se vuelve ilusorio. Y remata las ambigüedades la ambigüedad narrativa.

El universo “mágico” no se agota con los ciclos “verticales” ni con la conexión “horizontal” de los hechos en la línea “mágica”. Recordemos, por ejemplo, la relación de identidad y la despersonalización, típicamente borgeanas: ante todo en los nombres de los adversarios, que contienen el color rojo: Lönnrot y Red Scharlach; Lönnrot, con su “termeraria perspicacia”, puede perecer sólo a mano de quien se identifique prácticamente con su modo de ser y pensar; el Scharlach agonizante llega a abominar de su cuerpo, "llegue a sentir que dos ojos, dos manos, dos pulmones, son tan monstruosos como dos caras"; y finalmente, ¿que personalidad pueden tener estas piezas sobre un tablero cíclico repetitivo? Piezas, símbolos, funciones... El perseguidor y el perseguido, confundidos hasta en sus funciones "normales”, son en efecto un Jano bifronte...

Y de ahí se percibe otra tensión dialéctica en el universo borgeano: la apertura, el carácter esencialmente no acabado, abierto, de las historias relatadas. Aquí la apertura cíclica, repetitiva, pero que en otras obras puede revesitr la forma de infinita permutación de todos los elementos. Así el autor de la novela aparentemente caótica, “El jardín de senderos que se bifurcan”, opta simultáneamente por todas las alternativas. "Crea...diversos porvenires, diversos tiempos, que también proliferan y se bifurcan. De ahí las contradicciones de la novela... En la obra de Ts’ui Pên, todos los desenlaces ocurren; cada uno es el punto de partida de otras bifurcaciones.” En el Prólogo a la sección "Artificios”, de Ficciones, Borges sugiere en éste espíritu dos aperturas adicionales en "La muerte y la brújula”, la temporal y la especial: “...la venaganza podría ser heredada; los plazos podrían computarse por años, tal vez por siglos; la primera letra del Nombre podría articularse en Islandia; la segunda, en Méjico; la tercera, en Indostán...” La línea “mágica” de la fábula recrearía icónicamente el movimiento cíclico del universo imaginario.

Este juego entre una historia "compacta” y sus partes cíclicas "dispersas” se tematiza en “Tema del traidor y del héroe”, también de la sección “Artificios”. Los elementos dispersos se refieren a aspectos de las historias de Moisés, del rey David, de César, de Macbeth y de Lincoln, anteriores y posteriores a la historia que tiene lugar, digamos, en 1824. ${ }^{5}$ Ahora bien; las historias de César y de Macbeth fueron literarizadas por Shakespeare. Nolan, traductor de Shakespeare, copia a éste en apuro 
cuando fabrica su "guión” de la "realidad”. Esta "realidad” tiene lugar de manera prevista y pasa a la Historia como la Realidad. Sin embargo, su “inventor” deja en ella huellas que revelan su carácter postizo, de plagio literario. Ryan, bisnieto del héroetraidor Kilpatrick (interesante el nombre: Kil asociado con kill, “asesinar”, y patrick, con “patria”, o ¿ “Patria”?), descifra a partir de la Realidad la “realidad”. Pero, llevado como Nolan y el mismo Kilpatrick por el "interés mayor”, Ryan fabrica, con motivo del centenario del "héroe”, otra falsificación, a su vez “corroboración” de la Realidad. La Patria, la Raza, la Nación, el Sistema deben reposar sobre una "firme” tradición de la Realidad. Vertiginosa y fulminantemente, la historia situada en esta oportunidad, digamos en Irlanda, adquiere la más ardiente e implacable universalidad.

Finalmente, las últimas dos aperturas de "La muerte y la brújula" aludidas en el Prólogo: “...pese a los nombres alemanes o escandinavos, ocurre en un Buenos Aires de sueños: la torcida Rue de Toulon es el Paseo de Julio; Triste-le-Roy, el hotel donde Herbert Ashe recibió, y tal vez no leyó, el tomo undécimo de una enciclopedia ilusoria.” La postdata a El aleph (1949) podría ofrecernos quizá la explicación de la mistificante obnubilación de la realidad argentina en este relato. Dice Borges sobre "El hombre en el umbral” que lo situó “en la India para que su inverosimilitud fuera tolerable”. La alusión a Herbert Ashe vincula el relato de cierta manera (pasa al lector la “instrucción” de enlazarlo...) con “Tlön, Uqbar, Orbis Tertius”, de El jardín de senderos que se bifurcan (1941), “corroborando” así la veracidad de las circunstancias "personales”, pero ¡con que ambigüedad!: "recibió, y tal vez no leyó... de una enciclopedia ilusoria”. Las coordenadas particulares del universo borgeano permiten que hasta los prólogos y epílogos sean partes legítimas de las obras mismas.

Aperturas de varios niveles, subordinadas todas al nivel de la escritura y cerradas por él; cerradas, refractadas por las leyes constructivas de la obra de arte.

La estructura de los tres relatos comparados es sorpresivamente semejante: la acción detectivesca ocurre en un doble plano, cruzado a su vez por el movimiento cíclico del “universo”; quizá como compensación de esta ley ciega y fría, la acción esta intimizada por varios tipos de parentesco entre los protagonistas y por una comunicación particular entre un emisor y un destinatario, por encima de los protagonistas (el “narrador” y el "lector” implícitos “tras las espaldas” de los gémelos jánicos LönnrotScharlach) o de los interpretes de la "realidad”...; el valor de algún personaje, de su función “normal”, está puesto en tela de juicio, y en especial se pone al revés el género policial: el espía logra comunicar el mensaje, el criminal captura al detective y Ryan, en el relato policial "histórico", si bien descubre la verdad, sigue en la pauta programada de la falsificación...

De las variaciones particulares que nos importa señalar aquí, “Tema...” ofrece el importante estrato de la ambigua interrelación entre la realidad y la literatura, interrelación de recreaciones y plagios mutuos. Y hay un desplazamiento importantísimo de las permutaciones cíclicas: estas no afectan la historia central sino indirectamente; la historia de Kilpatrick, si bien postiza, si bien sus elementos estén 
diseminados en la Historia pasada y futura de la humanidad, y hasta en las versiones literarias de esta Historia, es en principio única y “original”; en ella, la repetición cíclica está suspendida: ¿qué interés tendría la revelación de que el héroe $x$ es traidor, si en otro "avatar” no lo es o es al revés? El movimiento cíclico se desplaza a la actividad de Nolan y Ryan. La universalidad de este relato esta construida de manera esencialmente distinta a la de la de "La muerte y la brújula". La universalidad en “Tema...” es más bien “por contagio”, porque sabemos que muchos otros mitos de la sociedad son igualmente postizos, si bien su estructura particular es siempre distinta. Borges frena así de manera particular el libre juego de permutaciones. Las leyes artísticas imponen su rienda al universo metafísico.

En la estructura de los tres cuentos que hemos enfocado, si bien ligeramente, se revela el "arte combinatoria” que rige el universo borgeano. Sería interesante abordar desde esta perspectiva los volúmenes particulares, especialmente el primero del período que nos interesa, El jardín de senderos que se bifurcan, en que la composición de las “piezas” es más patente. Es otra apertura de los relatos particulares al universo del conjunto.

Una nueva apertura del mundo narrativo borgeano nos lleva hacia “Tlön, Uqbar, Orbis Tertius”, cuento que abre El jardín..., como otro punto de partida. ${ }^{6}$

\section{LAS METAMORFOSIS DE TLON}

Veamos primero cómo un disparate metafísico se convierte aquí en una obra de arte. "Debo a la conjunción de un espejo y de una enciclopedia el descubrimiento de Uqbar.” En la primera lectura, un comienzo ordinario, ab ovo. Al mismo tiempo, esa inquietante metáfora de “conjunción”, palabra que se usa para designar "encuentros" de los astros... Y esos elementos ordinarios pero singularizados por la "conjunción”: un espejo y una enciclopedia... Espejo que refleja y desdobla y enciclopedia que desdobla y ordena... La lectura ulterior revela que el microcosmo del comienzo contiene ya el macrocosmo de la obra...

La narración pasa hábilmente a la situación “real”, en que dominan el problema de unas enciclopedias, ciertos proyectos literarios y el espejo: "El espejo inquietaba... el espejo nos acechaba...” El espejo se transforma pronto en algo “monstruoso” y hasta “abominable”, porque, como se dice, los espejos y la cópula "multiplican el número de los hombres”. La personificación diluye las fronteras “normales” y cualquier elemento inanimado puede crecer monstruosa y aforísticamente en importancia. Y de esa base singularizada empieza la búsqueda de Tlön y Uqbar, para confirmar el origen de la “memorable sentencia”. Ya esta primera página de “Tlön...” traza las inquietantes coordenadas del "mundo": ordinario, metafórico, personificado, monstruoso y aforístico. Es una sútil predisposición del lector, la que se repetirá todavía varias veces, para que éste luego devore lo que se le ofrezca... Y la preparación continua, ahora traspuesta a otro plano: el enigma de la enciclopedia que no contiene y otra que 
si contiene pero sin contener... y todo esto algo extraño, pero situado en una atmósfera "real” y hasta de una enumeración burocrática de detalles concretos...Sentimos que tras el relato palpita un misterio, pero al mismo tiempo el halo "real” concienzudamente construido nos convence de que el narrador es... digno de confianza.

Los primeros propósitos de toda relación fantástica estan alcanzados: el mundo “real” esta sútilmente desquiciado y al mismo tiempo está afirmada la fe en el narrador. Seguirá un juego de la tensión refrenada. Tlön puede ir surgiendo en sus primeras metamórfosis, como una de las regiones del Asia Menor y luego como un país utópico. Y de nuevo se pierde la pista...

El segundo capítulo se abre a partir de un salto temático y se intensifica la circunstancia personal "real” (la introducción de Herbert Ashe). Pero de nuevo, como de paso, se intercala un disparate sobre el "sistema duodecimal” en el que doce se escribe como " 10 ” y, una gradación, sobre la traducción de "tablas duodecimales” a “sexagesimales”, donde a su vez sesenta se escribe como "10". La "realidad” vuelve a perder su firmeza... Finalmente, con un "vértigo asombrado” descubre el narrador uno de los tantos tomos de la enciclopedia dedicada a Tlön y compara su emoción con la "Noche de las Noches" islámica cuando se abren las secretas puertas del cielo... Pero todavía no se entra en Tlön. Se describe detalladamente el tomo, pero la impresión de su “realidad” está como minada cuando leemos que aquél consta de mil y una... páginas. La anterior introducción del mundo islámico permite identificar inmediatamente esta sútil corrosión de la "realidad” del tomo enciclopédico... En este lugar, Tlön se metamorfosea en un planeta desconocido del que el tomo enciclopédico trae "un vasto fragmento metódico de la historia total... articulado, coherente, sin visible propósito doctrinal o tono paródico”. Pero de nuevo se vuelve a la situación paradójica, "real” por imaginaria, de una enciclopedia cuyos restantes tomos no los puede encontrar ni un "team” de nombres desde Néstor Ibarra hasta Alfonso Reyes. Por desesperación, este propone reconstruirlos. Paradójicamente, esta sugerencia tan “comprensible”, revela el origen de la enciclopedia. La “cuestión de Tlön” pasa a otro plano: ¿quiénes lo inventaron? La alusión a Brave New World (novela de A. Huxley, 1932) devuelve Tlön a la utopía, esta vez "futurista”, que ofrece la “amena” imagen de una sociedad repartida científicamente en castas. (Otra utopía, 1984, no aludida pero tanto más verosímil, intuye que esa era se abrirá mucho antes que "siete siglos A.F.”, es decir, “after Ford”; la realidad y las utopías se complementan...) El narrador vuelve a la "invención” y enumera las condiciones necesarias para la creación de esta enciclopedia. Su plan "es tan vasto que la contribución de cada escritor es infinitesimal”. La “realidad” otra vez roza el absurdo, pero inmediatamente se vuelve más verosímil: se rechaza lo más absurdo ("al principio se creyó que Tlön era un mero caos, una irresponsable licencia de la imaginación”) para hacer más plausible que "es un cosmos y las íntimas leyes que lo rigen han sido formuladas, siquiera en modo provisional” (lo de “cosmos” y de las "leyes” calma y lo "provisional” convierte el mayor absurdo 
casi en la realidad cotidiana...). Se necesita adelantar todavía dos aspectos inquietantes de Tlön (tigres transparentes y torres de sangre) para que el narrador pueda pedir la palabra y exponer, “sistemáticamente”, el “concepto de universo” de Tlön: termina un juego de tensiones y de refrenamiento, pero sólo para ceder lugar a otro juego narrativo.

Este concepto parte de Berkeley, y Tlön es como un planeta en que se realicen las teorías de este filósofo. Tlön es una metáfora realizada y el concepto de enciclopedia permite desarrollarla descriptivamente de manera "natural” y más variada. Pronto se nota que Tlön es la realización de todas las metafísicas idealistas. Y en este mundo idealista, ninguna doctrina "ha merecido tanto escándalo como el materialismo". En esta fase, el mundo de Tlön se afirma como una imagen inversa de nuestro mundo real, imagen en un espejo imaginario. Y esta condición inversa se afirma por una cachetada de disparates procedentes de varios órdenes de la vida (y de muchos de ellos se desarrollaron a su vez los cuentos de El jardín..., etc.). Pero aun este nivel sólo predispone para el siguiente tour de force metafísico: "Siglos y siglos de idealismo no han dejado de influir en la realidad.” Y se explica el origen de los “objetos secundarios", los llamados hrönir, producidos "realmente” por el esfuerzo de la imaginación o del deseo, y se explica su variado uso que va hasta la posible modificación del pasado (sin embargo, esto se hace en la Tierra corrientemente aun sin esta útil invención...). El final remata la línea ascendente, vinculándola sútilmente con el comienzo de la exposición sistemática: "Las cosas se duplican en Tlön; propenden asimismo a borrarse y a perder los detalles cuando los olvida la gente. Es clásico el ejemplo de un umbral que perduró mientras lo visitaba un mendigo y que se perdió de vista a su muerte. A veces unos pájaros, un caballo, han salvado las ruinas de un anfiteatro.” Aquí, donde el absurdo poético alcanza su cumbre de sutileza, las fronteras entre la realidad e irrealidad, disparate e imagen poética, se esfuman por el truco magistral de prestidigitación metafísica y artística. El lector hasta se olvida de que las “reglas del juego” -el rigor- están sacrificados a la seducción de la imagen poética.

La enciclopedia metafísica sistemática está refractada por las leyes artísticas constructivas. Borges no sólo sigue sútilmente las leyes no escritas de toda literatura fantástica, sino que realiza magistralmente también sus propios postulados de "El arte narrativo y la magia”.

\section{NUEVAS METAMORFOSIS DE TLON}

Ahora bien, ésta es sólo la primera parte de la historia. La "postdata de 1947" inicia un nuevo ciclo. ${ }^{7}$ Se comienza una vez más desde la circunstancia personal, se dan variantes de los escalones ulteriores y se termina el párrafo con la aparición de objetos hechos de la materia de Tlön. Este se independiza por completo de la Tierra 
y adquiere hasta "realidad" material. Es ahora cuando se abre, sorpresivamente, el último ciclo narrativo: hacia 1944, dice el narrador, fue descubierta toda la enciclopedia tlönista y en miles de versiones inundó la Tierra. Pero “algunos rasgos increíbles”, de que dio cuenta el "onceno tomo”, han sido eliminados o atenuados...: “...es razonable imaginar que esas tachaduras obedecen al plan de exhibir un mundo que no sea demasiado incompatible con el mundo real.” ¡Y la “realidad” cede a esta invasión de Tlön!:

Lo cierto es que anhelaba ceder. Hace diez años bastaba cualquier simetría con apariencia de orden -el materialismo dialéctico, el antisemitismo, el nazismopara embelesar a los hombres. ¿Cómo no someterse a Tlön, a la minuciosa y vasta evidencia de un planeta ordenado? Inútil responder que la realidad también está ordenada. Quizá lo esté, pero de acuerdo a leyes divinas -traduzco: a leyes inhumanas- que no acabamos nunca de percibir. Tlön será un laberinto, pero es un laberinto urdido por hombres, un laberinto destinado a que lo descifren los hombres. El contacto y el hábito de Tlön han desintegrado este mundo. Encantada por su rigor, la humanidad olvida y torna a olvidar que es un rigor de ajedrecistas, no de ángeles.

Borges, que ha creado tan sutilmente la existencia metafísica y artística del mundo de Tlön, se sirve del último truco: lo hace estallar convirtiéndolo en una metáfora de este mundo, de nuestro mundo contemporáneo y concreto. El orden metafísico utópico se apodera de nuestro mundo, es este mundo.

Esta última transformación de Tlön, sorpresiva y poderosa, marca una transgresión llamativa del género fantástico. La ficción fantástica se estrella; la imagen inversa, lúdica, se convierte en nuestra realidad cotidiana y universal; y esta "realidad", al revés, se convierte, vertiginosamente, en la más absurda de las ficciones, en una de las variantes de Tlön. Esta última “conjunción” e identificación de los “planetas” ha sido predispuesta tanto por la realidad de nuestro siglo como por la hábil estructuración artística. El mundo de Tlön crece desde nuestro mundo. Se afirma como una realidad independiente, si bien inventada: atrae hacia su realidad la de nuestro mundo. La serie de transformaciones y de inversiones es completa: nuestro mundo es Tlön. Con tal que por el momento sea un Tlön incompleto, más bien una encarnecida lucha de los Tlön, Uqbar y Orbis Tertius..., y todo esto, un Tlön elevado a la segunda potencia...

El final del relato rebasa los límites de la literatura fantástica, encabalgándose en la zona del realismo. Pero es al mismo tiempo un realismo sumamente sublimado e inofensivo. ¿O acaso no lo es la metáfora de Tlön, con sus graciosos disparates metafísicos, y pese a las "torres de sangre" mencionadas como de paso, al lado de las guerras devastadoras sostenidas bajo las banderas más distintas, de los campos de concentración y las cámaras de gas, del ramificado “archipiélago Gulag” y los manicomios para disidentes, de las reiteradas "liberaciones" de países "hermanos" 
por fuerzas armadas “fraternas”...y así ad nauseam? Lo más fuerte del realismo borgeano es el aspecto “subrealista”, la corrosión universal de la realidad.

\section{LA “FE DE LA ESPADA”}

En "Deutsches Requiem”, ${ }^{8}$ de El aleph (1949), los contornos reales de Tlön adquieren rasgos históricos aún más concretos. El relato trae la confesión de un criminal nazi, antiguo subdirector de un campo de concentración, en la víspera de su ejecución “por torturador y asesino”. “Quienes sepan oírme -dice el protagonista del cuento-, comprenderán la historia de Alemania y la futura historia del mundo. ...soy un símbolo de las generaciones del porvenir.” Es la historia de un intelectual (un simple criminal quizá no permitiría el planteo realizado) que "comprende” la Ley Histórica de la Nueva Epoca: “Comprendí... que estábamos al borde de un tiempo nuevo y que ese tiempo, comparable a las épocas iniciales del Islam o del cristianismo, exigía hombres nuevos... El nazismo, intrínsecamente, es un hecho moral, un despojarse del viejo hombre, que está viciado, para vestir el nuevo.” En este proceso de "forja de un Hombre Nuevo" el protagonista "sube” por varios escalones: entra en el Partido, “supera” su propia falta de "vocación de violencia”, se “desindividualiza” ("Individualmente, mis camaradas me eran odiosos; en vano procuré razonar que para el alto fin que nos congregaba, no eramos individuos.”), y espera su última prueba. Esta no viene en el campo de batalla, como desea, sino que es peor: es la tentación de piedad, el "último pecado de Zarathustra”, en un campo de concentración. El "Hombre Nuevo” destruye sádicamente sus víctimas para destruir su propia piedad... Por fin, esta vez, las victorias terminan en la derrota. El intelectual que pretende haber entendido la Ley Histórica, etc., se convierte en un ideólogo secreto, metafísico, de esta "Nueva Epoca” y buscando "el sentido de la derrota”, llega a sentir por ella "el misterioso y casi terrible sabor de la felicidad”. Le parece que ha descubierto su secreta “justificación”:

Hitler creyó luchar por un país, pero lucho por todos, aun por aquellos que agredió y detestó... El mundo se moría de judaísmo y de esa enfermedad del judaísmo, que es la fe de Jesús; nosotros le enseñamos la violencia y la fe de la espada. Esa espada nos mata... Muchas cosas hay que destruir para edificar el nuevo orden; ahora sabemos que Alemania era una de esas cosas... Se cierne ahora sobre el mundo una época implacable. Nosotros la forjamos, nosotros que ya somos su víctima. ¿Que importa que Inglaterra sea el martillo y nosotros el yunque? Lo importante es que rija la violencia, no las serviles timideces cristianas. Si la victoria y la injusticia y la felicidad no son para Alemania, que sean para otras naciones. Que el cielo exista, aunque nuestro lugar sea el infierno. 
Este texto ofrece un agudo diagnóstico del tremendo cambio ocurrido en nuestra época: el hombre, desprovisto súbitamente del antiguo marco metafísico, firme, que le imponía ciertas limitaciones, pero le daba una jerarquía de preferencia, ha intentado tomar las riendas de la vida en sus propias manos y se ha puesto en el camino del “Futuro”, de la ruptura con el “pasado podrido”, en el camino del radicalismo utópico y de la violencia. No es ya la vieja violencia espontánea, por pasión o por desesperación, ni es un mero gusto del crimen; ahora, con una bomba hay que poner una mecha metafísica: Tlön, Uqbar, Orbis Tertius...

El hombre ha dejado de ser “de Dios” y se ha vuelto "futurista”. Pero es un hombre-golem, diría con ironía Borges, que, cuanto más, "barre bien o mal la sinagoga”... Es un hombre-calibán, que del "lenguaje” ha aprendido sólo el "saber maldecir”. Así, este hombre dirige lo que no conoce y, desconociendo el presente, "planifica” el porvenir... Sólo que el "hrönir del Futuro", al materializarse, dista abismalmente del deseo que lo produjo; y del sumo se cae en trauma: de la amena utopía queda la realidad de la bayoneta...

E igualmente, desconociéndose que es el arte, se quiere "regularlo como el movimiento de trenes”, en la feliz expresión de un gran formalista ruso cuando todavía podía “investigar la verdad" y no necesitaba "seguir la Verdad”... Pero el arte es el hombre. Es sintomático que el arte sea mirado de reojo, como “mala hierba”, en todas las utopías. Es que el rigor de estas es geométrico, de ajedrecistas. El "juego de la Utopía” reposa sobre unas cuantas reglas fácilmente formulables; en cambio, la vida, el mundo, el arte, reposan sobre miles de reglas escasamente conocidas. Por lo tanto, la falibilidad de los argumentos y de la doctrina, la debilidad del cuerpo y del espíritu humanos, están “compensados” por la violencia de la expresión y de la praxis, por la "fe de la espada" o por la realidad de las bayonetas...

La proyección “desde adentro”, en un ejemplo excepcional, pero que será muy en breve trivial, como promete el protagonista y cumple el tiempo, le permite al autor un rigor vertiginoso del razonamiento que se mueve hasta en el límite del absurdo. Pero es que el absurdo, el Tlön, la utopía, son los secretos resortes de nuestra época, el secreto fundamento de su deshumanización geométrica... And yet, and yet... El camino del hombre no puede ir hacia atrás. ¿Es ésta una nueva afirmación de Tlön?

Borges trata al protagonista del relato como símbolo, genéricamente. En un ejemplo repugnante, aparentemente al margen de la humanidad, revela, sorpresivamente, la secreta esencia de nuestra época. La forja de un criminal nazi le permite modelar una historia cerrada, afortunadamente, que agudiza y actualiza el problema universal y pone de relieve su extrema inhumanidad. Dentro de la historia mencionada, Borges se limita a esbozar sólo el andamiaje general. Pero en el afán de generalizar, rebasa no sólo los límites modélicos del caso particular sino también los que corresponderían a nuestra época. La modernidad modélica de su héroe se hunde y se diluye en el laberinto de repeticiones genealógicas, típicamente borgeano; la 
actuación en el campo de concentración viene marcada por el sentimentalismo metafísico de identificación del torturador con sus víctimas ("Yo agonicé con él, yo morí con otro clisé grato a Borges; después tenemos la "plenitud de la experiencia" en la combinación de la victoria y de la derrota, que tiene las connotaciones del juego metafísico de Tlön; y, finalmente, lo del hechicero capturado en su propio laberinto, del rey David, del martillo y del yunque, del ciego y del infierno, que se repiten y repiten en las obras de Borges casi ad nauseam.

Otro llamativo ejemplo de esta pérdida en sus propios laberintos está ofrecido en la “Anotación al 23 de agosto de 1944” de Otras inquisiciones. Después de un agudo razonamiento viene este desvario metafísico: “Arriesgo esta conjetura: Hitler quiere ser derrotado. Hitler, de un modo ciego, colabora con los inevitables ejércitos que lo aniquilarán...” etc. (¿Dónde sería necesario situar esta “conjetura” para que sea más “tolerable”?)

Para la consideración del realismo en Borges no importa que la realidad esté presente de algún modo en él, por ejemplo: en forma de alusiones a su situación personal (las autorreferencias); como el ambiente argentino, vago o más real; o en forma de complementos apócrifos de la historia o de la literatura argentina (Martín Fierro); lo que importa es el modelado de una situación histórica en su dimensión social representativa. La "voluntad de realismo", que de vez en cuando brota "inexplicablemente” en Borges, está presente en él, sin embargo, en un piano considerablemente abstracto y especulativo. Aun en sus manifestaciones más llamativas, como la mencionada anatomía profética de nuestra época, el modelo histórico se diluye en el andamiaje metafísico general, se pierde en la supraestructura metafísica y sus clisés. Es otra variante de la aludida carrera metafísica, la paradoja fundamental de la obra borgeana.

\section{DEL LABERINTO DE IMAGINACION}

Es tiempo de mirar más de cerca el “extravío del argentino en la metafísica”. En su comienzo está el juego de la imaginación. Se proponen ciertas reglas y se sacan, más o menos rigurosamente, las consecuencias. Así leemos en "Penúltima versión de la realidad”, de Discusión: “Imaginémonos que el entero género humano sólo se abasteciera de realidades mediante la audición y el olfato. Imaginemos anuladas así las percepciones oculares, táctiles y gustativas y el espacio que éstas definen. Imaginémonos también -crecimiento lógico- una más afinada percepción de lo que registran los sentidos restantes. La humanidad -tan afantasmada a nuestro parecer por esta catástrofe- seguiría urdiendo su historia... La vida... sería tan apasionada y precisa como la nuestra."

Este juego imaginativo se nutre de cuanta "greguería” metafísica le cruce el camino... Pero Borges no se queda en copiar sistemas particulares, sino que los asume 
ecuménicamente a todos, transformándolos en una quintaesencia metafísica de profundas intuiciones y a veces no sin un cariz místico. En el fondo de ella están la idea del infinito y la del infinito de los infinitos. Confrontado con este trasfondo hipotético, el razonamiento que ha conducido a Nietzsche a la idea del eterno retorno, adquiere en Borges un matiz aún más radical: en el todo es posible, todo es igualmente verosímil, nada se excluye porque la ley operante es la de la permutación casual de un número de elementos que agota todas las posibilidades combinatorias y las posibilidades de las posibilidades... hasta el desmayo metafísico.

El espacio queda anulado o degradado en su significación: "La muerte y la brújula” tiene lugar aparentemente en algún país de Escandinavia; pero es sólo una versión onírica bonaerense, y podría ocurrir con igual derecho en Islandia, en México, etc.; y su espacio concreto es más bien sólo un sostén del laberinto urdido, existe sólo en su función. El tiempo es anulado en su unicidad, limitación e irreversibilidad; queda la secuencia narrativa que puede ser simultaneidad, anterioridad, repetición cíclica. Las leyes que encauzan "normalmente” la vida humana están como fulminadas... Y el crecimiento lógico: “imaginémonos” que el número de elementos sea infinito... (Aquí el vuelo poético se olvida de que la asunción consecuente de esto último significaría el desmoronamiento del Tlön metafísico: se afirmaría el valor del espacio y la unicidad del tiempo... El mundo sería siempre diferente, sin alcanzar nunca la Tortuga del “delirio circular”...)

Creemos que de lo dicho se desprende claramente que este universo imaginado como un infinito de posibilidades infinitas, más bien que un sistema metafísico particular, representa un andamiaje de posibles sistemas, pero que al mismo tiempo los excluye a todos: el infinito es demasiado "infinito” como para dejarse concretar en una versión particular; queda en el andamiaje de un libre juego de la imaginación... Quizas ésta sea también una de las causas del asombro general ante la metafísica borgeana que es tan radical hasta que se niega a si misma... Y de ahí paradojas sobre varios niveles.

Es sintomático que las ideas aparentemente mas sugerentes queden en ideas. Por ejemplo, la idea del "libro infinito" como un desdoblamiento del universo infinito queda en tema, en sugerencia acariciada en algunas variaciones, en las aperturas que hemos señalado; debido al radicalismo de su propio planteo, la realización sería siempre inferior a la idea.

De este problema inherente deriva quizá la característica estructural de Ficciones (El jardín...junto con “Artificios”, otra apertura...) y de El aleph-que representan la narrativa borgeana por antonomasia-, la tendencia a la exposición de ideas, típica de géneros didácticos, y de ahí también cierta dificultad con desarrollar estas ideas en historias, en relatos, dificultad en pasar de la reflexión sobre la posible realización de estas ideas a su recreación mimética (es quizá interesante anotar que Borges, hasta 1956, llama a estos resultados hibridos “piezas”). Y de ahí la apertura de principio de 
las obras borgeanas, y las aperturas concretas más variadas. De ahí también la frontera borrosa entre la idea y la realización, la complementación de las obras por prólogos, postdatas o por otras obras o volúmenes de las mismas. La apertura hacia la "an-tesala" de la creación, hacia la reflexión sobre la creación misma, corriente en la moderna narrativa, esta inversa en Borges y sus razones de ser son completamente distintas. Quizá es aquí donde hay que situar la afirmación de “La muralla y los libros” (Otras inquisiciones): “...esta inminencia de una revelación, que no se produce, es, quizá el hecho estético.”

\section{LA ESTETICA DEL ASOMBRO}

Sin embargo, al núcleo metafísico descrito se le imponen aún otras limitaciones: está refractado por las exigencias del arte. No se trata só1o de la composición, de la creación de un todo artístico en el sentido planteado en "El arte y la magia”. Se trata del propio valor de la "carpintería metafísica” y de su capacidad de sostener una obra de arte. Al caracterizar a los metafísicos de T1ön, Borges, creemos, nos revela su propia actitud: "Los metafísicos de Tlön no buscan la verdad ni siquiera la verosimilitud: buscan el asombro. Juzgan que la metafísica es una rama de la literatura fantástica.” Y si no es suficiente, he aquí este testimonio del epilogo a Otras inquisiciones: "Dos tendencias he descubierto ... en los misceláneos trabajos de este volúmen. Una, a estimar las ideas religiosas o filosóficas por su valor estético y aun por lo que encierran de singular y de maravilloso.” Sería ilusorio buscar en el ajedrecismo metafísico borgeano un sistema que aspire a la Seriedad, a la Verdad o, al menos, a la coherencia interna. El principio vigente es la estética del asombro; la elección del "material metafísico” sigue el propósito de asombrar al lector. Y este propósito anhelado rige no sólo la elección de entre las infinitas posibilidades imaginables, sino también el rigor de las consecuencias sacadas de las postuladas “reglas del juego”... "La metafísica es una rama de la literatura fantástica” es una frase memorable: revela a un espíritu romántico inverso y a un “teólogo sin fe”. En Borges se trata de una metafísica more aphoristic.

En la obra borgeana no se trata de la metafísica extraviada en el arte, como en Platón, sino “sólo” del arte extraviado en la metafísica. Cuanto más se aproxima aquel a ésta, tanto más se hunde en sus propias leyes artísticas constructivas. El piano metafísico es, cuanto más, sólo uno entre los muchos pianos de las obras. Y no es el piano, el objetivo de ellas, sino que estas oscilan libremente entre todos los niveles del significado, revelando y confirmando así su esencia de arte. El andamiaje metafísico borgeano ofrece sólo una parte del material para la obra de arte por armar...

Así se afirma, y se niega a la vez, la aguda observación de Nabokov de que en Borges uno se siente como en un pórtico, pero que no hay casa... Esto sería verdad si la casa fuera metafísica. Pero la “casa” de Borges es el arte. ¿Y que es el arte todo sino 
“pórtico”? ¿Qué es sino “mala hierba”, “copia malograda” ... que están precisamente por esa "imperfección" abiertas al arte? Abiertas a su propio "laberinto de concatenaciones", de que ya habló nadie menos que un Tolstoi...

La cantera de la metafísica del asombro que Borges se ha abierto para su obra, encierra aun otros escollos: primero, que un relato como “Tlön, Uqbar, Orbis Tertius” agote en principio toda la cantera. Segundo, hay que considerar el impacto de la “carpintería metafísica” sobre el carácter de las obras.

La típica trama borgeana es relacional, con bruscas permutaciones y con el fácil paso de un extremo a otro. La función, el esquematismo funcional (“función” según la terminología de V. Propp, Morfología del cuento de hadas, 1928), estan descubiertos hasta los "huesos". Hay sólo un mínimo de "carne” histórica, social e individual. Es la trama típica de la literatura trivial y de aventuras o del relato policial. En ella, curiosamente, tiene lugar la “conjunción” de cosas aparentemente tan dispares como la infinita permutación metafísica y la infinita combinatoria de esta subliteratura. Lo que salva a Borges es el asombro, la condensación y la complicación de estratos de la escritura y el fuerte halo metafísico, pero sólo cuando esto está reconocido como arte, cuando no es mero lastre pseudoerudito y cuando trae una información nueva, no agotada ya en potencia por sus obras anteriores.

En esta perspectiva, si no nos atrevemos a afirmar que Borges escribiese El aleph deliberadamente como una autoparodía, en demasiadas páginas del volumén es así. En su mayoría son variaciones de los temas de Ficciones, mero llenar espacios vacíos o hasta presagiados del esbozado tablero ajedrecístico. Quedan aforismos, brillantes párrafos, unos cuantos logros particulares como "La casa de Asterión”, "La secta del Fénix”, “Emma Zunz”, en que se atenúa el complejo andamiaje metafísico anterior y domina el tono de ambigüedad irónica en que se proyecta la realidad o el mito. Y quizas "El aleph".

Es significativo que en las mejores piezas narrativas de El hacedor (1960) prevalece un tono más íntimo, más personal: quien escribe es un hombre al borde de la muerte, ansioso de descorrer el velo, discretamente, ya no de la "muerte como acto imaginativo” de Tlön, sino de la muerte más real y más personal. Todos los diálogos, sean los de "vivos" o "de muertos", un elemento nuevo y característico de esta etapa creadora de Borges, no son sino soliloquios encubiertos del "hacedor”, reflexiones sobre su puesto en la tradición literaria argentina, sobre su obra y sobre su creación. No hay ningún complejo andamiaje metafísico con su laboriosa construcción a partir de la "realidad"; lo que hay es concentración en algún episodio central y rudimentario, un tímido roce con el misterio, con el implacable futuro.

En El informe de Brodie (1970), la gran máquina de la imaginación borgeana reaparece en pleno brillo; lo único que ha desaparecido es la gastada "carpintería" metafísica. 


\section{LAS CONCLUSIONES Y LAS APERTURAS}

Termina nuestra lectura desacralizadora, y para muchos quizá iconoclasta, pero tanto más humana. Hemos buscado la esencia del arte borgeano y creemos haberla encontrado precisamente en el arte: tras la imaginación metafísica se hallan los impulsos estético y aforístico, y la distancia irónica que ello sobreentiende. La metafísica borgeana, ¿no será la mística negativa, irónica, de la época sin Dios? Es decir, metafísica escrita por el más sútil de los parodistas. ${ }^{9}$ Basta volver a leer “Tlön, Uqbar, Orbis Tertius”, que abre la senda metafísica, para darnos cuenta de ello perfectamente.

Borges construye sus mundos “alternativos” a partir del juego de la imaginación, a partir de la realidad de la palabra (aparentemente la única realidad que reconoce); pero deja en ellos un tenue intersticio de "frivolidad" que nos hace saber que estos mundos que hemos soñado con él, "resistentes, misteriosos, visibles”, son de carácter alucinatorio y paródico. Los dos últimos términos marcan la doble génesis y la doble ontología de esas construcciones verbales estético-aforísticas. Dentro de este laberinto, la narrativa borgeana describe una curva que empieza muy próxima a la "realidad" (“Hombre de la esquina rosada”, 1935), luego se aparta explícitamente de ella, pero ya varias “piezas” de El aleph indican una vuelta hacia ella, que culmina en El informe de Brodie, pero quizá sin alcanzarla nunca...

Cuando Borges habla de la "montonía esencial” de su obra, tiene tal vez más razón en lo que se refiere a su obra basada en la vena metafísica, sea ensayo, narrativa o poesía. Así como "la historia universal es -según el mismo- la historia de unas cuantas metáforas”, su obra narrativa más característica es quizá el desarrollo de unos cuantos aforismos. En el arte no decide la cantidad sino la calidad. Y el arte narrativo borgeano tiene un núcleo genuino e intenso, que justifica su profunda irradiación sobre la actual narrativa hispanoamericana y hasta fuera de ese perimetro.

Esta irradiación empezó con la apertura del lenguaje: con la reflexión sobre la lengua en que se ha de escribir (El idioma de los argentinos, 1928) y con la realización; pasó por la apertura de la tradición nacional (“El escritor argentino y la tradición”, en Discusión): “Todo lo que hagamos con felicidad los escritores argentinos pertenecerá a la tradición argentina”; y culminó en el juego de la imaginación que tiene su correlato en la apertura de la "realidad” hacia la Realidad, y con respecto a esta última, no pensamos tanto en los laberintos metafísicos a que se abre la "realidad” y que se convierten, a su vez, en la camisa de fuerza... Pensamos más bien en la sútil corrosión universal de la "realidad". Corrosión metafísica y paródica, en que se hunde, necesaria y paradójicamente, su propio intenso de realismo...

Esta corrosión sútil y universal pone ante nosotros los Tlön más variados... pero con el efecto de agudizar nuestra mirada ante ellos y ante todas sus variantes escondidas en la realidad y disfrazadas de ella. Esto nos permite ver a la “realidad” más 
críticamente. En consecuencia, se nos impone una mayor libertad... pero también una mayor responsabilidad. Con este efecto “higiénico"-epistemológico, ético y practicoel juego metafísico de Borges adquiere todavía otra dimensión de profundidad. Hemos dicho que Borges es una "mala hierba” en las letras hispanoamericanas. Como muchas otras, esta también se revela como un Jano bifronte: de un lado está el aspecto corrosivo de su obra, que puede ser el germen de la posible "salud” de la realidad; pero de otro lado, si por la "libertad metafísica” nos olvidamos de que el hombre necesita ser libertado realmente; si nos dejamos silenciar por la "ética de la parálisis” de "los inmortales”; si quedamos en una mera embriaguez ante el juego metafísico como tal, caemos en la ceguera total: sería la victoria final de Tlön.

Borges mismo, quizás por algún instinto atávico, reafirma el tiempo despues de haberlo negado ingeniosamente, y en el "secreto argumento" de "El inmortal” sugiere que, después del roce corrosivo con el misterio, volvamos a hundirnos en nuestra falible condición humana, asumiéndola ahora más críticamente, “con incredulidad, silenciosa y felizmente” o "con alivio, con humilación, con terror”, como se quiera, y que dejemos el resto del juego a "los inmortales”, que participan de universos distintos... Quizá esta sería la más fecunda lectura y lección de Borges.

Romanisches Seminar der Universität Köln

EMIL VOLEK Arizona State University, Tempe

\section{NOTAS}

1 El ensayo "La perpetua carrera de Aquiles y la tortuga” apareció originalmente en Proa (enero 1929), y fue recogido en Discusión (1932). Bajo el título "Los avatares de la tortuga" se publicó en Sur (No. 63, diciembre 1939) y fue recogido en Otras inquisiciones (1952). En las ediciones posteriores de los dos volúmenes viene un juego "programado" de confusiones.

2 Al lado de los ejemplos lúdicos, hay también algunos más bien macabros. Así, un cubano, quiza creyendo hrönirmente que las Américas son su casa -quien con una carta "nonchalante" "de orientación”, ha impedido la publicación en Checoslovaquia de las recientes obras: a) de "reaccionarios con obra de infima calidad literaria", como Otero Silva y $b$ ) de "reaccionarios pero con buena obra literaria”, como Fuentes, Vargas Llosa, Garcia Márquez, Cortazar (“un caso mas complejo”) o hasta un Vinas (“un caso problemático")-, encomia en la tal carta por lo menos las cualidades poéticas de la prosa borgeana y sugiere, magnánimamente, que se espere para la eventual publicación hasta algún momento oportuno después de la muerte del autor, sobre todo porque ésta, ¡hélas!, puede tardar, porque, como se sabe, la familia de Borges está “plagada” de longevidad. Anotemos, sálo como ironía, que ya la obra de Borges estaba traducido al checo.

3 Para la exposición más detallada de las teorías borgeanas ver el artículo de E. Rodríguez Monegal, "Borges: una teoría de la literatura fantástica”, Revista Iberoamericana 95 (abril-junio 1976), pp. 177 189.

${ }_{4}$ Con ello no rechazamos a priori al realismo socialista como método artístico. Todo lo contrario, algo como "realismo de la sociedad socialista" sería completamente legítimo. Pero eso es precisamente lo que más temen los Partidos del Poder en "Tlön, Uqbar y Orbis Tertius".

5 Lo de rey David, a diferencia de los demás, queda en una alusión ambigua: “...Kilpatrick, presidiendo el último conclave, había firmado la sentencia de muerte de un traidor, cuyo nombre ha sido borrado”, resultando que ese traidor era él mismo. En "Deutsches Requiem", el suceso descrito, repetido casi 
textualmente, se adjudica al rey David; pero la indeterminación en nuestro caso puede tener un sentido deliberado: sustituyamos a "traidor" por "causa de la desgracia” ... y tenemos a Edipo, otro destino irónico.

6 “Tlön...” fue publicado por primera vez en Sur (No. 68, mayo 1940) tapas verde jade. A. M. Barrenechea ve su germen en un artículo borgeano de Sur (No. 18, 1936, p. 85), donde Borges "echa en cara a las utopías su pobreza” (Ver La expresión de la irrealidad en la obra de J. L. Borges, El Colegio de México, 1957, p. 122).

7 La "postdata", sin embargo, figura ya en el texto original del año 1940. Recordemos el comienzo: "Postdata de 1947. Reproduzco el artículo anterior tal como apareció en el número 68 de Sur (1940), sin otra escisión que algunas metáforas y que una especie de resúmen burlón que ahora resulta frivolo. Han ocurrido tantas cosas desde esa fecha... Me limitaré a recordarlas.” Al pasar a Ficciones cambia solo la ficha bibliográfica: “...tal como apareció en la Antología de la literatura fantástica, 1940, sin otra...” etc. La mistificación, puesta al desnudo en el año 1940 (Sur, Antología...) 1941 (Jardín...) o 1944 (Ficciones), se hace verosímil con el tiempo transcurrido. Hay que volver a la situación originaria para recuperarla.

8 Publicado por primera vez en Sur (No. 136, febrero 1946).

9 En este ensayo nos concentramos en la narrativa "metafísica" de Borges y dejamos de lado deliberadamente la "subliteratura borgeana", la "coproducción” con Bioy Casares, etc., cuyo resorte paródico es mucho más obvio y es también generalmente reconocido. 


\section{A Antiphýsis em Jorge Luis Borges}

“...'l’art de l'interprétation' n'est pas seulement la découverte du sens mais aussi l'assemblage d'elements inconscients chez le patient avec ceux, non moins inconscients, de 1'analyste” (Major, R.: 1973, 56)

\section{CENTRALIDADE DA MIMESIS}

Quando Aristóteles declara a superioridade da poesia perante a história (Poética IX, 3) implicitamente realça o papel da mímesis. Sua afirmação seria arbitrária se não pressupusesse o escalonamento de dois modos de refletir sobre a praxis humana: o da descrição dos eventos que sulcaram a face social do tempo e o do mythos poético. De fato, entretanto, que se entende por mímesis? Categoria central na reflexão do ocidente sobre a arte, a pergunta parece gasta, ociosa, senão acadêmica. Mas não o é, como basicamente nos demonstra o livro de H. Koller, Mimesis in der Antike e os comentários e retificações a que tem dado lugar (G. Else: 1958 e G. Sörbom: 1966). Séculos de tradição deformante, levam-nos comumente a identificá-la com uma problemática especular, tendência sobre a qual modernamente pesa a importância assumida, no século XIX, pela categoria do "reflexo". Contudo o exame dos textos em que surge a palavra e/ou seus associados, em emprego mesmo não conceitual, nos mostra que desfocamos seu nucleo semântico quando a tomamos como imitação, reflexo, espelho (Para o levantamento e comentario dos fragmentos a considerar, cf. G. Else: 1958, 73-90 e 245).

Contentar-nos-emos aqui em analisar dois destes usos: o de Esquilo, em Choêphoroe e o de Heródoto, n’As Histórias.

Na cena de Esquilo que nos importa, discutem Orestes e Electra. Depois da morte de Agamemnon, Clitemnestra se apressara em dar a seu povo um novo rei. Egisto, como mau padrasto, exilara Orestes e convertera Electra em serva do palácio. Junto 
ao túmulo do pai, encontram-se os irmãos e Orestes declara como realizará sua vingança:

Vestido então como estrangeiro, Com equipamento de viagem, chegarei à porta Junto com Pí ades, meu verdadeiro aliado, Fingindo a fala do Parnaso, imitando (mimoymémo)

A lingua e o sotaque dos fócios (...) (Choêphoroe, 321).

Orestes aproximar-se-á do palacio como estrangeiro, enganará o sentinela e cumprirá seu plano. Todo seu êxito, portanto, depende da eficácia do mimeisthai que planeja e realiza. Poderemos traduzi-lo efetivamente como imitação da linguagem dos fócios? Fazê-lo sem mais cuidados significará esvaziar-se a complexidade da voz grega. Esta nos parece implicar a copresença de dois semas, i.e., de dois elementos mínimos de cuja junção resulta a significação: o sema da semelhança e o da diferença quanto ao "referente”, simultaneamente atualizados pelo agente realizador da mímesis. O êxito desta depende de a diferença permanecer oculta, insuspeitada, apenas aflorando o lado da semelhança. Existe assim uma astucia da mímesis, conforme a feliz expressão de J. Guilherme Merquior (1971). Damos-lhe contudo outra interpretação. Tal astúcia consiste em subtrair do receptor parcela que, entretanto, compõe o fenômeno. Quando, por conseguinte, os humanistas do século XVI traduzem mímesis por imitatio indicam a perda de contato com o horizonte originário da palavra, deformação cuja gravidade só parece ser bem pesada em um século como o nosso, cuja arte questiona o próprio fundamento da arte ocidental: a confiança na phýsis, sem a qual não é pensável a importância da mímesis, pois esta não se cumpre sem um relacionamento (de semelhança e diferença) quanto àquela.

Vejamos contudo melhor o que se passa na cena de Esquilo. O sentinela que se deixa enganar pela astúcia da mímesis, permite que seja contrabandeada intra muros a diferença promotora da ação mimética. O sentinela vê, entra em contato com o sema aparente, supõe que o mimetés (Orestes) é um inofensivo mensageiro, ao passo que a mercadoria contrabandeada subverterá a ordem do palácio. E possivel dai generalizar: o mímema, i.e., a obra em que a mímesis se realiza, é lido pelo receptor da mesma maneira como fôra, pelo sentinela, o disfarce de Orestes: a diferença que contem não é tematizada. Deste modo, a obra de arte é convertida por nosso olhar em algo semelhante ao esperável por nós, i.e., em algo que é lido de acordo com a nossa codificação cultural. A alegada polissemia da obra de arte, a variedade de suas recepções, parece-nos assim resultante da astúcia da mímesis, ou seja, de um certo modo de nos colocarmos diante dela. A polissemia será uma propriedade inelutável da natureza da arte caso só possamos nos comportar diante dela da mesmíssima forma como o sentinela que escutara Orestes. Ora, se considerarmos a construção mimética 
supor dois níveis interrelacionados, nem por isso menos diferenciáveis, os da semelhança e da diferença, recebidos a partir do primeiro - pois é este o que realça na cena sintagmática -, poderemos, dentro de um ponto de vista teórico, acrescentar que a polissemia, tal como hoje comumente aceita pelos analistas da literatura, é diretamente dependente da ótica formada pela leitura que privilegia a semelhança. Ora, esta leitura, enquanto normal, não importando se ingênua ou filologicamente armada, e sintagmática. Nela, a sensação obscura da diferença é importante para que a receptor não considere o mímema a duplicação de algo que seria representado. Esta contudo é uma importancia forçosamente secundária, pois o decisivo, para a adesão do leitor, é que, de algum modo, ele se identifique, se projete, se reconheça no mímema. Ou seja, que na obra encontre a semelhança com suas expectativas. (Neste sentido, o estranhamento, a ostranenie dos formalistas russos significa o reconhecimento do papel da diferença, dentro, contudo, de uma leitura que permanece a privilegiar o sintagmático).

Mas, embora não pretendamos oferecer neste ensaio um estudo sistemático do significado da mímesis, não nos seria possível teorizar apenas com o apoio da passagem de Esquilo, porquanto a análise dos fragmentos relativos ao grupo do mimeisthai nos mostra a clara diferenciação de dois empregos da mímesis (sobre tais fragmentos, cf. Sörbom: 1966, cap. III). No primeiro caso, de que se tomou a passagem comentada do Choêphoroe como protótipo, o sema da diferença é ocultado do receptor, pois, se a sua presença for revelada, o mímema não surtirá o efeito desejado. Mas este não é o emprego mais comum da mímesis. Avulta a seu lado um tipo de uso de que tomamos como protótipo a passagem seguinte de Heródoto: “A mumificação é uma operação distinta. Quando um corpo e trazido para os embalsamadores, apresentam modelos em madeira, pintados de maneira a se assemelhar à natureza (memimeména), e de diferentes qualidades; diz-se que a espécie melhor e mais cara representa um ser cujo nome temo mencionar neste contexto; a seguinte é algo inferior e mais barata, enquanto a terceira é a mais barata de todas. Depois de apontarem estas diferenças de qualidade, perguntam quais das três é preferida e os parentes do morto, depois de concordarem quanto ao preço, se retiram e deixam os embalsamadores entregues a seu trabalho" (As Histórias: 2.86).

Obviamente, os embalsamadores não se comportam perante seus eventuais clientes como Orestes, perante o guarda de palácio. Enquanto este se esforçava em esconder sua condição de diferença dos fócios a que fingia pertencer, os embalsamadores procuram, ao contrário, acentuar a semelhança entre as maquetes de madeira que mostram e o estado em que virá a fixar o cadáver a eles entregue. A tal ponto esta semelhança e flagrantemente intencionada, que poderíamos mesmo nos perguntar se, no caso, o mimeisthai contém o sema diferença. Na verdade, contudo, a diferença entre o mímema apresentado (a maquete) e o "referente” (o corpo do morto)-continua presente, apenas mudando o seu modo de alocação. A diferença aí consiste na redução 
das proporções: a maquete é um “modelo reduzido” do que será, de fato, o embalsamado. Essa diferença contudo não provocaria objeções por parte dos clientes, que a tomavam como implícita. E implícita, irrelevante, ela se mostraria a qualquer outro cliente, desde que conhecedor ou participante do mesmo horizonte cultural dos egípcios. Ou seja, a diferença será considerada implícita por todo receptor pertencente ao mesmo campo cultural onde ela estiver prevista. Pertencer ao mesmo campo cultural significa pois partilhar das mesmas convenções sociais, tendo estas o papel de apagar a diferença contida no mímema, o qual assim passa a ser visto como naturalmente semelhante a seu referente. Não é por acaso que a conversão da mímesis em imitatio se firmou durante o Renascimento, em cuja produção pictórica a diferença do representado aparece de forma implícita (apaga-se a diferença entre o caráter tridimensional dos corpos representados e a superfície lisa do quadro).

Em suma, em ambos os casos vemos o produto mimético supor semelhança e diferença; em ambos, a diferença ter um tratamento subalterno, ser afastada do foco primeiro da leitura, para que, mediante o realce da semelhança, o receptor possa receber e aceitar o mímema. A distinção entre os dois contextos consiste apenas em que, no primeiro, o agente da representação (o ator ou o autor) procura conscientemente afastar o sema da diferença - o efeito da verossimilhança é então dependente da capacidade do mimetés de esconder a diferença -, ao passo que, no segundo, não e preciso este esforço consciente, pois o agente da representação conta, a priori, com a "conivência” do receptor, i.e., com o fato de a sua percepção já ser guiada por uma convenção cultural interiorizada, a qual o faz não notar a diferença. Em ambos os casos, a diferença é posta nos bastidores da leitura, torna-se o que não se pode tematizar mediante a leitura do visível, i.e., da construção sintagmática.

Já ha alguns anos (cf. L.C.L.: 1973) tem-nos parecido ser hoje possível constituirse uma leitura inversa, que procuraria ler o produto mimético pelo avesso, assim privilegiando o sema “naturalmente” posto na posição subordinada, a diferença. Não recordamos esta proposta senão para que se acentue claramente o desafio que encontramos na obra do escritor argentino. Com efeito, nossa hipótese teórica supõe a existência fundamental da mímesis - fundamentalidade que não é afetada mesmo quando seu prestígio decresce, desde o romantismo, entre as poéticas (cf. J. Boyd: 1968) -, a qual, como se deduz do exame precedente, permite considerar-se o texto literário como uma pega divisivel em cena e bastidores. Ora, embora nossa proposta teórica pretenda alguma originalidade, não é fato que esta hipótese de base se manifesta nas mais opostas correntes críticas contemporâneas? Desde o junguianismo até o marxismo, passando-se pela crítica psicanalítica e pelo estruturalismo, em todos os casos supõe-se que, na literatura, a superfície dada está sempre aquém da informação necessária. Como se explicaria esta identidade de partida de correntes tão opostas sem se admitir a centralidade da mímesis para o pensamento ocidental? Sem esta centralidade, não haveria sentido para a necessidade da hermenêutica. Sem ela, 
seria pensável a revolução freudiana? Desta maneira, admitir-se e reconhecer-se uma obra literária concebida como antiphýsis, como admitimos suceder em relação a obra de Jorge Luis Borges, parece nada menos que absurdo. Contudo, se não quisermos repetir a conduta do personagem que, no Galileu Galilei de Brecht, se recusava a olhar pela luneta, pois, aprioristicamente, sabia não poder admitir o que veria, teremos de nos esforçar na compreensão da antiphýsis borgiana. A seguir, caso ela se confirme, deveremos nos indagar se a sua existência não poe em xeque e não mostra a debilidade de uma hipótese análitica que, malgrado se oponha as interpretações miméticas, se confessa vinculada à realidade da mímesis. Isso forçosamente se dará a não ser que descubramos a antiphýsis supor, como a phýsis sobre a qual a mímesis se apóia, também uma cena oculta, um ponto cego não iluminado pela previsibilidade autoral. Ou seja, o próprio de uma ficção baseada na antiphýsis supõe ou que o texto se realiza na superfície de sua escritura, tornando arbitraria a interpretação, ou que a interpretação cabível consistiria na rearticulação de níveis autoralmente previstos, autoralmente aí colocados. Ao contrário, convertê-la na estrutura própria da mímesis, ha de supor que o realce da superfície é ilusório, insuficiente, embora isso não signifique dizer que a presença da antiphýsis não seja uma das marcas de singularização de tais obras no interior do conjunto das obras literarias.

\section{DETECCAO DA ANTIPHYSIS}

No primeiro livro de contos de Jorge Luis Borges, Historia universal de la infamia (1935), a heroicidade parece assumir um destino contraditório. Exaltada em "El hombre de la esquina rosada”, na maioria dos relatos, entre os quais destacamos “El espantoso redentor Lazarus Morell”, “El impostor inverosímil Tom Castro”, “El tintorero enmascarado Hákim de Merv”, ela é banalizada e pervertida. A heroicidade se dilui em farsa. A contradição no entanto é aparente. O “Hombre” faz parte do ciclo menor da mitologia gauchesca. Sua heroicidade é de papelão, supondo o jogo do teatro, onde, em Borges, ressalta o papel da narrativa hierática. Excluida a estória do inesperado assassino do tranca-ruas Francisco Real, lidamos com personagems cuja atuação, ainda quando de majestosa heroicidade e magnífica crueldade, esvazia o heróico e banaliza o cruel. O exemplo central é fornecido pela burla fracassada de Tom Castro.

Por que, entretanto, julgamos pertinentes estes dados para introduzir-se a questão da antiphýsis? Porque, na narrativa mimética, a concentração em condutas extraordinárias - o heroísmo, a perversidade, o comportamento singular - serve de guia para a experiência do leitor ${ }^{1}$, i.e., serve-lhe de meio de reconhecimento e identificação. Ou seja ainda, a obra literaria e um dos meios empregados para um relacionamento mimético e mimetizante. Borges, ao contrário, esmaga estes recursos. A astúcia de Húkim, que o levava a dirigir seus homens para o combate enquanto 
mantinha velado o rosto, justificando seu mistério por sua condição de profeta, despedaça-se sem remissão. Nada de divino havia em seu rosto, que se ocultava porque leproso. Falsa divindade, outro privilégio não lhe cabe senão o de ser atravessado pelas lanças de seus guerreiros.

A astúcia de Bogle tampouco alcança melhor destino. Enquanto esteve vivo, pôde manipular seu senhor, Tom Castro, de maneira que ele se pretendesse descendente de nobre e rica senhora inglesa. Uma carruagem qualquer acaba com a sutileza de Bogle e seu balofo senhor sente-se perdido, condenado e convertido em bufão.

Os exemplos poderiam ser multiplicados. Eastman, belicoso chefe de gang novaiorquina, destacado combatente na $1^{\text {a }}$ Grande Guerra, morre numa refrega banal, tendo por testemunho um anônimo gato. Morell, racists sulista, forjador de um plano para ganhar dinheiro com a falsa libertação dos escravos, é descoberto, foge, planeja terrível vingança, mas contra toda “justiça poética” morre fora do círculo heróico, de uma corriqueira congestão pulmonar.

Este crônico avesso do destino heréico não seria, sem dúvida, original na literatura. No Red Badge of Courage, Stephen Crane já fustigara a épica guerreira, que os filmes de far-west popularizariam. E, contemporâneo a Borges, Brecht fizera do ataque a expectativa de conduta dos personagens um meio para a técnica do distanciamento, cujo efeito, entretanto, era radical e obviamente oposto ao da literatura de Borges. De fato, enquanto Brecht questionava o efeito “culinário” da mímesis, para daí extrair um teatro político, Borges, já em seu início, ironizava as simetrias poéticas, com o fito de questionar a própria natureza da experiência ficcional. (Neste rumo, sua proximidade maior seria com Beckett). Questioná-la porquanto fundada no princípio da mímesis. Ora, para termos nítida a apreensão deste seu gesto inicial, observemos que a ficção supõe a mímesis por dois aspectos: enquanto criação e enquanto recepção. Enquanto criação, porque desvela uma correspondência, uma semelhança com a situação ou objeto representado, sem entretanto tematizar a diferença que assim emprega. Já em Platão encontramos expresso o papel da diferença, quando, falando dos nomes, observa: "Por certo, Crátilo, o efeito produzido pelos nomes sobre as coisas de que são os nomes seria ridiculo se, por cada aspecto, fossem inteiramente como elas. Pois tudo seria duplicado (...)” (Crátilo, 432, D). (A diferença é pressuposta, mas não indagada e, quando Platão o faz, é para submetê-la às substâncias hipostasiadas, ao reino das Idéias). A ficção ainda supõe a mímesis pelo lado da recepção porque a obra deve ser composta de tal maneira que permita ao receptor reconhecer a verossimilhança do enredo e, dai, identificar-se com ele. Por conseqüência, a banalização do excepcional pelo escritor argentino nos introduz na elaboração de uma experiência que, ao atingir a maturidade, se definirá como experiência contrária à mímesis, i.e., como experiência da antiphýsis. A Historia universal de la infamia permite-nos contudo verificar que 
a obra é a peça inicial do processo contra a mímesis e não a peça de um iniciante. Para demonstrá-lo, consideremos mais de perto o relato de Tom Castro.

Bogle procura fazer com que seu amo, apesar de todas as aparências em contrário, passe pelo afrancesado Roger Ch. Tichborne. A trama pareceria impossível, pois Tom Castro era o oposto do jovem militar, esbelto e sofisticado. Nada disso contudo impede que a burla avance e tenha êxito sobre Lady Tichborne. A chorosa senhora passa por cima dos erros de ortografia da carta do pretenso filho, dos erros de sua fisionomia e o recebe entre lágrimas e efusiva felicidade. Bogle, o arquiteto da trama, encontrara seu melhor aliado na vontade de crer da mãe: "Los repetidos e insensatos avisos de Lady Tichborne demostraban su plena seguridad de que Roger Charles no había muerto, su voluntad de reconocerlo” (Historia universal: 1935, 35-6).

Que isso, entretanto, tem a ver com nossa problemática? E que a mímesis não se limita a ter propriedades sêmicas contraditórias e entrelaçadas. Para que o mímema se mostre correspondente ao real é preciso - já que aquele não duplica a este - que ainda absorva o desejo de crer na correspondência; que mova a willing suspension of disbelief; que contenha um desejo capaz de dobrar a diferença. Noutras palavras: a estratégia da mímesis há de supor a vontade de ser persuadido, por parte do receptor. Como isso no caso se cumpre, "la madre reconoció al hijo pródigo y le franqueó su abrazo".

Este adendo não pretende apresentar Borges como um fino e irônico teorizador. Sua reflexão teórica está sempre a serviço da ficção que constrói, seus parâmetros são os de sua ficção, possuidora de seu mesmo “sotaque”. Dentro desta perspectiva é importante que, no combate à mímesis, Borges desde logo atente para a cumplicidade desta corn o desejo de ter, manifestado pela crença da Lady Tichborne. E asssim, enquanto nosso exame anterior nos levava a pensar a mímesis como um produto apenas da razão, o episódio comentado nos mostra que a ela ainda se estende uma dimensão emocional. A travessia de Borges nos permitirá melhor precisá-la: a vontade de crer da senhora inglesa provinha de um amor que se recusava a ser desenganado pela realidade. Eros, portanto, se insinua na expectativa da mimesis. "El objeto (es) educido por la esperanza”, como dira em Ficciones (1944, 29). Com isso se específica que o questionamento efetuado por Borges é da literatura sim, mas enquanto ela é um derivado da própria experiência da realidade. Em Borges, literatura e realidade estreitam seus laços e dizer de uma é falar da outra. Antes porém de penetrarmos nesta reflexão, insistamos na presença da antiphýsis. Para isso destacamos o conto de abertura de El Aleph (1949), "El inmortal”.

Em um volume da tradução da Iliada, feita por Pope, encontra-se um manuscrito que narra as aventuras de um tribuno militar romano. Guerreiro, depois viajante, Marco Flaminio Rufo depara-se com um peregrino que lhe declara estar à procura da cidade dos imortais. Abrasado pelo deserto, o ex-tribuno termina contudo por encontrá-la. Atam-lhe as mãos os trogloditas que vivem em torno. Indiferentes porém 
ao destino do forasteiro, nem abrandam sua sede, nem apressam sua morte. Ainda menos se incomodam com sua precária libertação. Um deles o acompanha. E com dificuldade que conseguirá responder às perguntas que Rufo lhe propõe em grego. Era Homero, que há mil e cem anos deixara de praticar a sua língua. Por ele, se esclarece o enigma da cidade. Os trogloditas eram, na verdade, os imortais, que, por sugestão de Homero, haviam erigido a cidade-labirinto. Se, deste modo, a cidade era uma "suerte de parodia o reverso y también templo de los dioses irracionales que manejan el mundo (...)” $(1949,19)$, seu proponente, Homero, então se converte em criador do culto aos deuses irracionais.

A ilação da fábula borgiana é bastante clara: se Homero é por nós conhecido como o primeiro que inspirou a reflexão posterior sobre a mímesis ${ }^{2}$ é porque não conhecemos a continuação de sua viagem temporal. Os livros impressos com seu nome não trazem mais que o cantor das ações, périplos e heróis memoráveis. Só um incógnito manuscrito diz de seu reverso: o cantor de Odisseus, o pai da argúcia humana, aquele que desafiara a vontade dos deuses, dedicara-se depois a tarefa contrária, a de construtor do caos. "Fué como un dios que creara el cosmos y luego el caos” (El Aleph: 1949,19). Do caos, ou seja, da antiphýsis. Borges, por conseguinte, inverte ficcionalmente a tradição de que se nutrem as ficções. Inversão ficcional que de imediato significa o questionamento da realidade. Borges parece-nos dizer: não ha um questionamento da mímesis que não seja um questionamento da phýsis. Uma à outra se associa porque a proposta da antiphýsis supõe, não a vontade, fosse até melancólica, de perenizar a fortuita ação humana pela durabilidade dos monumentos (escritos, pintados, esculpidos), mas, ao invés, a declaração de não identidade dos seres do mundo. Pois o próprio da phýsis é servir de criterio para o principio de identidade: “Tudo o que é aqui nomeado se mostra como alguma coisa que se distingue em relação àquilo que não é, a partir da phýsis” (Aristóteles: Livro B da Física, I). Ora, se não ha identidade, os objetos então se reproduzirão sem que alguma lei material alcance explicar sua multiplicarção - os hrön de “Tlön, Uqbar, Orbis Tertius” - e os individuos deixarão de pertencer a determinadas faixas do tempo. Trânsfuga do tempo, o anti-Homero de "El inmortal” instaura simultaneamente o ataque à mímesis e ao que chamamos realidade. Ora, se a identidade dos seres e das coisas era o principio sobre o qual se tornava possivel erigir a mímesis, sobre que base havera de se edificar a contraria antiphýsis? Se Borges tivesse pretensões de metafísico, seu caminho não seria o que adotou. Homem de ficção, contudo, ser-lheá suficiente tomar o livro como a base material de sua proposta. Será assim coerentemente invertido o topos clássico que tinha a natureza por um livro aberto, em que se poderia ler a escrita do divino. No escritor argentino, a natureza nada tern de submissa e transitiva ao livro, nem muito menos o livro remete a alguma natureza. Antiphýsis significa, na verdade, ausência de correspondencias, perda de lastro. Daí a metafísica reinante em Tlön afirmar que "todo estado mental es irreductible: el mero 
hecho de nombrarlo - id est, de clasificarlo-importa un falseo" (Ficciones: 1944, 22). Ausência de correspondências, perda do lastro representado pela phýsis, a antiphýsis passa a significar multiplicagdo de falsas correspondências. Isso está de acordo com o que observamos a seguir: ao livro, enquanto base material da experiencia borgiana, corresponde uma imagem central, o espelho, imagem mesma da antiphýsis.

Temos pois constituidas as seguintes cadeias antagônicas: do princípio de identidade, que se submetem as realia, resulta a possibilidade de correspondencia entre o produto mimético, o mímema, e a sua "fonte", sem que a diferença interposta entre os dois e internalizada pelo mímema impeça a identificação de um com o outro. (Remetendo ao nome de uma cidadezinha espanhola, massacrada pela experiência aérea alemã, em uma data precisa, a “Guernica” de Picasso ressalta a semelhança que o receptor deve conhecer para apreender sua trama mimética).

Em contraposição, através de Borges se constitui uma segunda cadeia: princípio de desagregação de tudo com tudo, donde ausência de residência no tempo, donde a impossibilidade doutra identificação sendo a falaciosa dos espelhos. O espelho é, portanto, o centro da antiphýsis.

Antes porém de caminharmos por esta via, é conveniente voltarmos sobre nossos próprios passos e destacarmos, se possível com maior nitidez, o que pressupõe a antiphýsis. Venhamos assim ao ponto que nos é mais familiar, o da phýsis da ficção. Supõe-se aí que o autor viva intensamente o seu personagem - as condições, fantasias e experiências que nele se nucleam-, até conseguir convertê-lo em um ser de palavras. O problema é saber que significa este viver intenso. A tendência normal do interprete e conceber o ente ficcional como uma projeção - compensatória? - do eu do escritor. A questão era melhor colocada por Spitzer, que via o personagem como o representante do eu ideal do escritor e não como o prolongamento de suas volições atualizadas ou atualizáveis. Daí, notando que a atitude da personagem-autora Marianne, seria a do próprio Marivaux, acrescentava Spitzer: “celle (l'attitude) de 'l'auteur malgré lui' puisqu'il aimerait mieux avoir 'l'esprit de la femme', plus complet que le sien” (Spitzer, L.: 1959, 271). Esta reflexão contudo aqui não nos interessa por si mesma. Pretendemos apenas destacar que entre o escritor e seus personagens se estabelece uma especie de amoroso entendimento. E através deste que se cria o ambiente de uma paixão a frio. A criação ficcional "imita” o comércio amoroso, mesmo o da paixão, com a diferença de, sendo paixão entre um ente e um projeto de ser, permite-se uma frieza impossível entre os corpos, daí uma possibilidade de conhecimento, inexistente na relação amorosa propriamente dita. Ora, se pensarmos na relação de Borges com seus personagens, tal como ele diretamente a tematiza, notamos acentuarem-se as divergencias. E a propósito exemplar "La busca de Averroes”. "Senti que Averroes, queriendo imaginar lo que es un drama sin haber sospechado lo que es un teatro, no era más absurdo que yo, queriendo imaginar a Averroes, sin otro material que unos adarmes de Renan, de Lane y de Asín Palacios” (El Aleph: 1949, 101). Averróis 
pertence a seu relato pela vontade e, ao mesmo tempo, pelo fracasso de o escritor entender, penetrar no outro.

Se a pretensão de entendimento chamaramos de paixão a frio, como a relação borgiana seria descrita? Não seria o avesso de uma paixão, no sentido de um relacionamento apático (sem pathos). Poderia sê-lo como um contra-olho, que tivesse a propriedade de ver-com-lucidez o que, no olho propriamente dito, seria um ver-comdesejo. Estas experiências contrárias apresentam contudo um eixo comum: olho e contra-olho, paixão e contra-paixão supõem a insatisfação consigo mesmo e, por extensão, a insatisfação com o lugar onde se esta. No primeiro caso, esta insatisfação mimetiza o outro (o outro real, na relação amorosa, o outro imaginário, na relação ficcional). Ou seja, como já notamos a propósito do relato de Tom Castro, estabelece uma correspondência, a partir do desejo de dobrar a diferença entre o desejado e o real do desejado. No caso de Borges, esta insatisfação se torna incrédula, permanece enquanto incrédula, e então ironiza a atividade mimética, descrê em sua capacidade de imaginar um Averróis ficcional. Ironia semelhante à que se institui pela estória de Pierre Ménard, com a diferença de que, neste relato, Borges não ironiza a intenção mimética do criador, mas o caráter mimético da interpretação literária. Tal caminho oferece ao analista da literatura a sugestão de um questionamento radical de seu ofício, que, no entanto, et pour cause, não tem sido praticado.

O que nos importa daqui extrair: se a antiphýsis supõe o questionamento da realidade e mesmo porque vê em eros antes a cegueira, o ditame cego de se acercar de um objeto do que a possibilidade de efetivo encontro. Em Borges, por conseguinte, a ficção não é pensável como um meio lançado contra o esquecimento, como um registro do perecível, como maneira de durar além da existência. Tal iniciativa implica acreditar-se que a vida contém algo digno de ser preservado. A ficção e pensada como antiphýsis porque a vida é tomada como experiência de pesadelo. A ficção tramada neste contexto se quer anteparo sim, mas anteparo contra a vida, faz-se vida simulada, invenção da vida impossível e não da que, glosando o verso de Manuel Bandeira, poderia ter sido. Esta ficção não remete, sequer como instância mediatizada, a formas de existência, mas sim a um encaixe de ficções, livros dentro de livros, comentarios ficcionais a textos também ficcionais, onde figuras muitas vezes reais, autores e amigos, remetem a diálogos ficcionais e relatos ficcionais fingem-se relatos do real. Disso advêm duas conseqüências. A primeira é a de que a antiphýsis borgiana instila uma literatura do fantástico e esta, uma experiência do horror, mesmo que sua prosa nada tenha com o romance gótico e sua prosa de corte clássico em nada recorde a forma do grotesco. A aniquilação ficcional da realidade não provoca alívio. A seu propósito não poderíamos repetir o que dizia Nietzsche a respeito da destruição que empreendia: “Abolimos o 'mundo-verdade': que mundo nos restou? Talvez o mundo das aparências?... Não! Com o mundo-verdade abolimos o mundo das aparências” (Nietzsche: 1888, 109). Enquanto Nietzsche acreditava que destruíra as categorias 
metafísicas de interpretação da realidade, e não só uma delas - a de verdade -, o que passava a impor a constituição doutro quadro interpretativo, a destruição borgiana não atinge de imediato senão à própria literatura, a sua pretensão de trazer o mundo para suas páginas, a suposição de profundidade que seus analistas lhe emprestam. Esta “desmistificação” não remete contudo a outro quadro, conforme o exemplo de Nietzsche, não indica outro veículo senão o da mesma literatura. Como bem escreve Nicolás Rosa, a obra de Borges realiza "la muerte de la literatura y paralelamente su exaltación” (Rosa, N.: 1974, 160). A realidade não é atingida senão por via da ficção. O combate que se trava é um irônico (ficcional) combate. Mas tudo isso não equivaleria à denúncia de um radicalíssimo esteticismo? Se não fosse excessivamente paradoxal apenas diria que em Borges encontramos uma forma inédita de gratuidade: a gratuidade do pesadelo. Embora a formulação já nos permitisse o afastamento da suspeita de esteticismo, pois não concebo um baseado na experiência nada gratificante do pesadelo, ela entretanto poderá provocar equívocos maiores que os esperáveis. Completemo-la por isso por meio do desenvolvimento da segunda conseqüência oriunda da antiphýsis do autor.

Em Borges, o mundo é concebido como uma combinatória finita. Em "Los Teólogos", por exemplo, encontramos a seguinte passagem: "Otros histriones discurieron que el mundo concluiría cuando se agotara la cifra de sus posibilidades” (El Aleph: 1949, 41). A discordancia entre as seitas concernia à unidade "existência”, na qual se haveria de cumprir a marca de iniqüidades confiada aos homens. Cumprase no interior de uma só existência ou na soma de várias, a questão permanece idêntica: as infâmias não são infinitas. Em Ficciones, a idéa é reencontrada, sem que ela se restrinja ao campo da perversidade. Resenhando o fictício The Approach to AlMu’tasim, de autor não menos fictício, Borges escreve: "Imposible trazar las peripecias de los diecinueve (capítulos) restantes. Hay una vertiginosa pululación de dramatis personae - para no hablar de una biografía que parece agotar los movimientos del espíritu humano (desde la infancia hasta la especulación matemática) (...)”(Ficciones: 1944, 38).

Como sempre entretanto devemo-nos perguntar em que esta concepção do mundo como finita combinatória se liga à experiência da antiphýsis. A prova imediata de seu elo não deixa de ser grosseira: diante de um texto mimético, nossa tendência é afirmar que o mundo de que se nutriu é variado, tão repleto de contingencias e acidentes que seria impossível prevê-los. Concebida nestes parâmetros, a literatura é a nucleação de uma realidade que, de tão fugaz, parece informe. E, se esta nucleação não é portadora de um significado, sua variedade interpretativa contudo seria sensivelmente menor que as multivalentes possibilidades do mundo-referente. Já em Borges, as relações se invertem. Ao mundo se reserva um campo limitado de possibilidades e então o mundo deixa de ser pensado como phýsis, pois “a phýsis é arké e, portanto, origem para e poder sobre a mobilidade e o repouso, a respeito de 
alguma coisa que está em movimento e que tem em si mesmo esta arké” (Heidegger: 1967, 190-1). Em troca, a literatura se pretende semelhante a um infinito caleidoscópio, tal a capacidade de transgredir fronteiras. Ficção de segundo grau, sendo a realidade a de primeiro, liberta da carga de declarar verdades ou de indicar caminhos, a literatura seria o ponto de concentração e convergência da ficção.

Tal prova tem contudo a desvantagem de utilizar a oposição mímesis x antiphýsis que antes se deveria mostrar correta. Em virtude da objeção, deveremos recorrer um caminho mais longo. Trata-se então de acentuar o papel desempenhado pelo jogo.

Fiéis ao princípio de economia que prevalece neste ensaio, remetemos para a “teorização” borgiana do jogo em "La lotería en Babilonia”. O relato refere as sucessivas mudanças que sofre a loteria babilônica, de modo a satisfazer a paixão comunitária pela atividade. O jogo, de início, se dirige tão só à esperança. Depois passa-se também a sortear a calamidade. Introduzem-se a seguir elementos não pecuniários, responde-se à devoção popular pela lógica e pela simetria. Modificações ainda mais amplas estendem o sorteio a toda a população. $\mathrm{O}$ jogo aos poucos já não é um jogo. E o próprio cotidiano. Atente-se para a passagem: murmura-se que a companhia encarregada recebia delações. Ela contesta com breve argumentação: “...la lotería es una interpolación del azar en el orden del mundo y (...) aceptar errores no es contradecir el azar: es corroborarlo” (Ficciones: 1942, 72). A sentença oracular se incorpora às mudangas das leis do jogo, que, em comum, declaram que o jogo adquiriu extensão idêntica à do mundo. $\mathrm{O}$ azar foi de tal modo capilarizado que este já não provoca surpresa, mas vem dotado de uma “misteriosa monotonía”. Noutras palavras, o azar já não produz choques, já não atinge a existência, porque se confundira com ela. $\mathrm{O}$ aperfeiçoamento do jogo retirou sua principal conseqüência: o efeito de azar. Como se Borges houvesse trabalhado com a intenção de abolir os famosos dados mallarmeanos. De fato, que significa a conjunção entre jogo e azar senão que o efeito daquele entrou na esfera de existência de alguém, penetrou em sua atmosfera? O efeito-azar só se produz quando o imprevisto de um ato pessoalmente nos atinge. Não consideramos azar que un tijolo caia na cabega de um passante, que um suicida, como inúmeras vezes noticiam os jornais, atinja, ao se precipitar, um inocente traseunte, a não ser que tenhamos um vínculo emocional com a vítima. A língua portuguesa chega mesmo a nos oferecer a possibilidade de alternativa vocabular: reservamos a palavra “azar” para uma conseqüência infeliz que afeta ao falante ou a alguém a que esta ligado. Em caso contrário, empregamos a palavra "acaso”.

A eliminação borgiana do azar quanto aos efeitos do jogo tornaria a este um mero exercício lúdico (gratuito), se a capilaridade alcançada pelo jogo não fosse a do pesadelo. Como diz em "Utopía de un hombre que esta cansado": "No conviene fomentar el género humano. Hay quienes piensan que es un órgano de la divinidad para tener conciencia del universo, pero nadie sabe con certidumbre si hay tal divinidad” (El libro de arena: 1975, 129). Não é tampouco ocasional que entre os 
pertences da Companhia lotérica apareça cifradamente o nome de Kafka: "Había ciertos leones de piedra, había una letrina sagrada llamada Qaphqa (...)” (Ficciones: 1942, 71).

Perguntamos então: como foi possível desligar o jogo de seu efeito "pessoal”, o azar, sem que se pusesse entre parênteses a emocionalidade que atravessa o jogador? Com a pergunta, retornamos ao relacionamento que a antiphýsis mantém com eros, com a paixão. Relacionamento por ausência, por suspensão. Este enlace nós parece decisivo para compreendermos por que a concepção do mundo como finita combinatoria decorre da antiphýsis. Embora o leitor possa percebê-lo por si mesmo, faremos de conta que precisamos completar o raciocínio. Lembramos para isso um dado simple: considerando que sá no "Ulrica” do Libro de arena a relação amorosa assume o primeiro plano do relato, sem dividir sua importancia com nenhum outro núcleo temático, não seria excesivo falar-se em uma impiedade borgiana face ao amor. Ora, ao menos no âmbito de seu universo ficcional, isso apresenta uma razão clara. O amor, na acepção visceral do termo, parece uma oportunidade de opção. Podia-se seguir este ou aquele caminho, construir-se esta vida ou preferir-se aquela diversa, inesperada e imprevisível caso não interviesse o outro, o “eleito”, e nos tivêssemos imposto o rumo em que afinal nos encontramos on consumimos. A ficção de Borges não diria o contrário, apenas leva as ultimas conseqüências a resultante deste paralelogramo. Estar possuido por eros leva a opções e optar é sempre perder. Se o mundo então parece comumente confundido com uma combinatoria infinita é por efeito das vias que não freqüentamos, impedidas pelas tantas opções que nos impõe a nossa historia passional. A propósito da estória de Tom Castro, já havíamos notado como Borges aproxima o êxito da mímesis ao desejo de ter o efeito da mímesis. O território da mímesis as assim o território de desejadas correspondências. Se, portanto, esta geografia nos surge povoada de inexauríveis acidentes é apenas porque nossos olhos se dedicaram a percorrê-la sob os limites impostos pela paixão. A paixão não escolhe senão para restringir. Com isso, o mundo ganha uma propriedade que não seria sua: passa a ser tomado como infinito. Desapaixonar os olhos, por conseguinte, seria colocá-los na posição de observadores. Sua vantagem: saber que somos finitude dentro da mesma finitude.

Em síntese, a instauração da antiphýsis como móvel ficcional supõe revelar a articulação da mímesis com eros - ponto sobre o qual voltaremos - e da antiphýsis com um jogo desacompanhado do efeito-azar.

Não se pretende com esta reflexão insinuar um Borges metafísico, a não ser que afirmássemos, como ele, que a metafísica é um ramo da literatura fantástica. Refletimos da maneira como o fizemos na tentativa de mostrar melhor a inter-relação das peças que formam a sua produção ficcional. Se, portanto, tivermos alcançado nosso alvo, teremos mostrado que o apagamento de eros é o elemento fundamental tanto na experiência da antiphýsis, quanto no questionamento da realidade. E, se já 
acentuamos que a primordialidade da antiphýsis corresponde a instituição doutro centro, o espelho, apresenta-se agora um teste para nossa dedução: que tern o espelho a ver com a subtração de eros? No campo dos imortais, a resposta é imediata. Entre eles, "no hay cosa que no esté como perdida entre infatigables espejos. Nada puede ocurrir una sola vez, nada es preciosamente precario” (El Aleph: 1949, 22), porque desconhecem a morte. "Lo elegíaco, lo grave, lo ceremonial, no rigen para los Inmortales” (idem). Mas a ausência de paixão é aí tão obrigada pela propria condição de imortalidade que a prova seria impugnada se não nos socorressem dois outros relatos. O primeiro é “Tlön, Uqbar, Orbis Tertius”. Encontramos de ínicio a ideia do livro como base material da invenção ficcional. O extraviado volume de uma enciclopedia ficticia abre a pista para a descoberta do perverso projeto de invenção de um mundo, de sua geografia, de sua geometria, de seus livros e de suas discórdias filosóficas, o mundo de Tlön. A descrição dos livros de Tlön rapidamente se associa à idéia geratriz do espelho: “También son distintos los livros. Los de ficción abarcan un solo argumento, con todas las permutaciones imaginables. Los de naturaleza filosófica invariablemente, contienen la tesis y la antítesis, el riguroso pro y el contra de una doctrina. Un libro que no encierra su contralibro es considerado incompleto" (Ficciones: 1944, 27). Mas Tlön não é apenas inventada. O tipo de ficção que supõe implica uma antirrealidade, pois séculos de idealismo influiram na ordem material, provocando "la duplicación de objetos perdidos". Ou seja, na base desta ficção perfila-se uma falsa cidade, uma fictícia cultura, entre seus produtos, os livros têm uma semelhança invertida, especular e seu pensamento apresenta não uma força de atração sobre as coisas, i.e., a capacidade de noméa-las - como generosamente supomos ter o pensamento sobre a phýsis -, mas uma verdadeira capacidade geradora, a de criar objetos.

O mesmo principio orienta nosso segundo exemplo, "Las ruinas circulares”. Nele se destaca um homem que se dedica à tarefa de sonhar outro homem, consegue pouco a pouco engendrá-lo, paternalmente é afligido pelo receio de que o filho venha a saberse um fantasma, a conhecer "su condición de mero simulacro" (Ficciones: 1944, 65). Alivia-o apenas a descoberta de ele próprio estar sendo sonhado por outro, propriedade que percebe ao descobrir que o fogo é incapaz de queimá-lo.

Como em Tlön, a antiphýsis borgiana é capaz de geração e os gerados pelo sonho não se queimam por serem ficciones. Seria arbitrário dizer-se porque concebidos à imagem do espelho? Como o sonho, o espelho é “gerador”, embora o produto do sonho seja o produto do desejo que subverte a imagem do real, ao passo que o espelho apenas reproduza esta imagem. Mas a divergência não é procedente no caso de Borges, porquanto o seu afastamento da mímesis provoca desde logo a proposta de uma literatura-espelho, conseqüente ã deformação mais grosseira da literatura de cunho mimético. Despojado da idéia de especularidade, o espelho em Borges é o repta a sexualidade. $\mathrm{O}$ criador de duplos. Antes porém de desdobrarmos a meada que se 
lança, procuremos saturar o campo interpretativo que construímos, seguindo Borges na aproximação que estabelece entre o espelho e o labirinto.

Embora tenha lido poucos analistas de Borges, nenhum deles deixa de se referir à primordialidade do labirinto. Não vamos repetir seus comentários. Lembro apenas os dos analistas que mais aprecio (P. Macherey e N. Rosa), para que assinale nossas concordâncias e divergências.

Macherey extrai o valor que concede ao escritor argentino de seu comentario ao papel que nele desempenha o labirinto. "Percorre-se o labirinto do relato pela avesso, em vista de uma saída irrisória, atrás da qual não há nada, nem centro nem conteúdo, nem a sombra de uma finalidade, pois que assim se recua em vez de avançar. O relato extrai sua necessidade deste desencaixe que o afasta de si mesmo e o liga a seu duplo: cada vez mais inelutável à medida que se percebe que responde menos às suas condições iniciais” (Macherey, P.: 1966, 279). Labirinto ao avesso, deste não derivam enigmas a solucionar, dele não se abrem portas que remetessem aos subterrâneos da ficção, onde o seu sentido estaria encerrado. "O problema seria então mal colocado. O relato tem por certo um sentido, mas este sentido não é o que se crê. Este sentido não resulta da escolha possível entre varias interpretações. A natureza deste sentido não é interpretativa; o sentido não deve ser procurado do lado da leitura, mas do lado da escritura” (Macherey, P.: 1966, 280-1). Por meio de seu ataque a literatura seguidora da mímesis, donde interpretativa, o escritor argentino desmistificaria a literatura em sua pretensao de alétheia: “O discurso oferece seus contornos ao verdadeiro sob a condição de se questionar a si mesmo, sob a condição de aparecer precisamente como um puro artifício: só progride necessariamente para um fim pela construção de sua própria inutilidade (pois que tudo fora dado de início); não improvisa seus episódios, em uma total liberdade, senão para enganar quem o escuta (pois tudo sera dado no fim)” (idem, 282).

O que em Macherey é um rápido aperçu - decisivo porém para sua posição contra o que considera a concepção "burguesa” da literatura -, desenvolve-se em Nicolás Rosa como labirintica e compacta peça, que não poderia ser bem considerada sem que se lhe reservasse um tópico exclusivo. Como isso entretanto prejudicaria a economia deste ensaio, limito-me a um breve comentário, naturalmente insuficiente.

O excelente analista argentino considera que, em Borges, o labirinto e a literatura se esclarecem mutuamente. "Si el Laberinto prefigura la Literatura es porque ambos condensan emblemáticamente la falsedad” (Rosa, N.: 1974, 140). Daí que Dédalo pudesse ser tomado como o signo sob o qual se elabora a literatura borgiana. $\mathrm{O}$ labirinto de Borges contudo se diferencia dos labirintos do mundo clássico e da medievalidade porque estes, associados ao simbolismo do mítico e do religioso, eram carregados de significação ao passo que, em Borges, seu enlace com a literatura nao se cumpre sem uma erosão semântica. O labirinto torna-se aqui imagem de si mesmo, não remete para outra presença, é imagem, ficção. Neste rumo, continua Rosa, Borges 
condensaria uma orientação da literatura, que seria observada em Flaubert, Proust, Joyce, Mallarmé: “Limpio de figuraciones, (el laberinto) se desplaza hacia el espacio literario como su sostén puro y adecuado: es la literatura misma, su propia sustancia: ni pensamiento mítico ni valor de consagración teológica, es simplemente el espacio donde la literatura puede mostrarse y desarrollar sus propias contradicciones (Rosa, N.: idem, 152-3).

Para Rosa, portanto, o esforço borgiano seria o de afastar o espaco literário do "vício" hermenêutico, que o toma por representante - expressão - de algo anterior, que nele se depositaria. "El sistema de escritura de Borges tiende a ese centro único e irrecuperable: el centro literario: una literatura que se constata a sí misma en los estadios literarios más peligrosos, volviéndose especularmente sobre su propio reflejo: el estadio narcisista” (Rosa, N.: ibidem, 155). Esquematicamente, para Rosa só pode haver a seguinte alternativa: on julgamos que a literatura oferece uma caminhada que nos dirige ao Signo maior (que declara a Verdade disso on daquilo), zelosamente por ela oculto, desvendado pelo intérprete ou verificamos que ela, em sua vertente contemporânea, ironiza a si mesma, mostra o desgasta a que submete o mundo, é testemunha de sua auto-erosão e contemporânea da incompreensão que assim passa a cerca-la. A qualidade da antiphýsis borgiana, antiphýsis que Rosa foi o primeiro a referir, estaria em nos revelar a defasagem entre a produção literária e seus analistas. “Acostumbrados como estamos a una lectura como traducción esotérica donde todo escrito literario remite a una ideología, un texto vacío como el de Borges se nos aparece como increíble” (ibidem, 172).

Embora incompleto, a finalidade deste resumo é tanto a de mostrar a desnecessidade de insistirmos sobre a função do labirinto em Borges, como para que, a seguir, transpareça nossa discordância final.

A alternativa de Rosa talvez ainda seja pobre. Estamos de acordo com a necessidade de alertar-se contra a miopia “expressionista” dos intérpretes, sempre dispostos a acrescentar as palavras do autor o achatante 'isso quer dizer que...' A crítica de Rosa ainda é particularmente pertinente em um continente quase sem crítica, como o sulamericano, onde os críticos ou fazem parte do círculo dos bem pensantes ou tendem a privilegiar os conteudismos lukácsianos. Também concordamos com a necessidade de ver-se a literatura como produção discursiva. Não cremos, porém, que sua produtividade seja declarada através da observação básica do que ela dessemantiza. Sob o receio de se confundir com os “hermeneutas”, como é o caso de Rosa, de se confundir com os estruturalistas, que é evidentemente o caso de Macherey, estes analistas deixam escapar um dado que nos parece substancial para a configuração da produção discursiva: o de que o relato cria uma semântica alheia à previsão autoral. Comecemos a vê-lo considerando duas narrativas onde o labirinto tem ingresso imediato: "La Casa de Asterión” e "El jardín de senderos que se bifurcan” (a consideração do segundo será depois detalhada). 
“La Casa de Asterión” retoma a narrativa mítica pelo avesso. No mito, o ponto de vista do narrador se desenrola a partir dos que são enviados para o monstro. $\mathrm{Na}$ ficção de Borges, o ponto de vista é o do próprio Minotauro. Ele espera com ansiedade que se cumpra a profecia que rezava a chegada de seu Salvador, aquele que lhe daria morte. Invertendo a ótica do narrador, teria Borges simplesmente instalado um corrosivo espelho? O sentido da inversão especular seria tão só o da inversão do sentido mítico? A discussão será estéril se antes não conhecermos a semântica do proprio mito. Afinal, que seria o mito do laberinto?

Frazer o associava aos ritos que visavam a legitimar um novo período de governo dos antigos reis gregos. Estes rituais, que supunham um sacrifício humano, se processariam de oito em oito anos, por ser "o período mais curto no fim do qual o sol e a lua realmente se encontram, depois de, por assim dizer, se justaporem, durante todo o intervalo” (Frazer, J. G.: 1922, 325). Aplicando com cautela tais considerações ao problema, escrevia ainda Frazer: "Sem ser indevidamente apressado, podemos supor que o tributo de sete jovens e sete donzelas que os atenienses eram levados a enviar a Minos em cada oito anos de algum modo se ligava com a renovação do poder do rei para outro ciclo de oito anos” (Frazer: idem, 326). Ou seja, a legitimação do rei se cumpria através de um procedimento que procurava provocar a fecundidade. As vítimas, “cruas” porquanto jovens, eram “cozidas”. A dedução nos é permitida por um comentário do próprio antropólogo inglês: “...sacrificadas por serem assadas vivas na imagem de bronze de um touro (...)” (Frazer: idem, idem). Tal conversão do cru em cozido era imposta para que, entre o rei e a terra, não se produzisse o curto-circuito da esterilidade. O sacrificio a Minotauro era, portanto, o preito por uma ansiosa fecundidade.

A consideração do mito por outro desvio corrobora a interpretação proposta. Não deveremos esquecer que, além de escultor e arquiteto, Dédalo se notabilizara pelo artefato que construíra para Pasífae, mulher de Minos. Como ela se apaixonara pelo touro sagrado, em homenagem ao qual Dédalo construíra o labirinto, o mesmo Dédalo fora convocado para que lhe construísse um artefato em forma de vaca. Colocandose em seu interior, Pasífae pudera aproximar-se do touro. Do coito com o animal, nascera o monstro, Minotauro, logo depois aprisionado no labirinto, por ordem de Minos, que, ao mesmo tempo, estendia sua vingança ao construtor, desterrando-o (in Hocke, G. R.: 1959, 253). Dédalo, por conseguinte, não deverá ser tomado apenas como arquiteto e construtor de imagens, aspecto privilegiado por Rosa, mas ainda como o propiciador da perversão.

Estas consideraçõoes nos permitem acentuar, por duas trilhas diversas, que a problemática do labirinto também envolve um claro aspecto sexual. Poder-se-ia contudo alegar que a via é improcedente, “extra-literaria”, pois nos afastaria de Borges. Cabe mostrar o contrário: a inversão do relato mítico não apaga o lastro sexual; apenas o relaciona a outro polo, pois o relato já não se coloca do ponto de vista 
da "vida”, i.e., da comunidade que esperava e propiciava o resultado fecundador do sacrifício, mas do ponto de vista da “morte”, interpretada como salvação do monstro fecundado, Asterión-Minotauro.

A via assim aberta nos permite destacar um pequeno aspecto de "El jardín de los senderos”. Albert, o inglês, revela a Yu-Tsun o que o seu ilustre antepassado de fato fizera. Não concebera, conforme atá então se acreditava, um livro e um labirinto, mas um indissociado livro-labirinto, que, ao mesmo tempo, era um labirinto-livro. O seu objeto tinha a propriedade de não optar por algum rumo ou por certa peripécia, que levaria ao esquecimento doutras também possíveis. Daí que, descoberto, o labirinto não desvela um enigma, porquanto se abre para a infinidade de portas, para a multiplicação incessante de enigmas. Como P. Macherey bem percebera, é notável o êxito da ironica inversao que o autor realiza: "Na casa de Albert, alem do nome de Albert que vai servir de termo cifrado, encontrou-se outra coisa: o labirinto em pessoa. O espião, cuja profissão e forçar os segredos dos outros, foi diretamente (mas sem o saber) ao lugar do segredo: enquanto que não buscava o próprio segredo, mas o meio de transmitir um segredo” (Macherey, P.: 1966, 283). Mas a inversão ainda apresenta outra deriva: se o próprio da paixão e estabelecer alternativas e se decidir-se perante elas e obturar os caminhos não escolhidos, então não escolher, permitir-se a adoção de todos os caminhos - possibilidade realizada pelo labirinto singular de Ts'ui Pên é negar-se ao exercício (limitador) da ... paixão. Borges, portanto, inverte o mito do labirinto de maneira mais conseqüente e entranhada do que poderiam admitir as interpretações mimetizantes, de maneira mais conseqüente do que talvez o próprio autor estaria disposto a admitir. A sua antiphýsis não é, portanto, um recurso apenas destinado a questionar o discurso literario; não e muito menos um recurso questionador da realidade. Como temos visto, um e outro se articulam com o questionamento de eros, com o principio da geração do diferente. E isso nos remete por fim à centralidade buscada do espelho. Através de seu retorno ao encadeamento analítico nos será possível aproximarmo-nos do significado do duplo.

O próprio do espelho e a formação de duplos naturais. Seria contudo um exemplo de lógica mecanicista afirmar-se daí que, sendo o espelho uma das obsessões borgianas, seria ele que provocaria a mesma insistência no duplo. Contra esta banalidade, deveremos dizer: o duplo apresenta incidência semelhante a do espelho porque as duas figuras têm uma raiz comum, que não se esgota em nenhuma de suas duas atualizações. Descobrir esta raiz comum será apreender pelo menos uma das dimensões do inconsciente do texto, não equivalente, acrescente-se, ao inconsciente do autor, porque, como já dissemos, o texto projeta o eu ideal do escritor e não o seu eu real.

Em passagens diferentes, Borges nos oferece a via para a explicaçãdo. Em "El tintorero enmascarado", encontramos: "Los espejos y la paternidad son abominables, porque la multiplican y afirman” (Historia universal: 1935, 90). E em “Tlön”, 
ficcionaliza-se Bioy Casares para se the fazer dizer "que los espejos y la copula son abominables, porque multiplican el número de los hombres” (Ficciones: 1944, 13). Frase que pertenceria à inventada Anglo-American Cyclopaedia, onde teria formulação ligeiramente diferente (cf. Ficciones, 14).

A cópula, daí a paternidade, colocam-se no mesmo horizonte dos espelhos: uns e outros seriam geradores. A identificação reiterada pelo autor procura conscientemente ludibriar o leitor. Na verdade, a cópula é o oposto do espelho. Aquela supõe a conjungdo de duas identidades, que geram uma terceira. O espelho, a duplicação de uma identidade por meio de uma "ficção", a imagem do refletido. Fecundidade contra a esterilidade do duplo. Antagonismo que se prolonga ao estabelecido entre mímesis e antiphýsis. Não seria entretanto precipitada a aproximação dos dois pares de opostos? Procuremos justificá-la.

No ensaio princeps sobre o narcisismo, "Zur Einfuhrung des Narzissmus" (1914), Freud afasta a afirmação do narcisismo como perversão e acata o ponto de vista de Rank, que vê no narcisismo um componente normal na maturação da libido. Mais importante do que isso, para Freud o narcisismo não seria apenas um "estádio", mas sim uma "estrutura", para empregarmos os termos de A. Green. O ensaio de 1914 nos é aqui decisivo porque mostra que o narcisismo ultrapassa a dictotomia entre libido do ego e libido objetal, sendo uma ponte entre as duas. Isso pois, segundo Freud, narcisismo não significa o mero amor por si mesmo, em detrimento da libido objetal. O narcisismo implica um quadro mais complexo. Na relação primeira do bebê com a mãe, o seio materno é um dos pólos indispensáveis para a relação prazenteira. A mãe não é vivida, experimentada como um outro, mas como o prolongamento de si mesmo, parte de uma experiência fusional. Esta vivência determina uma marca, que caracterizará o narcisismo. Em sua função "normal”, o narcisismo supõe um complemento externo, i.e., um investimento aloerótico, que, no entanto, remete para a dominância homoerótica. A satisfacção portanto se cumpre consigo mesmo, sob a condicdo embora de que haja um elemento externo, aloerótico ${ }^{3}$. (Não nos interessa aqui entrar no destino do narcisismo, na analise das condições que levam o narcisismo "normal” a se converter, em muitos casos, numa espécie de auto-reclusão, contra o investimento objetal).

Recorremos a questão do narcisismo, para que daí acrescente-mos: no comércio amoroso, "normal”, entra uma componente narcisica. E que significa isso dizer senão que, assim, penetra ainda uma componente mimética? O objeto amoroso atrai porque, embora não seja apenas narcisico, satisfaz o lado narcisico. A escolha amorosa seria assim mimética porque coloca em jogo uma correspondencia desejada que esconde uma diferença não apreendida, a identidade mesma do outro. A experiência do duplo e oposta à da cópula, aqui tomada como metonímia do jogo erótico. No duplo, é o um que se biparte, que se vê como parcelas rivais, embora estranhamente congraçadas e interdependentes. ${ }^{4} \mathrm{O}$ duplo e então a parodia da cópula. Mas não cogitamos de uma estrita aplicação psicanalítica, porque, em se tratando da análise de uma produção 
discursiva e não, basicamente, do sujeito desta produção, seríamos levados a deformar tanto o instrumental psicanalítico, quanto o nosso objeto. ${ }^{5}$ Deveremos ao invés acrescentar que, ficcionalmente, o duplo pode-se constituir de dois modos. O primeiro supõe o paralelismo entre a vivencia pessoal do duplo e sua constituição literária. A criação fala, no caso, de maneira mais direta, de uma problemática que podemos imaginar de fato pessoal. No segundo, tal paralelismo desaparece, não porque inexista um substrato pessoal, mas porque entre a vivência e a figura produzida se interpõe a ironia, forma de controle do engendramento ficcional. Do ponto de vista da analise do discurso literário, preocupada com o inconsciente do texto e não com o inconsciente de seu compositor, a diferença e de importância. Enquanto analista da literatura, me é bastante mostrar a articulação que estabelecem os termos "labirinto", "espelho", “duplo”, “exclusão irônica do pathos”, o mundo como combinatória limitada, termos componentes da antiphýsis. Através desta articulação, procuramos revelar que a peculiaridade de Borges está em compor uma ficção que, lucidamente, procura controlar e esmagar toda ponta de mímesis; em ser uma produção que pretende es esgotar nas manobras que prevê. Mas este orgulhoso projeto tem um limite. Em certo ponto da análise, vemos sua ficção dobrar-se sobre si mesma, escapar da onisciente consciencia que procurou dominá-la e, ao contrario, apresentar seu ponto cego. Este nos parece inscrito na figura do duplo. Submetido porém ao processo de irônico drible, ele não se mostra literalmente. A outra cena, os bastidores que a determinam, diretamente apenas transpira pela sensação de pesadelo que da prosa de Borges se levanta. Pesadelo contudo formulado com persistente lucidez. E do jogo entre a lucidez manifesta e o pesadelo em que o duplo se esgarça que resulta o caráter da produção borgiana: a produção do irrespirável.

\section{NOTA FINAL: OS DUPLOS NO JARDIM}

Não tentaremos a analise exaustiva de "El jardín de los senderos”, mas apenas destacar o que é fundamental para a concretização operacional do duplo, buscando uma saída para a ausência de uma estrita (e aqui improcedente) análise psicanalítica. ${ }^{6}$

Yu Tsun fôra catedrático de inglês em uma escola superior alemã, instalada na China. Yu Tsun contudo não é um apátrida. Sua chinesidade se choca com o duplo estrangeirismo que contém e não o abandonara. Um estrangeirismo de ordem temporal - sua anglicidade -, outro de ordem espacial, a Hochshule onde ensina. Este antagonismo interno apresenta-se mesmo na decisão que assume: espião, sabendo-se descoberto. Yu, contudo, não procura escapar, mas fazer chegar aos alemães o segredo que só ele sabe. Não que admire a Alemanha, "un país bárbaro, que me ha obligado a la abyección de ser un espía”, pois o que buscava era provar ao chefe, “aquel hombre enfermo y odioso”, “que un amarillo podía salvar a sus ejércitos”. O antagonismo portanto se torna patente. Contudo so estala diante de Albert. Entre os 
nomes da lista telefônica, o seu só fôra escolhido porque, sendo morto por Yu, os nomes de um e de outro apareceriam nos jornais ingleses e ao odioso chefe alemão não haveria de passar despercebido que Albert era o nome da cidadezinha onde os ingleses haviam concentrado sua potência de fogo. Porém, desde que Yu desce em Ashgrove, acumulam-se os indícios que começam a nos levar para fora da ambiência de um conto policial. As crianças o orientam como se soubessem que se dirigia à casa de Albert e a maneira como indicam o caminho - virar sempre à esquerda - lembra a Yu que este era o procedimento para chegar-se ao pátio central de um labirinto. $\mathrm{O}$ encontro com Albert não é menos estranho. O dono da casa parece que já o esperava. Borges então apresenta duas pistas contraditórias, ambas falsas. De um lado, recordando seu ilustre antepassado, Ts'ui Pên, o espião Yu recorda que seu bisavô fôra morto por um forasteiro; de outro lado, Albert, ao recebê-lo, torna verossímil a naturalidade que demonstra, declarando pensá-lo enviado pelo cônsul chinês, que "se empeña en corregir mi soledad”. Albert se desvencilha da condição de meio para a transmissão de um segredo militar. Para Yu, Albert deixa de ser um estranho, pois, como logo saberá, o inglês é aquele que se dedicou a decifrar os trabalhos de Ts'ui Pên - a novela e o labirinto -, aquele que tem em casa objetos e mais objetos, tomos manuscritos e jarros que são familiares a Yu. Teria sido Albert o assassino de seu bisavô? Não precisamos entrar pela especulação, pois fato menos conjuntural nos leva ao ponto que queremos. Albert é o sinólogo que conseguira a decifração de um documento que desafiara o entendimento dos próprios familiares de Yu, o livro que o próprio Yu até então considerava “un acervo indeciso de borradores contradictorios”. Albert é então personalido, já não é mais um anônimo que deveria ser morto. Melhor dito, por ele Yu descobre sua mais entranhada chinesidade. A medida que Albert é um sinólogo, à medida que o recebe e o adverte como amigo, à medida que privara com o misterioso feito de seu antepassado, já não é apenas um estranho, mas alguém que participa de seu círculo familiar. Contudo ele não e menos o estrangeiro, que, pelo saber, "furta" a Yu aquilo que, sendo de sua raça e de seu estrito círculo familiar, ele não fora capaz de entender. Ou seja, enquanto Albert fôra um dos porta-vozes do estrangeirismo de $\mathrm{Yu}$, ele agora se biparte, tendo um aspecto positivo e um negativo. Oro, o outro lado "estrangeiro" de Yu é presentado pela germanidade - enquanto ex-professor de uma Hochshule e atual espião a serviço do Kayser. Aparentemente, aqui não se dá a bipartição que vimos operada quanto a Albert. Seu chefe só recebe o epíteto de enfermo e odioso. Contudo, para elogiar Albert, Yu recorre a uma glória alemã: “... yo sé de un hombre de Inglaterra - un hombre modesto - que para mí no es menos que Goethe”. Doutra parte, quanto a sua chinesidade, o jogo de contrários não é menos evidente. Yu tem orgulho de sua raça, sente-se, através da conversa com Albert, parte de uma missão, procura, por seu feito, não se mostrar um inferior. Mas também se chama de "amarillo" - a Borges passaria despercebido que "yellow”, e verdade que na gíria americana, também significa covarde? - considera-se covarde e, no fim do 
relato, revela sua “innumerable contrición y cansancio”. Ou seja, de início Yu configura a figura do duplo por sua oposição interna (chinesidade x estrangeirismo). No decorrer da ação, esta oposição simples se multiplica. O primeiro elemento, chinesidade, ate então positivo, se bifurca - orgulhoso de sua raça (+), preocupado em não se mostrar inferior, mas sabendo-se covarde (-). O segundo elemento, o estrangeirismo, inicialmente negativo, duplamente se bifurca, porquanto quer o inglês, quer o alemão também se revestem de sinais positivos e negativos. Convertemos o que foi dito acima em gráficos que facilitarão o entendimento:

O Duplo em $\mathrm{Yu}$

1) Situação inicial:

\begin{tabular}{|l|c|}
\hline Chinesidade & + \\
\hline Estrangeirismo & - \\
\hline
\end{tabular}

2) Situação final

\begin{tabular}{l|c|c|c|c|}
\hline Chinesidade & + & - \\
\hline \multirow{2}{*}{ Estrangeirismo } & Anglicidade & + & - \\
\hline & Germanidade & - & + \\
\hline
\end{tabular}

Assim a morte final de Albert não é apenas uma exigencia do ofício de um zeloso espião. Matando-o, Yu confessa sua inferioridade. A princípio, ele a desconhecia (se era um anglicista, simetricamente Albert era um sinólogo). Só veio a sabê-la depois - o sinólogo descobre um misterio, não só ignorado pela comunidade chinesa, mas desprezado por seus próprios familiares. Mas o ato não o satisfaz, i.e., não restabelece a simetria por se vingar do "usurpador". Por isso em nenhum momento Yu deixa de se considerar covarde. Note-se ademais que, saindo de casa com uma bala apenas, não cogitara de matar seu perseguidor, Madden, o irlandês, tão marginal para a Inglaterra a que servia, quanto ele mesmo, do ponto de vista dos alemães. O episódio da a impressão de uma fatalidade. Qual seria ela senão a representada pelo desejo de matar o seu duplo? E qual a sua covardia senão a de saber que não resolvera o problema? Pois o duplo não tem aqui uma mera vertente pessoal. Ele é tratado como um problema antropológico, de choque de culturas.

Cabe-nos então por fim indagar: teria sido este aspecto também previsto pela consciencia autoral, extensão de uma problemática que Borges teria absorvido de autores a ele tão caros como um R. Kipling? Ora, ainda que a “origem” da questão possa ter esta procedência, a solução obviamente nada tem a ver com a solução 
“inglesa”. Acreditamos pois na alternativa contrária: este é o ponto cego que a consciencia borgiana não pôde iluminar. E por que não o poderia senão porque Yu se relaciona com a própria dilaceração borgiana, "partido" entre dois continentes?

Na literatura, o duplo não remete a uma problemática estritamente psicanalítica, seja porque não se trata da abordagem de um “paciente”, seja porque o discurso literário tem uma costura que não permite o acesso direto ao significante pessoal. $\mathrm{O}$ instrumental psicanalítico aqui se pãe a serviço de uma interpretação antropológica. E assim, vindo ao tema particular deste ensaio, terminamos por ver que a antiphýsis é comandada pelas mesmas regras a que a mímesis se submete, porque, seja psicanaliticamente, seja antropologicamente, os produtos individuais nunca coincidem com as intenções que o motivaram.

Pontifícia Universidade Católica

LUIZ COSTA LIMA do Rio de Janeiro

\section{NOTAS}

1 Este fato pode dar lugar a duas colocações: ou a que se inaugura com Platão e nunca deixou de ter seus representantes - a necessidade de controlar moralisticamente o texto de ficção - ou ao esforço de constituição de uma teoria da ficção, que já não se limite a diferença-la dos textos teóricos, de dominância conceitual, e dos pragmáticos. Em uma época como a atual, em que a ficção, por um lado, perde seu status de reconhecimento ainda ha pouco vigente pelo romance realista, por outro se banaliza pelos mass media e pela preocupação mercadológica de autores e editores, esta se torna uma tarefa fundamental para o teórico da literatura. A melhor abordagem que conheço a respeito encontra-se no ensaio de Karlheinz Stierle: "Was heisst Rezeption bei fiktionalen Texten?”, in Poetica, vol. 7, no. 3-4, Verlag B. R. Grüner, pp. 345-387, Amsterdam 1975.

2 Note-se que em Homero não aparece ainda nem mímesis, nem o grupo de palavras a ela associado: "Das Wort mímesis and seine Ableitungen sind eigenümlich spät bezeugt. Homer, Hesiod, die äolischen Dichter kennen es noch nicht”, H. Koller: Die Mimesis in der Antike, A. Francke, Verlag, Berna 1954, p. 13.

3 Esta reflexão não nos teria sido possível sem o seminário orientado peso Dr. Carlos Augusto Nicéias, no. $2^{\circ}$ semestre de 1976.

4 Para um desenvolvimento teórico da questão do duplo, cf. o nosso A perversão do trapezista (O romance em Cornelio Penna), cap. VII, §§ 2.1 e 3, Imago, Rio 1976.

5 Sobre os problemas da aplicação da psicanálise à crítica literária, cf. A. Green: "Le Double et 1'Absent”, in Critique, no. 312, maio 1973.

6 O problema do duplo na obra de Borges já fôra levantado por E. R. Monegal, in Borgès par lui-même, Seuil, Paris, 1970, especialmente pp. 108-111. Sua colocação contudo nos parece demasiado provisória. 


\section{REFERENCIAS BIBLIOGRAFICAS}

Aristóteles : : Arte poética, trad. de A. Pinto de Carvalho, DIFEL, São Paulo 1964.

Aristóteles $\quad$ : Física, o fragmento citado foi traduzido por M. Heidegger, in “Die Physis bei Aristoteles” (cf. Heidegger).

Borges, J.L. : Historia universal de la infamia. Ed. cit.: Emecé Editores, 1935 Buenos Aires 1954.

Borges, J.L. Ficciones. Ed. cit.: Emecé Editores, Buenos Aires 1956. 1944

Borges, J.L. $\quad$ : El Aleph. Ed. cit.: Emecé Editores, Buenos Aires 1957. 1949

Borges, J.L. $\quad$ : El libro de arena, Emecé Editores, Buenos Aires. 1975

Boyd, J. $\quad$ : The Function of Mimesis and its Decline, Harvard U. Press. 1968

Costa Lima, L. : Estruturalismo e teoria da literatura, Vozes, Petrópolis. 1973

Else, G.F. : “ “'Imitation’ in the Fifth Century”, in Classical Philology, vol. $1958 \quad$ LIII, no. 2, abril.

Esquilo : Choêphoroe, trad. de G. Thomson, in The Portable Greek Reader, organ. por W.H. Auden, The Viking Press, New York 1955.

Frazer, J.G. $\quad$ : The Golden Bough (abridged edition). Ed. cit.: The Macmillan 1922 Company, New York 1960.

Freud, S. : "Zur Einführung des Narzifmus”, in Gesammelte Worke, S. $1914 \quad$ Fischer Verlag, Frankfurt 1969.

Heidegger, M. : “Die Physis bei Aristoteles”. Trad. de F. Fédier, in M. Heidegger: 1967 Questions II, Gallimard, Paris 1968. 


\begin{tabular}{|c|c|}
\hline Heródoto & $\begin{array}{l}\text { : The Histories, trad. de Aubrey de Silincourt, Penguin, Londres, } \\
1921 .\end{array}$ \\
\hline $\begin{array}{l}\text { Hocke, G.R. } \\
1959\end{array}$ & $\begin{array}{l}\text { : Manierismus in der Literatur, trad. de R. Zanasi: Il Manierismo } \\
\text { della letteratura, Il Saggiatore, Milão, } 1965 .\end{array}$ \\
\hline $\begin{array}{l}\text { Koller, H. } \\
1954\end{array}$ & : Mimesis in der Antike, A. Francke, Berna. \\
\hline $\begin{array}{l}\text { Macherey, P. } \\
1966\end{array}$ & $\begin{array}{l}\text { : “Borgès et le récit fictif”, anexo } 2 \text { a Pour une Théorie de la } \\
\text { Production Littéraire, Maspéro, Paris. }\end{array}$ \\
\hline $\begin{array}{l}\text { Major, R. } \\
1973\end{array}$ & $\begin{array}{l}\text { : “Du pouvoir de l’interprétation”, in Nouvelle Revue de } \\
\text { Psychanalyse, no. 8, Gallimard, Paris. }\end{array}$ \\
\hline $\begin{array}{l}\text { Merquior, J.G. } \\
1972\end{array}$ & : A Astúcia da mimesis, J. Olympio, Rio. \\
\hline $\begin{array}{l}\text { Nietzsche, F. } \\
1888\end{array}$ & $\begin{array}{l}\text { : Götzen-Dämmerung, trad. de H. Albert: Le Crépuscule des } \\
\text { Idoles, Mercure de France, Paris } 1952 .\end{array}$ \\
\hline Platão & $\begin{array}{l}\text { : Crátilo, trad. de H.N. Fowler: Plato: Cratylus, Parmenides, } \\
\text { Greater Hippias, Lesser Hippias, Londres, } 1953 .\end{array}$ \\
\hline $\begin{array}{c}\text { Rosa, N. } \\
1974\end{array}$ & $\begin{array}{l}\text { : “Borges o la ficción laberíntica”, in Nueva novela } \\
\text { latinoamericana, vol. 2, organ. por J. Lafforgue, Paidós, Buenos } \\
\text { Aires. }\end{array}$ \\
\hline $\begin{array}{l}\text { Sörbom, G. } \\
1966\end{array}$ & : Mimesis and art, Svenska Bokförlagt, Bonniers. \\
\hline $\begin{array}{l}\text { Spitzer, L. } \\
1959\end{array}$ & : Romanische Literaturstudien, Max Niemeyer Verlag, Tübingen. \\
\hline
\end{tabular}




\title{
Para una Caracterización de la Escritura en los Relatos de Borges
}

\begin{abstract}
No hay ejercicio intelectual que no sea finalmente inútil. Una doctrina filosófica es al principio una descripción verosímil del universo; giran los años y es un mero capítulo -cuando no un párrafo o un nombre- de la historia de la filosofía. En la literatura, esa caducidad final es aun más notoria. El Quijote -me dijo Menard- fue ante todo un libro agradable; ahora es una ocasión de brindis patrióticos, de soberbia gramatical, de obscenas ediciones de lujo. La gloria es una incomprensión y quizás la peor. ${ }^{1}$
\end{abstract}

I

Escritura, la traducción española del término propuesto por Roland Barthes en Le Degré zéro de l'écriture (1953) y elaborado por Jacques Derrida en De la Grammatologie (1967) es ya un concepto generalizado tanto en la crítica de habla española como en la norteamericana. A pesar de que se ha formado en Buenos Aires -también en México, aunque en menor medida- un centro de traducción de los escritos estructuralistas ${ }^{2}$, apenas hay los comienzos de una aplicación sostenida de los conceptos del estructuralismo a las obras más importantes de la literatura latinoamericana. Se podría citar un cierto número de críticos y revistas que muestran interés por el “new criticism”, pero puede, asimismo, comprobarse la permanencia de un amplio sector crítico que utiliza la jerga estructuralista como una manera de eludir la asimilación responsable de los modelos estructuralistas. ${ }^{3}$

Este hecho -al cual debería agregarse el relativo desinterés entre la mayoría de los hispanistas norteamericanos por las mismas teorías- puede explicar, quizás, por que un escritor como Jorge Luis Borges continúa siendo estudiado desde un punto de vista temático antes que desde las posibilidades que ofrece la panoplia estructuralista. En otro lugar he escrito que los cuentos de Borges pueden ser abordados como la realización de una poética estructuralista -en tanto proyecto de producción de literatura, antes que de su estudio- implícita en las preocupaciones básicas del estructuralismo. ${ }^{4}$ Pero sólo contados críticos han mostrado algún interés por enfocar a Borges bajo el lente estructuralista. No es sorprendente que quienes lo han hecho sean los franceses, y que Rodríguez Monegal haya podido mostrar que su conocimiento parcial de la obra de Borges y su insuficiente dominio del español, han derivado en curiosas distorsiones. ${ }^{5}$ No obstante, debe agregarse al interés de estos críticos por un escritor latinoamericano el mérito de haberlo estudiado desde perspectivas novedosas para los críticos de habla inglesa y española. 
La escritura es sólo uno de los conceptos estructuralistas que pueden ser utilizados con provecho por la crítica borgeana. Que yo sepa, sólo tres ensayos lo han hecho: Jaime Giordano incluye una discusión de “La escritura del Dios” en un extenso estudio de la tipología de las escrituras generacionales en la narrativa latinoamericana; ${ }^{6}$ Walter Mignolo y Jorge Aguilar Mora hablan del motivo del libro como un principio de escritura en "Tlön, Uqbar, Orbis Tertius”, aunque su tratamiento es tentativo y parcial (la crítica de Borges, aun aquélla que se adscribe a muy precisos cánones descriptivos y analíticos, suele adolecer de mimética vaguedad, tal vez por contaminación de los textos que examina); ${ }^{7}$ y Noé Jitrik, en uno de los mejores estudios sobre Borges, estudia la intertextualidad de Ficciones. ${ }^{8}$ Aunque Jitrik no basa su estudio en el concepto de escritura, es claro que su interés por las estructuras subyacentes en Ficciones y los principios implícitos ligados a la producción de los textos literarios es, efectivamente, un intento de descubrir la escritura de la obra. ${ }^{9}$

II

Como dice Barthes, la escritura al mismo tiempo que enfatiza el estatuto lingüístico de los textos literarios, sobrepasa el enfoque restringido a la superficie textual que caracteriza al análisis retórico y estilístico de la literatura. El énfasis en la naturaleza escrita de la literatura lleva a una concepción del lenguaje literario como objeto primero del estudio crítico, y hacia un nivel abstracto en que es posible reconocer los principios estructurantes del texto literario. Estos principios resumen los objetivos y las posibilidades literarias que conducen a los textos reales y determinan, en consecuencia, sus características.

La escritura, en consecuencia, se sitúa en la misma relación con respecto a los textos reales, que la estructura profunda a la de superficie en la lingüística generativa y transformacional. En otras palabras, la escritura supone una aproximación al texto literario que busca responder a las preguntas sobre qué concepción de la naturaleza de la literatura, con sus pretensiones y limitaciones, han hecho posible este determinado texto; cuales son los principios que generan su lenguaje -retórica, estilo, forma- y lo hacen adecuado y necesario. Como concepto crítico, la escritura implica que toda literatura es el resultado de una concepción concerniente a la naturaleza de la literatura; que esa concepción está implícita en el texto literario específico, y que el intento de penetrar más allá de la superficie del texto hasta encontrar su escritura subyacente nos habilita para explicar los principios a partir de los cuales el texto literario ha sido generado. La escritura de un texto proporciona un principio metatextual que adecúa y justifica los detalles específicos de un texto literario. De la misma manera que la estructura profunda de un enunciado lingüístico, la escritura contiene la información necesaria, desde el punto de vista poético, para producir el texto literario; y, desde un punto de vista crítico, para analizarlo estructuralmente. Más aún, 
a diferencia de la crítica "interpretativa" que descarta la materialidad de las obras literarias, y la crítica formalista, que se detiene casi exclusivamente en la superficie textual de la obra, el concepto de escritura reconoce una tensión dialéctica entre los rasgos inmediatos de composición que se advierten en el proceso de lectura, y aquellos principios abstractos y subyacentes que dan cuenta de esos rasgos. Una obra literaria es al mismo tiempo superficie y modelo abstracto, no importa cuán vacilante o difícil de percibir sea esta relación dialéctica.

El ejemplo clásico de Barthes es el passé simple en la literatura francesa: ¿qué imagen de la literatura implica este use tradicional y no coloquial? En su respuesta, Barthes se refiere a la noción clásica de la literatura como un monumento, como un artefacto que se distingue del medio lingüístico y coloquial circundante por sus rasgos lingüísticos y estilísticos. ${ }^{10}$ Compárese, a este respecto, el ensayo de Spitzer sobre el "Yo empírico” y el "Yo poético” en la literatura medieval: ¿qué relación se sugiere entre literatura, hombre y sociedad, gracias al principio estructurante de un narrador en primera persona que se identifica a sí mismo por inconfundibles topoi (identificación que debe atribuirse a la necesaria competencia del lector como lector de textos) como un Todo-Hombre poético, antes que como un Yo individual y único? ${ }^{11}$ La respuesta a estas preguntas conduce a determinar un principio estructurador básico para los textos en cuestión, un principio que no sólo de cuenta de las propiedades reales de la composición del texto como un todo, sino que también proponga una forma propia y adecuada para la lectura del texto, lectura que constituye la contrapartida natural de la escritura. ${ }^{12}$

La escritura, en consecuencia, tiene que ver con mucho mar que los puros rasgos materiales del texto. Uno puede referirse a rasgos formales, estilísticos y retóricos, a motivos, topoi y temas; pero, tales detalles deben ser considerados en su interrelación, la cual es determinada por la escritura que “explica” su función en el texto:

[...] what we speak of as conventions of a genre or an écriture are essentially possibilities of meaning, ways of naturalizing the text and giving it a place in the world which our culture defines. To assimilate or interpret something is to bring it within the modes of order which culture makes available, and this is usually done by talking about it in a mode of discourse which a culture takes as natural. This process goes by various names in structuralist writing: recuperation, naturalization, motivation, vraisemblablisation. "Recuperation" stresses the notion of recovery, of putting to use. It may be defined as the desire to leave no chaff, to make everything wheat, to let nothing escape the process of assimilation; it is thus a central component of studies which assert the organic unity of the text and the contribution of all its parts to its meanings or effects. "Naturalization" emphasizes the fact that the strange or deviant is brought within a discursive order and thus made to seem natural. "Motivation", which was the Russian formalists' term, is the process of justifying items within the work itself by 
showing that they are not arbitrary or incoherent but quite comprehensible in terms of functions which we can name. Vraisemblablisation stresses the importance of cultural models of the vraisemblable as the sources of meaning and coherence. ${ }^{13}$

Así, desde un punto de vista crítico, la descripción de la escritura subyacente en un texto literario es un modo de aproximarse a é1, con el fin de establecer las estructuras de una relación entre ese texto y la experiencia que tenemos de é1. Uno no simplemente "lee" textos literarios, en el sentido de un contacto casual y gracioso con ellos, sino que más bien los asimila a las estructuras de la propia inteligencia y experiencia literaria. La percepción inconsciente de la escritura de un texto está en la base de esa asimilación en el acto de la lectura. Puede afirmarse, entonces, que la descripción de la escritura constituye una valiosa plataforma para la crítica literaria.

III

El objetivo de este estudio es establecer una caracterización parcial de la escritura en unos pocos de los cuentos más importantes de Jorge Luis Borges. No pretende descubrir una escritura genérica que pueda utilizarse como una lectura válida de su ficción como un todo. Sin embargo, debe quedar en claro que los cuentos han sido escogidos por su ejemplaridad canónica de la ficción borgeana y que, aunque se ponga énfasis en los principios motivacionales de los textos particulares, uno podría legítimamente postular la existencia de una macroescritura subyacente a la totalidad de sus escritos. Aunque los relatos han sido tomados de las cuatro principales colecciones de Borges, ${ }^{14}$ ellos no son estudiados cronológicamente. ${ }^{15}$

Las principales características de la escritura borgeana que serán sometidas a discusión son las siguientes:

1) La paradoja del texto literario que intenta registrar minuciosamente la vastedad del universo y el caos de la experiencia personal: la última es infinita; no así el texto literario, que es finito. De esta manera puede deslizarse sólo hasta un registro parcial de lo caótico e infinito, o puede traicionarlos imponiendo un orden de percepción que es meramente solipsístico y conveniente. En todo caso, el texto inutilizado como mensaje pragmático- se vuelve inútil. En “El aleph”, la pretensión de síntesis enmascara sin éxito el desorden del caos con la ironía que se genera en el punto de vista de un narrador frustrado y errático.

2) La falsedad del sistema, por el cual una filosofía impone un orden perceptual que hace lo banal espantoso (lo incidental e insignificante aparece revestido de un "significado trascendental”, en el interior de una vasta y abrumadora interpretación del universo), y viceversa, hace lo espantoso banal (lo infinito y caótico, la contemplación de momentos que producen horror al hombre finito se hallan banalizados 
por su reductora asimilación a un mero sistema filosófico o parafilosófico inventado por el hombre). En “Tlön, Uqbar, Orbis Tertius”, el narrador, después de revisar estos términos complementarios en los términos de un intento gratuito para la formulación de un sistema totalizador, procura neutralizar el horror del sistema y sus amenazantes imposiciones sobre la realidad retrayéndose hasta una banal actividad literaria que es tan gratuita como el amenazante sistema.

3) El rebato de lo "aléphico" verifica lo que el individuo cree haber descubierto. El hombre encuentra el aleph, la cifra perfecta del infinito y caótico universo. Aunque ese aleph no existe, el hombre lo encuentra, y en ocasiones cree haberlo descubierto. Los sistemas filosóficos son quasi-alephs, y los textos literarios son pseudo-alephs (su carácter engañoso se patentiza por la inevitable ironía del texto, una ironía que surge de su paradoja -lo finito versus lo infinito- y predispone a su apropiada lectura. Existen, sin embargo, alephs (necesariamente falsos) en la forma de los objetos: un punto en el espacio (“El aleph”), un libro (el buscado en "La biblioteca de Babel” y el encontrado en "El libro de arena”). La contemplación del presunto aleph, en la medida en que enfrenta al hombre finito con la visión del universo infinito y caóticouna visión que el intenta ver como una síntesis, pero que se le revela como un explosivo y desordenado amasijo de detalles -lo empuja a huir de la visión que le ofrece. En "El libro de arena”, el narrador es obligado a perder el libro aléphico en la Biblioteca Nacional para librarse de un objeto que compromete su salud porque lo provee -0 , al menos, así lo cree- de un conocimiento que sobrepasa la capacidad humana. Si el texto es aléphico, también debe ser rechazado, porque miente acerca y más allá- de nuestra capacidad para comprenderlo y asimilarlo. En "La escritura del Dios”, el descubrimiento de la escritura -la coincidencia de la palabra para Sagrada Escritura en el relato de Borges, y el término que subraya ciertos principios estructurales pueden ser tomados como indicativos de una homología entre los textos literarios y otros sistemas de conocimiento -no tiene que ver con la inteligibilidad, sino con el silencio: sea que la verdad descubierta es demasiado profunda para ser enunciada, sea que es demasiado banal, la consecuencia igualitaria del silencio que niega el texto y el texto sobre el texto, (i.e., el relato de Borges sobre la naturaleza de la Escritura) lo identifica.

4) La contemplación de lo infinito (porque es horrible) o su seudo-síntesis como sistema (porque es trivial) pueden amenazar la sanidad del individuo y retraerlo al rechazo de la contemplación del universo reduciéndolo a la aceptación de un sistema tergiversado. Pero, la adhesión al sistema (banal y ad hoc, repetimos) puede entrampar al hombre en la creencia de que está librándose del carácter atroz de la realidad reduciéndola a una interpretación: el sistema interpretativo, entonces, se convierte en una falsa seguridad que nos conduce, no a la liberación del horror de lo infinito y lo caótico, sino justamente a ellos. El sistema no puede evitar el caos que vanamente pretende reducir a un ordenado cosmos. En “La muerte y la brújula”, el sistema 
gratuito que ha sido elaborado por el detective armoniza con una realidad igualmente gratuita y trascendentalmente insignificante. Sin embargo, antes que evitar la realidad por su interpretación sistemática, Lönnrot la fomenta, y al final la sistemática solución para prevenir el crimen resulta ser el crimen, y la víctima el propio Lönnrot.

5) La necesaria confrontación con un exceso de significación, el "1ógico" resultado de la inadecuación de todas y cada una de las ordenadas percepciones de la experiencia. De esta manera, ningún acontecimiento o circunstancia tiene un significado, sino que más bien existe una fundamental ambigüedad o vaguedad como un resultado de la amplia escala de posibilidades motivadas por lo infinito y lo caótico. Por supuesto, la imposibilidad de un sentido unitario es un problema sólo cuando el hombre se siente obligado a extraerlo de su propia experiencia y del universo que lo rodea y enfrenta. Desafortunadamente, esta necesidad es una verdadera manía del hombre, y, como consecuencia es la causa directa de su frustración ante los sistemas de significación en un nivel general, y ante los textos literarios en un nivel más específico. En la medida en que los textos aspiran a ser sistemas significativos participan de la misma trama de tergiversación parcializando el infinito por su reducción al sistema finito del texto concluso y encuadernado. El intento de penetrar en el misterio del significado es, sin embargo, sólo un componente y no la solución de la fundamental ambigüedad de la experiencia. En "El aleph" los intentos de penetrar en el misterio del sentido derivan en un texto que oscila entre el detalle trivial y parcial de infinito (representación reductiva) y la interpretación distorsionada de la significación (falsa representación). En ambos casos, el sentido de lo que se presenta permanece elusivo e impenetrable -como no significativo, en último análisis-como si fuera previo a todo intento de exégesis. En “Guayaquil”, el problema de la ambigüedad del significado que subyace en buen número de los relatos de Borges deviene el principio estructural más importante del texto, y acontecimiento y texto se homologan en los términos de su fundamental sobresignificación/insignificancia. El mismo caso es el de “La escritura del Dios”. El texto literario empieza a interpretar un texto que empieza a interpretar acontecimientos y circunstancias en una regresiva reducción y falsificación del sentido.

6) A pesar de lo anterior, la manía del hombre por los sistemas interpretativos justifica esos sistemas y justifica la literatura. El mismo énfasis en la preocupación por lo filosófico y lo literario debe considerarse no sobre la propiedad de los sistemas y los textos generados, sino sobre la diversidad y curiosidad de la naturaleza de los detalles que es inherente a esos sistemas y textos. Esa diversidad y la curiosidad del detalle es la fábrica de la civilización y vale la pena su estudio en la medida en que da luz sobre un aspecto fundamental de la humanidad. Pero, al mismo tiempo la diversidad y el detalle de esta fábrica es, en último análisis, sólo una repetición de la infinita y caótica vastedad del universo. Una vez admitida la proliferación de los sistemas y los textos, damos carta blanca a un proceso que sólo tiene como final 
consecuencia la exacta repetición del universo. De aquí se deriva la visibilidad y el ocultamiento tanto de los detalles circunstanciales como de las referencias intertextuales (alusiones directas a una acomodación del fenómeno literario universal) en los escritos de Borges. ${ }^{16}$ En “Tlön, Uqbar, Orbis Tertius” o en “El aleph”, para mencionar sólo dos ejemplos significativos, hay una proliferación de detalles que amenazan con ahogar la presentación de sistemas interpretativos; esta pormenorización es sólo una repetición parcial de los detalles en el infinito y caótico universo que los sistemas y los textos no pueden, después de todo, subordinar a un orden. De este modo la pretensión de un orden en, por ejemplo, un texto literario, es directamente rechazada por el desorden inevitable de los detalles que es forzoso incluir en su intención de sistematizarlos.

Los precedentes principios de escritura en una serie de relatos de Borges, pueden fácilmente ser tomados como paradigmas temáticos. En cierto sentido son aspectos del tema en sus textos, pues hay cuestiones de significación a las cuales ellos intentan referirse. Pero, puede observarse que no se refieren a la significación en cuanto tal: el universo no esta reducido a una interpretación, a menos que ésta sea la imposibilidad de reducir el universo a una interpretación. ${ }^{17}$ Estos paradigmas que parecen tan cercanos a aspectos temáticos tienen que ver con los procesos de la significación, con sus limitaciones y con la aniquilación del sentido. De esta manera, se relacionan con los principios concernientes a la significación que operan en los relatos de Borges. Antes que significados, las historian borgeanas están dirigidas a ser relatos, textos literarios que funcionan en los términos de la tradición occidental, de la literatura como representación, significación e interpretación, sobre la base de los principios señalados. Los aspectos materiales de los relatos -cuestiones de retórica, estilo, forma, voz narrativa (no es un accidente que un buen número de los relatos de Borges presenten una primera personal “ignorante” y/o narradores erráticos) y aun cuestiones más específicas de tema y lugares comunes -son el reflejo directo de estos principios estructurales subyacentes. El último define la naturaleza de la experiencia sobre la cual la literatura está basada, y en consecuencia en su conjunto definen la naturaleza de la literatura, proporcionando los parámetros de su cumplimiento o fallo en cuanto literatura, sobre los cuales los textos han de basarse. En The Fantastic, Todorov distingue entre interpretación y "poética”, ésta, en el sentido en que está usada, es claramente una categoría, si no un sinónimo, de escritura:

Two different objects, structure and meaning, are implied here by two distinct activities: poetics and interpretation. Every work possesses a structure, which is the articulation of elements derived from the different categories of literary discourse; and this structure is at the same time the locus of the meaning. In poetics, one rests content with establishing the presence of certain elements within a literary work. But it is possible to achieve a high degree of certainty, for such knowledge may be verified by a series of procedures. The interpretive critic 
undertakes a more ambitious task: that of specifying -or it might be said of naming- the work's meaning. But the result of this activity cannot claim to be either scientific or "objective.” There are, of course, some interpretations that are more justified than others; but none can assert itself as the only right one. Poetics and criticism are therefore but instances of a more general opposition, between science and interpretation. This opposition, both terms of which, moreover, are equally worthy of interest, is never pure in practice; only an emphasis on one or the other activity permits us to keep them distinct. [...]

We have therefore tried to undertake a study of themes [=semantic constants] which would place them on the same level of generality as poetic rhythms; with that end in view we have established [for the study of fantastic literature] two thematic systems without claiming thereby to give an interpretation of these themes, as they appear in each particular work. ${ }^{18}$

En lo que a Borges concierne, el énfasis virtualmente uniforme en el estudio de su obra sobre la intepretación antes que sobre su poética, es sintomático de la confusión de estos dos objetivos de la critica moderna. De aquí, entonces, la insistencia de este ensayo sobre cuestiones de poética y escritura.

\section{III}

“El aleph”-si es posible o legítimo conceder a uno de los textos del estatuto borgeano este privilegio- puede considerarse un relato eje dentro del marco teórico establecido en la sección precedente. (Uno podría decir alegremente que el relato es, en cierta medida, un aleph de su ficción). Quizás más explícitamente que ningún otro relato, "El aleph” esta dirigido al problema de la composición literaria, a las limitaciones, no tanto del conocimiento humano, sino de la capacidad del hombre para organizar, sintetizar, capturar por la vía defectuosa del lenguaje tanto su conocimiento como su experiencia (los cuales no son, quizás, sino aspectos del mismo fenómeno). No cabe duda de que el aleph -el objeto en el espacio que sintetiza todos los puntos espaciales y temporales: el orden perfecto del caos cósmico- es la meta de los múltiples intentos por someter el universo a una síntesis objetiva.

En el relato de Borges hay tres pesquisas “aléphicas”, todas las cuales resultan frustradas, negadas o condenadas al fracaso; las tres están ligadas a un aleph que se entiende las contiene, un aleph que es, por su parte, destruido (o que permite que se lo destruya) y denunciado como un simulacro del verdadero (pero ausente) aleph. Las tres pesquisas son: 1) los intentos del narrador-partícipe -el personaje Borges- por describir la esencia de su amada muerta, Beatriz Viterbo; 2) los intentos de su primo, Carlos Argentino Daneri, de componer un extenso poema, La tierra, “una descripción del planeta” (p. 619); y por último, 3) los intentos de Borges, el narrador (i.e., el personaje que deviene autor) por describir la naturaleza del aleph que se le presenta, 
sus consecuencias, su falsedad, y la frustración de los tres intentos de poseerlo a través de la escritura. Pues la escritura -la composición del poema, la composición del relato “El aleph”, la composición de un adecuado elogio de Beatriz Viterbo- es vista como un acto de posesión en el sentido de que promete, falsamente por cierto, capturar acontecimiento y lenguaje en un monumento aléphico que resistirá la erosión del olvido y las cualidades aniquilantes de la realidad que, más allá del objeto, se mueve indiferentemente en una caótica confusión de acontecimientos.

Contra los tres intentos de síntesis, se ubican las circunstancias a su negación:

La realidad misma (i.e., el inevitable caos de tiempo y acontecimiento): La candente mañana de febrero en que Beatriz Viterbo murió, después de una imperiosa agonía que no se rebajó un sólo instante ni al sentimentalismo ni al miedo, noté que las carteleras de fierro de la Plaza Constitución habían renovado no sé qué aviso de cigarrillos rubios: el hecho me dolió, pues comprendí que el incesante y vasto universo ya se apartaba de ella y que ese cambio era el primero de una serie infinita. (p. 617; estas son las palabras iniciales del texto)

La memoria individual (debe notarse la ironía implícita en los siguientes pasajes): cambiará el universo pero yo no, pensé con melancólica vanidad; alguna vez, lo sé, mi vana devoción la había exasperado; muerta yo podía consagrarme a su memoria, sin esperanza, pero también sin humillación [... ]. De nuevo aguardaría en el crepúsculo de la abarrotada salita, de nuevo estudiaría las circunstancias de sus muchos retratos. Beatriz Viterbo, de perfil, en colores; Beatriz, con antifaz, en los carnavales de 1921; la primera comunión de Beatriz; Beatriz, el día de su boda con Roberto Alessandri; Beatriz, poco después del divorcio, en un almuerzo del Club Hípico; Beatriz, en Quilmes, con Delia San Marco Porcel y Carlos Argentino; Beatriz, con el pekinés que le regaló Villegas Haedo; Beatriz, de frente y de tres cuartos, sonriendo, la mano en el mentón... (pp. 617-18; la elípsis es del texto. Ante esta enumeración de fragmentos de Beatriz, el lector no puede menos que preguntarse si el narrador tiene una imagen precisa de la mujer.)

...Nuestra mente es porosa para el olvido; yo mismo estoy falseando y perdiendo, bajo la trágica erosión de los años, los rasgos de Beatriz. (p. 628; estas son las palabras finales del texto)

Lenguaje-literatura como lenguaje (la naturaleza lineal del lenguaje vs. la naturaleza simultánea de la experiencia y el acontecimiento): Arribo, ahora, al inefable centro de mi relato; empieza, aquí, mi deseperación de escritor. Todo lenguaje es un alfabeto de símbolos cuyo ejercicio presupone un pasado que los interlocutores comparten; ¿cómo transmitir a los otros el infinito Aleph, que mi temerosa memoria apenas abarca? Los místicos, en análogo trance, prodigan los emblemas: para significar la divinidad, un persa habla de un pájaro que de algún modo es todos los pájaros... [etc.]. Quizás los dioses no me negarían el hallazgo de una imagen equivalente, pero este informe quedaría contaminado de literatura, 
de falsedad. Por lo demás, el problema central es irresoluble: la enumeración, siquiera parcial, de un conjunto infinito... Lo que vieron mis ojos fue simultáneo: lo que transcribiré, sucesivo, porque el lenguaje lo es. Algo, sin embargo, recogeré. (pp. 624-25; es ineludible la impresión de que la última frase se dice en vano)

Símbolos aléphicos (de los cuales el lenguaje y la literatura son subcategorías específicas): Yo querría saber: ¿Eligió Carlos Argentino ese nombre, o lo leyó, aplicado a otro punto donde convergen todos los puntos, en alguno de los textos innumerables que el Aleph de su casa le reveló? Por increíble que parezca, yo creo que hay (o que hubo) otro Aleph, yo creo que el Aleph de la calle Garay era un falso Aleph. (p. 627)

Como puede observarse en estas citas, hay un sentido de futilidad y exasperación por la imposibilidad de lograr una síntesis aléphica satisfactoria. Más aún, hay una pronunciada ironía -y no queda claro si debemos atribuirla a Borges, el personaje, que estaría ironizando conscientemente sus propias afirmaciones, o si debemos acotarla como una función de la escritura (manifestándose a sí misma por la retórica de la ironía) de Borges, el autor- la cual, de un lado, refuerza la realización de las limitaciones de la comprensión (“pensó con melancólica vanidad”) y socava los escasos asertos de logro parcial (“Algo, sin embargo, recogeré”). ${ }^{19}$ El texto de Borges es, en consecuencia, su propio metacomentario: en cuanto narración comenta el fracaso de los tres intentos de controlar el conocimiento; en cuanto texto literario, enuncia claramente sus propios principios de escritura, proyectándose al efecto de que él también es un fracaso en su descripción del fracaso: “este informe quedaría contaminado de literatura, de falsedad” (de aquí se desprende el use que hace Borges de la palabra “ficción” - del verbo “fingir”- como descripción genérica de su literatura), “yo mismo estoy falseando, perdiendo...”.

Esta ironía -a menudo, claramente una ironía a expensas del narrador- está presente no sólo en los pasajes que describen el fracaso de Borges para retener la imagen de Beatriz y su fracaso para describir adecuadamente la naturaleza del aleph, en el cual ve una esperanza de experimentar una imagen totalizadora de la mujer. Está presente también en sus comentarios relacionados con Carlos Argentino Daneri y la fría y desconfiada relación entre los dos hombres. Quizás, en parte, la ironía del narrador debe ser considerada un instrumento consciente de su descripción de Carlos Argentino. Sin embargo, más a menudo sirve para caracterizar negativamente al narrador (que comunica marcados celos respecto de Argentino, como hombre y escritor) que a su antagonista. El resultado, entonces, es la impresión de que el narrador esta describiendo una relación que es incapaz de controlar y, como consecuencia, ante la cual le resulta difícil, si no imposible, dar la perspectiva correcta: en otras palabras, la relación entre Borges, el personaje, y Carlos Argentino es otro fenómeno que elude una síntesis apropiada. Desde el punto de vista de la 
acción narrada, la relación entre ambos tiene que ver con la común memoria de Beatriz, una pugna de reconocimiento literario, y el hecho de compartir el aleph, que Carlos Argentino muestra a Borges. En los tres casos, la narración muestra una base de incomprensión y fracaso: ambos han perdido a Beatriz irremediablemente; Borges pierde con Argentino una contienda literaria; Argentino pierde el aleph, en parte porque Borges no acepta ayudarlo en el esfuerzo por conservar la casa, en cuyo subsuelo está el aleph.

El aleph, en la medida en que es el signo o símbolo estructurante de la escritura del texto en el sentido de que mantiene la ilusión del conocimiento totalizador, es al mismo tiempo, en el nivel de la acción narrada, el punto central de referencia para la relación entre los dos hombres. Primero, es introducido de manera oblicua, cuando Borges describe el poema que Borges esta escribiendo; se da cuenta, más tarde, de que la fuente de información del poeta es el secreto aleph. De este modo, sólo en una visión retrospectiva podemos realmente atribuir sentido a la descripción que el narrador hace de tal poema, pues junto a su evidente desdén motivado por razones personales, es claro que ve el poema como una tediosa miscelánea:

Otras muchas estrofas me leyó que también obtuvieron su aprobación y su comentario profuso [i.e., los de Argentino]. Nada memorable había en ellas; ni siquiera las juzgué mucho peores que la anterior. En su escritura habían colaborado la aplicación, la resignación y el azar; las virtudes que Daneri les atribuía eran posteriores. Comprendí que el trabajo del poeta no estaba en la poesía; estaba en la invención de razones para que la poesía fuera admirable... (pp. 619-120)

Es sólo entonces cuando nos damos cuenta, junto con el narrador, de que Argentina, Daneri está describiendo lo que ve gracias al aleph, y entendemos que ese poema es tendioso y difuso porque quiere ser una reproducción fidedigna del caos infinito de la realidad: el aleph no sirve para sintetizar o resumir el universo sino para presentárnoslo en sus detalles mas aterradores.

Cuando Borges contempla finalmente el aleph, su propia descripción no puede ser más que un paralogizante revoltijo de desordenados detalles, antes que una síntesis. La descripción del narrador, que cubre más de dos páginas de texto en la edición original, concluye con la siguiente nota, próxima a la histeria:

... vi el Aleph, desde todos los puntos, vi en el Aleph la tierra, y en la tierra otra vez el Aleph y en el Aleph la tierra, vi mi cara y mis vísceras, vi tu cara, y sentí vértigo y lloré, porque mis ojos habían visto ese objeto secreto y conjetural, cuyo nombre usurpan los hombres, pero que ningún hombre ha mirado: el inconcebible universo. 
Sentí infinita veneración, infinita lástima. (p. 626; no se da el antecedente de tú, pero puede ser Beatriz Viterbo)

Lo importante no es el aleph en sí mismo, ni el hecho de que, en el nivel de la acción narrada, es probable que sea una decepción por parte de Argentino (esto explica la venganza por la cual el narrador se niega a cooperar para salvar la casa de la demolición y la falsedad que le atribuye al aleph al final del texto. Desde el punto de vista de la escritura se trata, más bien, de la aparición y ocultamiento de los pormenores. La plétora de detalles es característica del poema de Argentino, y lo es también de la evocación que el narrador hace de Beatriz y de su descripción del aleph y la visión que le entrega. Más aún, el detallismo inevitable de estos aspectos, depositados necesariamente en el texto mismo, lo cual obliga a su re-evocación, se halla complementada por la abundancia de detalles al nivel del texto. Esto es, Borges como narrador-personaje ubica los pormenores de la acción narrada dentro del contexto de una descripción que es, en sí misma, excesivamente detallada (el mejor ejemplo de esto es la pedantesca ironía de la Posdata del primero de marzo de 1943 (pp. 626ss). El resultado es una forma de extensa, si no infinita, regresión en la cual la abundancia de detalles obstaculiza cualquier acceso a una noción sintética de lo que pasa. Nos vemos enfrentados a un cenegal de detalles que constituyen una fiel imagen del aleph, con lo cual se nos niega todo acceso a una comprensión totalizadora de lo que pasa. Para extraer cualquier tipo de significación del texto mismo es necesario cerrar la conciencia a la mayor parte de los detalles. Alternativamente, podemos extraer alguna idea de la rina literaria entre los dos hombres y del concepto del aleph con su presencia en el mundo de la literatura. Lo que difícilmente podemos alcanzar es una interpretación última que integre los elementos dispersos y la carga de los pormenores en un sentido unificador. Es en este sentido que el aleph, antes que ser un símbolo del sentido del texto, es un signo organizador de una escritura subyacente que estructura el modo de nuestra lectura y experiencia del texto.

\section{IV}

"El aleph” apunta, en último término, a la imposibilidad de la literatura como un modo de conocimiento privilegiado y organizado. “Guayaquil”, para este lector el mejor de los once relatos que componen El informe de Brodie, está por su parte estructurado en los téminos del principio de ambigüedad.

En lingüística, que ha definido el concepto sistemáticamente, la ambigüedad se refiere a la circunstancia por la cual un determinado enunciado lingüístico representa más de una estructura sintáctico-semántica abstracta. Esto es, un enunciado es ambiguo si es capaz de sostener varias significaciones discretas, cada una de las cuales es posible de ser identificada una vez que relacionamos el enunciado concreto con la 
abstracción sintáctico-semántica; cuando las significaciones concretas no son recuperables, la frase debe definirse por su vaguedad antes que por su ambigüedad. En la escritura borgeana, la experiencia, la realidad, el acontecimiento son esencialmente ambiguos en la medida en que soportan una multiplicidad de significaciones que pueden ser al mismo tiempo complementarias y contradictorias (esto explica relatos como “La muerte y la brújula” o “El jardín de senderos que se bifurcan”, donde no hay una relación estable, de uno a otro, entre la significación y el enunciado manifiesto: en el caso de la primera historia, la falsa significación, el producto de los ejercicios intelectuales del detective, exige que la realidad se conforme a ella; dicha conformidad se transforma, por su parte, en la trampa asesina para el atildado investigador.) En la medida en que cada fenómeno tiene multiplicidad de sentidos, no hay prioridad ni criterio para la significación, lo cual equivale a negar la importancia y aún la identificación misma del sentido.

La estructura básica de Guayaquil es la de un texto que describe el misterio de un misterio: en el nivel de la acción narrada, el relato tiene que ver con dos historiadores que han de examinar y dar parte sobre un nuevo documento relacionado con el misterioso encuentro entre Bolívar y San Martín que condujo a la abdicación del último como jefe de las fuerzas revolucionarias en el área andina; en el nivel del texto, la descripción no llega a explicitar el misterio de por qué el historiador nativo (una vez más, Borges como narrador-personaje) condesciende con el historiador extranjero (un desharrapado judío que el narrador describe con términos desdeñosos). La acción narrada y el texto juegan paralelamente: un encuentro misterioso evoca un encuentro pasado igualmente misterioso, remoto en el tiempo y en el espacio; y un texto que falla, como será el caso de la profecía del historiador extranjero en relación con el nuevo documento, en explicar el misterio fundamental del encuentro. Deberá tenerse en cuenta que el documento en cuestión, como el texto mismo, tiene que ver con detalles del encuentro; sin embargo, el documento fue escrito por Bolívar, el vencedor en ese remoto contexto de personalidades, mientras que el texto "Guayaquil” es narrado (“escrito”) desde el punto de vista del vencido Borges. En todos estos niveles y detalles, el texto permite la representación de las configuraciones externas del acontecimiento, tales como el lenguaje, y en el caso del narrador, el pensamiento inexpresado. Pero significativamente, lo que se niega es lo que debiera ser el imperativo fundamental dirigido a un texto literario: la revelación, la “desambiguación”, del sentido.

La escritura básica del relato -el texto que proveerá detalles de acontecimiento y circunstancias, pero no su significación esencial-esta dada en su forma más directa por uso de un narrador en primera persona con características erráticas. Como en "El aleph" hay una plétora de detalles y una escasez de significaciones, y hay un narrador en primera persona que acumula detalles, pero que es incapaz de encontrar en ellos 
un sentido satisfactorio. Esto es claro desde la apertura del texto, que formaliza de inmediato los principios subyacentes de su escritura:

No veré la cumbre del Higuerota duplicarse en las aguas del Golfo Placido, no iré al Estado Occidental, no descifraré en esa biblioteca que desde Buenos Aires imagino de tantos modos y que tiene sin duda su forma exacta y sus crecientes sombras, la letra de Bolívar.

Releo el párrafo anterior para redactar el siguiente y me sorprende su manera que a un tiempo es melancólica y pomposa. Acaso no se puede hablar de aquella república del Caribe sin reflejar, siquiera de lejos, el estilo monumental de su historiador más famoso, el capitán Korzeniovski, pero en mi caso hay otra razón. El íntimo propósito de infundir un tono patético a un episodio un tanto penoso y más bien baladí me dictó el párrafo inicial. Referiré con toda probidad lo que sucedió; esto me ayudará tal vez a entenderlo. Además, confesar un hecho es dejar de ser el actor para ser un testigo, para ser alguien que lo mira y lo narra y ya no lo ejecutó. (p. 1062)

Por supuesto que la narración retrospectiva del acontecimiento no conduce al narrador a la comprensión que busca. La verdad es que el acto de la narración conduce a una negación de la escritura. El detallismo, en el nivel de la acción narrada, es el resultado de que el historiador extranjero le ha usurpado al narrador la posibilidad de examinar la carta de Bolívar y de preparar un ensayo histórico sobre ella. Pero, en el nivel del texto, la denegación es igualmente el resultado de haber fracasado con su propio documento concerniente al conflicto con el historiador extranjero sobre el documento histórico. La profecía del historiador de que la carta de Bolívar se convertirá, si no en inauténtica, al menos en una inútil falsificación del encuentro entre los dos caudillos de la independencia, es asimismo implícitamente una caracterización del propio texto de Borges relacionado con la naturaleza del encuentro entre los dos historiadores. Las palabras que cierran el texto enfatizan la homología entre los dos documentos y los dos encuentros, y el sentido de la futileza del texto funciona como un doble refuerzo del silencio y el misterio del sentido:

Releo estas desordenadas páginas, que no tardaré en entregar al fuego. La entrevista había sido corta.

Presiento que ya no escribiré más. Mon siège est fait. (p. 1067)

La función del narrador en primera persona es todavía más sutil. ${ }^{20}$ Si existe una separación de niveles entre acción narrada y texto, entre documento histórico y texto, entre un encuentro previo entre dos hombres y un documento concerniente al encuentro y al encuentro reciente que repite su antecedente histórico en más de un detalle (por ejemplo, la descripción de Zimmerman, el historiador extranjero, en las 
páginas 1063-64, evoca los detalles del retrato de Bolívar), existe también una separación de niveles para la voz narrativa. En el nivel del texto, tal como lo hemos caracterizado, la voz narrativa es la realización inmediata de la escritura subyacente relacionada con la frustrante imposibilidad de acceder al sentido. Pero en el nivel de la acción narrada -la acción que da lugar a un texto que repercute en la acción y que envuelve en su estructura un reflejo homólogo de la naturaleza de la acción: misterio, carácter errático, silencio- el narrador confiesa una ironía deliberada, la deliberada falsificación del encuentro. La ironía es el refugio del individuo que posee la verdadera significación de un acontecimiento y que subraya la ignorancia o el conocimiento parcial de otros participantes en el acontecimiento. Así, el narrador se burla del imperfecto español de Zimmerman, de su traje y costumbres ridículos (éstas últimas se presentan como una parodia del judío servil) y de sus frecuentes confusiones respecto de detalles básicos (“-;Mi primer error, que no será el ultimo! Yo me nutro de textos y me trabuco; en usted vive el interesante pasado” [p. 1064]. “-En materia bolivariana (perdón, sanmartiniana) su posición de usted, querido maestro, es harto conocida” [p. 1065]. La ironía del narrador pretende desacreditar a Zimmerman y subrayar el pathos de que haya sido claramente derrotado por el extranjero inferior. Pero, la ironía es también el resultado directo de la utilización de un narrador en primera persona con características que lo dotan de escasa confiabilidad: como autor, Borges establece una distancia irónica entre su conocimiento de la patética autocompasión de Borges el narrador y el propio autoconocimiento del último, claramente limitado. En ambos niveles la ironía funciona como un refuerzo de la escritura del misterio y de la inadecuación textual. Y, de este modo, el conocimiento declarado, que, en el nivel de la acción narrada permite la ironización del narrador, deviene en el nivel del texto una falta de conocimiento que lo hace objeto de la ironía del texto.

Se da por supuesto que la realización última de la inadecuación del propio conocimiento, es lo que obliga al narrador a descubrirse en un determinado pathos. El narrador reconoce que es, a su vez, una víctima de la ironía de Zimmerman (“Sospecho que el error fue deliberado” [p. 1064]), y que esta necesariamente comprometido en una falsificación del acto de escritura que espera se convierta en una explicación para sí mismo, y de sí mismo: "Lo sucesivo del lenguaje indebidamente exagera los hechos que indicamos, ya que cada palabra abarca un lugar en la página y un instante en la mente del lector...” (p. 1064).

Las características que hemos descrito en "Guayaquil” revelan un texto que se destruye a sí mismo; abundan las trivialidades y la sustancia significante esta ausente, hay una ironía que pretende que el conocimiento es el ironizado, hay una homología en que los acontecimientos personales e históricos son ocultados por el misterio de su significación e igualados como acontecimientos erráticos; y, finalmente, la versión oficial del narrador (que, a su vez, se homologa a la versión oficial de Bolívar, 
contenida en el documento primero) es mucho menos una interpretación que una autojustificación y un registro de la derrota. Todos estos factores que dan lugar a la configuración del texto y sus rasgos estilísticos y temáticos, deben ser entendidos como un precipitado de la escritura subyacente en "Guayaquil”. Esta escritura es, sin lugar a dudas, la consecuencia de la concepción borgeana del arte narrativo. Parte de la conversación entre Borges, el narrador-participante, y Zimmerman nos provee de una excelente caracterización de esta concepción, al mismo tiempo que nos remite de nuevo a la homología entre el documento histórico y el texto literario, entre corresponsallector y Bolívar escritor-narrador:

-Que sean de puño y letra de Bolívar -me contestó- no significa que toda la verdad esté en ellas. Bolívar puede haber querido engañar a su corresponsal o, simplemente, puede haberse engañado. Usted, un historiador, un meditativo, sabe mejor que yo que el misterio está en nosotros mismos, no en las palabras. Esas generalidades pomposas me fastidiaron y observó secamente que dentro del enigma que nos rodea, la entrevista de Guayaquil, en la que el general San Martín renunció a la mera ambición y dejó el destino de América en manos de Bolívar, es también un enigma que puede merecer el estudio.

Zimmerman respondió:

-Las explicaciones son tantas... (p. 1066)

“Tlön, Uqbar, Orbis Tertius” empieza con una referencia a una conversación entre Borges y Bioy Casares acerca de los narradores en primera persona, los cuales pueden ser más engañosos que confiables en su calidad de informadores-participantes, y “La escritura del Dios” pretende alcanzar una significación que pensamos se consigue, pero que el narrador se niega a compartir con el lector, negando así la racionalidad de su texto. Entendemos, por cierto, que esta negación enmascara el hecho de que la significación no ha sido hallada realmente, o que no puede ser expresada en términos humanos y lingüísticos, lo cual es lo mismo que no haberla encontrado. Es evidente que existe una continuidad entre estas historias, en las cuales uno va desde la imposibilidad de acceder al sentido a la multiplicidad del sentido, desde la imposibilidad de comunicar el sentido a la negación del sentido. Aunque esta continuidad no constituya la finica en la abrumadora escritura de las ficciones borgeanas, no puede negarse que se nos presenta como un principio innegable para una amplia variedad de textos que desde Ficciones se proyectan a los más recientes relatos del autor. 
Este trabajo ha examinado en detalle sólo dos textos borgeanos, y ha hecho referencia solamente a un puñado de otros. Estudiar comprensivamente todas las ficciones de Borges derivaría en un panorama superficial de las docenas de títulos que ha publicado, o en un compendio que, inconscientemente, desafiaría la espaciosa pedantería de las secciones de "El inmortal”, “El aleph”, "Pierre Menard”. Puede ponerse en cuestión una actitud crítica que pretenda la caracterización adecuada del corpus completo de los escritos de un autor, tomando como punto de partida un sólo marco teórico. La premisa de este estudio, sin embargo, es que la crítica puede predisponernos a una adecuada lectura de un autor o de un completo de escritos; que una descripción satisfactoria de un número limitado de obras es mús valiosa que el trabajo sobre breves referencias a muchas obras, y que más aún que el análisis “total” que descuida las obras en sí mismos. El concepto de escritura implica un concepto de lectura y, como Noe Jitrik ha intentado demostrar, implica también un concepto de trabajo crítico (un término que prefiere al de crítica por la contaminación que este concepto tiene con los factores de juicio e interpretación). ${ }^{21}$ En todo caso, hay consenso entre muchos de los críticos e investigadores contemporáneos de la literatura de que la única meta verdadera de la crítica es la identificación de las normas, los principios, las premisas que hacen la literatura posible, esto es, identificar la escritura que la motiva. Y este ensayo, antes que proveer al lector con interpretaciones fáciles y tranquilizantes de una literatura que es, a la vez, perturbadora y difícil, proporciona en último análisis una caracterización de la escritura borgeana que coincide con las palabras - casi casuales-del propio autor en el "Prólogo" a El informe de Brodie. Estas palabras, en efecto, pueden leerse como una caracterización sumaria de su escritura así como del enigma fundamental que los mismos textos comportan:

He intentado, no sé con qué fortuna, la redacción de cuentos directos. No me atrevo a afirmar que son sencillos; no hay en la tierra una sola página, una sola palabra, que lo sea, ya que todas postulan el universo, cuyo más notorio atributo es la complejidad. Sólo quiero aclarar que no soy, no he sido jamás, lo que antes se llamaba un fabulista o un predicador de parábolas y ahora un escritor comprometido. No aspiro a ser Esopo. Mis cuentos, como los de las Mil y Una Noche, quieren distraer o conmover y no persuadir. (p. 1021) 


\section{NOTAS}

1 Jorge Luis Borges, “Pierre Menard, autor del Quijote,” en sus Obras completas (Buenos Aires: Emecé Editores, 1974), pp. 449-50. Todas las citas se hacen por esta edición, y la paginación se incluye con la cita.

2 En especial los materiales publicados por la editorial Nueva visión a partir de mediados de los años 60 .

3 Ver David W. Foster, “La nueva narrativa vista por la nueva crítica,” Nueva narrativa hispanoamericana, 4 (1974), 227-50.

4 “Borges and Structuralism: Toward an Implied Poetics,” Modern Fiction Studies 19 (1973), 341-51.

5 Emir Rodríguez Monegal, “Borges y la nouvelle critique,” Revista Iberoamericana 80 (1972), 367-90.

6 "El nivel de la escritura en la narrativa hispanoamericana contemporánea, "Nueva narrativa hispanoamericana 4 (1974), 299-306. Ver también de Giordano, "Forma y sentido de 'La escritura del Dios’ de Jorge Luis Borges,” Revista Iberoamericana 78 (1972), 105-15.

7 "Borges, el libro y la escritura," Caravelle 17 (1971), 187-94.

8 “Estructura y significación en Ficciones de Jorge Luis Borges,” en su El fuego de la especie, ensayos sobre seis escritores argentinos (Buenos Aires: Siglo XXI Argentina, 1971), pp. 129-50. Debe notarse también el estudio de Nicolás Rosa, “Borges y la ficción laberíntica," en Jorge Lafforgue, Nueva novela latinoamericana (Buenos Aires: Editorial Paidós, 1969-71), II, 140-73. Sin embargo, es difícil saber cuando Rosa hace hincapié en la escritura y cuando está hablando de temática.

9 Bien que no hable específicamente de la escritura, el trabajo de David Maldavsky sobre la estructura semiótica de los cuentos de Borges sigue fielmente los conceptos barthianos: "Un enfoque semiótico de la narrativa de J. L. Borges,” Nueva narrativa hispanoamericana 3, 2 (1973), 105-19.

10 Ver pags. 31ff. de la traducción al ingles: Writing Degree Zero, and Elements of Semiology (Boston: Beacon Press, 1970).

${ }^{11}$ Leo Spitzer, “Note on the Poetic and Empirical 'I' in Medieval Authors,” Traditio 4 (1946), 414-22.

12 Un ejemplo paradigmático del estudio de la escritura de un texto hispánico es el trabajo de Noe Jitrik, "La perifrástica productiva en Cien años de soledad," en su Producción literaria y producción social (Buenos Aires: Editorial Sudamericana, 1975), pp. 19-47.

13 Jonathan D. Culler, Structuralist Poetics: Structuralism, Linguistics, and the Study of Literature (Ithaca, N.Y.: Cornell University Press, 1975), pp. 138-39.

${ }_{14}$ Ficciones (1944), El aleph (1949), El informe de Brodie (1970), El libro de arena (1975).

${ }^{15}$ Hay un grueso número de estudios críticos dedicados a Borges, muchos de la década del 60. Aunque muchos son superficiales y repetitivos, las mejores aproximaciones han detallado cuestiones como temas, influencias, conceptos filosóficos, y, más recientemente, los contactos entre Borges y la nueva narrativa. Sin embargo, a pesar de que algunos de los ensayos realmente importantes se dirigen a las cuestiones planteadas en el presente estudio, que yo sepa ninguno aborda a Borges en términos de una escritura coherente. Ana María Barrenechea, "Borges y la narración que se autoanaliza,” Nueva Revista de Filología Hispánica 24 (1975), 515-27, habla de lo que viene a ser un elemento especial de esta escritura: el texto autoconsciente (ver nuestro punto 6). Sin embargo, Barrenechea no se vale del concepto de escritura, y los rasgos autoanalíticos que ella describe se atribuyen a un nuevo concepto de retórica narrativa, lo cual los limita al nivel superficial de estrategias de la composición, en vez de focalizarlos en términos de una escritura abstracta a la que corresponden en virtud a su naturaleza como principios generadores del texto.

16 Aunque Borges pareciera quedar excluido por las limitaciones cronológicas que se proponen, muchos de los comentarios de Todorov sobre el género de lo fantástico son apropiados a la obra del argentino. Es más, las palabras que cierran su estudio son directamente pertinentes a la escritura de Borges que estamos describiendo:

[...] Words are not labels pasted to things that exist as such independently of them. When we write, we do merely that -the importance of the gesture is such that it leaves room for no other experience. At the same time, if I write, I write about something, even if this something is writing. For writing to be possible, it must be born out of the death of what it speaks about; but this death makes writing itself impossible, for there is no longer anything to write. Literature can become possible only insofar as it 
makes itself impossible. Either what we say is actually here, in which case there is no room for literature; or else there is room for literature, in which case there is no longer anything to say. As Blanchot writes in La Part du Feu: "If language, and in particular literary language, were not constantly advancing toward its death, it would not be possible, for it is this movement towards its impossibility which is its condition and its basis."

The operation which consists of reconciling the posible with the impossible accurately illustrates the word "impossible" itself. And yet literature exists; that is its greatest paradox.

Tzvetan Todorov, The Fantastic, a Structural Approach to a Literary Genre (Ithaca, N.Y.: Cornell University Press, 1975 [publicado originalmente en francés en 1970; la traducción al inglés fue publicada originalmente en 19731), p. 175.

17 Sobre las constantes temáticas y simbólicas de la obra de Borges, ver Emir Rodríguez Monegal, "Símbolos en la obra de Jorge Luis Borges,” Studies in Short Fiction 8 (Winter 1971), 64-77. Carter Wheelock por poco llega a tender un puente entre temas y escritura en The Mythmaker, a Study of Motif and Symbol in the Short Stories of Jorge Luis Borges (Austin: University of Texas Press, 1969).

18 Todorov, pp. 141-43.

19 Sobre los narradores borgeanos, ver Thomas E. Lyon, "Borges and the (Somewhat) Personal Narrator," Modern Fiction Studies 19 (1973), 363-72.

20 En lo que se refiere a las voces narrativas de los cuentos de El informe de Brodie, ver Owen L. Kellerman, “Borges y El informe de Brodie: juego de voces,” Revista Iberoamericana 81 (1972), 66370. Lanin A. Gyurdo estudia el cuento “Guayaquil” en "Rivalry and the Double in Borges' 'Guayaquil'” Romance Notes 15 (1974), 1-10.

21 En la introducción a la colección de ensayos que se cita en nota 12. 


\section{Emergencia, Espacio, “Mundos \\ Posibles": Las Propuestas \\ Epistemológicas de Jorge L. Borges}

Nadie está en algún día, en algún lugar; nadie sabe

el tamaño de su cara.

J.L. Borges

\section{INTRODUCCION}

El objetivo de este artículo es el de considerar la noción de emergencia en relación a la práctica textual literaria y en conexión con la conceptualización de tal práctica: en el proceso literario existen momentos de cambios que modifican el sistema de tal manera de poder identificar en ellos un "momento de catástrofe” (R. Thom, 1974). Estos momentos establecen, de facto, una relación especial con la interpretación puesto que el "momento de catástrofe" invalida, por lo general, los modelos interpretativos existentes. El punto de catástrofe se manifiesta, entonces, mediante la aparición de estructuras textuales particulares y por las relaciones que éstas establecen con la interpretación. Pueden ambas ser definidas, adaptando a K. Hempel, (1965: 259-264), como: una estructura textual $e$ del objeto te6rico $\mathrm{T}_{\mathrm{x}}$ (texto) es emergente, en relación a una teoría $\mathrm{T}_{\mathrm{r}} \mathrm{y}$ a una clase de proposiciones de la teoría $\mathrm{T}_{\mathrm{r}}$, si $e$ no puede ser descrita y explicada satisfactoriamente por las proposiciones de la teoría. Las estructuras textuales emergentes producen cierto desfasaje con respecto a las pautas (modelos) disponibles de interpretación. Las relaciones que se establecen entre estructura emergente e interpretación pueden dar como resultado:

1) una negación de ellas (“crítica negativa”) dado que las estructuras emergentes escapan a un sistema de valores presupuesto y normativo, con respecto a "lo que debe ser el texto literario";

2) una apología de ellas en el momento en que ciertas "zonas conceptuales emergentes” permiten la prolongación de las estructuras textuales emergentes en el discurso que construye la zona conceptual;

3) un reconocimiento intuitivo de las estructuras textuales emergentes que, en la carencia de un discurso conceptual, lleva a interpretar las primeras reduciéndolas a 
una estructura conceptual en vigencia sobre la que, precisamente, opera la zona textual emergente: en este caso, el discurso conceptual "reduce” y atenúa el efecto del momento de catástrofe.

Los casos 1) a 3) resumen, a mi parecer, la historia de la crítica sobre Borges. A su vez ilustran el problema de las relaciones entre estructuras textuales emergentes (ETE) y zona conceptual emergente (ZCE). Rápidamente, estas relaciones suponen: a) una base ZCE, en el sistema literario o fuera de él, que genera ETE (i.e., en el caso de Borges, las matemáticas, la conceptualización del tiempo derivada de las teorías físicas, etc.); b) la configuración, en el campo de una disciplina (e.g. estudios literarios) de una ZCE que permite captar ETE (i.e., en el caso de Borges, los desprendimientos de la especulación sobre el signo).

De acuerdo al cuadro así presentado, los textos de Borges serán tomados como una instancia específica (y un ejemplo paradigmático) de estructuras textuales emergentes en la literatura hispánica contemporánea. De esta manera, en II, una primera particularidad de las estructuras textuales emergentes será analizada como traducción; ello nos permitirá situar la práctica borgiana en relación con una zona conceptual emergente, que se remonta a G. Frege, y que tiene por objeto el proceso de la significación. En III, el concepto de traducción, será ligado a ciertas formas internas de organización de los textos de Borges sobre las cuales podemos identificar las zonas emergentes: el concepto de discontinuidad articulará algunos de sus rasgos específicos. A su vez, el concepto de discontinuidad será relacionado, por un lado, con el de traducción; mientras que, por el otro, se planteara el problema de la necesidad de una epistemología diferencial (sugerida con respecto a la física contemporánea por G. Bachelard, 1934; por los mismos años en que Borges comienza sus escritos en prosa), como base explicativa de los fenómenos de discontinuidad. En IV, se retomará la noción de discontinuidad, tratando de indagar en los posibles modelos que describan adecuadamente los fenómenos que el concepto designa. Para ello se apelará a modelos de la lógica multivalente (IVa.) y de la topología (IVb.), dando por sentado que estas transposiciones quedan, por el momento, a nivel puramente metafórico. La justificación de estas operaciones está sugerida por la propia práctica de Borges: las bases sobre las que se construye la topología o la lógica multivalente son, muchas veces, las mismos sobre las que se construyen los textos borgianos: no creo que sea por azar que en Historia de la eternidad (1936), una cuestión retórica como la metáfora sea seguida por la discusión del tiempo, sino porque la poética de Borges es una poética que se basa sobre una "filosofía del conocimiento".

\section{COMUNICACION, TRADUCCION Y PROCESAMIENTO DE LA INFORMACION}

La lingüística moderna nos acostumbró a pensar el acto lingüístico en términos de comunicación. Tal hipótesis no tardó en ser transpuesta a la conceptualización del 
mensaje poético (Jakobson, 1960). Tampoco tardaron en aparecer las objeciones a ambas hipótesis desde la lingüística misma (Ducrot, 1968), la filosofía (Derrida, 1967a) y la semiología (Kristeva, 1969). El modelo comunicacional enfatiza la estructura del mensaje a la vez que su posición: después de su emisión y antes de su recepción. De ahí que la manera más simple de representarlo gráficamente lo situé, en una organización de izquierda a derecha, entre el emisor y el receptor. La gramática generativo-transformacional no es una excepción dado que al intentar la modelización de la competencia lingüística, se analiza el enunciado (frase/mensaje) para deducir de él las reglas que permiten su codificación y descodificación.

Retendré del punto precedente la exigencia y la necesidad de modificación del modelo comunicacional en relación a la conceptualización de $\mathrm{T}_{\mathrm{x}} \mathrm{y}$ de su teorización. En primer lugar, el proceso de la comunicación no involucra sólo al emisor, al receptor y al mensaje, sino también al programa que permite esta operación. Tal programa no se reduce a la mera competencia lingüística; es, más bien, un “mecanismo” que permite la selección y organización de la información en términos conceptuales. La maquinaria conceptual condiciona y canaliza, por su misma naturaleza, las maneras en las cuales representamos el mundo en el discurso. Este mecanismo no es invariable ni tampoco innato: su funcionamiento esta regulado por el trabajo teórico-conceptual que él mismo permite y que, por un proceso de retroalimentación, conduce a modificar sus reglas de funcionamiento. Dicho de otra manera, podemos pensar el mundo externo como una fuente que envía cúmulos de información caótica. El sistema perceptual (tanto fisiológico como "mental”) selecciona las informaciones físicas según las posibilidades fisiológicas de los órganos de percepción, siempre que tales estímulos no sobrepasen un umbral específico más allá del cual la información no puede ser procesada. Las ondas sonoras que sobrepasan la capacidad auditiva, por ejemplo, no son realmente informaciones. En la recepción de mensajes verbales, el oído y la vista seleccionan los estímulos físicos que luego el programa analiza conceptualmente. Este programa no está excento de un sistema de valores que condiciona históricamente la organización de la información. En el espacio del texto, inseparable del universo (textual) del sentido, el programa opera como mecanismo de traducción. ${ }^{1}$

Si el texto se concibe como traducción, es entonces necesario distinguir dos niveles operativos:

1)Laproducción textual es el resultado de un proceso de traducción/transformación del sentido. Como tal, este proceso pre-supone un programa. En consecuencia, el texto no sólo se define como traducción/transformación del sentido sino como transformación del propio programa. Esta operación es conocida en la "historia de la literatura” por la novedad que constituyen, en un momento, los períodos, las escuelas, o los movimientos literarios.

2) La teoría es el resultado de un proceso de análisis de la información textual y de la re-elaboración del programa que genera los modelos a través de los cuales la información se analiza. 
Ahora bien, si el programa (en tanto mecanismo conceptual) genera modelos, éstos no son homogéneos sino heterogéneos: las diversas "interpretaciones" de un texto, por ejemplo, evidencian esta heterogeneidad. En el caso de la interpretación de los textos de Borges ésta se manifiesta cuando se consideran:

1) La “interpretación” basada en la hipótesis según la cual el texto opera en base a temas y estilo (Barrenechea, 1957; Alazraki, 1968). ${ }^{2}$

2) Aquellas que presuponen que el texto debe ser "crítico" en relación a la realidad (?) (Fuentes, 1969).

3) Aquellas que presuponen que la significación del texto reside en su estructura particular (Jitrik, 1968; Gertel, 1971).

En resumen, el programa en tanto maquinaria textual, genera traducciones; el programa, en tanto maquinaria conceptual, genera modelos.

Al postular el concepto de emergencia, el problema mayor para la teoría del texto es la elaboración de modelos que permitan la descripción de estructuras textuales emergentes y, a la vez, expliciten los dispositivos comunes de la maquinaria conceptual y de la maquinaria textual. Es en un tal dispositivo donde sería posible situar el punto de convergencia de la práctica teórica y de la práctica textual. De este modo, ambas serían manifestaciones particulares de una (re)distribución epistémica en un momento histórico determinado. Las secciones que siguen intentan desarrollar estas sugerencias.

\section{LO ANALOGICO Y LO DISCONTINUO}

La analogía puede definirse como un mecanismo discursivo (verbal y no verbal) que opera sobre las pautas “normativizadas” de un período histórico. La versión platónica articula este fenómeno en relación a la copia (imagen verosímil) y al simulacro (imagen no-verosímil). Como copia degradada, el simulacro "esta construido sobre una disparidad, sobre una diferencia e interioriza, por lo tanto, una disimilitud" (Deleuze, 1969: 297). Locke, en la división de la ciencia (Ensayo sobre el entendimiento humano, Libro IV, XXI), afirma que, como las cosas no se hacen presentes al entendimiento, es necesario que un signo las represente; y estas formas de representación son ideas. Las ideas, a su vez, pueden ser divididas en reales o fantásticas, en adecuadas e inadecuadas y en verdaderas o falsas (Libro II, XXX). Una extensión de la copia y del simulacro es aquí posible: real, adecuada, verdadera/fantástico, inadecuado, falso. Los ejemplos (al estilo borgiano) podrían multiplicarse: la referencia, como unidad cultural, produce el efecto de "presentificación” del objeto, al menos hasta Frege. ¿Cómo debe ser entendida esta afirmación? y ¿cómo se relaciona con los textos de Borges?

La conceptualización del texto como traducción señala a la vez un desplazamiento en la zona de la producción textual y una diferencia entre diversas formas discursivas. Referirnos a Borges después de esta asunción no es nada difícil. "Los traductores de Las 1001 noches” (1935) ${ }^{3}$ (no sólo porque la palabra está en el título) es una 
indagación del acto de traducir como transformación del espacio textual. Genette (1964) observa que, a primera vista, la obra de Borges parece poseída por el "demonio de la relación” (“demon du rapprochement') o de la manía que la tradición universitaria llama "estudio de fuentes." Algunos de sus artículos se reducen a un catálogo de diversas entonaciones, a través de los siglos, que ha tomado una idea, un tema, una metáfora. Genette encuentra en esta manía la "concepción de la literatura de Borges" que resume en la frase de Tlön: “.... se ha establecido que todas las obras son obra de un sólo autor, que es intemporal y es anónimo” (p. 324). Llevando la observación de Genette hacia mis propósitos, agregaría que "el demonio de la relación” es otra manifestación del espacio del texto donde la traducción "trabaja."

Afirmar hoy que el espacio del texto reside en la traducción, encontrar en los textos de Borges esta actividad, no es sino parte del proceso en el cual la épistémè moderna intenta resolver el problema del signo y el referente, de la copia y del simulacro. La noción de traducción desplaza la barra entre significante y significado para situarla entre el signo y el objeto. Tal operación se encuentra en Frege (1892) cuando interpone la representación entre el signo, la referencia y el sentido. Según Frege “.... no existe ninguna objeción para hablar del sentido sin más, en el caso de la representación, en cambio, para ser estrictos, hay que añadir a quién pertenece y en qué momento" (pp. 54-55). O, de otra manera, "La referencia de un nombre propio es el objeto mismo que designamos con él; la representación que tenemos entonces es totalmente subjetiva; entre ambas se halla el sentido, que ciertamente ya no es subjetivo como la representación, pero, con todo, tampoco es el objeto mismo” (p. 55). La barra entre el signo y el objeto opera, en Borges, como generador, ausente, no mencionado, oculto bajo el texto pero forzando en éste el desplazamiento del objeto. Cito sólo algunos ejemplos: “Las Kenningar” (1933) se multiplican en los signos “del otro lado" de la barra, traduciéndose unas en otras; en "La metáfora” (1936), se corrige la concepción aristotélica en cuando ésta funda "la metáfora sobre las cosas y no sobre el lenguaje.” ¿Qué mejor ejemplo, además, de la presión de la barra cuando, al hablar de Carriego ("Una vida de Evaristo Carriego" [19301), el indefinido "una” deja abierto el campo de la significación en relación al objeto? Como si el título no fuera suficiente para marcar la multiplicación del objeto en el proceso de la significación, antes de llegar a escribir la primera frase afirmativa "Carriego era entrerriano, de Pararia” (p. 34), el discurso se propone como traducción y transformación de la información, de la regulación de sentidos dispersos dejando, a la vez, el lugar para otros dispositivos y para otras transformaciones: "Poseo recuerdos de Carriego: recuerdos de recuerdos de otros recuerdos, cuyas mínimas desviaciones originales habrán oscuramente crecido, en cada nuevo ensayo. Conservan, lo sé, el idiosincrásico sabor que llama Carriego y que nos permite identificar un rostro en una muchedumbre" (p. 33). En el universo del sentido, como proceso textual de la significación, la traducción opera antes de la clasificación (discursos filosóficos, literarios, científicos) transformando las informaciones del espacio textual al confrontar la trayectoria de 
una metáfora, de una idea, de una definición, de la historia de un nombre o de la historia (universal) de la infamia.

La tradición posterior a Frege acentuó el aspecto ontológico de la polémica signo/ referente. Quine (1962) ofrece un resumen y propone una solución al sugerir que lo importante no es lo que hay sino lo que alguien dice que hay. Por lo tanto, la controversia ontológica se reduce a una controversia de lenguaje (conceptual) que debe tomarse en forma análoga a nuestra aceptación de una doctrina científica: adoptamos el esquema conceptual más sencillo en el cual sea posible ordenar lo desordenado. La barra entre el signo y el objeto tiene consecuencias importantes en la filosofía de la ciencia. El rechazo de la tesis ontológica de la referencia en Quine tiene como correlato en Popper (1935) el rechazo de las teorías “existencialistas.” Estas son reemplazadas por el constante movimiento, en el universo de la significación, de las conjeturas y de las refutaciones (de la traducción): la barra entre el signo y el objeto derrumba la doctrina de una realidad última y con ella la doctrina de una explicación última. Que este hecho, como problema y no como receta, sea uno de los generadores de los textos borgianos no parece estar en cuestión. A cada paso, antes de que el texto sea producido, la separación de la referencia funda, genera, el enunciado. En el mundo de la traducción, no hay diferencias entre el texto literario y el científico dado que antes de ser literarios o científicos son textos: las discusiones que libra Popper contra las teorías existencialistas que pretenden llegar a la verdad última, en vez de pensar las teorías como un mundo de traducción y de transformación, es también una asunción de los metafísicos de Tlön quienes "Saben que un sistema no es otra cosa que la subordinación de todos los aspectos del universo a uno cualquiera de ellos” (1940, p. 23).

Este fenómeno nos sitúa en un aspecto del proceso de producción de la significación: las formas textuales en el movimiento de la épistémè. El discurso clasificado analógico (quizás sea esta una de las bases del concepto de mimesis) puede concebirse como el discurso que re-produce el objeto simbólico normativizado por la referencia, sea este discurso del orden de la figura, de la sintaxis, del léxico, etc. La norma cambia de un período a otro, pero, a su vez, se conservan las reglas básicas sobre las cuales un discurso puede ser clasificado como analógico. En forma general, esta regla podría esquematizarse como continuidad sintáctica y semántica (Kristeva, 1968). En tanto que para un discurso clasificado como discontinuo valdría la regla de la discontinuidad sintáctica y semántica. En un discurso natural, “Juan llegó a casa, se bañó y luego se desvistió” o "A las ocho Juan llegó a casa al mismo tiempo que tomaba un tren para California” son frases que alteran la continuidad. En ambas, la relación de contigüidad (adyacencia, inmediatez) entre "bañarse/desvestirse”, "llegar a casa/tomar el tren”, produce un efecto disruptivo en la continuidad (sin interrupción) como alteración del esquema de la referencia: no es “común” que alguien este, a la vez, en dos lugares distintos. El discurso analógico, por lo tanto, sería aquel tipo de discurso que respeta la continuidad en la contigüidad; es discontinuo aquel que opera 
una alteración de la continuidad y en el cual nuestra intuición reconoce una ruptura entre dos hechos (sintagmas) adyacentes. Es posible intuir que los relatos de Borges (así como cierta literatura posterior; e.g. los cuentos de Cortazar, Farabeuf de Elizondo) se articulan sobre la discontinuidad. Ahora bien, si la discontinuidad puede concebirse como un tipo especial de contiguidad entre dos "mundos posibles," se podrían sugerir sus características formales de la manera siguiente:

1) El elemento $a$ tiene la función $x$ en el "mundo posible" $X_{1}$.

2) El elemento $a$ tiene la función $y$ en el "mundo posible" $X_{2}$.

3) $X_{1}$ y $X_{2}$ son "mundos posibles” en relación (R) de contiguidad.

Sería todavía posible integrar a los “axiomas” precedentes, un operador (P) en el cual se especificarían las características de las dependencias semánticas de continuidad y de discontinuidad como "predicados de segundo orden", determinando la relación primaria de contigüidad. Este esquema podría proseguirse en un desarrollo formal de algún modelo topológico en el cual sería posible especificar un punto móvil o flotante, donde diríamos que $a$ tiene la función y según la posición de $\mathrm{X}_{2}$. (Volveré sobre este punto en IV.b.) Como todo modelo formal, este desarrollo nos llevaría a especificar las regularidades lógicas de las relaciones de continuidad, contigüidad, discontinuidad. Antes de sugerir esta posibilidad, y teniendo en cuenta las observaciones anteriores en relación a discursos concretos (los de Borges), me detendré en algunas ambigüedades interpretativas provocadas por los fenómenos discontinuos para, en un segundo momento, sugerir ciertos desplazamientos en la "zona conceptual.” Estos conducen, por un lado, a caracterizar los rasgos discursivos de la discontinuidad y, por otro, a volver sobre las "condiciones de la interpretación."

En “El Sur” (1953), el momento de contigüidad de dos acontecimientos narrativos (fin de la hospitalización/viaje al Sur) puede ser reconocido como continuo (es “común” después de ser hospitalizado tener un período de reposo). No obstante, reconocemos en esta relación de superficie un elemento de discontinuidad porque no “estamos seguros” (no es posible decidir) si "realmente” fue al campo o no. Esta interpretación es derivada de una asunción de base: el discurso analógico que justifica la expresión “si realmente fue al Sur.” Este tipo de interpretación (y sus variantes) son conocidas. Gertel (1971, pp. 35-55) facilita el trabajo citando algunas de ellas: Allen Phillips (1963) considera dos lecturas, una lineal (continua) y otra en la cual el viaje al sur es incluido como sueño. La relación de inclusión (como bien señala Gertel desde otra perspectiva) es una lectura basada en el discurso analógico: la causa del sueño es el golpe en la frente y la fiebre que provoca. Alazraki (1968) propone, basado en la sugerencia de Borges (posdata de 1956, p. 116: “'El Sur’ puede ser leído como sucesión de hechos novelescos y también de otro modo”) que “En 'El Sur' ese otro modo sería leerlo como cifra de la historia argentina toda; este sentido se trasluce leyéndolo en el contexto de otro cuento -'Martín Fierro’- donde Borges aborda el tema de la historia argentina y la reduce a su símbolo: 'un pobre duelo a cuchillo’” (p. 107). Ese "otro modo" es el que marca el cuento en su construcción discontinua. 
Gertel caracteriza esta interpretación como “sentido trascendente del cuento” (p. 39). A su vez, propone (en forma de resumen) tres posibilidades de lectura: 1) la lectura lineal, de continuidad narrativa; 2) la interpretación de la secuencia viaje al sur como imbricación de lo "imaginario" en lo "real”; 3) Dahlmann regresa, después de la muerte, a un pasado anacrónico a vivir su propia muerte. Esta interpretación, sugerida por C. Wheelock (1969), es la que conviene retener de acuerdo a mis propósitos en la medida en que muestra la realización de un mismo hecho (la muerte de Dahlmann) como punto móvi1 entre dos "mundos posibles."

Al destacar la sugerencia de Wheelock no es mi propósito favorecer esta interpretación sobre las otras, sino considerar las condiciones de interpretación en relación a la formulación del principio de discontinuidad. Intentaré, entonces, describir rápidamente tales artificios discursivos retomando los “axiomas” 1, 2 y 3 (página 363).

4) “El Sur,” título, puede ser articulado como punto móvil que conecta dos "mundos posibles" ("axiomas” 1 y 2): el sur pasado y el sur presente; la primera muerte, la segunda muerte. Las intervenciones del narrador ("Ciego a las culpas, el destino puede ser despiadado con las mínimas distracciones” (p. 188) y “A la realidad le gustan las simetrías y los leves anacronismos” (p. 189) construyen sintagmas paralelos: "Dahlmann había conseguido” para la primera, "Dahlmann había llegado" para la segunda.

5) Estos hechos permiten inferir (“axioma” 3):

5.a) Los acontecimientos son continuos considerados en su construcción paralela.

5.b) Los acontecimientos son discontinuos considerados en su dependencia semántica entre diferentes "mundos posibles," cf. 4.

Por cierto que hay un salto entre las características discursivas señaladas y la interpretación de una segunda lectura como sueño causado por la fiebre. El salto es también una reducción: implica leer lo discontinuo según el modelo de la interpretación de lo continuo. Por ejemplo, Gertel (1971) sugiere que “el momento final de la historia real y la fantástica ocurren en el mismo instante temporal” (p. 37; subrayado agregado). La discontinuidad del mismo instante (como punto móvi1) en dos "mundos posibles," es reducida a la continuidad cuando éstos son concebidos como "fantástico y real”: aplicación del paradigma copia/simulacro a un texto que la cuestiona.

Del análisis anterior se deriva que si postulamos el discurso discontinuo como transformación del discurso analógico, operamos un desplazamiento (epistemológico) en la organización del programa que genera la descripción de modelos. Al mismo tiempo, identificamos estructuras particulares como estructuras emergentes. El desplazamiento operado indica (en la teoría y en aquellos textos en los cuales tales estructuras pueden ser definidas) zonas emergentes como manifestaciones parciales relacionables con procesos paralelos en otras áreas conceptuales. El proceso de (re)distribución de la épistémè que, para el caso de la ciencia física, sugería (por los 
mismos años de varios textos de Borges) G. Bachelard (1934, 1940), se toca con los problemas de la teoría del texto y de la práctica textual. El "nuevo espíritu científico" exige, en la concepción de Bachelard, una epistemología adecuada a su emergencia; una epistemología integral que trace el ámbito operativo de cada hipótesis, de cada concepto y que sea convergente con ella. Parafraseando, podemos agregar que "el nuevo espíritu textual” necesita también de una epistemología diferencial que trace el ámbito operativo de las estructuras textuales emergentes y de los modelos que dan cuenta de ellas.

\section{MODELO NARRATIVO, ESPACIO TOPOLOGICO Y “MUNDOS POSIBLES”}

En la sección III he intentado señalar de qué manera la barra entre el signo y el objeto genera estructuras discursivas particulares paralelas a la emergencia de una epistemología no-cartesiana que se diseña en la macro y en la micro física (Bachelard, 1934; Reichenbach, 1951). La interferencia de esta epistemología en el campo de las “ciencias humanas” lleva a comprender que en el análisis de los procesos de “comunicación” es necesario elaborar una zona conceptual adecuada a las preguntas que provoca la emergencia de estructuras textuales. El problema reside, como ha sido señalado en I, en especificar la convergencia entre ZTE y ZCE. Ha sido también sugerido que esta convergencia puede intuirse en relación al dispositivo epistémico signo/referente, como dispositivo común a la práctica textual y a la práctica conceptual. Sobre este último punto Bachelard señala que el filósofo, anterior a la emergencia de la epistemología no-cartesiana, cree a menudo que una noción es el substituto de una cosa, en vez de concebir que una noción es un momento (de transformación) en la evolución del pensamiento (1940: 50). Podemos encontrar el correlato borgiano en “La postulación de la realidad” (1932) y “La penúltima versión de la realidad” (1932) sin mencionar el acento puesto sobre este aspecto por la ya conocida elaboración de M. Foucault (1966).

El objetivo de esta sección es el de discutir, a base del contexto epistemológico señalado, posibles modelos de análisis de estructuras textuales emergentes referidas antes por la noción de discontinuidad. En IV.a, discutiré la limitación de los modelos narrativos disponibles para describir y explicar ciertas estructuras textuales. Esto no es una crítica al modelo per se sino, más bien, un caso concreto en el cual estructuras textuales y estructuras conceptuales entran en conflicto y en movimiento. En IV.b, desarrollaré, desde otra perspectiva, un modelo topológico a partir de los "axiomas" 1, 2 y 3 (página 363).

IV.a. En el sentido convencional de la palabra, el relato se concibe y construye por sucesivos acoplamientos de elementos antropomorfizados (Greimas, 1966: 117; Bremond, 1966: 76). Esta primera constatación puede tener diferentes derivaciones y correlaciones entre práctica y modelos. Estos se resumen en el esquema que sigue: 

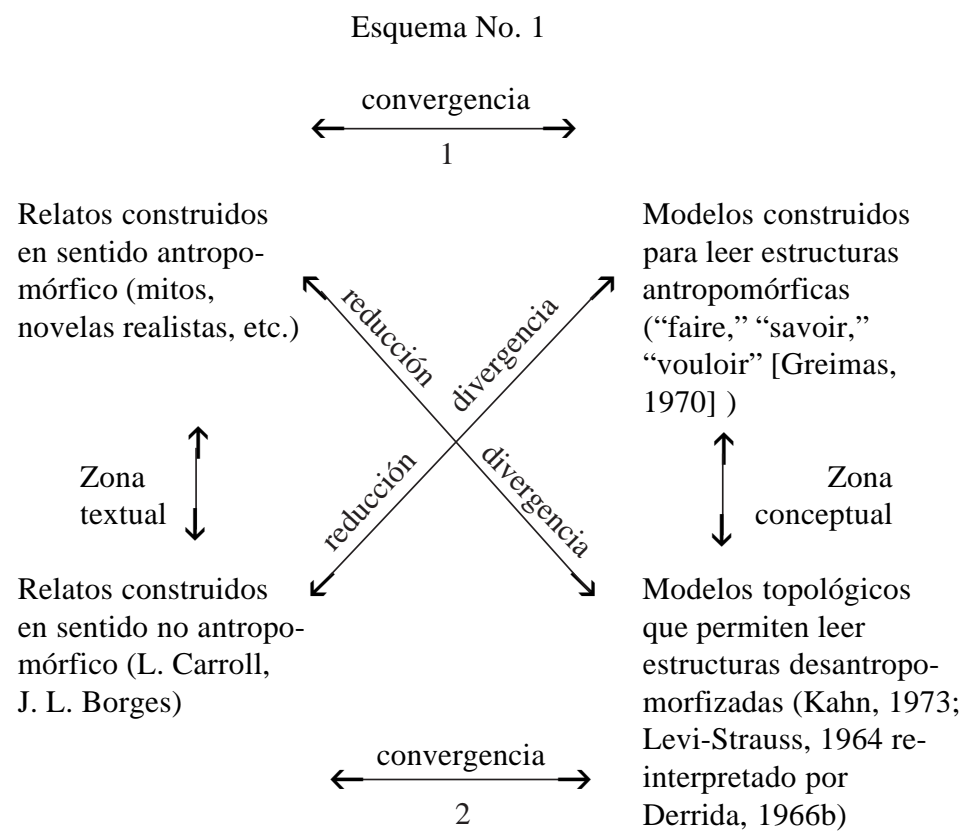

Las convergencias en (1) corresponderían a la familia lógica aristotélica, geometría euclidiana, estructuras narrativas continuas, modelos narrativos antropomorfizados; en tanto que las convergencias en (2), a la familia lógica no-aristotélica ("manyvalued logic”), geometría noeuclidiana, relatos discontinuos y modelos desantropomorfizados. Como indicación general de estas correspondencias, baste recordar lo siguiente: Bachelard (1940) observa que la teoría de la relatividad desplaza la noción de simultaneidad del rango de noción evidente al rango de noción definida bajo condiciones experimentales explicitas. En la misma línea de reflexión, Reichenbach $(1927 ; 1951)$ insiste en la necesidad de la definición coordinativa exigida por las geometrías no-euclidianas, en las cuales el enunciado $a$ y también el enunciado no- $a$ pueden ser probados.

Como resultado se acepta la existencia de varias y no sólo de una geometría. El aparente e insoluble problema es un pseudo-problema si se tiene en cuenta que los axiomas de una teoría no son verdaderos ni falsos sino arbitrarios. La misma exigencia de definición coordinativa es aplicada a la noción de tiempo. Reichenbach (1927), extendiendo los resultados de la física relativista a la epistemología, llega a demostrar que la "simultaneidad" de dos acontecimientos es una decisión imposible en base a la "experiencia humana." Por lo tanto, ella debe ser tratada como definición coordinativa 
(pp. 123 y ss.). O como lo señala también Bachelard (1940: 120), la lógica aristotélica, indispensable para la vida común, no tiene por qué ser generalizada.

Los modelos del relato, en su forma estructural (Todorov, 1969; Bremond, 1966; Greimas, 1970) o generativa (van Dijk, 1970; Pavel, 1973), son modelos antropomórficos y como tales, continuos. Antropomórficos por las articulaciones del "vouloir," "savoir," "faire”; continuos porque en la relación entre las proposiciones que forman una secuencia, la continuidad selecciona la realización de una de dos posibilidades: acción a cumplir/proceso de cumplimiento o ausencia de proceso/éxito o fracaso de la acción a cumplir. En otras palabras, el proceso de la secuencia implica un proceso de selección en el cual una y sólo una de las posibilidades se actualiza. No es este el caso en algunos relatos de Borges, en los cuales no hay selección ya que todas las posibilidades se cumplen. No obstante, en los relatos de Borges, como en cualquier otro, las dos lecturas son posibles y a ello se ha hecho referencia, en el punto anterior, al hablar de “interpretación lineal” (lectura antropomórfica) y de relación entre “mundos posibles” (lectura desantropomorfizada). Esta segunda vía permite ver los relatos de Borges no tanto como analogía con la “acción humana”, sino como derivaciones de sus discusiones teóricas. Un buen ejemplo lo constituye "Nueva refutación del tiempo” (1946) en el cual la discusión teórica se ve interrumpida por "un cuento" que interfiere en la demostración pero que, a la vez, es parte de ella. A la inversa, es común encontrar en los relatos intervenciones teóricas que los interrumpen, pero que, a la vez, forman parte de ellos: "La muerte y la brújula” (1942), por ejemplo, se proyecta constantemente sobre las indagaciones cabalísticas, las reflexiones sobre la paradoja de Zenón, las reflexiones sobre la circularidad del tiempo, etc.

Ahora bien, de que manera sería posible -a partir de las consecuencias extraídas del esquema 1- relacionar la conceptualización del “tiempo" en la filosofía de la ciencia con las estructuras particulares de algunos relatos de Borges y con modelos narrativos que las representan? Comencemos con dos ejemplos de "El jardín de senderos que se bifurcan” (1941): el primero es una “discusión teórica”; el segundo, el esquema narrativo derivado de tal discusión.

(1) A diferencia de Newton y de Schopenhauer, su [Ts'ui Pên] antepasado no creía en un tiempo uniforme, absoluto. Creía en infinitas series de tiempos, en una red creciente y vertiginosa de tiempos divergentes, convergentes y paralelos. Esa trama de tiempos que se aproximan, se bifurcan, se cortan o que secularmente se ignoran, abarca todas las posibilidades. No existimos en la mayoría de esos tiempos; en algunos existe usted y no yo; en otros, yo, no usted; en otros, los dos. En 6ste, que un favorable azar me depara, usted ha llegado a mi casa; en otro, usted, al atravesar el jardín, me ha encontrado muerto; en otro, yo digo estas mismas palabras, pero soy un error, un fantasma [pp.109-110].

(2) En todas las ficciones, cada vez que un hombre se enfrenta con diversas alternativas, opta por una y elimina las otras; en la del casi inextricable Ts'ui Pên, 
opta -simultáneamente- por todas. Crea, así, diversos porvenires, diversos tiempos, que también proliferan y se bifurcan. De ahí las contradicciones de la novela. Fang, digamos, tiene un secreto; un desconocido llama a su puerta; Fang resuelve matarlo. Naturalmente, hay varios desenlaces posibles: Fang puede matar al intruso $\left[E_{2}\right]$, el intruso puede matar a Fang $\left[E_{3}\right]$, ambos pueden salvarse $\left[\mathrm{E}_{4}\right]$, ambos pueden morir[ $\left.\mathrm{E}_{5}\right]$, etcétera. En la obra de Ts'ui Pên, todos los desenlaces ocurren; cada uno es el punto de partida de otras bifurcaciones [p. 107].

Por cierto que sería poco satisfactorio “aplicar” en estos casos el modelo narrativo continuo, según el cual el "acto a cumplir” puede tener "un proceso de cumplimiento” o "no tenerlo,” etc. El modelo narrativo continuo toma una sola línea como "real” y reduce las otras alternativas no realizadas: lo realizado excluye automáticamente las otras posibilidades y el tiempo es representado de manera unidireccional. Los ejemplos de Borges anulan el dominio de las alternativas "no realizadas”, dado que todas ellas son igualmente posibles y todas se cumplen. No se trata aquí de variantes sino de una historia que abarca alternativas incompatibles en un sistema ramificado. Por lo tanto es en la "lógica multivalente" donde podemos encontrar modelos más adecuados para representar estas características (Rescher, 1968: 54-111).

Supongamos una secuencia de acontecimientos $\mathrm{E}_{1} \ldots \mathrm{E}_{2} \ldots \mathrm{E}_{4}$. El modelo narrativo continuo, de tiempo unilineal, asume que si el acontecimiento $E_{1}$ es la causa de $E_{2}, E_{1}$ es anterior a $\mathrm{E}_{2}$. En estos casos hay siempre una marca en el acontecimiento (Reichenbach, 1927: 36) o en la organización narrativa del acontecimiento (Barthes, 1966: 11-14) que permite tal decisión. En un modelo de alternativas ramificadas, podemos ver la serie $E_{1} \ldots E_{2} \ldots E_{4}$ como una entre varias: $E_{1} \ldots E_{2} \ldots E_{5}, E_{1} \ldots E_{3} \ldots E_{6}$, etc. Antes de proseguir este desarrollo, es conveniente relacionar el esquema abstracto con los ejemplos borgianos. Traduzcamos las proposiciones de la cita (2) a las secuencias alternativas de acontecimientos que acabamos de esquematizar:

Fang, digamos, tiene un secreto $\left(\mathrm{E}_{0}\right)$

Un desconocido llama a la puerta $\left(\mathrm{E}_{1}\right)$

Fang puede matar al intruso $\left(\mathrm{E}_{2}\right)$

El intruso puede matar a Fang $\left(\mathrm{E}_{3}\right)$

Ambos pueden salvarse [Fang se salva $\left(\mathrm{E}_{4}\right)$; el intruso se salva $\left.\left(\mathrm{E}_{5}\right)\right]$

Ambos pueden morir [Fang muere $\left(\mathrm{E}_{6}\right)$; el intruso muere $\left(\mathrm{E}_{7}\right)$ ] etcétera

Todas estas posibilidades pueden ser representadas en un diagrama en forma de árbol (Prior, 1957; Rescher y Urquhart, 1971: 68-76). 
Esquema No. 2

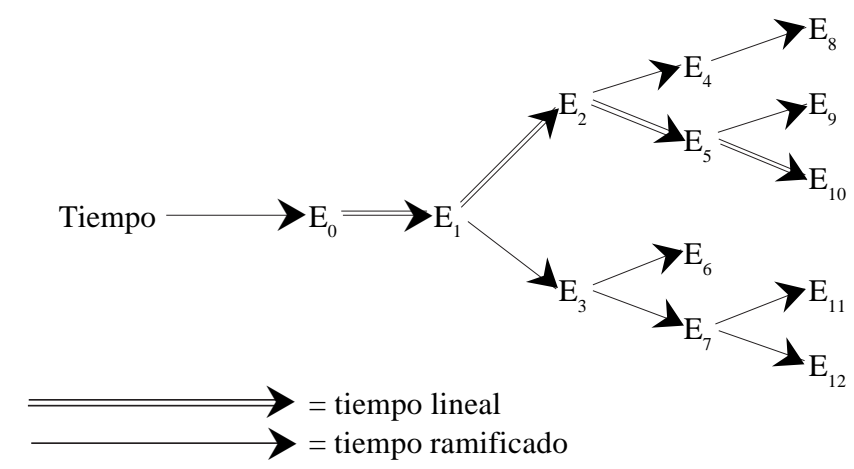

El modelo ramificado de la lógica temporal y las estructuras ramificadas de los relatos de Borges, trastornan el concepto newtoniano-kantiano de la dimensionalidad temporal (Kant, Crítica de la razón pura, Libro I). La diferencia entre ambas radica en que el modelo kantiano permite una posible configuración de acontecimientos (una historia), en tanto que el modelo ramificado, la configuración de posibles acontecimientos (varias historias). El modelo lineal toma una secuencia $\left(\mathrm{E}_{1}, \mathrm{E}_{2}, \mathrm{E}_{5}\right.$, $\mathrm{E}_{10}$ )y deja las otras como alternativas posibles. En “El jardín...”, por el contrario, todas se realizan simultáneamente. En "La otra muerte” (1949) el “escándalo de la razón” (p. 79) proviene de la realización de dos alternativas en conflicto que crean “...dos historias universales. En la primera $\left[\mathrm{E}_{1}, \mathrm{E}_{2}, \mathrm{E}_{10}\right]$ Pedro Damian murió en Entre Ríos, en 1946; en la segunda $\left[E_{1}, E_{3}, E_{7}\right]$ en Masoller, en 1904” (p. 78).

Recomencemos y tratemos de explicitar el funcionamiento de este modelo en relación al modelo lineal. Supongamos un relato en el cual puede definirse un número finito de secuencias $\mathrm{S}_{1}, \mathrm{~S}_{2}, \mathrm{~S}_{3} \ldots \mathrm{S}_{\mathrm{n}}$. El modelo narrativo deberá tener en cuenta una lista sucesiva de ellas a través de una expansión temporal, desde el intervalo emésimo (inicial) hasta el intervalo enésimo (final):

$$
s(m), s(m+1) \ldots . . s(n-1), s(n)
$$

Supongamos que nuestro propósito es analizar una secuencia cualquiera $\mathrm{S}_{\mathrm{i}}$ que puede ser descrita como Prohibición, Transgresión, Prohibición violada. Por s(i) representamos una proposición cualquiera de la secuencia. Para cada caso, s(i) depende de un tiempo específico t(i). Las secuencias del relato están entonces sujetas a varias leyes de transición que rigen tanto el orden de las proposiciones como el de las secuencias. Una de ellas podría ser deterministica (Rescher y Urquhart, 1971:163) expresada: "si $s(\mathrm{i})_{\mathfrak{t}}$, entonces $\mathrm{s}(\mathrm{j})_{\mathrm{t}}+_{1}$." Con un ejemplo, "si el brujo pide a la princesa que vaya al jardín [s(i) en un tiempo (t)], entonces la princesa va al jardín [s(j) en un 
tiempo posterior $(\mathrm{t}+\mathrm{l})]$.” Otra podría ser probabilística. A esta ley refiere Bremond (1964: 9-10) cuando menciona que en el proceso de construcción del relato, el narrador tiene la libertad de elegir entre varias probabilidades: la ley determinística remite a la secuencia realizada; la ley probabilística remite al proceso de realización de la secuencia. En consecuencia, esta ley puede ser resumida: "Si s(i), entonces $\left.\mathrm{s}_{\mathrm{t}} \mathrm{j}_{1}\right)$ o $s\left(\mathrm{j}_{2}\right)$ o $\mathrm{s}\left(\mathrm{j}_{3}\right)$ en $\mathrm{t}+\mathrm{l}$." Siguiendo el ejemplo anterior "Si el brujo pide a la princesa que vaya al jardín [s(i) en un tiempo $(\mathrm{t})]$, la princesa $o$ va al jardín $\left[\mathrm{s}\left(\mathrm{j}_{1}\right)\right]$ o va a su habitación $\left[s\left(j_{2}\right) \ldots\right.$ en un tiempo $\left.(t+l)\right]$.” En fin, una tercera ley correspondería a la realización de secuencias en un tiempo ramificado : "Si s(i), entonces $s\left(\mathrm{j}_{1}\right)$ y $\mathrm{s}\left(\mathrm{j}_{2}\right) \ldots$ en un tiempo $(\mathrm{t}+\mathrm{n})$.” Siguiendo el mismo ejemplo, "La princesa va al jardín y a su habitación y al lago en diversos tiempos $(\mathrm{t}+\mathrm{n})$ todos los cuales son simultáneos y posteriores a ( $\mathrm{t})$.” $\mathrm{O}$, lo que es lo mismo, Fang mata al intruso y el intruso mata a Fang, etc. Esta última ley puede tener otras derivaciones y una de ellas la practica Borges en "La obra de Herbert Quain” (1941). En la tercera ley, que corresponde al esquema 2, la representación es de izquierda a derecha. No obstante, es posible pensar en una ramificación de derecha a izquierda a partir de s(i). En este sentido, "La obra de Herbert Quain” no sólo sería otro ejemplo de ramificación temporal y de trastorno de la concepción monodimensional del tiempo, sino que trastornaría el espejismo de la relación narrativa “causa/efecto” que produce el relato continuo en el cual, lo que viene después se nos presenta como causado por lo que ocurrió antes (Barthes, 1966: 11-14).

Las consecuencias epistemológicas de la práctica borgiana adquieren mayor sentido si a las conexiones sugeridas anteriormente (Bachelard, Reichenbach) agregamos el paralelismo que existe entre el "mundo borgiano" y el "mundo de la física cuántica” (DeWitt, 1970). En ésta, el universo es concebido como constante automultiplicación, como una multiplicidad de "sub-mundos," cada uno de ellos posible de ser medidos cuánticamente. En esta perspectiva, el cosmos es la contrapartida de la superposición lineal de vectores, cada uno de los cuales representaría realidades observables como realidades realizadas. Por el contrario, según la visión cuántica, la situación del observador que mide el resultado en el sub-mundo, conduce al hecho paradójico de la pérdida de otros sub-munds ${ }_{2},{ }_{3}, 4 .$. en los cuales la "realidad” de otros observadores entra en conflicto con la nuestra. En otras palabras, en "el mundo en que vivimos" tendemos a pensar la distinción entre el "mundo actual” y otros "mundos posibles” pero no realizables. La teoría cuántica lleva al extremo el desplazamiento antropocéntrico de la concepción del mundo y de la epistemología no-cartesiana. En forma paralela el desplazamiento epistemológico de las propuestas de Borges, llevan a pensar que si no reconocemos otros mundos más que el de nuestra experiencia diaria y familiar, es debido a nuestras restricciones antropocéntricas.

IV.b. Retomemos los “axiomas” 1, 2 y 3 desde otra perspectiva:

A) La dependencia semántica entre “mundos posibles.” 
B) La situación del “punto móvil” en las dependencias semánticas entre mundos posibles.

Con respecto a (A), podemos pensar en un “modelo semántica extendido” en el cual el complejo de rasgos semánticas se organiza mediante dos tipos de reglas: 1) un conjunto de reglas que especifique los campos isotópicos (Greimas, 1966: 69-100); 2) un conjunto de reglas que permita la organización espacial de complejos semánticos. Con respecto a (B), un conjunto que especifique las relaciones entre estos espacios.

El aspecto (A) conduce a concebir el relato, de manera metafórica, como un "universo" semántica compuesto por una cantidad $n$ de "mundos posibles." Si asumimos que los "mundos (son) posibles" unos con respecto a los otros, entonces el modelo narrativo tiene "galaxias" como su objeto de estuido (Kahn, 1973:7). Es desde esta perspectiva que podemos concebir un texto como un espacio (universo). Tal espacio esta compuesto, a su vez, de sub-espacios $\left(\mathrm{X}_{1}, \mathrm{X}_{2}\right)$ cuyos elementos son puntos-semas $\left(\mathrm{x}_{1}, \mathrm{x}_{2}, \mathrm{x}_{3}\right) \mathrm{y}\left(\mathrm{v}_{1}, \mathrm{v}_{2}, \mathrm{v}_{3}\right)$. No me detendré en los requisitos formales del espacio topológico (D. W. Hall, 1955:52-56). Mi objetivo es aquí la posibilidad de concebir tales modelos en la teoría del texto y las consecuencias epistemológicas que de ella pueden derivarse. Basta decir que el texto se define como el conjunto de colecciones, en un espacio $\mathrm{E}$, que son el resultado de las aplicaciones entre los puntossemas (elementos) de un conjunto de sub-espacios $\left(\mathrm{X}_{1}, \mathrm{X}_{2} ; \mathrm{Y}_{1} \ldots \mathrm{Y}_{\mathrm{n}}\right)$. Cada colección constituye un texto parcial (una galaxia). Un espacio textual topológico $\mathrm{T}$ se define en E como colección $\mathrm{T}_{\mathrm{n}}$ de aplicaciones de $\mathrm{X}_{\mathrm{i}}$ en $\mathrm{X}_{\mathrm{n}}$.

Supongamos entonces las posibilidades de "interpretar" (en el sentido de un modelo formal; M. Bunge (1972) los puntos-semas (elementos) de los sub-espacios $\mathrm{X}_{1}$ y $\mathrm{X}_{2}$, (ambos pertenecen a $\left.\mathrm{E}\right)$ :

$$
\begin{aligned}
& \mathrm{X}_{1}: \mathrm{x}_{1}=\text { argentinidad } \quad \mathrm{X}_{2}: \quad \mathrm{v}_{1}=\text { temporalidad } \\
& \mathrm{x}_{2}=\text { incidente } \quad \mathrm{v}_{2}=\text { ruralidad } \\
& \mathrm{x}_{3}=\text { alemanidad (origen de Dahlmann) } \quad \mathrm{v}_{3}=\text { urbanidad } \\
& \mathrm{x}_{4}=\text { accidente }
\end{aligned}
$$

En primer lugar, es necesario observar que tal interpretación esta sobredeterminada por el modelo y responde, además, a una intuición básica de la lectura. Este hecho plantea, a otro nivel, problemas relativos al "criterio de relevancia” a utilizar cuando se trata de interpretar un modelo en relación a realizaciones concretas. Problemas distintos a la relación "mediata” entre el modelo y la interpretación abstraída de realizaciones concretas, puesto que lo que interesa es la construcción del modelo. No obstante, podemos sugerir, en defensa de la arbitrariedad, dos criterios de relevancia en la interpretación anterior: 1) El sur, como espacio, está marcado desde el título; 2) no todo el "cuento" se refiere al sur; además 3) el sur está referido, explícitamente, como temporalidad. La selección de semas en la interpretación es, por lo tanto, una 
“pregunta” que se impone al texto y que permite no la aplicación, sino la “descripción” y el juego entre el modelo y el texto. Este tipo de operación, obviamente, es valida para toda "critica”, con la diferencia de que ésta, en general, no explicita los modelos ni las interpretaciones que de ellos se derivan.

De acuerdo con la definición del texto como espacio, la colección de aplicaciones en los sub-espacios $\mathrm{X}_{1} \mathrm{y} \mathrm{X}_{2}$, dependerá del tipo de relaciones que establezcamos entre los puntos-semas. De modo que estos pueden tener configuraciones diferentes si:

1) Consideramos las isotopías (argentinidad, alemanidad; presente/pasado). 2) Consideramos una isotopía no sólo en sus rasgos semánticas opuestos, sino (también) en su relación con las secuencias de orden narrativo: presente/urbanidad/ruralidad (estancia en el sur); pasado/argentinidad/ ruralidad (sur como "esencia” de lo argentino), etc.

3) Consideramos la organización sémica en relación a un tiempo bifurcado y a la realización de dos acontecimientos en distintos “mundos posibles": la “doble” muerte de Dahlmann.

La justificación de este procedimiento es el siguiente. Podemos imaginar que en el proceso de producción de un texto se introduce cierta información inicial (no importa que en el proceso "real” el párrafo inicial sea introducido cuando el texto esta terminando), sobre la cual se harán depender las informaciones subsiguientes. De cada elemento (lexema) elegido, no es la infinita (o quizás finita pero de número abundante) ramificación posible de semas que el texto (o quien escribe) “elige.” La reconstrucción de este proceso es la determinación de cuales entre los semas posibles de un lexema, se eligen en el texto. Por ejemplo: si el lexema “cordero” aparece en un discurso, éste puede haber sido introducido por algún sema que permite la derivación de lexemas regionales o bíblicos, o, como en el caso de Góngora, por el sema "blancura." Sema que determinará la derivación de un conjunto heteróclito de lexemas tales como “espuma,” “perlas,” “nieve,” “cisnes” (Alonso, 1946: 202). Para ilustrar mejor este mecanismo, podemos comenzar por considerar en "El Sur” la posibilidad de definir varios conjuntos de puntos-semas organizados en sub-espacios:

\begin{tabular}{|c|c|c|}
\hline $\mathrm{X}_{1}$ : & $\begin{array}{l}x_{1} \\
x_{2} \\
X_{3}\end{array}$ & $\begin{array}{l}\text { \{urbano } \\
\text { \{urbano, presente }\} \\
\text { \{urbano, presente, accidente }\end{array}$ \\
\hline $\mathrm{Y}_{1}$ : & $\begin{array}{l}\mathrm{y}_{1} \\
\mathrm{y}_{2} \\
\mathrm{y}_{3}\end{array}$ & $\begin{array}{l}\{\text { rural }\} \\
\text { \{rural, presente }\} \\
\text { \{rural, presente, incidente }\end{array}$ \\
\hline$X_{2}$ : & $\begin{array}{l}\mathrm{v}_{1} \\
\mathrm{v}_{2} \\
\mathrm{v}_{3}\end{array}$ & $\begin{array}{l}\text { \{accidente }\} \\
\text { \{accidente, incidente }\} \\
\text { \{accidente, incidente, argentinidad }\end{array}$ \\
\hline
\end{tabular}




$$
\begin{array}{lll}
\mathrm{Y}_{2}: & \mathrm{w}_{1} & \text { \{alemanidad } \\
& \mathrm{w}_{2} & \text { alemanidad, argentinidad } \\
& \mathrm{w}_{3} & \text { \{alemanidad, argentinidad, rural }
\end{array}
$$

Llegado a este punto, podemos trabajar con dos conjuntos a la vez o tratar, de manera más compleja, de considerar las proyecciones en tres conjuntos (Barbut, 1969: 25). La proyección o aplicación de un conjunto en otro, como se ve, nos permite una combinatoria, si no infinita, al menos de un número elevado de posibilidades. Consideremos un ejemplo de aplicación (relación entre elementos de diversos conjuntos). Tomemos los conjuntos $\mathrm{Y}_{1}, \mathrm{Y}_{2}$ y $\mathrm{X}_{1}$; consideremos una aplicación $f$ de $\mathrm{Y}_{1}$, en $\mathrm{Y}_{2} \mathrm{y}$ una aplicación g de $\mathrm{Y}_{2}$ en $\mathrm{X}_{1}$. En estas aplicaciones, a cada elemento $y$ de $\mathrm{Y}_{1}$, corresponde un elemento $w$ de $Y_{2}: w=f y$. Fórmula semejante para los otros conjuntos, de manera que $g$ es una aplicación de $\mathrm{Y}_{2}$ en $\mathrm{X}_{1}: x=g w$.

Esquema No. 3

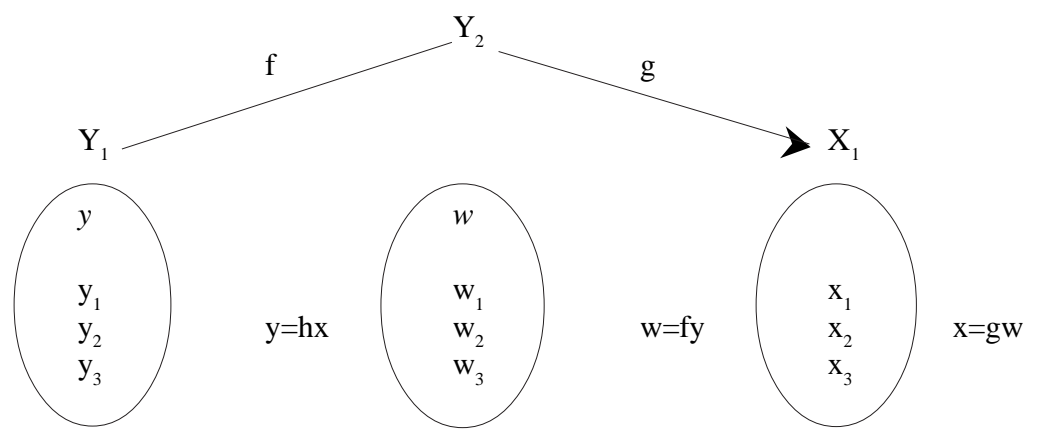

$\mathrm{h}$

Especificando estas relaciones se pueden configurar las colecciones:

$\mathrm{f}_{1}=\{$ rural $\},\{$ accidente $\}$

$\mathrm{f}_{2}=\{$ rural, presente $\},\{$ accidente, incidente $\}$

$\mathrm{f}_{3}=\{$ rural, pasado, incidente $\},\{$ accidente, incidente, argentinidad $\}$

etcétera

En forma semejante, se pueden especificar las aplicaciones $g\left(g_{1}, g_{2}, g_{3}\right)$. Ahora bien si, por definición, $w=$ fy y $x=g w$, por substitución $y=h x$ donde $h$ es una aplicación de $\mathrm{X}_{1}$ en $\mathrm{Y}_{1}$. Esta operación nos conduciría a configurar nuevas colecciones.

El ligero esquema anterior, que no tiene más pretensiones que la de ser una sugerencia más concreta de la modificación del modelo narrativo en un modelo 
semántica extendido (considerando el texto como espacio), deja los siguientes puntos para nuevas consideraciones:

1) En primer lugar, tal esquema es una forma de describir los “axiomas" 1,2 y 3 en donde el operador $(\mathrm{P})$ ha sido aquí considerado como aplicaciones entre conjuntos.

2) En segundo lugar, el esquema nos permite volver sobre las condiciones de interpretación y comprobar que las interpretaciones "críticas" tienen como base no explícita una colección de combinaciones. Lo cual indica que las restantes alternativas son base para otras (múltiples) interpretaciones. Es en este sentido que todo texto (cuento, novela) tiene, a medida que los episodios se expanden, mayores posibilidades combinatorias y, en consecuencia, un aumento considerable de las interpretaciones. Los “mundos posibles” aumentan y de ellos dependen los modelos de interpretación. La emergencia conceptual radica aquí en el énfasis en las condiciones de interpretación (crítica) más que en su realización misma.

Ahora bien ¿de qué manera este modelo captura emergencias textuales? El procedimiento seguido hasta aquí, si bien es cierto que posibilita una modificación del modelo narrativo, también es cierto que su validez se extiende a todo universo narrativo y no sólo a particularidades especificar entre diferentes tipos de narración; como sería el caso de ciertos relatos de Borges.

Es entonces necesario introducir nuevos conceptos para explicitar la relación (R) del "axioma” 3 (pagina 363). El texto moderno se caracterizaría por la particularidad de la relación de contigüidad en la cual un elemento (punto-sema) circula entre dos sub-espacios. En otras palabras, habría siempre un elemento de una aplicación $(w=f y)$ que es el mismo en $w$ y en $y$, pero que resultaría imposible "fijarlo" en $w$ o en $y$. Tomemos de nuevo un ejemplo que, por otra parte, ha sido ya señalado desde otra perspectiva de análisis: Gertel (1971:51) enumera un tipo especial de relaciones entre significante y significado en su análisis de "El Sur." Modificaré algunos de sus resultados.

Significante

1) /roce/

"un leve roce en la cara” (p. 194)

"algo en la oscuridad le rozó la

frente” (p. 188)

2) /coche de plaza/

"Dahlmann había llegado al sanatorio en un coche de plaza y ahora un coche de plaza lo llevaba a Constitución” (p. 189)

\section{Significado}

1) un murciélago, un pájaro

2) una bolita de miga

1) después del accidente (sanatorio)

2) antes del incidente (Constitución) 


$\begin{array}{ll}\text { 3) /Dahlmann/ } & \text { 1) el otro } \\ & \text { 2) el mismo }\end{array}$

"era como si a un tiempo fuera dos

hombres” (p. 191)

En primer lugar, es necesario destacar que el sub-conjunto de significantes está constituido sobre una base relacional diferente a la de los puntos-semas. Por lo tanto, ellos constituyen un nuevo sub-espacio en $\mathrm{E}$ que podemos denominar $\mathrm{S}_{1}$. En su aspecto formal, esta determinación plantearía exigencias de definiciones relacionales entre configuraciones espaciales de diferente base organizacional. Partiendo de la asunción metafórica de que esta operación es posible e intentando relacionar los elementos de $\mathrm{S}_{1}$ \{ /roce/, /Dahlmann/, /coche de plaza/ \} con los elementos de los restantes sub-espacios vemos que, a través del significado, cada uno de ellos circula al menos en dos "mundos posibles" (pares de colecciones). /Roce/ circula entre accidente (pájaro, murciélago) e incidente (bolita de miga); /Dahlmann/ entre alemanidad y ruralidad; /coche de plaza/ entre urbanidad y ruralidad. Este fenómeno es el que determina muchas de las interpretaciones que atribuyen "realidad" a un mundo e "imaginación, sumo, alucinación” a otro. El modelo topológico nos permite, partiendo del mismo hecho, derivar otro tipo de consecuencias. Así, desde una perspectiva formal, estructuras tales como el desplazamiento del punto-significante ofrecen suficientes sugerencias como para extender y modificar el modelo bosquejado en el esquema 3. Podríamos aquí partir del agregado de un sub-índice $w_{\mathrm{s}}=f y_{\mathrm{s}}$, con el cual se incorporaría a la fórmula un nuevo elemento que llevaría a complejizar el modelo formal para dar cuenta de estructuras de este tipo. Desde una perspectiva metafórica, lo que interesa en la movilidad del punto-significante, es que indica una instancia textual como instancia paradojal en la cual el punto-móvil es un punto de doble faz que se desplaza entre diferentes "mundos posibles." Si retomamos la definición de una colección como un texto parcial (galaxia), lo cual sería una línea en el espacio textual topológico en E, podemos dar a esa línea la fuerza de una cadena determinante (Alexandroff y Urysohn, 1929) que "cohere” espacios relacionales divergentes: sémicos, significantes, temporales. Tomando el sub-espacio temporal cuya organización depende de una cadena determinante, podemos trazar -en éste- un tiempo bifurcado que sostiene la realización del mismo hecho en diferentes "mundos posibles”: la muerte de Dahlmann en el sanatorio y la muerte de Dahlmann en el sur. La aplicación del sub-espacio significante en el sub-espacio temporal determinaría la movilidad de cualquiera de los puntos-significantes de $S_{1}$, en los diferentes "mundos posibles” del tiempo bifurcado.

Esta posibilidad de teorización que ofrece el texto moderno escapa a la lógica de lo "real" y de lo "imaginario". En las aplicaciones entre subespacios y entre subespacios y colecciones, las derivaciones epistemológicas adquieren todo su peso: la emergencia del punto móvi1 en el texto y en la teoría del texto. La emergencia del 
punto móvil como estructura (textual) descentrada (como topologización del nudo y expansión de la red) genera un grupo considerable de textos de Borges. "La casa de Asterión” (1957) es una red de la cual cada uno de sus puntos contiene a los otros. Cada nudo contiene a la red: “Todas las partes de la casa están muchas veces, cualquier lugar es otro lugar” (p. 69). Desplazamiento del punto móvil en donde un instante (una parte, un lugar) es todos las partes y todos los lugares [alteración sintáctica: "Nadie está en algún día...”; “La esfera de Pascal” (1951:16) ]. El punto-sema de un subespacio es un punto móvil flotante entre los varios sub-espacios, entre las colecciones haciendo los “mundos (a la vez) posibles”: "Simuló ser Abenjacán, mató a Abenjacán y finalmente fué Abenjacán” [“Abenjacán el Bojarí, muerto en su laberinto” (1952: 134)]. Las citas podrían multiplicarse. Recuerdo "La biblioteca de Babel” que, como "La casa de Asterión, es el punto en constante movimiento.

Las consecuencias epistemológicas de estas propuestas borgianas, sin espacio ya para extenderme en ellas, las resumo en el borde: recuerdo la discusión capital de Derrida (1967b) en torno al “centro” (punto fijo) y a la “estructura descentrada," cito, larga y libremente, a Michel Serres (1972):

He aquí cómo, a mi parecer, se plantea el problema del punto fijo. Kant pasa, no sin razón, por haber llevado a cabo la revolución copernicana en la filosofía. Ahora bien, una lectura atenta de los pensadores de la edad clásica revela que el problema del centro del mundo es también, entre ellos, un modelo o una proyección en el espacio cósmico de un problema más general que es el del punto fijo, cualquiera sea su naturaleza. A nivel de los modelos, la variación recorre los dominios del saber teórico o práctico: el punto fijo puede ser el punto de equilibrio o de apoyo de la estática, el centro de gravedad, el polo de un movimiento cinemática, el origen de la referencia en general ... la invariante de una transformación, es decir, el elemento irreductible de la estabilidad y de la referencia.... En dos palabras, el problema del punto fijo, postulado formalmente, revela una estructura común a los filósofos del clasicismo, estructura que modela todas las regiones de la enciclopedia, de las matemáticas a la mecánica, de la tecnología a la metafísica, de la visión histórica a la meditación religiosa (p. 136).

Agreguemos: de la practica textual a la teoría del texto. Borges lo trastorna en la practica textual; la teoría del texto comienza a descentrarlo.

University of Michigan

WALTER MIGNOLO

\section{NOTAS}

1 “Traducción. Figura Rhetórica de que se usa repitiendo una misma palabra en diversos sentidos. ...se sigue muy bien a estas porque tiene esta representación de palabras, y pudiera 
sentarse entre las de mutación, o trastrueque" (Diccionario de Autoridades; subrayado agregado).

2 No me refiero a los autores, sino a las interpretaciones que contienen los libros citados. Ambos, Barrenechea y Alazraki, han modificado estas primeras aproximaciones y ellas (como ejemplo de la zona conceptual emergente) tienen cercanas relaciones con algunas de las proposiciones de este artículo (cfr., A. M. Barrenechea: "Borges y la narración que se autoanaliza”, NRFH, XXIV, 2, (1975); 515-527); J. Alazraki: “Tlön y Asterión: Anverso y reverso de una epistemología”, Nueva narrativa hispanoamericana, Vol. 1, No. 2 (1971); 21-33.

3 La paginación de las citas de Borges refieren a Obras Completas (Buenos Aires: Emecé Editores, 1954). Para las fechas señaladas en cada texto me sirvo, además de las que están marcadas por el mismo Borges, de Horacio J. Becco, Jorge Luis Borges; Bibliógrafa Total (1923-1973) (Buenos Aires: Casa Pardo S.A., 1973) y de la bibliografía compilada por A. M. Barrenechea (1957). Las fechas importan en relación a los cambios epistemológicos en las ciencias físicas (Reichenbach, Bachelard).

\section{REFERENCIAS}

Alazraki, Jaime

1968 La prosa narrativa de Jorge Luis Borges (Madrid: Gredos). Alexandroff, Paul y Urysohn, Paul

1929 Memoire sur les espaces topologiques compacts (Amsterdam:

Alonso, Damaso

1946 Ensayos sobre poesía española (Buenos Aires: Revista de Occidente, Argentina).

Bachelard, Gaston

1934 Le nouvel esprit scientifique (10a edición; Paris: P.U.F., 1968).

$1940 \quad$ La philosophie du non (Paris: P.U.F.).

Barbut, Marc

1969 Mathématiques des sciences humaines: I-Combinatoire et algèbre

Barrenechea, Ana María (Paris: P.U.F.).

1957 La expresión de la irrealidad en la obra de Jorge Luis Borges (México: El Colegio de México).

Barthes, Roland

1966 "Introduction à l'analyse structurale des récits," Communications, $8,1-27$.

Bremond, Claude

1964 "Le message narratif," Communications, 4, 4-32.

1966 "La logique des possibles narratifs,” Communications, 8, 60-76. 
Bunge, Mario

1972

Deleuze, Gilles

1969

Derrida, Jacques

1967a

1967b

DeWitt, B.S.

1970

van Dijk, Teun A.

1970

Ducrot, Oswald

1968

Foucault, Michel

1966 Les mots et les chases (Paris: Gallimard).

Frege, Gottlob

1892

Fuentes, Carlos 1969

Genette, Gerard

1964

Gertel, Zunilda

Greimas, A.J.

1966

1970

Hall, D.W. 1955

Hempel, Carl G. 1965

Jakobson, Roman

1960 García Molina y J. Sempre (Barcelona: Ariel), 9-38.

Logique du sens (Paris: Minuit).

De la grammatologie (Paris: Minuit).

L'écriture et la différence (Paris: Seuil). (Barcelona: Ariel, 1973). (Paris: L’Herne), 323-327.

Sémantique structurale (Paris: Larousse). Seuil), 157184.

Elementary Topology (New York: John Wiley). “

“Conceptos de modelo,” en M. Bunge Teoría y realidad, Trad. J.L.

“Quantum Mechanics and Reality,” Physics Today (Sept.), 30-35.

“La meteteoria del raconto,” Strumenti Critici, 12, 141-164.

“Le structuralisme en linguistique,” en O. Ducrot, T. Todorov et al. Qu'est-ce que le structuralisme? (Paris: Seuil), 13-96.

Estudios sabre semántica, Trad. del alemán por Ulises Moulines

La nueva novela hispanoamericana (México: Joaquín Mortiz).

“La litterature selon Borges,” en Dominique de Roux (ed.) L 'Herne

“'El Sur’, de Borges; Busqueda de identidad en el laberinto,” Nueva Narrativa Hispanoamericana, Tomo 1, No. 2, 35-55.

“Eléments d’une grammaire narrative,” en Greimas Du sens (Paris:

Aspects of Scientific Explanation (New York: The Free Press).

“Closing Statement: Linguistics and Poetics,” en T. Sebeok (ed.), Style in Language (Cambridge, Mass.: M.I.T. Press), 350-377. 
Jitrik, Noe

“Structure et signification de Fictions de J.L. Borges," Linguistique et Littérature, Colloque de Cluny (La Nouvelle Critique), 107114).

Kahn, Edward 1973

“Finite-State Models of Plot Complexity,” Poetics, 9, 5-20.

Kristeva, Julia 1968 “La productivité dite texte,” Communications, 11, 59-83. 1969 Sèméiotikè. Recherches pour une sémanalyse (Paris: Seuil). Levi-Strauss, Claude $1964 \quad$ Le cru et le cuit (Paris: Plon).

Pavel, Thomas G. 1973 "Some Remarks on Narrative Grammars,” Poetics, 8, 5-30.

Phillips, Allen W. 1963 “ ‘El Sur’ de Borges,” Revista Hispánica Moderna, XXIX, 2, 140147.

Popper, Karl R. 1935 La lógica de la investigación científica, Trad. del inglés por Víctor Sánchez de Zavala (Madrid: Editorial Tecnos, 1971).

Prior, Arthur N. 1957 Time and Modality (Oxford: Clarenden Press). Quine, Willard Van Orman

1962 Desde un punto de vista lógico, Trad. del inglés por Manuel Sacristan (Barcelona: Ariel).

Reichenbach, Hans

1927 The Philosophy of Space and Time, Trad. del aleman por Maria Reichenbach y John Freund (New York: Dover, 1958).

1951 The Rise of Scientific Philosophy (Berkeley-L.A.: Univ. of California).

Rescher, Nicholas 1968 Topics in Philosophical Logic (Dordrecht: D. Reidel).

Rescher, Nicholas y Urquhart, Alasdair 1971 Temporal Logic (New York-Wein: Springer-Verlag).

Serres, Michel 1972 Hermès II, L'interférence (Paris: Minuit).

Thom, René 1974 “Stabilité structurelle et morphogenése”, Poetics, 10: 106-152.

Todorov, Tzvetan 1969 Grammaire du Décaméron (The Hague: Mouton).

Wheelock, Carter, 1969 The Mythmaker (Austin: Univ. of Texas Press). 


\title{
"Dios Acecha en los Intervalos": Simulacro y Causalidad Textual en la Ficción de Borges
}

\author{
Ses traits m'étaient devenus courants, chargés d'un sens \\ médiocre, mais intelligible comme une écriture qu'on lit et \\ ne ressemblaient plus en rien à ces caractères bizarres, \\ intolérables que son visage m'avait présentés le premier \\ jour. \\ Marcel Proust, A la recherche du temps perdu \\ Esas tautologías (y otras que callo) son mi vida entera. \\ Jorge Luis Borges, "Nueva refutación del tiempo"
}

Borges, a diferencia de Plotino, acepta ser retratado. Acaso apenas vea los rasgos borrosos de esa imagen otra que es la suya, acaso los ignore, acaso considere que los disjecta membra que componen su imagen -que componen toda imagen, cuando se la reconoce, cuando se la lee-incurren, como las descripciones que reprocha a ciertos autores, en un error estético. Acaso no niegue, para verse en ese rostro fijo, la posibilidad de invertir los términos del epílogo de El hacedor: en lugar de descubrir que el paciente laberinto de líneas que ha trazado coincide con su cara, única, descubrir que su cara -que sólo puede ver en el espejo, reflejada como relato- es imagen, punto de partida de un paciente laberinto narrativo.

"Bastante me fatiga tener que arrastrar este simulacro en que la naturaleza me ha encarcelado. ¿Consentiré además que se perpetúe la imagen de esta imagen?” (OI, $88)^{1}$. Borges acepta el retrato de Borges, pero como Plotino - a quien traduce en el texto citado con énfasis curioso-, sabe que es reflejo, simulacro de una unidad perpetuamente móvi1, heterogénea, a la vez anverso y reverso: ineficaz en cuanto se intenta detener sus rasgos. Al escribir, Borges mina con aplicación esa imagen quieta, monstruosa y clasificada, como “el inmóvil y terrible museo de los arquetipos platónicos” $(H E, 16)$. Intenta desligarse del simulacro, torpe copia que procura repetir to inasible. El simulacro que denuncia se llama metáfora, se llama personaje, se llama trama, se llama la literatura y su autor. También Borges, también yo: “mi vida es una fuga y todo lo pierdo y todo es del olvido, o del otro” $(H, 51)$. 
El texto de Borges surge de una doble desconfianza. Desconfianza de la impostura -de la máscara que reemplaza el rostro- pero también desconfianza del rostro que, en cuanto se lo intenta detener, se vuelve máscara, como la del velado profeta de Jorasán. Muy temprano en su obra, recalca Borges su descreimiento ante esa duplicidad:

Esas fintas graduales (penosas como un juego de caretas que no se sabe bien cual es cual) omiten su nombre verdadero -si es que nos atrevemos a pensar que hay tal cosa en el mundo (HUI, 56).

Señala la misma confusión -inevitable y fecunda- en el ejercicio literario: en las Mil y una noches, "Las antesalas se confunden con los espejos, la máscara esta debajo del rostro, ya nadie sabe cual es el hombre verdadero y cuales sus idolos” (HE, 133).

"Nada de eso importa”, añade Borges: "ese desorden es trivial y aceptable como las invenciones del entresueño”. Sin embargo se siente en su obra menos la aceptación de ese desorden, de esa multiplicación desconcertante de la realidad y de sus máscaras no menos reales, que el temor y cierta desaprobación. Un texto de Silvina Ocampo recuerda, en el plano anecdótico, la perturbación de Borges ante el disfraz. ${ }^{2}$ Las "biografías infames” de Historia universal de la infamía ilustran la misma inquietud: son ejercicios que a través de la parodía y de la exageración confirman, más de los que conjuran, ese mismo desconcierto. Nombrar, para Borges, parecería significar un peligro: el de fijar un reflejo y creer en é1, desatendiendo el económico principio taxativo de Occam: no hay que multiplicar en vano las entidades. Nombrar es ceder a la ilusión que mantuvo vivo a Marino, desencantado e iluminado en su lecho de muerte:

Marino vio la rosa, como Adán pudo verla en el Paraíso, y sintió que ella estaba en su eternidad y no en sus palabras y que podemos mencionar o aludir pero no expresar y que los altos y soberbios volúmenes que formaban en un ángulo de la sala una penumbra de oro no eran (como su vanidad soñó) un espejo del mundo, sino una cosa mas agregada al mundo $(H, 31)$.

Nombrar - detener con la palabra- es quizás también transgredir una prohibición que parece marcar, éticamente, la obra de Borges como la de ciertos precursores suyos, de origen puritano, cuyos textos lo han formado y en quienes, de algún modo, se reconoce: es desobedecer la interdicción (y caer en la consiguiente tentación) de crear ídolos, objetos verbales que, en el momento de la lectura, puedan confundirse con una esencia a la que sólo ha de aludirse pero que no ha de ser nombrada. Las referencias a Stevenson y a Hawthorne en los textos de Borges son algo más que mero tributo. El primero recurre con persistencia: es “una de las figuras más queribles y más heroicas de la literatura inglesa” (ILI, 51) y Borges lo señala notoriamente como "hijo 
de puritanos” (OI, 87). Para Borges, ni Stevenson, ni Hawthorne -a quien dedica acaso su mejor ensayo de crítica simpática- dejaron "de sentir nunca que la tarea de escritor era frívola o, lo que es peor, culpable” (OI, 87).

Ignoro si Borges concuerda plenamente con esta declaración lapidaria, si siente lo que para é1 sintieron Hawthorne y Stevenson. Lo cierto es que, como ellos, teme y desarma, con fidelidad casi religiosa, las imágenes que establece con idéntica fe. "La imagen es hechicería -anota en Inquisiciones. Transformar una hoguera en tempestad, según hizo Milton, es operación de hechicero. Trastrocar la luna en un pez, en una burbuja, en una cometa -como Rossetti lo hizo, equivocándose antes de Lugones-es menor travesura” $(I, 28)$. Borges no llega a denunciar, con la convicción y la ingenuidad de Stevenson, el artificio o el hechizo que fundamenta una cara, un personaje: aquellos títeres con cara de madera, con vientres llenos de aserrín, que descarta Stevenson (después de haberlos creado) en beneficio del incidente o de la trama de sus relatos. Tampoco llega a trasladar esos artificios, como para purgar desvíos, a las moralidades y fábulas que le achaca a Hawthorne. Sin embargo los dos procederes le son, de algún modo, afines, como posibles excesos entre los que se sitúa sin definirse del todo. El del escocés que, acaso culpable, desprecia al personaje literario; de cuya obra recuerda Borges no sólo la prosa admirable sino también, algo perversamente, la figura inolvidable del bucanero ciego. El del moroso norteamericano que, sintiendo quizás la misma culpa, redujo el ambiguo mundo de sus sueños a ejercicios didácticos para disculparse. El mismo borroso Hawthorne -recuerda Borges-, arrinconado en un cuarto en el que escribe sólo para sí, anota en 1840: "Si antes hubiera conseguido evadirme, ahora sería duro y áspero y tendría el corazón cubierto de polvo terrenal...En verdad sólo somos sombras” (OI, 93). No difieren demasiado estas líneas de las no menos resignadas que fundamentan el desconcierto de "Borges y yo".

La penuria del simulacro o la tentación del simulacro, por fin ineficaz, no deja de inquietar la obra de Borges. No en vano abundan los traidores en sus textos: "la traición implica una ficción con una superficie engañadora que se muestra y un trasfondo que permanece oculto y es la sustancia traidora”. ${ }^{3}$ Borges añora como "aventura heroica" el texto que cambia el mundo al "añadir provincias al Ser, /al/ alucinar ciudades y espacios de la conjunta realidad” $(I, 28)$ y a la vez preve el consecuente "bochorno:”

Hay que manifestar ese antojo hecho forzosa realidad de una mente: hay que mostrar un individuo que se introduce en el cristal y que persiste en su ilusorio país (donde hay figuraciones y colores, pero regidos de inmovible silencio) y que siente el bochorno de no ser más que un simulacro que obliteran las noches y que las vislumbres permiten $(I, 29)$.

Borges condena la vana repetición, el necio intento de añadir otra ilusión, otro objeto -nombrado, memorable, por sútil que parezca- que llegue, por simple 
redundancia, a invalidar un mundo: una serie y un conjunto vividos, recordados, escritos. “¿No basta -se pregunta- un solo término repetido para desbaratar y confundir la historia del mundo, para denunciar que no hay tal historia?” (OI, 25). Diferenciéndose de sus precursores - de los griegos a quienes acude, de los puritanos con quienes simpatiza- no establece categorías, niveles, posibilidades de salvación personal o de consuelo filosófico. No remite a un conjunto ideal o a un Verbo fundador para justificar su crítica. Para Borges los arquetipos platónicos no difieren básicamente del inepto Golem, que hasta “el gato del vecino” -o “del rabino”, en una nueva versión:

las jerarquías son insignificantes -encuentra ineficaz. Los arquetipos no son irresolubles: son tan confusos como las criaturas del tiempo. Fabricados a imagen de las criaturas, repiten esas mismas anomalías que quieren resolver. La Leonidad, digamos, ¿cómo prescindirá de la Soberbia o de la Rojez, de la Melenidad y la Zarpidad? A esa pregunta no hay contestación y no puede haberla: no esperemos del término leonidad una virtud muy superior a la que tiene esa palabra sin el sufijo (HE, 21).

El antinominalismo de Borges -su empeño en no nombrar, para no crear idola, para no condenarse a la palabra única que por fin nada crea salvo a sí misma-trabaja su obra. El efecto más obvio, en el plano narrativo, es la subversión de lo esperable, de lo que el lector de ficción, por pereza, considera inamovible. Los personajes que pueblan su ficción son dobles, múltiples, por fin anónimos, como el narrador de "El inmortal”: “Como Cornelio Agrippa, soy dios, soy héroe, soy filósofo, soy demonio y soy mundo, lo cual es una fatigosa manera de decir que no soy” ( $A, 21)$. Las tramas de los relatos borgeanos se superponen, deliberadamente varían historias previas, propias o ajenas, se complican hasta-aparentemente-negar su originalidad: así Ryan que, en "Tema del traidor y del héroe”, “comprende que él también forma parte de la trama de Nolan” $(F, 141)$; así también el gaucho de "La trama” $(H, 28)$ que muere "y no sabe que muere para que se repita una escena.” Las buscas que emprenden los personajes -subsiste en Borges como un lejano eco de Bunyan- acaban en huecos, metas elusivas que no confirman al peregrino sino lo entregan "aún más desvalido, a las Furias” (OI, 83), o al desconcierto. Los momentos epifánicos de los relatos aparecen contagiados, como en la "Biografía de Tadeo Isidoro Cruz” o, como en "El Zahir” y en “El Aleph”, calculadamente prostituidos por la parodía. Obra, a lo largo de las ficciones, el rechazo del ilusorio nombre, de la posible palabra que podría fijar, de modo peligroso e inequivoco, un ser, un itinerario, un objeto. Obra también, paralelamente, la tentación de aceptar ese nombre y esa palabra, de incurrir en el simulacro. Si se nombra, en la obra de Borges, se nombra siempre con cautela y con desvío, también con resignación: procurando no crear sino aludir, con plena conciencia de que la alusión es otra forma -sin duda más humilde- del nombre. 
El conjetural idioma de Tlön que propone Borges evita el sustantivo con aplicación: corresponde a un mundo que, para sus habitantes, "no es un concurso de objetos en el espacio; es una serie heterogénea de actos independientes” ( $F, 20)$. El idioma -más bien, los idiomas: propone Borges para los dos hemisferios de Tlön dos modos de rehuir el nombre-aparece como un fluir lingüístico que en lugar de fijarse en el sustantivo se detiene, intermitentemente, en lo que pueda modificarlo. El mero hecho de nombrar -de clasificar- en Tlön "importa un falseo" (F, 22). Lo mismo ocurre con los números: afirman los matemáticos de Tlön “que la operación de contar modifica las cantidades y las convierte de indefinidas en definidas” $(F, 26)$. No hay en Tlön números ni nombres (fijos, definitorios, alienadores), no hay -se procura que no haya- luna. Como l'absente de tous bouquets aparece innominada, aludida o convocada por el desvío- Transposición, decía Mallarmé -que evita el nombre directo. En el hemisferio austral no se dice surgió la luna sobre el río sino hacia arriba detrás duradero-fluir luneció. En el hemisferio boreal el sustantivo se evita mediante la acumulación de adjetivos; nuevamente no hay luna, ni lunas, sino aéreo-claro sobre oscuro-redondo o anaranjado-tenue-del-cielo. De estas nuevas combinaciones escribe Borges que son "objetos ideales, convocados y disueltos en un momento, según las necesidades poéticas” $(F, 21)$. Ambas maneras de esquivar el sustantivo coinciden con la imaginación extravagante de Marco Flaminio Rufo en "El inmortal”:

Pensé que Argos y yo participábamos de universos distintos; pensé que nuestras percepciones eran iguales, pero que Argos las combinaba de otra manera y construía con ellas otros objetos; pensé que acaso no había objetos para é1 sino un vertiginoso y continuo juego de impresiones brevísimas. Pensé en un mundo sin memoria, sin tiempo; consideré la posibilidad de un lenguaje que ignorara los sustantivos, un lenguaje de verbos impersonales o de indeclinables epítetos $(A, 17)$.

Estos objetos políticos, cuyo carácter elusivo y transitorio subraya Borges, aparecen como marcas de una pausa, como paliers dentro del fluir lingüístico, dentro del "vertiginoso y continuo juego" escriturario: en ellos se detiene, provisoriamente, el hablante o el escriba. Recuerdan, en el plano del lenguaje, los razonamientos de Hermann Lotze citados por Borges para eludir la “multiplicación de quimeras”: Lotze "resuelve que en el mundo hay un sólo objeto: una infinita y absoluta sustancia, equiparable al Dios de Spinoza. Las causas transitivas se reducen a causas inmanentes: los hechos, a manifestaciones o modos de sustancia cósmica” (OI, 153). Del mismo modo podría decirse que en Tlön hay un sólo objeto, una infinita y absoluta sustancia lingüística que obedece al mismo propósito: evita el sustantivo, cifra por excelencia de la quimera o del simulacro fijo y paralizador ${ }^{4}$, para detenerse sólo esporádicamente -en el momento en que se enuncia o se escribe- en manifestaciones (hacia arriba detrás duradero-fluir lunecio) o en modos (aéreoclaro sobre oscuro-redondo) de ella 
misma. Sin embargo el propio Borges es el primero en señalar las fallas de este utópico planteo basado en el rechazo del nombre único:

El hecho de que nadie crea en la realidad de los sustantivos hace, paradójicamente, que sea interminable su número. Los idiomas del hemisferio boreal de Tlön poseen todos los nombres de las lenguas indoeuropeas -y otros muchos más ( $A$, 22).

La falaz identidad propuesta por el coito -cita Borges el terrible pasaje de Lucrecio: “así Venus engaña a los amantes con simulacros” (HE, 35)-, por el espejo, por los arquetipos, por la palabra cratílica, es para Borges vano intento de reproducción. Comprenden demasiado tarde el rechazo de Plotino Judá León -que dejó la inacción “que es la cordura” $(O P, 169)-$, el hombre gris de "Las ruinas circulares”, el tintorero enmascarado: cultivadores todos, al fín de cuentas, de un "arte de impíos, de falsarios y de inconstantes” (HUI, 84). La reproducción resulta intolerable porque de ella se esperaba inocentemente $-\mathrm{y}$ acaso con fe orgullosa- un reflejo aproximativo. Nos enfrenta con la ineficacia de lo que procurábamos convocar idéntico, con la torpeza de "un ojalá no fuera” (TE, 35)

Red Scharlach, en "La muerte y la brújula”, llega a sentir, desde su ilusoria unicidad, "que dos ojos, dos manos, dos pulmones, son tan monstruosos como dos caras” (F, 155). Marco Flaminio Rufo, confrontado no con la monstruosidad de lo igual sino con la parodia dispar, igualmente monstruosa, se niega a describir la Ciudad de los Inmortales que por fin descubre. No es el conjunto armónico que su mente había soñado sino su "parodia o reverso" $(A, 19)$ : “un caos de palabras heterogéneas, un cuerpo de tigre o de toro, en el que pulularan monstruosamente, conjugados y odiándose, dientes órganos y cabezas, pueden (tal vez) ser imágenes aproximativas" $(A, 15)$. La copia, la repetición -idéntica, en el caso de Scharlach; intencionalmente contradictoria, en el caso de los Inmortales que asolan la primera ciudad para construir con las ruinas su puntual parodia o reverso- es igualmente monstruosa y en ambos casos intolerable.

Igualmente intolerable, igualmente paródica, es la reproducción que practica el autor del texto, condenado -tanto cuando anota luna como cuando escribe aéreoclaro sobre oscuro-redondo- al simulacro. Directo, queriéndose mimético en el primer caso, claramente desviado y pasajero en el segundo, el simulacro, de las dos maneras, inevitablemente nombra y repite lo ya escrito. Todo texto reproduce, necesariamente, el texto previo: lo inquieta y a la vez es inquietado por é1. El Quijote de Menard y el de Cervantes -caso límite de reproducción, también ejercicio de modestia- son tan perturbadores como los dos ojos y los dos pulmones de Red Scharlach: aparentemente redundantes y sin embargo necesarios. La metáfora, o la alusión, que es toda escritura es simulacro, a la vez nombre y desvío: hablar -y escribir- “es incurrir en tautologías” $(F, 94)$. De las dos personas que buscan un lápiz, 
en “Tlön. Uqbar, Orbis Tertius”, la primera acaso ofrezca el mejor ejemplo de economía verbal, de desconfianza ante la palabra: "lo encuentra y no dice nada". La segunda encuentra un segundo lápiz "más ajustado a su expectativa” $(F, 27)$. El texto permite sospechar que dirá algo, que la existencia del lápiz, en este universo idealista, coincidirá con su percepción y su nomenclatura: que se añadira, en ese instante, otro objeto al mundo.

Cuando se escribe, só1o queda una posibilidad, que Borges asume plenamente: la de entonar diversamente la metáfora -“metáfora o simulacro” (OI, 131)- no para fijarla ingenuamente como novedad sino para señalar, a través de esa entonación diversa, los avatares en los que se detiene, imprevisiblemente, un continuum literario:

No hay ejercicio intelectual que no sea finalmente inútil. Una doctrina filosófica es al principio una descripción verosímil del universo; giran los años y es un mero capítulo -cuando no un párrafo o un nombre- de la historia de la filosofía. En la literatura, esa caducidad final es aún más notoria $(F, 55) .^{5}$

Pierre Menard, no exento de superstición -no puede imaginar el universo sin una interjección de Poe, sin Le bateau ivre, sin The Ancient Mariner-entona diversamente, letra por letra, en la Nîmes del siglo veinte, el Quijote: puede hacerlo porque considera personalmente que “el Quijote es un libro contingente, el Quijote es innecesario. Puedo premeditar su escritura, puedo escribirlo, sin incurrir en una tautología. /.../ Mi recuerdo general del Quijote, simplificado por el olvido y la indiferencia, puede muy bien equivaler a la imprecise imagen anterior de un libro no escrito” ( $F, 52)$. Del mismo modo, sin incurrir en la tautología, había obrado Pascal al cifrar, con "vértigo, miedo y soledad”, su concepción del mundo: “Una esfera infinita, cuyo centro está en todas partes y la circunferencia en ninguna” $(O I, 17)$. Menos de un siglo antes Giordano Bruno había afirmado que "el universo es todo centro, o que el centro del universo está en todas partes y la circunferencia en ninguna” (OI, 15). Para Giordano Bruno, la concepción exultante significaba una liberación; para Pascal, que escribe las mismas palabras, como Menard las de Cervantes, la concepción es espantosa. Ni Pascal, ni Menard (ni Borges) restituyen por fin “el difícil pasado -operan y divagan con é1” $(D, 9)$. Escribe Borges en su vindicación de la cosmogonía de Basilides que importa menos el riesgo de multiplicar entidades que "la buena conversión de esos pesados símbolos vacilantes” $(D, 64)$. Como en el problemático cielo de los teólogos, son sinónimos en su concepción de la literatura, los verbos conservar y crear. "La conservación de este mundo es una perpetua creación” (HE, 33) y la metáfora es un simulacro del que podremos arrepentirnos pero que no logramos eludir.

El descreimiento literario - descreimiento del rostro y también de su máscara; del nombre que no se pronuncia y de la metáfora que es igualmente tautológica $-^{6}$ es en el caso de Borges, como en el de los precursores que reivindica en El tamaño de mi esperanza, "manantial de obras”. ${ }^{7}$ Al evitar el nombre directo, la versión única, al acudir al desvío o a la multiplicidad, Borges practica con fe una literatura que, como 
la filosofía de Tlön, es un ejercicio des Als $O b$. Sabe que cae en la trampa de Marino, sabe que "el otro tigre" siempre queda fuera, pero se reserva la posibilidad de mantener la duda y la ilusión. No hablo ya de las categorías narrativas tradicionales que mina para no asentarse en ellas -personajes, tramas, voz narrativa univalentesino de un ritmo de composición salteado, disonante y asombroso (como la metafísica de Tlön) que marca el conjunto de su obra.

Del texto de Borges puede decirse lo que é1 del universo ideal de Plotino: "un repertorio selecto que no tolera la repetición y el pleonasmo" (HE, 16). Pero la selección de Borges no sólo evita la repetición y el pleonasmo: desconfía, higiénicamente, de la previsible sucesividad - “intolerable miseria” (HE, 35)- de las palabras. También desconfía de esa otra repetición no escrita pero igualmente intolerable: la "superstición ética" que fija, empobreciéndolo, el hábito de lectura: "He advertido que en general la aquiescencia concedida por el hombre en situación de leyente a un riguroso eslabonamiento dialéctico, no es más que una holgazana incapacidad para tantear las pruebas que el escritor aduce, y una borrosa confianza en la honradez del mismo" ( $I$, 84).

La selección que practica Borges -para ser, en un mundo "textual" donde todo se ha dicho, donde todo se repite, donde lo escrito es tautología- aparece signada por la ruptura y el hiato. Así lo entiende Foucault, al calificar de monstruoso, en la enumeración de la problemática y pérfida enciclopedia china citada en "El idioma analítico de John Wilkins" (OI, 142), el blanco intersticial: "no son imposibles los 'animales fabulosos', puesto que se los designa como tales; es imposible la estrecha distancia que los separa de los perros sueltos o de los que de lejos parecen moscas, a los que se yuxtaponen". ${ }^{8}$ Ese blanco, esa estrecha distancia difícilmente aceptable, es característica esencial de la obra borgeana. Se la podría descartar o clasificar, reduciéndola, como simple rasgo de estilo. Sin duda, en la concepción de la literatura que proponen los textos de Borges -a la vez desconfianza del nombre y necesidad de nombrar- significan mucho más.

La obra de Borges es, desde el comienzo, llamado de atención sobre lo desarticulado, sobre la descomposición. Descomposición de la personalidad -"superstición occidental”, dice Borges, en "La Personalidad y el Buddha"-, descomposición del tiempo lineal, de la historia literaria (prestigiosa metáfora del mero tiempo sucesivo, anotado), del pensamiento orientado y didáctico, de la aceptada secuencia narrativa, del personaje rotundo (como lo quería Forster), fabricado a base de pura acumulación. Así lo demuestran el añicamiento del tiempo practicado por Dunne, la desconstrucción de la obra de Herbert Quain, el Kafka que inquieta y postula a sus precursores, los avatares de la tortuga, el teólogo Juan de Panonia que perturba al teólogo Aureliano como Aureliano perturba a Juan de Panonia, Pierre Menard que inquieta a Cervantes como Céline a Tomás de Kempis, Pedro Damián, el otro muerto, que afantasma a Pedro Damían que afantasma a Pedro Damían. El uno, no se cansa de afirmar Borges parafraseando el Parménides, es realmente muchos (OI, 152). 
La posible desarticulación que Borges no olvida, que no permite olvidar a su lector, toca no só1o la estructura del texto literario sino la letra misma, la aceptada sucesividad de la escritura. Recuerda Borges la horrible imaginación de Swift: aquellos hombres que, en la tercera parte de Gulliver's Travels, son “incapaces de conversar con sus semejantes, porque el curso del tiempo ha modificado el lenguaje, y de leer, porque la memoria no les alcanza de un renglón a otro”. "Cabe sospechar -añade Borges- que Swift imaginó este horror porque lo temía, o acaso para conjurarlo mágicamente” (OI, 226). Cabe sospechar que Borges, al reproducir esa pesadilla extrema de la descomposición lingüística, acaso obedezca a las mismas razones. Imagina la misma mutilación en el último párrafo de "El Inmortal”, al comentar la última declaración del que ha sido Homero, del que en breve será Nadie y será todos porque estará muerto:

Cuando se acerca el fin, escribió Cartaphilus, ya no quedan imágenes del recuerdo; sólo quedan palabras. Palabras, palabras desplazadas y mutiladas, palabras de otros, fue la posible limosna que le dejaron las horas y los siglos ( $A$, 26).

Esta mutilación y este desplazamiento, salteado ejercicio extremo del lenguaje que Borges teme y corteja, encuentra un eco en su lectura de Plotino: "Los objetos del alma son sucesivos, ahora Sócrates y después un caballo, siempre una cosa aislada que se concibe y miles que se pierden; pero la Inteligencia Divina abarca juntamente todas las cosas $(H E, 14)$. Como la Inteligencia Divina de Plotino el enunciado borgeano -lo que Foucault llama el "non-lieu du langage"- abarca y sostiene tanto la palabra mutilada, la cosa aislada, como la pérdida contra la que se perfila. La descomposición que mueve el texto de Borges sólo se comprueba, por fin, en ese enunciado: detenido en el lugar de una letra que es móvi1, susceptible de variadas lecturas. Como los objetos poéticos de Tlön, los textos de Borges "convocados y disueltos en un momento, según las necesidades poéticas” $(F, 21)$ son pausas de un fluir literario que conjugan satisfactoriamente, en el espacio de la lectura, lo roto, lo desplazado, lo heteróclito: ahora Sócrates y después un caballo.

Como para recalcar esa detención salteada de lo pasajero dentro de lo móvil, ese rescate inopinado de épaves inconexas, insiste Borges, con cierto deleite, en lo incomunicado y lo impenetrable. Recuerda en "Los avatares de la tortuga” que Bradley "no se limita a combatir la relación causal; niega todas las relaciones”. Y añade: "Transforma todos los conceptos en objetos incomunicados, durísimos. Refutarlo es contaminarse de irrealidad” (OI, 154). Esta declaración se prolonga narrativamente -si cabe la distinción de géneros- en "Tlön, Uqbar, Orbis Tertius”, donde lo aislado, perfectamente incomunicado e irreductible, contamina la verosimilitud planteada al comienzo del relato, hace ceder una realidad ("lo cierto es que anhelaba ceder” [F, 331]) y permanece en ella, corroyéndola. Así la brújula cuyo 
temblor logra inquietar "las finas cosas inmóviles” ( $F, 31)$ contiguas. Así el cono, pesadísimo y minúsculo, que rescata el narrador después de una nebulosa borrachera. Paralelamente a la desarticulación de Tlön, a su multiplicación contradictoria -y recuérdese que Tlön es por fin la enumeración de un anatopismo que surge del idioma de un anatopismo previo, Ugbar $-{ }^{10}$ aparece la insistencia en lo concreto. A medida que la descripción de Tlön se complica, a medida que se empeña Borges en desarticularlo, en desubicarlo, aparecen los “objetos incomunicados, durísimos”: las aisladas monedas de cobre (en un sofisma "cuyo renombre escandaloso equivale en Tlön al de las aporias eleáticas” [ $F, 24]$ ), el concreto lápiz, la máscara de oro, la espada arcaica, las ánforas de barro y el mutilado torso del rey, para culminar con la brújula y el cono que perturban claramente el mundo al que pertenece el narrador.

Los dos últimos objetos son los más obviamente disonantes, los más "incomunicados" porque marcan sin duda la intrusión de un mundo radicalmente distinto del que se plantea al comienzo del relato: quizás por eso sean, en resumidas cuentas, los menos interesantes. Más sorprendentes, en un plantea basado -nuevo simulacro- en un idioma y en una literatura, donde ninguna doctrina "ha merecido tanto escándalo como el materialismo” (F, 24), son los hrönir y los ur. Lápices o máscaras que, fabricados sólo por el lenguaje, existen: mimando la dureza de objetos que el lector reconoce como concretos porque lo remiten a una realidad extraliteraria, pero cuya factura reside sólo en la literatura. No es casual que al hablar de estos curiosos productos acuda Borges, para explicar su aparición, a la distracción y al olvido, a la sugestión y a la esperanza: todos términos que más de una vez, y con énfasis diverso, ha reivindicado para el ejercicio literario. Si se practica una lectura retrospectiva de “Tlön, Uqbar, Orbis Tertius” se comprenderá que tan duras e incomunicadas como los perturbadores hrönir o ur, o como los clausurados tropos que cita Borges en "Las kenningar”, son las combinaciones del tipo aéreo-claro sobre oscuro-redondo, por el mero hecho de enunciarlas. "Son, para de alguna manera decirlo, objetos verbales, puros e independientes como un cristal o como un anillo de plata”, dice Borges tanto de los tropos islándicos como de los poemas de Quevedo. Objetos duros e incomunicados, a la vez reflejan y desvían, como ese cristal en el que Borges cifra su “Arte poética” $(O P, 222)$ :

También es como el río interminable

Que pasa y queda y es cristal de un mismo

Heráclito inconstante, que es el mismo

Y es otro, como el río interminable.

Se observa en la obra de Borges -acaso como consecuencia de la desarticulación que roza sistemáticamente y de la momentánea fijación en lo duro e incomunicado que añora- el continuo deleite de la interpolación. En el ensayo sobre "Los traductores de las 1001 noches” se complace, al pasar, en los desniveles de la versión de Edward 
Lane: "Alguna vez la falta de sensibilidad le es propicia, pues le permite la interpolación de voces muy llanas en un párrafo noble, con involuntario buen éxito” $(H E, 106)$. La “cooperación de palabras heterogéneas” que señala en Lane no difieren, en el fondo, de la cooperación de secuencias heterogéneas que comentará en otros textos. Es doctrina, por ejemplo, en la Babilonia borgeana, “que la lotería es una interpolación del azar en el ordén del mundo y que aceptar errores no es contradecir el azar: es corroborarlo" $(F, 72)$.

De nuevo surge la interpolación, en los ensayos de Borges sobre los avatares de Aquiles y la tortuga. En los dos textos se detiene Borges en la reconstrucción que propone Lewis Carroll: quizá no el avatar más elegante, ni el que menos difiere de Zenón (queda esa gloria, según Borges, para William James), pero ciertamente el que propone más rupturas, más abismos incontrolables, y mayor humor. Imagina Carroll, al término (primera ruptura obvia) de la interminable carrera, una apacible conversación entre "los dos atletas" (OI, 154). La conversación es más bién una payada, en la que la infatigable tortuga se empecina en provocar a Aquiles, logrando que interpole -primero con indignación, luego resignado- una infinita proposición hipotética entre la segunda premisa del silogismo y la conclusión: si $a$ y $b$ son válidas, $z$ es válida; si $a, b$ y $c$ son válidas, $z$ es válida; si $a, b, c$ y $d$ son válidas, etc. Lewis Carroll, anota Borges, “observa que la paradoja del griego comporta una infinita serie de distancias que disminuyen y que en la propuesta por él crecen las distancias” (OI, 155). Así es, gracias a la docilidad razonadora de Aquiles y a la fe asintótica, por así decirlo, de la tortuga. La variante de Lewis Carroll, tromperaison ${ }^{11}$ humorístico, se basa en el puro placer de la interpolación: no en la conclusión de una carrera que (inexplicablemente) ha terminado, no en la culminación del "claro razonamiento" silogístico, sino en el placer de dilatar la clausura (la fijación: el nombre definitivo) de un intercambio, paradójicamente razonable, de palabras.

Por fijas y limitadas que aparezcan las leyes de este diálogo cada vez más distanciado -diálogo cuyo mayor encanto reside en la inmanejable perspicacia de la tortuga que, como Croce, "sirve para cortar una discusión, no para resolverla” $(D, 67)$ no difiere tanto su progreso del de otras series que aparecen en la obra borgeana. Las interpolaciones de Aquiles, aguzado por la tortuga, seguirán si se quiere un ritmo previsible pero se alejarán cada vez más vertiginosamente -al crear nuevas proposiciones hipotéticas- de las premisas que iniciaron la aparente coherencia de la serie. Llegará un punto en que coincidirán con las palabras mutiladas y desplazadas del inmortal, con los términos trabajados por el tiempo y el olvido a los que no logran dar coherencia los personajes de Swift. Palabras, razonamientos sin referente, que sólo son porque son enunciadas, que han perdido el postulado inicial que las justificaría.

Abundan en la obra de Borges estas series - de palabras, de hechos, de seres, de razonamientos- donde prima, más que la continuidad, la deliberada interpolación y el aislamiento. Al considerar "La duración del infierno" establece Borges una 
significativa jerarquía de espantos: "El atributo de eternidad es el horroroso. El de continuidad -el hecho de que la divina persecución carece de intervalos, de que en el Infierno no hay sumo- lo es más aún, pero es de imaginación imposible” $(D, 99)$. Algunas de las series propuestas por Borges, como la que toma de Lewis Carroll, ofrecen la ilusión de la continuidad y de la coucatenación. Otras -las más frecuentesaclaran desde un comienzo los blancos, los intervalos, que las integran. La taxonomía del enciclopedista chino en que se detiene Foucault no difiere de la enumeración de los hrönir de Tlön, serie igualmente perturbadora a fuerza de interpolación y de hiato: “los hrönir de segundo y de tercer grado/.../ exageran las aberraciones del inicial; los de quinto son casi uniformes; los de noveno se confunden con los de segundo; en los de undécimo hay una pureza de líneas que los originales no tienen” $(F, 29)$. No difiere tampoco del sistema inventado por la memoria de Funes, pululación espantosa y sórdida -“como vaciadero de basums” $(F, 123)$ - cuyo origen es la economía del nombre y la nitidez de las percepciones únicas propuestas en serie:

Su primer estímulo, creo, fue el desagrado de que los treinta y tres orientales requirieran dos signos y tres palabras, en lugar de una sola palabra y un solo signo. Aplicó luego ese disparatado principio a los otros números. En lugar de siete mil trece, decía (por ejemplo) Máximo Pérez (F, 124).

El vertiginoso mundo de Funes, compuesto por "un vocabulario infinito para la serie natural de los números /y/ un inútil catálogo mental de todas las imágenes del recuerdo" no carece, para Borges, de "cierta balbuciente grandeza” $(F, 125)$. Los tres casos citados -la enciclopedia china, el catálogo de hrönir, la mente de Funesrecuerdan y a la vez perturban la declaración de Santo Tomás que parafrasea Borges:

El mundo es un interminable encadenamiento de causas y cada causa es un efecto. Cada estado proviene del anterior y determina el subsiguiente, pero la serie general pudo no haber sido, pues los términos que la forman son condicionales, es decir, aleatorios. Sin embargo, el mundo es; de ello podemos inferir una no contingente causa primera, que será la divinidad (OI, 153).

En las series propuestas por Borges los términos también son aleatorios pero cada elemento no proviene, claramente, del anterior y no determina el subsiguiente. La serie borgeana "pudo no haber sido" y sin embargo es, como el mundo que justifica la divinidad no contingente de Santo Tomás. Es, en este caso, injustificada; porque se la ha escrito y porque el texto resultante instaura su propia causalidad. Texto que no se justifica desde afuera, es mero sostén contingente de sí mismo, inevitable y pasajero lugar de reunión. No difiere, en su precariedad, del yo parcelado cuya existencia y nadería proclamaba Borges en Inquisiciones: 
Ocurrióseme que nunca justificaría mi vida un instante pleno, absoluto, contenedor de los demás, que todos ellos serían etapas provisorias, aniquiladoras del pasado y encaradas al porvenir, y que fuera de lo episódico, de lo presente, de lo circunstancial, no éramos nadie. Y abomine de todo misteriosismo $(I, 90)$.

De hecho convoca Borges, en los itinerarios de sus personajes y en el trazado de sus tramas, esos instantes plenos y absolutos, epifanías utópicas y ucrónicas con las que querría interrumpir la miserable sucesividad temporal. Del mismo modo opera, más modestamente, la trivia circunstancial que rescata tanto en sus personajes como en sus tramas o sus escasas descripciones. Con ella graba aisladamente instantes, gestos, como Stevenson: recalca énfasis, simbólicos o meramente descriptivos, que marcan un corte en el relato. Del mismo modo, también, se organiza el discurso borgeano, con rupturas enmascaradas que radicalmente inquietan la ristra, aún más pobre, establecida por la mera continuidad de la escritura y por el hábito de sus beatos lectores.

“And yet, and yet ....Negar la sucesión temporal, negar el yo, negar el universo astronómico, son desesperaciones aparentes y consuelos secretos” declara Borges en “Nueva refutación del tiempo” (OI, 256). También como desesperaciones aparentes y consuelos secretos pueden considerarse, en su obra, la desarticulación sistemática y la salteada detención en la rigidez de lo incomunicado que rompen la prevista sucesividad textual y la superstición del texto único y fijo. Borges cuestiona e inquieta los componentes del destino del hombre porque teme el anverso del conjunto heterogéneo que imagina: un destino (un yo, un tiempo, un mundo) determinado por la severa causalidad, espantoso "porque es irreversible y de hierro" (OI, 256). Tan atroz, por su clausura, como la idea "de un dios que fabrica el universo para fabricar su patíbulo” $(01,133)$. De la misma manera cuestiona los componentes del texto -que califica de "hecho móvi1"- porque teme y repudia “el concepto de texto definitivo / que/ no corresponde sino a la religión o al cansancio" $(D, 106-107)$. Porque sabe además que "la página de perfección, la página de la que ninguna palabra puede ser alterada sin daño, es la más precaria de todas” $(D, 48)$.

Sin embargo, paralelamente a estos consuelos -verdaderos motivos del texto borgeano- subsiste en la obra la añoranza o el deseo de una sucesión, de una concatenación satisfactoria de causas y efectos que no necesariamente habrá de seguir los modelos habituales. No en vano se detiene Borges en el regressus in infinitum ya citado, mediante el cual Santo Tomás explica el mundo. Comenta además con minucia, a lo largo de su obra, el cúmulo de argumentos postulados sobre la ley de causalidad. Acaso para conjurarlos; en todo caso sin elegir ninguno, atraído por todos, y cotejándolos con lúcida perplejidad. Al presentar la poesía gauchesca, en Discusión, propone, a partir de una respuesta de Whistler, que "el menor de los hechos presupone el inconcebible universo e, inversamente, que el universo necesita el menor de los hechos” $(D, 11)$.” En “La creación y P. H. Gosse” recuerda el texto donde John Stuart 
Mill razona "que el estado del universo en cualquier instante es una consecuencia de su estado en el instante previo y que a una inteligencia infinita le bastaría el conocimiento perfecto de un sólo instante para saber la historia del universo, pasada y venidera” $(O I, 38)$. Pero significativamente añade:

Mill no excluye la posibilidad de una futura intervención exterior que rompa la serie. Afirma que el estado $q$ fatalmente producirá el estado $r$; el estado $r$, el $s$; el estado $s$, el $t$; pero admite que antes de $t$, una catástrofe divina-la consummatio mundi, digamos- puede haber aniquilado el planeta. El porvenir es inevitable, preciso, pero puede no acontecer. Dios acecha en los intervalos.

En el mismo ensayo recuerda Borges el planteo con que Philip Henry Gosse intenta explicar, a su vez, la causalidad. Como Mill propone una serie temporal, rigurosamente causal e infinita, pero quebrada por un acto no futuro sino pretérito: la Creación. Para Gosse:

El estado $n$ producirá fatalmente el estado $v$, pero antes de $v$ puede ocurrir el Juicio Universal; el estado $n$ presupone el estado $c$, pero $c$ no ha ocurrido, porque el mundo fue creado en $f$ o en $h$. El primer instante del tiempo coincide con el instante de la Creación, como dicta San Agustín, pero ese primer instante comporta no sólo un infinito porvenir sino un infinito pasado. Un pasado hipotético, claro está, pero minucioso y fatal (OI, 39).

Ambos razonamientos atraen a Borges porque se detienen en la ley de causalidad. Cabe sospechar, sin embargo, que lo atraen aun más porque, cada uno a su manera, propone un sistema de causa a efecto signado -como el silogismo de la asintótica tortuga- por una ruptura que pone en tela de juicio la manía concatenatoria. Mill establece un porvenir inevitable y preciso, Gosse un pasado minucioso y fatal. Pero en ambas series de causas y efectos -y quizá la de Gosse, de "elegancia un poco monstruosa”, atraiga más a Borges-Dios acecha en los intervalos.

De manera semejante (acaso más modesta) acecha Borges en los intervalos de la causalidad literaria, que no difiere de la concatenación filosófica: no es más, no menos, que "una coordinación de palabras" (OI, 155). Examina la causalidad planteada entre autores ("Kafka y sus precursores"), entre textos ("La flor de Coleridge”), entre las palabras de una misma obra ("El arte narrativo y la magia”). Declara con convicción que "en el orden de la literatura, como en los otros, no hay acto que no sea coronación de una infinita serie de causas y manantial de una infinita serie de efectos $(O I, 20)$. Sabe que la Iliada y la Odisea, aun cuando, como lectores distanciados, "ignoramos infinitamente los énfasis” de Homero, "registran relaciones precisas entre cantidades incógnitas” $(D, 108)$. Poco tiene que ver sin embargo la causalidad literaria que defiende, en "El arte narrativo y la magia", con el 
encadenamiento previsible de "la morosa novela de cáracteres /que/ finge o dispone una concatenación de motivos que se proponen no diferir de los del mundo real”. En cambio reivindica Borges, para la literatura, una causalidad dictada por "la primitiva claridad de la magia” (D, 88).

Urge descartar las connotaciones más inmediatas de la palabra magia, que poco tienen que ver con la causalidad descrita por Borges, como urge descartar el epitéto fantástico con que a menudo se clasifica (y se deforma) su obra. Entendidos en su sentido más trivial empobrecen el texto de Borges y todo texto: justifican y paralizan beatamente la sorpresa en sí, aislada, desde el yelmo de El castillo de Otranto hasta el hacia arriba detrás dunadero-fluir luneció de Tlön. Al apelar a "la primitiva claridad de la magia,” Borges alude a una causalidad literaria harto más complicada. No recurre al encadenamiento de milagros, a la acumulación de rupturas: milagros o rupturas que se suman desmañadamente, por el solo hecho de "romper” con un hábito previo de lectura, y que sin duda, por la mera vocación de ruptura sistemática que las anima, inauguran una causalidad escasamente menos férrea que la de la morosa novela de carácteres. ${ }^{13}$ Recuerdan la superstición criticada por Borges: "no se fijan en la eficacia del mecanismo, sino en la disposición de sus partes. Subordinan la emoción a la ética, a una etiqueta indiscutida más bien” $(D, 46)$.

La causalidad que sugiere Borges no niega la causalidad mezquina que solemos atribuir a la realidad o a su pariente pobre, la novela realista, pero tampoco la endosa; la incluye y la perfecciona, en “peligrosa armonía”: "Es la coronación o pesadilla de lo causal, no su contradicción. El milagro no es menos forastero en ese universo que en el de los astrónomos. Todas las leyes naturales lo rigen, y otras imaginarias” (D, 89). La causalidad textual, para Borges, implica la posibilidad de incluir, de encadenar, de nivelar, en un mismo discurso literario, la simpatía y la distancia, el conjuro y la confianza; de emitir, con coherencia y sucesivamente, el nombre tautológico y su lejano simulacro, el libro y el contralibro que aquel supone.

La distancia-el placer de la distancia- es constante en la obra de Borges. Artículo de fe del ultraísmo - “nos enardeció la metáfora por la precisión que hay en ella, por su algebraica forma de correlacionar lejanías” ( $I$, 97)-, aparece enunciada, en términos de la secuencia narrativa, en sus textos más tempranos. En Evaristo Carriego se insiste en "la perduración de rasgos aislados", en la "continuidad de figuras que cesan” $(E C, 16)$. El mismo placer de la lejanía encuentra una formulación paralela en el ensayo sobre las kenningar de Historia de la eternidad. Reivindica Borges en esa época el placer del asombro, la eficacia del contacto heterodoxo entre las palabras de un texto. El "ultraísta muerto” que analiza las kenningar se complace en señalar el espacio entre el nombre y el tropo, recuerda que "luna de los piratas no es la definición más necesaria que reclama el escudo" $(H E, 46)$ pero que la reducción implicaría una "pérdida total”. Se detiene en el signo pierna del omóplato, kenning que inscribe la rareza fundamental e inesperada del brazo humano. No desconoce Borges "la desairada verdad” (HE, 44): que las kenningar, eran prefijados desvíos del nombre, 
meras convenciones literarias como acaso lo fueron los epitétos homéricos. ${ }^{14}$ Indaga no obstante las kenningar, como el vinoso mar, o la negra sangre, porque son “expresiones que recurren, conmovedoramente a destiempo" $(D, 107)$. (También a destiempo -o a destexto- cita Borges en "Las kenningar" un dístico aislado de Quevedo (HE, 46): el placer que le procuran los dos versos distanciados recuerda el de aquel lector que menciona Alfonso Reyes, detenido en un imprevisible rescate del texto gongorino: “la playa azul de la persona mía”).

Inauguran “Las kenningar” la clara atracción borgeana por el destiempo, por el destexto, por el dislate, aun cuando Borges emplee este término de modo peyorativo para criticar el poema que atribuye a Gracian. Aparecerá el mismo término más tarde, cambiado de signo, para calificar la “admirable ambición” de Pierre Menard. Al fin de cuentas el error que Borges achaca a Gracian no es tanto su dudoso empleo de asombrosos desvíos figurativos como la deliberada justificación con la que suprime las distancias que postula. Gracián peca por "la aposición de cada nombre y su metáfora atroz, la vindicación imposible de los dislates” (HE, 48). En el poema que cita Borges, Gracian escribe y razona, de algún modo, como el cronista del siglo dieciséis cuya reacción recuerda Borges: ante una sirena domesticada "razonó que no era un pescado porque sabía hilar, y que no era una mujer porque podía vivir en el agua” $(D, 85)$. Si en "Las kenningar" se detiene Borges, algo morosamente, en las aisladas felicidades de la poesía islándica que "nos extrañan del mundo” (HE, 65), intuye, ya en esa época, la posibilidad de una distancia más profunda, básica: distancia que se establece menos entre el objeto poético -solitariamente asombroso, como la poema del omóplato, solitariamente eficaz- y su fondo referencial, que entre la palabra y el texto en que se inserta.

La obra entera de Borges lleva al lector, casi didácticamente, del asombro inevitable ante el artificio político - una imagen ultraísta, una kenning, los animales que “acaban de romper el jarrón” (OI, 142)-al asombro ya más complejo que provoca la inclusión de estos artificios en un contexto puramente literario -los animales que acaban de romper el jarrón junto a los que de lejos parecen moscas, Máximo Pérez junto a El ferrocarril- al asombro final que finalmente (aunque se lo olvide) suscita la arbitraria concatenación de toda escritura. Borges reniega de sus primeros libros, esforzadamente asombrosos, se declara harto de los laberintos de sus ficciones y reclama la simplicidad y la alusión para sus escritos últimos: no menos escandalosos, no menos inquietantes, finalmente, que los primeros. En "la penúltima versión de la realidad" condena una sabiduría que se funda "sobre una mera comodidad clasificatoria $(D, 39)$. Como Marcel Schwob, en el prólogo a las Vidas imaginarias, podría también declarar: "El arte no clasifica; desclasifica". La desclasificación, la incomodidad radical, fundamenta el texto borgeano.

Borges por fin acepta su retrato como acepta su texto y las palabras que lo componen. Con plena conciencia de que “nadie está en algún día, en algún lugar”, que “nadie sabe el tamaño de su cara” $(O I, 16)$. "La Realidad -y, habría podido agregar, 
la literatura- es como esa imagen nuestra que surge en todos los espejos, simulacro que por nosotros existe, que con nosotros viene, gesticula y se va, pero en cuya busca basta ir, para dar siempre con él” $(I, 119)$. Acepta con la misma conciencia que tampoco hay lugar fijo para la obra, "siempre capaz de una infinita y plásitca ambigüedad" $(O I, 127)$. Que

La literatura no es agotable, por la suficiente y simple razón de que un sólo libro no lo es. El libro no es un ente incomunicado: es una relación, es un eje de innumerables relaciones. Una literatura difiere de otra, ulterior o anterior, menos por el texto que por la manera de ser leída” (OI, 218).

Acepta por fin, lúcidamente, que el nombre-tautología o simulacro-es inevitable "tela de trajes" $(O I, 227)$ que se visten y se desechan, interpolación perpetua en un discurso infinitamente repetido que sólo podemos captar en el ínfimo presente en que escribimos o en que respondemos con nuestra lectura. Sólo "un dios, un sueño y un hombre que está loco, y que no lo ignora” (OI, 223) pueden pronunciar, con fe, la tautología por excelencia que los fija, identificándolos. Soy El que Soy, dice Jehová; Soy lo que soy, soy lo que soy, repetía, loco y moribundo, Swift. El sueño al que se refiere Borges -el mediocre soldado francés de All's Well That Ends Well que imagina Shakespeare-, acaso logre nombrar y nombrarse verdaderamente: ser, una vez que se descubre su impostura, a través de una genuina impostación, mezcla de evidente descreimiento y de curiosa confianza en su palabra. Ya no sere capitán, pero he de comer y beber y dormir como un capitán; esta cosa que soy me hará vivir (OI, 226): en esa materia indecisa existe y se asienta, diciéndose, Parolles, cuyo nombre quizá no era casual. El texto de Borges, con menos ingenuidad pero con igual fervor, ha elegido, para ser, el mismo fundamento.

Princeton University

SYLVIA MOLLOY

\section{NOTAS}

1 Cito por los textos de Borges publicados por Emecé (a excepción de Inquisiciones y de El tamaño de mi esperanza, publicados por Proa), que abrevio: A (El Aleph, 1957); D (Discusión, 1957); EC (Evaristo Carriego, 1955); F (Ficciones, 1956); H (El hacedor, 1960); HE (Historia de la eternidad, 1953); HUI (Historia universal de la infamia, 1954); I (Inquisiciones, 1925); OI (Otras Inquisiciones, 1960); OP (Obra poética: 1923-1966), 1966); TE (El tamaño de mi esperanza, 1926).

2 “Images de Borges”, L' Herne, Paris, 1964, p. 27.

3 Marcial Tamayo y Adolfo Ruiz Díaz, Borges: enigma y clave (Buenos Aires: Nuestro Tiempo, 1955) p. 63.

4 "El sustantivo da nombre a cada cosa, por qué, una vez que la cosa ha sido nombrada, escribir sobre ella. El nombre es adecuado o no lo es. Si es adecuado, por qué seguir nombrando, si 
no lo es no lleva a nada nombrar”. Traduzco de Gertrude Stein, “Poetry and Grammar”, Look at Me Now and Here I Am (Londres: Penguin Books, 1971), p. 125. El texto de Stein rechaza el uso del sustantivo con aplicación parecida a la de los hablantes de Tlön.

5 Ver el reverso de ese avatar, propuesto en "La lotería en Babilonia”: ante las críticas sobre la Compañía, esta, “con su discreción habitual, no replicó directamente. Prefirió borrajear en los escombros de una fábrica de caretas un argumento breve, que ahora figura en las escrituras sagradas” $(F, 71)$.

6 O del texto que no se "escribe" y de la simulación, no menos tautológica, que lo reemplaza, como indica el prólogo de Ficciones.

7 "Nuestra famosa incredulidá no me desanima. El descreimiento, si es intensivo, también es fe y puede ser manantial de obras. Díganlo Luciano y Swift y Lorenzo Sterne y Jorge Bernardo Shaw. Una incredulidá grandiosa, vehemente, puede ser nuestra hazaña” (TE, 10).

8 Traduzco de Michel Foucault, Les Mots et les choses (Paris, Galfimard, 1966), p. 8.

9 Sur, 192-194 (1950), p. 34. Cito la frase final del texto: "Buddha Gotama equivale estrictamente a N.N.', escribió Otto Franke; cabría contestarle que el Buddha quiso ser N.N”.

10 "La sección idioma y literatura /de Uqbar/ era breve. Un solo rasgo memorable: anotaba que la literatura de Uqbar era de carácter fantástico y que sus epopeyas y leyendas no se referían jamás a la realidad, sino a las dos regiones imaginarias de Mlejnas y de Tlön...” $(F, 16)$.

${ }^{11}$ Ver Hans Magnus Enzenzberger, "Estructuras topológicas de la literatura moderna”, Sur, 300 (1966), p. 15.

12 Ver también "La otra muerte” $(A, 78)$ y “Sobre Oscar Wilde” $(O I, 117)$. En el último texto equipará Borges las causas y efectos de un destino a atributos individuales: “/ .../ la noción de cada individuo encierra a priori todos los hechos que a este le ocurrirán. Según este fatalismo dialéctico, el hecho de que Alejandro el Grande moriría en Babilonia es una cualidad de ese rey, como la soberbia”.

13 Así los “vastos y casi inextricables periódos” erigidos por Aureliano, en “Los teólogos”, para no coincidir con Juan de Panonia: "De la cacofonía hizo un instrumento. /.../ Agustín había escrito que Jesús es la vía recta que nos salva del laberinto circular de los impíos; Aureliano laboriosamente trivial, los equipará con Ixión, con el hígado de Prometeo, con Sisifo, con aquel rey de Tebas que vió dos soles, con la tartamudez, con loros, con espejos, con ecos, con mulas de noria y con silogismos bicornutos" $(A, 37)$.

${ }^{14}$ Conjetura Borges que los epitétos homéricos pueden haber sido "lo que todavía son las preposiciones: obligatorios y modestos sonidos que el uso añade a ciertas palabras y sobre los que no se puede ejercer originalidad” $(D, 1081)$. 


\section{“Tlön, Uqbar, Orbis Tertius”: Creación de un Lenguaje y Critica del Lenguaje}

En la ya extensa bibliografía crítica en torno a la obra de Jorge Luis Borges, son relativamente escasos aquellos ensayos que centran su atención en mayor o menor grado, y con mayor o menor detenimiento, en el relato “Tlön, Uqbar, Orbis Tertius”. Entre esos, consideramos particularmente valiosos los de Frances Wyers Weber, James E. Irby y Jaime Alazraki. ${ }^{1}$ A grandes rasgos, los artículos de Frances Weber y Jaime Alazraki tienden a interpretar el relato como parafrasis (“metáfora”, lo llama Alazraki) de una gnoseología fundamentada en el escepticismo, que en diversos modos niega al hombre acceso a verdades inamovibles acerca del mundo que to rodea. Frances Weber explica que “Tlön, Uqbar, Orbis Tertius”, al igual que otros cuentos de Borges, intenta llamar la atención de los lectores al hecho de la naturaleza conjetural de todo conocimiento y representación ("the conjectural character of all knowledge and all representation”. ${ }^{2}$ Jaime Alazraki lleva a cabo un utilísimo y cabal resumen del creciente escepticismo epistemológico de los científicos contemporáneos, desde Freud y Heisenberg hasta Frank Rhodes y Claude Lévi-Strauss, que postula la arbitrariedad de los sistemas erigidos por las distintas ciencias para describir y explicar la realidad circundante, la creciente conciencia de que los esquemas científicos, considerados por muchos como fiel espejo del universo, pueden muy bien no ser más que complejas construcciones de la mente humana. Alazraki advierte marcadas coincidencias entre estas posturas gnoseológicas y la que aparece transparentada a modo de metáfora en el cuento “Tlön,...” El crítico considera a “Tlön, Uqbar, Orbis Tertius" como la expresión más completa de una "alquimia” que "consiste en mostrarnos nuestra realidad, lo que hemos aceptado como nuestra realidad, transfigurada en sumo, en una fantasmagoría más del espíritu que nada o muy poco tiene que ver con ese mundo real que se propone penetrar". ${ }^{3}$

Entendemos que las consideraciones de la Profesora Weber, quien ve inscrita en el cuento una expresión simbolica de la naturaleza conjetural de todo conocimiento y las del Profesor Alazraki, quien advierte también inscrita en el relato una metáfora de la invención por parte del hombre de esquemas que él cree representaciones fieles del mundo externo -de la realidad-y que no son sino "fantasmagorías del espíritu" 
son justas y eficaces, pero sólo si se aplican parcialmente, y no al cuento en su totalidad. Vistas como símbolos o metáforas de todo el relato, estas consideraciones, valiosas, de otra parte, porque nos ayudan a entender otras narraciones de Borges (pensamos en la agudísima relación de los postulados de Alazraki con "La casa de Asterión”), conducen inevitablemente a quienes las sostienen a conclusiones de las cuales diferimos. En el análisis que sigue se advierte con claridad, creemos, que ni “Tlön, Uqbar, Orbis Tertius” culmina en una disolución nihilista, producto de un “negative thinking” de parte de Borges (Frances Weber), ${ }^{4}$ ni que Tlön y su “visión del universo" sea una paráfrasis de nuestro mundo: que el mundo sea, ahora, Tlön (Alazraki; Irby también parece acercarse a esta conclusión). ${ }^{5}$

El análisis a que sometemos a "Tlön, Uqbar, Orbis Tertius” en las páginas subsiguientes parte del supuesto de que los principios gnoseológicos que postula el cuento están inscritos en el desarrollo de la trama, en la estructura misma del relato y en un hábil, lúcido y complejísimo manejo de un lenguaje cuyas coordenadas de referentes varían y que el autor vincula con la sucesión de eventos en la narración. El procedimiento que Borges sigue en “Tlön...” intenta explorar, así lo que consideramos, algunos aspectos fundamentales de la naturaleza y límites de todo lenguaje, de tal forma que se podría entender el relato como una tentativa de “crear” un lenguaje para luego llevar a cabo una devastadora crítica del lenguaje. ${ }^{6}$ James Irby ha señalado con gran atino que uno de los aspectos formales más sorprendentes de “Tlön...” es "the mirroring of plot elements in the verbal texture of the tale”. ${ }^{7}$ Podríamos decir que es ese nuestro punto de partida hacia un análisis que si bien es limitado y, en cierto modo, esquemático intenta explicar ese vertiginoso relato en términos de una unidad narrativa.

\section{ESTRUCTURA CIRCULAR DE LA NARRACION}

“Tlön, Uqbar, Orbis Tertius” está estructurado al modo de las “muñecas rusas” o las “cajas Chinas”. Un mundo fantástico contiene un segundo mundo fantástico que, a su vez, contiene un tercero. En los cuentos de Borges, este recurso aparece con bastante frecuencia (recuérdense "Las ruinas circulares”, "El Aleph”, "El jardín de senderos que se bifurcan”, entre otros). Tampoco falta en sus ensayos a veces la mención pasajera de este recurso, a veces el examen detenido de sus implicaciones dentro de la obra estudiada. En “Magias parciales del Quijote”, Borges discurre largamente sobre aquellos personajes ficticios que son lectores o espectadores de sus propias historias: Don Quijote es lector del Quijote; Hamlet espectador de Hamlet, Shaharazad en la noche DCII de Las mil y una noches narra Las mil y una noches; Rama en los capítulos finales del Ramayana, escucha a sus hijos contar su propia historia (que es el Ramayana) y que les habla sido enseñada por el poeta Valmiki (personaje del Ramayana) quien es, a un mismo tiempo, el autor del Ramayana.

Veamos en detalle la estructura de “caja china” de “Tlön, Uqbar, Orbis Tertius”. La estructura interna, el andamiaje, consiste en tres dimensiones de fantasia, que a su 
vez corresponden a lo que llamaremos más adelante tres “parametros” de referentes lingüísticos.

En el transcurso de una conversación casual, Bioy Casares menciona a Borges una aseveración de cierto heresiarca de Uqbar. Bioy ha extraído esta sentencia de un artículo sobre ese país en una enciclopedia pirática, The Anglo-American Cyclopedia. El artículo sobre Uqbar sólo existe en el ejemplar que posee Bioy. Comenzamos a sospechar que Uqbar, sin más, es un país imaginario (Primera dimensión de la fantasia). Borges lee el artículo sobre Uqbar. Allí se habla, en la sección sobre idioma y literatura, de Tlön. La literatura de Uqbar, que es de carácter fantástico, “no se refiere jamás a la realidad, sino a las dos regiones imaginarias de Mlejnas y Tlön” (p. 80). Tlön, pues, es una región imaginaria de un país imaginario (segunda dimensión de fantasía). Luego, Borges descubre un tomo de A First Encyclopaedia of Tlön, en cuya elaboración ha participado un tal Herbert Ashe, amigo de su padre. A la larga, Borges se entera de un plan de parte de los "modestos demiurgos" forjadores de la enciclopedia de Tlön para sacar otra enciclopedia escrita en una de las lenguas de Tlön y que se llamaría Orbis Tertius. Orbis Tertius es un mundo descrito en el lenguaje de un planeta imaginario que, a su vez, es una "región” de un país inexistente (tercera dimensión de fantasía). ${ }^{8}$

Veamos ahora como esta estructura de “caja china” es a un mismo tiempo circular. El cuento comienza con el recuerdo, dentro de un marco "real”, de una sentencia apócrifa procedente de un artículo apócrifo de una enciclopedia pirática. Esto conduce al descubrimiento de la enciclopedia de Tlön, a la descripción de su mundo, y a vislumbrar la posibilidad de la existencia de Orbis Tertius. Al final del cuento, “objetos” de Tlön, su historia y su lengua comienzan a invadir, a minar y, eventualmente, a desintegrar la realidad. Es decir, un mundo fantástico que se origina en los libros termina por transformar, precisamente a través de libros, el mundo que, dentro del marco del relato, podemos considerar "real”. El laberinto circular que nos anunció Borges, pues, existe. Falta examinar los medios que emplea el autor para conducirnos a través de esta serie de transformaciones.

\section{ASPECTOS “MAGICOS” DEL LENGUAJE}

Si por un lado Borges nos ha dicho que Tlön es un laberinto urdido por hombres, nos ha indicado también que es un laberinto "destinado a que lo descifren los hombres”. Quizá sería útil recalcar que aquí “descifrar” tiene el sentido de interpolar significados que discrepen de los literales en un texto lingüístico. Veremos que en “Tlön, Uqbar, Orbis Tertius”, Borges emplea un lenguaje progresivamente cifrado, cuyos parámetros de significado varían según nos vamos internando-progresivamente también- en la Primera, Segunda y Tercera dimensiones de fantasía. Así, convendría antes que nada definir el parametro de base del cual vamos a partir: el mundo esta cifrado, aunque muy imperfectamente, en el lenguaje. 
Al referirse el relato, nos interesa examinar la primera oración:

Debo a la conjunción de un espejo y de una enciclopedia el descubrimiento de Uqbar. (F, p. 13)

Espejo y enciclopedia aquí no son precisamente equivalentes, pero en el pensamiento de Borges existen vínculos entre una palabra y la otra. Varias veces se ha referido Borges a los libros como un “espejo” del mundo. Así Marino, en "Una rosa amarilla”, muere desencantado al darse cuenta de que sus libros de poesía "no eran (como su vanidad lo soñó) un espejo del mundo, sino una cosa más agregada al mundo” (H, pp. 31-32). Y en "El primer Wells” añade:

La obra que perdura es siempre capaz de una infinita y plástica ambigüedad; es todo para todos, como el Apóstol; es un espejo que declara los rasgos del lector y es también un mapa del mundo. (O I, pp. 126-127)

Pero quizá lo más importante es el hecho de que ya en la Edad Media, uno de los nombres que se le daba a las enciclopedias era el de speculum. ${ }^{10}$ Espejo, por otra parte, tiene también, en la obra de Borges, la acepción de "memoria”. Así, en "La busca de Averroes”, dice el narrador: "La memoria de Albucásim era un espejo de íntimas cobardias” (A, p. 95). El espejo en el relato “Tlön...” bien puede ser un símbolo de la memoria que se nutre de los libros; y la enciclopedia, un imperfecto "espejo" del mundo real y que se refleja en la memoria. Hasta aquí estamos en una dimensión que podríamos llamar "real objetiva” en el contexto del cuento. Son reales Borges y Bioy, es real Ramos Mejía, consideramos real la quinta y la Anglo-American Cyclopaedia. ${ }^{11}$ Pero Bioy recuerda la famosa frase del heresiarca de Uqbar, leída en una enciclopedia: "los espejos y la cópula son abominables, porque multiplican el número de los hombres”. Cabría añadir: también los libros -tanto los históricos como los de carácter apócrifo o fantástico- multiplican, como los espejos y la cópula, el número de los hombres. La memoria de Bioy ha sido contaminada por una frase de un hombre inexistente. La fantasía comienza a introducirse en la "realidad".

1. "Creación” de un lenguaje que comienza a cambiar de las designaciones habituales (conceptos y objetos extemos) a designaciones figuradas. Primera dimensión de la fantasía.

Borges el personaje busca y encuentra el artículo apócrifo sobre Uqbar, que sabemos es un país inexistente. Y ya comienza el lenguaje a "cifrarse” en la primera dimensión de fantasía. Veamos algunos ejemplos. Las fronteras de Uqbar tienen como punto de referencia “ríos y cráteres y cadenas de esa misma región”. La voz frontera no tiene ya la acepción que nosotros solemos dar a ese término, puesto que los puntos de referencia son únicamente internos. Una frontera, en nuestro mundo, separa un país de otro y así tiene puntos de referencias tanto internos como externos. 
Una vez que desaparecen los puntos de referencia externos, la palabra frontera pierde lo más de su significado. Uqbar es un país que se contiene a sí mismo. Si no lo hubiéramos sospechado de antemano, el análisis lingüístico del texto nos permitiría intuir que es un país de índole imaginaria. Otro ejemplo: al descubrir la literatura de Uqbar, Borges nos dice que es de carácter fantástico, que se refiere a las regiones imaginarias de Mlejnas y Tlön y que no se refiere “jamás a la realidad”. La voz realidad tiene aquí otro sentido del que solemos adjudicarle. En un país fantástico, la “realidad” consistiría en una adecuación de lo que allí ocurre a las leyes arbitrarias bien sean de índole natural o psicológica- que el cuentista ha prefijado como corrientes y normales para esa región. Tenemos un último ejemplo. Al descubrir la parte histórica de Uqbar, Borges nos comunica que "a raíz de las persecuciones religiosas del siglo trece, los ortodoxos buscaron amparo en las islas... donde no es raro exhumar sus espejos de piedra” ( $F$, pp. 15-16). El examen detenido de la frase espejos de piedra nos puede suministrar, por una parte, algunos indicios acerca de la naturaleza de la "realidad” en Uqbar, por otra, del sentido que allí tienen las voces ortodoxo y heresiarca.

Examinemos primero: espejos de piedra. En nuestro mundo, este tipo de objeto no puede existir ya que la voz piedra, en este contexto, contradice la voz espejo. Los espejos no pueden ser de piedra, ya que las piedras -exceptuando algún caso rarísimono emiten reflejo alguno y por lo tanto no pueden constituir materia de espejos. Ahora bien, refiriéndonos a la parte del relato que trata de las doctrinas idealistas de Tlön, nos enteramos que allí se niega la existencia objetiva de la materia. Los “ortodoxos” de Uqbar, pues, son idealistas, pero idealistas que afin habitan -a diferencia de los habitantes de Tlön- un mundo donde existe la materia como una realidad objetiva. El hecho de que aún se "exhumen” los espejos de piedra, de que estos objetos existan independientemente de los procesos mentales de un individuo, nos da una clave para intuir el sentido de la voz "realidad" en Uqbar. Asimismo podemos deducir el sentido de la voz "heresiarca”. Si los “ortodoxos” (los idealistas) de Uqbar padecieron persecuciones, parecería justo suponer que los "heresiarcas” eran aquellos que proponían la doctrina opuesta al idealismo: el materialismo. Así, la cita del "heresiarca” de Uqbar recordada por Bioy al principiar el relato cobra un nuevo sentido. El heresiarca citado por Bioy es materialista, puesto que, aunque reniega de los espejos (los clasifica de “abominables”, no de “inexistentes”), acepta su existencia objetiva y su capacidad de reflejar imágenes de objetos y seres vivos.

El transito de la primera dimensión de fantasía a la segunda tiene asimismo equivalentes lingüísticos. Al pasar del mundo de Uqbar al mundo de Tlön, Borges nos habla en un "lenguaje de transición”. Antes de describirnos la visión del universo (Weltanschauung) de Tlön, nos habla de sus "tigres transparentes” y de sus "torres de sangre” ( $F$, p. 20). Está empleando metáforas. Pero pronto sabremos por qué. Todos los sustantivos en Tlön "sólo tienen un valor metafórico” ( $F$, p. 25). ${ }^{12}$ 
2. Empleo de un lenguaje cuyas designaciones son únicamente el lenguaje mismo. Segunda dimensión de la fantasía.

Una vez que penetramos en el mundo de Tlön, la lengua cambia de parámetros y se "cifra" a una segunda potencia. Lo primero que descubrimos es que en Tlön "Su lenguaje y las derivaciones de su lenguaje -la religión, las letras, la metafísicapresuponen el idealismo". Descubrimos muy pronto que ese mundo es "sucesivo, temporal, no espacial” ( $F$, p. 25) como lo es también el lenguaje. Aún más. La vertiginosa verdad es que Tlön es un planeta hecho, constituido exclusivamente por el lenguaje, puesto que la doctrina idealista de Berkeley -según la entiende Borgesniega la existencia objetiva de la materia. ${ }^{13}$ Sin referentes externos el mundo se convierte en una serie de ideas y sensaciones cuyo único referente es el lenguaje mismo. Así, esa primera oración que nos indica que el elemento básico constituyente de Tlön es el idealismo establece un nuevo parametro lingüístico. Todo el lenguaje empleado en la descripción subsiguiente de los distintos aspectos de Tlön -su teoría del lenguaje, su literatura, su metafísica, su geometría- tendrá que ser descifrado con referencia constante a este nuevo parámetro. Veamos unos pocos ejemplos.

"Siglos y siglos de idealismo", escribe Borges, "no han dejado de influir en la realidad. No es infrecuente, en las regiones más antiguas de Tlön, la duplicación de objetos perdidos” ( $F$, p. 27). Las palabras realidad y objetos no tienen aquí la acepción que tienen en nuestro mundo cotidiano. En un mundo que rige el idealismo, la "realidad" consiste exclusivamente en lo que se piensa y se siente, sin más referente que el pensamiento y el sentimiento. ${ }^{14}$ Dentro del marco de esa "realidad", todo es posible. El pensamiento, el sentimiento, la imaginación no tienen otras fronteras que las de sus propias posibilidades. Por otra parte, la voz objeto está igualmente "cifrada”. En un planeta idealista, el mundo existe como un tránsito de ideas en las mentes de sus habitantes. De ahí que los objetos consistan en la concreción lingüística de esas ideas y sensaciones. Así, por ejemplo, en el hemisferio boreal de Tlön:

Hay poemas famosos compuestos de una sola enorme palabra. Esta palabra integra un objeto poético creado por el autor. ( $F$, p. 21)

Lo mismo sucede con las voces encontrar y perder cuando Borges describe la naturaleza de los hrönir:

Dos personas buscan un lápiz, la primera lo encuentra y no dice nada; la segunda encuentra un segundo lápiz no menos real pero más ajustado a su expectativa. Esos objetos secundarios se llaman hrönir y son, aunque de forma desgañada un poco más largos. Hasta hace poco los hrönir fueron hijos casuales de la distracción y del olvido. (F, p. 27)

Pues bien, si los objetos no existen sino en la mente de los habitantes de Tlön, perder un objeto equivale a olvidarlo, encontrarlo a recordarlo. De ahí que el que 
“encuentra” el "segundo lápiz” lo halla "más ajustado a su expectativa”. La última frase de la cita nos da un indicio para ayudarnos a descifrar el acertijo lingüístico. ${ }^{15}$

Y llega el momento en que el Borges narrador intenta descifrar su propio lenguaje. Al describir una de las doctrinas metafísicas de Tlön, nos dice que los Tlönistas:

Saben que un sistema no es otra cosa que la subordinación de todos los aspectos del universo a uno cualquiera de ellos. Hasta la frase "todos los aspectos" es rechazable, porque supone la imposible adición del instante presente y de los pretéritos. Tampoco es lícito el plural "los preteritos" porque supone otra operación imposible... (F, p. 23)

Se podrían citar otros ejemplos de esta "cifra" del lenguaje concorde con una segunda dimensión de fantasía, pero, entre estos, ninguno más interesante que aquellos donde Borges emplea parámetros matemáticos de significado. La palabra que designa una cifra numérica está, a su vez, “cifrada” y así se impone una reconversión aritmética de lo que las cifras significan en Tlön a lo que las cifras significan en nuestro mundo cotidiano. Veamos dos ejemplos.

El "heresiarca” de Tlön que expone la teoría del materialismo del "undécimo siglo”. "Siglo, de acuerdo con el sistema duodecimal”, comenta Borges en una nota al pie, "significa un período de ciento cuarenta y cuatro años” ( $F$, p. 24). Anteriormente, en el transcurso del relato, Herbert Ashe había hablado a Borges del sistema duodecimal de numeración donde el 12 se escribe 10. Podríamos expresar un siglo de nuestro mundo en términos de un binario: 10 x 10. En Tlön, donde el 12 se escribe 10, un siglo equivaldría a 12 × 12 = 144. Para obtener la fecha que nos indique el comienzo de ese undécimo "siglo" en Tlön -número que en nuestro mundo sería redondohabría que multiplicar por una unidad inferior al número del siglo, en este caso por 10. La fecha que obtenemos: 144 x $10=1440$. Ahora bien, fue el 1440 cuando Nicolás de Cusa publicó De docta ignorantia-considerado por los historiadores de la filosofía como la más importante de sus obras- y De coniecturis. Recordemos que el "heresiarca” de Tlön intenta probar con el sofisma de las nueve monedas de cobre la existencia "real", es decir una existencia independiente de los procesos mentales de los Tlönistas, de esas monedas, aduciendo tácitamente que aunque las nueve monedas encontradas al final del sofisma no eran iguales entre sí, eran idénticas a las perdidas el martes anterior. El heresiarca resume su pensamiento de este modo:

El lógico pensar que ha existido -siquiera de un modo secreto, de comprensión vedada a los hombres- en todos los momentos de esos tres plazos. ( $F$, p. 24)

En su History of Medieval Philosophy, Maurice de Wulf explica la teoría del conocimiento de Nicolás de Cusa de la siguiente forma: 
In addition to the senses, which attain to corporeal things in a gross and confused manner, man possesses a "reasoning reason" which expresses reality in abstract concepts according to the principle of contradiction. The knowledge we attain from this reason is limited and relative for there are no two things alike; the beings which reason grasps are separate and incommensurable. Hence, human science is composed of conjectures. The integral truth of a thing is hidden in God from Whom things spring, and in Whom they lie beyond our reach. ${ }^{16}$

La contraposición de la razón y los sentidos, la afirmación de que no hay dos colas iguales en el mundo externo (lo cual serviría como argumento para combatir las doctrinal idealistas), y la aseveración de que la verdad integral del conocimiento parcial que obtenemos por medio de la interacción de la razón y los sentidos esta contenida en Dios (Comp.: "Es lógico pensar que han existido -siquiera de un modo secreto, de comprensión vedada a los hombres-...”) parece encuadrar -aunque, ciertamente, de una manera hiperbólica-con el pensamiento del "heresiarca” de Tlön.

Un poco más adelante, Borges nos dice que “cien años” después, un “ortodoxo” promulgó una teoría más audaz que la del "heresiarca”. Las voces cien años están igualmente cifradas. Cien años en Tlön, cabría recordar, equivalen a 144 en el mundo en que vivimos. Así, la fecha de la promulgación de la segunda teoría equivale a 1440 $+144=1584$. Ahora bien, en "La esfera de Pascal". Borges hace los siguientes comentarios acerca de Giordano Bruno:

...para Giordano Bruno, la rotura de las bóvedas estelares fue una liberación. Proclamó, en la Cena de las Cenizas, que el mundo es el efecto infinito de una causa infinita y que la divinidad está cerca, "pues está dentro de nosotros más aún de lo que nosotros mismos estamos dentro de nosotros”... Esto se escribió con exultación en 1584, todavía a la luz del Renacimiento... (O I, p. 15, subrayado nuestro)

El panteísmo expresado por Bruno en la cita anterior se aproxima mucho al “panteismo idealista” promulgado por una “conjetura feliz” del “ortodoxo” de Tlön:

Esa conjetura feliz afirma que hay un sólo sujeto, que ese sujeto indivisible es cada uno de los seres del universo y que estos son los órganos y máscaras de la divinidad. (F, p. 26)

Vemos, pues, que al describir la visión del universo en Tlön, Borges “cifra” el lenguaje no só1o respecto de parámetros de significado lingüísticos, sino también respecto de parámetros de significado de índole matemática. 
3. Empleo de un lenguaje que se designa a sí mismo para, a la vez, designar conceptos y objetos externos pertenecientes al mundo cotidiano. Tercera dimensión de la fantasía.

El tránsito a la "realidad objetiva" en la tercera parte del relato lleva, junto e íntimamente vinculado al problema de los parámetros lingüísticos, un entrecruzamiento de los planos de fantasía y realidad. La fantasía comienza a disolverse en la realidad hasta tal punto que parece desplazarla. Pero el producto de esta interacción de planos no es un mundo de pura fantasía. Más bien, los planos de fantasía y realidad se funden para producir, proyectado en el futuro, un tercer mundo que no podríamos calificar ni de fantástico ni de real, sino de "real-fantástico". Este último mundo, como veremos, constituirá el equivalente de Orbis Tertius.

Borges inicia esta tercera parte del relato con una descripción de la situación que pretende ser realista. El autor narra los orígenes de la "sociedad secreta" iniciadora de la que, a la larga, resultó ser la Primera Enciclopedia de Tlön, el resurgimiento de esa sociedad en América a mediados del siglo XIX, y los proyectos de Ezra Buckley. Los nombres de personajes reales están mezclados con otros de personajes ficticios: Herbert Ashe y Buckley coexisten con Martínez Estrada, Dalgarno y George Berkeley. Pero pronto se rompe el delicado equilibrio. El autor nos comunica que "objetos" de Tlön están invadiendo el mundo real. Menciona dos: una brújula y un cono que es “imagen de la divinidad en ciertas religiones de Tlön” ( $F$, p. 32). Pues bien, estos objetos no son sino metáforas "solidificadas".

Tomemos primero la brújula. La brújula tiene que ser una metáfora por las siguientes razones: Primero: presuponiendo la posible existencia objetiva de una brújula en Tlön, su utilidad sería nula puesto que la geometría de ese planeta -además de afirmar que "el hombre que se desplaza modifica las formas que lo circundan""desconoce las paralelas” ( $F$, p. 22). Desconocer las paralelas es negar la posibilidad de trazar longitudes y latitudes. En un mundo sin longitudes y latitudes, una brújula serviría más que para orientarse, para extraviarse; no tendría otra función que la de sembrar la confusión y el desvarío. Segundo: En Tlön, planeta sometido a la doctrina del idealismo, no existen, como ya hemos apuntado, los objetos materiales, puesto que es un mundo constituido únicamente por el lenguaje. La brújula no podía, pues, existir. Tercero: En el lenguaje que constituye ese planeta ni siquiera existen los sustantivos. Así, los contradictores del "especioso argumento" del heresiarca materialista afirma que "todo sustantivo (hombre, moneda, jueves, miercoles, lluvia) sólo tienen un valor metafórico” ( $F$, p. 25).

Tomemos el ejemplo del cono. El cono, escribe Borges, es una "imagen de la divinidad en ciertas religiones de Tlön”. Al escribir Borges sobre la metáfora de la esfera en Pascal, metáfora que, entre otros, Sir Thomas Browne empleó para designar la divinidad, afirma:

... lo significativo es que la metáfora que usa Pascal para definir el espacio es empleada por quienes le precedieron (y por Sir Thomas Browne en Religio Medici) para definir la divinidad. 
Y anade una nota al pie:

Que yo recuerde, la historia no registra dioses cónicos, cúbicos o piramidales, aunque sí ídolos. (O I, p. 137)

Convendría explorar un poco más a fondo el concepto de metáfora "solidificada" puesto que este concepto es, en sí, contradictorio. La metáfora es un fenómeno estrictamente lingüístico. Fuera de los ámbitos de la lengua, su existencia es impensable. En nuestro mundo, ni las metáforas pueden convertirse en objetos -es decir, “solidificarse"-, ni los objetos pueden, en rigor, convertirse en metáforas. Un abismo real separa la palabra de la cosa que designa, el significante del significado. En un artículo sobre Quevedo, Borges discurre brevemente sobre la naturaleza de la metáfora. Observa que a Quevedo:

Las trivialidades o eternidades de la poesía (las metáforas), le incomodaban por ser fáciles, pero mucho más por ser falsas. Olvidó, al censurarlas, que la metáfora es el contacto momentáneo de dos imágenes, no la metódica asimilación de dos cosas. (O I, p. 59)

La metáfora, para Borges, no puede existir en el tiempo -como no sea en la temporalidad del lenguaje, que es sucesivo- ya que es un "contacto momentáneo de dos imágenes”; tampoco puede existir en el espacio ya que es el contacto de dos imágenes y no la asimilación de dos cosas. Imágenes y cosas quedan, pues, en contraposición una respecto de la otra. Así, en Tlön-mundo constituido exclusivamente por imágenes y sensaciones traducidas al lenguaje-no pueden existir, como ya hemos anotado más de una vez, cosas; en nuestro mundo cotidiano no pueden existir objetos cuya materia -y aquí la enigmática nota al pie de Borges "Queda... el problema de la materia de algunos objetos” (p. 92), nos da un indicio de la contradicción- sea el lenguaje, a menos que esto ocurra por medio de una “magia particular”. Esta magia, en “Tlön...”, la opera el lenguaje mismo. La voz objeto, empleada por Borges en “cifra” al describir el mundo de Tlön y que allí significa una serie de "sensaciones e imágenes” concretizadas en palabras, coincide, en la última parte de la narración, con la voz objeto según la entendemos en nuestro mundo real y que significa “cosa”. Coincidencia inverosímil e imposible, podríamos pensar. Y estamos en lo cierto. Así, la coincidencia entre imagen y cosa, su fusión y asimilación, resulta ser una transfusión "mágica”. Veamos ahora cómo esta fusión "mágica” de imagen y cosa constituirá las bases de “Orbis Tertius”.

Intentemos, antes que nada, aclarar las coincidencias y divergencias de A First Encyclopaedia of Tlön (también transcrita a veces como: "la Primera Enciclopedia de Tlön”) y Orbis Tertius. Borges, al mencionar estas dos “obras”, parece incurrir en varias contradicciones que pueden ocasionar confusión. 
La primera vez que se mencionan las voces “Orbis Tertius”-pasando por alto el título del relato- es cuando Borges el personaje descubre el tomo XI de A First Encyclopaedia of Tlön. Escribe Borges:

Me puse a hojearlo y sentí un vértigo asombrado y ligero que no describiré, porque ésta no es la historia de mis emociones sino de Uqbar, Tlön y Orbis Tertius. (F, p. 18)

Sobre la importancia del hecho de que “Orbis Tertius” no aparezca impreso en cursiva, hablaremos más adelante. Bastaría, por ahora, anotar que ninguna de las tres locuciones aparece en cursiva.

La segunda vez que aparece citado “Orbis Tertius” es cuando Borges el personaje encuentra en la primera página de la First Encyclopaedia of Tlön un papel de seda que cubre una de las láminas en colores con un óvalo azul estampado con las palabras: Orbis Tertius. Escribe Borges:

En la primera página y en una hoja de papel de seda que cubría una de las láminas en colores había estampado un óvalo azul con una inscripción: Orbis Tertius. (F, p. 18)

Notemos los siguientes rasgos: la inscripción esta estampada en una hoja de papel de seda (el papel de seda es casi transparente), sobre una lámina de colores (la lámina en colores se transparenta, con toda probabilidad, a través del papel de seda de tal suerte que el óvalo azul con la inscripción Orbis Tertius aparecerá como si estuviera yuxtapuesto a la lámina), y “Orbis Tertius” está impreso en cursiva. De este último rasgo podríamos inferir que se trata de un libro y, puesto que esta estampado en la primera página de la enciclopedia que Borges se dispone a hojear, es un segundo título de la First Encyclopaedia of Tlön.

La tercera vez que Borges cita la locución nos suministra información más detallada respecto de "Orbis Tertius". En 1914, la "sociedad secreta” envía a sus colaboradores el último volumen de la Primera Enciclopedia de Tlön:

La edición es secreta. Los cuarenta volúmenes que comprende... serían la base de otra más minuciosa, redactada no ya en inglés, sino en alguna de las lenguas de Tlön. Esa revisión de un mundo ilusorio se llama provisoriamente Orbis Tertius y uno de sus modestos demiurgos fue Herbert Ashe... (F, p. 31)

En esta ocasión, las palabras de Borges nos suministran varias indicaciones precisas e importantes respecto a “Orbis Tertius”. “Orbis Tertius” es una “enciclopedia” que es una revisión de la Primera Enciclopedia de Tlön, escrita en alguna de las lenguas de Tlön. Anotemos que Orbis Tertius tiene que estar redactada en "alguna” de las lenguas de Tlön. Recordemos, asimismo, que el tomo XI quo Borges encuentra 
está “redactado en inglés”. El proyecto final de Orbis Tertius, pues, no puede ser el tomo que Borges encuentra en Adrogué. Lo que sí podríamos inferir -aunque con cautela- es que en el tomo que Borges hojea coexisten la First Encyclopaedia of Tlön y el esbozo de Orbis Tertius. Ese tomo es un tomo de transición. Uno de los indicios es el siguiente: en el lomo del volumen XI, las indicaciones alfabéticas se encuentran ya en una de las lenguas de Tlön, mezclada con el inglés: Hlaer to Janqr. Este rasgo nos puede indicar o que una parte de los encabezamientos alfabéticos de los artículos están escritos en esa lengua de Tlön y otra parte en inglés, o bien (aunque quizá menos probable) que todos los encabezamientos de los artículos del volumen están escritos en esa lengua de Tlön y los artículos en sí están redactados en inglés. Cuando Borges descubre el volumen XI declara que "estaba redactado en inglés” ( $F$, p. 18). El otro rasgo que nos indica que el tomo XI es de transición es el hecho de que aparezcan láminas en colores. Sobre esto hablaremos un poco más adelante.

La última mención de “Orbis Tertius” nos da indicios aún más claros de que el volumen XI es un ejemplar de transición donde coexisten la Primera Enciclopedia de Tlön, de una manera definida, y Orbis Tertius aun de un modo indefinido. La mención aparece en la "Postdata de 1947":

Hacia 1944 un investigador del diario The American... exhumó en una biblioteca de Memphis los cuarenta volúmenes de la Primera Enciclopedia de Tlön. Hasta el día de hoy se discute si ese movimiento fue casual o si lo consintieron los directores del todavía nebuloso Orbis Tertius. (Ibid., p. 33)

Tengamos en cuenta que es la primera vez que se pone a la disposición del público en general la Primera Enciclopedia de Tlön y su visión del universo (las ediciones anteriores habían sido secretas). Pero aún así, Borges se pregunta si ese acto fue causal o si "lo consintieron los directores del todavía nebuloso Orbis Tertius". Las voces todavía nebuloso implican que para esa época (1944) Orbis Tertius todavía no tiene existencia definida y determinada, como la tiene, por ejemplo, la Primera Enciclopedia de Tlön.

De las observaciones anteriores, y de las aparentes contradicciones internas que encierran, inevitablemente surgirá la pregunta: si Orbis Tertius coexiste con y en la Primera Enciclopedia de Tlön, pero aún es un proyecto que queda por realizarse en su totalidad, ¿en qué consiste, a fin de cuentas, Orbis Tertius?

Los razonamientos que hemos venido siguiendo hasta ahora nos dejan muy pocas alternativas coherentes que den respuesta satisfactoria a esta pregunta. Tendríamos que empezar por examinar las voces “Orbis Tertius”. "Orbis Tertius” puede significar a la vez, "tercer círculo”, “tercera enciclopedia” y “tercer mundo”. En el contexto del desarrollo del relato de Borges, las últimas dos significaciones parecen coincidir. La locución “Orbis Tertius” aparece estampada en el cuento de dos formas distintas: en cursiva (lo cual implicaría una obra, un "libro”), y en letra de imprenta corriente, en redonda (en una secuencia donde se enumeran lugares “geográficos”). Borges ha 
escrito que el relato es "la historia de Uqbar, Tlön y Orbis Tertius”. Uqbar y Tlön son “países” y “planetas” y, en este contexto, Orbis Tertius lo ha de ser también. "Orbis Tertius”, pues, será un mundo y una enciclopedia a la vez, será una enciclopedia viva y palpitante. En el contexto del cuento, es éste el único modo de explicar la locución en los términos de la definición dada por Borges. “Orbis Tertius”, escribió Borges, es la revisión “minuciosa” de la Primera Enciclopedia de Tlön en “alguna de las lenguas de Tlön”. Pues bien, en los últimos dos párrafos del cuento, Borges indica que "El contacto y el hábito de Tlön han desintegrado este mundo". Añade que "Ya ha penetrado en las escuelas el (conjetural) 'idioma primitivo' de Tlön”. Ya se han reformado algunas de las ciencias, otras esperan su turno. El relato concluye con una proyección hacia el futuro:

Entonces desapareceran del planeta el inglés y el francés y el mero español. El mundo sera Tlön. (F, p. 34)

Si el mundo se convierte eventualmente en Tlön, y habla alguna de sus lenguas, con las ciencias, la metafísica, las matemáticas reformadas de acuerdo con los razonamientos o desatinos de Tlön, entonces el mundo que conocemos se convierte en una disparatada y pesadillesca-pero no por ello menos real y palpable-enciclopedia viva. Ese mundo -fusión de dos contrarios: el mundo exclusivamente idealista de Tlön y el nuestro donde, dichosa o desdichadamente, existe la materia-constituirá un tercer mundo, será el equivalente de “Orbis Tertius”. Allí, la imagen y la cosa se habran fundido una en otra para formar objetos que no existen ni pueden existir en nuestro mundo. Si las metáforas "solidificadas" parecen objetos extraños cuando empiezan a surgir en el mundo real, en “Orbis Tertius” serán lo común y corriente.

Es ahora, una vez que vemos lo que Borges entendía al escribir el término "Orbis Tertius”, cuando podemos intentar explicar su extraña coexistencia con A First Encyclopaedia of Tlön. La tentativa de la "sociedad secreta” que forjó esta enciclopedia era contaminar el mundo real con el mundo de Tlön. El modo más directo era por medio de la introducción de su lenguaje, ya que ese mundo estaba constituido de lenguaje. En el volumen XI, ya lo hemos apuntado, se comienza a introducir en el mundo real la lengua, o una de las lenguas, de Tlön. Otro de los medios que podrían utilizarse era la representación gráfica de los objetos y los seres que no existen sino en calidad de metáforas en Tlön. Las representaciones gráficas serían inconcebibles en aquel planeta ya que sus habitantes piensan que nada "que existe en el espacio puede perdurar en el tiempo”. Las representaciones gráficas perduran en el espacio y en el tiempo. Las "láminas en colores” de la Primera Enciclopedia de Tlön son el comienzo de la fusión de los dos mundos, el comienzo de la fusión entre la imagen y la cosa, las primeras metáforas “solidificadas”. De ahí que sobre estas láminas este calcado el óvalo azul con la inscripción Orbis Tertius, casi un anuncio de la futura destrucción del mundo real. 


\section{CONCLUSION}

Hemos dado la vuelta al círculo. El relato comenzó con un recuerdo de Bioy Casares extraído de un libro apócrifo. El cuento términa con una invasión destructora del mundo real por “objetos” (que no son sino ideas) provenientes de un mundo falso, divulgados por un libro apócrifo: la First Encyclopaedia of Tlön. El cuento en su totalidad parece contener una advertencia, advertencia por lo demás positiva, acerca de las limitaciones inherentes a ciertos aspectos de la naturaleza misma del lenguaje. Sacamos ideas de los libros, nutrimos nuestra imaginación y nuestra memoria de esos extraños signos que son letra de imprenta y que constituyen un aspecto del lenguaje. Hablamos, y al hablar divulgamos esas ideas. Pero el lenguaje, sin más referentes que él mismo, no nos puede permitir distinguir entre lo apócrifo y lo auténtico, entre lo falso y lo verdadero. Nos servimos del lenguaje para comunicar sabiduría; nos podemos servir del lenguaje, también, para engañar y engañarnos, para traicionar y traicionarnos y hasta, quizá, para destruirnos.

Por medio de una gradación sucesiva del lenguaje donde se han establecido distintos y opuestos parametros de significados para después hacerlos converger y asimilarse, Borges nos ha hecho creer en un mundo imaginario, urdido por hombres, capaz de invadir un mundo real y hacerlo desaparecer. La yuxtaposición y asimilación de parámetros de significados lingüísticos han llevado a cabo una operación “mágica”. Para crear esa concatenación de eventos extraordinarios, Borges no se ha servido sino de "un juego preciso de vigilancias, ecos y afinidades" ( $D$, p. 90$)$. Vigilancias, ecos y afinidades que están predicadas en algo que nos es muy “real”, accesible, cotidiano e inevitable: el lenguaje mismo.

Universidad de Puerto Rico

ARTURO ECHAVARRIA FERRARI

\section{NOTAS}

1 Citamos en el orden cronológico de publicación: Francis Wyers Weber, "Borges’s Stories: Fiction and Philosophy" en Hispanic Review, vol. XXXVI, no. 2, abril de 1968, pp. 124-141; James E. Irby, “Borges and The Idea of Utopia”, en Books Abroad (Norman, Oklahoma), vol. 45, no. 3, Verano de 1971, reimpreso en The Cardinal Points of Borges, Norman, University of Oklahoma Press, 1971, pp. 35-45 (en lo sucesivo, citaremos por esta edición); y Jaime Alazraki, “Tlön y Asterión: anverso y reverso de una epistemología”, originariamente publicado en Nueva Narrativa Hispanoamericana, vol. I, no. 2, septiembre de 1971, y reimpreso, con variantes, bajo el título de “Tlön y Asterión: metáforas epistemológicas” en Jorge Luis Borges. El escritor y la crítica [comp. por Jaime Alazraki], Madrid, Taurus, 1976, pp. 183-200 (en lo sucesivo citaremos por esta edición).

2 Weber, Op. cit., pp. 140-141.

3 Alazraki, Op. cit., p. 191.

4 Weber, Op. cit., p. 135.

5 “...el mundo es, ahora, Tlön”, Alazraki, Op. cit., p. 200. Cf., además, pp. 193, 195. James Irby, por otra parte, escribe: “... The mental powers, vicissitudes and vertigos of Tlön are our 
own world, our world of reality as shifting symbol, of relentless time and unknown ultimate pattern, here paradoxically turned about and fabled to help us perceive it more acutely as such” (Irby, Op. cit., p. 43; el subrayado es del autor).

${ }_{6}$ Jaime Alazraki apunta el hecho de que "en Borges, la narración fantástica se desliza sobre ese equilibrio creado por la relación significante-significado...” (Op. cit., p. 184) Más adelante, sin embargo, al aproximarse al estudio de los cuentos de Borges, propone: "El lenguaje, como instrumento de conocimiento, deja de ser una traducción para convertirse en una paráfrasis, de reflejo de la realidad deviene una realidad independiente: significado y significante abandonan la paralela para abrirse en un ángulo sin posible punto de intersección” (Ibid., p. 188). Si bien coincidimos con el énfasis que el Profesor Alazraki presta al carácter arbitrario del lenguaje frente a la realidad, entendemos que, por lo menos, en "Tlön, Uqbar, Orbis Tertius” Borges lanza una clara advertencia respecto de los peligros que lleva la postulación de un mundo donde significante y significado se abran "en un ángulo sin posible punto de intersección”.

7 Irby, Op. cit., p. 41.

8 Permítasenos esta simplificación provisional. Más adelante intentaremos una explicación detallada de lo que podría significar Orbis Tertius. Por lo pronto convendría aclarar lo siguiente: en la primera parte del cuento, Orbis Tertius convive y, hasta cierto punto, forma parte de la Primera Enciclopedia de Tlön. En la tercera parte del cuento, el concepto de “Orbis Tertius” cobrará cada vez mayor autonomía hasta que, en un futuro previsible para el Borges narrador, se convierte en una entidad autónoma. Veremos entonces que lo que llamamos “tercera dimensión de fantasía” coincide con el marco real de esa tercera parte del cuento.

9 Empleamos aquí las voces “mágico” y “magia” en la acepción de Borges en un ensayo "El arte narrativo y la magia”. "Magia”, pues, como la "pesadilla de lo causal” y en lo que se refiere al arte del relato (aunque en ese ensayo Borges se refiere primordialmente a la novela) como el despliegue, en el transcurso de una narración, de "un juego preciso de vigilancias, ecos y afinidades” ( $D$, p. 90). Coincidimos con la afirmación de Emir Rodríguez Monegal respecto de que en la obra de Borges la "magia” o lo "mágico" poco o nada tiene que ver con "el uso que, desde Franz Rob y Massimo Bontempelli, hasta Arturo Uslar Pietri, Alejo Carpentier y Miguel Ángel Asturias... se le viene dando en la crítica contemporánea” (“Borges: una teoría de la literatura fantástica” en Revista Iberoamericana, vol. XLII, no. 95, p. 183).

${ }^{10}$ Véase Enrique Anderson-Imbert, "Nueva contribución al estudio de las fuentes de Borges” en Filología, Año VIII, Números 1-2, Buenos Aires, 1962, “‘Orbis’, en efecto, era uno de los nombres que, en la Edad Media, se daban a las enciclopedias. Otro era ‘speculum'” (11). Entre las más conocidas se podría citar el Speculum Maius de Vicente de Beauvais.

${ }^{11}$ El narrador describe la Anglo-American Cyclopedia, como una "reimpresión literal” de la Britannica de 1902. La Anglo-American Cyclopedia, en cambio, no existe, cf. Mary Berg, The Non-Realistic Short Stories of Leopoldo Lugones, Horacio Quiroga and Jorge Luis Borges, Tesis doctoral inédita, Harvard University, Cambridge (Massachussetts), 1969. Esta excelente tesis señala gran número de fuentes respecto a “Tlön...”.

${ }^{12}$ Se podría llevar a cabo un análisis detallado (que no cabría aquí) de la concepción del lenguaje en el "planeta” Tlön tomando como referencia sistemática la concepción del lenguaje de Fritz Mauthner. En Borges: teoría del lenguaje y la literatura, tesis doctoral inédita, Harvard University, Cambridge, (Massachusetts), 1976, hemos explorado con más 
detenimiento los vínculos entre la teoría de Mauthner y la que parece estar inscrita tanto en los cuentos como en los ensayos de nuestro escritor.

13 James Irby propone que Tlön es el mundo de la "escritura”: “Tlön is also the world of writing, of escritura, which consists in the meaningful permutation and alignment of signs according to inherent laws and not in the mere transcription of some prior, non verbal reality" $(O p$. cit., p. 42). Nosotros proponemos que Tlön es no sólo el mundo de la escritura, sino el de la lectura, el del lenguaje todo.

${ }^{14}$ Irby indica: "In Tlön thought and reality are one...”, Op. cit., p. 37.

${ }^{15}$ Irby se acerca también a esta afirmación: "The narrator caps his summary of the Eleventh volume with a very brief description of how objects fade and disappear from view when forgotten. The idea of proliferation is then abruptly juxtaposed with that of loss, and, retroactively, the idea of forgetting suggests that the preceding discussion of hrönir was, at least in part, an extended metaphor of the process of memory, as well as historiography" (Irby, Op. cit., p. 38).

${ }^{16}$ Maurice de Wult, History of the Medieval Philosophy, Vol. III, trad. de Ernest Messenger, Longmans, Green and Co., Londres, 1926, p. 214. Borges cita a de Wulf en OI, p. 214. 


\title{
Adolfo Bioy Casares y Jorge Luis Borges: La Utopía como Texto*
}

\author{
... la función utópica del espíritu se confunde \\ exactamente con la función poética por excelencia, con \\ la facultad de hacerse ilusiones y recrearse con ellas, \\ que Coleridge ha definido en esta fórmula magistral: \\ "La suspención voluntaria del descreimiento". \\ Alfonso Reyes, “Las utopías”, Los trabajos y los días. ${ }^{1}$
}

Dentro del laberinto de textos en el cual se inscriben las obras de J. L. Borges y A. Bioy Casares, la relación que se establece entre los textos de ambos autores es de extremada importancia. Una discusión de la utopía borgiana "Tlön, Uqbar, Orbis Tertius" en relación con las "novelas-isla” de Bioy Casares y, particularmente, con Plan de evasión, podría servir de útil introducción a este complejo tema.

Si bien el prólogo de Borges a La invención de Morel de Bioy Casares podría considerarse como la indicación más evidente de una estética narrativa compartida por ambos autores, existen aún signos anteriores no sólo de una afinidad "teórica", sino tambión de una relación textual. Ya en 1936 Borges reseña La estatua casera, una de las primeras novelas de Bioy Casares, y aunque en general expone sus reparos contra el surrealismo incoherente del joven autor Bioy Casares, cree advertir en ciertas "lúcidas" páginas "la voz fundamental -y futura-del escritor". ${ }^{2}$ Borges incluso elogia el hecho de que la novela es "una enérgica vindicación de los cuentos "fantásticos", y comienza su profética reseña con una declaración que es también, de hecho, una vindicación de la literatura fantástica:

Sospecho que un examen general de la literatura fantástica revelaría que es muy poco fantástica. He recorrido muchas utopías -desde la epónima de More hasta Brave New World- y no he conocido una sola que rebase los límites caseros de la sátira o del sermón y que describa puntualmente un falso país, con su geografía, su historia, su religión, su idioma, su literatura, su música, su gobierno, su controversia matemática y filosófica... su enciclopedia, en fin; todo ello articulado y orgánico, por supuesto, y (me consta que soy muy exigente) sin alusión a los trabajos injustos que padeció el capitán de artillería Alfredo Dreyfus. (p. 85)

En su ensayo "Borges and the Idea of Utopia”, James Irby se al pasaje citado arriba como una directa anticipación de "Tlön"3 cuento Borges explica cómo un artículo en un "ejemplar anómalo” de una enciclopedia piratesca revela la existencia 
de un país utópico en un planeta desconocido, y termina revelando que la enciclopedia excluye y es a la vez esa utopía, tal como el relato “Tlön” es la enciclopedia de esa enciclopedia. Las tempranas referencias de Borges a las deficientes utopías del pasado, y su proyecto de una rigurosa utopía “enciclopédica” parecen anunciar ya no solamente su cuento sino también el resultado de la "futura voz” de Bioy Casares: Plan de evasión. El texto crítico de Borges termina con una burlona referencia al personaje histórico de Dreyfus. Por otro lado, Dreyfus (que según Borges, debería ser excluído de todo texto utópico, puesto que su mención simboliza el detalle irrelevante y el artificio ineficaz del realismo) desempeña, irónicamente, un papel importante en Plan. Digo irónicamente, porque su inclusión parecería a primera vista una refutación del idealismo de Borges y una afirmación de que el espacio novelesco permite la inclusión de detalles irrelevantes. Pero lo que justamente sucede en Plan es que Bioy no sólo se burla del naturalismo situando aparentemente su relato en un lugar real, la Isla del Diablo, o usando el nombre Dreyfus como apodo de un personaje; sino que utiliza esos detalles, esos nombres, como ecos, como pistas falsas, afirmando así, paradójicamente el diálogo lúdico con los no menos paradójicos textos de Borges.

La “invención” de el Tercer Orbe -Orbis Tertius- de, “Tlön”, que Borges profetiza en esta reseña es también, metafóricamente, la invención de "Boorges”, el tercer escritor, nacido del diálogo de los textos de Borges y Bioy Casares. Quiero decir que si en la reseña de La estatua casera, Borges prefigura ya su relato “Tlön”-que será publicado por primera vez el mismo año en que aparece La invención de Morel, 1940 -también prefigura futuros textos de Bioy Casares, esos textos que, según Borges, por su “rigor de invención” superarán no sólo los de Huxley, sino también los de More, Swift y Wells:

De las novelas imaginativas de Wells (y aún de las de Swift) sabemos que hay en cada uno un solo elemento fantástico; de las 1001 Noches, que buena parte de su maravilla es involuntaria, ya que los egipcios del siglo trece creían en los talismanes y los conjuros. En resumen: poco me asombraría que la Biblioteca Fantástica Universal no pasara de un tomo de Lewis Carroll, de un par de films de Disney, de un poema de Coleridge y (por distracción del autor) de los Opera omnia de Manuel Galvez. (pp. 85-86)

De esta manera, a la vez que Borges manifiesta su admiración por los precursores que han intentado la creación de textos utópicos en los que las leyes de lo fantástico predominan sobre las de la realidad cotidiana, señala los errores de esos escritores admirados por él y Bioy Casares, quizás como una manera sutil de revelar a este último la dificultad de semejante tarea. Sir Thomas More, aunque digno de admiración por sugerir que la utopía es un lugar que no existe en ninguna parte al usar el nombre utopía (ningún lugar) en vez de eutopia (buen lugar), se muestra demasiado interesado en la satira social para preocuparse por el aspecto metafísico. Brave New World de Huxley 
es una sátira del presente más que una verdadera fantasía del futuro o de algun lugar y tiempo inexistentes. En efecto, Borges se burla de la novela de Huxley al referirse a Orbis Tertius como “este brave new world”, ${ }_{4}^{4}$ y en “Tlön”, así como también en Plan, se alude constantemente a la tradición de la utopía. La burla o la ironía consiste precisamente en el hecho de que Orbis Tertius -nombre con que los antiguos cosmógrafos se referían a la tierra-así como el “new world” de Huxley, no es tal nuevo mundo sino la proyección de un mundo viejo.

Incluso el admirado H. G. Wells -cuyas obras son profecías de una realidad otra y contienen verdaderos elementos fantásticos- no logra crear textos totalmente liberados de las riendas del realismo. Y análogamente, Swift -cuyos Yahoos son parodiados por Borges en "El informe de Brodie”- usa lo fantástico como pretexto para la sátira social. En su reseña de La estatua casera, Borges trata de señalar a Bioy Casares que el mayor obstáculo para lograr lo fantástico es su intención moral. Bioy, bajo la influencia antirracionalista del surrealismo, consideraba una cobardía escribir coherentemente sobre realidades humanas que serían mucho más eficazmente reveladas en su incoherencia. Borges sostiene que la falsa coherencia del realismo y la incoherencia del surrealismo son en realidad defectos, no por razones morales, sino estéticas: ambas son soluciones simplistas y superficiales. El verdadero desafío sería escribir relatos fantásticos que a la vez poseyeran una rigurosa lógica.

Al reseñar Luis Greve, muerto (1937) -colección de cuentos de Bioy que precede a Morel-, Borges señala una “superación” operada en la obra de aquel y la importancia que el joven autor ya ha alcanzado en el campo de la literatura fantástica:

Nuestra literatura es muy pobre de relatos fantásticos. La facundia y la pereza criolla prefieren la informe tranche de vie o la mera acumulación de ocurrencias. De ahí lo inusual de la obra de Bioy Casares. En Caos y en La nueva tormenta la imaginación predomina; en este libro -en las mejores páginas de este libroesa imaginación obedece a un orden. Nada tan raro como el orden en las operaciones del espíritu, ha dicho Fenelón. ${ }^{5}$

Entre esas mejores páginas, cuyo manejo riguroso, lúcido y consistente de lo fantástico elogia, Borges incluye el relato que da título al libro y "Los novios en tarjetas postales”, cuyo tema prefigura en cierto modo el de Morel.

En su prólogo a Morel -etapa final de esta serie cronológica de comentarios sobre las obras de Bioy Casares-, Borges explica desde un punto de vista crítico el éxito del autor en la elaboración de un texto efectivamente fantástico, una verdadera utopía hermética. Bioy Casares ha explicado recientemente este salto a la utopía en términos más íntimos y ha referido en sus declaraciones cómo decidió escribir sobre una isla distante y sobre personajes que no fueran argentinos porque: 
Quería lograr una distancia de mí mismo. Era como si yo fuera en cierto modo un enfermo, y no quería contaminar mis buenas intenciones... ....Mejor que no hablara de la República Argentina, de personas que conocía... ...Tenía que hablar de cosas que desconocía: Venezuela, las islas del Pacífico, los canadienses franceses. Cosas tomadas de los diccionarios. ${ }^{6}$

El viaje a la isla, pues, era para él como un salto metafórico al texto: saltar de la conciencia de sí mismo a la conciencia misma del texto; de la vida, al arte. ${ }^{7}$

Los signos de una interrelación textual entre “Tlön” y Plan, no se encuentran solamente en los comentarios de Borges sobre los textos de Bioy Casares, sino también en los de este último sobre los textos de aquel. Si el prólogo a Morel permitió a Borges defender la invención fantástica de Bioy Casares contra los campeones del realismo, la reseña que este último escribe sobre El jardín de senderos que se bifurcan (1941) -donde “Tlön” es incluído por primera vez en libro-es, de entrada, una defensa

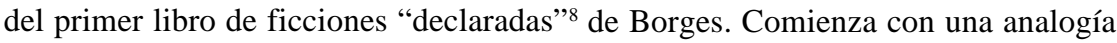
entre Borges y los filósofos de Tlön:

Borges, como los filósofos de Tlön, ha descubierto las posibilidades literarias de la metafísica; sin duda el lector recordará el momento en que también él, sobrecogido, las presintió en una página de Leibnitz, de Condillac o de Hume. La literatura, sin embargo, sigue dedicada a un público absorto en la mera realidad; a multiplicarle su compartido mundo de acciones y de pasiones. Pero las necesidades suelen sentirse retrospectivamente, cuando existe lo que ha de satisfacerlas. El jardín de senderos que se bifurcan crea y satisface la necesidad de una literatura de la literatura y del pensamiento. ${ }^{9}$

Esta reseña reúne los fragmentos de una estética borgiana sobre la literatura de to fantástico. Bioy no sólo sugiere la necesidad de escribir "una literatura de la literatura”, sino también de un lector (no sólo Borges, sino "el lector”) de literatura filosófica que sea escritor de una literatura basada en esas lecturas. En otras palabras, el lector como escritor, tal como lo ha formulado Rodríguez Monegal. ${ }^{10}$ En su reseña Bioy Casares separa las ficciones de Borges en dos géneros: obras filosóficas y relatos de ficción, y conviene con Borges en que “el género policíaco ... ... ha producido un ideal: un ideal de invención, de rigor, de elegancia (en el sentido que se da a la palabra en las matemáticas) para los argumentos” (p. 61). Bioy continúa destacando cómo la fusión de elementos reales e irreales en los relatos de Borges -él mismo aparece como personaje menor en “Tlön”- sirve para intensificar la realidad de un mundo ideal (o de un mundo como idea) en “Tlön” y otros textos de carácter berkeliano.

Bioy termina su reseña con un ataque contra aquellos que consideran los relatos de. Borges como "entretenimientos”, contra los que piensan que la única verdadera literatura latinoamericana es la de carácter telúrico. Advierte el subyacente caracter 
fascista de esa otra falsa utopía, la novela regionalista que pretende ser la realidad, la pampa, cuando lo cierto es que no es más que otra versión del artificio pastoril, tan artificial como los idilios de Teócrito o los sonetos modernistas de Darío. Bioy Casares concluye:

De la pampa nos quedan los viajes largos y algunas incomodidades. Estamos en la periferia de los grandes bosques y de la arqueología de América. Creo, sin vanagloria, que podemos decepcionarnos de nuestro folklore. Nuestra mejor tradición es un país futuro. (p. 61)

La utopía es algo que está siempre más allá de todo alcance. Tal ha sido el sentido de América y su literatura desde que nacieron ambas de la pluma y el pensamiento europeos. Es en esta amplia tradición de la utopía de la imaginación en la que Bioy sitúa a Borges -y, de hecho, a sí mismo.

La obra literaria utópica, a la manera en que la concibe More, consiste en la narración y descripción de aventuras en un país ideal que podría existir y que-dentro de la ficción del texto de More- efectivamente existe. De esta manera, el texto, en su mero nivel físico, es una especie de microcosmos de ese país. Por otro lado, dentro de la metafísica idealista de la literatura que Borges y Bioy proponen, el texto es una utopía porque él mismo es ese “país-que-está-en-ninguna-parte” un microcosmos o, a veces, macrocosmos; una reducción o una expansión de otras utopías que, en última instancia son inevitablemente otros textos. América, la realidad, es cualquier experiencia que el turista o el natural puedan tener. América, la utopía, es todo texto de ficción, desde Colón y Shakespeare hasta Sarduy y Thomás Pynchon, los cuales han recreado, de alguna manera, una imagen de esa imagen.

Así pues, podemos considerar-como ya hemos sugerido anteriormente-que de la misma manera en que Morel anuncia o prefigura a Plan; el relato “Tlön”, ese otro utópico texto borgiano, es también la prefiguración de este último, estableciéndose entre ambos textos una relación en la que Plan viene a ser el macrocosmos del microcosmos “Tlön”.

“BIOY CASARES”, PERSONAJE DE “TLON, UQBAR, ORBIS TERTIUS”

El personaje principal en “Tlön” es el narrador en primera persona, máscara de Borges-autor, pero entre las otras máscaras que Borges adopta en este texto polisémico, es significativa la que representa el personaje "Bioy Casares”. El relato comienza:

Debo a la conjunción de un espejo y de una enciclopedia el descubrimiento de Uqbar. El espejo inquietaba el fondo de un corredor en una quinta de la calle Gaona, en Ramos Mejía; la enciclopedia falazmente se llama The AngloAmerican Cyclopaedia (New York, 1917) y es una reimpresión literal, pero 
tambión morosa, de la Encyclopedia Britannica de 1902. El hecho se produjo hará unos cinco años. Bioy Casares había cenado conmigo esa noche y nos demoró una vasta polémica sobre la ejecución de una novela en primera persona, cuyo narrador omitiera o desfigurara los hechos e incurriera en diversas contradicciones, que permitieran a unos pocos lectores -a muy pocos lectoresla adivinación de una realidad atroz o banal. (Ficciones, p. 13)

Veamos primeramente la última parte de este fragmento: la discusión sobre una novela escrita en primera persona por un narrador contradictorio, y en la cual algunos lectores pudieran descifrar la expresión de alguna "realidad atroz o banal”, es de hecho, como algunos estudiosos ya han señalado, la prefiguración misma de "Tlön”. En el relato, el narrador constantemente presenta datos contradictorios que sirven para socavar cuanto ha dicho, y a través de los cuales el lector puede vislumbrar esa manera atroz, aunque sencilla -tal como la realidad “atroz” y "banal” de los relatos de Kafka, se expande contagiosamente. El punto de vista de una primera persona contradictoria y limitada se emplea a menudo en las ficciones de Borges. La referencia a este recurso en el primer párrafo de “Tlön” -que hasta ahora no ha sido estudiado en esta dimensión-podría considerarse también como la prefiguración de las contradictorias voces en primera persona de Plan, novela ésta en la que la contradicción es aún más intensa que en el relato de Borges, ya que en “Tlön” los personajes “Borges” y "Bioy Casares” solamente se plantean la posible escritura de una "novela”. El mencionado recurso no es original, cosa que el mismo Borges sería el primero en señalar. En su próogo a Morel, menciona dos textos en los que se emplea el punto de vista de la primera persona con este caráter limitado y contradictorio: The Turn of the Screw de James y Le Voyageur sur la Terre de Julian Green. Esta contradictoria voz en primera persona, viene a ser una distorsión de aquella testimonial y fidedigna caracterítica del Robinson Crusoe de Defoe, y es la que encontramos en los textos de Bioy Casares; es la que en lugar de afirmar la realidad de la aventura utóica, la pone en tela de juicio. Mientras que en la Utopía de More y en la novela de Defoe la ficción acredita el testimonio del viajero; en La isla del Dr. Moreau, en la novela de Green, en Morel y finalmente, en Plan, la ficción revela la creciente imposibilidad de llegar a alguna verdad objetiva o absoluta.

La diferencia entre Morel -considerada como una utopía irónica- y Plan, así como "Tlön” -considerados más bien como textos anti-utópicos- puede señalarse mediante la comparación de la voz en primera persona que ocurre en los tres textos. En Morel, toda la novela está contada por medio del artificio de un diario que lleva el anónimo protagonista.

Aunque en las notas al pie de la página aparece un editor anónimo que contradice al redactor del diario, éste no se contradice a sí mismo. Es la invención misma -la máquina cinematográfica en tres dimensiones de Morel- la que es motivo principal del misterio y cuya explicación sólo se ofrece satisfactoriamente al final. Aún cuando 
el protagonista debe morir, vivirá siempre en la "ilusión de felicidad" que es la película, a menos que la máquina sea destruída. Por otro lado, en Plan, la narración está a cargo de Antoine Brissac que inserta en su relato fragmentos de las cartas del protagonista, Enrique Nevers. En sus cartas, Nevers se contradice constantemente, provocando así la desconfianza del lector hacia él. Tío Antoine, que es la voz principal en primera persona, se convierte, en cierto sentido, en la personificación del indeciso lector. El también se contradice a sí mismo, ya que por momentos parece simpatizar con Nevers, aunque mayormente lo desprecia. Nunca llegamos a saber lo que realmente sucede a Nevers, aunque es poco probable que pueda, como el anónimo protagonista de Morel, conseguir siquiera la ilusión de una felicidad utópica. Por su parte, el narrador de "Tlön”, ese personaje que se llama "Borges” sugiere hacia el apocalíptico final del relato, que él continuará con su proyecto de traducir el Urn Burial de Sir Thomas Browne, aunque esa realidad -como el mismo- será eventualmente obliterada por la irrealidad del Tlön (p. 34).

Nevers y el narrador de “Tlön” son, pues, prisioneros de una utopía pesadillesca, han caído en una especie de pozo sin fondo. El protagonista de Morel reconoce que la realidad es una ilusión, pero al menos él puede creer todavía en la ilusión de las Islas Felices.

En el citado fragmento de “Tlön” se deja al lector la responsabilidad de descifrar esa realidad que esta entretejida con innumerables contradicciones. Así como Borges, "lector” de equivocal enciclopedias, escribe la historia de “Tlön”, y Tío Antoine, "lector" de las dudosas cartas de Nevers, escribe la explicación y la apología de la historia de este; de la misma manera, el lector enfrentado a narraciones contradictorias, debe escribir su propia versión. El texto sólo existe cuando es leído, así como Tlön sólo existe en su enciclopedia. Sólo existe el reflejo, en el espejo, cuando hay ojos que lo miran.

Esto nos lleva a revisar la primera frase de “Tlön”: "Debo a la conjunción de un espejo y una enciclopedia el descubrimiento de Uqbar” (p. 13). El espejo, tal como un mapa, refleja algo que no es. Como es sabido, el espejo es símbolo de todo lo que refleja una realidad o un ideal, pero ofrece solamente la ilusión de ese supuesto origen o centro, e.g. la naturaleza es el espejo de Dios. El espejo puede ser un texto, como en efecto, en Through the Looking Glass de Lewis Carroll, es el texto el que refleja un mundo del otro lado del espejo en el que todo está invertido. Pero al leer a Borges comenzamos a sospechar que el espejo, tal como ese monstruoso mapa de uno de sus relatos, no es más el símbolo de un objeto o una idea particular, sino un significante que se autosignifica, es decir, que se refleja a sí mismo puesto que no existe realidad fuera de él. ${ }^{11}$ El espejo en “Tlön” refleja a su vez una interminable galería de espejos. El espejo en "Tlön” simultáneamente distorsiona y dice la verdad sobre el juego de reflejos que existe entre Borges y Bioy Casares. Así vemos como en el cuento Borges le atribuye al personaje "Bioy Casares" la frase sobre los espejos y la paternidad, 
cuando en realidad todo es una invención suya. Aún más, Borges atribuye su propia obsesión pesadillesca con los espejos a "Bioy Casares”. Para este, en la vida real, el espejo significa lo contrario, i.e. un mundo hermoso y ordenado. Análogamente podemos advertir que si el espejo -tal como la enciclopedia de Tlön- revela un universo pesadillesco y perfectamente coherente, el espejo que es también ese mundo concebido en la película de Morel, es un paraíso ordenado donde el protagonista vivirá para siempre con su hermosa Faustine. Sin embargo el espejo adquiere otras dimensiones monstruosas en Plan, donde las islas desiertas que vislumbran los hombres en los espejos de sus celdas se convierten en la escena del horror. El carácter distópico de “Tlön” parecería invadir, en efecto, las inicialmente utópicas islas de los textos de Bioy Casares. La conjunción del espejo y la enciclopedia aparece también en Plan. Nevers (de la misma manera que los “Borges” y "Bioy Casares" de "Tlön” -y de la vida real), obtiene toda su información sobre las prisiones en una enciclopedia, en este caso, el famoso Larousse. Así pues, así como la historia de “Tlön” se origina en el descubrimiento de una extraña frase en una enciclopedia, las extrañas ficciones de Borges y Bioy, se “originan” (así) en la información trivial contenida en las enciclopedias.

La paradójica presencia del personaje "Bioy Casares” y su utilización como imagen-espejo de Borges-autor, se balancea con su paradójica ausencia al final del relato. Si en la vida real Bioy Casares nada tiene que ver con el descubrimiento de “Tlön”, si es cierto que ha colaborado con Borges en la traducción del capítulo quinto del Urn Burial de Browne, dato que Borges omite en su cuento. En el último párrafo, el narrador escribe que el contacto con Tlön destruirá eventualmente toda la realidad:

Entonces desapareceran del planeta el inglés y el francés y el mero español. El mundo será Tlön. Yo no hago caso, yo sigo revisando en los quietos días del hotel de Androgué una indecisa traducción quevediana (que no pienso dar a la imprenta) del Urn Burial de Browne. (p. 34)

Como el espejo, Borges distorsiona constantemente una verdad aparente; lo hace dos veces: cuando omite el nombre de su colaborador en la traducción y también cuando dice que nunca la publicará. En el número iii (de enero 1944) de Sur, un fragmento de la traducción fue incluído bajo la firma de los dos colaboradores. Pero el hecho de que el nombre de Bioy Casares aparezca en “Tlön”, es un "hecho”. Bioy es la imagen-espejo de Borges y viceversa, y consecuentemente, en su compleja relación como “colaboradores”, una verdad aparentemente objetiva-sus personalidades individuales- se torna borrosa. Imágenes claramente definidas se convierten en olas de imágenes infinitas; el origen de una imagen no puede ser discernido claramente. Podría decirse que los textos de Borges y Bioy son imágenes-espejos, como comenzamos a vislumbrar en el caso de “Tlön” y Plan. El Urn Burial, es otro espejo en el cual ambos textos se reflejan. 
El Urn Burial, "that magnificent set of baroque paradoxes on inmortality" (Irby, p. 418), es un emblema/paradójico en "Tlön” y Plan que funde a ambos textos en esa textura única que es el artificio pastoril. La urna es el símbolo del arte -segón la concepción de Browne y Keats- en el que la dicotomía mortalidad/inmortalidad se funde en un recipiente único, la eterna obra de arte. Borges retuerce la paradoja: la urna y su comentario -el Urn Burial-, símbolos de la eternidad de la obra de arte se convierten en metáforas del texto como traducción, en el cual se oblitera el concepto de originalidad de "la eterna obra de arte". En el idealismo pesadillesco del país de Tlön, el "origen” es siempre algo inalcanzable; el nombre Dios, una ilusión, y las únicas cosas reales son duplicados, hrönir, que son descubiertos en excavaciones (pp. 27-28), como las norfolkianas urnas de Browne. Pero el texto continúa existiendo infinitamente, no como un todo eterno, sino a través de inevitables trasmutaciones. De esta manera, mientras Borges plantea la inutilidad de traducir el Urn Burial, ya que toda existencia será obliterada o arrasada, irónicamente es la actividad misma de la traducción la que sobrevive en el ausente centro de la "metafísica" tlöniana. A este respecto nos parece pertinente el planteamiento de Irby, parafraseado del libro de Gerard Genot (Borges, Florence, 1969):

The narrator's refuge in translation only confirms the extent of Tlön's influence, for the union of such disparate figures as Quevedo and Sir Thomas Browne into one text is but another version of its critical practices. (Irby, p. 419)

La urna, artificio pastoril, traducción de un ideal pastoril a un signo artificial (e.g. en Keats), es también uno de los muchos signos de resurrección, recreación y traducción que señala la continuidad textual y a la vez el juego de inversiones y comentarios entre "Tlön” y Plan. Plan se burla de la utopía idílica de los simbolistas (particularmente de su “teórico" René Ghil), en la cual se consuma una correspondencia jerárquica y simbólica entre las palabras y las ideas. En Plan el fracaso del Dr. Castel al tratar de provocar visiones paradisíacas en los presos de la isla del Diablo, es comparable al fracaso de Ghil en su intento de crear símbolos absolutos. Novelísticamente, Plan reactiva la ruptura surrealista-expresionista de esta armonía de dicotomías, la metáfora se torna violenta e incomprensible, un signo de discordancia y ambigüedad. Así mismo, la utopía tlöniana es una reactivación de esa hispánica rama de los movimientos de vanguardia, el ultraísmo, en el que como es sabido, Borges participó activamente. Irby señala que:

Borges began his literary career around 1920 as an affiliate, first in Spain, later in Buenos Aires, of the so-called ultraista movement, an enthusiastic but rather incoherent version of futurism which exalted the juxtaposition of violent metaphors as the sole poetic device. Borges, however, far from incoherent, tried to establish in his own manifestos and essays of the period a theory of metaphor 
based on clear philosophical principles. These writings repeatedly display three themes: (1) the use of Berkeleyan idealism to break down substantive reality and even the continuities of space and personal identity-into a flux of immediate perceptions, (2) the combinational rearrangement of these perceptions by means of metaphor to form new poetic realities, and (3) the fervent hope that the future would bring a collective realization of his theories. (p. 414)

“The use of Berkeleyan idealism to break down substantive reality”, fundamento de la metafísica tlöniana, es también la base del experimento de Castel. En “Tlön” la presencia de Berkeley es evidente. En la “posdata” de 1947 -que es más bien un toque futurista, ya que el relato incluía esa posdata cuando apareció primeramente en 1940 , el narrador nos informa que había un tal George Berkeley entre los miembros de la sociedad secreta creada en el siglo XVIII para inventar un país (p. 30). Esta información es una ligera distorsión de un verdadero episodio de la vida del filósofo, que, en efecto, en 1728, en América, intentó crear infructuosamente una comunidad dedicada a la existencia como percepción. ${ }^{12}$ La mención del siglo XVIII es también significativa ya que es éste el período de la contradicción barroca, i.e., la caída de España, el ascenso de América; la metáfora de la urna que significa simultáneamente vida y muerte.

Más adelante en la “posdata”, el borgiano narrador revela que la sociedad secreta europea resurgió en América en el siglo XIX. Uno de sus afiliados -un "ascético millonario”, Ezra Buckley, cuyo apellido al pronunciarse suena como Berkeley-, tiene cualidades que, como el oxímoron ultraista, se niegan unas a otras. Es librepensador, pero también defensor de la esclavitud -nos informa el narrador en una nota al pie de la página-; es millonario, pero también idealista. El siniestro Buckley amplía el propósito de la sociedad -continúa el narrador:

Le dice que en América es absurdo inventar un país y le propone la invención de un planeta. A esa gigantesca idea añade otra, hija de su nihilismo: la de guardar en el silencio la empresa enorme. Circulaban entonces los veinte tomos de la Enciclopedia Britannica; Buckley sugiere una enciclopedia del planeta ilusorio. (p. 30)

De esta manera nos enteramos que el nombre, la Enciclopedia, no simboliza una original realidad sustantiva -el planeta-, sino que precede -y excluye- esa realidad. Es por ello que cuando un objeto del país llamado Tlön, conocido primeramente a través de la enciclopedia, aparece efectivamente en la tierra, el narrador escribe: “Tal fue la primera intrusión del mundo fantástico en el mundo real” (p. 30). El relato mismo es semejante a ese objeto, ya que cuando terminamos su lectura, no hay planeta ni enciclopedia de Tlön, sino únicamente el relato como una intrusión fantástica en el mundo "real". 
El hecho de que Morel, “Tlön”, y Plan niegan la existencia y realidad sustantiva de las utopías que tratan, se destaca con énfasis en los mismos títulos de los textos, los cuales consisten en nombres que -como la enciclopedia tlöniana y el nombre Dreyfus-, niegan la realidad a la que parecen referirse. La negación de la realidad sustantiva se expresa claramente en “Tlön”, ya que el lenguaje que se habla en el país de Tlön se compone solamente de verbos y adjetivos, es decir, no existe sustancia alguna, solamente acciones y cualidades. No existe la continuidad del sustantivo, sólo la discontinuidad de un flujo de percepciones.

Aunque en Plan no hay referencia directa a Berkeley, el concepto de William James del mundo como percepción utilizado en el experimento de Castel, procede del idealismo de Berkeley. Incluso la cita de Blake que hace Castel confirma esta relación, ya que el idealismo de este último es coincidente con el de Berkeley: Blake también insiste en que sólo existen realidades mentales, o mejor, como señala Northrop Frye: "Blake, the visionary, insists that everything in the physical world which we call real is a matter of perspectives and associations". ${ }^{13}$ La referida cita de Blake, tomada de su libro The Marriage of Heaven and Hell, atribuye a los pájaros la imaginación humana, fundiendo así sujeto y objeto en uno sólo. ${ }^{14}$ En efecto, la poesía de Blake sintetiza continuamente los opuestos; todas las metamorfosis son una metamorfosis: Orc, el dios de Blake, es una síntesis de San Jorge, Prometeo, Moisés y Adonis, y por consiguiente, es matador de dragones, titán encadenado, iniciador de una nueva cultura humana y dios vivificador (Frye, p. 225). Blake, así como Berkeley, representa una ruptura de las correspondencias jerárquico-simbólicas entre objeto y sujeto, entre lo visible y lo invisible. Sobre esta dimensión de Blake, considerado como unificador del sujeto/objeto, Ana Balakian, en su libro The Symbolist Movement, ha observado que aunque Blake, "el visionario”, ha sido asociado con los románticos y los simbolistas, es más claramente un precursor de los modernistas -esos primeros creadores de los movimientos de vanguardia. ${ }^{15}$ En Blake se anula la disyunción cielo/ infierno, los contrarios devienen unidad, tal como en las violentas metáforas que caracterizan las obras expresionistas de Borges y Bioy Casares.

Tanto en “Tlön” como en Plan reaparece la presencia de un filósofo idealista en la mención común de Schopenhauer. En “Tlön”, la negación del ego individual-y por ello, de la dicotomía entre sujeto y objeto- se expresa en la consideración del anonimato de Shakespeare, asunto aludido también en Plan, como hemos visto. El pasaje de "Tlön” que aludo es el siguiente: “Todos los hombres, en el vertiginoso instante del coito, son el mismo hombre. Todos los hombres que repiten una línea de Shakespeare, son William Shakespeare” (p. 25). Aunque en este texto el pensamiento no se atribuye directamente a Schopenhauer, una variación del mismo sí es atribuída al filósofo, en otro relato, "La forma de la espada”, en el que Borges escribe: “Acaso Schopenhauer tiene razón: yo soy los otros, cualquier hombre es todos los hombres, Shakespeare es de algún modo el miserable Vincent Moon” (Ficciones, p. 133). 
Al tratar en “Tlön” el tema de la negación del ego individual, Borges aclara que "Schopenhauer (el apasionado y lúcido Schopenhauer) formula una doctrina muy parecida en el primer volumen de Parerga and Paralipomena” (p. 26). La referencia a Schopenhauer aparece casualmente en Plan otra vez en el contexto de la negación de una verdad objetiva, o sea, cuando Tío Antoine registra burlonamente las lucubraciones de Nevers sobre el mundo de los sueños, que para él es irónicamente más palpable que el mundo de la vigilia, ya que en los sueños resulta mucho más real que el destino de uno es producto de la propia voluntad. Antoine escribe: "De estas pobres lucubraciones, Nevers pasa a no sé qué fantasía metafísica, evoca a Schopenhauer, y, pomposamente, narra un sueño...” (p. 122). Como es usual en el sistema contradictorio de Bioy, esas ideas de Nevers que Antoine trata superficialmente, son por lo general, pistas importantes y provocadoras para el lector. En su reseña de El jardin de senderos, él había señalado dos influencias principales en las ficciones de Borges: los libros de filosofía y la novela detectivesca. Pero el "subtexto" de idealismo berkeliano y pesimismo de Schopenhauer que acaba por obliterar la realidad material, también oblitera la base filosófica de “Tlön” y Plan. Lo que queda es la estructura detectivesca de las pistas falsas y nombres equívocos, el "camouflage”, la infinita búsqueda de "la verdad”, del “centro”, i.e., “Tlön” termina en media res con la amenaza de la intrusión del mundo fantástico en el mundo real; en Plan, Nevers que desea estar en las celdas del centro para evitar las imágenes-espejo creadas por el Dr. Castel en las celdas exteriores, nunca llega a alcanzar el “centro”, nunca resuelve su odisea, su destino permanece detenido, como sugiere A. Borinsky. ${ }^{16}$

La filosofía es obliterada en "Tlön” porque se convierte en una rama de la literatura fantástica, o como escribe el narrador:

Los metafísicos de Tlön no buscan la verdad ni siquiera la verosimilitud: buscan el asombro. Juzgan que la metafísica es una rama de la literatura fantástica. Saben que un sistema no es otra cosa que la subordinación de todos los aspectos del universo a uno cualquiera de ellos. Hasta la frase "todos los aspectos" es rechazable, porque supone la imposible adición del instante presente y de los pretéritos. Tampoco es lícito el plural "los pretéritos", porque supone otra operación imposible... (p. 23)

La invención de un lenguaje, la apariencia de "dadaist creations (...like the “transparent tigers” and “towers of blood” in Tlön)” (Irby, p. 417), así como las extrañas frases que Dreyfus pronuncia en Plan, forman parte de la ruptura vanguardista con el orden empírico. No hay una filosofía única, así como en Plan no hay una fórmula única para lograr el sumo de las Islas Afortunadas. Cada hombre es un sistema de percepción diferente, es otro lenguaje. 
La ausencia de literatura fantástica en la biblioteca de Castel, de la que Nevers se queja, refleja inversamente el carácter totalmente fantástico de las bibliotecas de Tlön:

También son distintos los libros. Los de ficción abarcan un sólo argumento, con todas las permutaciones imaginables. Los de naturaleza filosófica invariablemente contienen la tesis y la antitesis, el riguroso pro y contra de una doctrina. Un libro que no encierra su contralibro es considerado incompleto. (p. 27)

Este reflejo inverso, evidencia del diálogo entre ambos textos, es también evidencia de sus divergencias. La biblioteca de “Tlön” es una síntesis de todas las ficciones de Borges -infinitas permutaciones de un sólo argumento- y de todos sus ensayos que simultáneamente proponen y niegan sus temas. La biblioteca de Plan, por otro lado, es incompleta y Nevers alude a los nombres de diferentes textos y autores a lo largo de la narración, pero en ninguna parte Bioy Casares sintetiza la totalidad de "su biblioteca”. "Tlön” es un breve relato sobre el descubrimiento y la descripción de todo un planeta utópico (o distópico); Plan es una novela sobre una particular isla utópica (o distópica). La diferencia entre sus sistemas se manifiesta: Borges sintetiza el conocimiento, en tanto que Bioy Casares lo analiza. Esto se revela más claramente si comparamos con el argumento de Plan un fragmento de “Tlön” que, aparte del párrafo inicial con que comienza el relato, parece quizás, la más clara evidencia de que este último es en cierta manera, la prefiguración de la novela. En el país de Tlön, las ideas preceden a los objetos, los objetos no son más que meros duplicados de esas ideas, y estos duplicados, como ya hemos mencionado, son los llamados hrönir. Veamos el fragmento a que nos referimos:

Esos objetos secundarios se llaman hrönir y son, aunque de forma desairada, un poco más largos. Hasta hace poco los hrönir fueron hijos casuales de la distracción y el olvido. Parece mentira que su metódica producción cuente apenas cien años, pero así lo declara el Onceno Tomo. Los primeros intentos fueron estériles. El modus operandi, sin embargo, merece recordación. El director de una de las cárceles del estado comunicó a los presos que en el antiguo lecho de un río había ciertos sepulcros y prometió la libertad a quienes trajeran un hallazgo importante. Durante los meses que precedieron a la excavación les mostraron láminas fotográficas de lo que iban a hallar. Ese primer intento probó que la esperanza y la avidez pueden inhibir; una semana de trabajo con la pala y el pico no logró exhumar otro hrön que una rueda herrumbrada, de fecha posterior al experimento. Este se mantuvo secreto y se repitió después en cuatro colegios. En tres fue casi total el fracaso; en el cuarto (cuyo director murió casualmente durante las primeras excavaciones) los discípulos exhumaron -0 produjeron- una máscara de oro, una espada arcaica, dos o tres ánforas de barro y el verdinoso y mutilado torso de un rey con una inscripción en el pecho que 
no se ha logrado descifrar. Así se descubrió la improcedencia de testigos que conocieran la naturaleza experimental de la busca... ... Las investigaciones en masa producen objetos contradictorios; ahora se prefiere los trabajos individuales y casi improvisados. (pp. 27-28)

Si por un momento consideramos metafóricamente el relato "Tlön” como el objeto ideal en su completo estado de condensación y pureza, Plan podría entonces considerarse como su duplicación ligeramente alargada (“un poco más largos”), es decir, su hrön. El pasaje del fragmento citado en el que se narra que un director de una cárcel del estado -de ese "país-en-ninguna parte” de Tlön, Uqbar, Orbis Tertiuspromete liberar a los prisioneros que puedan encontrar o, en cierto sentido, "producir masivamente” esos objetos o meros duplicados (o ilusiones, de acuerdo a una visión platónica de la realidad); tal pasaje, repetimos, es ciertamente la prefiguración de la misteriosa aventura de las Islas de la Salvación -otro “país-en-ninguna-parte” que sólo existe en el texto. Castel promete la libertad a sus hombres si ellos, en pago, se someten a su experimento de producción masiva de ilusiones. El experimento de Castel fracasa por la misma razón que fracasa el experimento tlöniano: "Las investigaciones en masa producen objetos contradictorios” (p. 28).

El único experimento posible es la experiencia de cada lector, que siempre será ligeramente distinta de la de otro. Esa experiencia, tal como la del narrador de "Tlön" y como la de Nevers en Plan, pertenece a esa categoría de "los trabajos individuales y casi improvisados” (p. 28). El lector, aunque pueda tener ciertas ideas preconcebidas, nunca sabe exactamente que es lo que va a encontrar hasta que no lee el texto.

\section{EL TEXTO UTOPICO/DISTOPICO/HETEROTOPICO}

La anti-utopía o distopía, es decir la inversión pesadillesca de la utopía ideal y perfectamente ordenada, aparece en la historia literaria casi simultáneamente con la utopía. En efecto, ya en la primera obra titulada propiamente Utopía -la de Sir Thomas More-, la dimensión pesadillesca de la utopía está presente. De entrada, More se decide por un nombre que indica "ningún lugar”, un lugar inasible, inalcanzable, tal como a menudo lo son los objetos de nuestros deseos en las pesadillas. Por otro lado, el “mundo real”, la Inglaterra que el viajero utópico de More contrasta con el país de Utopía, es descrito en términos casi kafkianos. Recuérdese, por ejemplo, aquel pasaje en que las pacíficas ovejas aparecen como animales feroces que devoran literalmente todo el campo inglés -infinita metáfora de la expulsión de los campesinos por los especuladores en la lana empeñados en convertir la tierra de cultivo en campo de pastoreo.

Se puede sugerir, pues, una analogía en la que el texto “Tlön” es la utopía y el texto Plan es el comentario de esa utopia; relación que recuerda la de la utopía 
imaginaria y el “informe” de Sir Thomas More sobre ella. Sin embargo, apartándonos de este sistema simbólico de dicotomías y volviendo a una visión más amplia, sugerida a lo largo de este trabajo, es necesario destacar que tanto Plan como “Tlön” y Morel y los otros textos que se han discutido o mencionado, se inscriben, de hecho, en la bifurcada tradición de la literatura pastoril y utópica. Se trata de un tipo de literatura que -mediante su presentación de una aventura ideal o extraordinaria-se reconoce a sí misma como un artificio, admitiendo así la imposibilidad de alcanzar esos ideales, y cuyos diversos textos no son más que “fragmentos” utópicos que se inscriben en ese otro cuerpo utópico mayor, el texto literario general, la frase es simbólica del texto completo, cada "fragmento”, i.e., cada texto, es autónomo, se estructura dentro de su propio orden. ${ }^{17}$ Pero cada "fragmento" también representa el ambiguo proceso de comunicación con otros “fragmentos” aunque expresando a la vez su propia autonomía; la de ser una parodia de algo anterior aunque operando, sin duda, una inversión en dicha parodia.

Cada nuevo texto es una intrusión más "del mundo fantástico en el mundo real” (p. 31). En efecto, la "sirena de oro” que Carlota ofrece ominosamente a Nevers al comienzo de Plan y que sobrevive "milagrosamente" tanto a la codicia de este como a la de los prisioneros, es como un eco de los objetos de Tlön que irrumpen en la realidad objetiva, uno de los cuales es tan condensado y pesado -tal como el relato mismo- que al tomarlo en sus manos produce al narrador la sensación de repugnancia y miedo. Como la urna, estos objetos son signos aterradores del texto, porque son reales y a la vez fantásticos, fuera del control racional del sujeto; aterradores porque su inmortalidad destaca aún más violentamente la sustancia mortal del hombre; pero también son consoladores porque ellos representan un orden que sobrevive la inconsistencia y el deterioro del hombre. Ellos son su inmortalidad, y conforman una realidad "no demasiado compatible con el mundo real” que permanece como un orden al que el hombre puede aferrarse, un orden que cada sucesivo lector puede descifrar, en uno que le permite detener ese caos que le amenaza desde afuera y desde dentro, el caos de sus fluctuantes e ilusorias percepciones. El narrador de “Tlön” escribe:

Hace diez años bastaba cualquier simetría con apariencia de orden -el materialismo dialéctico, el antisemitismo, el nazismo- para embelesar a los hombres. ¿Cómo no someterse a Tlön, a la minuciosa y vasta evidencia de un planeta ordenado? Inútil responder que la realidad también está ordenada. Quizá lo esté, pero de acuerdo a leyes divinas -traduzco: a leyes inhumanas- que no acabamos nunca de percibir. Tlön será un laberinto, pero es un laberinto urdido por hombres, un laberinto destinado a que lo descifren los hombres. (pp. 33-34)

Entonces ¿por qué “Tlön” y Plan resultan anti-utópicos? En realidad, ambos textos no son ni utópicos ni anti-utópicos, sino heterotópicos, para seguir la definición 
que ofrece Michel Foucault de “Tlön” y las ficciones de Borges en general. ${ }^{18} \mathrm{La}$ heterotopía, es decir, la utopía heterogénea, contiene a la vez elementos pesadillescos y de ensueño, monstruosos e ideales y, como las violentas metáforas del ultraísmo, tiende a borrar la disyunción utopía/anti-utopía. La utopía ya contiene esta contradicción desde que se origina -el "bower of blisse" es siempre también el jardín de la desesperación. Los textos de Borges y Bioy Casares añaden a este proceso, la conciencia expresa de que la unión final de estas disyunciones no se produce ni afuera, en la realidad, ni en el futuro, sino dentro del texto, donde lo fantástico y lo real, inseparables, provocan esa "incertidumbre” infinita, esa vacilación de que habla Irene Bessiere en Le Recit Fantastique: la poétique de l'incertain. ${ }^{19}$ El texto contiene, pues, la pesadilla y el consuelo de un mundo fantástico perfectamente ordenado que gira infinitamente sobre sí mismo. El protagonista de Morel escribe sobre el irónico triunfo de esta pastoral utópica, consoladora e inquietante a la vez:

La eternidad rotativa puede parecer atroz al espectador; es satisfactoria para sus individuos. Libres de malas noticias y de enfermedades, viven siempre como si fuera la primera vez, sin recordar las anteriores. Además, con las interrupciones impuestas por el régimen de las mareas, la repetición no es implacable. (p. 127)

En Morel, la realidad caótica amenaza vagamente el orden fantástico. El redactor del diario escribe:

Serán por desgracia, paraísos vulnerables, porque las imágenes no podrán ver a los hombres, y los hombres, si no escuchan a Malthus, necesitaran algún día la tierra del más exiguo paraíso y destruirán a sus indefensos ocupantes o los recluirán en la posibilidad inútil de sus máquinas desconectadas. ( p. 124)

Este pasaje resulta sumamente profético, tanto del "futuro" como de Plan, aunque dentro de los límites de Morel, el experimento utópico se lleva a cabo con éxito.

En “Tlön” el orden fantástico parece dominar el mundo real, y la posibilidad de su triunfo total es aterradora: “El mundo será Tlön” (p. 34). Pero en Plan, donde ocurre una eterna rotación semejante a la de Morel (los hombres duermen todo el día y de noche caminan dormidos en una eternidad que si, al menos, es inicialmente satisfactoria para ellos, resulta atroz para el espectador), la heterotopía incluye otro nivel de comentario que va más allá de Morel y “Tlön”. El caos del mundo externo entra en el texto, la unión definitiva ha ocurrido; la amenaza externa de la destrucción del experimento del Dr. Castel ha sido realizada desde dentro por la intervención de un loco asesino que se llama “el Cura”. Nuestra última visión de este, “desconectado” de su celda, caminando inútilmente hacia la puerta (y sus manos de fantasma presionando el cuello de Nevers), mientras este último continúa absorto con las notas de Castel: 
En seguida el Cura empezó a caminar hacia la puerta, lentamente. El espanto no abandonaba su rostro.

Nevers estaba distraído. No se inquietó al sentir en la nuca la presión de unas manos débiles, como de fantasma. Había encontrado en el escritorio una carpeta... (p. 151)

El desastre que se profetiza en Morel, la inutilidad de la máquina cinematográfica desconectada en un mundo caótico, se realiza totalmente en Plan, cuyo final se abre hacia un caótico “afuera”. Las últimas palabras de Castel en sus notas forman una frase incompleta: "El mundo...” (p. 162). De manera semejante terminan las últimas palabras de Nevers: “Amanece. He oído un disparo, Me asomaré. Después vuelvo...” (p. 165). Las sospechosas frases finales de Xavier también quedan incompletas:

Pienso con misericordia que esa absurda mentira pueda llegar a Saint-Martín, y ser empleada por Pierre para torturar a mi idolatrada Irene, para reprocharle su pasión hacia mi... (p. 167)

El narrador Tío Antoine -o el autor, Bioy Casares- cierra el libro con un “Etcétera” (p. 167).

Nevers nos recuerda al narrador de “Tlön”, quien a pesar de esa obliteración de toda realidad, aprueba ese metódico proceder. En sus últimas palabras, Nevers reconoce que las víctimas no importan, que lo que verdaderamente importa es "el exaltado, y tranquilo, y alegre, trabajo de la inteligencia” (p. 165).

Y sin embargo, Plan excede a Morel y aun a “Tlön” como texto heterotópico por su final abierto, y porque la incertidumbre entre lo real y lo fantástico es mayor. Su extremada negación de la realidad se funde insólitamente con el caos y el desorden de esa realidad que amenazan negar su negación.

Tufts University Traducción de Jorge Oliva, Columbia University

SUZANNE JILL LEVINE

*Este trabajo corresponde a un capítulo de mi libro sobre Bioy Casares de próxima publicación por Monte Avila Editores, Caracas, Venezuela.

\section{NOTAS}

1 Obras completas de Alfonso Reyes (México: Fondo de Cultura Económica, 1959), Tomo IX, p. 274.

2 J. L. Borges, "La estatua casera”, Sur, año VI, no. 18 (Buenos Aires, Marzo, 1936), p. 86.

3 James E. Irby, “Borges and the Idea of Utopia,” Books Abroad, Summer 1976, pp. 412-416.

4 “Tlön, Uqbar, Orbis Tertius,” Ficciones (Buenos Aires: Emecé Editores, 1967), p. 19.

“Tlön” apareció primero en Sur, en 1940, y luego en la Antología de literatura fantástica, 
publicado también ese mismo año; finalmente fue incluído en el libro de relatos El jardín de senderos que se bifurcan (1941).

5 J. L. Borges, "Luis Greve, muerto”, Sur, no. 39 (Dic. 1937), p. 86.

6 "Las utopías pesimistas de Adolfo Bioy Casares", entrevista de Danubio Torres Fierro, Plural, no. 55 (abril 1976), p. 49.

7 Alfred A. MacAdam ha señalado al respecto: "La vida solitaria del hombre en la isla es una metáfora para el escritor que se encierra con su texto. Su viaje a la isla es el que hace cualquier autor cuando escribe, y la página en blanco es la isla que puebla de imágenes" ("Narrativa y metáfora: una lectura de La invención de Morel”, p. 3; ponencia en el XVI Congreso del Instituto Internacional de Literatura Iberoamericana, Michigan State University, 1973).

8 Historia universal de la infamia (1935), primer libro de relatos de Borges, no fue aceptado como ficción. Igual suerte corrieron algunos relatos de El jardín. El mismo Bioy Casares creyó inicialmente que "El acercamiento a Almotásim” era una reseña bibliográfica y trato de conseguir el libro al que Borges se refería. Fue precisamente Bioy Casares el primero en definir los relatos de Borges como un género hibrido entre el ensayo y la ficción.

9 Sur, no. 92 (mayo 1942), p. 60.

10 E. Rodriguez Monegal, “Borges: the reader as writer”, TriQuarterly, no. 25 (Fall 1972), pp. 102-143.

${ }^{11}$ El relato "Del rigor en la ciencia," sobre un mapa monstruoso que cubre totalmente el territorio que representa, apareció en El hacedor.

12 Berkeley, A New Theory of Vision and Other Writings, Everyman's Library (1910; London: J. M. Dent and Sons Ltd.; N. Y.: E. P. Dutton and Co., Inc., 1938), Intro. A. D. Lindsay, p. viii.

${ }^{13}$ Northrop Frye, A Fearful Symmetry: A Study of William Blake (1947; Princeton: Princeton University Press, 1970), pp. 14-16, p. 41.

${ }^{14}$ Al citar el poema, Bioy traduce al español: “¿Cómo sabes que el pájaro que cruza el aire no es un inmenso mundo de voluptuosidad, vedado a tus cinco sentidos?” (p. 153).

${ }^{15}$ A. Balakian, The Symbolist Movement (N.Y.: Random House, 1967), p. 15.

${ }^{16}$ A. Borinsky, "Names, Camouflage, Error. Notes to A Plan for Escape by Adolfo Bioy Casares” (MS.)

17 Stanley Edgar Hyman, “Kenneth Burke and the Critisism of Symbolic Action”, The Armed Vision (1947; N.Y.: Vintage Books, 1955), p. 327.

${ }^{18}$ Michel Foucault, Les Mots et les Choses (Paris: Editions Gallimard, 1966), Preface, pp. 810. Escribe Foucault:

Les utopies consolent: c'est que si elles n'ont pas de lieu réel, elles s'épanouissent pourtant dans un espace merveilleux et lisse; elles ouvrent des cités aux vastes avenues, des jardins bien plantés, des pays faciles, même si leur accès est chimérique. Les hétérotopies inquietant, sans doute parce qu'elles minent secrètement le langage, parce qu'elles empêchent de nommer ceci et cela, parce qu'elles brisent les noms communs ou les enchevêtrent, parce qu'elles ruinent d'avance la "syntaxe," et pas seulement celle qui construit les phrases, - celle moins manifeste qui fait "tenir ensemble” (à côté et en face les uns des autres) les mots et les choses. C’est pourquoi les utopies permettent les fables et les discours: elles sont dans le droit fil du langage, dans la dimension fondamentale de la fabula; les hétérotopies (comme on en trouve si fréquemment chez Borges) dessèchent le propos, arrêtent les mots sur eux-mêmes, contestent, dè acine, toute possibilité de grammaire; dénouent les mythes et frappent de stérilité le lyrisme des phrases (pp. 9-10).

${ }^{19}$ (Paris: Librairie Larousse, 1974). 


\section{La Imagen Metafísica en la Poesía de Borges}

El dilema que Borges se ha planteado en su poesía es la traslación de la imagen, que es simultanea, en lenguaje, que es sucesivo y temporal. La trayectoria de su lírica ha sido esta dilucidación estética.

El verso de Borges, respondiendo a tal búsqueda, ha evolucionado desde un profuso barroco inicial, con predominio de la metáfora ultraista, hasta su concentrada poesía metafísica actual. La particularidad de la poética borgiana está en haber interpretado el arte contemporáneo como continuidad y superación, más que como ruptura con la tradición. En sus libros iniciales, Fervor de Buenos Aires (1923), Luna de enfrente (1925), Cuaderno San Martín (1929), el poeta aspira ya a un arte intemporal mediante la transmutación de la realidad en una visión metafórica personal. En esta época ultraista, sin embargo, la metáfora borgiana logra sólo una fusión momentánea de elementos discontinuos; no trasciende lo real, aunque aporte una evasión de la realidad. ${ }^{1}$ De allí que Borges, en las sucesivas ediciones de su obra poética, continúe aún reelaborando aquellos poemas que él ha llamado "los áridos versos de la equivocación ultraista”. ${ }^{2}$

En el momento crucial de su trayectoria poética, durante los años de su escasísima producción lírica, entre 1930 y 47, Borges descubre en el símbolo oxymoron la posibilidad de unificar elementos disímiles y concentrar el sentido sucesivo del lenguaje en un barroco de contención que identifica contrarios. El laberinto en su poesía es caos, pero tambión es el centro secreto de una verdad. El hombre es el Otro y es el Mismo; el sueño unifica realidad y ficción. Por vía del oxymoron como signo bivalente, el poeta rescata la doble proyección semántica de la imagen, identificando así un sistema de contrarios en una unidad lingüística. Dicha condensación lírica implica, sin embargo, intensa búsqueda, pues la palabra asume el sentido de una cifra, una clave, cuya funcionalidad depende de la interrelación dentro del sistema poético. ${ }^{3}$

La preocupación de Borges por tal condensación lírica alcanza su climax en Elogio de la sombra, publicado en 1969, si bien podríamos señalar la iniciación de esta etapa en a1gunos poemas incorporados a la edición de Obra poética de 1967, como "El forastero”, “El laberinto”, “El instante.” Este ascenso del poeta en su 
creación -que según Borges señala es "modesta y secreta complejidad”4- se traduce en un renovado lenguaje lírico de contención, por vehículo del oxymoron como figura conductora de la imagen dinámico-metafísica. Nuestro propósito en este análisis es mostrar en que consiste esta concepción de la imagen en la poesía de Borges, como funciona en la estructura del poema y que valores aporta a la lírica hispana.

I

En el estudio de la imagen poética hemos de considerar dos categorías fundamentales según su función lingüístico-semántica: ${ }^{5}$ (1) La imagen estática, predominantemente visual y auditiva, expresa la apariencia fisica y sensorial de los objetos. En este tipo de imagen, aun los sentimientos se describen con la apreciación sensorial que caracteriza la poesía conventional clásica y romántica. ${ }^{6}$ (2) La imagen dinámica, por el contrario, muestra el movimiento y el modo en que los objetos actúan e interactúan. La diferencia esencial entre ambas está en el foco. En la imagen estática, aquel se concentra especialmente en las cualidades externas o sensaciones que en general se transmiten con relativa facilidad a la imaginación del lector. En la imagen dinámica, el foco no está en el objeto mismo sino en la acción y, especifícamente, en el movimiento. La imagen estática es comparable a la pintura y la escultura; la dinámica, al ballet y la danza. Aunque la última es menos común que la estática, se manifiesta, sin embargo, en todas las épocas y es significativa de los momentos barrocos. La imagen dinámica puede presentar gradaciones, desde la comparación de acciones físicas, hasta una total intelectualización de los términos en la acción. Algunos poemas del ultraísmo borgiano muestran ya una preferencia por la imagen dinámica. Borges identifica los objetos por su realidad intrinseca, más que por las cualidades físicas de estos, como es notorio en los versos siguientes:

Sótano circular de la base que hacía vertiginoso el jardín, daba miedo entrever por una hendija tu calabozo de agua sutil.

"Fluencia natural del recuerdo" (C, p. 20)

La imagen resultante de la relación “sótano circular [pozo]/jardín” no se resuelve en una representación concreta, estática, como doble del jardín reflejado en el pozo. El foco, en cambio, está en el movimiento que implica el adjetivo vertiginoso, que agiliza las imágenes estáticas "sótano circular” y “calabozo de agua sutil.”

En el poema “Arrabal” es más notoria la intelectualización mediante una acción mental que unifica identidades concretas, presentes, (manzanas diferentes e iguales) con su símil específico, abstracto (una sola manzana): 


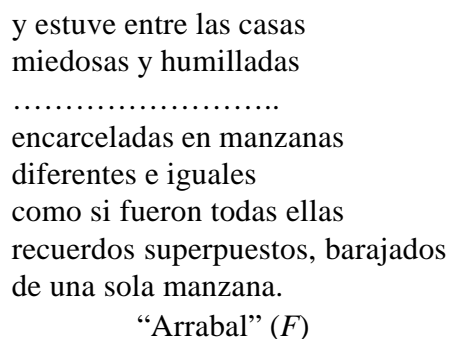

En otros poemas es más evidente el propósito de unificar la identidad del ser concreto con su doble remoto, en una captación simultánea, que prefigura ya la condensación metafísica que desarrollará el poeta en la época de madurez lírica:

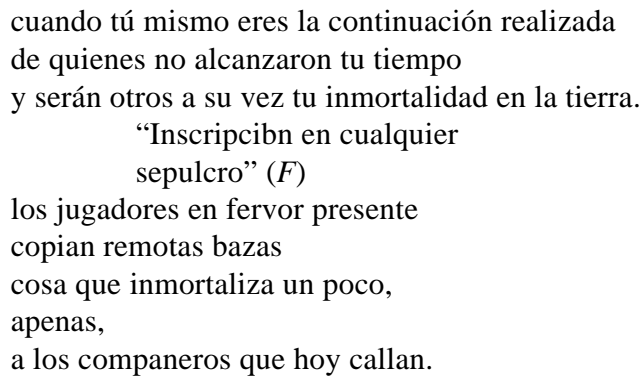

En “Inscripción en cualquier sepulcro” tú mismo se identifica con los que antes fueron y con los que serán, así como en "El truco” los jugadores repiten el mismo acto de aquéllos que han muerto.

La imagen metafísica en la poesía borgiana es, por to tanto, una clase de imagen dinámica que en su más lograda expresión muestra la acción del pensamiento y la imaginación como unificadora de dos términos distantes, aparentemente incompatibles. La poesía metafísica, si bien tiene su época de florecimiento en la primera mitad del siglo XVII con la poesía arquetípica de John Donne y de sus continuadores George Herbert, Henry Vaughan y Richard Crashaw, es una forma lírica que tiene cultores en todos los tiempos. T. S. Eliot, refiriéndose especificamente a la poesía de Donne, describe la imagen metafísica como " “far-fetched' in its comparison of dissimilar objects.”7 Henry Wells en Poetic Imagery identifica la llamada imagen "radical” con la metafísica, y la define como una unificación de los dos términos de una metáfora en un limitado y estrecho punto de encuentro, ya que vistos de otro modo, los términos son incongruentes e ilógicos. ${ }^{8}$

En la poesía actual de Borges, mediante la imagen dinámico-metafísica que identifica términos distantes y opuestos, el poeta captura el sentido de la realidad 
como íntima experiencia poética. La técnica de la imagen metafísica borgiana implica un movimiento mental desde un objeto, generalmente concreto (que llamaremos término básico) a otro predominantemente abstracto, creado en la mente del poeta (término de relación), que fija y cierra en simultaneidad el movimiento de la imagen. Veámoslo en el soneto “Las cosas,” de Elogio de la sombra.

\author{
... ¡Cuantas cosas \\ Limas, umbrales, atlas, copas, clavos, \\ Nos sirven como tacitos esclavos, \\ Ciegas y extranamente sigilosas! \\ Durarán más allá de nuestro olvido; \\ No sabran nunca que nos hemos ido.

$$
\text { (E, p. 69) }
$$

"Las cosas," como sinécdoque de la siguiente enumeración caótica (Limas, umbrales, atlas, clavos) constituyen el término básico. Dichos objetos carecen en sí mismos de cualidades poéticas en sentido tradicional, ya que no hay propósito de connotar belleza o dar una cualidad descriptiva, sino de ver los objetos de una manera conceptual analítica. El término cosas no es poético, pero se enriquece líricamente en la expansión del movimiento de la imagen. En la primera relación disímil "cosas/ tácitos esclavos” la correspondencia se establece según la concepción personal del poeta; sometimiento, domesticidad de las cosas y los esclavos. No interesa en este caso como son las cosas según sus cualidades, sino cómo actúan en la experiencia y el pensamiento del poeta: “nos sirven como tácitos esclavos”. Esta relación expansiva progresa a su vez en una imagen dinámica. Desde el objeto cosas, caracterizadas por una connotación metonímica inanimada -ciegas, sigilosas- se tiende una curva mental a una abstracción total, "durarán más allá de nuestro olvido”. El término oxymoron olvido ${ }^{9}$ implica la ausencia de su opuesto -la memoria,- y por elusión nos da la alusión a la muerte, que se completa en la irónica inversión semántica del último verso: "No sabrán nunca [las cosas ] que nos hemos ido."

En "Las cosas," como en otros sonetos de Borges de estructura estrófica shakesperiana, ${ }^{10}$ el cierre del dístico final permite fijar la imagen dinámica en una unificación sintagmática de singular precisión. El efecto se logra por el movimiento de clausura de la rima, coincidente con el cierre del movimiento del verso. La estructura cerrada que unifica elementos opuestos, paradójicamente, sugiere una ambigua valoración semántica en el pensamiento pesimista que la imagen conlleva: las cosas -tácitos esclavos- perduran más que nosotros, sus poseedores.

Esta progresiva intelectualización de la imagen dinámica es característica de los poemas metafisicos de Borges. En “Heráclito” (E, p. 19), escrito en versos libres, el poeta parte de motivos comunes y metáforas tradicionales para recrear la visión del tiempo sucesivo, pero la originalidad está en la progresión metafísica del movimiento de la imagen. Los trece versos que constituyen la primera parte del poema, amétricos 
y sin rima, tienen unificación rítmica estructural en el motivo de los crepúsculos, reiterado dos veces:

\author{
El segundo crepúsculo \\ La noche que se ahonda en el sueño. \\ La purificación y el ovlido. \\ El primer crepúsculo. \\ La mañana que ha sido el alba. \\ El día que fue la mañana. \\ El día numeroso que será la tarde gastada. \\ El segundo crepúsculo \\ Ese otro hábito del tiempo. la noche. \\ La purificación y el olvido. \\ El primer crepúsculo ... \\ El alba sigilosa y en el alba \\ La zozobra del griego.
}

Con evidente intención, el poema y el ciclo temporal se inician con el segundo crepúsculo-momento preferido de la meditación borgiana-para culminar exactamente en mitad del poema (verso 13) con el primer crepúsculo: “el alba sigilosa,” como cierre del ciclo y a la vez apertura de un retorno infinito. La imagen, que es expansiva y continuada, crea el movimiento temporal: 1 ) regresivo: de un presente a un preferido: "La mañana que ha sido el alba/El día que fue la mañana.” 2) progresivo: "El día numeroso que será la tarde gastada.” La doble dirección del juego temporal está dada por el movimiento del verso mismo, intensificado en el juego verbal ha sido, fue, será. El presente, "fugit irreparabile tempus," es el inestable momento que fue (nochemañana-alba), y será (día-tarde-noche), pues ya deja de ser. Sin embargo, significa la posibilidad de la reiteración cíclica en el retorno de la imagen: "El segundo crepúsculo”, “El primer crepúsculo”, versos anafóricos, como paradigmas cristalizados cuya repetición a distancia adquiere su validez en la unificación del sintagma y en la interrelación del contexto; son los mismos y también distintos. ${ }^{11}$ Se trata del tiempo cíclico de los platónicos y los pitagóricos, aunque no hay mención directa de la filosofia y mitología como ocurre en otros poemas borgiaños que tienen la misma temática temporal, tales "La noche cíclica” (OP, p. 138) y “Arte poética,” (OP, p. 217). "Heráclito" se caracteriza por la notoria sencillez del vocabulario y el empleo de motivos cotidiaños llevados a un plano abstracto. Sin embargo, existe una intrinseca complejidad semántica en la conducción de la imagen dinámica, intensificada en la segunda parte del poema:

¿Qué trama es ésta

del será, del es y del fue? 
El hablante lírico y Heráclito se identifican en la inquisición radical, que es aún más específica y urgente en los versos que siguen:

¿Qué río es éste

por el cuál corre el Ganges?

Desde el objeto río (término básico) que lleva implícito el tiempo, el pensamiento tiende una curva mental a un término más lejano, que es una abstracción arquetípica: el Ganges, el río por excelencia. Es todos los ríos y el río único, la esencia metafísica de la identidad río. La imagen oxymoron identifica los dos términos distantes. El mismo/El otro, en la relación imprevista: río (tiempo)-Ganges. El río no interesa por sus cualidades concretas, sino por su concepción metafísica. Río-Ganges, términos aprentemente homónimos implican distintas connotaciones. Río alude al tiempo como corriente sucesiva y Ganges es específicamente el río como identidad única y arquetípica. Pero en los versos siguientes hay una inversión de la imagen que trae un cambio de situación: “El río me arrebata y soy ese río.” La imagen dinámica une dos términos disímiles en una simultaneidad y sincronía: río/soy. A la vez que acrecienta su significiado metafisico condensa su valor emocional intrínseco. En los últimos tres versos del poema la verdad revelada es también frustración ante la imposibilidad de fijarla como absoluta, incertidumbre que acentúa la repetición del adverbio “acaso,” y el único encabalgamiento del poema: sombra/Surgen.

Acaso el manantial está en mi.

Acaso de mi sombra

surgen fatales e ilusorios, los días.

Los tres versos desarrollan dos imágenes continuadas. La primera, estática, unifica los elementos disímiles “manantial (tiempo)/en mí.” La segunda es la reiteración de la anterior, pero en orden inverso y con notorio efecto dinámico. El pensamiento lógico del principio del poema se reintegra en su misma inversión. De mi -sombra- fluye el tiempo, a la vez fatal e ilusorio.

En los dos últimos versos, la imagen dinámica fija la contradicción de la realidad que nace de la ilusión de quien la percibe. Borges nos da en la imagen oxymoron la visión espejo, contradictoria y doble. No se trata ya de símbolo oxymoron sino de imagen, porque es una visión intelectual que en su dinámica unidad crea a la vez una doble y única captación. No es un objeto que significa otro o está por otro, sino un signo doble cuya semántica contradictoria se da simultáneamente y en recíproca unidad, como a través de un cristal (tiempo/soy); positivo y negativo, anverso y reverso de un espejo. ${ }^{12}$

Si bien en "Heráclito” predomina la connotación temporal, en otros poemas como “New England” y “Acevedo” la imagen alcanza una notoria espacialización, 
con todo el sentido equívoco e ilusorio con que Borges aplica la teoría de Berkeley esse es percipi a la experiencia poética. La realidad, como sueño-creación del hablante, puede tomar todas las proyecciones de la percepción íntima. En "New England, 1967” (E, p. 31) la ambigüedad del signo oxymoron sueño refine en el verso inicial el doble y equívoco plano real/irreal que significa New England en la visión del poeta:

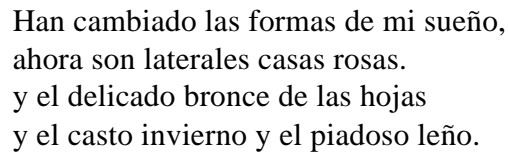

En el segundo cuarteto el tiempo sucesivo (los crepúsculos) rescata la ilusoria presencia del pasado religioso, “un antiguo rumor de Biblia y guerra.” Pero en el tercer cuarteto la realidad pretérita cobra un sentido irrecuperable en el lento presente.

Pronto (nos dicen) llegará la nieve

y América me espera en cada esquina, pero siento en la tarde que declina

el hoy tan lento y el ayer tan breve.

De improviso, en la aparente frustración y pesimismo del cierre del verso, se abre una nueva imagen que, en ruptura con la lógica anterior, tiende una línea mental a una abstracción espacio-intemporal en captación discontinua y simultánea:

Buenos Aires, yo sigo caminando

por tus esquinas, sin porqué ni cuando.

Este dístico final constituye la imagen dinámica con que culmina el proceso lírico que logra la fijación simultánea en el cierre del verso. Se da así, por la imagen, la conjunción de una entidad espacial concreta: “New England”-término básico (nueva realidad-sueño del poeta), con otra distante, aparentemente inconexa y abstracta, "Buenos Aires" - termino relacional, que adquiere la validez de realidad única y definitiva. Las esquinas de "América" (New England) se transfieren en esquinas porteñas. Las Mismas son las Otras. El poeta rompe cronología y espacio. Buenos Aires, omnipresente, esté en el principio y el fin. "Sin porqué ni cuándo" revela una verdad interior. No hay causa ni tiempo explicable, pero es realidad plena como experiencia auténtica en la "visión" del poeta. ${ }^{13}$ El lenguaje muestra en el texto que no se trata de poesía filosófica dada conceptualmente, sino de imagen, "visión" metafísica que identifica dos términos distantes en una simultaneidad. Por magia de la poesía, el espacio y el tiempo original encarnan en el instante simultáneo de la imagen. 
En “Acevedo" (E, p. 103), los “Campos de mis abuelos” surgen como contemplación interior: “indefinidos campos que no puedo/ del todo imaginar.” El término básico, como realidad concreta y punto de partida (campos de Acevedo), es paradójicamente impreciso, visión subjetiva, más interior y abstracta que fisica. En los versos siguientes la realidad es aún más ideal y remota, temporal y espacialmente.

Y no he mirado aun esas cansadas

Leguas de polvo y patria que mis muertos

Vieron desde el caballo [...]

El sustantivo "leguas,” que sugiere extensión y movimiento espacial ampliado en las metonimias “polvo”, “patria”, se expande a su vez en el adjetivo “cansadas” y en la mención “mis muertos vieron...” con una proyección temporal hacia el pasado. En el tercer cuarteto funciona la imagen dinámica que conduce la acción del pensamiento:

La llanura es ubicua. Los he visto

En Iowa, en el Sur, en tierra hebrea,

En aquel saucedal de Galilea

Que hollaron los humaños pies de Cristo.

El poeta unifica en una línea mental, como visión interior, los campos de Acevedo con los del Sur, Iowa, Galilea y, finalmente, los identifica con el hablante mismo, en su activo presente.

No los perdí. Son míos. Los poseo

En el olvido, en un casual deseo.

El término básico campos, aparentemente neutro, enriquece su valor poético y emotivo en el desarrollo de la imagen dinámica, que tiene doble plano: (1) espacial (el Sur, Iowa, Galilea) -términos que, separados, son disímiles, fragmentarios, y nada dicen de su relación; (2) personal-subjetivo -la íntima posesión del poeta. Paradójicamente cuanto más se universaliza el término básico, es más firme y subjetiva su unificación con el hablante. El dístico final establece la ilusoria realidad como íntima permanencia, en tanto el énfasis en los pronombres míos, los, fija como elemental y definitiva, la posesión del objeto que el poeta nunca tuvo concretamente.

En el poema “Elogio de la sombra” (E, p. 155), los primeros versos son una explicación de la etapa “vital” alcanzada por el poeta, referida mediante imágenes estáticas, con el tono conversacional de un monólogo o meditación.

La vejez (tal es el nombre que los otros le dan) puede ser el tiempo de nuestra dicha.

El animal ha muerto o casi ha muerto. 
Vivo entre formas luminosas y vagas

que no son aun la tiniebla.

En la progresión de la búsqueda lírica, Borges lleva a su plenitud la desnuda complejidad de la imagen. El poeta se identifica con su destino ante la vejez y la muerte en actitud idealista:

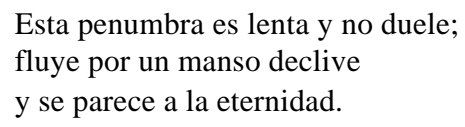

La sugerencia lírica de la alusión “penumbra” [vejez] es el término básico que se expande en la abstracción de una visión estática y permanente; la eternidad. Los versos que siguen conducen al climax del proceso lírico con una singular concentración de la imagen dinámica:

Del Sur, del Este, del Oeste, y del Norte, convergen los caminos que me han traído a mi secreto centro.

Sur, Este, Oeste, Norte, son términos neutros en sí mismos, lenguaje referencial que adquiere proyección poética en la acción del pensamiento, al identificar los puntos cardinales como caminos de retorno al centro original. El punto mítico, simultaneidad de todas las contradicciones, que es principio y fin del universo y de la experiencia de la vida, se unifica así con la intimidad del hablante, su "secreto centro." En el momento crucial de la trayectoria vital, la vejez -como mediadora entre vida y muerte- vislumbra la presencia del mundo mítico original. El adjetivo secreto en su intrinseco poder semántico prefigura ya el alcance último como experiencia irrevelable.

El poema culmina con la enumeración de los caminos que conducen al "secreto centro”, enumeración caótica, analítica, que fluye irracionalmente de la memoria e imaginación del poeta.

Esos caminos fueron ecos y pasos,

mujeres, hombres, agonías, resurrecciones,

días y noches,

entresueños y sueños,

cada ínfimo instante del ayer y de los ayeres del mundo,

la firme espada del danes y la luna del persa,

los actos de los muertos,

el compartido amor, las palabras,

Emerson y la nieve y tantas cosas.

Ahora puedo olvidarlas. Llego a mi centro, 


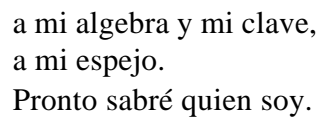

Los términos de la enumeración caótica, como paradigmas errátiles y fragmentarios, se identifican metonímicamente en caminos-tantas cosas, términos básicos de la imagen dinámica que, en progresión intelectual, abarca los cuatro versos finales. Esta línea mental tiene que apoyarse en los elementos caóticos enumerados anteriormente, que son todo el acervo de la vida, para dar de pronto un orden imprevisto: "Llego a mi centro," imagen que se reitera en tres símbolos: mi algebra, mi clave, mi espejo. Algebra y clave son la cifra, la ecuación que se resuelve en un signo único y descubre en un instante una verdad, una revelación intemporal. Por eso puede olvidarlas [tantas cosas ] pues son ya su cifra, su definitiva posesión y pertenecen a una de las vastas zonas de la memoria: el olvido. El último símbolo, mi espejo, que notoriamente ocupa todo un verso, adquiere la plena sugerencia que significa el oxymoron en la lírica borgiana como conjunción de anverso y reverso en unidad. El espejo es la repetición de la imagen y es el descubrimiento de la identidad única y doble: El Mismo, el Otro. El verso final, con el verso en futuro: "Pronto sabré quien soy,” enfrenta la dilucidación del enigma ya prefigurado anteriormente en el verso "Llego a mi centro": retorno al yo, principio elemental que es también la muerte, como verdad definitiva. El verso final del poema, en su cierre estructural tiene, sin embargo, una significación ambigua, ya que la última revelación será incomunicable.

Es importante señalar que en la evolución de la poesía de Borges esta técnica de condensación de la imagen dinámica se basa particularmente en la metonimización del oxymoron. La metáfora implica una relación sustitutiva, paradigmática, en un mismo nivel o jerarquía lingüística; uno equivale al otro, por ej. Ciudad/laberinto; río/ tiempo. La metonimia, en cambio, comprende un proceso semiótico de una jerarquía a otra. Significa un principio de subordinación e integración de dos niveles. En el oxymoron borgiano una unidad remite a otra y asimismo la contiene. El olvido, encierra su opuesto -la memoria. El laberinto-caos se integra en el nivel del orden. El espejo como identidad anverso, incluye su reverso.

Como se infiere en nuestro análisis, cada oxymoron es una simultaneidad doble; no es simple yuxtaposición sino conjunción subordinante de uno en otro. El oxymoron metonimizado opera como figura de contigüidad e implica una simultánea identidad de doble significado que permite el ambiguo juego semántico en una unidad de significación.

La imagen dinámica en la lírica borgiana, según hemos mostrado, significa un renovado lenguaje de condensación en la poesía hispánica del presente. Este nuevo lenguaje, sin embargo, tiene sus raíces en la más auténtica tradición de la poesía 
metafísica. La técnica estilística de la imagen borgiana y su irónica contradicción semántica presentan notoria relación con la poesía de John Donne, el creador más personal de la poesía metafísica inglesa.

Sin proponernos hacer un estudio comparativo entre ambos poetas en este análisis, nos interesa señalar algunas actitudes líricas similares. Si bien Donne y Borges no se relacionan estrictamente en la concepción filosófica y en la temática de su poesía -Donne indaga su duda metafísica en la religión, el amor, la ciencia y la filosofia, en tanto Borges propone sus inquisiciones como juego estético y como irónica conjetura de una sola verdad que incluye a todas-ambos poetas, sin embargo, coinciden en la captación metafísica de la realidad como revelación de la experiencia íntima. Teniendo en cuenta que la metafísica busca trascender del objeto concreto a un ente fundamental más allá de todo objeto, el conocimiento metafisico debe realizarse en el interior del sujeto. Este conocimiento ha de basarse específicamente en la autenticidad de la intuición originaria, que es el momento último y a su vez el esencial y primario. En metafísica la sensibilidad es fuente de conocimiento y toda verdad alcanzada, aunque discutible, debe contar con la veracidad de la experiencia íntima, que es la única garantía de la metafísica.

En la lírica de Donne y en la de Borges, la verdad como experiencia íntima conforma una poética y a su vez fundamenta una ética, que no es dogmática, sino una cosmovisión, verdad resultante de la suma de contradicciones del conocimiento humano, lo que hace su alcance más notable. En ambos poetas el sentido contradictorio de la identidad de las diferencias logra su unificación por la imagen dinámicometafísica. En “The Second Anniversary” de Donne, como en "Heráclito” de Borges, el movimiento de la imagen recrea la sucesión y simultaneidad temporal en la contradictoria unidad del universo.

Nore are, (Although the river keep the name)

Yesterdaies waters, and to daies the same. ${ }^{14}$

En la poesía de Donne, la fragmentaria dispersión de círculos, esferas, mapas, se resuelve en la conducción de la imagen dinámica.

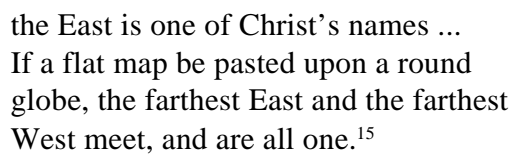

El movimiento circular de la imagen identifica el término básico (Este) con su opuesto (Oeste) en un mismo punto de conjunción. Como en los versos de "Elogio de la Sombra," los puntos cardinales, los caminos, conducen a un centro único. La diversidad espacial es ilusoria; diferentes nombres de una misma ubicuidad: 
Is the Pacifique Sea my home? Or are

The Easterne riches? Is Jerusalem?

Anyan, and Magellan, and Gibraltare,

All streights, and none but streights, are wayes to them

Whether where Japhet dwelt, or Cham, or Sem. ${ }^{16}$

La imagen dinámica unifica la cosmovisión del universo donde cada punto del espacio, como término geográfico, es un microcosmos, centro de una experiencia total. Esta ubicuidad espacio-temporal halla su más significativa expresión en la poesía erótica de Donne. El amor, como acto unificador es microcosmos de una unidad total:

Love, all alike, no season knowes, nor clyme,

Nor houres, dayes, moneths, which are the rags of time.

Shine here to us, and thou art every where;

This bed thy center is, these walls, thy spheare. ${ }^{17}$

El paralelismo "bed-center/ wall-spheare” implica una línea mental imaginativa que condensa su expansion al unificar dos términos aparentemente dísimiles. En los poemas de Donne, como en los de Borges, la imagen dinámica puede presentar ya sea una conjunción abrupta que unifica elementos distantes en un mismo contexto y aun en un mismo término, o bien puede alcanzar una proyección notoriamente expansiva en la unificación de los términos. En el famoso poema “A Valediction: Forbbiding Mourning” Donne identifica a los amantes en su separación, más allá de la muerte, con un verso de abrupta condensación oxymorónica: “Our two soules therefore, which are one.” Sin embargo, el poema logra su originalidad cuando esta identificación se proyecta a la estrofa siguiente, con la expansión que transmite la imagen dinámica:

If they be two, they are two so

As stiffe twin compasses are two,

Thy soule the fixt foot, makes no show

To move, but doth, if th' other doe.

Such wilt thou be to mee, who must

Like th' other foot, obliquely runne.

Thy firmnes drawes my circle just,

And makes me end, where I begunne.

$$
\text { (CP, p. 88) }
$$

El término relacional de la imagen dinámica (los pies del compás) no es poetico en si mismo, pero adquiere su valor lirico en el movimiento mental que relaciona dos 
elementos en apariencia incongruentes, compás/amantes. La imagen en fuga (el pie móvil del compás) infiere una disyunción en la separación, pero a su vez logra la unificación y el encuentro en el retorno de la línea del círculo. El pie en fuga envuelve al que firmemente está en el centro.

Esta identificación de dos amantes en Uno se reitera en otros poemas de Donne. En “The Extasie” (CP, p. 132), el diálogo une a los amantes en una voz única capaz de hablar por ambos en un monólogo:

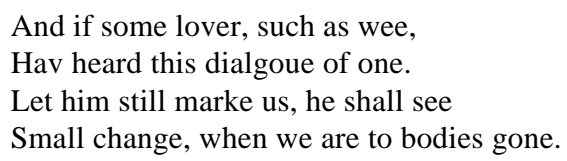

And if some lover, such as wee,

Hav heard this dialgoue of one.

Let him still marke us, he shall see

Small change, when we are to bodies gone.

$$
\text { (CP, p. 132) }
$$

En "Loves Infinitenesse” ( $C P$, p. 100) la unidad y totalidad, se logra en una notable imagen que refine condensación y expansión: "Be one, and one another All."

La importante coincidencia de la relación y unidad de los opuestos en la poesía de Donne y en la de Borges, radica en el sentido que ambos poetas confieren a la identidad del ser, como anverso y reverso de una unidad. En Borges, como también en Donne, la realidad es resultante de la experiencia íntima. Para ambos autores el hombre es uno y todos los hombres, simulacro e imagen de Dios. En el cuento de Borges “Los teologos,” (El Aleph, 1957, p. 35), Juan de Panonia, el hereje, y Aureliano, el ortodoxo, más allá de la muerte, en "la insondable divinidad,” forman una misma persona. En "thyme to God my God in my Sicknesse,” Donne identifica el árbol de Adán y la cruz de Cristo, y en dinámica conjunción los unifica con el hablante mismo.

We thinke that Paradise and Calvarie,

Christs Crosse, and Adams tree, stood in one place;

Looke Lord, and find both Adams met in me;

(CP, p. 391)

La significativa coincidencia entre la lírica de Borges y la de Donne implica la contradictoria búsqueda de la unidad de las diferencias, punto básico que conecta la poesía del siglo XX con la de los poetas metafisicos del XVII. En el caso particular de la comparación entre la obra de los dos autores que estudiamos, la importancia reside especialmente en la técnica y en la semántica de la imagen dinámica: (1) El foco de la imagen dinámica está en la acción del pensamiento. (2) No hay propósito de connotar belleza en el sentido descriptivo tradicional, sino de intelectualizar el objeto. (3) La captación intelectual implica la contención emocional como experiencia íntima. (4) En ambos poetas el término fragmentario halla la conjunción con su opuesto en la misma curva lingüístico-mental de la imagen dinámica. 
Si confrontamos los poemas analizados, veremos, sin embargo, que en la poesía de Donne, generalmente, la expansión de la imagen se percibe más explícitamente en el paralelismo metafórico entre lo concreto y lo abstracto, con su unificación en la línea mental de la imagen. En la poesía de Borges, en cambio, es predominante la condensación de los dos términos dispares con sentido metonímico. Con frecuencia los opuestos se subordinan recíprocamente identificándose en un mismo término oxymoron, básico elemento lingüístico-semántico de la escritura borgiana. Sin embargo, tanto en la poesía de Donne como en la de Borges, la imagen expresa en simultaneidad la unidad de las diferencias y muestra el reverso como última forma de la realidad. Donne, espíritu cristiano, cuestiona la condenación del suicidio en "Biathanatos." ${ }^{18}$ En "The Litanie” expresa que las divisiones religiosas "are all virtual beans of one sun” y agrega "Let not my minde be blinder by more light.” Borges, en "El espejo de los enigmas” (Otras inquisiciones, 1960, p. 173) retoma las sentencias de San Pablo en Per Speculum Enigmate: "Vemos todas las cosas al revés.” "Nosotros estamos en el cielo y dios sufre en la tierra." "Los goces de este mundo serían los tormentos vistos al revés, en un espejo.”

Donne declara en un momento crucial del siglo XVII, "The new philosophy calls all in doubt;” en tanto Borges, en el siglo XX, admite como última verdad, todas las conjeturas posibles. En este sentido lo que singulariza el pensamiento borgiano con respecto al de Donne es la posibilidad de transmutar la duda metafísica en ironía cósmica. Superando los límites de la religión, la ciencia y la filosofia, Borges descubre la ética de una estética, punto crucial donde todas las diferencias se encuentran.

Como conclusión de nuestro estudio, podemos afirmar que Borges incorpora a la lírica hispánica contemporánea la originalidad de una imagen dinámica cuya básica estructura es renovación de la más auténtica poesía metafísica tradicional. La originalidad de Borges, en cuanto a técnica y semántica, tiene un carácter singular en este momento del siglo XX en que el fragmento y la ruptura de la realidad tienden a mostrarse poéticamente por la desintegración del signo en el espacio móvil de la página, como es predominante en el concretismo y otras formas de la poesía espacial.

En la imagen poética borgiana el juego sintáctico afirma en el verso mismo la simultaneidad de los términos discontinuos, y el oxymoron -verdadero corpus de la escritura como signo y como imagen-condensa e identifica la dinámica diferencia de los opuestos.

University of Wisconsin, Madison

ZUNILDA GERTEL

\section{NOTAS}

1 El ultraísmo, surgido en España en 1918 asimila los rasgos significativos de las corrientes del arte vanguardista, especialmente del cubismo y del creacionismo. Borges trae también a esta pluralidad de "ismos" los valores del expresionismo alemán. Ya en Buenos Aires, en su manifiesto "Ultraísmo,” Nosotros, XXXIX, (1921), p. 466, expone sus principios 
fundamentales con criterio más reflexivo y con intención de examinar la literatura anterior, “colmada” y “cumplida”, a la que opone las posibilidades de la novísima estética. En los poemas del ultraísmo borgiano, la metáfora personifica y da animismo a los objetos, sin una plena transmutación de lo concreto en lo abstracto. Se advierte especialmente en las imágenes de transcendencia temporal: "El poniente de pie como un arcángel/ tiranizó el sendero...”; “Juntamente caducan/ la población y la tarde” (de Fervor de Buenos Aires, 1923; páginas sin numerar). Para una ampliación del concreto de la metáfora ultraísta, véase nuestro estudio Borges y su retorno a la poesía (New York, 1968). pp. 83-91 y 105-121.

2 Véase “Macedonio Fernández,” Sur, no. 209-210 (marzo-abril, 1952), p. 146. Con frecuencia la crítica actual al estudiar el ultraísmo borgiano, no recurre a los textos originales de los tres primeros libros en verso Fervor de Buenos Aires, Luna de enfrente y Cuaderno San Martín, sino a las versiones posteriores de éstos publicadas en Poemas $(1943,1954,1958)$ y en Obra poética (1964, 1967), con la consecuente falta de autenticidad textual en el análisis (Usaremos en adelante las respectivas abreviaturas $F, L, C, P, O P$ ). La búsqueda de perfectibilidad, como una constancia de la poesía borgiana, lleva al autor a reelaborar sus poemas primeros con numerosos cambios y supresiones. Es importante confrontar las diferentes versiones textuales de un mismo poema para comprobar que numerosos versos han pasado así de la imagen ultraísta de las primeras ediciones a la metafísica de las últimas versiones. En 1969 se han reeditado los tres primeros libros de versos en dos volumenes: (1) Fervor de Buenos Aires, (2) Luna de enfrente y Cuaderno San Martín. En estas reediciones hay nuevos y significativos cambios con respecto a las versiones anteriores de los mismos tíitulos.

3 En “Poema conjetural” ( $P$, 1943, pp. 170-172), Borges logra por primera vez el símbolo arquetipo de su poesía, el oxymoron como unidad lingüística con doble significado. Refine en esta poesía tres claves temáticas de su mundo político. 1) La identidad como doble (el Mismo, el Otro): el protagonista, Laprida, es también el Otro, el gibelino Buoconte, personaje de La divina comedia, ambos identificados en la clave, la cifra de un destino. 2) El laberinto con sentido de caos, encierra el orden, la verdad del destino humano que se descubre ante la muerte. 3) El espejo como duplicación de la imagen, y como imagen única, definitiva, donde el rostro del hombre es el de Dios: "A esta ruinosa tarde me llevaba/ el laberinto múltiple de pasos/ que mis días tejieron desde un día/ de la niñez; Al fin he descubierto/ la recóndita clave de mis años, / la suerte de Francisco de Laprida,/ la letra que faltaba, la perfecta/ forma que supo Dios desde el principio./ En el espejo de esta noche alcanzo/ mi insospechado rostro eterno. El círculo/ se va a cerrar. Yo aguardo que así sea” (Lo subrayado es nuestro).

4 Véase el prólogo de Elogio de la sombra (Buenos Aires: Emecé, 1969). Todas nuestras citas referidas a esta obra corresponden a dicha edición. En adelante usaremos la abreviatura $E$. Entre los últimos libros de poemas de Borges, El oro de los tigres (1972) se caracteriza también por una significativa condensación de la imagen. En nuestro análisis tomamos específicamente poemas de $E$, pues consideramos que presentan el momento climax de madurez de la poesía borgiana.

5 A. S. Brandenburg, en “The Dynamic Image in Metaphysical Poetry,” PMLA, LVII (1942), pp. 1093-45, hace un significativo análisis de ambas categorías.

6 A. Brandenburg cita como ejemplo la imagen de Keats “valley lillies whiter still than Leda's love” (Endymion, 1.), e incluye en esta clasificación las comparaciones del petrarquismo de los sonetistas isabelinos. 
7 T. S. Eliot: “Donne in Our Time,” A Garland for John Donne, T. Spencer, ed.; Gloucester (Mass.), 1958, p. 16.

8 Henry Wells, Poetic Imagery Illustrated From Elizabethan Literature (New York: Columbia University Press, 1924), pp. 126-127. H. Wells esquematiza la imagen radical como un cono, uno de cuyos extremos posee escaso valor imaginativo en sí mismo, pero que intrinsecamente tiene poder de irradiar significativas sugerencias.

9 El olvido como la memoria tienen connotacibn “oxymorónica” en la poesía metafísica borgiana. Cada término incluye en sí mismo a su opuesto. En “Un lector,” (E, p. 151) se dice: "por que el olvido/ es una de las formas de la memoria, su vago sótano,/ la otra secreta cara de la moneda."

${ }^{10}$ El soneto borgiano, forma poética frecuente en su poesía de madurez, sigue la técnica y concentración del soneto inglés. En la mayor parte de sus sonetos, Borges no separa estróficamente los tres cuartetos y el dístico; prefiere encadenar los catorce versos en una sola tirada.

${ }^{11}$ Es evidente la condensación semántico-temporal de la imagen, ya que Borges no emplea los términos "amanecer” y "anochecer" como en poemas anteriores, sino "primer crepúsculo," "segundo crepúsculo,” como motivos cotidianos-recurrentes de una misma unidad cíclica.

${ }^{12}$ Para una ampliación del análisis de este poema véase nuestro artículo “'Heraclito,' conjunción de opuestos,” Kentucky Romance Quarterly, 2 (1972), pp. 237-250.

13 Esta ubicuidad de Buenos Aires como imagen "mental” del poeta se expresa por alusión en "El forastero," escrito en 1966 y publicado en $O P$, 1967, (p. 259). En este poema la imagen dinámica trae la imprevista inversión de la realidad en los versos finales. El forastero, para quien Buenos Aires es una ciudad “de otro lenguaje y otro cielo," se identifica con el poeta (El Otro, El Mismo), quien extranjero también bajo otros cielos, recobra en ellos la visión única de Buenos Aires: “Antes de la agonía/el infierno y la gloria nos están dados;/ andan ahora por esta ciudad, Buenos Aires,/ que para el forastero de mi sueño/ (el forastero que yo he sido bajo otros astros)/ es una serie de imprecisas imágenes hechas para el olvido."

14 “The Second Anniversary," The Complete Poetry of John Donne, New York University Press, 1968, p. 302. En adelante nos referiremos a este título con la abreviatura CP.

15 "Letter to Sir Robert Cane Knight," The Complete Poetry and Selected Prose of John Donne, Toronto: Random House, 1958, p. 396.

16 "Hymne to God my God, in my Sicknesse," CP, p. 391.

17 “The Sunne Rising," CP, p. 93.

${ }^{18}$ Borges ha manifestado su admiración por Donne, y en el ensayo sobre "El Biathanatos” en Otras inquisiciones, 1960, pp. 129-133, analiza la paradójica defensa del suicidio que Donne sugiere: "el declarado fin del "Biathanatos" es paliar el suicidio; el fundamental, indicar que Cristo se suicidio.” Borges descubre en el texto de Donne, la idea barroca de un Dios que crea el universo para fabricar su patíbulo. De ello deduce la siguiente conclusión: "somos fragmentos de un Dios que en el principio de los tiempos se destruyó, ávido de no ser. La historia universal es la oscura agonía de estos fragmentos.” 


\section{Borges o el Dificil Oficio \\ de la Intimidad: \\ Reflexiones sobre \\ su Poesía más Reciente}

A partir de 1967, fecha de publicación de la última edición de su Obra poética, Borges escribe cuatro colecciones nuevas: Elogio de la sombra (1969), El oro de los tigres (1972), La rosa profunda (1975) y La moneda de hierro (1976). Su producción poética de estos últimos siete años iguala en cantidad a su obra poética publicada entre 1923 (Fervor de Buenos Aires) y 1967 (El otro, el mismo). Los cambios registrados entre estos dos ciclos son significativos, formal y temáticamente. El más notable entre estos últimos es su voluntad de intimidad. Como Eliot, el primer Borges parece comprender la poesía "not as a turning loose of emotions, but as an escape from emotions; not as the expression of personality, but as an escape of personality". El aparente impersonalismo de sus primeros libros define una verdadera estética del pudor y del gesto épico. Estos temas reaparecen en sus últimas colecciones pero en ellas Borges explora en profundidad un tema apenas enunciado en su poesía anterior: la intimidad del hombre que trasciende la máscara del poeta. Desde la vejez y el saldo de una obra plenamente realizada, Borges se confiesa.

Ante el inesperado hallazgo del volumen undécimo de la Primera Enciclopedia de Tlön, el narrador (Borges) declara sobrecogido: "Me puse a hojearlo y sentí un vértigo asombrado y ligero que no describiré, porque ésta no es la historia de mis emociones sino de Uqbar y Tlön y Orbis Tertius”. ${ }^{1}$ ¿Una efusión de Borges? ¿Un artificio del narrador que se vuelve sobre su narración y la cuestiona, comenta o corrige? ¿Una sonrisa de incredulidad respecto a su propia ficción? ¿Un guiño travieso al lector ingenuo? Si, todo eso, pero además una velada profesión de fe que declara los alcances y limitaciones de su arte. Borges se niega a la novela, al libro vasto, por un escrúpulo de economía, como lo ha afirmado en varios textos, pero además porque siendo la función de la novela, según é1, “crear un personaje real y mostrar el carácter del héroe” (O.I., 194, 220), tal empeño implica una morosa y trabajada excursión por el territorio de sus emociones y el mundo de su intimidad. Borges se niega a tales excursiones. Una voluntad de artificio y de irrealidad (que el considera "condición del arte") le hace decir respecto a la novela psicológica: "Los rusos y los discípulos de los rusos han demostrado hasta el hastío que nada es 
imposible: suicidas por felicidad, asesinos por benevolencia; personas que se adoran hasta el punto de separarse para siempre, delatores por fervor o por humildad...” Para concluir: "Esa libertad plena acaba por equivaler a pleno desorden. Por otra parte, la novela 'psicológica' quiere ser también novela 'realista': prefiere que olvidemos su carácter de artificio verbal y hace de toda vana precisión (o de toda lánguida vaguedad) un nuevo rasgo verosímil. Hay páginas, hay capítulos de Marcel Proust que son inaceptables como invenciones y a ellos nos resignamos, sin saberlo, como a lo insípido y ocioso de cada día”. ${ }^{2}$ El cuento en cambio, “fábula de situaciones”, se ajusta más eficazmente al carácter de invención de la literatura. Borges deplora la condición de "informe" de cierta novela psicológica, su estéril alarde de "transcripción de la realidad” y exalta la literatura como un objeto artificial, el texto como "un férreo sistema de simetrías, de coincidencias y de contrastes”. ${ }^{3}$ Su preferencia por lo fantástico constituye una oblicua formulación de su poética: si la novela realista se atiene a la crónica como criterio de verosimilitud, la narración fantástica es solamente inverosímil en relación a esa crónica, no lo es en cuanto testimonio de la imaginación. Concluir que la fantasía es un arbitrio y que la verdad habita en las versiones de la realidad postuladas por la novela realista equivale a afirmar que la vida de vigilia es más verdadera que el mundo desorbitado de los sueños. Como los sueños, las imágenes de la literatura fantástica son máscaras de su creador pero el creador esté en ellas metamorfoseado y así lo reconoce Borges. Interrogado sobre el supuesto "impersonalismo" de sus cuentos, respondió: “No, (con tristeza). Si dejan tal impresión es por mera torpeza mía, porque yo los he sentido muy profundamente. Los he sentido tan profundamente que los he contado, bueno, usando símbolos extraños para que los lectores no se enteraran de que eran todos más o menos autobiográficos. Son relatos sobre mí mismo, sobre mis experiencias personales. Me imagino que es mi timidez anglosajona, ¿no?’. ${ }^{4}$ La entrevista es de 1967. Tres años antes, en Madrid, Borges ofrece una respuesta semejante. Entrevistado por Gómez de la Serna, comenta respecto a la literatura fantástica: "Pero lo fantástico no es ni arbitrario ni gratuito. Me expreso por medio de símbolos, o más bien diría que determinadas imágenes se forman en mí, a través de las cuales cobro conciencia de ciertas verdades. Algunos creen que yo comienzo por una proposición abstracta. Es lo contrario. Parto siempre de una situación humana, de una posibilidad concreta. Si no sería un moralista y no un poeta". ${ }^{5}$ En una tercera entrevista del mismo año ha explicado en relación al aparente impersonalismo de su obra: "Esa suerte de misterio que según algunos lectores parece 'existir' en mi obra, no se debe a un deseo de mistificación, sino a una suerte de pudor; quisiera en el fondo alcanzar una mayor intimidad, no solamente con los otros sino conmigo mismo". ${ }^{6}$

Lo común en las tres respuestas es una defensa o justificación de la timidez y del pudor. Más que negarse a escribir sobre sí mismo, Borges se niega a la fácil confesión, a la intimidad romántica, al egocentrismo existencial. Acosado por el destino de "sus 
antepasados de muerte romántica”, exalta la valentía de héroes y cuchilleros dispuestos a morir en defensa de un ideal o de una virtud más cara que sus propias vidas. Los derroteros y las derrotas de un Roquentin, por ejemplo, le aburren; las hazanas de un héroe épico, en cambio, ganan su admiración. De ahí su preferencia por Shaw de quien ha dicho:

Creo que además de ese Shaw circunstancial, hay en Shaw un sentido épico, y que es el único escritor de nuestro tiempo que ha imaginado y presentado héroes a sus lectores. En general, los escritores tienden a mostrar las flaquezas de los hombres y parecen complacerse en sus derrotas; en cambio, en el caso de Shaw hay personajes como Major Barbara o César, que son personajes heroicos que uno puede admirar. Eso es muy raro en la literatura contemporánea. La literatura contemporánea desde Dostoiewsky y aun antes, desde Byron, parece complacerse más en las culpas, en las flaquezas del hombre. En cambio, en la obra de Bernard Shaw hay una exaltación de las mayores virtudes humanas. Por ejemplo, que un hombre pueda olvidarse de su propio destino, que a un hombre no le importen sus venturas, que pueda decir como nuestro Almafuerte: “A mí no me interesa mi propia vida”, porque le interesa algo que está más allá de las circunstancial personales. ${ }^{7}$

La defensa que Borges hace del pudor, entonces, no es un alegato de la debilidad o del mero impersonalismo; es una afirmación de un sentido épico de la vida y un esfuerzo por trascender su inmediatez. El poeta olvida su biografía para ser ese hombre que esencialmente es o quiere ser: Walt Whitman "es el modesto periodista Walter Whitman, oriundo de Long Island, que algún amigo apresurado saludaría en las aceras de Manhattan, y es, asimismo, el otro que el primero quería ser y no fue, un hombre de aventura y de amor, indolente, animoso, despreocupado, recorredor de América” ${ }^{8}$ Para Borges, Leaves of Grass es una epopeya: "Whitman se impuso la escritura de una epopeya de ese acontecimiento histórico nuevo -la democracia americana". ${ }^{9}$ El héroe de esa epopeya es Whitman, un innumerable Whitman que olvida al otro de Long Island y de las aceras de Manhattan para desdoblarse en los destinos infinitos de una nación en ciernes. El esfuerzo poético de Borges apunta a una dirección semejante aunque sus temas y propósitos difieran. La Argentina de Borges no es la América de Whitman, pero, como el poeta del Norte, Borges se reconoce menos en el modesto bibliotecario que por esos años escribía "Vida y muerte le han faltado a mi vida”, que en las gloriosas vidas de sus antepasados muertos a caballo. Borges ha dicho de esos nueve años en una oscura biblioteca del suroeste de la ciudad de Buenos Aires: "Fueron nueve años de sólida infelicidad"; ${ }^{10}$ pero su realidad por esos años es menos esa miserable biblioteca que la ciudad conjurada desde su poesía, menos las dos horas diarias de tranvía entre su casa y esa biblioteca que los libros leídos durante la rutina del viaje. En su poesía de esos años no hay ni una palabra de 
ese mundo indigente y banal. Si el destino épico de sus antepasados le ha sido negado en el campo de batalla, Borges convertirá la literatura en su batalla. No son sus flaquezas y derrotas las que triunfan en su poesía de esa época. De sus libros juveniles emerge una ciudad reconquistada: "La ciudad esta en mi como un poema/ que no he logrado detener en palabras” (OP, 32). Borges rescata viejos barrios, calles ignoradas del arrabal, plazas suspendidas en la tarde, íntimos jardines, ponientes herrumbrados, almacenes rosados, sepulcros, horizontes, ciudad que se disuelve en la llanura, y con esos adarmes funda por tercera vez Buenos Aires, fundación mítica de una ciudad hecha de nostalgia y de historia familiar:

A mi ciudad de patios cóncavos como cántaros y de calles que surcan las leguas como un vuelo, a mi ciudad de esquinas aureoladas de ocaso y arrabales azules, hechos de firmamento. A mi ciudad que se abre clara como una pampa, yo volví de las tierras antiguas del naciente y recobre sus casas y la luz de sus casas y esa modesta luz que urgen los almacenes

$(\mathrm{OP}, 96)$

Si para Whitman cantarse a sí mismo es cantar las multitudes en que se desgrana América, y para Neruda el canto general de América es su propio canto como canto de todos, para Borges la patria es apenas ese diálogo íntimo con las calles de Buenos Aires, "no las calles enérgicas,/ molestadas de prisas y ajetreos,/ sino la dulce calle de arrabal/ enternecida de penumbra y ocaso" (OP, 17): "Mi patria es un latido de guitarra, unos retratos y una vieja espada” $(\mathrm{OP}, 80)$. Una patria entrañable que más que loar se cultiva como una amistad: "Grato es vivir en la amistad oscura/ de un zaguán, de una parra y de un aljibe” (OP, 30). La historia de esa patria entrañable "que condesciende a higuera y aljibe" no puede ser otra que la historia de sus propios antepasados, una historia en que el destino del país se confunde con el destino de su sangre como en la amistad el yo y el tú se entrelazan en un diálogo verbal y de destino:

Una amistad hicieron mis abuelos con esta lejanía y conquistaron la intimidad de la Pampa y ligaron a su baquía

la tierra, el fuego, el aire, el agua.

$(\mathrm{OP}, 88)$ 
Pero además de los temas de la ciudad íntima y la patria entrañable, las primeras colecciones (Fervor de Buenos Aires, Luna de enfrente y Cuaderno San Martín) incluyen también poemas de inquietud metafísica, como “Amanecer”, y de materia literaria, como "Manuscrito hallado en un libro de Joseph Conrad”. Estos temas son todavía la excepción y solamente a partir de El otro, el mismo, que reúne su producción poética escrita entre Cuaderno San Martín (1929) y Elogio de la sombra (1969), devendrán lo dominante. Los primeros temas, lejos de desaparecer, alcanzan en esta colección de madurez su más concentrada intensidad -basta leer, por ejemplo, los dos sonetos titulados "Buenos Aires” y el memorable "Poema conjetural”-, pero lo central será ahora la reflexión filosófica, sus preferencias literarias y las paradojas de la cultura. De esta época data el tan citado epílogo a El hacedor, libro que incluye una buena porción de los poemas recogidos más tarde en El otro, el mismo; en ese epílogo Borges retoma el motivo de vida y literatura, formulado primero desde el prólogo a Discusión, y reitera: "Pocas cosas me han ocurrido y muchas he leído. Mejor dicho: pocas cosas me han ocurrido más dignas de memoria que el pensamiento de Schopenhauer y la música verbal de Inglaterra” (H, 109). La literatura y las aventuras del pensamiento alcanzan en su poesía adulta la magnitud de una pasión: Gracián, Quevedo, Camoens, Ariosto, Milton, la Biblia, Homero, la Gesta de Beowulf, Snorri Sturluson, Swedenborg, Jonathan Edwards, Emerson, Poe, Whitman, Heine, CansinosAssens, Spinoza -son algunos de los nombres de esa pasión.

Para algunos esta poesía puede parecer excesivamente sofisticada e impersonal, más próxima al intelecto que al corazón, pero solamente si se identifica al corazón con facilidades sensibleras y a la poesía, no como la invención del poeta de su propia realidad, Paz dixit, sino como una mera efusión confesional. Para Borges la poesía es una música, un sueño dirigido y un espejo "que nos revela nuestra propia cara”; una manera de decir que "la literatura es fundamentalmente un hecho sintáctico", ${ }^{11}$ que la realidad de crónica es tan empobrecedora como las noticias de los periódicos y que los sueños y los mitos nos devuelven a ese ser que íntimamente somos. El poema es "un objeto artificial” como Lo son todas las creaciones del hombre-Lévi-Strauss ha definido la cultura como "ese mundo artificial en el cual vivimos como miembros de una sociedad" 12 -, y cada escritor escribe, como ha observado Borges, "no sobre lo que quiere sino sobre lo que puede”. Sus tres últimas colecciones -El oro de los tigres (1972), La rosa profunda (1975) y La moneda de hierro (1976)-presentan variaciones de esos temas a que nos ha acostumbrado su poesía: la patria íntima, el culto de los mayores, la pasión por los libros, la preocupación filosófica, la ceguera, la germanística de Inglaterra y de Islandia, los antepasados, el tiempo, el olvido y la memoria, la vejez, la muerte.

Una variación no es la repetición de un tema sino su desarrollo, un esfuerzo por hilar más fino y encontrar una versión más, la final, de esas imágenes que en la obra de todo escritor se sobreponen como láminas de sueños borradas por la vigilia. Pero 
esa versión última no coincide con la cronología; es apenas un nuevo ángulo desde el cual el mismo tema reaparece revelado con la profundidad a que accede desde esa redescubierta perspectiva: “Otro poema de los dones” no es la mera reiteración de "Poema de los dones” sino su complemento, un punto focal de intensidad y claridad diferentes.

Junto a estos temas, aunque no agotados, ya recorridos, emerge un Borges más dispuesto a hablarnos de sí mismo, no de la persona creada por la literatura, no del escritor que "trama su literatura” para justificar al otro, sino justamente de ese "otro que vive y se deja vivir”, un Borges asediado por “las miserias de cada día”, prisionero de la condición humana, un hombre ciego que "una u otra mujer han rechazado”, en resumen, un Borges más dispuesto a contarnos esas “pocas cosas que le han ocurrido”. Indicios de ese Borges aparecen ya en sus primeros libros. Son poemas que evocan una mujer (“Ausencia”), celebran su hermosura (“Sábados”, “Trofeo”), se duelen de su ausencia (“Despedida”), sellan una despedida ("Dualidá en una despedida”), hacen un voto ("Two English Poems”). Dejan un sabor, como toda poesía amatoria, de nostalgia y pasión frustrada. Son poemas que por ser excepción confirman la regla y en su entusiasmo exaltado corresponden a una edad de ilusa y elusiva exuberancia. Hay que esperar hasta 1964 para encontrar un segundo asalto de intimidad. Cronológicamente, el salto no es menos abrupto: entre los poemas juveniles de tema amoroso y ese poema que lleva como título el año de su composición (“1964”), Borges ha publicado Otras inquisiciones y las tres colecciones más importantes de su obra narrativa, ha sido descubierto en Europa y los Estados Unidos y ha recibido el Premio Nacional de Literatura y el Premio Internacional Formentor. Un escritor plenamente realizado y, sin embargo, un hombre que se siente profundamente desdichado; oigamos cómo lo dice él mismo en el segundo de los dos sonetos compuestos en 1964 y así titulados:

Ya no seré feliz. Tal vez no importa.

Hay tantas otras cosas en el mundo;

Un instante cualquiera es más profundo

Y diverso que el mar. La vida es corta

$\mathrm{Y}$ aunque las horas son tan largas, una

Oscura maravilla nos acecha,

La muerte, ese otro mar, esa otra flecha

Que nos libra del sol y de la luna

Y del amor. La dicha que me diste

Y me quitaste deberá ser borrada;

Lo que era todo tiene que ser nada.

Sólo me queda el goce de estar triste,

Esa vana costumbre que me inclina 
Al Sur, a cierta puerta, a cierta esquina.

$(\mathrm{OP}, 256)$

Borges se solaza todavía en la patria íntima, tema al cual volverá en sus tres últimos libros de poesía, pero el tono épico ha sido reemplazado ahora por un tono elegíaco; véase, por ejemplo, "Elegía del recuerdo imposible” y "Elegía de la patria” de La moneda de hierro. Si en "Inscripción sepulcral”, de 1923, el coronel Isidoro Suárez es el héroe que:

Dilató su valor sobre los Andes.

Contrastó montañas y ejércitos.

La audacia fue costumbre de su espada.

Impuso en Junín término venturoso a la lucha

y a las lanzas del Perú dio sangre española.

Escribió su censo de hazañas

en prosa rígida como los clarines belísonos.

$(\mathrm{OP}, 29)$

en “Coronel Suárez”, de 1976, Suárez es percibido en su intimidad de hombre y en su condición de héroe, pero de esa condición quedan apenas las cenizas de la gloria y la metáfora del bronce no invulnerables a la obra del tiempo:
Alta en el alba se alza la severa
Faz de metal y de melancolía.
Un perro se desliza por la acera.
Ya no es de noche y no es aún de día.
Suárez mira su pueblo y la llanura
Ulterior, las estancias, los potreros,
Los rumbos que fatigan los reseros,
El paciente planeta que perdura.
Detrás del simulacro lo adivino,
Oh joven capitán que fuiste el dueño
De esa batalla que torció el destino:
Junín, resplandeciente como un sumo.
En un confín del vasto Sur persiste
Esa alta cosa, vagamente triste.

(MH, 17)

La resignación, melancolía y tristeza de este Suárez elegíaco son de una pieza con el tono resignado del soneto “1964”. Borges, como Suárez, contempla las cenizas del 
pasado ("Lo que era todo tiene que ser nada”); la dicha pasada, de Borges, como la gloria antigua, de Suárez, se borran en el agua del tiempo y “sólo queda el goce de estar triste”, en Borges, y “esa alta cosa, vagamente triste”, en Suárez. En el soneto “Junín”, de 1966, se mezclan las dos voces (y los dos destinos) y el tono de resignación cede a un sentimiento de futilidad: la ceguera y el olvido dejan sobre el fuego apagado apenas una ceniza o una sombra: “Acaso buscas por mis vanos ojos/ el épico Junín de tus soldados (...)/ Te imagino severo, un poco triste (...)” (OP, 286).

Con “1964” Borges inicia un ciclo de poemas dedicados a su vocación de infelicidad. Si los dos poemas de los dones representan un esfuerzo de gratitud por todo lo que tuvo, desde "el pan y la sal” hasta "la felicidad de los otros", “Alguien”, de 1966, es su reverso: el poema de lo que no tuvo. Los dones son apenas "modestas limosnas"; la felicidad, en cambio, es un misterio que, como los dioses, se manifiesta desde su ausencia, esta menos en el individuo que en la especie y es más un reflejo que resplandece desde una distancia primordial y cuya fuente no está en nosotros. Del fondo de estas cavilaciones asciende otra vez la mirada de la muerte con una promesa de cielo o infierno:

Un hombre trabajado por el tiempo, un hombre que ni siquiera espera la muerte (las pruebas de la muerte son estadísticas y nadie hay que no corra el albur de ser el primer inmortal), un hombre que ha aprendido a agradecer las modestas limosnas de los días: el sueño, la rutina, el sabor del agua, una no sospechada etimología, un verso latino o sajón, la memoria de una mujer que lo ha abandonado hace ya tantos años que hoy puede recordarla sin amargura, un hombre que no ignora que el presente ya es el porvenir y el olvido, un hombre que ha sido desleal y con el que fueron desleales, puede sentir de pronto, al cruzar la calle, una misteriosa felicidad que no viene del lado de la esperanza sino de una antigua inocencia, de su propia raíz o de un dios disperso. Sabe que no debe mirarla de cerca, porque hay razones más terribles que tigres que le demostraran su obligación 


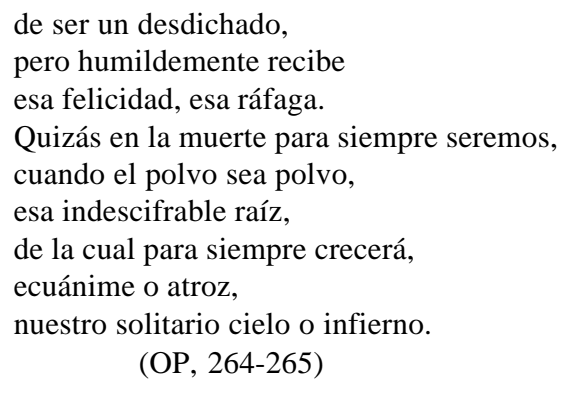

En “Elegía”, de 1963, esa “obligación de desdicha” se abre a través de un pasado poblado con mares solitarios y lejanos países, con enciclopedias y atlas, con espadas y espejos, para dejarnos frente al "rostro de una muchacha de Buenos Aires,/ un rostro que no quiere que lo recuerde”. Este motivo del amor negado es el tema del dístico apócrifo “Le regret d'Heraclite”: "Yo, que tantos hombres he sido, no he sido nunca/ aquel en cuyo abrazo desfallecía Matilde Urbach” (OP, 332). Borges vuelve al amor como la medida, tal vez la única, de la paz, y detrás de sus “mitologías” y “sus pequeñas magias inútiles" descubre un gran dolor: "El nombre de una mujer me delata./ Me duele una mujer en todo el cuerpo" (OT, 61). Pero la amenaza del amor ("El amenazado" es el título de ese poema) no amengua un estado de soledad que es la condición de un hombre y, tal vez, de todos los hombres: "Un sólo hombre ha sentido en el paladar la frescura del agua, el sabor de las frutas y de la carne./ Hablo del único, del uno, del que esta siempre sólo” (OT, 69), y esa condición se define en "El centinela" como una avasalladora esclavitud: "Vuelvo a la esclavitud que ha durado más de siete veces diez años” (OT, 77). El amor puede manifestarse en esa amenaza y en ese dolor como "una magia inútil”, ser un Proteo cuyo verdadero rostro se oculta entre efímeros rostros, o tal vez una multitud de caras que se niegan a la única cara de la felicidad, pero, como la sangre, está en el hombre: se lo puede postergar o sublimar, huir de é1, para finalmente comprobar que todos los caminos conducen inevitablemente a él:

“¿De qué me servirán mis.talismanes:.el.ejercicio.de las letras, la vaga erudición, el aprendizaje de las palabras que usó el áspero Norte para cantar sus mares y sus espadas, la serena amistad, las galerías de la Biblioteca, las cosas comunes, los hábitos, el joven amor de mi madre, la sombra militar de mis muertos, la noche intemporal, el sabor del sueño?

Estar contigo o no estar contigo es la medida de mi tiempo.”

$(\mathrm{OT}, 61)$

El tema recurre, como una variación, en el soneto “Al triste”. La tristeza nace de un sentimiento de futilidad ante esos "talismanes" que antes fueron todo y que ahora 
aceptan el fracaso de su momentáneo exorcismo. Los trabajos del amor son tan implacables como la vida misma; todas la máscaras que el arte crea para reinventar la vida o colmar su vaciedad son tan falibles como la ciencia de Fausto ante las promesas de Mefistáfeles o la vejez de Kohelet ante la muerte. Frente al amor sucumben libros, espadas, tiempo y hasta el mismo verso que inscribe su propia derrota:

Ahí está lo que fue: la terca espada

Del sajón y su métrica de hierro,

Los mares y las islas del destierro

Del hijo de Laertes, la dorada

Luna del persa y los sin fin jardines

De la filosofía y de la historia,

El oro sepulcral de la memoria

Y en la sombra el olor de los jazmines.

Y nada de eso importa. El resignado

Ejercicio del verso no lo salva

Ni las aguas del sueño ni la estrella

Que en la arrasada noche olvida el alba.

Una sola mujer es tu cuidado,

Igual a las demás, pero que es ella.

(OT, 87)

Borges acepta su condición de poeta, la literatura como su inexorable realidad: "No haber caído, / como otros de mi sangre, / en la batalla./ Ser en la vana noche/ el que cuenta las silabas” (OT, 22), y desde esa condición de hombre de letras realizado explora ahora su soledad, sus desengaños y desdichas. Como Kohelet, que desde su sabia vejez reflexiona sobre el brillo perdido de las vanidades humanas, este Borges septuagenario accede a la verdad cruda de la intimidad: "Y detrás de los mitos y las máscaras,/ el alma, que está sola” (OT, 25). Retorna al pasado, pero no a un pasado visible signado en esa vida dedicada a los libros y consignado en su obra literaria, sino a un pasado invisible, a un tiempo reversible en el cual la inscripción pudo haber sido diferente: ¿Dónde estará mi vida, la que pudo haber sido y no fue?”(OT, 41). Pero el tiempo es irreversible y su respuesta, el olvido:

Esas cosas no son. Otra es mi suerte:

Las vagas horas, la memoria impura,

El abuso de la literatura

Y en el confín la no gustada muerte.

Sólo esa piedra quiero. Sólo pido

Las dos abstractas fechas y el olvido.

(OT, 45) 
Ya Guillermo Sucre ha observado que en Borges el olvido es una forma de posesión y que de la misma manera que "la vida adquiere sentido a partir de la muerte misma”, el olvido es también la realización última de la memoria. ${ }^{13}$ En el poema “El pasado” de El oro de los tigres evoca los mitos y las máscaras del tiempo transcurrido para concluir: "Esas cosas pudieron no haber sido./ Casi no fueron. Las imaginamos/ en un fatal ayer inevitable./ No hay otro tiempo que el ahora, este ápice/ del ya será y del fue, de aquel instante/ en que la gota cae en la clepsidra” (OT, 18).

El instante es el vértice visible que cancela y a su vez manifiesta el cono del pasado, y es en este ahora inmediato y paradójicamente hecho de pasado en el que la poesía de Borges se detiene. El olvido y la muerte pertenecen a ese instante en que, como un cruce de caminos, se sale de la memoria y de la vida para llegar al único centro posible que espera detrás del instante, pero el instante es un puente, y para Borges un puente último desde el cual puede atalayar lo que fue y lo que no fue: “... Todo esto estoy cantando y asimismo/ la insufrible memoria de lugares de Buenos Aires/ en los que no he sido feliz/ y en los que no podré ser feliz” (OT, 153).

En la colección siguiente, La rosa profunda, Borges explora una vez más el vedado territorio de su intimidad. Junto a los temas que forman el bulbo de su poesía -los antepasados y la patria, la memoria y el olvido, el ejercicio de la literatura y los libros- recurren reflexiones sobre el amor frustrado, la soledad y la muerte. En el primer poema, “Yo", Borges se retrata como el cuerpo de vísceras y huesos que el otro arrastra, como el poeta soñado desde sus mitos, para concluir en uno de sus versos más desgarradores: "Soy el que envidia a los que ya se han muerto" (RP, 13). La muerte es una forma más del olvido: “Cuando yo muera morirá un pasado” (RP, 123), que se salva parcialmente en la literatura: “el verso es la única memoria” $(\mathrm{RP}, 45)$. Pero detrás de los mitos de la poesía esta la muerte grande: “Soy eco, olvido, nada” (RP, 53) y la pesadumbre del destino que no fue: "Soy el que es nadie, el que no fue una espada" (RP, 53), “No soy el oriental Francisco Borges/ que murió con dos balas en el pecho” (RP, 107). En “Talismanes” Borges hace un balance de sus mitologías (un ejemplar de la primera edición de la Edda Islandorum de Snorri impresa en Dinamarca, los cinco tomos de la obra de Schopenhauer, los dos tomos de las Odiseas de Chapman, las Empresas de Saavedra Fajardo, líneas de Virgilio y de Frost), un balance de objetos que cifran su pasado ("una espada que guerreóen el desierto”, "un mate con un pie de serpientes que mi bisabuelo trajo de Lima”, "un prisma de cristal”, "unos daguerrotipos borrosos”, "un globo terráqueo de madera que me dio Cecilia Ingenieros y que no fue de su padre", "un bastón de puño encorvado que anduvo por la llanuras de América, por Colombia y por Texas”, "varios cilindros de metal con diplomas”, "la toga y el birrete de un doctorado") y un balance del saldo que el tiempo deja en el recuerdo ("la memoria de una mañana”, "la voz de Macedonio Fernández”, “el amor o el diálogo de unos pocos”); en el último verso concluye: “Ciertamente son talismanes, pero de nada sirven contra la sombra que no puedo nombrar, contra la sombra que no debo nombrar” (RP, 136). 
“Inventario”, del mismo volumen, propone una conclusión semejante; recuerda las enumeraciones prolijas a que nos acostumbró la poesía de Neruda hasta en el use del verbo anafórico hay, pero en Borges la tirada no es una exaltación del caos o la celebración de una olvidada belleza o un esfuerzo de multitud aprendido en Whitman, sino una manera de hurgar en el pasado, una forma de ponernos otra vez ante el olvido desde la memoria - "la memoria, esa forma del olvido" dice en "El ciego", y en "Inventario" concluye: “Al olvido, a las cosas del olvido, acabo de erigir este monumento" (RP, 30). Para este Borges que sentencia "La meta es el olvido" y que desde la breve alegoría "El prisionero” percibe la vida como una prisión y la muerte como una libertad, como su más íntimo anhelo, la poesía es "un alto río que sigue resonando en el tiempo”, una música hecha con los objetos y seres del pasado, con “máscaras, agonías y resurrecciones”, y además una música que finalmente se rinde a los secretos de la intimidad.

En una entrevista reciente hecha por William Buckley para la televisión americana, Borges dijo de pasada: "I will welcome death since I am very tired, since life has few pleasures left for me”. De esta resignada aceptación de la muerte, aunque como la forma más alta de realización de la vida ("Llego a mi centro,/ a mi algebra y mi clave,/ a mi espejo./ Pronto sabré quien soy”, dice en el poema que cierra Elogio de la sombra), emerge mucha de su última poesía como una larga meditación sobre el olvido y la muerte. De este talante deriva también una voluntad de confesión y un tono conmovedoramente elegíaco. Borges viola su recato porque sabe que en esa hora de aceptaciones y reconciliaciones el pudor puede ser una miseria más de nuestra vanidad y porque ahora recordar las flaquezas es olvidarlas. Ya no importa, y lo dirá: "Soy un triste” (MH, 73). Tal es el sentido del poema “Elegía del recuerdo imposible” que abre la colección La moneda de hierro. Es un íntimo balance (como "Inventario" y “Talismanes”) de recuerdos (vividos, leídos o imaginados) y deseos. Recuerda lo que una vez tuvo y desea lo que no pudo tener, pero en ninguno de los dos casos se trata de poseer, de vivir o revivir, sino apenas de recordar, de la posibilidad de una evocación última ante la inminencia del olvido total. El tono es elegíaco porque lo que fue es una memoria que el tiempo deshace implacable, y lo que no fue no podrá ya ser. El poema es la respuesta desde la literatura a ese recuerdo imposible, su realización por el lenguaje, pero al verbalizar el "recuerdo imposible" el poema replantea el espacio infranqueable entre las palabras y las cosas. Es un espacio íntimo que antes de ingresar al olvido debe ser recorrido aunque la evocación tome apenas la forma de un voto irrealizable:

Qué no daría yo por la memoria

De que me hubieras dicho que me querías

Y de no haber dormido hasta la aurora,

Desgarrado y feliz. (MH, 14) 
El logro de esta poesía reside menos en la confesión que en la aceptación del fracaso confesado, es menos un acto de fácil sentimentalismo que un gesto de matiz épico. Entre la actitud de complacencia ante las derrotas que Borges censuraba en la novela psicológica y su actitud de resignada aceptación ante su fracaso de felicidad, presente en su poesía última, media una distancia semejante a la que separa la novela que exalta las flaquezas humanas del poema épico que celebra virtudes que trascienden las circunstancias puramente personales. Y sin embargo esta poesía última es eminentemente personal. Lo es en cuanto habla de la infelicidad de un hombre, pero en el contexto todo de su obra esa voz solamente permitida desde la vejez adquiere la dimensión de un silencio, es una astilla de luz que acentúa aún más la oscuridad rasgada. Hasta 1964, tiene 65 años, más allá de los pocos poemas juveniles de tema amatorio, ni una sola palabra de ese mundo íntimo y personal. Borges hace su obra como un héroe épico libra sus batallas: olvidando su propio destino personal. Sabe que la espada de sus abuelos no le ha sido permitida: convertirá el ejercicio de la literatura en su espada. Sus poemas que acceden a la intimidad definen, por contraste, una obra que posterga el yo personal o que lo sublima en los juegos y los fuegos de la imaginación. “Un hombre que entreteje endecasíbalos” (MH, 140) es su definición de sí mismo: el poeta que escoge la literatura como un destino, el poeta que busca en las pasiones de la cultura una sordina a sus propias pasiones, el poeta que hace del destino de los otros su propio destino. Próximo al ocaso de su vida, su exabrupto de intimidad es, más que una flaqueza, un acto heroico: la desdicha como una culpa para que la obra se cumpla.

Borges vuelve a su yo más íntimo como Ulises a su Itaca: "harto de prodigios”. Sus prodigios son las “simétricas porfías del arte que entreteje naderías”, pero como el héroe homérico Borges sabe que solamente después de haber recorrido los prodigios, de la aventura o del arte, es posible el regreso. "Se vuelve a yo como a una casa vieja” escribió Neruda en uno de sus libros póstumos. ${ }^{14}$ Para Borges ese retorno desde su poesía equivale a una confesión: el pecado de no haber sido feliz. Hay momentos de su obra que ilustran ese diálogo callado entre los dos Borges: en la prosa “Borges y yo” y más recientemente en el poema “El centinela” de El oro de los tigres. Es un diálogo en el que sólo se oye la voz del otro, la del escritor; la voz del hombre, en cambio, es apenas una queja de su larga esclavitud al destino y a las preferencias del otro: "Yo vivo para que Borges pueda tramar su literatura y esa literatura me justifica” (H, 50). Es esta elección del destino del otro y la subsecuente supresión en su poesía de aquel que "se perderá definitivamente" la que define su gesto como un acto heroico. También Borges, como los héroes épicos, dice a lo largo de su obra dedicada al destino del otro: “A mí no me interesa mi propia vida, porque me interesa algo que está más allá de las circunstancias personales”. Solamente en raros y tardíos momentos de intimidad Borges cede la palabra a ese yo personal que se confiesa brutalmente. La versión más reciente de esa confesión es el poema “El remordimiento" incluido en La moneda de hierro. En su íntimo reconocimiento hay visos trágicos: la 
certeza de una vida dedicada a la literatura que sabe que en ese acto, a sabiendas o no, a queriendas o no, sacrifica su felicidad personal:

He cometido el peor de los pecados

Que un hombre puede cometer. No he sido

Feliz. Que los glaciares del olvido

Me arrastren y me pierdan, despiadados.

Mis padres me engendraron para el juego

Arriesgado y hermoso de la vida,

Para la tierra, el agua, el aire, el fuego.

Los defraudé. No fui feliz. Cumplida

No fue su joven voluntad. Mi mente

Se aplicó a las simétricas porfías

Del arte, que entreteje naderías.

Me legaron su valor. No fui valiente.

No me abandona. Siempre esta a mi lado

La sombra de haber sido un desdichado.

(MH, 89)

Esta confesión final y descarnada no es una arenga sobre el sufrimiento. Tampoco una dolorida tirada de quejas y ayes. Menos todavía un lacrimoso lamento. Es un reconocimiento de la desdicha como un pecado y la aceptación de ese pecado como una culpa de destino. Este soneto, como otros, quiebra el pudor resguardado en su literatura y lo reestablece desde la literatura, porque haber sido desdichado, no haber sido feliz, no es un suplicio que se grita como un amargo resentimiento o una sufrida angustia, sino una culpa que se expía desde el pudor mismo, desde ese silencio con que los héroes sobrellevan sus adversidades. No se trata, sin embargo, de un heroísmo mitológico sino apenas de ese condición de todo hombre inmerso en el absurdo de su propio destino. "Un destino no es mejor que otro, pero todo hombre debe acatar el que lleva adentro", observa Borges en "Biografía de Tadeo Isidoro Cruz”. Tal es el sentido de su propia aceptación. El heroísmo de todo hombre es un antiheroísmo no menos estoico que el del héroe épico y entre sus hazañas figura la desdicha. Comentando sobre su cuento "La case de Asterión”, Borges ha dicho: "En el epilogo a El Aleph, llamo a Asterión 'mi pobre protagonista'. Lo llamo así porque, siendo un ser ambiguo e impar, esta condenado fatalmente a la soledad. Ningún hombre está hecho para la felicidad". ${ }^{15}$ Su vocación de infelicidad, entonces, es menos una queja personal que una aserción de una condición común a todos los hombres, menos la voz de un hombre que la expresión del destino inexorable del género humano. Joyce ha escrito que el artista "transmutes the daily bread of experience into the radiant body of everliving life”; desde su más salvaguardada intimidad, Borges, y en general el poeta, nos obliga a romper máscaras, a trascender 
convenciones y a desandar nuestras propias evasiones para confrontarnos con ese ser que olvida sus miserias para que triunfe algo que no comprende del todo pero que, sabe, vale más que sus miserias.

University of California, San Diego

JAIME ALAZRAKI

\section{La Jolla}

\section{NOTAS}

1 Jorge Luis Borges, Ficciones. Buenos Aires, Emecé, 1963. Se emplean las siguientes abreviaturas: Ficciones: F, El Aleph: A, El hacedor: H, Otras inquisiciones: OI, Obra poética: OP, Elogio de la sombra: ES, El oro de los tigres: OT, La rosa profunda: RP, La moneda de hierro: $\mathrm{MH}$.

2 Jorge Luis Borges, Prólogos con un prólogo de prólogos. Buenos Aires, Torres Agüero, 1975, p. 23.

3 Jorge Luis Borges, “Los libros”. Sur, Buenos Aires, No. 111, enero de 1944, p. 74.

4 Ronald Christ, “Jorge Luis Borges; An Interview”. Paris Review, Winter-Spring, 1967, p. 155.

5 Ramón Gómez de la Serna, “Borges en Paris”. Alcor, 1964, No. 33.

${ }^{6}$ Gabriella Toppani, "Intervista con Borges”. Il Verri, Milan, XVIII, dic. 1964, p. 98.

7 Rita Guibert, “Entrevista a J.L.B.” en Siete voces. México, Editorial Novaro, 1974, p. 116.

8 Jorge Luis Borges, Prólogos con un prólogo de prólogos, o.c., p. 172.

9 Ibid. p. 171.

${ }^{10}$ Jorge Luis Borges, “An Autobiographical Essay”. The Aleph and Other Stories, 1933-1969; edited and translated by N.T. di Giovanni in collaboration with the author. New York, Dutton, 1970, p. 241.

${ }^{11}$ Jorge Luis Borges, “Elementos de preceptiva”. Sur, Buenos Aires, año III, No. 7, abril 1933, p. 161.

12 Claude Lévi-Strauss, Arte, lenguaje, etnología. México, Siglo XXI, 1968, pp. 131-132.

${ }^{13}$ Guillermo Sucre, "Borges: El elogio de la sombra”. Incluido en Borges, el escritor y la crítica (ed. de J. Alazraki), Madrid, Taurus, 1976, p. 109.

${ }^{14}$ Pablo Neruda, “Se vuelve a yo”. El mar y las campanas. Buenos Aires, Losada, 1973.

15 J. Irby, N. Murat y C. Peralta, Encuentro con Borges. Buenos Aires, Galerna, p. 29. 


\section{Dios en la Obra de Jorge L. Borges: Su Teología y su Teodicea}

\section{INTENCION}

En una entrevista de 1967 Borges reconoce que las constantes que determinan su obra literaria son, por orden de preferencia: 1) el tiempo; 2) Dios; 3) la ilusión de eternidad tanto en la precaria condición humana, como en la búsqueda de identidad del hombre consigo mismo y con su destino; y 4) la libertad. ${ }^{1}$

Aquí estudiaremos la segunda de estas constantes: el tema de Dios, a fin de deducir de la obra borgeana, el pensamiento teogénico que en ella predomina y la creencia personal del autor. Es decir, intentaremos ver cual es su teología y su teodicea.

Más que descubrir una tesis o estructurar una teoría, desearíamos entrar en su pensamiento escrito, que ha sido llamado, con justeza, por Claude Mauriac "la métaphysique fiction”. ${ }^{2}$ Así respetamos la convicción de Borges, quien afirma, reiteradamente, que no reconoce en su obra tesis ni pensamiento sistemático como tal: "repudio todo pensamiento sistemático-dice-porque siempre tiende a trampear. Un sistema conduce necesariamente hacia la trampa”. ${ }^{3}$

Las fuentes para este trabajo serán sus Obras completas, en su edición de 1974, las dos publicaciones posteriores y cuatro anteriores, sus Prólogos a obras ajenas, su Autobiographical Essay, su Epistolario con Alfonso Reyes, sus charlas y finalmente sus Entrevistas. De sus polémicas, sobre el tema, tendré en cuenta la única que conozco, de 1976. La de 1973, que provocó la protesta de la Curia mexicana, sé que apareció en El cronista comercial de Buenos Aires del 28 de diciembre de 1973, pero no he podido consultarla.

Es, a veces, difícil distinguir en su pensamiento lo que es una cita indirecta o asimilación inconsciente. Verdad es que toda la obra es él, porque según propia afirmación: "toda literatura es autobiográfica. Todo es poético en cuanto nos confiesa un destino, en cuanto nos da una vislumbre de él ....” ${ }^{4}$

¿Es Borges religioso, cristiano, católico, protestante, o deísta?

Cuando Gloria Alcorta le pregunta: “que des critiques considérent qu’il existe un element de foi dans ton oeuvre”, Borges contestó: “C’est probable. Peut-être ce genre de chose me travaillet-il sans que je le sache. La religion ne m'a jamais interesse que du point de vue intellectuel”. ${ }^{5}$ 
Y cuando Selden Roldan pregunta a Norman de Giovanni:

Does his religion have anything to do with this self abnegation? Not really, Norman replied. But his religion is one of the things that makes Borges so different from other Latin American intellectuals. Though his mother is a devout Catholic and his father was an atheist, Borges is a Protestant at heart. "What Protestant church do you think I should join?” he once asked me only half jokingly.

Ethics and belief in the value of work are central with Borges. When we were working on the autobiography last year, I wrote the phrase "Amateur Protestant that I am...," and he exclaimed with delight: "That's exactly it”. ${ }^{6}$

Partiremos pues del hecho de que su obra literaria y su persona son fuentes de esta inquisición implícita y explícitamente:

en trance de Dios y de la inmortalidad, soy de los que creen. Mi fe no es unamunesca e incómoda; mis noches saben acomodarse en ella para dormir y hasta despachan realidad bien soñada en su vacación. Mi fe es un puede ser que asciende con frecuencia a una certidumbre y que no se abate nunca a incredulidad. No entiendo a los mecanicistas, incrédulos de que un solo átomo irrepresentable pueda perderse y muy seguros de la escondibilidad final de su yo.

Al universo no le permiten escamotear una particula de materia pero si una infinitud de almas. ${ }^{7}$

Así escribía en 1928, y así escribió dos años antes:

En el siglo pasado hubo muchos hombres que, no creyendo en lo divino, se atarearon a novelarlo y lo hicieron a su imagen y semejanza, quiero decir, ruinmente. ${ }^{8}$

De no haber mediado otras afirmaciones, se hubiera acortado el camino para la deducción final.

En efecto, en su entrevista con William F. Buckley, el 1 de febrero de 1977, grabada en Buenos Aires y televisada el 18 del mismo mes, en los Estados Unidos, el dijo:

Well, I suppose he (Dante) was intensely religious. For example, I can’t think of myself a Roman Catholic, or even a Christian. ${ }^{9}$

Más de 170 veces nombra Borges a Dios con mayúscula y 37 con minúscula en la edición de sus Obras completas; en Inquisiciones otras 15; en El tamano de mi esperanza, 16; en El idioma de los argentinos, edición M. Gleizer, 19 ocasiones; en su Autobiographical Essay, 5; en La rosa profunda, 7; en La moneda de hierro, 11 y 46 veces en Prólogos. En las 22 entrevistas consultadas habla en 19 de ellas.

Este término, Dios, puede ser investigado bajo el punto de vista filosófico, por la mera razón natural, que es lo que la teodicea estudia, y desde el ángulo de la fe o revelación, que es propio de la teología. En otras palabras Borges cree en Dios por la revelación solamente, o por las pruebas de la razón natural. 
Dejo a un lado la discusión de que si se debe entender a Dios para creerle, o si se debe creer en El para entenderlo, porque Borges ni la menciona ni la toca indirectamente.

Igualmente omito los textos que no tienen relación con su propio pensamiento personal y credo religioso indicado por él mismo.

Al ser interrogado por Maria Esther Gilio si

¿Fue educado en alguna religión?

Borges contestó:

Voy a explicarle. Mi madre era católica como todas las señoras argentinas, es decir, sin entender absolutamente nada de religión. Mi padre era libre pensador, como todos los señores argentinos también. Como Spencer. Mi abuela paterna era muy religiosa, protestante. Cuando llegó el momento de la primera comunión, mi padre me dijo: "Mira, para mi es una ceremonia absurda, pero para tu madre es muy importante. ¿Querés hacer la primera comunión o querés esperar a haber llegado a alguna conclusión sobre estos hechos? Mi hermana eligió hacer la primera comunión y es católica, yo elegí no hacerla y soy libre pensador todavía, aunque eso parezca anticuado. $^{10}$

No obstante, no será difícil encontrar en alguna parroquia, dentro del perimetro que incluya a la calle Tucumán, el certificado de bautizo católico de Joée Francisco Isidoro Luis Borges Acevedo. Tengamos en cuenta por último, cómo Borges se sitúa con respecto a la religión.

Yo me he criado en un ambiente cristiano; mi abuela sabía la Biblia de memoria, mi madre era católica, mi padre era ateo, pero no de un modo militante, ni político. ${ }^{11}$

Aseveración tomada de su reciente polémica con el Rector de la Universidad de Jujuy, en diciembre de 1976 y que confirma lo que dijera a Rita Guibert en su entrevista de 1968:

Siendo católico, me siento atraído por el protestantismo. Yo creo que lo que me atrae en el protestantismo, es la ausencia de una jerarquía. ${ }^{12}$

\section{LAS RELACIONES DE BORGES CON LA TEOLOGIA}

La teología propiamente dicha, o sobrenatural, es la disciplina que estudia a Dios por la vía de la revelación, que nos descubre la naturaleza y cualidades de Dios, fundamenta la cristología y eclesiología y se adentra en la soteriología y mariología.

Las relaciones de Borges con la teología son siempre indirectas como fuente de posibilidad literaria. Es decir, considera las ideas religiosas y filosóficas únicamente en función del elemento maravilloso que ellas encierran, sólo por su valor estético y literario.

Pero, como es obvio, este procedimiento subjetivo, crea sin quererlo Borges, una nueva visión fantástica de Dios, que consecuentemente y paradójicamente produce o refleja su propia creencia o teología y su propio pensamiento natural o teodicea.

Por eso él ha podido decir que "Las invenciones de la filosofía no son menos fantásticas que las del arte”. ${ }^{13}$ 
Y, “que la teología como sistema filosófico -incluso la de mis autores preferidospertenece a la literatura fantástica". ${ }^{14}$

No vamos a analizar el uso literario que Borges hace de la religión y de la filosofía de la Divinidad, sino que por el contrario, intentaremos descubrir en el uso literario su idea personal de Dios según la fe o revelación.

Y desde ya, podemos decir de Borges lo que él escribiera en Otras inquisiciones, acerca de Quevedo, su escritor favorito:

La grandeza de Quevedo es verbal. Juzgarlo un filósofo, un teólogo o (como quiere Aureliano Fernández Guerra) un hombre de estado, es un error que puede consentir el título de sus obras, no el contenido. ${ }^{15}$

\section{Anticonfesionalismo católico}

Borges conoce la teología, especialmente la protestante, no la rechaza, pero duda de ella y guarda una fobia, a lo largo de toda su obra, para la teología católica, que es la que menos ha estudiado. Así lo dijo a Milleret: "Por ejemplo, he leído muchos libros de teología, sobretodo de teología protestante”. ${ }^{16}$

[...] Tengo en mi casa una pequena biblioteca sobre el budismo. Pero todo eso me interesó como una especie de aventura intelectual. Nunca pensé en hacerme budista, ¿no? ${ }^{17}$

Antes había indicado que usar las posibilidades literarias de la filosofía idealista

no significa forzosamente que yo crea en la filosofía de Berkeley o de Schopenhauer, por el hecho de que hays utilizado sus posibilidades literarias, ni que las practique, ni que les haya dado mi fe, ni mi convicción. Por ejemplo, también leí mucho a Spinoza, pero no soy spinoziano. ${ }^{18}$

Llama la atención el interés que tiene Borges en decir que no es católico o que no gusta del catolicismo. Ha escrito:

La Historia Universal de Chesterton es más linda que la de Wells. Lo que no me gusta de Chesterton es que fuese católico. No to entiendo... Yo creo que Belloc le hizo mucho mal porque le metió en la cabeza la idea que la religión católica se basa en el sentido común. ${ }^{19}$

A Chesterton lo leo y lo releo y lo considero como un amigo personal. Evidentemente yo sé que es un hombre muy injusto y no comparto su catolicismo. ${ }^{20}$

Descubrí un poco más tarde a otro escritor y creo haber leído todos sus libros, se trata de León Bloy. No soy católico, es decir que mi admiración es sobre todo literaria y no humana, pues como hombre no lo encuentro simpático. ${ }^{21}$

En una reciente entrevista, hace su presentación: “Soy profesor de literatura inglesa en la Universidad Católica (aunque ciertamente no soy católico)”"22, ¿ésta su actitud es por temor a ser juzgado por la fe de su bautismo? porque como él mismo dice: “Como todo 
escritor que profesa un credo, Chesterton es juzgado por él, reprobado o aclamado por él. Su caso es parecido al de Kipling a quien siempre to juzgan en función del Imperio Britanico". ${ }^{23}$

\section{Antisistematización}

Consecuentemente, entre sus antipatías está el dogmatismo y estructura de la teología. Se pueden dar muchas citas y quien las desee las encontrará en el "Indice Analítico" bajo “Dios de los escolásticos” o “Dios de los teólogos”. Bastaran dos de ellas:

Porque hay momentos en que me siento cristiano, y luego pienso que admitirlo comporta aceptar todo un sistema teológico, veo que realmente no lo soy. ${ }^{24}$

El convertículo de monstruos sentados que gangosean en su noche un credo servil es el Vaticano...25

Como la mayor alabanza de Swedenborg escribe en el prólogo a sus Mystical Works: "En su obra entera no se descubrirá un sólo silogismo; no hay sino tersas y tranquilas afirmaciones". ${ }^{26}$

Aun admitiendo las antinomías, de que tanto gusta Borges, cuesta creer que en Inquisiciones pudo escribir estas alabanzas a la teología cristiana:

La teología-que los racionalistas desprecian-es en última instancia la logicalización o tránsito a lo espiritual de la Biblia, tan arraigadamente sensual. Es el ordenamiento en que los pensativos occidentales pusieron la obra de los visionarios judaicos. ¡Qué bella transición intelectual desde el Señor que al decir del capítulo tercero del Génesis paseábase por el jardín en la frescura de la tarde, hasta el Dios de la doctrina escolástica cuyos atributos incluyen la ubicuidad, el conocimiento infinito y hasta la permanencia fuera del Tiempo es un presente inmóvil y abrazador de siglos. ${ }^{27}$

\section{Antitrinitarismo}

Asunto fundamental del Credo cristiano es la Trinidad de Dios. Borges la niega por considerarla teratológica.

... los griegos engendraron la quimera...; los teólogos del siglo II, la Trinidad, en la que inextricablemente se articulan el Padre, el Hijo, y el Espíritu Santo... Hollywood acaba de enriquecer ese vano museo teratológico; por obra de un maligno artificio que se llama doblaje. ${ }^{28}$

Sin embargo en la cuarta de las seis últimas conferencias que comenzó a dictar en el Teatro Coliseo de Buenos Aires, el 15 de Junio de 1977, dijo:

Las otras religiones exigen mucho de nuestra credulidad. Por ejemplo: si somos cristianos, tenemos que creer que una de las tres personas de la divinidad se encarnó en un hombre y fue crucificado hace mil novecientos setenta y tantos años. ${ }^{29}$ 
Borges no se contradice, ahora en sus 78 años, ni antes, como veremos luego. Su razón no comprende la Trinidad, pero su fe presta credibilidad al misterio. Porque, precisamente como Borges escribió: “Sustancia de las cosas que se esperan, demostración de cosas no vistas, definió San Pablo la fe”. ${ }^{30}$

Además, aún cuando es contradictorio ser cristiano-católico y negar la Trinidad, no lo es siendo cristiano-swedenborgeano. En su True Christian Religion escribió el teólogo sueco:

But how the things written in the World respecting the Trinity are to be understood, -whether, that there are three Gods, who is essence and hence in name are one God; or, that there are three objects of one subject, so that they are only qualities or attributes of one God, which are so named, or in another way, -reason left to itself can by no means see. ${ }^{31}$

Al decir Borges que la Trinidad es invención del siglo II, parece desconocer la Didache, del año 90 de nuestra era, que la testimonia, si es que no quiere dar más antigüedad a los Evangelios, en expresión suya, "una de las obras más ricas que los hombres poseen”32; rompiendo así toda tradición y enseñanza judaica y helénica, porque el catolicismo no es, como afirma Borges, solamente "un conjunto de imaginaciones hebreas supeditadas a Platón y a Aristóteles”33; se escribió ya en el siglo I:

En cuando al bautismo hacedlo con agua viva, después que habréis dicho: Bautizad en el nombre del Padre y del Hijo y del Espíritu Santo. ${ }^{34}$

Hay dos ensayos incluidos en sus Obras completas, que tratan de la Trinidad en Dios: “Una vindicación de la Cábala” e "Historia de la eternidad”. Interesa notar que en el segundo ha incorporado párrafos exactamente iguales al primero.

En antítesis, que no es contradicción, Borges, que en más de treinta ocasiones en sus escritos se rebela contra este misterio cristiano, impelido por una creencia soterrada en lecturas de familia y personales, confiesa que

Desligada del concepto de redención, la distinción de las tres personas en una tiene que parecer arbitraria. Considerada como una necesidad de la fe, su misterio fundamental no se alivia, pero despuntan su intención y su empleo. Entendemos que renunciar a la Trinidad - a la Dualidad por lo menos- es hacer de Jesús un delegado ocasional del Señor, un incidente de la historia, no el auditor imperecedero, continuo, de nuestra devoción. Si el Hijo no es también el Padre, la redención no es obra directa divina; si no es eterno, tampoco lo será el sacrificio de haberse rebajado a hombre y haber muerto en la Cruz. ... Así puede justificarse el dogma. ${ }^{35}$

Borges ha leído con devoción, sin duda alguna, las obras teológico-místicas de Emanuel Swedenborg, quien enseña que la Trinidad se entiende o se justifica sólo por la Encarnación, hasta el punto de que antes de la creación del mundo, no existió la Trinidad: 
The Trinity of God was formed after the world was created, and actually in the fullness of time, and then in God incarnate, who is the Lord the Saviour Jesus Christ. ${ }^{36}$

Poco antes preguntabamos como era posible que Borges hubiera desconocido el documento llamado Didache, de la primera centuria cristiana, para afirmar que el misterio de la Trinidad había sido inventado por los teólogos del siglo II. Habíamos olvidado consultar a Swedenborg, a quien Borges presta credibilidad y admiración insospechadas $\mathrm{y}$ en quien piensa con frecuencia.

S.Ch.S: Borges: ¿Piensa usted más frecuentemente en el pasado que en el futuro? J.L.B.: Sí, pienso en el pasado porque el pasado es real, está lleno de personas interesantes; por ejemplo Platón, por ejemplo Swedenborg... ${ }^{37}$

Escribir sobre él, sería para Borges un final soñado:

Pensé en escribir sobre Emanuel Swedenborg y luego sentí que podía referirme a él sólo como místico. Pero tratándose de una personalidad tan vasta sería necesario una serie de especialistas o una enciclopedia. ${ }^{38}$

El teólogo de Estocolmo había, en efecto escrito años antes;

Neither did it (Trinity) come into the minds of the Apostoles, as is evident from their writings in the Word. And that it did not come into the mind of any one in the Apostolic Church prior to the Council of Nice... ${ }^{39}$

Llama la atención, con todo, que Borges no hubiera cotejado las palabras citadas con las siguientes del mismo Swedenborg, para no caer en común contradicción:

But in the Word of the New Testament it (the Holy Spirit) is frequently mentioned, -in the Evangelists, as well as in the Acts of the Apostles, and in their Epistles. The reason is, that then -when the Lord came into the world,-- there first was the Holy Spirit; for it goes forth out of Him from the Father. ${ }^{40}$

Borges, como vamos viendo, sigue y asimila a Swedenborg, en quien encuentra hasta semejanza con su apellido, y a quien le gustaría llamar "el hombre más extraordinario que hubo en la tierra”. ${ }^{11}$ Esta admiración reverente por el autor de Arcana Coelestia y del Daedalus hyperboreus, entre otras obras, lleva a Borges a contradecirse consigo mismo en su apreciación. No puede ser más duro contra Juan, autor del Apocalipsis:

San Juan Evangelista, docto en toda grandiosa farolería y en toda canallada literaria, cuenta que tras la luna sangrienta y del sol negro y de los cuatro ángeles en las cuatro esquinas del mundo, fue hecho silencio en el cielo casi por media hora. ${ }^{42}$ 
En cambio, cuando va a enjuiciar las conversaciones con los ángeles, los mensajes escritos de Dios y las visiones, que afirma Swedenborg tuvo durante treinta años, escribe:

Consideremos ahora las coherentes y múltiples visiones que ciertamente encierran mucho de milagroso. William White ha observado agudamente que otorgamos con docilidad nuestra fe a las visiones de los antiguos y propendemos a rechazar las de los modernos o nos burlamos de ellas. Creemos en Ezequiel porque lo enaltece lo remoto en el tiempo y en el espacio, creemos en San Juan de la Cruz porque es parte integral de la literatura española, pero no en William Blake, discípulo rebelde de Swedenborg, ni en su aún cercano maestro. ¿En qué precisa fecha cesaron las visiones verdaderas y fueron reemplazadas por las apócrifas? ${ }^{43}$

Es más ecuanime y acertado el parecer de la Enciclopedia Británica:

It is, however, in the field of theology that the name of Swedenborg is chiefly known, and the circumstances in which he turned to theological studies have tended to obscure his reputation as a great scientist and philosopher. ...Because of his otherworld experiences Swedenborg has often been regarded as a spiritualist "medium",.... Nor can he properly be classed among the mystics, for his dry, matterof-fact accounts of the spiritual world and in his acutely reasoned theology there is a little in common with mystics. ${ }^{44}$

Igual contradicción encuentro cuando critica el uso figurado de los escrituristas, al que lo llama “analogía trivial” ${ }^{45}$ y pondera la teoría de las correspondencias swedenborgeanas que en la práctica son otras analogías pero con significación teosófica o cabalística, que tanto impresionan a Borges.

Conjeturó (Swedenborg) que cada palabra de la Escritura tiene un sentido espiritual y llego a elaborar un vasto sistema de significaciones ocultas. Las piedras, por ejemplo, representan las verdades naturales; las piedras preciosas, las verdades espirituales; los astros, el conocimiento divino; el caballo, la recta comprensión,... etcetera. ${ }^{46}$

\section{Antiprovidencialismo}

El Dios filosófico de Borges, como veremos en la segunda parte de este estudio, es, antropomórficamente hablando un Dios sin corazón, un terrible Dios prefijó los días y agonías. ${ }^{47}$

Hay un arquetipo posible: Dios es tan generoso con el hombre, que le ha dado todo, hasta la posibilidad del Infierno. Pero quien sabe si estas regalos convienen, ¿¿no? ${ }^{48}$

Ha escrito sin embargo, en antitético balancín de poesía:

Loada sea la misericordia

De Quien, ya cumplidos mis setenta años 
Y sellados mis ojos

Me salva de la venerada vejez..$^{49}$

Con todo, Borges se aparta de la Revelación, al no aceptar una remuneración de premio o castigo, y en caso de hacerlo, prefiere el sistema swedenborgeano. En una de las conversaciones con Sorrentino, Borges dijo:

Lo que menos me ha interesado en La Divina Comedia es el valor religioso. Es decir me han interesado los personajes, me han interesado sus destinos, pero todo el concepto religioso, la idea de premios y de castigos, es una idea que no he entendido nunca. La idea de que nuestra conducta personal puede interesarle a la Divinidad, y la idea de que mi vida personal - esto ya lo he dicho alguna vez- puede merecer castigos eternos o recompensas eternas me parece absurda. ${ }^{50}$

Más aún, ha llegado a escribir: “desconfiaríamos de la inteligencia de un Dios que mantuviera cielos e infiernos". ${ }^{51}$

Y hablando de Pascal afirma: "No es místico; pertenece a aquellos cristianos denunciados por Swedenborg, que suponen que el cielo es un galardón y el infierno un castigo..." Y en nota añade: "Para Swedenborg, como para Boehme, el cielo y el infierno son estados que con libertad busca el hombre, no un establecimiento penal y un establecimiento piadoso." ${ }^{22}$ Borges sintetiza admirablemente la cuestión en estas palabras:

No sé qué opinará el lector, de tales conjeturas semiteosóficas. Los católicos (léase católicos argentinos) creen en un mundo ultraterreno, pero he notado que no se interesan en é1. Conmigo ocurre lo contrario; me interesa y no creo. ${ }^{53}$

\section{Antiinmortalismo}

Consecuentemente, Borges no cree en la inmortalidad del alma, ahora al fin de su vida. Esta afirmación dio origen precisamente, a las inculpaciones polémicas del Rector de la Universidad Nacional de Jujuy, Monseñor Germán Mallagaray, en diciembre de 1976. Hemos dicho que al final de su vida ésta es su creencia, porque al comienzo de su carrera literaria pensaba o creía en lo contrario. Cuando analiza aquel soneto de Quevedo, cuyo último terceto termina "Su forma dejarán, no su cuidado. / Serán ceniza, más tendrá sentido,/ Polvo serán, más polvo enamorado,” soneto al que llama Borges “una de las más intensas páginas de su autor: es decir de la literatura mundial”, escribió en 1928,

En trance de Dios y de inmortalidad, soy de los que creen. ...Mi fe es un puede ser que asciende con frecuencia a una certidumbre y que no se abate nunca a incredulidad. ${ }^{54}$

En ese mismo año, al criticar las “Coplas” de Jorge Manrique, afirmó:

No descreo de la eficacia estética de las “Coplas”. En ellas está la forzosidad del morir, pero nunca lo disparatado de ese acto ni el azoramiento metafísico a que nos invita ni un esperanzarse curioso en la inmortalidad. ${ }^{55}$ 
Pero ya en 1936, llama "a la eternidad, un juego o una fatigada esperanza" ${ }^{56}$, y posteriormente, al prologar a su favorito Swedenborg, dice:

Seremos lo que somos. Los terrores y alarmas de la agonía, que suelen darse cuando el moribundo está acobardado y confuso, no tienen mayor importancia. Creamos o no en la inmortalidad personal, es innegable que la doctrina revelada por Swedenborg es más moral y más razonable que la de un misterioso don que se obtiene, casi al azar, a última hora..$^{57}$

Por fin, en 1977, en su respuesta al rector de la Universidad de Jujuy, precisa:

Las cosas en realidad no fueron así. Yo le dije a un señor, de cuyo nombre prefiero olvidarme, que no creía en la inmortalidad del alma, y que para mí la muerte era una esperanza. La esperanza de terminar de una vez con todo, incluso con Jorge Luis Borges. El hecho de que yo no crea en la inmortalidad del alma no significa que yo descreyera de Dios. Además no sé si Dios necesita de mi inmortalidad para sus fines. Eso es todo lo que dije. Totalmente inofensivo. Pero fue tornado como una blasfemia $\mathrm{y}$ un ataque a toda la Iglesia. ${ }^{58}$

\section{Cristología}

Sin ánimo de abarcar la mayoría de los tópicos que sugiere la lectura de las obras de Borges, intento cerrar esta primera parte con la Cristología borgeana.

Con verdadera inquietud pregunta Borges:

¿Quién al andar por el crepúsculo o al trazar una fecha de su pasado, no sintió alguna vez que se había perdido una cosa infinita?

Los hombres han perdido una cara, una cara irrecuperable, y todos querían ser aquel peregrino (soñado en el empíreo bajo Rosa) que en Roma ve el sudario de la Verónica y murmura con fe: Jesucristo, Dios mío, Dios verdadero ¿así era, pues, tu cara?

Si realmente supiéramos cómo fue, sería nuestra la clave de parábolas y sabríamos si el hijo del carpintero fue también el Hijo de Dios.

Y en apremio de nostalgia, continúa: "Pablo la vio como una luz que lo derribó; Juan, como el sol cuando resplandece en su fuerza; Teresa de Jesús, muchas veces, bañada en luz tranquila, y no pudo jamás precisar el color de los ojos”. 59

Más que intelectual inquisición, descubrimos en estas palabras sentida añoranza por a1guien que se ama y se admira; porque es “Jesús el mayor de los maestros orales, que una sola vez escribió unas palabras en la tierra y no las leyo ningún hombre”. ${ }^{60} \mathrm{E}$ insiste en su prólogo al Retorno de Don Quijote de Alberto Gerchunoff:

Y nada he dicho del más alto de todos los maestros orales, que hablaba por parábolas y que, una vez, como si no supiera que la gente quería lapidar a una mujer, escribió unas palabras en la tierra, que no ha leído nadie. ${ }^{61}$ 
En efecto, "Felices los que guardan en la memoria las palabras de Virgilio o de Cristo, porque estas darán luz a sus días”. ${ }^{62}$ Ya que:

Para el cristiano, la vida y la muerte de Cristo son el acontecimiento central de la historia del mundo; los siglos anteriores lo prepararon, los subsiguientes lo reflejan. ${ }^{63}$

Y hay razon para ello. El es el Verbo de Dios hecho carne:

$$
\begin{aligned}
& \text {... Dios quiere andar entre los hombres } \\
& \text { Y nace de una madre, como nacen } \\
& \text { Los linajes que en polvo se deshacen, } \\
& \text { Y le será entregado el orbe entero, } \\
& \text { Aire, agua, pan, mañanas, piedra y lirio } \\
& \text { Pero después la sangre del martirio, } \\
& \text { El escarnio, los clavos y el madero. }{ }^{64}
\end{aligned}
$$

Descubrir a Cristo supone estar habituado a El: “los ojos ven lo que están habituados a ver: Tácito no percibió la Crucifixión, aunque la registra su libro”. ${ }^{65}$ Por lo cual merece recriminación Baltasar Gracián, quien "no vio al fatal Edipo en el exilio,/Ni a Cristo que se muere en un madero". ${ }^{66}$ Esta, en cambio es la causa por la que es "sagrado" el "Libro que abarca el tiempo y que la historia/Del rojo Adán rescata la memoria/Y la agonía del Crucificado". ${ }^{67}$

Y esta es la razon por la que

los hombres, a lo largo del tiempo, han repetido siempre dos historias: la de un bajel perdido que busca por los mares mediterráneos una isla querida, y la de un Dios que se hace crucificar en el Gólgota. ${ }^{68}$

Su crucifixión, empero, fue por el bien de la humanidad.

... y le preguntó si Cristo se dejó matar para salvar a todos los hombres. Espinosa, que era librepensador pero que se vio obligado a justificar lo que les había leído, le contestó:

-Sí. Para salvar a todos del infierno.

Gutre le dijo entonces:

-¿Qué es el infierno?

-Un lugar bajo tierra donde las ánimas arderán y arderán.

- ¿Y también se salvaron los que le clavaron los clavos?

-Sí- replico Espinosa, cuya teología era incierta. ${ }^{69}$

Con estos textos, que no están sacados fuera de contexto, he reconstruido el ícono de Cristo del no-evangelio de Borges.

JLB: No, usted debe decirlo, que yo no tengo mensaje, que no soy un evangelista. 
JM: Nunca habrá un libro titulado Borges el evangelista.

JLB: No, así to espero. ${ }^{70}$

Llama, por esto, la atención, el libro de John Dominic Crossan, recientemente publicado, Raid on the Articulate, cuyo subtítulo es Comic Eschatology in Jesus and Borges, en el que se paragonan sus dos mensajes en nombre de "una visión ciertamente más antigua que el Cristianismo y posiblemente más sabia”, llamada la visión órfica, según la cual "el único orden objetivo es el lenguaje mismo" ${ }^{71}$

Deliberadamente he dejado de exponer o discutir el aparente, literario politeísmo de Borges, por estar fuera de este estudio el examinar "las posibilidades literarias" que de la filosofía o religión hace uso el autor. Su teología y teodicea es monoteísta.

Pienso que el tránsito del politeísmo a la religión de un Dios único es fácil, mientras lo contrario me parece difícil. Si usted empieza por un Dios todopoderoso, entonces se hace muy difícil agregar otros, ¿no ${ }^{72}$

He dejado también a un lado el problema de Dios y el mal, con los matices maniqueístas, gnosticistas y swedenborgeanos que hay en la obra de Borges. "Creo que basta un dolor de muelas para negar la existencia de un Dios todopoderoso". ${ }^{73}$

Igualmente no trataré, por ahora, el misticismo gneosológico o el valor del silencio en la palabra, porque ello sería nuevamente discernir "las posibilidades estéticas” y no las ideas teogénicas personales. Se podría estudiar su mística filosófica dentro de la influencia de Swedenborg, como ya se ha hecho con Novalis, Blake y Ballance. ${ }^{74}$ Comparar al intelectualista Borges con Juan de la Cruz o Teresa de Avila en sus experiencias místicas, es no estar de acuerdo con el significado de teología mística. Borges pertenece al humanismo occidental pero en materia teológica con muchas acotaciones. Escuchémosle:

Estoy identificado con el Occidente, pero pienso que las palabras Oriente y Occidente están mal elegidas. No creo que el cristianismo sea fundamental, salvo como cultura. Hay una manera cristiana de ser ateo, una manera católica o protestante... Es un poco injusto hablar de Occidente como cristianismo. ${ }^{75}$

Más que contradicciones encuentro en Borges, con respecto a su fe, incertidumbre. Felizmente é1 mismo lo dijo hace poco delante del auditorio que llenó el Teatro Coliseo de Buenos Aires:

No estoy seguro de ser cristiano y estoy seguro de no ser budista. ${ }^{76}$

Palabras que hacen eco a las que dijera en El tamaño de mi esperanza:

cada uno intenta justificarse y cree poder contar, allá en la arraigadura del fuero interno, con la amistad de Dios. ... De este mi credo literario puedo aseverar to que del religioso: es mío en cuanto creo en él, no en cuanto inventado por mí. ${ }^{6 \mathrm{~b}}$ 


\section{LAS RELACIONES DE BORGES CON LA TEODICEA}

Si la teología estudia al Dios de la fe o revelación, la teodicea investiga la causa del ser estudiado en la ontología o sea, al Dios de la razón natural, en su naturaleza y atributos.

En este capítulo voy a exponer la idea y racionabilidad que de la divinidad hay en el pensamiento de Borges, dentro de su posición afirmativa, negativa o agnóstica.

\section{Naturaleza del Ente a se}

Dejando de un lado los lugares que no hacen relación con el pensamiento personal de Borges, nos encontramos con la idea de una divinidad inmaterial y trascendente dentro de una formalización occidental cristiana. Por eso nos sorprende la afirmación puesta en nota, de Kajo Niggestich donde leemos: "El dios que habla Borges no es el dios del cristianismo, sino más bien la figura de un creador, la figura antípoda del mundo laberíntico de Ulises". ${ }^{77}$

Escuchemos al propio Borges:

Leemos ahí que ...Moisés... preguntó a Dios su Nombre y Aquel le dijo: Soy El Que Soy. Antes de examinar estas misteriosas palabras, quizás, no huelgue recordar que para el pensamiento mágico o primitivo, los nombres no son símbolos arbitrarios sino parte vital de lo que definen... Moisés preguntó al Señor cual era Su nombre: no se trataba, lo hemos visto, de una curiosidad de orden filosófico, sino de averiguar quien era Dios, o más precisamente, que era... ¿¿Qué interpretación ha suscitado la tremenda contestación que escuchó Moisés? Según la teología cristiana, Soy El Que Soy declara que sólo Dios existe realmente, o como enseñó el Maggid de Mesritch, que la palabra yo sólo puede ser pronunciada por Dios... Según esta primera interpretación, Soy El Que Soy, es una afirmación ontológica. ${ }^{78}$

Borges conoce ese constitutivo formal de la divinidad, y así afirma de Sir Thomas Browne: "Toda su vida fue impaciente de las minucias y prolijidades del dogma, pero no dudó nunca en lo esencial: en la aseidad de Dios, en la divinidad del espíritu”. ${ }^{79}$

Dios es, pues, el Ser con mayúscula y así lo específica más de 170 veces en su obra y lo reconoce por ejemplo, en Inquisiciones, cuando hablando de la creación poética, escribe: "Añadir provincias al Ser, alucinar ciudades y espacios de la conjunta realidad, es aventura heroica”. ${ }^{80}$

\section{Los atributos divinos: 1 . Unidad, verdad y bondad}

Si la esencia de Dios es su existencia, El poseerá las propiedades del Ser absoluto, que "prima facie”, por necesidad, son la unidad, la verdad y la bondad.

En el prólogo a la Obra crítica de Pedro Henríquez Ureña, encuentro:

Pedro había frecuentado las obras de Bergson y de Shaw que declaran la primacia de un espíritu, que no es, como el Dios de la tradición y escolástica, una persona, sino todas las personas y, en diverso grado, todos los seres. ${ }^{81}$ 
Anteriormente había afirmado en la presentación al libro de Weatherhead, After Death: "Dios... que solitariamente perdura fuera del tiempo". ${ }^{22} \mathrm{Y}$ en ese final admirable de su "Avatares de la tortuga", concluye diciendo: "Nosotros (la indivisa divinidad que opera en nosotros) hemos soñado el mundo". ${ }^{83}$

En aquellos cuartetos endecasílabos en que recrimina los laberintos, retruécanos y emblemas de Baltasar Gracián, se pregunta:

¿Qué sucedió cuando el inexorable

Sol de Dios, la Verdad, mostró su fuego?

Quizás la luz de Dios lo dejó ciego

En mitad de la gloria interminable. ${ }^{84}$

Que Dios sea bondad solamente Borges lo afirma en dos textos. El uno, en su última obra, cuando inspirado en el arco iris, que apareció después del diluvio en señal de reconciliación y paz escribe:

El Arco del Señor surca la esfera

Y nos bendice. En el gran arco puro

Están las bendiciones del futuro,

Pero también está mi amor, que espera. ${ }^{85}$

El otro texto se halla dubitativamente en la entrevista con Napoleón Murat:

Yo diría que la idea de Dios, de ser sabio, todopoderoso y que además nos quiere, es una de las más atrevidas creaciones de la literatura fantástica. Preferiría con todo, que la idea de Dios perteneciera a la literatura realista. ${ }^{86}$

\section{Los atributos divinos: II. Infinitud, inmensidad y eternidad}

Si Dios es el Ser “a se”, Dios es -existe- necesariamente, y por to tanto, está fuera de todo lo que es para nosotros signo de contingencia, y por ende, no tendrá límite espacial ni temporal. De ahí que el segundo grupo de los atributos o cualidades divinas sean su infinitud, la inmensidad y la eternidad, que a simple vista parecen nociones negativas, pero que en realidad son, como bien indica Grison: “une plenitude d'être, de présence a tout être, et de totale présence á soi-même”. ${ }^{87}$ Borges habla muchas veces del infinito y muy especialmente en sus cuentos “Tlön” “La Biblioteca de Babel” y “La muerte y la brújula”. Hubiera querido escribir la "Biografía del infinito” y así

Yo anhele compilar alguna vez su móvil historia... Cinco, siete años de aprendizaje metafísico, teológico, matemático, me capacitarían (tal vez) para planear decorosamente ese libro. Inútil agregar que la vida me prohibe esa esperanza, y aún ese adverbio. ${ }^{88}$

En carta que estoy esperando, creo me sera aclarado con precisión este punto. Porque no confío que Borges se haga leer estas páginas ya que de los trescientos libros que se han escrito sobre él, únicamente ha leído uno. 
No, I've only read one book, a book published by a Bolivian -his name was Tamayo, and an Argentine writer, Ruiz-Díaz. That's the only book I've read about me, and they tell me there are some 300 books that have been written about me. But I think the writers should choose a better subject. ${ }^{89}$

A la pregunta que le hiciera Richard Burgin (¿Y qué me dice del infinito?) Borges contestó:

El infinito sí (es terrífico), porque el infinito es un problema intelectual... Se podría preocupar también como dijo el poeta Latino, sobre siglos y siglos que lo precedieron antes de que uno existiera, se podría preocupar también sobre el pasado sin fin, en cuanto futuro sin fin deshabitado por uno... el infinito si es un problema. ${ }^{90}$

Pero la nota de infinitud con connotación personal solamente la he encontrado dos veces y la segunda de ellas, más como perfección negativa, si así podemos decir:

Sospecho que la palabra infinito fue alguna vez una insípida equivalencia de inacabado; ahora es una de las perfecciones de Dios en la teología y un discutidero en la metafísica y un énfasis popularizado en las letras y una finísima concepción renovada en las matemáticas y una verdadera intuición al mirar el cielo. ${ }^{91}$

El infierno es una mera violencia física, pero las tres inextricables Personas importan un horror intelectual, una infinitud ahogada, especiosa como contrarios espejos. ${ }^{92}$

Para quien conoce las funciones que en las "posibilidades literarias” desempeña el tema "infinito" con sus sistemas, en la obra estética de Borges, fácil le será reconocer la influencia swedenborgeana también aquí. El autor de Opera philosophica et mineralia afirmó:

Every thing is finite; and the infinite is in finite things as in its receptacles, and in man as in its images. Men cannot but confound the Divine Infinity with infinity of space; and as they cannot conceive of the infinity of space as other than a mere nothing, as it really is, they disbelieve the Divine Infinity..$^{93}$

Ambos se angustian ante la incapacidad del lenguaje humano. Como solución Borges sugiere:

Admitamos lo que todos los idealistas admiten: el carácter alucinatorio del mundo. Hagamos lo que ningún idealista ha hecho: busquemos irrealidades que confirmen ese carácter. ... ${ }^{94}$

Y Swedenborg:

For the next few years he eagerly looked for a language (symbolic or scientific) in which the relations between the Infinite and the finite creation could be expressed with mathematical exactitude. ${ }^{95}$ 
La inmensidad de Dios, que supone que El está fuera de toda medida, aspecto negativo, y que está presente en todo ser y en todo lugar, aspecto positivo, es considerada lateralmente por Borges cuando en Otras inquisiciones afirma:

En los primeros siglos de nuestra era, los teólogos habilitaban el prefijo omni, antes reservado a los adjetivos de la naturaleza o de Júpiter; cunden las palabras omnipotente, omnipresente. ${ }^{96}$

En su poema "La moneda de hierro" no puede ser más explícito: "La tarde y la mañana. Dios en cada criatura./Dios es el inasible centro de la sortija”. ${ }^{97}$ Esta cualidad de Dios, la omnipresencia, inspira otro poema suyo:

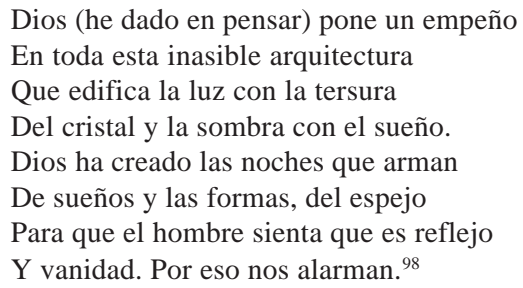

Y madruga en la "hora elemental del dia en que Dios no ha creado los colores". ${ }^{99}$ En el "Otro poema de los dones”, antes de agradecer "Por Swedenborg,/ que conversaba con los ángeles por las calles de Londres”, comienza: “Gracias quiero dar al divino/Laberinto de los efectos y de las causas/Por la diversidad de las criaturas/Que forman este singular universo". ${ }^{100}$

En 1927 había precisado:

Para el creyente, las cosas son realización del verbo de Dios - primero fue nombrada la luz y luego resplandeció sobre el mundo-; para el positivista son fatalidades de un engranaje. ${ }^{101}$

Y al contarnos la muerte de Sir Thomas Browne, como fiel cronista de la sinceridad de su fuero interno, registró: “A semejanza de don Rodrigo Manrique, dio el alma a quien se la dio, cercado de su mujer, de hijos, y de hermanos y criados”. ${ }^{102}$

En su "Historia de la eternidad”, Borges pasa revista a las principales teorías que existen acerca de ella, para luego terminar con la suya, que es la de una eternidad sin Dios. Pero de ello ni el autor ni el lector, deducen que Dios no sea eterno. En el prólogo a El idioma de los argentinos Borges nos habla sin más de la eternidad como "un misterio y esperanza” y ya distingue, como dos términos de significación diferente, inmortalidad y eternidad. La primera, más que privilegio es privación de vida, y la segunda, como he citado, es una esperanza misteriosa. El ha dicho: "Lo que de veras fue no se pierde; la intensidad es una forma de eternidad”. ${ }^{103}$ Silogísticamente, podríamos continuar, es así que Dios existe esencialmente, luego será; pero Borges no ha formulado en ningún lugar 
esta segunda parte del silogismo. En cambio, acercándose a la sencillez de su pueblo, canta: “Alguien ya contó los días/ Alguien ya sabe la hora/ Alguien para Quien no hay/ Ni permuras ni demora”. ${ }^{104}$

Antes había discutido sobre la libertad del libre albedrio y en inquietud casi insoluble escribió:

Nos abate que nuestro futuro ya esté, con minuciosa prioridad, en la mente de Alguien. Elucidado este punto Boecio nos recuerda que para Dios, cuyo elemento es la eternidad, no hay antes ni después, ya que la diversidad de los sitios y la sucesión de los tiempos es una y simultánea para El. ${ }^{105}$

Y explícitamente declara: “Los teólogos definen la eternidad como la simultánea y lúcida posesión de todos los instantes del tiempo y la declaran uno de los atributos de Dios". ${ }^{106}$ Uno de los cuentos de El Aleph termina: "La gloria sea con Aquel que no muere”.

\section{Los atributos de Dios: III. Ciencia y actividad}

Restan tres cualidades que conciernen a la naturaleza íntima de Dios, pero que tienen relación con este mundo contingente, sobre el cual Dios piensa, ve y ejerce su poder, o sea sus acciones "ad extra”, es decir la ciencia de Dios, su voluntad y actividad.

En "Una vindicación a la cábala” afirma Borges:

Al Señor, al perfeccionado Dios de los teólogos, que sabe de una vez -uno intelligendi modo-no solamente todos los hechos de este repleto mundo, sino los que tendrian su lugar si el más evanescente de ellos cambiara los imposibles también. Imaginemos ahora esa inteligencia estelar, dedicada a manifestaciones, no en dinastías ni en aniquilaciones ni en pájaros, sino en voces escritas. Imaginemos asimismo, de acuerdo con la teoría pre-agustiniana de inspiración verbal, que Dios dicta, palabra por palabra lo que se propone decir. ${ }^{107}$

No se le escapa a Borges el conflicto entre la ciencia y la libertad humana:

Davidson omite a Cicerón; también omite al decapitado Boecio. A éste deben los teólogos, sin embargo, la más elegante de las reconciliaciones del albedrío humano con la Providencia Divina. ¿Qué albedrío es el nuestro si Dios, antes de encender las estrellas, conocía todos nuestros actos y nuestros más recónditos pensamientos? Boecio anota con penetración que nuestra servidumbre se debe a la circunstancia de que Dios sepa de antemano como obraremos. Si el conocimiento divino fuera contemporáneo de los hechos y no anterior, no sentiríamos que nuestro albedrío queda anulado. Nos abate que nuestro futuro ya esté, con minuciosa prioridad, en la mente de Alguien. Elucidado ese punto, Boecio nos recuerda que para Dios, cuyo puro elemento es la eternidad, no hay ni antes ni después, ya que la diversidad de los sitios y la sucesión de los tiempos es una y simultánea para El. Dios no prevé mi porvenir; mi porvenir es una de las partes del único tiempo de Dios, que es el inmutable presente. ${ }^{108}$ 
Años después, sin embargo, dira en sus Conversaciones a Burgin: "Puede que haya un Dios que desee que yo siga viviendo, o que piense que el universo no me necesita. Después de todo, no me necesitó hasta 1899 cuando nací. Fui dejado de lado hasta entonces. ${ }^{109}$

Como síntesis del pensamiento borgeano sobre la ciencia divina en lo que se refiere a la remuneración de los actos humanos citaré su respuesta a F. Sorrentino, porque es precisa y corta:

La idea de que nuestra conducta personal pueda interesarle a la Divinidad, y la idea de mi vida personal -esto ya lo he dicho alguna vez- (muchísimas en sus escritos) puede merecer castigos eternos o recompensas eternas me parece absurda. ${ }^{110}$

Sin embargo había dicho en la "Historia de Rosendo Juárez”: “Todo había sido para bien; la Providencia sabe lo que hace”. ${ }^{111}$ Que Dios sea todopoderoso y sabio lo dijo en su entrevista con Murat y queda citado posteriormente. Y en la milonga de "Jacinto Chiclana” reflejó la idea de su ambiente: “Sólo Dios puede saber/ La laya de aquel hombre/ Señores, yo estoy cantando/ Lo que se cifra en el nombre”. ${ }^{112}$

Pero de que Dios sea sabio y todopoderoso no se sigue que también pueda hacer los absurdos:

En la Suma Teológica se niega que Dios pueda hacer que lo pasado no haya sido, pero nada se dice de la intrincada concatenación de causas y efectos, que es tan vasta y tan íntima que acaso no cabría anular un sólo hecho remoto, por insignificante que fuera, sin invalidar el presente. Modificar el pasado no es modificar un solo hecho; es anular sus consecuencias, que tienden a ser infinitas. ${ }^{113}$

En su "Historia de la eternidad” sintetiza admirablemente el obrar de Dios:

Los teólogos no ignoran que si la atención del Señor se desviara un solo segundo de mi derecha mano que escribe esta recaería en la nada, como si la fulminara un fuego sin luz. Por eso afirman que la conservación de este mundo es una perpetua creación y que los verbos conservar y crear tan enemistados aquí, son sinónimos en el Cielo. ${ }^{114}$

Aún cuando, a veces, es difícil precisar hasta qué punto Borges da suyas las palabras de sus comentarios, deduzco que Jorge Luis Borges conoce bien la teodicea cristiana en lo que se refiere a la idea de Dios, su naturaleza y atributos, así como también conoce este concepto en otras filosofías, lo cual es fácil comprobar siguiendo el "Indice Analítico", que he formado de este término, en sus obras.

\section{La racionabilidad de la creencia en Dios. Las pruebas}

Borges distingue perfectamente entre fe y razón. De la primera escribió hace 41 años. "Sustancia de las cosas que se esperan, demostración de cosas no vistas, definió San Pablo la fe". ${ }^{115}$ 
Como dije en la primera parte, no pretenderé dilucidar si primero entendemos para creer o si primero creemos para entender. ¿Cuál es la prioridad entre racionabilidad y credibilidad? De hecho tenemos dos afirmaciones de Borges: ... "de que yo no crea en la inmortalidad no significa que yo descreyera de Dios”. ${ }^{116}$ Y más luego: “Todo es posible, hasta Dios. Fíjese que ni siquiera estamos seguros de que Dios no exista”. ${ }^{117}$ Esta segunda parte de su respuesta la encuentro explicitada en su contestación a la pregunta si Dios es para él una hipótesis: “JLB: Sí, y una hipótesis cercana a lo fantástico; acaso también inconcebible, inconcebible incluso para los teólogos”. ${ }^{118}$

Conviene tener en cuenta lo que escribió Swedenborg sobre el conocimiento de Dios, pues Borges lo sigue de cerca: "The first is, that there can be no knowledge respecting God, and consequent acknowledgment of God, except by revelation”. ${ }^{119}$ Por lo tanto precisa preguntar si Borges acepta alguna prueba racional de la existencia de este Dios personal con las cualidades o atributos encontrados en sus escritos.

Uno de sus críticos, Manuel Ferrer, aduce como prueba borgeana de la existencia de Dios la cita que damos a continuación. Yo creo que ha sido tomada fuera de contexto. Para mi prueba lo contrario:

La religiosidad del ateísmo, la sinrazón de la lógica y el esperanzamiento de quien se juzga desesperado, son otros tantos ejemplos de la traza espiritual que informa su obra. Todos ellos -desplegados o no por su facundia (de Unamuno), pero latentes de continuo en sus páginas-son aspectos del siguiente pensamiento sencillo: Para negar una cosa, hemos primero de afirmarla, siquiera sea como asunto de nuestra negación. Desmentir que hay un Dios es afirmar la certeza del concepto divino, pues de lo contrario ignoraríamos cual es la idea derruida por la negación precitada y por carencia de palabras nuestra negación no podría formularse.

Hasta aquí se cita el texto de Borges, pero el crítico olvida que su verdadero pensamiento esta en las palabras que siguen:

Pasajes de un mecanismo intelectual idéntico al manipulado en la falacia anterior abundan en su obra y son escándalo asombroso de muchos lectores de allende y aquende el océano. Pero mi empeño de hoy no estriba en desarmar las artimañas que practica con destreza tan impetuosa Unamuno, sino en comentar y ensalzar su nobilísima actuación de poeta. ${ }^{120}$

a. La prueba cosmológica. Conoce Borges el llamado argumento cosmológico, y por el año de 1932 lo cita sin negarlo ni aprobarlo:

Santo Tomás de Aquino recurre a él (el regressus in infinitum) (Suma Teológica, 1, 2,3 ) para afirmar que hay Dios. Advierte que no hay cosa en el universo que no tenga una causa eficiente y que esa causa claro está es el efecto de otra causa anterior. El mundo es un interminable encadenamiento de causas y cada causa es un efecto. Cada estado proviene del anterior y determina el subsiguiente, pero la serie general pudo no haber sido, pues los términos que la forman son condicionales, es decir aleatorios. 
Sin embargo, el mundo es; de ello podemos inferir una no contingente causa primera que será la divinidad. Tal es la prueba cosmológica; la prefiguran Aristóteles y Platón; Leibniz la redescubre. ${ }^{121}$

En 1974 Borges incluye este artículo en sus Obras completas, pero le ha añadido la siguiente nota a pie de página: "Un eco de esa prueba ahora muerta, retumba en el primer verso del Paradiso: La gloria de Colviche tutto move”. ${ }^{122}$

b. La prueba ontológica. Otra de las pruebas o argumentos de la existencia de Dios es el ontológico o anselmeano, por ser su autor el arzobispo de Cantorbury, San Anselmo. Borges la cita, la conoce, la juzga y la aplica en lo que él llama, con un poco latín y mucho sarcasmo, “Argumentum ornithologicum”, argumento de los pájaros o pajarero...

En su crííica a “Un soneto de don Franciso de Quevedo” en 1928, apunta de pasada “...las sedicentes pruebas dialécticas de que hay Dios, la ontológica, la cosmológica, la moral, la histórica y las que queden”. ${ }^{123}$ Posteriormente, en Otras inquisiciones, afirma: "La realidad procede por hechos, no por razonamientos; a Dios le toleramos que afirme (Exodo, 2, 14) Soy El Que Soy, no que declare y analice, como Hegel o Anselmo, el argumentum ontologicum". ${ }^{124}$

En la entrevista con Burgin, cuando éste arguye contra la existencia de Dios con la presencia de los males físicos, le contesta:

Ah, sí, claro. La verdad es que hay muchos argumentos contra Dios, pero sólo hay cuatro para su existencia.

Burgin: ¿Cuatro argumentos? ¿Cuáles?

Borges: Bueno, uno es el argumento ontológico, que parece ser un simple truco. Es de la siguiente manera, ¿ Puedes imaginar un ser perfecto, todo-poderoso, sapientísimo, etc., sí o no?

Burgin: Sí.

Borges: Entonces, ¿ंexiste ese ser o no?

Burgin: Bueno, la respuesta es, si lo imaginamos, existe.

Borges: No, no. Entonces se diría que no, o que no lo sabe.

Burgin: ¿Hay que decir que no?

Borges: O que no lo sabe. Entonces aquí el argumento acaba de una manera muy poco convincente, según yo lo veo. Podemos imaginamos un ser perfecto, un ser sapientísimo, todopoderoso, etc., muy bien, pero si ese ser no existe, Entonces no es perfecto. Porque difícilmente un ser que no exista será perfecto. Así que hay que añadirle la existencia. No es un argumento muy convincente, ¿verdad? Y aun se puede empeorar. Seguía así: ¿Existe Dios? No lo sé. ¿Existe el hombre? Bueno, parece que existe. Entonces pensamos que si Dios es eterno, omnipotente y todo lo demás, ¿̇no puede conseguir lo que el hombre ya tiene desde un principio? Dios, que es tan sabio, ¿no puede ni tan siquiera equipararse a la Humanidad? En fin, claro, eso no es un argumento. Si hablas de que Dios no va a poder lograr su existencia estas ya suponiendo su existencia ¿no? Porque si no existes no puedes lograr nada ni fracasar en nada. ${ }^{125}$ 
Más de ocho siglos hace que Anselmo escribió en su abadía normanda del Bec su Proslogion, (en castellano, alocución) y en él, el argumento que lleva su nombre. Los mayores filósofos han venido a incidir uno tras otro, sobre él mismo y no a la ligera, sino como punto capital de su filosofía, Kant, Descartes, Leibniz, Wolff y Hegel entre otros. No debo ocuparme de la estructura dialéctica ni de la fuerza probatoria del argumento. Pero sí restablecer el sentido genuino anselmeano, que aquí esta falseado por subestimación sicológica de Borges, que supongo lo leyó en una buena traducción. O ¿debo aplicar a él lo que escribiera de los filósofos de sus “Tlön, Uqbar, Orbis Tertius”, para así evitarme disquisiciones?: "los metafísicos de Tlön no buscan la verdad, ni siquiera la verosimilitud: buscan el asombro". ${ }^{26}$

Anselmo escribe:

Et quidem credimus to esse aliquid quo nihil maius cogitari possit. An ergo non est aliqua talis natura, quia "dixit insipiens in corde suo: non est dens”? Sed certe ipse insipiens, cum audit hoc ipsum quod dico: aliquid quo maius nihil cogitari potest, intelligit quod audit; et quod intelligit in intellectu eius est, etiam si non intelligat illud esse.... Et certe id quo mains cogitari nequit, non potest esse in solo intellectu. Si enim vel in solo intellectu est, potest cogitari esse et in re, quod maius est. Si ergo id quo maius cogitari non potest, est in solo intellectu: id ipsum quo maius cogitari potest. Sed certe hoc esse non potest. Existit ergo procul dubio aliquid quo maius cogitari non valet, et in intellectu et in re. ${ }^{127}$

La traduccion parafraseada, para mejor inteligencia, es:

El mismo insensato, al decir que no hay Dios, entiende lo que dice, y si decimos que Dios es algo tal que nada pueda pensarse mayor, también lo entiende, y por lo tanto está en su entendimiento. Lo que niega el insensato es que Dios además, este "in re”, niega que lo haya en realidad. Pero supongamos que, en efecto, Dios exista solamente en el entendimiento; podemos pensar entonces que existiera también en realidad, y esto es más que lo primero. Por tanto, podemos pensar algo mayor que Dios, si este no existe.

Pero esto esta en contradicción con el punto de partida, según el cual Dios es tal que no puede pensarse mayor. Es decir, la suposición de que no exista sino en el entendimiento, es contradictoria y, por lo tanto, imposible.

Luego necesariamente hay Dios, no sólo en el entendimiento, sino también en realidad.

Dicho en otros términos: si sólo existe en el entendimiento, no cumple la condición de ser un ente tal que nada pueda pensarse mayor, y esto quiere decir que no es de Dios de quien se habla y no hay cuestión. ${ }^{128}$

La fuerza dialéctica de esta argumentación, a simultáneo, es ciertamente conocida y aprovechada por Borges, que a base de ella ha elaborado su "Argumentum Ornithologicum” para probar que Dios existe: "Cierro los ojos y veo que una bandada de pájaros... no se cuantos pájaros vi ...Si Dios existe, el número es definido, porque Dios sabe cuantos pájaros vi. Si Dios no existe, el número es indefinido...” 
En buena forma silogística debiera continuar: Es así que ese número es en sí definido para ese único. Alguien que llamé Dios; luego Dios existe. Borges continúa de esta manera:

Si Dios no existe, el número es indefinido, porque nadie pudo llevar la cuenta. En tal caso, vi menos de 10 pájaros (digamos) y más de uno, pero no vi nueve, ocho, siete, seis, cinco, cuatro, tres o dos pájaros. Vi un número entre diez y uno, que no es nueve, siete, seis, cinco, etcétera. Ese número entero es inconcebible; ergo Dios existe. ${ }^{129}$

Comenta al respecto Jaime Rest:

Con singular causticidad, indudable rigor y complaciente juego verbal, a la comprobación ontológica Borges opone o suplementa un posible argumentum ornithologicum. ${ }^{130}$

Borges aquí no opone ni añade nada al argumento anselmeano, pues usa el mismo método de demostración a simultáneo o quasi a priori, que consiste en establecer un lazo de unión entre dos conceptos que se aplican a una misma realidad y expresan dos conceptos ontológicamente simultáneos.

¿Qué piensa Borges de ésta como de las demás pruebas, que las conoce bien? Ya, en 1928, escribió: "Yo pienso de ella lo que de las sedicentes pruebas dialécticas de que hay Dios, la ontológica, la cosmológica, la moral, la histórica y las que queden: pienso que su única virtud no dudosa es la de convencer a ya convencidos”. ${ }^{131}$

En 1974 le pregunta Burgin: ¿’Le parece que se ha malgastado mucha filosofía argumentando la existencia de Dios, o todavía puede disfrutar con todo ello? Borges: Yo puedo disfrutar mucho con todo ello, como ciencia ficción. La imaginación disfruta. Pero no creo que nadie pueda tomarselo demasiado en serio. Desde luego, puedes creer en Dios, me atrevería a decir que hay un Dios, pero no creo en él a causa de esos argumentos”. ${ }^{132}$

Porque él se atreve a creer en Dios sin sistemas ni escolástica, pudo escribir que buscaba para su empresa literaria un "Criollismo, pues, pero un criollismo que sea conservador del mundo, del yo, de Dios y de la muerte. A ver si a1guien me ayuda a buscarlo". ${ }^{133} \mathrm{Al}$ final de su estudio sobre Borges, Claude Mauriac ha podido afirmar con acierto "Des religions on des philosophies, il utilise avec virtuosité les possibilités littéraires, allant de paradoxe en paradoxe jusqu' aux frontieres de l’invisible, de l’inconnu, et peut-être de la verité". ${ }^{134}$

En "El enigma de Edward Fitzgerald”, Borges ha dejado escrito:

El año 617 de la Héjira, Umar está leyendo un tratado que se titula El Uno y los Muchos; un malestar o una premonición lo interrumpe. Se levanta, marca la página que sus ojos no volverán a ver y se reconcilia con Dios con aquel que acaso existe y cuyo favor ha implorado en las páginas difíciles de su algebra. ${ }^{135}$

Posteriormente a todas sus declaraciones, este año, (1977), urgido por la polémica confiesa: 
Yo no soy misionero cristiano ni del agnosticismo. ...Todo es posible hasta Dios. Fíjese que ni siquiera estamos seguros de que Dios no exista. ${ }^{136}$

En su último libro de poesía, concluye:

\author{
Pero en algún recodo de tu encierro \\ Puede haber un descuido, una hendidura. \\ El camino es fatal como la flecha \\ Pero en las grietas está Dios, que acecha. ${ }^{137}$
}

\title{
IV. CONFIRMACION Y DISCREPANCIAS
}

Terminado este estudio llegaron a mis manos cuatro entrevistas y dos libros en los que hay referencias al pensamiento teogénico de Borges, no solamente como posibilidad literaria sino también metafísica.

Y creo que es, en la entrevista con Georges Charbonnier donde indica con más claridad que en otras ocasiones la existencia de estos dos: "En ese cuento, y lo espero de todos mis cuentos, hay una parte intelectual y otra más importante, según creo, el sentimiento de la soledad, del carácter misterioso del universo, del tiempo y lo que es más importante: de nosotros mismos, para decirlo de una buena vez: de mi mismo". ${ }^{138}$

También, en esta conversación Borges deja de mostrarse renuente a su afición por la metafísica: “La matemática y la filosofía, la metafísica, siempre me han interesado”. ${ }^{139}$

Por este diálogo sabemos también que cuando Borges tenía veinte o veinticinco años se reunía todos los sábados hacia las once de la noche hasta el amanecer, para hablar de literatura y también “¡Hablabamos mucho de la existencia o inexistencia del yo, del tiempo, de Dios, de la inmortalidad, del universo, del infinito, etc., y todo esto era apasionante para nosotros!”140

Y cuando Charbonnier le pregunta si podemos trascender nuestra circunstancia, Borges le contesta dándonos una cita más para lo que yo llamaría la angustia de futuro o la nostalgia de Dios en Borges. Borges contestó:

Sobre todo cuando vivimos en lo temporal, en lo sucesivo. No vivimos en la eternidad, en lo esencial. Siempre estamos en la circunstancia, y esta es una forma de consolarlos en la desgracia, ¿no es así? Cuando cae una desgracia sobre nosotros, pensamos: Si, me sucedió hoy en la noche, pero mañana será otro día, las cosas serán un poco distintas.... Lo que dice usted concierne a una naturaleza esencial, pero, como sabe, sería menester saber si lo esencial existe, si es algo más que las circunstancias. Si yo mismo soy algo más que la sucesión del lunes, martes, miercoles, jueves, etc., y que la sucesión de los instantes que componen esta serie. Quizá existo de otra manera, digamos, si hay Dios. Quizá entonces existo de una manera esencial. ${ }^{141}$

Cuando enfocamos con un reflector un sitio determinado de tal manera queda iluminado el centro que la periferia queda a oscuras. El libro Borges y la Cábala de Saúl 
Sosnowski de tal manera descubre los contactos cabalísticos borgeanos que los otros elementos constitutivos de la obra quedan ignorados. Para lo que he dado en llamar la nostalgia de Dios sería una prueba más ese encuentro y búsqueda previa del Verbo "que es un axioma ‘sine qua non' de la Cábala y por medio del cual Dios ha creado el universo”. No una prueba metafísica del propio pensamiento de Borges sino una prueba más de cómo utiliza las posibilidades literarias de la teosofía o de la Cábala. Y como bien escribe Sosnowski "El elemento lúdico parece esconderse tras toda aserción y sentencia". ${ }^{142}$

De tal manera Saúl Sosnowski recalca las relaciones y correlaciones de la Cábala, por ejemplo en "La escritura del Dios”, que parece que la genuina interpretación de ese cuento sería la cabalística. Escuchemos al propio Borges:

"La escritura del dios” es también (como "Hombre de esquina rosada) una historia autobiográfica. Pasó once días con sus noches en cama, bajo un calor argentino. ... Pensé en una visita que hice -creo que era muy niño-al jardín zoológico de Buenos Aires. Pensé que las manchas sobre la piel del jaguar, del leopardo, parecían signos. Uni esos dos elementos: la experiencia espantosa -estar inmóvil y encadenado-y la idea de las manchas, escritura sobre la piel del jaguar. Por otro lado acababa de leer libros sobre experiencia mística, sobre posibilidad de comunicarla. De estas tres cosas surgió la historia. El traductor alemán le encontró un título muy bello. No "La escritura del Dios”, sino “Die Theologen”, es decir, "Los teólogos”. ${ }^{143}$

Borges: Imágenes, memorias, diálogos de María Esther Vázquez, es un libro más de conversaciones, pero a la vez distinto de los demás, como dice el mismo interrogado: "Muy otra cosa es, lo confiamos, este libro cuya materia es un diálogo cómodo entre dos amigos, que desde una fecha ya algo remota, se conocen y se quieren... Para mí este libro tiene, por lo menos, una irrefutable virtud: la de haberme reconciliado con Borges”. ${ }^{144}$

En el "Indice Analítico" he precisado los tópicos que hacen referencia a Dios.

Confirma aquí, definitivamente, que es un literato y no un filósofo: “Considero muy justo lo de Anderson Imbert. Si, es verdad, No soy filósofo ni metafísico; lo que he hecho es explorar o explorar -es una palabra más noble- las posibilidades literarias de la filosofía”. ${ }^{145}$ Y cuando a continuación M. E. Vázquez insiste en que los estudiantes le tienen como un abanderado de sus diferentes tendencias idealista, estructuralista, materialista, estoica, etc., él asevera:

Están equivocados. Si fuera idealista, por ejemplo, esto sería una certidumbre y yo no tengo certidumbres: más bien tengo dudas. Ahora bien, si estuviera convencido de que Berkeley tiene razón, de que el universo es un sueño o, como decían los hindúes, un sueño de Brahma, entonces ya sería una certidumbre y no la tengo. Ni siquiera estoy seguro de todo sea un sueño. Lo veo como una posibilidad o como una esperanza, quizá. Si he participado de esa filosofía, ha sido para los propósitos particulares del cuento y mientras lo escribía.

Explicitando esta antinomia existencial, que llega a la contradicción, continúa: "Yo, por ejemplo, niego la exterioridad de los sentidos, pero vivo como todo el mundo porque no se puede vivir de otra manera". ${ }^{146}$ 
En la primera parte de este estudio he indicado el antiprovidencialismo del pensamiento teológico de Borges. En nuevos textos vuelve ahora al tema, pero con la nueva connotación a la incomprensibilidad divina, en la “aparente injusticia” de Dios.

... esta manana hablé sobre el Libro de Job, sobre la aparente “injusticia” de que Dios permita al hombre virtuoso ser desdichado.

-Usted tiene una especial predilección por el Libro de Job, ¿no?

Sí. Pensemos que es un poema dramático y que se juzgó el primero de todos los libros... En otros libros del Antiguo Testamento, Dios aparece como un padre, como un juez o como un rey, pero aquí se limita a señalar su poder e invoca a dos de sus criaturas más extrañas: el behemoth que puede ser el elefante o el hipopótamo, y el leviatán que puede ser la ballena o el dragón. Es decir que Dios aquí toma, no sólo como pruebas de su poder sino como símbolos de ese poder y de su carácter incomprensible, a dos criaturas monstruosas. ${ }^{147}$

Y comenta en la respuesta siguiente: "Dios no dice que ha obrado justamente, Dios dice que su esencia es ser incomprensible, casi monstruoso para los hombres, tal sería la extraña moralidad de ese poema del Antiguo Testamento". ${ }^{148}$

Aquí Borges toca uno de los más difíciles problemas teológicos, la “incomprehensibilitas” divina, que en términos comunes sería la desproporción que existe entre el objeto-persona infinita, Dios, y la persona-cognoscente, el hombre, finito, que permanece en calidad de tal, en su infinitud, aún cuando sea elevado a la visión beatífica. En su última charla sobre La Divina Comedia dijo con razón en Junio de 1977: “Dios está más allá de todo juicio humano”. ${ }^{149}$ Por ello, el teólogo alemán Karl Rahner ha podido escribir:

The Christian is the true and most radical sceptic. For if he really believes in the incomprehensibility of God, he is convinced that no individual truth is really true except in the process which necessarily belongs to its true essence, the process in which the truth becomes a question which remains unanswered because it is asking about God and His incomprehensibility. ${ }^{150}$

Su cristología queda, en estas entrevistas de M. E. Vázquez, enriquecida por varios pasajes, en especial el siguiente:

-Jesucristo fue justo.

-Y además, tiene que haber sido un hombre extraordinario. Al mismo tiempo, si una persona cree que es Hijo de Dios, si confiesa opiniones tan extraordinarias como esa, no sé hasta dónde podemos juzgarlo. Indudablemente, es una de las personas más raras y admirables con que ha contado el mundo. Pero no sé si los cristianos se parecen a Cristo. ${ }^{151}$

Su anticonfesionalismo queda aquí también confirmado con un rotundo: "Yo no profeso ninguna religión”. ${ }^{152}$ Aun cuando es religioso: 
-Donde sentí más el pasado germánico de Inglaterra fue en una pequeña iglesia sajona, cerca de Lichfield...Entré y en la penumbra del templo cumplí un voto que yo había hecho muchos años antes en Buenos Aires, sin esperanza de poder realmente cumplirlo: dije el Padre Nuestro en Inglés antiguo, en esa vieja iglesia sajona y logré al cabo de diez siglos, digamos, que volviera a resonar en esa iglesita el "Faether ure, thu eart on heovenum, sie thin nama gehalgot..." Creo que lo hice para darle una pequeña sorpresa a Dios. ${ }^{153}$

¿Quién no descubre su honda religiosidad crucificada de angustia y perplejidad en “su oración”?

Mi boca ha pronunciado y pronunciará, miles de veces y en los dos idiomas que me son íntimos, el padre nuestro pero sólo en parte lo entiendo. Esta mañana, la del primero de Julio de 1969 , quiero intentar una oración que sea personal, no heredada. ${ }^{154}$

Porque Borges sabe lo que es vivir una religión, escribió con toda verdad y sinceridad años antes:

Morir por una religión es más simple que vivirla con plenitud; batallar en Efeso contra las fieras es menos duro (miles de mártires oscuros lo hicieron) que ser Pablo, siervo de Jesucristo. ${ }^{155}$

He encontrado que el profesor Emir Rodríguez Monegal también se refiere, en uno de sus artículos, al pensamiento teogénico de Borges. Busca allí el fundamento del pensamiento filosófico borgeano y dice:

Pero en sus ensayos "metafísicos" retomados y nunca concluidos en suma, se manifiesta en todos esos textos una convicción última: la irrealidad del mundo apariencial, la irrealidad del yo individual. Esta "metafísica” descansa además en la negación de todo socorro sobrenatural y en la empecinada denuncia de las fábulas de la teología. En un artículo sobre Edward Fitzgerald, el traductor de Omar Khayyam, que está ahora recogido en Otras inquisiciones, Borges se excusa de las incursiones teológicas de Fitzgerald con una frase que podría aplicar también a él: Todo hombre culto es un teólogo, y para serlo no es indispensable la fe. ${ }^{156}$

Desde luego la metafísica no debe esperar una ayuda sobrenatural porque el plano de la filosofía es precisamente el natural, el de la razón y no el de la fe. Borges distingue bien entre metafísica y teologóa. Y en este caso no se puede sostener que el conocimiento implique la práctica por la fe, como nadie espera que todo crítico o profesor de literatura, por ejemplo, deba ser un poeta o literato.

Por lo demás, no hay en la obra de Borges una “empecinada denuncia de las fábulas de la teología”. La denuncia supone una falta y en ningún sitio he encontrado que Borges acuse a la teología de culpa. Para él, como se ha podido ver en la primera parte de este estudio, la teología es parte de la mejor literatura fantástica, donde caben las fábulas por 
supuesto así como el dogma trinitario es para Borges un absurdo monstruoso, pero para el cual intenta dar una explicación dentro de la escuela swedenborgeana. A algunos misterios Borges los respeta, como la muerte soteriológica de Cristo, y a otros no los menciona en absoluto.

Así Borges, en su "Respuesta” a la polémica de Jujuy, escribió:

De ninguna manera quise ofender a nada ni a nadie. ¿Cómo voy a ofender a algo tan importante en la historia de la cultura como el cristianismo y a la Iglesia Católica? Como tampoco ofendería a la Iglesia anglicana, luterana al islamismo o al budismo... siempre me interesó mucho la teología. ${ }^{157}$

Fábula es aquello que no tiene fundamento real y es falso. En oposición escuchemos a Borges en su diálogo con Usar Fernández Moreno en 1966: “En cambio, si un místico ha tenido la experiencia inmediata de Dios, o lo que es lo mismo de la verdad, no puede comunicarla a los otros, porque, para él, ese sonido corresponde a esa experiencia y para los otros es simplemente una palabra en el diccionario, una palabra de contenido vago". ${ }^{158}$

En cuanto a la cita hecha de "El enigma de Edward Fitzgerald", debo indicar que no se refiere a E. Fitzgerald, sino a uno de los personajes del cuento, Umar ben Ibrahim, quien "Es ateo, pero sabe interpretar de un modo ortodoxo los mis arduos pasajes del Alcorán, porque todo hombre culto es un teólogo, y para serlo no es indispensable la fe”. ${ }^{159}$

La cita, por lo demás, da pie a un juicio incompleto de la persona, pues Borges luego de indicar que Umar escribe cuartetas en "los intervalos de la astronomía, del álgebra y de la apologética”, que es la ciencia que expone la verdad de una religión, añade a sólo ocho líneas de distancia:

Se levanta, marca la página que sus ojos no volverán a ver y se reconcilia con Dios, con aquel Dios que acaso existe y cuyo favor he implorado en las páginas difíciles de su álgebra. ${ }^{160}$

El profesor Rodríguez Monegal, para corroborar que no hace falta la fe para la teología, cita los cuentos en que se examina a hist6ricos o ap6critos heresiarcas. Puede ser que asi sea, yo prefiero atenerme al parecer del finico libro de critica que ha sido leido por Borges: “... I’ve only read one book, a book published by a Bolivan -his name was Tamayo, and an Argentine writer, Ruiz-Díaz. That's the only book I've read about Me”. ${ }^{161}$

En este privilegiado libro se lee:

No interesa a Borges la doctrina como tal, en pro o en contra de una ortodoxia determinada, sino la coexistencia de ortodoxia y herejía, como enriquecimiento de una posibilidad casi literaria de diferentes modalidades que un argumento puede asumir. El problema de su verdad queda excluido...Mejor dicho, los únicos méritos que una doctrina puede alegar son su riqueza inventiva, su atractivo de juego intelectual cuya trascendencia de antemano excluye. ${ }^{162}$ 
Al final de la página que vamos comentando termina Rodríguez Monegal: "De ahí que su última convicción ‘teológica’ pueda encontrarse en aquella frase tan destructora de uno de sus relatos más importantes, “Tlön, Uqbar, Orbis Tertius”: ¿Cómo no someterse a Tlön a la minuciosa y vasta evidencia de un planeta ordenado? Inútil responder que la realidad también está ordenada. Quizá lo esté, pero de acuerdo a leyes inhumanas -que no acabamos nunca de percibir”. ${ }^{163}$

Que en este cuento, que apareció por primera vez en el No. 68 de la revista Sur (mayo de 1940) se encuentre la última convicción, en sentido meramente temporal, queda excluído porque Borges ha seguido escribiendo por más de 37 años. Ni creo que eso sea lo que piensa Borges.

Antes de considerar si aquí se encuentra la “última convicción teológica” de Borges, debemos recordar lo que se dice en este mismo cuento: "Los metafísicos de Tlön no buscan la verdad ni siquiera la verosimilitud: buscan el asombro” ${ }^{164}$ No encuentro en que sentido sea este párrafo la última convicción teológica. Marcial Tamayo al referirse al mismo párrafo citado por Rodríguez Monegal, comenta: “La excelencia de esas leyes provienen precisamente del hecho de haber sido maquinadas por hombres y destinadas a otros hombres, a toda la humanidad, no sólo para que las acaten sino para que minuciosamente acometan la tarea de descifrarlas. Las leyes de Tlön son, pues, mandato y cifra, misterio y ordenamiento."

Cita aquí las palabras de Borges y continúa: "La ventaja, el atractivo de que goza esta invención reside en primer lugar en su plenaria inteligibilidad. ...Las leyes de nuestro orbe dictadas por Dios persistirán inamovibles, no nos quedará otro expediente que acatarlas” ${ }^{165}$

¿Por qué no dar por última convicción teológica de Borges las palabras suyas escritas en 1952 ?

La imposibilidad de penetrar el esquema divino del universo no puede, sin embargo, disuadirnos de planear esquemas humanos, aunque nos conste que estos son provisorios. ${ }^{166}$

En la entrevista con Carlos Cortínez encontramos, por desgracia, muy sintetizada, aquella famosa conversación que tuvieron Borges con su madre acerca de Dios.

No recuerdo cómo la conversación derivó hacia las creencias religiosas de cada cual. Entonces ella me declaró su fe con una simplicidad no exenta de dramatismo... me contó un sueño que ella tuvo cuando murió su padre: él se le acercaba, muy fatigado, y le aseguraba, de un modo que no ha podido olvidar, que Dios existe. ...Dos o tres veces fue interrumpido por su hijo que oponía razones de su escepticismo. Era paradójico oir a Borges desconfiar de la seriedad de los sueños, para no dejarse convencer por la belleza del relato de su madre. En una de esas, ella sin molestarse pero con la superioridad del creyente lo hizo callar:

-¡Deja Georgie, tú no piensas en estas cosas...!

Preguntó Cortínez a Borges: 
¿Cómo concibe a Dios?

-Como algo o alguien infinitamente lejano hacia el cual nos acercamos vanamente.

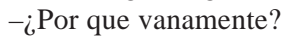

-Porque lo más probable es que si ese encuentro se produce no lo entenderíamos y a Dios no le interesaríamos en absoluto. Un santo o un hombre de genio han de parecerle tan insignificantes como un pecador o un imbécil. ${ }^{167}$

Junto a su madre Borges, que niega la inmortalidad del alma, vuelve a sentir la nostalgia de Dios, en su posible "encuentro".

Por esto quizás cuando canta a su padre muerto, se olvida también de su teoría de la no inmortalidad y escribe:

\author{
Te he visto morir sonriente y ciego \\ Nada esperabas ver del otro lado, \\ Pero tu sombra acaso ha divisado \\ Los arquetipos que Platón el Griego \\ Soñó y me explicabas. Nadie sabe \\ De que mañana el mármol es la llave. ${ }^{168}$
}

La lápida sepulcral para su padre será más que loza que se cierra, llave que abre puertas a un mañana del otro lado.

La mención de su padre trae a la memoria aquella disputa que tuvieran los dos acerca de la frase sanmartiniana "Serás lo que debes ser, y si no, no serás nada”, y que Borges nos cuenta en "Respuesta a la encuesta entre los escritores":

Mi padre discutía conmigo esa interpretación; afirmaba que San Martín dijo más o menos: "Serás lo que debes ser"- serás un caballero, un católico, un argentino, un miembro del Jockey Club, un admirador de Uriburu, un admirador de los extensos rústicos de Quirós- “y si no, no serás nada”- serás un israelita, un anarquista, un mero guarango, un auxiliar primero; la Comisión Nacional de Cultura ignorará tus libros y el doctor Rodríguez Larreta no lo remitirá los suyos, avalorados por una firma autógrafa... Sospecho que mi padre se equivocaba. ${ }^{169}$

Y tambión cuando, según nos cuenta en su Autobiographical Essay,

My father.. once, he told me that I should take a good look at soldiers, uniforms, barracks, flags, churches, priests and butcher shops, since all these things were about to disappear. The prophecy has not yet come true, unfortunately. ${ }^{170}$

Epílogo de todas estas citas bien puede ser ésta de El libro de arena, libro de su preferencia: "Sé la Verdad pero no puedo razonar la Verdad. El inapreciable don de comunicarla no me ha sido otorgado". ${ }^{171}$ 


\section{CONCLUSION}

\section{En síntesis}

En la urdimbre de la obra borgeana se entrelaza un agnosticismo filosófico, en su teodicea, que considera a Dios como una hipótesis, de la que resulta imposible admitir la realidad de su contenido, por carecer de la posibilidad de verificarlo.

Este pensamiento se entrecruza con una tendencia sicológica de su teología, que cree en Dios, con una fe, que ha evolucionado bergsoneanamente, de un catolicismo inicial, a un swedenborgeanismo cristiano, cristocéntrico, con personales características de un eclecticismo escéptico.

Brevemente, Borges cree en el Dios del Cristianismo, pero su fe no supera la incertidumbre de su razón. Por ello no participamos de la opinión de quienes como Guillermo Sucre pueden afirmar: "No hay un Dios visible en él, sino más bien una suerte de potencia neutral o impersonal”. ${ }^{172}$ Nos conformamos más bien con aquellos críticos, como Rest y Kazin, que dicen:

Borges no cuestiona las creencias sino, más bien los intentos de sistematizarlas, de hacerlas demostrables. Por añadidura, algo hay que excede su eclepticismo y logra imponerse por una convicción propia; es la existencia de Dios.173

For Borges, too, the “imagination” he constantly celebrates -and works in-is God. ${ }^{174}$

University of Pittsburgh

OSWALDO E. ROMERO

\section{NOTAS}

Jean de Milleret, Entrevistas con Jorge Luis Borges (Caracas: Monte Avila, 1970), pp. 113-117.

Claude Mauriac, L'Allittérature contemporaine (Paris: A. Michel, 1969), p. 169.

J. de Milleret, op. cit., p. 59.

4 J. L. Borges, El tamaño de mi esperanza (Buenos Aires: Proa, 1976), p. 258.

5 Gloria Alcorta. “Entretiens”, L’Herne (Paris, 1964), p. 406.

6 S. Roldán, Tongues of Fallen Angels (New York: McClelland, 1974), p. 24.

7 J. L. Borges, El idioma de los argentinos (Buenos Aires: M. Gleizer, 1928), pp. 81-82.

8 J. L. Borges, El tamaño de mi esperanza, p. 100.

9 William F. Buckley, Firing Line (Columbia, S.C.: SECA, 1977), p. 11.

10 M. E. Gilio, Borges (Buenos Aires: El Magrullo, 1976), p. 15.

11 Manuel Caldeiro. "Yo acuso a Borges...”, Gente, XII, No. 597 (Buenos Aires, Enero 6 de 1977), p. 74

12 R. Guibert. "Borges habla de Borges”, Life en español, XXXI, No. 5 (11 de marzo de 1968), p. 58.

13 J. L. Borges, Obras completas (Buenos Aires: Emecé, 1974), p. 669.

14 J. de Milleret, op. cit., p. 114.

15 J. L. Borges, op. cit., p. 661.

16 J. de Milleret, op. cit., p. 59.

17 Ibid.

18 Ibid.

19 Ernesto Sabato, Diálogos, (Buenos Aires: Emecé, 1976), pp. 100-101.

20 James Irby, Encuentro con Borges (Buenos Aires: Galerna, 1968), p. 91.

21 Op. cit., p. 87.

22 P. Montecchia, Reportaje a Borges (Buenos Aires: Crisol, 1977), p. 11.

23 J. L. Borges, Obras completas, p. 694. 
24 R. Guibert, loc. cit. cf. Zisman, A. J., Libre, No. 3 (Paris, 1972), pp. 16-21.

25 J. L. Borges, Obras completas, p. 698.

26 J. L. Borges, Prólogos, (Buenos Aires: Torres Agüero, 1975), p. 156.

27 Op. cit., pp. 149-150.

28 J. L. Borges, Obras completas, pp. 283-284.

29 J. L. Borges, “El Budismo”, La Opinion, II, 58 (Buenos Aires, 5 al 11 de Agosto, 1977), p. 43.

30 J. L. Borges, El idioma de los argentinos, (Buenos Aires: M. Gleizer, 1928), p. 183.

31 Emanuel Swedenborg, Compendium of the Theological Writings, (New York: Swedenborg Foundation, 1974), p. 94.

${ }^{32}$ Fernando Sorrentino, Siete conversaciones, (Buenos Aires, 1973), p. 115.

33 J. L. Borges, Obras completas, p. 696.

34 Rouet de Journel, Enchiridion Patristicum, (Roma: Saler, 1937), p. 1.

35 J. L. Borges, Obras completas, p. 210.

${ }^{36}$ Op. cit., p. 88.

37 Susana Chica Salas, “Conversación con Borges” (En Revista Iberoamericana, vol. XLII, JulioDiciembre de 1976, Nums. 96-97, p. 586).

38 Ernesto Sabato, op. cit., p. 156.

39 Emanuel Swedenborg, op. cit., p. 88.

${ }^{40}$ Ibid, p. 85.

41 J. L. Borges, Prólogos, p. 153.

42 J. L. Borges, El tamaño de mi esperanza, p. 110.

43 J. L. Borges, Prólogos, pp. 156-157.

44 A. Cm., Swedenborg, Emanuel, “Encylcopaedia Britannica”, ed. William Benton, XXI (1972) 503.

45 J. L. Borges, Obras completas, p. 701.

46 J. L. Borges, Prólogos, p. 161.

47 J. L. Borges, Obras completas, p. 983.

48 E. Sábato, Diálogos, p. 102.

49 J. L. Borges, Obras completas, p. 1137.

50 F. Sorrentino, Siete conversaciones con J. L. B., p. 74. Ver “Apendice”.

51 J. L. Borges, Obras completas, p. 698.

52 Ibid, p. 704.

53 Ibid, p. 282.

54 J. L. Borges, El idioma de los argentinos, p. 81.

${ }^{55}$ Ibid, p. 96.

56 J. L. Borges, Obras completas, p. 353.

57 J. L. Borges, Prólogos, p. 158.

58 Manuel Caldeiro. “Borges se defiende”, Gente, XII, 598 (Buenos Aires, Enero 6 de 1977), p. 74.

59 J. L. Borges, Obras completas, p. 800.

60 Ibid, p. 714.

61 J. L. Borges, Prologos, p. 66.

62 J. L. Borges, Obras completas, p. 1012.

63 Op. cit., p. 702.

${ }^{64}$ Op. cit., p. 893. cf. p. 977.

65 Op. cit., p. 754.

66 Op. cit., p. 881.

67 Op. cit., p. 996.

68 Op. cit., p. 1070.

69 Op. cit., p. 1071.

70 J. de Milleret, Entrevistas con J. L. B., p. 111.

${ }^{71}$ Op. cit., (New York: Harper \& Row, 1976).

72 J. de Milleret, op. cit., p. 115.

73 Sábato, Diálogos, p. 101. 
74 Jacques Roos, Aspects litteraires du mysticisme philosophique, (Strasbourg: P. H. Heitz, 1951) 460 p.

75 Irby, Encuentros con Borges, (Buenos Aires: Galerna, 1968), pp. 108-109.

76 J. L. Borges, “El Budismo”, La Opinión, II, 58 (Buenos Aires, 5 al 11 de Agosto, 1977), p. 43.

${ }^{76 b}$ Op. cit., pp. 101 y 146.

77 Kajo Niggestich, “Ulises-Descrifrador-Golem...”, Iberoromania (Madrid, 1975) No. 3, Nueva Serie, p. 59.

78 J. L. Borges, Obras completas, pp. 750-751.

79 J. L. Borges, Inquisiciones, (Buenos Aires: Proa, 1925), p. 31.

80 Ibid, p. 28.

81 J. L. Borges, Prólogos, p. 86.

82 J. L. Borges, Obras completas, pp. 280-281.

83 Ibid, p. 258.

84 Ibid, p. 882.

85 J. L. Borges, La moneda de hierro, (Buenos Aires: Emec6, 1976), p. 115.

86 James Irby, Encuentros con Borges, (Buenos Aires: Galema, 1968), p. 105.

87 Michel Grison, Theologie Naturelle ou Theodicee, (Paris: Beauchesne, 1965), p. 125.

88 J. L. Borges, Obras completas, p. 254.

89 William F. Buckley, op. cit., p. 3.

90 R. Burgin, Conversaciones con J.L.B., p. 155.

91 J. L. Borges, El idioma de los argentinos, p. 12.

92 J. L. Borges, Obras completas, p. 359.

93 E. Swedenborg, Compendium of the Theological Writings, p. 10.

94 J. L. Borges, Obras completas, p. 258.

95 I. Jo., “Swedenborg, Emanuel”, Encyclopaedia Britannica, 15th. ed. Vol. XVII, p. 855.

96 J. L. Borges, op. cit., p. 737.

97 J. L. Borges, op. cit., p. 155.

98 J. L. Borges, Obras completas, p. 815.

99 Ibid, p. 883.

${ }^{100}$ Ibid, p. 936.

101 J. L. Borges, Inquisiciones, p. 27.

102 Ibid, p. 32.

${ }^{103}$ Op. cit., p.8 y p. 99

104 J. L. Borges, Obras completas, p. 969.

${ }^{105}$ Ibid, p. 233

${ }^{106}$ Ibid, p. 648.

${ }^{107}$ Ibid, pp. 211-212.

${ }^{108}$ Ibid, p. 283.

${ }^{109}$ Op. cit., p. 156.

${ }^{110}$ F. Sorrentino, Siete Conversaciones, p. 74.

111 J. L. Borges, Obras completas, p. 1036.

112 Ibid, p. 960.

${ }^{113}$ Ibid, p. 575.

${ }^{114}$ Ibid, p. 363.

$115 \mathrm{~J}$. L. Borges, El idioma de los argentinos, p. 183.

${ }^{116}$ M. Caldeiro, “Borges se defiende”, Gente, XIII, (6 Enero 1977), p. 74.

${ }^{117}$ Ibid.

${ }^{118}$ J. de Milleret, Entrevistas, p. 114.

${ }^{119}$ E. Swedenborg, op. cit., p. 14.

${ }^{120}$ J. L. Borges, Inquisiciones, pp. 100-101. El libro de Ferrer es Borges y la Nada, (London: Tamesis Book, 1971), p. 57

${ }^{121}$ J. L. Borges, Obras completas, p. 256.

${ }^{122}$ Ibid. Menciona esta prueba tambión en la p. 704. 
${ }^{123}$ J. L. Borges, El idioma de los argentinos, p. 81.

124 J. L. Borges, Obras completas, p. 698.

${ }^{125}$ Burgin, Conversaciones con J.L.B., pp. 156-157.

${ }^{126}$ J. L. Borges, Obras completas, p. 436.

${ }^{127}$ Anselmo, Opera Omnia, (Edinburg: Nelson \& Sons, 1946) Vol. I, pp. 101-102.

${ }^{128}$ Julián Marías, San Anselmo, (Madrid: Rev. de Occidente, 1944), p. 19.

129 J. L. Borges, Obras completas, p. 787.

${ }^{130}$ J. Rest, El laberinto del universo, (Buenos Aires: Librerias Fausto, 1976), p. 38.

${ }^{131} \mathrm{~J}$. L. Borges, El idioma de los argentinos, p. 81.

${ }^{132}$ R. Burgin, Conversaciones, p. 156.

133 J. L. Borges, El tamaño de mi esperanza, p. 10.

${ }^{134}$ C. Mauriac, L'Alitterature contemporaine, p. 180.

135 J. L. Borges, Obras completas, p. 689.

${ }^{136}$ M. Caldeiro, “Borges se defiende”, Gente, XII, No. 598, p. 74.

${ }^{137}$ J. L. Borges, La moneda de hierro, p. 127.

${ }^{138}$ G. Charbonnier, El escritor y su obra, (Mexico, 1975), p. 16.

${ }^{139}$ Ibid, p. 15.

${ }^{140}$ Ibid, p. 27.

${ }^{141}$ Ibid, pp. 64-65.

${ }^{142}$ Saúl Sosnowski, Borges y la Cábala, (Buenos Aires: Hispamérica, 1976), p. 48.

${ }^{143}$ Ibid, pp. 94-95.

${ }^{144}$ María Esther Vázquez, Borges: Imágenes, memorias, diálogos (Caracas: Monte Avila, 1977), pp. 1112.

${ }^{145}$ Op. cit., p. 105.

${ }^{146}$ Ibid, pp. 105-106

${ }^{147}$ Ibid, p. 146.

${ }^{148}$ Ibid, p. 146

149 J. L. Borges, “La Divina Comedia”, La Opinión, (Buenos Aires, 12-18 de Agosto 1977), p. 44.

${ }^{150}$ Karl Rahner, “Thomas Aquinas on the Incomprehensibility of God”, discurso leído en Duquesne University, Pittsburgh, PA. Noviembre 9, 1974, p. 16.

${ }^{151}$ Op cit., p. 90.

152 Op. cit., p. 210

${ }^{153}$ Op. cit., pp. 70-71.

154 J. L. Borges, Obras completas, p. 1014

${ }^{155} \mathrm{Ibid}, \mathrm{p} .578$.

${ }^{156}$ Emir Rogríguez Monegal. “Borges: el lector como escritor”. Textos en el aire, ed. Julio Ortega (Barcelona: Tusquets, s.f.), pp. 292-29.

157 Op. cit., p.74.

${ }^{158}$ A. Obhgado y C. Fernández Moreno, “Entrevista con Jorge Luis Borges”, Cuadernos Hispanoamericanos, 201 (Madrid, Sept. 1966), p. 741.

159 J. L. Borges, Obras completas, p. 688.

${ }^{160}$ J. L. Borges, Obras completas, p. 689

${ }^{161}$ W. F. Buckley, Firing Line, (Columbia, S.C.: SECA, 1977), p. 3.

${ }^{162}$ M. Tamayo y A. Ruiz-Díaz, Borges, enigma y clave, Buenos Aires: Nuestro Tiempo, 1955), p. 58.

${ }^{163}$ E. Rodríguez Monegal, op. cit., pp. 293-294.

164 J. L. Borges, Obras completas, p. 436

${ }^{165}$ M. Tamayo, op. cit., pp. 143-144.

166 J. L. Borges, Obras completas, p. 708

${ }^{167}$ Carlos Cortínez, “Con Borges”, Anales de la Universidad de Chile, (Santiago, Enero-diciembre, 1967) No. 125, pp. 141-143.

168 J. L. Borges, La moneda de hierro, p. 81.

169 J. L. Borges, “Respuesta a la encuesta entre escritores”, Latitud, 1 (Buenos Aires, febrero, 1945), p. 4. 
${ }^{170}$ J. L. Borges, The Aleph, (New York: Bantam Book, 1971), p. 138.

171 J. L. Borges, El libro de arena, (Buenos Aires: Emecé, 1975), p. 84.

172 Guillermo Sucre, “La biografía del infinito”, Eco, XXI/5 No. 125 (Bogota, Setiembre, 1970), p. 486.

${ }^{173}$ J. Rest, El laberinto del universo, (Buenos Aires: Libreria Fausto, 1976), p. 36.

${ }^{174}$ Alfred Kazin, “Meeting Borges”, New York Book Review, (New York, May 2, 1971), p. 5.

\section{INDICE ANALITICO}

\section{OBRAS COMPLETAS}

Dios en general: 17, 29, 33, 39, 59, 70, 73, 107, 135, 200, 209, 251, 261, 281, 282, 301, 327, 338, 342, 356, 360, 361, 384, 395, 412, 415, 417, 441, 447, 461, 466, 500, 501, 506, 511, 512, 514, 517, 523, 550, 554, 556, 560, 574, 583, 584, 593, 595, 596, 597, 598, 599, 601, 602, 607, 608, 614, 615, 624, 637, 638, 649, 651, 652, 658, 679, 680, 686, 689, 690, 698, 702, 703, 714, 715, 716, 720, 721, 722, 737, 738, 746, 749, 750, 751, 752, 763, 786, 787, 800, 801, 804, $\quad 807,813,815,830,835,840,854,865,868,882,883,885$, 886, 887, 890, 892, 896, 906, 909, 910, 915, 925, 929, 930, 934, 936, 961, 983, 987, 996, 997, 1010, 1011, 1049, 1057, 1060, 1103, 1106, 1108, 1111, 1114, 1137.

Dios con minúscula: 96, 304, 375, 415, 540, 550, 708, 726, 750, 782, 800, 803, 817, 869, 871, 890, 897, 906, 985, 1070, 1084, 1086, 1120, 1122, 1128.

Dios, definición: 737, 750, 751, 936, 969, 1103; nombre: 885; solitario: 40, 281; trinitario: 209, 210, 211, 280, 283, 238, 359, 360, 361, 362, 388, 372; verdad: 881, 882; omni sapiente: 211; remunerador: 235, 236, 237-8, 281, 698, 704, 865, 910, 916, 917, 926; providente: 283, 1036; paciente: 282, 283; creador: 815, 883, 936, 650-652; eterno: 283, 360, 361, 362, 363, 364, 365, 868, 960, 648; y albedrio: 283; incierto: 216; invención: 280, 281, 936; pruebas: 256, 787, 698; terrible: 983, 1137; de Platón: 927; de Spinoza: 200; de Basílides: 213, 214; de escolásticos: 686, 698, 722, 648, 650; de los judíios: 715, 720; de los cristianos: 715, 716, 86, 488; de los musulmanes: 715; determinista: 720; y el mal: 614; y el imposible: 574, 575, 607; panteísmo: 438, 637, 639, 690, 702, 705, 800, 804, 925, 927.

Jesucristo: 493, 494, 506, 515, 516, 517, 551, 553, 641, 650, 661, 679, 701, 702, 714, 727, 742, 754, 870, 881, 893, 918, 970, 996, 999, 1000, 1003, 1012, 1070, 1071, 1128, 800, 1010.

Swedenborg: 281, 704, 720, 771, 909, 936. 


\section{INQUISICIONES}

Dios de los teólogos: 149, 24, 25; Dios remunerador: 35; Dios y aseidad: 31; Dios y criaturas: 34, 125; Dios y panteísmo: 59; Dios e incredulidad: 129, 130; Dios del creyente: 27; Dios del agnóstico: 28, 639; Dios del positivista: 27; Dios inmortalidad: 35, 36.

\section{EL TAMAÑO DE MI ESPERANZA}

Dios: 5, 10, 18, 23, 32, 51, 63, 64, 65, 67, 86, 87, 102, 111; Dios y los ángeles: 64-69; Dios y creación: 18, 63; Dios y encarnación: 87; Dios y fe: 10, 23; Dios y noche: 111; Dios y visión: 65.

\section{EL IDIOMA DE LOS ARGENTINOS}

Dios: 38, 51, 74, 78, 81, 107, 129, 154, 160; Dios y pruebas: 81; Dios y eternidad: 8, 99; Dios e inmortalidad: 79, 81, 82, 96, 108, 109, 161; Dios y fe: 56, 81, 183; Dios y ateo: 74; Dios y teológos: 38; Dios y cielo católico: 51, 82, 98-99; Dios y cielo musulmán: 52; Dios y cielo budista: 52; Dios y castigo: 51, 154; Dios y moral: 37, 38; Dios y muerte: 97.

Dioses: 56, 139.

Jesucristo: 37.

Metafísica: 8.

\section{LA ROSA PROFUNDA}

Dios: 53, 75, 91, 107, 156, 17; Dios del agnóstico: 91, 107; Dios de Proteo: 75, 79; Dios de Heráclito: 139; Dios con minúscula: 53, 79, 107; Dios Señor: 157.

\section{LA MONEDA DE HIERRO}

Dios: 77, 81, 85, 94, 103, 115, 119, 127, 139, 147, 155; Dios invisible: 103; Dios no remunerador: 155; Dios del agnóstico: 77; Dios de Espinoza: 119, 120; Dios de Platón: 81. 


\section{PROLOGOS}

Dios: 15, 33, 34, 38, 50, 66, 69, 70, 71, 84, 86, 87, 100, 103, 107, 120, 121, 133, 140, 141 , 143, 153-158, 160, 161, 166.

Dios falso y verdadero: 120; Dios remunerador: 15, 70, 71, 158, 87; Dios trinitario: 161; Dios permisivo: 141; Dios e inmortalidad: 38, 70, 71, 158; Dios y panteísmo: 38; Dios y los teólogos: 86, 155, 161; Dios y agnosticismo: 120, 121; Dios y los Evangelios: 84, 141; Dios y la Biblia: 15, 107, 157, 161; Dios y Calvino: 33, 69, 86, 35. 140; Dios y Swedenborg: 15, 100, 153-158, 141; Dios y presbiterianismo: 33; Dios y anglicismo: 141, 143; Dios y cristianismo: 86, 87; Dios y fe: 154, 155, 157, 161, 133; Fe de Roma: 69; Dios y sacerdote: 141; Dios e iglesia: 161.

Jesucristo: 50, 66 .

\section{ENTREVISTAS}

Buckley:

Catolicismo: duda: 11; Cristianismo: duda: 11.

Burgin:

Dios: Problema: 156; Dios infinito: 156; Dios no providente: 156; Dios Prueba anselmeana: 156-157.

Irby:

Catolicismo: 87, 91; Dios: naturaleza: 105; Dios literatura fantástica: 105.

Méndez:

Agnosticismo: 25.

Milleret:

Dios, creencia: 59; Dios metafísica: 81; Dios Biblia, Cábala: 111; Dios agnosticismo: 114, 116; Dios culpabilidad: 116, 154; Dios teólogo: 114; Dios Providencia: 114-115; Dios Platonismo: 115; Dios Politeísmo: 115.

Vázquez, María Ester:

Dios, bondad: 146; Dios justicia: 146; Dios criador: 158-159; Dios y el mal: 55, 145-148; Dios e incomprensibilidad: 148; Dios no visible: 160; Dios de Spinoza: 128; Dios de Berkeley: 105; Dios judío: 158; Dios omnipoderoso: 135, 146; Dios y nombre secreto: 150; Dios y el más allá: 66-67, 134, 135; Dios y los amuletos: 146, 147; Dios y Espíritu Santo: 35, 48, 145; Dios y el Padre Nuestro: 70, 71; Dios y experiencia mística: 49. 
Biblia, su primer libro: 35.

Catolicismo y cristianismo: 92, 106, 162, 165, 171, 172.

Conversion religiosa: 162 .

Jesucristo, otro Adán 147; Jesucristo, Dios: 167; Jesucristo: omnipotente: 189; Jesucristo, crucifixión: 89, 165, 167, 189; Jesucristo, su imagen: 166.

María, 148, 149; Misa, 166; Milagros, 165; Panteísmo, 128, 158; Religión y literatura, 128; personal 190, 209-210; Suicidio, 189.

Swedenborg, 138, 149, 152; cielo e infierno, 136, 137; y ascetismo, 136, 137.

Vaticano, 66. 


\section{El Evangelio Según Borges}

Para algunos críticos El informe de Brodie (1970) parecía iniciar un capitulo diferente en la obra cuentística de Borges. Junto a una prosa más despojada, en la cual era visible lo coloquial (y hasta lo coloquial rioplatense a veces marcado) se destacaba la visible intención de situar varias de esas historias en una como cadena oral, convirtiendo los cuentos en verdaderos relatos. ${ }^{1}$ A ese rasgo parecía sumarse otro, infrecuente en la obra borgiana: el de que casi todos los textos allí reunidos apuntaban a una marcada sencillez, a una posible ausencia de complicación o de complejidad. Borges mismo, con su aguda conciencia artística, se tomó el trabajo de comentar este último aspecto. En el prólogo del libro (calmo, irónico, levemente recorrido de una inocencia cargada de astucia sabia) advirtió:

He intentado, no sé con qué fortuna, la redacción de cuentos directos. No me atrevo a afirmar que son sencillos; no hay en la tierra una sola página, una sola palabra, que lo sea, ya que todas postulan el universo, cuyo mas notorio atributo es la complejidad. Sólo quiero aclarar que no soy, ni he sido jamás, lo que antes se llamaba un fabulista o un predicador de parábolas y ahora un escritor comprometido. No aspiro a ser Esopo. Mis cuentos, como los de las Mil y Una Noches, quieren distraer o conmover y no persuadir... (pp. 7-8)

La lectura de estos relatos parece crear, a primera vista, la sensación -o la sospecha- de que son mucho menos complejos que los contenidos en El Aleph o en Ficciones. Es evidente que lo que ha variado aquí es el estilo, la forma en que Borges utiliza la lengua para comunicar al lector sus contenidos. Pero estos últimos siguen siendo complejos, apuntan siempre a una riqueza significativa y alusiva que va mucho más allá de lo directamente mentado. Creer que estamos ante un Borges diferente, simple, ante un narrador cuya complejidad ha disminuido porque ahora necesita dictar sus textos, es caer en una de las tantas trampas que su obra prepara y tiende cuidadosamente al lector no prevenido. Esta prosa ha abandonado los barroquismos de "El Inmortal” o de "Los teólogos"; pero sigue persiguiendo una multiplicidad 
significativa a través de alusiones, inferencias, cabos sueltos, etimologías, situaciones, imágenes, y demás recursos borgianos.

Quisiéramos aquí señalar algunos aspectos del cuento mas logrado de este conjunto. Como escribiera el mismo Borges en el prólogo ya citado:

Debo a un sumo de Hugo R. Moroni la trama general de la historia que se titula "El evangelio según Marcos”, la mejor de la serie; temo haberla maleado con los cambios que mi imaginación o mi razón juzgaron convenientes. (p. 9)

El titulo adelanta un aspecto de la obra borgiana que parece haber escapado al interés crítico: el de los textos de contenido, intención o problemática religiosa. ${ }^{2}$ En numerosas partes de sus libros Borges ha mostrado no solamente preocupación e interés por los asuntos religiosos, sino que el tema de Dios, el de las herejías, el de las relaciones del hombre y la divinidad, desplazan en ellos un volumen mucho más importante del que a primera vista parece señalar su crítica. Como prueba de lo anterior basta enumerar algunos textos al azar: "El Aleph", "El Zahir", "Inferno I", "La casa de Asterión”, "La escritura del Dios", "Los teólogos", "Tres versiones de Judas"; las notas sobre problemas religiosos como "Paradiso, XXXI, 108", "Argumentum Ornithologicum”, "Lucas, XXIII” (poema), "La duración del infierno”, "Una vindicación del falso Baquílides”, "Una vindicación de la cabala”, y las varias notas laterales que tocan temas religiosos en Otras inquisiciones.

Un examen de los aspectos religiosos del cuento inspirado en el evangelio de San Marcos, permite señalar algunas claras coincidencias (o resonancias, sería más exacto) entre el desarrollo del relato y la historia que narra esa parte del Nuevo Testamento. Borges sitúa el relato en 1928, exactamente en los "últimos días del mes de marzo" (p. 127), lo cual permite comprobar que remite directamente a la Pascua (cfr. con San Marcos, 14, 1-2, donde se lee "Dos días después era la Pascua, y los días de los panes sin levadura...”). ${ }^{3}$

El protagonista del relato se llama Baltasar Espinosa. Lleva el nombre de uno de los Reyes Magos y su apellido -de clara resonancia judía- remite o anticipa también al sentido de su futura pasión (¿de aquí lo de espinas...?). Es un estudiante de medicina. Recuérdese que los médicos eran antiguamente magos, y que para seres primitivos y analfabetos -como los que lo rodearan durante su estada en la estancia La Colorada-el ser médico posee conocimientos y poderes casi mágicos, inexplicables por otra vía que lo sobrenatural o lo religioso. Según el relato es "uno de tantos muchachos porteños” y nada lo distingue de los otros. Es un hombre como tantos, al que sólo le resta un examen para ser médico.

Borges le adjudica además de estos saberes técnicos dos características que explican ciertos gestos posteriores, y tendrán asombroso efecto sobre sus oyentes. La facultad oratoria (recuérdese que más adelante el protagonista se pondrá de pie para leerles el Evangelio), y una "ilimitada bondad" que lo lleva a no querer ganar nunca, 
para no molestar o degradar a los otros. En el texto tiene la edad de Cristo durante la Pasión, treinta y tres años.

En cuanto a la religiosidad de Espinosa, el autor le adjudica una simplísima recomendación materna que el protagonista cumplirá durante toda su vida: "todas las noches rezara el Padrenuestro e hiciera la señal de la cruz. A lo largo de los años no había quebrado nunca esa promesa” (pp. 127-128). Para no diferenciarlo de todos los demás argentinos de su tiempo, Borges le adjudica opiniones y puntos de vista idénticos a los de muchos de sus coetáneos y coterráneos (p. 128). Este es el protagonista; junto a Espinosa estarán los otros actores del drama, aquellos que lo convierten -o lo identifican- con el agonista del Gólgota: los Gutre.

Pero hagamos una síntesis del argumento. Espinosa es invitado por su primo a visitar una estancia en la provincia de Buenos Aires, que se llama La Colorada. A los pocos días queda solo porque Daniel, su pariente, debe viajar a la Capital por razones de negocio. Una lluvia inesperada cae sobre la zona y desborda el río Salado, el cual inunda todos los alrededores de la estancia, cortando sus caminos. El capataz de la estancia, Gutre, con sus hijos, salva a costa de muchos trabajos la mayoría de los animales del establecimiento. La inundación crece y se encuentran todos aislados completamente del resto del mundo. Al tercer día las aguas han crecido tanto que hacen inhabitable la vivienda del capataz y Baltasar invita a la familia a ocupar una habitación en la casa grande, que es donde él mismo vive.

Deseoso Baltasar de llenar las horas vacías, les lee a sus inesperados huéspedes pasajes del Nuevo Testamento y, en especial, el Evangelio según San Marcos. En una lenta identificación los oyentes van confundiendo al que lee, con el protagonista de lo que lee (a Espinosa con el mártir del Gólgota) y en un proceso que es el núcleo mismo del relato, coincidiendo con la fecha de la historia de Jesús, Espinosa es tratado como éste, y en la última palabra del relato, será llevado a la Cruz.

Por tanto los otros actores (y tal vez habría que decir los verdaderos fautores, los auténticos hacedores y ejecutores) son los Gutres. El padre es el capataz de La Colorada y Borges insiste en destacar su primitivismo y la mudez y tosquedad de todos ellos:

los Gutres eran tres: el padre, el hijo, que era singularmente tosco, y una muchacha de incierta paternidad. Eran altos, fuertes, huesudos, de pelo que tiraba a rojizo y de caras aindiadas. Casi no hablaban. (pp. 128-129)

La otra descripción de los Gutres aparece insertada más adelante, en medio del desarrollo del relato. Ya ha tenido lugar la inundación y se adelantan ahora antecedentes históricos de estos extraños huéspedes. Su nombre originario era Guthrie, oriundos de Inverness, en Escocia. Habían llegado a la Argentina a comienzos del siglo diecinueve "y se habían cruzado con indios": 
La crónica cesaba hacia mil ochocientos setenta y tantos; ya no sabían escribir. Al cabo de unas pocas generaciones habían olvidado el inglés; el castellano, cuando Espinosa los conoció les daba trabajo. Carecían de fe, pero en su sangre perduraban, como rastros oscuros, el duro fanatismo del calvinista y las supersticiones del pampa (p. 132).

Un examen superficial del nombre de estos descendientes de escoceses e indios, muestra dos líneas etimológicas con una raíz básica. Por una parte se remite a la palabra alemana Gott ('Dios'), derivada de la antigua germánica Got y el teutónico Guda ('el ser invocado=Dios'), que a su vez proviene del Indo-Europeo Ghu-tó-m, donde $G h u$ = ‘orar, rezar, invocar’. Los Gutres serían entonces los que invocan a Dios, los que buscan y llaman a Dios.

Por otro lado, el inglés da -como el alemán- además de la línea God ('Dios’), la de Good, cuyo correspondiente alemán Gut significan ‘bueno’ y ‘bien’, pero también 'estancia, hacienda, propiedad'. El adjetivo gut, gutes, da en español 'bueno’, ‘lo bueno’. Esta otra línea podría llevar a descubrir en el nombre Gutres a 'los buenos, los bondadosos, los inocentes’, algo así como los pobres de espíritu, los limpios e inocentes de espíritu.

El sufijo $-I E R$, así como la forma $-R I E$ en inglés, denota 'ocupación carrera, forma de trabajo, condición’, y está relacionada con el latín - arius. Por tanto el nombre de los autores y ejecutores del drama debe (o puede) ser traducido como 'los que hacen lo bueno', 'los invocadores de Dios', ¿los que buscan, inocentes y buenos, a Dios...?

Es evidente que Borges juega aquí con el aura significativa, con el entorno aludido y evocado por estos significados, y ellos conllevan toda esta suma de sugerencias semánticas que, de alguna manera, se corresponden con la función que los Gutres desempeñarán, sin saberlo, en el trágico relato. Así se comprende la observación del narrador, reiterada, sobre el embrutecimiento, la primitivización de estos escoceses en contacto con el campo y la soledad, la lenta caída hacia las formas más elementales de vida, lo que los lleva a olvidar su lengua paterna y a comprender apenas la adquirida. Este hecho de la primitivización de los europeos en contacto con las formas de la naturaleza y la vida americana, es una constante que se dio en la realidad histórica y que algunos autores y narradores argentinos han señalado con frecuencia. ${ }^{4}$ También debe tenerse en cuenta el sentido irónicamente trágico de la referencia a que conservaban "el duro fanatismo del calvinista y las supersticiones del pampa.” Ya veremos que esta observación, deslizada casi al pasar, está destinada a aumentar el margen de ambigüedad, de distanciamiento, entre lo que se narra y la posible inteligencia o comprensión que el que narra puede tener del material que esta narrando.

Inverness es un condado (“county”) de Escocia y también una aldea que es hoy una pequeña ciudad. El actual castillo de Inverness fue construido por Malcolm III 
(Canmore), después de arrasar aquel en el que -se dice- Macbeth asesino a su padre, Duncan I (Duncan fue ejecutado por Macbeth en 1040). Allí está localizada, entonces, la leyenda de Macbeth, expresión simbólica de la ambición de poder y testimonio de la lucha mortal y secular que sostuvieron los celtas (primitivos habitantes de la zona) y los noruegos, que la invadieron. Inverness también fue el centro de la oposición jacobina a los monarcas ingleses. Es un lugar que parece haber fascinado a Borges, o que le atrae por razones personales ya que lo menciona en algún otro texto de su pluma. ${ }^{5}$

Esto nos hace pensar que los Guthrie (el plural inglés sería Guthries) son, por una parte, hombres primitivos arrastrados por una emoción religiosa casi salvaje. Por otra, funcionan y actúan en la historia como un ser indiviso empujado por la divinidad; “son” agentes de un Dios y, tal vez oscuramente, o encarnan y cumplen su voluntad. En ese sentido la familia carece de rostros o de características individuales, actúa como una sola personalidad dividida en tres miembros indiferenciados. No alcanzan a distinguirse, ni a tener un nombre personal. El padre, el hijo y la hija, dos hombres y una mujer, parecen apuntar -oscuramente- a una forma de trinidad. También puede pensarse que simbolizan al pueblo palestino, ¿el que condenará al sacrificio al futuro Mesías...?

Estas y otras tesis (como la posibilidad de relacionar la hija con cierto aspecto de lo femenino en Dios, o con el Espíritu Santo) levemente sugeridas o insinuadas en el cuento, son una de las tantas pistas, de los numerosos indicios directos o indirectos que pululan en el texto, y lo pueblan de oscuros contenidos teológicos y bíblicos cuya misión -creemos- es ir levantando, construyendo en el espíritu del lector un aura religiosa, una atmósfera bíblica que permitirá relacionar la historia que Borges narra, con la que lee a los Gutre el protagonista...Los indicios que relacionan ambas realidades son numerosos; iremos señalándolos a lo largo del cuento.

La inundación desempeña en el texto una función esencial: desde el punto de vista fáctico permitirá el acercamiento y la convivencia de los Gutre con Baltasar. Simbólicamente aisla y separa a los personales del mundo civilizado. ${ }^{7}$ Esta situación de insularidad esta muy bien acotada por el narrador:

En cuanto a sus hermanos y a su padre, ya sabrían por Daniel que estaba aislado -la palabra, etimológicamente, era justa- por la creciente. (p. 132)

Esta soledad y aislamiento absolutos posibilitados por una zona rodeada de agua, instala lo que ahora ocurrirá en un ámbito muy especial doblemente separado del contorno cotidiano y conocido. Ubica la acción en una comarca fuera de la geografía concreta (del espacio determinado y reconocible) en un espacio vago e inalcanzable. Y a la vez rodea los hechos de una muy peculiar atemporalidad. Todo lo que ocurrirá ahora tendrá lugar en una tierra perdida, en un sitio lejano y fronterizo (=una isla) y en un tiempo fuera del tiempo. La atemporalidad facilitará y hará más verosímil la 
terrible alegoría y permitirá su cumplimiento, así como favorecerá el desarrollo del oscuro proceso de identificación que se irá cumpliendo en el alma de los silenciosos y fanáticos Guthries.

La inundación puede y debe relacionarse con el Diluvio bíblico. Un sueño que le acaece a Baltasar parece permitir esta identificación:

Una noche soñó con el Diluvio, lo cual no es de extrañar; los martillazos de la fabricación del Arca lo despertaron y pensó que acaso eran truenos (p. 134).

$¿$ Los martillazos, corresponden a la terrible tarea de los Gutres que preparan la Cruz? ¿O son apenas una confusión -en la duermevela de Baltasar -entre truenos y los ruidos de la construcción del Arca? Obsérvese, sin embargo, que esta referencia posee en el relato una función semejante a la de la inundación: acentúa la atmósfera de intemporalidad e irrealidad y remarca en el espíritu del lector el vago sentimiento de lejanía bíblico-religiosa. Es una manera de agregar a la específica indicación -que ya está en el título del cuento-referida al Nuevo Testamento y a uno de los Evangelios, otra clarísima al Antiguo y, sobre todo, al más arcaico de sus libros, el Génesis (si no el más antiguo en cuento a su fecha de composición, el primero en el orden de la teogonía judeo-cristiana).

Nótese además que los hijos de Gutre son tres, como eran tres los de Noe. Aunque en el Génesis se trata de tres varones (Sem, Cam y Jafet) y aquí de dos varones y una mujer.

El relato (que es un típico proceso dramático en el cual quienes rodean a un hombre lo van convirtiendo en otro diferente, y ese Otro ha sido definido y dibujado por el mismo a través de sus palabras) es un proceso de cambio, de transformación del protagonista, que se va señalando a través de dos notas: a) la acentuación de actitudes y referencias y resonancias religiosas; b) leves y sostenidos cambios en su apariencia externa y también en sus formas íntimas. El único que no parece tener clara conciencia de este tremendo y terrible y complejo proceso es quien lo sufre y lo cumple, Baltasar. Esta ceguera, que es una de las formas más admirables de la llamada ironía trágica, sólo parece develarse al final, en las últimas palabras del narrador.

El cuento dice que hacía calor y que comenzó la tormenta. Su inicio es recibido con alivio religioso por Espinosa:

El calor apretaba y ni siquiera la noche traía un alivio. En el alba, los truenos lo despertaron. El viento zamarreaba las casuarinas. Espinosa oyó las primeras gotas y dio gracias a Dios. El aire frío vino de golpe. Esa tarde, el Salado se desbordó (p. 129).

En muchas actitudes y aun observaciones o pensamientos de Espinosa hay una como inocente ceguera. ¿Da gracias a Dios porque llega un alivio para el calor 
sofocante...o inconscientemente sabe que gracias a la tormenta se pondrá en contacto con los Gutre y se cumplirá su Pasión...? Más tarde, cuando están todos juntos en la casa principal, Baltasar se ha dejado crecer la barba. El mismo tiene conciencia de que ese simple hecho ha cambiado su apariencia externa:

Espinosa, que se había dejado crecer la barba, solía demorarse ante el espejo para mirar su cara cambiada (p. 131).

Esta circunstancia casi casual, agrega a la visión de los Guthries un nuevo elemento de coincidencia entre el agonista del Evangelio y el estudiante de medicina. Primitivos, supersticiosos, inocentes, un hombre con barba (a ellos, que suponemos lampiños) los lleva a encontrar semejanzas que otros no verían. Y esa circunstancia se acentúa, se destaca de modo marcado y absorbente, en el mundo cerrado y cercano en que viven.

Deseoso de entretener las horas vacías Baltasar lee a sus huéspedes varios textos. Comienza con Don Segundo Sombra, que parece no interesar al capataz, ya que trata la vida de un resero, oficio que también Gutre ha desempeñado. ${ }^{8} \mathrm{Al}$ descubrir una Biblia y elegir para leerles el texto de San Marcos, las referencias y resonancias religiosas (y las coincidencias con el mismo Evangelio que lee) se adensan y hacen más frecuentes. Baltasar lee una Biblia inglesa que perteneció a la familia de los Guthrie. Al leerla traduce directamente al español (lo cual podría ser una reminiscencia de Marcos, 16, 17-18: “A los que creyeren, acompañarán estos milagros: en mi nombre lanzaran los demonios, hablaran nuevas lenguas...”).

El ex-estudiante de oratoria recuerda las clases que recibiera años antes, y alentado por la atención de su extraño y silencioso auditorio y público, "se ponía de pie para predicar las parábolas” (p. 133), lo cual parece una clara alusión a Marcos, (2, 13 y 4), cuando Jesús predicaba junto al mar (recuérdense los comentarios que el narrador pone en boca de Baltasar, comparando a la pampa con el mar, y a los terrenos anegados con el agua que rodea una isla). ${ }^{9}$ Nótese además como Borges, con un astuto uso del verbo aumenta la coincidencia entre lo leído en el texto, y lo que hace el que lee ese mismo texto: las parábolas, al ser leídas de pie por Baltasar, reasumen su antiguo valor oratorio; además el texto acota que las "predicaba...”.

En la misma página 133 aparece otra reminiscencia bíblica:

Una corderita que la muchacha mimaba y adornaba con una cintita celeste se lastimó con un alambrado de pica. Para parar la sangre, querían ponerle una telaraña; Espinosa la curó con una pastilla. La gratitud que esa curación despertó no dejó de asombrarlo.

Este episodio debe relacionarse (fue relacionado por los oyentes de Espinosa) con los milagros que describe San Marcos, en los capítulos 1, 2, 3, 5, 6, 7, 8 y 9 donde 
Jesús cura a endemoniados, leprosos, paralíticos, ciegos, un niño loco, etc. Cada uno de estos hechos va acentuando, agregando nuevos argumentos, nuevas realidades concretas, a la identificación entre quien lee el Evangelio, y el agonista de esos Evangelios.

Cada nueva lectura del mismo texto va acercando e identificando -en la mente y el alma de sus silenciosos y obedientes oyentes primitivos- a Baltasar con el Jesús que ellos redescubren y reconocen a través del texto milenario. Y los hechos parecen reforzar esa identificación, porque no solo lo que escuchan y los gustos y acciones del que les había, contribuyen a esa identificación. También los Guthrie comienzan a actuar aceptándola, acomodan su actitud a la nueva situación que determina ese reconocimiento silencioso. Es por eso que miman al hombre con el que conviven obedeciendo sus menores deseos y atendiendo sus mínimos gustos. También valoran como sagrados los restos de pan que Baltasar deja en la mesa:

...ahora, ausente del patrón, él había tomado su lugar y daba órdenes tímidas, que eran inmediatamente acatadas. Los Gutres lo seguían por las piezas y por el corredor, como si anduvieran perdidos. Mientras leía, notó que le retiraban las migas que el había dejado sobre la mesa. Una tarde los sorprendió hablando de él con respeto y pocas palabras (pp. 133-134).

Varias son aquí las reminiscencias del Nuevo Testamento. La obediencia de los Apóstoles, la desorientación que los invade en ciertos instantes (como en Marcos, 10, 32 “...estaban sus discípulos como atónitos, y le seguían llenos de temor”). La notable referencia al misterio de la Eucaristía (Marcos, 14, 22) que debe verse también como una forma de bendición (los panes tocados por Baltasar están benditos...).

La ironía trágica, esa condición del agonista que es el único ciego, el único que no advierte -hasta el último instante- que todo lo lleva hacia un final irremisible e inevitable, esa ceguera que no le permite advertir que cada cosa que hace -por inocente y casual que ella parezca- decide y dirige su destino, aparece numerosas veces en el relato. El único que no alcanza a atisbar -siquiera-la identificación a que está sujeto es, claro, Baltasar.

La cronología de la Pasión tradicional esta cuidadosamente marcada y respetada en el cuento:

El temporal ocurrió un martes. El jueves a la noche lo recordó un golpecito suave en la puerta...El día siguiente comenzó como los anteriores (pp. 134-135).

Baltasar será crucificado el viernes. Y también la hora coincide con lo que señala el texto de San Marcos $(15,25)$. El cuento indica:

Después del almuerzo, le pidieron que releyera los últimos capítulos. Espinosa durmió una siesta larga, un leve sueño interrumpido por persistentes martillos y por vagas premoniciones. Hacia el atardecer... 
Además de esta coincidencia cronológica, relaciónese lo de las premoniciones, con Marcos, 14, 34-36. El problema de la cronología y de las horas esta resuelto por Borges ateniéndose al relato tradicional. Por otra parte en ningún momento nuestro escritor toca el vasto y polémico asunto de la historicidad y de la existencia terrena de Jesús ${ }^{10}$, ni se hace problema sobre ello.

Hay otras identidades con el texto bíblico. Cuando Gutre interroga a Baltasar sobre el infierno, su definición (p. 135) debe relacionarse con la de Marcos (9, 42-48). Y la pasión de Baltasar está inspirada en la versión bíblica (Marcos, 10, 33-34), así como otras coincidencias (Marcos, 15, 16-39).

El viernes, el capataz interroga a Baltasar sobre la razón de la muerte de Cristo, y si sus victimarios fueron salvados. Espinosa, que ignora casi todo sobre teología, "se vio obligado a justificar lo que había leído” (p. 135), esto es, da las respuestas ortodoxas. Todavía ignora y no comprende este interés del padre, y hasta siente cierto temor por el episodio que ha vivido la noche anterior con la muchacha. Después duerme una siesta y, al despertarse, Baltasar que esta por irse y espera el fin de la inundación para volver a la Capital, dice: "Ya falta poco". Gutre da a sus palabras un sentido totalmente distinto, porque está esperándolo, junto con sus hijos, para el sacrificio. Así es como las palabras de Espinosa se convierten en un "consumatum est” sobre sí mismo (Cfr. Marcos, 14, 41).

En las últimas líneas del relato (p. 136) la familia solicita su bendición, de rodillas sobre el piso de piedra, y después realiza con e1 los mismos gestos que los soldados romanos en el Gólgota:

Después lo maldijeron, lo escupieron y lo empujaron hasta el fondo. La muchacha lloraba. Cuando abrieron la puerta, vio el firmamento. Un pájaro gritó; pensó: Es un jilguero. El galpón estaba sin techo; habían arrancado las vigas para construir la Cruz.

Obsérvese la mirada de Baltasar hacia el Cielo, y el canto del pájaro que puede relacionarse con el gallo de San Pedro.

Hay un episodio, sin embargo, que rompe todas estas coincidencias y similitudes. Es el que tiene lugar el jueves por la noche (la noche anterior al Viernes en que Baltasar será crucificado). Este episodio resulta muy difícilmente insertable en el contexto bíblico y, a la vez, representa una de las mayores dificultades interpretativas del cuento. Copiamos el pasaje:

El jueves a la noche lo recordó un golpecito suave en la puerta que, por las dudas, el siempre cerraba con llave. Se levantó y abrió: era la muchacha. En la oscuridad no la vio, pero por los pasos notó que estaba descalza y después, en el lecho, que había venido desde el fondo, desnuda. No lo abrazó, no dijo una sola palabra; se tendió junto a él y estaba temblando. Era la primera vez que conocía a un 
hombre. Cuando se fue, no le dio un beso; Espinosa pensó que ni siquiera sabía como se llamaba. Urgido por una íntima razón que no trató de averiguar, juró que en Buenos Aires no le contaría a nadie esa historia (pp. 134-135).

La muchacha se entrega como una forma de ceremonia casi religiosa; nada en sus gestos y actitudes permiten deducir una justificación erótica o lúdica (que es una de las más altas formas del amor humano). No abraza a Baltasar, no habla con él, no lo besa. Cumple algo que la aterra o teme: tiembla, y en lo cual interviene su voluntad (u otra fuerza externa a ella que la empuja u obliga a realizar un acto del que no participa). Y esta es la primera nota que debe destacarse: es un rito, el cumplimiento de una promesa o de una orden acatada, o una forma de agradecimiento lo que lleva a una virgen, a entregarse a Baltasar. Se entrega sin participar ni reaccionar.

Si nos instalamos en el relato, podríamos explicar esta actitud de ella como una forma de agradecimiento. Baltasar ha curado a su corderita; al no tener que darle, le entrega lo único que ella considera valioso: su cuerpo. Otra posibilidad, siempre dejando de lado toda motivación religiosa en la muchacha sería esta: ella siente profundo agradecimiento por él. Se opone a que lo maten (recuérdese que llora cuando lo llevan a la cruz, p. 136), pero como sabe que su destino está sellado y es irreversible, le regala su cuerpo, como el más magnífico presente que puede hacer a un condenado a muerte...

Si pensamos ahora en las relaciones alegóricas o en las reminiscencias bíblicas del pasaje, las interpretaciones podrían ser varias. Todas espinosas y ninguna suficientemente aceptable. Si partimos de la idea de que ella, como los otros Gutres (padre y hermano) está segura de que Baltasar es un nuevo Cristo reencarnado, y de que su destino es idéntico al del Evangelio, podrían aducirse algunas hipótesis. Sabe que Baltasar será insultado, golpeado, escarnecido, crucificado. Que su muerte será de las más terribles y dolorosas. Y quiere darle lo más valioso que tiene, que es lo único que tiene. Ella, como la mujer pobre que entrega dos denarios para el Señor, da mucho más que los ricos (San Marcos, 12, 42-44). También puede pensarse que ella corresponde en el texto a la mujer que lleva ricos ungüentos para ungir el cuerpo y los cabellos del Señor antes de su Pasión, y ella le da lo único bueno y alegre que posee (Marcos, 14, 3-9).

Si buscáramos una conexión alegórica, también podríamos pensar que la entrega sexual se corresponde analógicamente con la entrega de Jesús a los romanos. La joven entra en la habitación por la noche, como Judas en la granja de Getsemaní, e identifica a Cristo con un acto -aparentemente- de amor, para que sea capturado.

Hay algo que no debe ser dejado de lado, y es que ella va y se entrega a Baltasar, como en una ceremonia. Baltasar acepta el presente y como lo considera ilegal (o por lo menos que afectará la honra de su padre y su hermano), se limita a aceptarla y tomarla, y decide que guardara silencio sobre el hecho. Y ella, como parte indiferenciada de los Gutre, debemos suponer que ejecuta una decisión colectiva. ¿Qué lleva a los 
Gutre a esta resolución...? También las respuestas son varias, ninguna objetivamente demostrable, y todas (como todo el cuento) lastradas de ambigüedad. Una será que los Gutre desean una prueba de la humanidad de Baltasar, de que es realmente un hombre; y la entrega sexual comprueba su corporalidad. Ellos necesitan estar seguros de que él será el agente de su salvación, y para esto deben saber que pueden matarlo en la cruz.

También puede apuntarse una forma primitiva de posesión de esa divinidad, que ellos encuentran encarnada en Baltasar. Los Gutre, como totalidad, crucificaran a su salvador. Desean poseer, como herencia, una parte de esa divinidad, y lo harán buscando engendrar un hijo posible de Baltasar en la muchacha. ${ }^{11}$

Podemos volver además a la idea ya expuesta de que los Gutre representan al pueblo eterno: todo hombre de todos los tiempos, y aquí representarían el pueblo, la gente palestina de la época de Herodes. Claro que aceptar este punto de vista supondría toda una interpretación borgeana (y herética) del hecho mismo de la Pasión y divinización de Cristo: el Jesús real sufrió un destino muy parecido al de Baltasar, fue identificado con Dios por un pueblo inocente y primitivo, y aeeptó esa condición un poco impuesta y resuelta por los otros. Y Baltasar reiteraría una historia ocurrida hace dos mil años, la de un hombre transformado en Dios por la gente que lo rodea, que acepta ese destino.

Hay también un hecho obvio que no debemos dejar de lado. Tal vez la más prudente de las lecturas de este episodio (y del cuento) consista no solamente en ver las similitudes y reminiscencias astutamente destacadas por Borges, sino también las notables diferencias. Y tal vez este aspecto (este episodio) este destinado esencialmente a mostrar las enormes diferencias que separan a Baltasar, de Cristo. Lo que ha querido mostrar Borges con esta parte del cuento es algo más trágico, lo más trágico de todo: los parecidos e identidades entre Baltasar y el protagonista del Evangelio son casuales, son producto de la falsa comprensión de la realidad por un conjunto de seres primitivos, engañados por uno o dos datos sin importancia. Y empujados por un fanatismo oscuro y feroz. La muchacha se entrega por curiosidad, por capricho, por motivaciones religiosas, por orden de su padre, como una forma de agradecimiento, por dar una última y definitiva alegría a quien va a morir, etc. etc. No interesa por que lo hace. Lo fundamental es que Borges aquí ha repetido, sobre un cañamazo argumental distinto, una idea constante en su obra: la del eterno retorno, la de la ahistoricidad y reiteración de los gestos y los actos humanos.

El episodio del jueves por la noche está puesto allí para señalar las diferencias absolutas entre Baltasar y el protagonista del Evangelio. Su muerte repetirá, como en un espejo distante situado en la eternidad, una historia ocurrida hace muchos años, encarnada por un hombre cualquiera. No se olvide que estas coincidencias entre ciertos actos humanos, entre ciertos episodios, han deslumbrado a Borges. Esta idea de la reiteración de la historia es una de las paradojas que ha obsesionado a Borges toda su vida. Ya en "La doctrina de los ciclos" y en "El tiempo circular” (ambos textos en Historia de la eternidad) así como en la "Nota sobre Walt Whitman” (en 
Discusión), Borges analizó la teoría del tiempo cíclico e intentó sintéticamente su historia, desde Pitágoras hasta Nietzsche. ${ }^{12}$ De todas las versiones de esta teoría nuestro escritor ha dicho que prefiere aquella que postula que los ciclos se repiten infinitamente, pero en lugar de ser iguales, son similares (Historia de la eternidad, Buenos Aires, 1953, p. 94).

La historia del asesinato de César, por ejemplo, aparece en varios de sus cuentos; en unos se corresponde con la verdad histórica de la Roma del siglo I antes de Cristo (así en "La trama” de El Hacedor). ${ }^{13}$ En otros casos los hechos no se inspiran en la historia concreta, sino en la versión que de ella diera Shakespeare en uno de sus dramas (“Tema del traidor y del héroe”, en Ficciones). Creemos que en esta reiteración inesperada, indeseada, terrible del Evangelio, Baltasar cumplirá el destino que le es impuesto a través de la visión que de él se da en un texto escatológico. Y las diferencias entre el protagonista que está en el texto predicado, y el protagonista del relato, confirma las similaridades con que la historia cíclicamente se repite de modo infinito y siempre inevitable.

University of Cincinnati

RODOLFO A. BORELLO

\section{NOTAS}

1 Léanse las observaciones que hicimos en "Habla coloquial y lengua literaria en las letras argentinos”, Anales de Literatura Hispanoamericana, Madrid, Universidad Complutense, 1972, no. 1, pp. 36-42. Todas las citas que se harán de El informe de Brodie, están tomadas de la primera edición, Buenos Aires, Emecé, 1970.

2 Imposible acotar todas las alusiones al tema religioso que aparecen en estudios sobre Borges; pero los dedicados especialmente a ese aspecto de su obra son escasos. El único que toca especialmente ese asunto es “Fascinación de la kabbale”, volumen de Homenaje de L'Herne, Paris, 1964, pp. 265-271. Como buena síntesis del llamado 'panteísmo’ borgiano, véase el capítulo/homónimo del excelente libro de Jaime Alazraki, La prosa narrativa de J.L.B., Madrid, Gredos, 1968, pp. 60-82. Es importante también recordar algo que Borges escribió hace años sobre sus preocupaciones religiosas: "No sé que opinará el lector, de tales conjeturas semiteosóficas. Los católicos (léase los católicos argentinos) creen en el mundo ultraterreno, pero he notado que no se interesan en él. Conmigo ocurre lo contrario; me interesa y no creo”, Discusión, Buenos Aires, 1957, p. 174.

3 Todas las citas del Evangelio se toman de Nuevo Testamento de Nuestro Señor Jesucristo, traducción del Dr. Félix Torres Amat, anotado por Mons, Dr. Juan Straubinger, Buenos Aires, Guadalupe, 1949.

4 El tema de la barbarización de los europeos en contacto con la vida elemental de América, es asunto que aparece en numerosos cronistas, y que se dio como una constante en el Río de la Plata, sobre todo en los primeros siglos de la Conquista y hasta aparece documentada durante los siglos XVIII y XIX. En varias narraciones de Benito Lynch, el novelista argentino, aparece reiterada esta idea aplicada al efecto deletéreo -de tipo cultural y aun con respecto a las costumbres y los valores- que la vida solitaria del campo, ejerce sobre los europeos cultos (véase por ej. Los caranchos de la Florida, El inglés de los güesos, etc.). 
5 En “El Aleph”: “...vi en Inverness a una mujer que no olvidaré”, El Aleph, Buenos Aires, 1961, p. 165. ¿Hay otros textos donde el lugar reaparece en su obra?

6 Ese leve pellizco “...de incierta paternidad...”, aplicado a la hija mujer de Gutre parece acotar distintas interpretaciones: que ella era distinta a su padre y a su hermano, que sería hija de otro padre, que no tendría nada que ver con la familia, ¿que apunta oscuramente a simbolizar el Espíritu Santo..?

7 Un cuento magistral de Ezequiel Martínez Estrada apela también a la insularidad de una inundación, para convertir a un grupo de gente en símbolo de la humanidad, véase $L a$ inundación, Buenos Aires, Cuadernos de la Quimera, Emecé, 1944.

${ }^{8}$ Borges ha adjudicado a Baltasar ideas, gustos y actitudes que son las suyas, las de su educación y su tiempo. Para no citar el texto del cuento, véanse las ideas de p. 128; el padre de Baltasar, como el de Borges, era librepensador y lector de Spencer, p. 127; las cosas que descubre Espinosa sobre el campo, reaparecen en otros textos descubiertas por Borges, p. 129; le gusta el café con mucha azúcar, como a nuestro escritor, p. 134; son irónicas las observaciones que hace sobre qué es una guitarreada (p. 131) y las de la indiferencia con que la gente campesina escucha relatos sobre el campo, o con las que oye la poesía gauchesca: Borges siempre ha sostenido que el género -y el interés por lo gauchesco- es un invento ciudadano, una chifladura de hombres cultos... Como el mismo escritor observó en el epílogo de El libro de arena, Buenos Aires, Emecé, 1975, p. 180, comentando "El Congreso": "En su decurso he entretejido, según es mi hábito, rasgos autobiográficos”.

9 En diversas partes de su obra Borges ha atribuido -o ha unido- a los viajeros ingleses, la imagen de comparar la pampa con el mar. En este relato, pp. 129-130, relaciona esa metáfora con Hudson. Es importante recordar que la comparación ya esta en La Cautiva de Esteban Echeverría, publicada en 1837 (versos 1-15).

${ }^{10}$ En su relato Borges no ha pretendido en ningún caso rodear de datos precisos -o aun históricos-las referencias a la vida concreta de Nuestro Señor. Esto sería por otra parte muy difícil ya que la historia verdadera de Jesús -el problema de su historicidad- ha dado origen a una inmensa y polémica bibliografía cuya extensión y complejidad la hace simplemente inalcanzable aun para los especialistas. Para quien se interese en este vasto problema puede consultarse como obra general de referencia a Charles Guignebert, Jesús, México, Uteha, 1961, vol. XLIV de "La Evolución de la Humanidad”, traducción de A. Garzón del Camino (véase especialmente la parte dedicada a la Pasión, pp. 357 y ssgs.). La parte sobre Cronología ha sido bien estudiada por Guignebert, pp. 367-373. Pueden también consultarse algunas de las grandes enciclopedias, como la de Religión y Ética de Hastings, 1908-1921; el Dictionaire d'archeologie chretiene... de Dom Cabrol y Leclercq, 1903; The Catholic Encyclopedia, 1917, etc. etc. Desconozco la bibliografía española sobre el tema. Es además indispensable diferenciar la esfera de la fe (y dentro de ella la teología católica ortodoxa, de la protestante), y lo relativo a la realidad histórica propiamente dicha.

Borges ha partido de la relación del segundo Evangelio, al que sigue en general con bastante fidelidad, y ha situado su historia en un contexto distinto, quedándose solamente con los aspectos más elementales del relato tradicional.

${ }^{11}$ El episodio esta relacionado además con un hecho espinoso y complejo: el de la sexualidad de Jesús, cuestión que en la tradición católica y en la protestante en general ha sido rechazada. Para la ortodoxia católica (y para casi todas las sectas heterodoxas) Jesús fue casto y puro durante toda su vida humana. Hay un cuento famoso (por el escándalo que produjo su heterodoxia) que escribió D. H. Lawrence, quien siguiendo su idea de que la 
sexualidad es un componente fundamental de la existencia del hombre, imaginó una experiencia sexual para el Mesías entre la Resurrección y la Asunción; véase El hombre que murió.

12 El tema, el más constante de toda su obra, alcanza su más admirable realización en "La noche cíclica”, poema de 1949: "Lo supieron los arduos alumnos de Pitágoras: / Los astros y los hombres vuelven cíclicamente; / Los átomos fatales repetirán la urgente / Afrodita de oro, los tebanos, las ágoras...” (Obra poética, Buenos Aires: Emecé, 1964, pp. 142-143).

1 Es conducente reproducir aquí parte del cuento en el que Borges, más que repetir el episodio romano, escribe la historia del grito patético y resignado con que César ve que uno de sus asesinos es aquel que crió como un hijo (“Tú también, hijo mío!”, que el dramaturgo inglés y Quevedo recogieron). Luego relaciona aquel lejanísimo episodio, con este de un gaucho: "Al destino le agradan las repeticiones, las variantes, las simetrías: diecinueve siglos después, en el sur de la provincia de Buenos Aires, un gaucho es agredido por otros gauchos $\mathrm{y}$, al caer, reconoce a un ahijado suyo y le dice con mansa reconvención y lenta sorpresa (estas palabras hay que oírlas, no leerlas): ‘¡Pero, che!’ Lo matan y no sabe que muere para que se repita una escena”, El Hacedor, Buenos Aires, Emecé, 1960, p. 28. Baltasar también parece morir para reiterar una dramática y terrible escena de trascendencia ecuménica. 


\title{
Textos y Contra-Textos en \\ "E1 jardín de senderos que se bifurcan”
}

\author{
"Any text is the absorption and transformation of \\ a multiplicity of other texts." \\ Julia Kristeva \\ Semeiotikè (Paris, 1969)
}

Hasta ahora el cuento “El jardín de senderos que se bifurcan” ha sido considerado como una narración al estilo de Chesterton, un "sencillo" cuento de detectives con ciertos alardes metafísicos que caracterizan la totalidad de la obra borgiana: laberintos, vidas paralelas y juegos con el tiempo. Al hablar de la colección de cuentos El jardín de senderos que se bifurcan, aun Borges ha calificado su cuento como "policial”: "Las ocho piezas de este libro no requieren mayor elucidación. La octava ('El jardín de senderos que se bifurcan') es policial: sus lectores asistirán a la ejecución y a todos los preliminares de un crimen, cuyo propósito no ignoran pero que no comprenderán, me parece, hasta el último párrafo.”1

Tal vez las consideraciones críticas hasta este momento han sido basadas en esta calificación de Borges. Martin Stabb, por ejemplo, considera el cuento una narración esencialmente realista, con elementos fantásticos interpuestos. ${ }^{2}$ No obstante, un cuidadoso análisis de la obra revela un juego, no sólo de intratextualidad entre los diversos planos, sino de intertextualidad, sugerida concretamente por la doble realidad del cuento.

Para facilitar el análisis de la entidad semántica abarcada por "El jardín de senderos que se bifurcan”, y para distinguir los diversos niveles de la realidad ficticia de esta entidad o sea, para analizar su intratextualidad, se utilizará un esquema de planos. Este esquema posibilitará la captación de parte del lector de los diversos planos de la realidad ficticia y de las múltiples y contradictorias relaciones plasmadas por el juego de la intertextualidad. En primer lugar, hay que señalar que la entidad "El jardín de senderos que se bifurcan” se refiere a una serie de realidades ficticias. Al principio, esa entidad sería un libro de cuentos, publicado en 1941, que llevaba el título El jardín de senderos que se bifurcan. Dentro de esta realidad ficticia, aparece el plano A, un cuento denominado también "El jardín de senderos que se bifurcan," y encajada dentro del plano A, se distingue otra serie de textos/realidades. 
El plano A empieza por citar un texto de Liddell Hart, la Historia de la Guerra Europea, texto y plano que denominaremos B. ${ }^{3}$ Luego, aparece el texto de la declaración de Yu Tsun, texto que según el narrador ficticio “arroja una insospechada luz sobre el caso” (p. 101) narrado en el plano B. El texto de la declaración de Yu Tsun o sea, el plano $\mathrm{C}$, se extiende hasta el final del plano A, reemplazando a B, y convirtiéndose en el primer plano de la narración. El cuento termina con la narración enmarcada de C: “NNo sabe (nadie puede saber) mi innumerable contrición y cansancio”” (p. 116). Al final el lector no sale otra vez ni al plano B ni al plano A, y el plano $\mathrm{C}$ reemplaza a los planos ficticios anteriormente esbozados.

Dentro del plano C se establecen otras entidades que también corresponden a la entidad semántica "El jardín de senderos que se bifurcan.” Primeramente, Yu Tsun emprende un viaje que lo hace seguir una trayectoria laberíntica para llegar a la casa de Stephen Albert: “'La casa queda lejos de aquí, pero usted no se perderá si toma ese camino a la izquierda y en cada encrucijada del camino dobla a la izquierda", (p. 106). El consejo de siempre doblar a la izquierda le recuerda que tal era el procedimiento común para descubrir el patio central de ciertos laberintos. El camino baja y se bifurca, entre las ya confusas praderas, hasta conducirlo a un pabellón en el centro del cual lo espera Stephen Albert. Y éste le dice sin ningún preámbulo: “‘¿Usted sin duda querrá ver el jardín? -¿El jardín? -El jardín de senderos que se bifurcan. ... -El jardín de mi antepasado Ts’ui Pên’” (p. 108). Aquí la entidad semántica apelada por “el jardín de senderos que se bifurcan” cobra otro significado, significado que abre otro plano en la realidad ficticia, un plano D o sea, el fenómeno evocado por “El jardín de senderos que se bifurcan” de Ts’ui Pên. Como se verá a continuación, el plano D encierra un misterio, una doble realidad, un libro/laberinto, que será motivo de la conversación entablada entre Stephen y Yu Tsun.

Antes de seguir adelante, conviene resumir esquemáticamente los diversos planos de la entidad semántica:

\section{DIAGRAMA I}

$$
\begin{aligned}
& \mathrm{A}=\quad \begin{array}{l}
\text { Cuento (“El jardín de } \\
\text { senderos que se bifurcan” }
\end{array} \\
& \mathrm{B}=\quad \begin{array}{l}
\text { Texto de Liddell Hart } \\
\mathrm{C}=\quad \text { Declaración de Yu Tsun }
\end{array} \\
& \mathrm{D}=\quad \begin{array}{l}
\text { "El jardín de senderos que } \\
\text { se bifurcan de Ts’ui Pên” }
\end{array}
\end{aligned}
$$

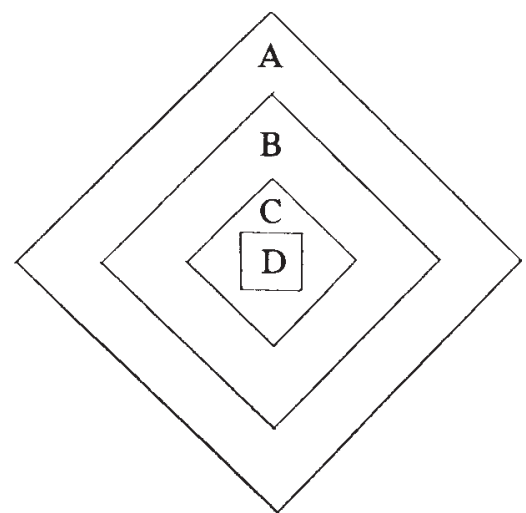

Al dibujar la caja china de relaciones textuales, se evidencian los típicos textos/ estructuras/metáforas que pueblan la obra narrativa de Borges: el mapa visto por 
Hladik, los espejos de Lewis Carroll, el Golem y la edición de Las mil y una noches de Weil que nunca logró leer Dahlmann, etc. Como regla general la estructura de caja china o el regressus infinitus, junto con el juego del doble, ilustran la temática de la ilusoriedad del yo y apuntan hacia ciertas verdades encarnadas en la filosofía oriental idealista. ${ }^{5}$

Considerada así, la estructura de caja china de "El jardín de senderos que se bifurcan” sería un ejemplo de la adecuación de la forma al contenido, donde el medio es el mensaje. Sin embargo, la imagen de la caja china es lineal; un hombre soñado por otro implica un regreso infinito. Puesto que tales juegos apuntan hacia la ilusoriedad del ser, Yu Tsun debe reconocer su ilusoriedad, hecho que en el texto C no se comprueba claramente.

La multiplicidad de planos textuales se presta a una variedad de lecturas hipotéticas que responden a las diversas interpretaciones posibles de los estratos textuales superpuestos y de los elementos simbólicos latentes en cada estrato. La primera lectura se basará en el esquema de la caja china, donde cada caja o plano se mantiene como un fenómeno aislado. En esta primera lectura la encadenación de acontecimientos será explicada por medio de las leyes de causa y efecto, leyes implícitas en el pensamiento dialéctico occidental. No obstante, también se vislumbrara la existencia de una serie de fenómenos que parecen contradecir la teoría, también occidental, de las leyes de probabilidad o sea, las leyes del juego occidental. ${ }^{6}$ Dentro del pensamiento dialéctico estos hechos constituyen meras coincidencias.

Primera lectura:

Descartando por el momento la relación del libro de cuentos El jardín de senderos que se bifurcan con el plano A, empezaremos con los textos encajados en A o sea, con B. En el primer párrafo el narrador ficticio cita parafrásticamente el texto de Liddell Hart:

En la página 22 de la Historia de la Guerra Europea, de Liddell Hart, se lee que una ofensiva de trece divisiones británicas (apoyadas por mil cuatrocientas piezas de artillería) contra la línea Serre-Montauban hacia sido planeada para el veinticuatro de julio de 1916 y debió postergarse hasta la mañana del día veintinueve. Las lluvias torrenciales (anota el capitán Liddell Hart) provocaron esa demora -nada significativa, por cierto- (p. 101).

Aunque la voz narradora se demora en enumerar una serie detallada de hechos, termina observando que la demora citada no era "nada significativa, por cierto.” Al calificar la demora como poco importante, el lector se despista y no presta demasiada atención a los detalles previamente enunciados. Luego, sin más ni más, el narrador continua diciendo: “'La siguiente declaración, dictada, releída y firmada por el doctor Yu Tsun, antiguo catedrático de inglés en la Hochschule de Tsingtao, arroja una insospechada luz sobre el case'” (p. 101). Puesto que el mismo narrador ha calificado de insignificante la demora causada por las lluvias torrenciales, el lector se inclina a 
pensar que lo que sigue en el plano C, tendrá alguna vinculación con la ofensiva de las trece divisiones británicas, apoyadas por mil cuatrocientas piezas de artillería, contra la línea Serre-Montauban en el norte de Francia.

La declaración de Yu Tsun empieza in medias res y el lector, intrigado por el mundo del protagonista, pronto pierde conciencia de la naturaleza enmarcada de lo narrado. Sin embargo, el lector perito en materia perteneciente a la Primera Guerra Mundial, verá dentro de poco una posible vinculación entre B y C cuando llega al pasaje:

pensé que ese guerrero tumultuoso [ Richard Madden ] y sin duda feliz no sospechaba que yo poseía el Secreto. El nombre del preciso lugar del nuevo parque de artillería británico sobre el Ancre. Un pájaro rayó el cielo gris y ciegamente lo traduje en un aeroplano y a ese aeroplano en muchos (en el cielo francés) aniquilando el parque de artillería con bombas verticales. Si mi boca, antes que la deshiciera un balazo, pudiera gritar ese nombre de modo que lo oyeran en Alemania (p. 103).

La vinculación entre B y C es obvia porque el río Ancre está situado cerca de la línea Serre-Montauban (véase el diagrama II). ${ }^{7}$ Pero este mismo lector no podrá vislumbrar el plan que utilizará Yu Tsun para comunicar el nombre del nuevo parque de artilleria. ${ }^{8}$

DIAGRAMA II

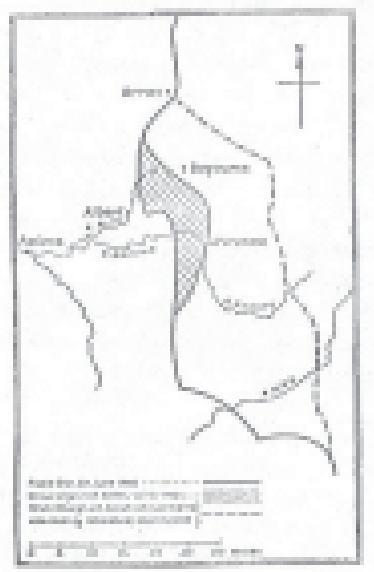

$\mathrm{Al}$ adentrarse en la acción del plano $\mathrm{C}$, el lector se desvanece en el lenguaje mimético, entregándose cada vez más al mundo de Yu Tsun; un mundo dramático, 
lleno de peligro, un verdadero James Bond amarillo, un espía chino perseguido por el implacable capitán irlandés, pistolas automáticas, una huida frenética. ${ }^{9} \mathrm{Y}$ dentro de toda esa acción melodramática anglo-alemana, hay el paulatino reconocimiento de parte del lector de que las acciones de su espía amarillo están condenadas de antemano, porque en el plano $\mathrm{C}$ se delata (entre paréntesis) lo que le espera al muy astuto Yu Tsun: “'En mitad de mi odio y de mi terror (ahora que no me importa hablar de terror: ahora que he burlado a Richard Madden, ahora que mi garganta anhela la cuerda)'” (p. 103). En esa primera lectura, el protagonista es concebido existencialmente: se encuentra en una situación limítrofe y elige libremente su propio destino.

El lector desprevenido se entrega al lenguaje mimético de lo narrado del plano C, impulsado por la situación precaria del protagonista. Dentro del mundo de Yu Tsun el lector siempre está consciente del poco tiempo que le queda al espía. La tensión crece dentro de la realidad tangible del cuento policíaco; Yu Tsun tiene que llevar a cabo su plan antes de que lo mate Madden. El ímpetu del tiempo se destaca a cada paso, subrayando la situación límite del protagonista: “'Me apresuré [...] Recorrí los coches"” (p. 105). Se advierte la importancia del horario de trenes-fortuitamente, Yu Tsun se adelanta a su perseguidor por unos cuarenta minutos.

El rápido, emocionante e intrigante desarrollo de la trama atrapa al lector hasta que el plano $\mathrm{C}$ sufre un repentino cambio de orientación, un cambio que señala otro nivel de lo narrado. Durante el viaje se nota un marcado contraste entre el ambiente previo de Staffordshire y el ambiente tranquilo, nocturno de Ashgrove, y el movimiento staccato de lo narrado cede a un ritmo más lento, contemplativo. El viaje por tren en la obra borgiana casi siempre implica un viaje al otro mundo, el tránsito al otro lado. En “El Sur,” por ejemplo, Dahlmann, al emprender el viaje (alucinatorio o no), pasa por una ruptura entre el tiempo presente y el tiempo pasado, reviviendo el destino de otro. ${ }^{10}$ Parecido a lo que ocurre en “La muerte y la brújula,” el escenario aquí adquiere un aspecto confuso, un aire misterioso e irreal que suele señalar la irrupción del mundo sagrado en el mundo profano. ${ }^{11}$ Llega al atardecer, tiempo amorfo entre día y noche, tiempo que corresponde a un posible hueco, un intersticio en la realidad. Al bajar del tren, Yu Tsun no puede distinguir la cara de los dos niños que quedan en la zona de sombra. Uno le interroga: “ ¿¿Usted va a casa del doctor Stephen Albert? Sin aguardar contestación, otro dijo: La casa queda lejos’” (p. 106). Las preguntas y advertencias de los niños plantean un problema para el lector. ¿Cómo saben ellos que Yu Tsun quiere ir a la casa de Stephen Albert? Sugiere momentáneamente el paso a un sistema ilógico. El que conozca la obra de Borges, por ejemplo, “La muerte y la brújula” y “El Zahir”, se dará cuenta que el escenario implica una serie de símbolos cargados de interrogantes metafísicos: “'Les arrojó una moneda (la última), bajó unos escalones de piedra y entre en el solitario camino. Este, lentamente, bajaba. Era de tierra elemental, arriba se confundían las ramas, la luna baja y circular parecía acompañarme””'(p. 106). Mediante la acumulación de imágenes repletas de resonancias 
polivalentes, Borges establece una etapa mítica, y por lo tanto, atemporal, en el desarrollo realista de la trama.

El camino laberíntico presente recuerda el laberinto pasado de Ts'ui Pên, el bisabuelo de Yu Tsun:

Algo entiendo de laberintos; no en vano soy bisnieto de aquel Ts'ui Pên, que fue gobernador de Yunan y que renunció el poder temporal para escribir una novela que fuera todavía más populosa que el Hung Lu Meng y para edificar un laberinto en el que se perdieran todos los hombres. Trece años dedicó a esas heterogéneas fatigas, pero la mano de un forastero lo asesinó y su novela era insensata y nadie encontró el laberinto (p. 106).

Bajo los árboles del jardín inglés, el chino medita en ese laberinto perdido:

Pensé en un laberinto de laberintos, en un sinuoso laberinto creciente que abarcara el pasado y el porvenir y que implicara de algún modo los astros. Absorto en esas ilusorias imágenes, olvidé mi destino de perseguido. Me sentí, por un tiempo indeterminado, percibidor abstracto del mundo (p. 107).

En este estado fugaz, el protagonista olvida momentáneamente su "destino de perseguido" y se siente "indeterminado, percibidor abstracto del mundo." El protagonista pierde la sensación de su yo, pero hay un algo que contempla, distanciado, indeterminado, lo que Yu Tsun esta haciendo. ${ }^{13} \mathrm{Al}$ contemplar las ilusorias imágenes provocadas por el laberinto de su antepasado, Yu Tsun pierde contacto con su realidad, con su destino de espía, y por lo tanto, con su naturaleza existencial.

Se amontonan los acontecimientos ilógicos (el jardín simétrico, la música china, etc.), o sea, las coincidencias fortuitas. Stephen Albert, al principio, cree que la aparición de Yu Tsun obedece a la intervención de Hsi Veng, uno de los cónsules chinos: “Veo que el piadoso Hsi P'êng se empeña en corregir mi soledad”” (p. 103). Después, Albert reconoce a Yu Tsun como el bisnieto de Ts'ui Pên y quiere saber si le interesa ver "el jardín de senderos que se bifurcan.” El chino y el inglés zigzaguean por los senderos simétricos hasta llegar a la biblioteca, en la cual se confunden los libros occidentales y orientales. Yu Tsun se sienta en un diván frente a un alto reloj para estar consciente, en cada momento, del correr del tiempo. El chino esta desconcertado ante la serie de coincidencias fortuitas, pero se mantiene resoluto: “'Mi determinación irrevocable podía esperar”' (p. 109).

En el nivel del contenido referencial del discurso, Albert está describiendo cómo descifró el diáfano misterio del libro/laberinto de Ts’ui Pên. Mientras el lector sigue el proceso de raciocinio de Albert, proceso que revelará el Secreto de "El jardín de senderos que se bifurcan” de Ts'ui Pên, la sintaxis simbólica del cuento (plano A) ya ha tejido una estructura textualmente laberíntica (recuérdese el Diagrama I), dentro de la cual están atrapados los dos protagonistas y el lector enajenado. ${ }^{14}$ 
El contenido referencial del diálogo de los actores también está modificado e intensificado por la disposición física de los protagonistas, otra estructura simbólica del discurso: los hablantes están sentados en el centro de una biblioteca, ${ }^{15}$ dentro de la íntima casa, dentro del pabellón, dentro del centro de los senderos que al bifurcarse han construido un laberinto espacial, laberinto que complementa el laberinto textual. Así, en la biblioteca, en el centro del laberinto físico y textual, discuten el Secreto de otro laberinto, el de Ts'ui Pên. Al hablar del Pabellón de la Límpida Soledad que hace más de cien años se erguía en el centro de un jardín tal vez intricado, la disposición física actual de los hablantes crea un desdoblamiento atemporal, que implica una secreta unidad entre el plano C y el plano D.

La sensación de duplicidad se intensifica cuando Albert explica que la clave era un fragmento de una carta, un fragmento que hace posible descifrar la realidad bifurcada del libro/laberinto del plano D. Este plano comprende la entidad semántica apelada por el término "El jardín de senderos que se bifurcan”, frase que aparece en el fragmento de la carta. Hasta el descubrimiento de Albert, los historiadores habían creído que había dos realidades, un libro (a) y un laberinto (b) o sea que $a \neq b$. Pero el manuscrito remitido de Oxford, un fragmento nada más de una carta escrita por el propio creador Ts'ui Pên, es decir, un texto (c), sirve para iluminar la secreta relación entre $a$ y $b$. Así $c$ impone una solución antiaristotélica al enigma de $a \neq b$, solución en que $a \neq b$ y $a=b$. El manuscrito de Ts'ui Pên es un jardín de senderos que se bifurcan. Así, en la entidad semántica apelada por D, se encuentran dos textos totalmente entretejidos; vista por fuera la textura es la de $a$ (un libro) y vista por dentro es $b$ (un laberinto). ${ }^{16}$ El texto $a$ y el texto $b$ existen simultáneamente en el plano D, plano que es también un texto de A.

Luego, dentro del plano C, en un gesto sumamente laberíntico, Albert abre el cajón y produce el fragmento, clave del plano D. Sólo ahora aparecen los puentes significativos que explicaran la relación estructural entre el plano D y los planos A, $\mathrm{B}, \mathrm{y} \mathrm{C}$. El fragmento $c$ funciona como un texto del plano D, texto análogo y paralelo al texto C. Tanto el fragmento $c$ como el texto $C$ deben arrojar "una insospechada luz sobre el caso.” Aunque está fuera del alcance de esta primera lectura del cuento, precisa destacar que tal como $c$ aclara el significado del plano D o sea, el verdadero significado del enigma $a \neq b$, en la segunda lectura el texto de Yu Tsun, fragmento de una declaración, arrojara una insospechada luz sobre el texto de Borges. Dicho de otro modo, el cuento escrito por Borges, denominado como el plano A, debe revelar su Secreto, al cotejar C con B y A. En fin, los planos A, B, y C funcionan como el macrocosmo textual del microcosmos textual de $\mathrm{D}$, compuesto de $a, b, \mathrm{y} c$.

Volviendo al diálogo entablado entre Albert y Yu Tsun, se ve que el descubrimiento de Albert apunta al hecho de que, a diferencia de Las mil y una noches donde un cuento, texto microcósmico, se abre infinitamente en el texto macrocósmico, el libro de Ts’ui Pên es un libro infinito, basado en la imagen de la bifurcación infinita en el tiempo, no en el espacio. Según la descripción de Albert, el libro de Ts’ui Pên no corresponde a ninguna de las tres categorías narrativas propuestas por Todorov: 1) 
Enchaînement, que consiste simplemente en yuxtaponer diferentes historias, una a continuación de otra; 2) Alternance, que es la narración de dos historias dadas simultáneamente en forma fragmentaria; ni 3) Enchâssemente, que es el relato de una fábula en el interior de otra. ${ }^{17}$

Pasando otra vez al lenguaje mimético del plano C, la ironía y el doble sentido de las palabras de Albert son patentes:

Fang, digamos, tiene un secreto; un desconocido llama a su puerta; Fang resuelve matarlo. Naturalmente, hay varios desenlaces posibles: Fang puede matar al intruso, el intruso puede matar a Fang, ambos pueden salvarse, ambos pueden morir, etcétera. ... Alguna vez, los senderos de ese laberinto convergen; por ejemplo, usted llega a esta casa, pero en uno de los pasados posibles usted es mi enemigo, en otro mi amigo (p. 112).

Las palabras de Albert, palabras que fabrican un mundo (texto) ficticio hipotético, reproducen en la mente del lector los posibles desenlaces de la ficción actual del plano C. Otra vez se crea una duplicidad, una repetición clandestina, entre los dos niveles: 1) el nivel del contenido referencial del discurso de Albert que crea un mundo hipotético (“digamos”), una ficción, y 2) el nivel del mundo del plano C, también una ficción.

Mientras Albert habla de las infinitas series de tiempos divergentes y paralelos explorados por el bisabuelo de Yu Tsun, un antepasado asesinado por un forastero, se destacan los paralelos, puentes significantes, entre el escenario actual y el de más de cien años. Y por segunda vez Yu Tsun siente vértigo:

Recuerdo las palabras finales, repetidas en cada redacción como un mandamiento secreto: Así combatieron los héroes, tranquilo el admirable corazón, violenta la espada, resignados a matar y a morir.

Desde ese instante, sentí en mi alrededor y en mi oscuro cuerpo una invisible, intangible pululación. No la pululación de los divergentes, paralelos y finalmente coalescentes ejércitos, sino una agitación más inaccesible, más íntima y que ellos de algún modo prefiguraban (p. 113).

Las reacciones vertiginosas del protagonista siempre son provocadas por la contemplación de las ilusorias imágenes del laberinto/mandala de Ts’ui Pên. Al explicarle el sentido de "El jardín de senderos que se bifurcan” (plano D), Albert traza la imagen de un laberinto que termina convergiendo en el tiempo con el plano C:

Creía en infinitas series de tiempos, en una red creciente y vertiginosa de tiempos divergentes, convergentes y paralelos. Esa trama de tiempos que se aproximan, se bifurcan, se cortan o que secularmente se ignoran, abarca todas las posibilidades. No existimos en la mayoría de esos tiempos. [...] En éste, que un favorable azar me depara, usted ha llegado a mi casa [...], en otro, yo digo estas 
mismas palabras, pero soy un error, un fantasma. [...] El tiempo se bifurca perpetuamente hacia innumerables futuros. En el uno de ellos soy su enemigo (pp. 114-115)

En el momento en que el contenido referencial del discurso de Albert desemboca en la acción del tiempo actual del plano C, Yu Tsun siente vértigo de nuevo:

Volví a sentir esa pululación de que hablé. Me pareció que el húmedo jardín que rodeaba la casa estaba saturado hasta lo infinito de invisibles personas. Esas personas eran Albert y yo, secretos, atareados y multiformes en otras dimensiones de tiempo (p. 115).

Inmerso en el mundo del plano C, el lector y Yu Tsun rechazan como absurdas las fantásticas divagaciones del sinólogo inglés porque les está hablando de ideas y filosofías ya olvidadas, elaboradas en un jardín muy alejado en el tiempo y el espacio del de Albert. Yu Tsun alza los ojos y através del cristal de la ventana, ve acercarse a Richard Madden. En una serie de acciones muy rápidas, mata a Albert y el cuento termina. En el último párrafo el lector descubre el ingenioso plan de Yu Tsun:

Abominablemente he vencido: he comunicado a Berlín el secreto nombre de la ciudad que deben atacar. Ayer la bombardearon; lo leí en los mismos periódicos que propusieron a Inglaterra el enigma de que el sabio sinólogo Stephen Albert muriera asesinado por un desconocido, Yu Tsun. El Jefe ha descifrado ese enigma. Sabe que mi problema era indicar (a través del estrépito de la guerra) la ciudad que se llama Albert y que no hallé otro medio que matar a una persona de ese nombre (p. 116).

El lector, deslumbrado ante el repentino desenlace y el descubrimiento del Secreto plan de Yu Tsun, casi no presta atención a los detalles del plano B. Recuerda solamente que el párrafo inicial del cuento versaba sobre un porque de artillería, situado cerca del pueblo Albert en las orillas del Ancre. Aunque en el cuento se manifiesta estructuralmente el patrón de enchâssement, la relación entre los textos B y C es la de enchaînement, la yuxtaposición de diferentes historias, una a continuación de otra, de modo que el texto $\mathrm{C}$ muestra una relación causal con el texto B. Así, la relación entre el plano B y C es clara, sencilla y sumamente lógica. La conversación entre Albert y Yu Tsun ha sido un breve paréntesis metafísico dentro de una narración realista regida por las leyes de causa y efecto. Las coincidencias eran fortuitas pero nada misteriosas; cabían dentro del sistema de las leyes de la teoría de probabilidad. Al final Yu Tsun no es un error ni un fantasma y Albert y Yu Tsun existen.

Segunda lectura:

En la segunda lectura quedan en pie los planos textuales indicados en la primera. Aquí se encuentra el fragmento de un texto (plano C), plano escrito por el viejo 
catedrático de inglés de Tsingtao, momentáneamente radicado en Inglaterra como espía, misionero de guerra. El misionero de guerra busca a Stephen Albert, un inglés de Fenton, sinólogo y antiguo misionero de paz en Tientsin. Dentro del imago mundi de la Biblioteca donde se confunden libros occidentales y orientales [lo subrayado es nuestro], el escenario mítico-sagrado sugiere la posibilidad de la misteriosa coincidentia oppositorum y la entrada en la zona sagrada del mandala. ${ }^{18} \mathrm{El}$ hombre oriental no reconoce en el occidental la imagen de su doble invertido, aunque después (o antes, dentro de la secuencia narrativa de $\mathrm{C}$ ) dice: “Además, yo sé de un hombre de Inglaterra -un hombre modesto- que para mí no es menos que Goethe. Arriba de una hora no hablé con él, pero durante una hora fue Goethe’” (p. 104). No obstante, dentro del desarrollo de la acción del plano $\mathrm{C}$, para Yu Tsun, el sinólogo inglés es un instrumento. No se fija mayormente en sus ojos grises y barba gris. No presta atención a su rostro que era " "sin duda el de un anciano, pero con algo inquebrantable y aun inmortal”” ni al hecho de que “"algo de sacerdote había en é1”” (p. 109). Yu Tsun lo mata tal como Harry, sin prestar atención a las advertencias de Pablo, mata a su doble Hermine en el Teatro Mágico de Steppenwolf. ${ }^{19} \mathrm{Ni}$ Yu Tsun ni Harry escuchan el mensaje de sus guías espirituales, un mensaje de los Inmortales.

No obstante, los dos hombres, Yu Tsun y Stephen, son idénticos y opuestos, reflejos invertidos del mismo espejo, que se confunden en una curiosa coincidentia oppositorum. Los nexos significativos que efectúan la unión de los opuestos son los siguientes:

Yu Tsun (A)

q1 viejo catedrático de inglés

q2 chino en Inglaterra

q3 espía, agente de guerra

q4 en la biblioteca se convierte en estudiante de Stephen Albert

Stephen Albert (B)

q1 viejo sinólogo

q2 inglés en China

q3 misionero, agente de paz

q4 en la biblioteca asume el papel de guía o de profesor de Yu Tsun

Así $\mathrm{A}=(\mathrm{q} 1, \mathrm{q} 2, \mathrm{q} 3, \mathrm{q} 4)$ y B = (q1, q2, q3, q4), una serie matemática totalmente simétrica donde $\mathrm{A} \neq \mathrm{B}$ y $\mathrm{A}=\mathrm{B}$. También puede añadirse otro factor q5; el chino espera su muerte implacable a manos de forasteros ingleses, mientras que el inglés es asesinado por un chino.

Antes de enfrentarse con Albert, Yu Tsun piensa en su propio destino:

Me pareció increíble que ese día sin premoniciones ni símbolos fuera el de mi muerte implacable. A pesar de mi padre muerto, a pesar de haber sido un niño 
en un simétrico jardín de Hai Feng Lyo, ahora, iba a morir? Después reflexionó que todas las cosas le suceden a uno precisamente, precisamente ahora. Siglos de siglos y sólo en el presente ocurren los hechos: innumerables hombres en el aire, en la tierra y el mar (p. 102).

El único tiempo accesible a Yu Tsun es el presente, el tiempo en que su yo existencialista se manifiesta. ${ }^{20}$ Según el espía, es sólo el momento presente cuando “'todo lo que realmente pasa me pasa a mi'” [el subrayado es nuestro] (p. 102). Rechaza las advertencias de Albert: él no duplica el destino de su bisabuelo; Yu Tsun es un hombre moderno, existencialista, auténtico que elige libremente su destino. Para él su existencia si precede su esencia. Sus acciones no pueden representar una inversión de los actos que ocurrieron hace más de cien años. No es un avatar simétricamente opuesto del hombre que murió a manos de un forastero en un jardín de senderos que se bifurcaban. Los actos del bisabuelo no prefiguran los de Yu Tsun. El fragmento de la carta de Ts'ui Pên no prefigura el fragmento de la declaración de Yu Tsun. Aquí no basta un solo término repetido, ni muchos, para desbaratar y confundir la serie del tiempo. ${ }^{21}$ Dentro del mundo del fragmento de su declaración (plano C) Yu Tsun es y el lector no duda de la realidad del ingenioso espía chino que logra comunicar el Secreto a su Jefe alemán, comunicación que facilita la aniquilación del parque de artillería mediante bombas verticales. Desde el punto de vista de Yu Tsun, ha vencido por haber comunicado a Berlín el secreto nombre de Albert, y se supone que a causa del bombardeo aceman, la ofensiva contra la línea SerreMontauban debió postergarse.

No obstante, Liddell Hart (plano B) anota en el texto inserto en el plano A que "las lluvias torrenciales [ ... ] provocaron esa demora” (p. 101). El texto citado, la Historia de Liddell Hart, existe en ambos lados del cristal ficticio: 1) es un texto que existe dentro de la realidad del plano A, y 2) es un texto que existe fuera del plano A y B o sea, fuera del mundo ficticio de Borges y por lo tanto pertenece al Mundo de la realidad del lector. Según el narrador ficticio, la demora no era nada significativa. En A History of the World War 1914-1916 del historiador Basil Henry Liddell Hart se lee:

The bombardment [de ametralladoras y otras armas] began on June 24th; the attack was intended for June 29th, but was later postponed until July 1st, owing to a momentary break in the weather. ${ }^{22}$

En su capítulo épico sobre la ofensiva de Somme (de la línea Serre-Montauban), el capitán narra (en un estilo sumamente borgiano) los pormenores de la batalla:

This postponement, made at French request, involved not only the spreading out of the ammunition over a longer period, and a consequent loss of intensity, but a greater strain on the part of the assaulting troops, who, after being keyed up for the effort, had to remain another forty-eight hours in cramped trenches under 
the exhausting noise of their own gunfire and the enemy's retaliation conditions made worse by torrential rain which flooded the trenches. ${ }^{23}$

La existencia del texto de Liddell Hart dentro de A abre un nuevo plano de intertextualidad, un plano que integra un texto del Mundo del lector. Al cotejar el texto del Mundo del lector, la Historia de Liddel Hart, con el texto inserto en el plano B, el texto de Ts'ui Pên, se revela una serie de insospechados paralelismos e inversiones, engendrados por el juego de intertextualidad. En el texto de Ts'ui Pên todos los desenlaces ocurren, cada uno es el punto de partida de otras bifurcaciones. El manuscrito de Ts'ui Pên incluye dos escenas cuyas palabras finales, repetidas en cada redacción, eran como un mandamiento secreto: “'Así combatieron los héroes, tranquilo el admirable corazón, violenta la espada, resignados a matar y a morir’” (p. 113). Este refrán remata un mismo capítulo épico de Ts’ui Pên:

En la primera, un ejército marcha hacia una batalla a través de una montaña desierta; el horror de las piedras y de la sombra le hace menospreciar la vida y logra con facilidad la victoria; en la segunda, el mismo ejército atraviesa un palacio en el que hay una fiesta; la resplandeciente batalla les parece una continuación de la fiesta y logran la victoria (p. 112).

En el texto de Liddell Hart también hay un juego entre el exagerado optimismo (el palacio en el que hay una fiesta) y las realidades tácticas de la batalla (una montaña desierta, el horror de las piedras y de la sombra). Según la Historia Oficial citada por Liddell Hart:

'Increasing optimism' was shown by Haig. [...] What is perhaps more remarkable is the way his chief subordinates joined in the chorus of optimism, singing so loudly as apparently to drown the doubts. ${ }^{24}$

El falso y descaminado optimismo de los oficiales ingleses llegó a las tropas en las trincheras quienes se lanzaron ciegamente a la muerte. De los cien mil soldados que salieron de las trincheras a las 7,30 de la mañana del primero de julio, cincuenta mil cayeron heridos o muertos. Nadie quería comprender la ineficacia de su artillería ni la disposición poco estratégica de los emplazamientos de las ametralladoras británicas. Aquel optimismo construyó en la mente de los participantes una realidad totalmente ilusoria, realidad que provocó una de las masacres más sangrientas de la Primera Guerra Mundial.

Los oficiales alemanes tampoco estaban en contacto con la realidad porque, desde febrero, la construcción de nuevas hutas por ambas orillas del Ancre debe haberles prevenido de los preparativos de los ingleses. En Inglaterra todo el mundo sabía que se preparaba una ofensiva cerca de Albert: 
By the middle of June, all England was discussing the 'Big Push.' Everyone knew it was coming; that was common knowledge. The only thing that the people were not quite sure of was the exact day of the attack. ${ }^{25}$

Tal vez lo más irónico es que, a pesar de prognósticos fidedignos y de múltiples advertencias del próximo ataque, transmitidos por agentes en el estranjero, el Jefe alemán Falkenhayn continuaba creyendo que los preparativos británicos cerca de Albert eran "too blantant to be true." ${ }^{26}$ No fue hasta el 5 de julio, cuatro días después de la batalla, que Falkenhayn se convenció de que Albert sí era el lugar elegido para la ofensiva.

Al analizar los juegos intertextuales entre los datos suministrados por el manuscrito "El jardín de senderos que se bifurcan” del plano D, y los datos suministrados por el autor del texto B o sea Liddell Hart, se observa que las advertencias de Stephen Albert encerraban la interpretación verdadera; Yu Tsun es un error, un fantasma, y Yu Tsun y Albert no existen en la mayoría de los tiempos. El ingenioso plan que Yu Tsun lleva a cabo dentro del tiempo del mundo ficticio no representa más que una bifurcación en el tiempo del Mundo del lector. En el mundo ficticio Yu Tsun contempla un pájaro y ciegamente lo traduce “'en un aeroplano y a ese aeroplano en muchos (en el cielo francés) aniquilando el porque de artillería con bombas verticales”” (p. 103). Pero en el tiempo paralelo y bifurcado del Mundo del lector, los pájaros del cielo gris de Albert no se convirtieron en aviones (pájaros grandes), y las bombas del mundo de Yu Tsun se tradujeron en gotas de lluvia, porque la ciudad francesa de Albert nunca fue bombardeada durante esa ofensiva de la línea Serre-Montauban.

Al cotejar el texto de Liddell Hart con el texto A, se observa que el fragmento de la declaración de Yu Tsun juega un papel análogo al de la carta de Ts'ui Pên, carta que reveló que no había una doble realidad compuesta de un libro y un laberinto. Del mismo modo en el plano A no hay dos realidades; no hay un cuento y un jardín de senderos que se bifurcan. El cuento es un jardín de senderos que se bifurcan. Lo verdaderamente insólito de "El jardín de senderos que se bifurcan" (A) es que la estructura y el contenido del cuento ilustran concretamente el significado de la entidad semántica. En la primera lectura se señaló que la relación entre la historia de Liddell Hart y la historia de Yu Tsun parece encarnar la categoría narrativa de enchaînement, una lectura lógica lineal, donde se yuxtaponen dos historias, una a continuación de otra. Los vínculos entre $\mathrm{B}$ y $\mathrm{C}$ dentro de la lectura lógica lineal se explican por medio de las leyes de causa y efecto. A la vez, la estructuración del cuento también apunta hacia el enchâssement, una estructura basada en la caja china, Las mil y una noches, etc. Pero el texto literario comentado dentro de C (el libro de Ts'ui Pên) revelaba una cuarta categoría narrativa, la de la bifurcación.

Al yuxtaponer las dos historias, $\mathrm{B}$ y C, se produce efectivamente una bifurcación del mismo hecho. En uno de los porvenires, el del lector, cayeron lluvias torrenciales, y en otro, el de Yu Tsun, eran bombas verticales. Desde la perspectiva del lector enajenado del cuento, Albert, entendido en su plano de ciudad, fue destruido; los 
personajes y su mundo son una realidad. Desde la perspectiva del lector de la Historia de Liddell Hart, Albert no fue destruido como ciudad, pero sí como personaje. Desde esa perspectiva, los personajes y su mundo son una ficción. Pero visto simultáneamente desde ambas perspectivas, el cuento es una bifurcación, otra realidad posible más para el lector, una realidad ficticia que pasa a formar parte del Mundo del lector. Mediante el juego interno y externo de textos paralelos, Borges logra que los personajes ficticios y las personas reales comparten $s u(s)$ mundo(s). Yu Tsun emerge del marco de la ficción para cambiar el pasado del Mundo occidental sin que el lector se de cuenta.

El cuento (plano A) funciona como las páginas 917 a 921 del volumen XLVI de la enciclopedia falazmente llamada The Anglo-American Cyclopaedia (Nueva York, 1917). Pero existe una diferencia fundamental entre los juegos textuales de los cuentos. Con respecto a “Tlön, Uqbaf, Orbis Tertius”, Bioy Casares y Borges figuran en ambos lados del cristal narrativo. Dentro de su mundo ficticio son personajes que descubren la secreta sociedad que surgió para inventar un planeta ilusorio que fuera a reemplazar el mundo de Borges y de sus amigos. La brújula de la princesa Faucigny Lucinge y los conos de metal reluciente, del diámetro de un dado, fueron las primeras intrusiones materiales del mundo fantástico en el mundo del Borges ficticio. La brújula y los conos emergen del marco del mundo inventado del planeta ilusorio de Tlön, Uqbar, Orbis Tertius, para fundirse con el otro mundo inventado dentro del cuento “Tlön, Uqbar, Orbis Tertius.” El juego de los planos textuales que giran alrededor de la entidad semántica de “Tlön, Uqbar, Orbis Tertius” recapitula el juego de la entidad semántica de "El jardín de senderos que se bifurcan”.

Al final del cuento “Tlön, Uqbar, Orbis Tertius”, un mundo ficticio es reemplazado por otro y pronto “el mundo será Tlön” (p. 36). El mundo del Borges ficticio es absorbido por el mundo inventado. Según el Borges ficticio, el contacto y el hábito de Tlön desintegran "este mundo", el mundo ficticio de segundo grado, ya que en las memorias un pasado ficticio ocupa el sitio de otro. En el caso de Tlön la irrupción del mundo ficticio es acompañada por la inserción en “este mundo”, el del Borges ficticio, de objetos ficticios, una brújula y los conos. Pero en el caso de "El jardín de senderos que se bifurcan”, el Mundo del lector es reemplazado por el mundo ficticio del cuento (plano B) porque el lector acepta el hecho de que Albert haya sido bombardeado. Y los críticos, heresiarcas inconscientes, han inventado otros artefactos ficticios en el Mundo del lector. Puesto que los críticos no se han fijado en que Borges esta jugando con la Historia de la Guerra Europea, y por lo tanto, con la bifurcación del tiempo, en las aseveraciones a menudo negativas, se ha engendrado un tipo de bifurcación espacial. En una versión crítica la ciudad de Albert se desprende del mapa y cruza el Canal Inglés para radicarse en Inglaterra, y en otra la ciudad avanza un poco al noroeste hasta pararse en Bélgica. ${ }^{27}$

Mediante el metalenguaje crítico, se ha fundado dos ciudades más, dos escenarios totalmente apócrifos donde, según los críticos (ciegos continuadores de la secreta sociedad de los Tlönistas, y también dioses de metamundos ficticios), cayeron "las 
bombas verticales” del bombardeo ficticio de la línea Serre-Montauban. Las ilusorias ciudades críticas de Bélgica y de Inglaterra, suscitadas del Albert ficticio francés, se asemejan a los hrönir, artefactos esencialmente idealistas, construidos por la mente humana a base del hrön anterior.

El cuento "El jardín de senderos que se bifurcan” es una muestra concreta del modelo narrativo propuesto por el texto literario interno, el libro/laberinto de Ts'ui Pên. Al mismo tiempo encarna el patrón del juego de los diversos textos internos y externos de los cuentos que componen la colección de El jardín de senderos que se bifurcan; el juego entre dos mundos, entre la realidad y la ficción. ${ }^{28}$ En este juego interno y externo de textos paralelos que caracterizan los cuentos de la colección, predomina el motivo, del libro/laberinto donde un plano, del texto critica e ilustra la lectura de otro texto, real o inventado, o sea, donde los comentarios del autor ficticio versan sobre libros/laberintos inventados; acuérdese de las múltiples obras escritas o traducidas por Pierre Menard. La crítica interna de los libros/laberintos inventados o verdaderos, es en realidad una crítica solipsista de la obra de Borges, hecha por el propio Borges. Anotemos, por ejemplo, la teoría literaria, vigente en Tlön, que aboga por una narrativa inusitada: “También son distintos los libros. Los de ficción abarcan un solo argumento [tal vez el problema de la conjunción de realidad/ficción], con todas las permutaciones imaginables. [...] Un libro que no encierra su contralibro es considerado incompleto” (p. 28). Las obras de Herbert Quain, su Abril March, una "novela regresiva ramificada" o su novela policial, The God of the Labyrinth, prefiguran el patrón del cuento “El jardín de senderos que se bifurcan”, y al mismo tiempo estas obras ficticias de Borges se hallan dentro de la colección del mismo título, lo cual constituye otro juego crítico.

En "El jardín de senderos que se bifurcan” Borges propone unos fragmentos de libros y documentos, auténticos y fantásticos, y a veces simples indicaciones argumentales para que el lector construya con ellos un puente hacia la realización de la conjunción de realidad/ficción. Aquí no le basta la abolición del tiempo lineal y el espacio, ya demasiado disueltos en la novela contemporánea; ataca de raíz el principio de causalidad, tanto en el nivel de la estructuración del cuento, como en el de su sentido. Mediante el juego combinatorio de los diversos planos de la realidad ficticia, el texto se abre para que, en última instancia, el lector resulte el verdadero protagonista de esta aventura literaria.

Antes de concluir el presente trabajo hay que destacar que aun en el texto A y por lo tanto en el Mundo de Borges, aparece un pequeño error, un mínimo fantasma temporal, creado inconscientemente por el propio autor: la ofensiva contra la línea Serre-Montauban no fue planeada para el veinticuatro de julio de 1916 como alega el narrador, sino para el veinticuatro de junio de 1916. Pero en una obra que aboga por la bifurcación infinita en el tiempo, se perdona una bifurcación más. 


\section{NOTAS}

1 Jorge Luis Borges, Ficciones (Buenos Aires: Emecé, 1956), p. 11. A continuación todas las citas textuales vendrán de esta edición.

2 Martin Stabb, Jorge Luis Borges (New York: Twayne Publishers, 1970), p. 128.

3 Vale recordar que en 1914 Borges viajó a Europa con su familia, quienes se refugiaron de la guerra en Ginebra hasta 1919. Así Borges veía muy de cerca los acontecimientos de esa batalla que se estaba desarrollando en Francia, a unas trescientas millas de su casa.

4 Para reproducir con fidelidad la edición citada, los puntos suspensivos señalados dentro de corchetes serán nuestros.

5 Véase Ana María Barrenechea, La expresión de la irrealidad en la obra de Jorge Luis Borges (México: El Colegio de México, 1957) para una discusión del tiempo cíclico y la ilusoriedad del ser.

6 Richard Burgin, Conversations with Jorge Luis Borges (New York, 1970), pp. 125-127; Arthur Koestler, "Seriality and Synchronicity" en The Roots of Coincidence: An Excursion into Parapsychology (New York, 1973), pp. 82-104; y el Appendix I de The Case of the Midwife Toad (London, 1971) del mismo autor, donde además de abordar el interesante tema del Alytes obstetricans, dedica una sección muy importante a la obra clásica de Paul Kammerer, Das Gesetz der Serie (Stuttgart-Berlin: Deutsche Verlags-Anstalt, 1919). El problema de las series akausales o sea, las que no obedecen las leyes de causa y efecto del pensamiento dialéctico, aparece en C. G. Jung y Wolfgang Pauli, "Synchronizitat als ein Prinzip akausaler Zusammenhange,” Naturerklärung and Rsyche. Studien aus dem C. G. Jung-Institut, IV (Zurich, 1952).

7 El mapa es una adaptación del de Brian Gardner, The Big Push (London: Cassell, 1961), p. 159.

8 Es de notar que según The New Funk \& Wagnalls Encyclopedia, Vol. I (New York: Unicorn Publishers, 1951), 209, el pueblo de Albert anteriormente se llamaba Ancre.

9 Félix Martínez-Bonati, La estructura de la obra literaria (Barcelona: Seix-Barral, 1972), p. 72. "El lenguaje mimético es como transparente; no se interpone entre nosotros y las cosas de que habla. Mientras los momentos no narrativos-descriptivos del discurso del narrador, nos remiten a la presencia de éste, ya que imponen su ser lenguaje y son su lenguaje, sus actos qua narrador, su interioridad sensible, el discurso mimético nos lleva a las cosas del mundo. Dicho más exactamente: el estrato mimético no lo vemos como estrato lingüístico. Sólo lo vemos como mundo; desaparece como lenguaje. Su representación del mundo es una ‘imitación' de éste, que lo lleva a confundirse, a identificarse con él. El discurso mimético se mimetiza como mundo. Se enajena en su objeto."

${ }^{10}$ Respecto al viaje, véase la interpretación de Zunilda Gertel, “'El Sur’ de Borges; Búsqueda de identidad en el laberinto,” Nueva Narrativa Hispanoamericana, I, num. 2 (1971), 37-55.

${ }^{11}$ Véase Mircea Eliade, The Sacred and the Profane (New York: Harcourt, Brace \& World, 1957) y Le Mythe de 1'eternel retour: archétypes et répétition (Paris: Librairie Gallimard, 1949); Roslyn M. Frank, "Lo profano y lo sagrado en 'La muerte y la brújula,” Nueva Narrativa Hispanoamericana, V (enero-set., 1975), 127-135.

${ }^{12}$ El viaje al otro lado siempre viene acompañado de una serie progresiva de símbolos metafísicos. Al cotejar la escena del viaje descrita en "El jardín de senderos que se bifurcan" con la de "La muerte y la brújula", se destacan los paralelismos: 
“El jardín...”

...mis ojos... registraban la fluencia de aquel día que era tal vez el último, y la difusión de la noche... La tarde era intima, infinita (pp. 105-106).

Se detuvo el tren, casi en medio del campo. Nadie grito el nombre de la estación. (p. 106).

...bajé unos escalones de piedra y entré en el solitario camino... (p. 106).

Llegué, así, a un alto portón herrumbrado. ... (p. 107).

El húmedo sendero zigzagueaba como los de mi infancia en simétrico jardín (p. 108).
"La muerte..."

Era una de esas tardes desiertas que parecen amaneceres... (p. 157).

El tren paro en una silenciosa estación de carga... (p. 157).

Lonnrot echó a andar por el campo... (p. 157).

Una herrumbrada verja definía el perímetro irregular de la quinta. ... De nuevo ante el portón infranqueable... (p. 157).

Vista de cerca, la casa de la quinta de Triste-le-Roy abundaba en inútiles simetrías y en repeticiones maniáticas... (p. 157).

13 Jorge Luis Borges, “Nueva refutación del tiempo,” en Otras Inquisiciones, Obras Completas, III (Buenos Aires: Emecé, 1957), 240-241. Dice el autor: “Admitido el argumento idealista, entiendo que es posible -tal vez, inevitable- ir más lejos. Para Hume no es lícito hablar de la forma de la luna o de su color; la forma y el color son la luna; tampoco puede hablarse de las percepciones de la mente, ya que la mente no es otra cosa que una serie de percepciones. El pienso, luego soy cartesiano queda invalidado; decir pienso es postular el yo, es una petición de principio; Lichtenberg, en el siglo XVIII, propuso que en lugar de pienso, dijéramos impersonalmente piensa, como quien dice truena o relampaguea. Lo repito: no hay detrás de las caras un yo secreto, que gobierna los actos y que recibe las impresiones; somos únicamente, la serie de esos actos imaginarios y de esas impresiones errantes.” El subrayado es del autor.

${ }^{14}$ Martínez-Bonati, p. 64. "Si un discurso mimético de personaje adquiere, por su extensión y contenido, el carácter de narración, la estructura de la obra se duplica (como en la llamada 'narración enmarcada'), y puede multiplicarse indefinidamente (como en las narraciones de personajes de Las mil y una noches), trasladándose cada vez la base narrativa (con sus propiedades estructurales) al nuevo discurso mimético. Inversamente, adecuadas menciones identificadoras del origen de nuevas frases, pueden retrotraer la función fundamental. Tales narraciones superpuestas, o puestas una dentro de otra, tienen todas la misma naturaleza lógica, pero no la misma jerarquía lógica...”

${ }^{15}$ La biblioteca en la obra borgiana suele representar el imago mundi, una reproducción del cosmos. Véase, por ejemplo, "La Biblioteca de Babel”, incluído en la colección "El jardín de senderos que se bifurcan”.

${ }^{16}$ El "texto", según su naturaleza etimológica, es el textus (lat.), "lo tejido,” del participio pasado de texere, "tejer."

17 Tzvetan Todorov, "Les catégories du récit litteraire,” Communications, núm. 8 (1968), p. 140. 
${ }^{18}$ Era Nicolás de Cusa quien se aprovechó de la expresión coincidentia oppositorum para definir la naturaleza de Dios del modo menos imperfecto. Lo empleamos aquí para referirnos a una serie de ritos, mitos y teorías asociados con la unión de los contrarios y el misterio de la totalidad. Véase Mircea Eliade, Mephistopheles and the Androgyne (New York: Sheed and Ward, 1965), pp. 80-81.

${ }^{19}$ Herman Hesse, Steppenwolf (New York: Frederick Ungar Publishing, 1929). Es de notar que entre los Inmortales de Steppenwolf figura Goethe.

${ }^{20}$ La antipatía que siente Borges por el existencialismo es patente. Para apreciar sus opiniones sobre los escritores existencialistas (Sartre, Kierkegaard y Unamuno), véase Burgin, pp. 123-124.

${ }^{21}$ Borges, “Nueva refutación del tiempo,” p. 244.

22 Basil Henry Liddell Hart, A History of the World War 1914-1916 (London: Faber \& Faber, Lmtd, 1935), p. 314. Para una discusión de la ofensiva de Somme, véase capítulo 6, pp. 303331.

${ }^{23}$ Ibid., pp. 314-315.

${ }^{24}$ Ibid., p. 311.

${ }^{25}$ Gardner, p. 61. Véase también Anthony H. Farrar-Hockley, The Somme (Philadelphia: Dufour Editions, 1964) y John Buchan, The Battle of the Somme (New York: Doran, 1917).

${ }^{26}$ Liddell Hart, p. 309. "The one redeeming factor was that despite accurate predictions and warnings of the attack both from the immediate army command (the Second) and from agents abroad, Falkenhayn continued to believe that it was only a preliminary to the real blow further north, apparently feeling that British preparations were too blatant to be true."

27 Según Carter Wheelock, The Myth-maker: A Study of Motif and Symbol in the Short Stories of Jorge Luis Borges (Austin y London: University of Texas Press, 1969), pp. 120-121: “'The Garden of Forking Paths' is a more interesting story; but it requires little further comment. The usual symbols appear [...] Yu Tsun has to find a way of conveying to him [al Jefe] the name of an English city [lo subrayado es nuestro] named Albert.” Martin Stabb, pp. 128-129, también juzga negativamente el cuento: “'El jardín de senderos que se bifurcan,' though one of Borges' most popular stories, suffers from several important defects. For one thing, given the rather implausible, and certainly artificial nature of the plot, Borges seems too serious. [...] For another, the long discussion of the ancient Chinese labyrinth appears to be little more than a reworking of material Borges has expressed better elsewhere. [...] In short, this tale presents one of the very few cases of Borges' attempting to insert a genuine element of fantasy into an essentially realistic, if unlikely, narrative [...] the story seems, at least to the writer, unconvincing. [...] In the last paragraph of the story we learn that the newspaper reports of the murder of one Stephen Albert by a certain Yu Tsun reach Berlin, and that from them the chief German Intelligence officer [el texto sólo menciona 'el Jefe'] easily extracts a vital bit of information: namely, that the British were amassing artillery preparatory for an offensive at the Belgian town [lo subrayado es nuestro] of Albert."

${ }^{28}$ Los cuentos reunidos en la colección de El jardín de senderos que se bifurcan son los siguientes: “Tlön, Uqbar, Orbis Tertius," "El acercamiento a Almotásim,” "Pierre Menard, autor del Quijote,” "Las ruinas circulares,” "La lotería en Babilonia,” "Examen de la obra de Herbert Quain,” "La Biblioteca de Babel,” y “El jardín de senderos que se bifurcan.” 


\section{Literalidad y Transposición: "Las Repercusiones Incalculables de lo Verbal”}

Dentro de las ficciones de Borges, "La muerte y la brújula”1 se destaca tanto por pertenecer claramente a un género -la narración policíaca- como por el tratamiento inusitado de las convenciones del género. La lectura más rápida del relato, con miras a condensar el argumento, es tarea sencilla:

Un rabino que se disponía a asistir a un congreso talmúdico aparece muerto de una puñalada en el cuarto del hotel donde se hospeda. El comisario Treviranus, hombre pragmático, supone -a partir de una deducción de causa a efecto- que la muerte fue accidental: un ladrón habría entrado por error en el cuarto del rabino, buscando el de otro huésped del hotel, cuyos zafiros quería robar. Al advertir su error habría matado al rabino, único testigo de su intento frustrado. El detective Lönnrot quiere, por el contrario, descifrar una secuencia no desencadenada por el azar sino por la condición religiosa del rabino. Otros dos crímenes sucesivos -uno en el oeste de la ciudad y el otro en el este, con los cuales se dibuja un triángulo místico pues el primer asesinato ha tenido lugar en el norte- parecen justificar la hipótesis de Lönnrot. Finalmente, él mismo descubre que Treviranus tenía razón: el primer crimen, casual, sirvió para que tramara su venganza contra el detective un pistolero que le había jurado la muerte. El pistolero, Red Scharlach, previó la conjetura de Lönnrot: que el asesinato del rabino se relacionaba con leyendas de muertes rituales practicadas por la secta de los Hasidim. La suposición acertada permitió a Scharlach planear la serie de crímenes que culminaron con la muerte del propio Lönnrot, víctima de su excesiva afición a formular hipótesis interesantes (p. 500).

Un primer contacto con este relato podrá producir tantos resúmenes como lectores posibles, y ninguna síntesis ajena podrá sustituir el acto mismo de una primera lectura; también, inevitablemente, ese primer recorrido será insuficiente. En efecto, la intuición cabal del texto en cuanto paradigma, en cuanto "eje de innumerables relaciones”, sólo se alcanza ante trozos breves, de poesía preferiblemente. Y aun la aprehensión de la poesía se completa y acendra en lecturas sucesivas. Por todo esto es válido afirmar que únicamente al concluir un 
texto se está en condiciones de practicar la "segunda lectura aplicada” que-como ha observado Barthes- es la que requieren los textos modernos. ${ }^{2}$ El objeto de estas páginas es apuntar datos para proyectos de lecturas aplicadas, de niveles diferentes, que pueden ser ayudadas y acaso estimuladas mediante detalles externos al texto y mediante comentarios respecto a ciertos detalles internos del texto.

Como todo escrito literario, "La muerte y la brújula” es una organización autónoma integrada por núcleos de energía procedentes de diversos órdenes de realidades. Esos núcleos se han transformado para entrar en el texto -o al entrar en él-; pero por la misma carga dinámica que hizo posibles las transformaciones, mantienen esos núcleos los vínculos con sus referentes de distinto orden. Esa carga, permanentemente activa, es el potencial de innumerables lecturas. ${ }^{3}$

Borges ha comentado que los hechos del relato ocurren en un "Buenos Aires de sueños”. ${ }^{4}$ Es decir, que se procuró establecer un setting esencial que captara, en una suerte de generalización abstracta, ciertas precisiones necesarias; también -aunque no explicitado por el autor pero no por eso menos evidente-significa que el setting está organizado en buena medida con procedimientos oníricos.

La trama requería especificaciones que conformaran un encuadre riguroso; para eso la topografía de los barrios de Buenos Aires resultaba adecuada: sería posible dibujar un enorme triángulo equilátero imaginario que partiera del Norte, pasara por el Oeste y llegara finalmente al Este. Con una prolongación hacia el Sur, el triángulo se convertiría en un rombo, exactamente como se da al final de la historia. Esas puntualizaciones geográficas reales han pasado a la ficción como disimuladas por cambios notables con respecto al modelo: por ejemplo, los nombres extranjeros Hôtel du Nord, rue de Toulon, Liverpool House, Triste-le-Roy. ${ }^{5}$ Con todo, la topografía es tan verdadera que la ciudad de Buenos Aires emerge, inconfundible, ${ }^{6}$ pese a nombres externos de calles y lugares y pese a que los nombres de los personajes proceden de textos diversos o acumulan -bajo la apariencia escandinava o sajona, como los del detective y el pistolero- significados simbólicos. Erik Lönnrot es Rey Rojo; Red Scharlach repite la misma combinación, ya que a Rojo Escarlata ${ }^{6}$ bis se añade el apodo de El Dandy. Este apodo, en efecto, parece una trasposición del significado de Erik: Scharlach, conductor -guía, modelo, jefe, como los dandies mundanos- de una banda de malhechores, se mueve con una aisance que contrasta con la torpeza suicida del excesivamente imaginativo Erik Lönnrot. También es simbólico el apellido Treviranus, fabricado sobre la palabra latina tresviri, triunvirato; el comisario es tres en uno ya que refine características del comisario y detective clásicos del relato policial y también capta la trampa tendida por el pistolero. En cuanto a su germánico apelativo, Franz, es una reiteración de su antisemitismo, o un posible nombre judío.

La afirmación de que el Buenos Aires del cuento es un Buenos Aires de sueños indica otro cambio con respecto a los referentes, acaso más importante desde el punto de vista del dinamismo narrativo. Hay condensaciones y 
anacronismos semejantes a los de los sueños, que operan activamente dentro de la organización y en el transcurso de la historia. Así, con nombres extraños y anacronismos, se crea un ambiente brumoso que contrasta con la arquitectura tan estricta de la trama y que, paradójicamente, al establecer un interjuego entre lo esfumado y lo puntual da mayor realce al marco de precisiones dentro del que se traban el error de Lönnrot y la venganza de Scharlach. Transformados pero reconocibles, ciertos datos objetivos de la realidad extratextual funcionan eficazmente como encuadres de los distintos episodios.

Desde el Norte de Buenos Aires desciende el Río de la Plata, sólo aludido en el texto en la cualidad inconfundible de sus aguas "del color del desierto" (p. 499) Un hotel lujoso se levanta cerca del río; no se llama, como en el relato, Hôtel du Nord, sino Plaza Hotel, como tantos hoteles lujosos del mundo. El cuento se publicó en 1942: hace treinta y cinco años no abundaban en Buenos Aires los edificios muy altos pero ni aun entonces el Plaza Hotel podía ser considerado una torre, como se designa en el texto al Hôtel du Nord. La realidad se ha tornado ficción por medio de un proceso característico de los sueños: el Hôtel du Nord del cuento condensa dos imágenes en una; el hotel verdadero y el Kavanagh, primer rascacielos residencial que se levantó -frente al Plaza- en la década de 1930 se integran en el "alto prisma que domina el estuario” del texto. ${ }^{7}$ De esta manera, el primer crimen se comete en un Norte verdadero de Buenos Aires, en un imaginario edificio moderno que resume la apariencia de tres instituciones odiosas: sanatorio, cárcel, prostíbulo y que sintetiza localización y características de dos construcciones reales. Esta síntesis, a su vez, tiene una función doble. Una, hacia afuera del texto, es una cíitica velada a los admiradores de la arquitectura moderna que en pocos años cambió el aspecto de la ciudad de Buenos Aires. Borges ha expresado muchas veces su preferencia por las casas de barrio, bajas, viejas, modestas, a las que llamó en el poema "Las calles de Buenos Aires” con que se abre Fervor de Buenos Aires "austeras casitas", 8 y a las que exaltó en "Nueva refutación del tiempo": "La calle era de casas bajas y aunque su primera significación fuera de pobreza, la segunda era ciertamente de dicha. Era de lo más pobre y de lo más lindo". ${ }^{9}$ Además de la alusión a la semejanza del hotel con instituciones odiosas semejanza debida, a no dudarlo, a la apariencia arquitectónica- que lleva a otros lugares dentro de la propia obra de Borges, en el contexto de "La muerte y la brújula" esa torre es indicio múltiple: en cuanto figuración de sanatorio y de cárcel repite funciones que la quinta de Triste-le-Roy desempeñó antes de empezar la historia. Sanatorio: Red Scharlach, herido por la policía, agonizó en ella nueve noches ${ }^{9} \mathrm{bis}$ y allí sintió, según declara a Lönnrot: “que el mundo es un laberinto, del cual era imposible huir, pues todos los caminos, aunque fingieran ir al norte o al sur, iban realmente a Roma” (p. 506); cárcel: "Roma, que era también la cárcel cuadrangular donde agonizaba mi hermano” (ibid.). Asimismo, la torre del Norte es indicio que prefigura el mirador de la quinta, donde Lönnrot morirá a manos de Scharlach. La 
tercera semejanza -casa mala- preanuncia uno de los usos de la taberna de la rue de Toulon del tercer episodio (p. 502).

Para volver a las funciones más explícitas del escenario del primer crimen: al imaginario Hôtel du Nord alberga a la primera víctima, el imaginario pero no imposible Marcelo Yarmolinsky, ${ }^{10}$ delegado a un congreso imaginario e imposible: no existen congresos talmúdicos. En el mismo hotel se hospedaba un anacrónico dignatario del Imperio romano. Como otro Tetrarca de Galilea -aquél, histórico: Herodes Antipas-, este ficticio funcionario judeo-romano del cuento, dueño de fabulosos zafiros, es de alguna manera responsable de la muerte de un judío inocente.

El segundo crimen se comete en el Oeste, y la historia no sólo se desplaza en el espacio sino que también parece retroceder en el tiempo. Ese Oeste desolado recorrido por gendarmes -en que se insertan con la economía de una toma cinematográfica imágenes favoritas de Borges: el callejón con tapias rosadas, la desaforada puesta de sol-no corresponde a un Buenos Aires donde ya se habían construido rascacielos. El anacronismo conviene para escenario de la muerte del criminal Daniel Simón Azevedo: resumen de otros personajes de los antiguos y pendencieros arrabales del Norte -Rosendo Juárez, Francisco Real-, ${ }^{11}$ que, como él, solamente manejaban el cuchillo (p. 501). Esa clase de bandidos ya se había vuelto prototipo legendario, símbolo del coraje, antes de que hubiera en la ciudad edificios como torres; pero Daniel Simón Azevedo es un personaje arquetípico incluso por otras razones. Hasta en su nombre -el único relativamente plausible, aunque también engañoso, de todo el cuento-se inscribe un simbolismo. El apellido Azevedo -versión portuguesa de la forma española Acevedo, apellido materno de Borges- delata ascendencia judía, es decir raíces ancestrales que se remontan a un pasado ibérico muy anterior a la conquista de América. El retroceso en el tiempo no como flash back sino como anacronismo ya se advierte en el recurso hiperbólico de un imposible tetrarca, dueño de zafiros inverosímiles, causa indirecta del primer crimen. En el segundo episodio, el anacronismo presenta aspectos más complejos, más elaboradamente oníricos. Así, como en el lenguaje de los sueños, en el episodio de la muerte de Azevedo un sentido inmediato a la vez descubre y encubre otro sentido; ${ }^{12}$ de esa manera el desplazamiento topográfico-temporal unifica distintas lecturas posibles. La más superficial, la más inmediata, es la mera anécdota en el plano del relato policial, que Red Scharlach proporciona a Lönnrot como explicación del asesinato de Azevedo (p. 506). Otro orden de lectura va más lejos, y en él se establecen vínculos sorprendentes entre Azevedo y su víctima casual. Yarmolinsky es también un prototipo; pero en el rabino se resumen, como contraparte del "medio siglo de violencia” (p. 506) practicada individualmente por Azevedo, los sufrimientos de una raza sometida a violencia colectiva. Dice el narrador: "Nunca sabremos si el Hôtel du Nord le agradó; lo aceptó con la antigua resignación que le había permitido tolerar tres 
años de guerra en los Cárpatos y tres mil años de opresión y de pogroms” (p. 499). Hay otras antítesis entre el rabino y el involuntario ejecutor de su muerte. Azevedo era un delator y un traidor; Yarmolinsky, un amante de los libros, un manso estudioso de la religión judía. Pero las oposiciones son sólo formas antitéticas en que se manifiesta una semejanza básica: la misma raza, las muertes igualadoramente violentas. Estas semejanzas están subrayadas por dos símbolos -o por un símbolo que toma dos formas-: la gran capa anacrónica que cubre el cadáver de Yarmolinsky (p. 499) destaca metonímicamente la dignidad anónima de la antigua función sacerdotal. Convertida en el poncho de Azevedo, ${ }^{13}$ realza la proyección de este personaje, en quien se compendian malhechores anónimos y legendarios, acaso arrastrados al delito exclusivamente por el azar y la vida dura, otra versión de la injusticia. Por lo demás, la secreta identidad de los opuestos es tópico deliberado en la literatura de Borges, y en el contexto de "La muerte y la brújula" la aproximación entre Azevedo y Yarmolinsky es como un ensayo de la identificación final de Lönnrot y Scharlach.

El tercer episodio es otra trampa -más compleja que el indicio de la sentencia escrita en la pared de la pinturería a cuya puerta yacía Azevedo- que Red Scharlach tiende a Lönnrot. El falso crimen y fingido secuestro ocurren en una calle del Este de la ciudad, próxima al puerto. Años antes de componer ficciones Borges había descrito el modelo real de la ficticia rue de Toulon en el poema "El Paseo de Julio": "Puerto mutilado sin mar, encajonada racha salobre/ [...] Barrio con lucidez de pesadilla al pie de los otros/ [...] tu noche calentada en lupanares pende de la ciudad/ [...] sufres de caos, adoleces de irrealidad”. ${ }^{14}$ Una vez más un texto de Borges traslada y adapta elementos de otro, estableciendo una interdependencia que los ilumina mutuamente; así, en el marco de "La muerte y la brújula”; las que en el poema aparecen como puras designaciones han explicitado una capacidad polivalente: el cuento arroja nueva luz, carga de significado, anecdotiza lo que el poema expone sin mediaciones. La dársena -en la realidad una mezcla turbia de agua de río con rachas de mar- en el poema es “encajonada racha salobre”; en el cuento es, además, indicio que se anuda con otros pasajes del contexto a través de la enunciación del narrador: "Rumbo a la dársena inmediata, de agua rectangular, los tres subieron al cupé y desaparecieron” (p. 502; subrayados míos). Los tres y rectangular insisten en la alternancia ambigua entre tres y cuatro, establecida desde la primera página del cuento. ${ }^{15}$ También, la “dársena rectangular” reitera la forma del “alto prisma que domina el estuario” (p. 499) a la vez que anticipa el "mirador rectangular" (p. 504) de la quinta, donde morirá Lönnrot. "Barrio con lucidez de pesadilla”, designa el poema; en el relato la lucidez y el mal sueño se combinan de otra forma en la experiencia de Lönnrot al llegar a la quinta de Triste-le-Roy. Perdido y aterrado en la casa que parece de pesadilla con sus "inútiles simetrías y repeticiones maniáticas” (p. 504), trata de mantener el control negando la realidad, formulándose explicaciones racionales -lúcidas- para conjurar el 
presentimiento siniestro: "La casa no es tan grande, pensó. La agrandan la penumbra, la simetría, los espejos, los muchos años, mi desconocimiento, la soledad” (p. 505). El cuento despliega los componentes del caos meramente enunciado en el poema: “el cosmorama y la lechería, el burdel y los vendedores de biblias” (p. 502). La irrealidad, apenas mentada en el verso, se particulariza y estalla en el carnaval del cuento, que justifica disfraces, máscaras, pantomima. Otra vez, como en síntesis onírica, en la pantomima de Scharlach y sus hombres se superponen situaciones, haciendo del simulacro un símbolo múltiple. ${ }^{16}$ Planeado para dar una pista falsa a Lönnrot, el pretendido rapto del falso Gryphius reproduce como caricatura expresionista -onírica- una situación anterior al relato: los hombres que simulan raptar al apócrifo Gryphius, a quien aparentan haber herido, habían rescatado a Scharlach de un tiroteo con la policía, del que no pudo huir el hermano del pistolero (p. 505). Pero a la vez se ensaya una de las escenas finales: los dos arlequines de reducida estatura que se llevan al tambaleante Gryphius-Scharlach de la Liverpool House (502) son los mismos hombres del pistolero, "de pequeña estatura, fornidos y feroces”, que maniatan a Lönnrot en el mirador de la quinta (p. 505). Junto al de los nombres, hay un notorio anacronismo en el pasaje: el anticuado cupé en que los arlequines se llevan a su supuesta víctima es el mismo coche de otra época en que los mismos hombres habían rescatado al pistolero salvándolo de caer en manos de la policía (p. 502 y p. 505). El marco del carnaval sirve para que Scharlach urda la farsa, que Lönnrot cree pero cuya naturaleza de simulacro no pasó inadvertida a Treviranus. También están justificados por el carnaval los nombres de las más distintas procedencias que -como otras máscaras más solapadas que las de los hombres disfrazadoscontribuyen al caos y la confusión. El dueño de la Liverpool House, irlandés, se llama como el protagonista de Finnegan's Wake de Joyce; los apellidos Ginzberg, Ginsburg, Gryphius pertenecen a personajes reales, relacionados con estudios bíblicos y hebraicos, ${ }^{17}$ como, por cierto, el de Baruj Spinoza, firmante de la carta y el plano que recibe Treviranus. Estos cuatro útimos nombres son otras tantas caretas del organizador y actor principal de la pantomima. Por otra parte otro irlandés -precursor anónimo de Black Finnegan- intentó convertir a Scharlach al cristianismo durante su refugio en la quinta (p. 506).

El pueblo del sur donde culmina el relato está aún más alejado del norte -en donde se establece, con el primer crimen, el primer punto del triángulo o rombo imaginarios- que el barrio desolado donde muere Azevedo y que la calle maloliente del Este donde se lleva a cabo el simulacro de secuestro y crimen del fingido Gryphius. Como en los tres pasajes anteriores, los datos topográficos son verídicos pero no el nombre. Por lo demás, el Sur como meta final del destino es otro tópico recurrente en la literatura de Borges, y se justifica en la geografía. Hacia el sur de Buenos Aires se extiende la zona más vieja de la ciudad: Dahlman, protagonista de “El Sur”, considera que al atravesar el límite entre norte y sur de Buenos Aires se “entra en un mundo más 
antiguo y más firme”; ${ }^{18}$ recuérdese que Dahlman viaja hacia su muerte y que "pudo sospechar que viajaba al pasado y no sólo al Sur”. ${ }^{19}$ Borges pasó muchos veranos de su infancia en Adrogué, uno de los pueblos suburbanos del Sur que establecen -o establecían- la transición entre la zona urbana y la llanura. En "Nueva refutación del tiempo" escribe Borges: “cada vez que el aire me trae un olor de eucaliptos, pienso en Adrogué, en mi niñez”. ${ }^{20} \mathrm{El}$ hotel de Adrogué tiene un papel importante en “Tlön, Uqbar, Orbis Tertius”. ${ }^{21}$ En una conversación con Victoria Ocampo, en 1969, insistió Borges: “Al pensar en Adrogué, no pienso en el Adrogué actual deteriorado por el progreso [...], sino en aquel perdido y tranquilo laberinto de quintas, de plazas, de calles que convergían y divergían, de jarrones de mampostería y de quintas con verjas de fierro. ["Una herrumbrada verja definía el perímetro irregular de la quinta” (p. 504).] En cualquier lugar del mundo en que me encuentre, basta el olor de los eucaliptus para que yo vuelva a ese Adrogué perdido que ahora sólo existe en mi memoria”. ${ }^{22}$ Los recuerdos de Adrogué y de una de sus casas se inscriben en un poema recogido en "El Hacedor”:

\author{
Su olor medicinal dan a la sombra \\ Los eucaliptus: ese olor antiguo \\ Que, más allá del tiempo y del ambiguo \\ Lenguaje, el tiempo de las quintas nombra. \\ [...] \\ Cada objeto conozco de este viejo \\ Edificio: las láminas de mica \\ Sobre esa piedra gris que se duplica \\ Continuamente en el borroso espejo. \\ Y la cabeza de león que muerde \\ Una argolla y los vidrios de colores \\ Que revelan al niño los primores \\ De un mundo rojo y de otro mundo verde. ${ }^{23}$
}

Vivos en la memoria del autor como testimonio de placenteras sensaciones infantiles, esos vidrios -esos rombos- de colores detentan una carga aterradora en "La muerte y la brújula”. Se transforman, en la pared de la pinturería del Oeste donde es muerto Azevedo, en el indicio secreto de que a Lönnrot lo espera la muerte en un lugar con rombos. El indicio se repite en los disfraces de arlequín de los falsos raptores del seudo Gryphius. Finalmente, en el mirador de la quinta de Triste-le-Roy proporcionan la última visión del mundo a Lönnrot: "Miró los árboles y el cielo subdivididos en rombos turbiamente amarillos, verdes y rojos” (p. 507).

La distribución topográfica de Buenos Aires se integra, para constituir el marco del relato, con ciertos principios básicos de la religión judía, que el pistolero Scharlach 
resume con claridad borgeana. El día hebreo empieza al anochecer y dura hasta el anochecer siguiente; el nombre hebreo de Dios no puede pronunciarse sino sólo escribirse en la forma abreviada de las cuatro letras del tetragrámaton. A estos preceptos ortodoxos se suman restos de una leyenda según la cual algunos miembros de la secta de los Hasidim, establecida en el siglo XVIII, llevados por una exaltación mística incontrolable habrían llegado al crimen ritual para encontrar el nombre secreto de Dios (pp. 506-507). Los puntos básicos de la ortodoxia judía y la leyenda en contra de los Hasidim se dan en estado puro, como premisas que no se afirman ni se niegan, como no se discuten los puntos geográficos. Simplemente se toman en sí, para entretejer la trama rigurosamente geométrica del relato. ${ }^{24}$

Pero también el motivo de la ortodoxia judía suscita alusiones relacionadas con la época y el medio en que se escribió el cuento: Segunda Guerra mundial, apogeo del antisemitismo nazi; Argentina: país donde el antisemitismo y los regímenes totalitarios de derecha han tenido (y tienen) un prestigio digno de causas más defendibles. Algunas alusiones de "La muerte y la brújula” no se captan fácilmente si se desconoce la tendencia antisemita de ciertos grupos de argentinos.

En "Nueva refutación del tiempo" Borges dice: “cada vez que oigo a un germanófilo vituperar el yiddish, reflexiono que el yiddish es, ante todo, un dialecto alemán.” ${ }^{25}$ Vale la pena cotejar el comentario y su formulación con el final del primer diálogo entre Treviranus y Lönnrot: Treviranus repuso con mal humor:

-No me interesan las explicaciones rabínicas; me interesa la captura del hombre que apuhaló a este desconocido.

-No tan desconocido -corrigió Lönnrot-. Aquí están sus obras completas. Indicó [...] una fila de altos volúmenes [...] El comisario los miró con temor, casi con repulsión. Luego, se echó a reír.

-Soy un pobre cristiano -repuso-. Llévese todos estos mamotretos, si quiere; no tengo tiempo que perder en supersticiones judías.

-Quizá este crimen pertenece a la historia de las supersticiones judías-murmuró Lönnrot.

-Como el cristianismo -se atrevió a completar el redactor de la Yiddische Zeitung. Era miope, ateo y muy tímido (p. 500).

Como organización y significado, la declaración que en el final del diálogo se divide entre Lönnrot y el periodista judío es similar a la de Borges sobre el yiddish. Curiosamente, además, las características del redactor del diario judío coinciden con las del entonces joven Borges: miope, ateo y muy tímido. Como los pintores renacentistas que estampaban su autorretrato en personajes secundarios relegados a un rincón del cuadro, Borges se había divertido asignándose un papel anónimo, accidental, en el cuento. Otro personaje accidental, otro periodista, ofrece una especie de contrapunto del redactor judío. El nombre de Ernst Palast, a quien se atribuyen 
feroces declaraciones antisemitas, disimula -bajo una germanización sarcástica sin duda transparente para los contemporáneos- el de Ernesto Palacio, escritor católico colaborador de la revista Criterio. ${ }^{26}$

Las palabras y actitudes de Treviranus traslucen prejuicios antisemitas convencionales; pero las manifestaciones del antisemitismo, que aisladas podrían quedar como simples rasgos de una caricatura, no están desconectadas. El prejuicio a la vez sustenta el pragmatismo del comisario y establece una corriente dialéctica entre su sentido práctico -apoyado en su prejuicio- y el entusiasmo exaltado con que el detective se deja llevar por las implicaciones místicas del asesinato del rabino. Ese entusiasmo -alimentado por la condición de especulador de Lönnrot: amante del razonamiento y también de las aventuras mentales que deforman el razonamiento en obsesión- es el extremo opuesto del sentido común de Treviranus, quien sueña casi obtuso en su simple sensatez.

Este punto nos traslada no sólo a la lectura del cuento como integración de elementos extratextuales -la realidad geográfica o los principios de la religión judía: también nos lleva más allá de los cambios que se operan en él de los propios textos de Borges. Nos muestra la escritura en cuanto trasgresión de una lectura; nos revela que "La muerte y la brújula" trastrueca las pautas fijadas en los tres modelos de relatos policiales establecidos por su creador, Edgar Poe: “The Murders in the rue Morgue”, “The Mystery of Marie Rogêt” y -sobre todo- “The Purloined Letter”.

Con la muerte de Lönnrot culmina una desviación respecto al modelo de cuento policial ya planteada en la primera página. Lönnrot -enuncia el narrador- "se creía un Auguste Dupin, un puro razonador, pero algo de aventurero había en él y hasta de tahur” (p. 499). Paradójicamente, Lönnrot personifica las debilidades a las que Auguste Dupin -el detective francés creado por Poe- atribuye el fracaso de un oficial de policía en "The Murders in the rue Morgue": "he erred continually by the very intensity of his investigation. He impaired his vision by holding the object too close. He might see, perhaps, one or two points with unusual clearness, but in so doing he, necessarily, lost sight of the matter as a whole". ${ }^{27}$ Lönnrot vio "one or two points with unusual clearness”: "La secreta morfología de la malvada serie” (p. 499) y también previó el cuarto crimen (ibid.) pero, en cambio, "lost sight of the matter as a whole": ni adivinó que la muerte de Yarmolinsky había sido fortuita, ni consiguió evitar el último asesinato.

En “The Purloined Letter”, el detective Auguste Dupin vence a su contrincante gracias a la "identification of the reasoner's intellect with that of his opponent". ${ }^{28}$ Exactamente lo que hace el oponente de Lönnrot para atraparlo: “Comprendí que usted conjeturaba - dice Scharlach- que los Hasidim habían sacrificado al rabino; me dediqué a justificar esa conjetura [...]. Todo lo he premeditado, Erik Lönnrot, para atraerlo a usted a las soledades de Triste-le-Roy” (p. 507). Estos desvíos con respecto al canon del relato policial no implican, con todo, una caricatura del modelo. La nueva 
lectura que "La muerte y la brújula" propone para el cuento policial -o, dicho de otra manera, la nueva versión que ofrece de situaciones clásicas- se basa en inversiones paródicas, irónicas pero no burlescas. La ironía, al cambiar los papeles del detective y del malhechor, anula diferenciaciones psicológicas-0, mejor, anula la predestinación que la función marca en el cuento policial-, y así es posible que el triunfo de Scharlach altere la convención básica del género. Por otra parte, la alteración se consigue porque Scharlach se identifica con Lönnrot: ha pensado como él, de alguna manera ha sido él. Esa compenetración estaba prevista en el nombre doble de detective y pistolero, se repite en el Hermes de dos caras del jardín simétrico de la quinta de Triste-le-Roy y vuelve a invertirse en la corrección final que Lönnrot hace a Scharlach, proponiéndole un laberinto de una sola línea para cuando vuelve a matarlo. Identificacióndespersonalización: los personajes parecen convertirse en lugares vacíos, de paso, por los que transitan sensaciones similares. ${ }^{29}$ Lönnrot percibe en la voz de Scharlach "una fatigada victoria, un odio del tamaño del universo, una tristeza no menor que aquel odio" (p. 505). Levemente modificados, esos sentimientos aparecen muy poco más adelante en el texto como "un poco de frío y una tristeza impersonal, casi anónima" (p. 507) que invaden a Lönnrot y a los que opone la débil resistencia del razonamiento final con que corrige el plan de su asesino. Esta despersonalización ya se había planteado menos intensamente en la figura arquetípica del estudioso rabino y en la estampa simbólica del cuchillero traidor, a su vez, respectivamente esbozos del razonador Lönnrot, del criminal Scharlach. El trastrueque de los papeles -insinuado en Yarmolinsky y Azevedo y muy evidente en Lönnrot y Scharlach- inviste a los personajes de "La muerte y la brújula" de una cualidad metafórica, ausente en los personajes del relato policial tradicional. Así, transgredir las normas del género ha significado abrirlo: enriquecerlo inscribiendo en él el motivo de la identidad y del destino, preocupaciones persistentes en la obra de Borges. ${ }^{30}$ Lönnrot no es -no puede ser-el detective típico; en cambio puede ser el hombre expuesto a su propio destino, una versión más de los otros hombres finalmente anónimos del relato, que funcionan como etapas de una única aventura. Abierto, el relato policial permite que Lönnrot sea avatar de un hombre real, de cualquier hombre: “era semejante a los otros, vale decir, que no era nadie, o que era apenas una algarada confusa, persistiendo en el tiempo y fatigándose en el espacio". ${ }^{31}$ Scharlach, por su parte, repite otros personajes literarios: "Cumplida su tarea de justiciero, ahora era nadie. Mejor dicho era el otro: no tenía destino sobre la tierra y había matado a un hombre”. ${ }^{32}$

En las páginas anteriores, resumiendo algunos datos, omitiendo otros deliberadamente y por cierto dejando afuera otros sin advertirlo, he propuesto para "La muerte y la brújula" una lectura final metafórica. Otros caminos habrían podido conducir a una meta similar; pero tanto detrás de ellos como de los esbozados explícitamente hay lecturas mucho más complejas: sólo repetibles en la forma única del "eje de innumerables relaciones" que el texto concierta. En esas 
lecturas -pretextos para tornarse escritura-, "No sólo es ingenioso lo que refieren; es también simbólico de procesos que de algún modo son inherentes a todos los destinos humanos. [...] capaz de una plástica ambigüedad; es todo para todos, como el Apóstol; es un espejo que declara los rasgos del lector y es también un mapa del mundo. Ello debe ocurrir, además, de un modo evanescente y modesto, casi a despecho del autor; éste debe aparecer ignorante de todo simbolismo”. ${ }^{33}$

Herbert H. Lehman College (CUNY)

MARIA LUISA BASTOS

\section{NOTAS}

1 Jorge Luis Borges, Obras completas (Buenos Aires: Emecé, 1974), pp. 499-507. Todas las citas corresponden a esta edición.

2 Barthes describe dos tipos de lectura: "I’une va droit aux articulations de l'anecdote, elle considere l'étendue du texte, ignore les jeux de langage... l'autre lecture ne passe rien; elle pèse, colle au texte, elle lit, si l'on peut dire, avec application et emportement, saisit en chaque point du texte l'asyndète qui coupe les langages -et non l'anecdote: ce n'est pas l'extension (logique) qui la captive, l'effeuillement des vérités, mais le feuilleté de la significance [...]. Or paradoxalement (tant l'opinion croit qu'il suffit d'aller vite pour ne pas s'ennuyer), cette seconde lecture, appliquée (au sens propre), est celle qui convient au texte moderne, au texte-limite.” Roland Barthes, Le plaisir du texte (Paris: Editions du Seuil, 1973), pp. 22-23. Subrayados del autor.

3 Borges suele expresar una sorpresa bastante parecida al desdén ante las interpretaciones críticas de su obra: "I write a story; I think of it as being rather poor, then the general critic comes along and makes it a very rich story. He works in connotations, explanations, says that such and such scene stands for a symbol of something else... But when I write, I am really writing in terms of the story, especially in terms of the plot and of the characters, but I don't think of them as being, let's say, symbols of the Universe or standing for the evolution of humanity, or for my thoughts concerning Utopia.” Pero inmediatamente concede: “After all, I suppose, a book is what comes out in the reading. When a book is closed it is merely a thing among things [...]. But when somebody is reading it, then something is happening, and that happening is the book of course, and not the mere symbols on the page, because that is just its printing." Eduardo Calad y María T. Rocha, “An Interview with Jorge Luis Borges”, Meridiano 7, 3 (Otofio 1976), p. 17.

4 Borges, Obras completas, op. cit., p. 483.

5 Estos nombres - "términos que significan objetos o zonas de objetos captados desde una muy determinada perspectiva” (Marcial Tamayo y Adolfo Ruiz Díaz, Borges enigma y clave [Buenos Aires: Nuestro Tiempo, 1955], p. 38)- reproducen asociaciones analógicas similares a las oníricas. El Hôtel du Nord está en el Norte, como el Plaza; Buenos Aires es un puerto, como Toulon y Liverpool. El antiguo Paseo de Julio -la rue de Toulon-era la calle del puerto. Bajo las especies de un locativo francés, Triste-le-Roy alude crípticamente al triste destino de Erik Lönnrot: la raíz germánico-escandinava de Erik es forma nórdica equivalente a la latina rex.

6 Para Tamayo y Ruiz Díaz, "el Hotel junto al río, incluso por su nombre extranjero, portuario, alude a Buenos Aires”. Op. cit., p. 46. 
${ }^{6 b i s}$ Cf. Tamayo y Ruiz Díaz, Op. cit., p. 39. También: Jorge Luis Borges, The Aleph and Other Stories (New York: Bantam Books, 1970), p. 194.

7 Una fotografía del Kavanagh publicada en el número de la revista Atlántida dedicado al Cuarto Centenario de la fundación de Buenos Aires, en 1936, tiene esta leyenda: "El gigantesco edificio Kavanagh, uno de los más altos de Buenos Aires”. Atlántida, 837 (octubre de 1936).

8 Borges, Op. cit., p. 17.

9 Op. cit., p. 765.

9bis El número no es casual: “The nine has been a 'magic number' for centuries. According to the traditional symbolism of numbers, it represents the perfect form of the perfected Trinity in its threefold elevation". Jolande Jacobi, "Symbols in an individual analysis", en Man and His Symbols, compilado por C. J. Jung y M-L von Franz (Dell: New York, 1977) p. 367. Ver también J. E. Cirlot, A Dictionary of Symbols (New York: Philosophical Library, 1962). Para las implicaciones cabalísticas del número nueve, ver: Jaime Alazraki, "Borges and the Kabbalah”, TriQuarterly, 25 (Fall 1972), p. 244.

${ }^{10}$ Ver, con respecto al nombre de Yarmolinsky: Tamayo y Ruiz Díaz, Op. cit., p. 38; Alazraki, Op. cit., pp. 242-243 y Saúl Sosnowski, Borges y la Cábala (Buenos Aires: Hispamérica, 1976), pp. 86-87.

${ }^{11}$ Cf. "Hombre de la esquina rosada", en Borges, Op. cit, pp. 329-334.

12 'Le rêve et ses analogues s'inscrivent ainsi dans une région du langage qui s'annonce comme lieu des significations complexes où un autre sens tout à la fois se donne et se cache dans un sens immédiat”. Paul Ricoeur, De 1'interprétation (Paris: Seuil, 1965), p. 17. Subrayado del autor.

${ }^{13}$ Tamayo y Ruiz Díaz, Op. cit., p. 46: "la segunda puñalada se consuma en inconfundibles arrabales. El asesinado es Daniel Simón Azevedo, en quien la capa anacrónica que envolvía a Yarmolinsky se ha vuelto poncho."

${ }^{14}$ Borges, Op. cit., p. 95. El poema fue recogido en Cuaderno San Martín (1929). En 1930 el nombre del Paseo de Julio se cambió por el del fundador de la Unión Cívica Radical, Leandro N. Alem. También es anacrónica para 1942 la caracterización de la "torcida rue de Toulon”. En el número de Atlántida mencionado en la nota 7 se señala el año 1930 como de progresos notables para la ciudad de Buenos Aires, que se atribuyen a la "libertad de acción” que el gobierno dejó al intendente José Guerrico; entre los cambios, el del Paseo de Julio: "reducto de las antiguas bandolas y de los figones para marineros, que hasta poco tiempo atrás fueron algo así como una vincha sucia ciñendo la cabeza de la ciudad, cambia de aspecto. Eliminados sus jardines centrales, que, más que adornarla [a la ahora Avenida Leandro N. Alem], la afeaban entorpeciendo el tráfico, adquiere un ancho tres veces mayor. Se reemplazan totalmente en pocos meses sus gastados adoquines por pavimento asfáltico, con amplias veredas con refugios centrales para peatones, colocándose a lo largo de la nueva avenida 154 columnas ornamentales con dos pocos de 500 watts cada una, que disipan definitivamente la sordidez tradicional de la calle.” Atlántida, 837 (Octubre de 1936), p. 101.

15 Tamayo y Ruiz Díaz se refieren con detalle a la significación simbólica y al valor de indicios de las reiteradas menciones y alusiones al color rojo (Op. cit., pp. 42-45). No menos importante es el interjuego entre las cifras tres y cuatro -cargadas de simbolismo místico, alquímico, psicológico- que también funcionan como indicios en la textura de la anécdota, en los que no sólo se acumulan las significaciones simbólicas tradicionales sino hasta alusiones locales. Tamayo y Ruiz Díaz subrayan que el crimen de Azevedo se comete el tres 
de febrero, "fecha argentina que se hace porteña en un parque de Palermo” (Op. cit., p. 46): fecha de la batalla de Caseros, que terminó con la dictadura de Juan Manuel de Rosas. Sin duda la coincidencia quiere hacer de Azevedo un avatar de Rosas, marcando la calidad de cuchillero del dictador argentino. Para una síntesis apretada pero útil del significado simbólico de los números tres y cuatro, ver: J. E. Cirlot, A Dictionary of Symbols, op. cit. Para otras implicaciones de la alternancia entre tres y cuatro, ver: C. J. Jung, Psychology and Alchemy (Princeton: Princeton University Press, 1962), especialmente pp. 228-230.

16 "II y a symbole lorsque le langage produit des signes de degré composé où le sens, non content de désigner quelque chose, désigne un autre sens qui ne saurait être atteint que dans et par sa visée”. Paul Ricoeur, Op. cit., p. 25.

17 Tamayo y Ruiz Díaz, Op. cit., p. 38. Cf. también Sosnowski, Op. cit., p. 87.

${ }^{18}$ Borges, "El Sur", en Obras completas, op. cit., p. 526.

${ }^{19} I d$., p. 528. Véanse también estos comentarios de Borges en una conversación pública: “[...] the word 'sur' is a fine word -there you come across the large, open spaces [...]. And so I think of the South in terms of the past of my country.” "Borges at N.Y.U.”, en TriQuarterly, 25 (Fall 1972), p. 449.

${ }^{20}$ Borges, Obras completas, op. cit., p. 763.

21 "Triste-le-Roy es el hotel donde Herbert Ashe recibió, y tal vez no leyó, el tomo undécimo de una enciclopedia ilusoria”. Borges, Op. cit., p. 483.

${ }^{22}$ Victoria Ocampo, Diálogo con Borges (Buenos Aires: Sur, 1969), p. 53.

${ }^{23}$ Borges, Op. cit., p. 841. Emir Rodríguez Monegal ya señaló que esos rombos “viennent, sans aucun doute, du fond de l'histoire personnelle de Borges, de ses vacances d'enfant à l'Hôtel d'Adrogué, plein de couloirs terrifiants”. También ha observado que el tema de los rombos “est la métaphore de la secrète symétrie de l’histoire policière.” Emir Rodríguez Monegal, Borges par lui-mgme (Paris: Seuil, 1970), p. 83.

${ }^{24}$ Por lo menos en el nivel más estrictamente anecdótico de la narración en cuanto relato policíaco. Jaime Alazraki ha anotado, por otra parte, que "los libros enigmáticos y a menudo esotéricos" que se mencionan crean un aura de fantasía para el lector no familiarizado con la Cábala. Alazraki, Op. cit., p. 243.

${ }^{25}$ Borges, Op. cit., p. 763.

${ }^{26}$ Ernesto Palacio también colaboró en el periódico Martín Fierro. Otro nacionalista, Manuel Gálvez, lo considera uno de los pocos “escritores de raza” con que contó Martín Fierro. Cf. Manuel Gálvez, La Argentina en nuestros libros (Santiago de Chile: Ediciones Ercilla, 1935), p. 78, n. 1.

${ }^{27}$ Edgar Allan Poe, Tales, Poems and Essays (London: Collins, 1952), p. 341.

${ }^{28}$ Id., p. 408.

${ }^{29}$ Cf. Sylvia Molloy, “La composición del personaje en la ficción de Borges”, $N R F H$, no. 1, tomo XXVI (1977)

30 "The killer and the slain, whose minds work in the same way, may be the same man. Lönnrot is not an unbelievable fool walking into his own death trap but, in a symbolic way, a man committing suicide”. Borges, en The Aleph and Other Stories (New York: Bantam Books: 1970), p. 194.

${ }^{31}$ Borges, Inquisiciones (Buenos Aires: Proa, 1925), p. 89.

32 “El fin”, en: Borges, Obras completas, op. cit., p. 521.

33 “El primer Wells”, en: Borges, Obras completas, op. cit., p. 698. 


\section{El Desplazamiento Como Metáfora en Tres Textos de Jorge Luis Borges}

En un libro de reciente publicación, Jaime Rest ha puntualizado los aspectos nominalistas de la obra de Jorge Luis Borges. ${ }^{1}$ Quizá quepa discutir en ese planteamiento la exclusión absoluta que se hace allí del ingrediente platónico: pero entendido éste no ya como convicción ideológica -ya que estamos de acuerdo en que casi la única afirmación que en esa obra se consuma es la del nominalismo-, sino como una hipótesis lúcida más, junto con las provenientes de filosofías y teologías de distinta procedencia. Gracias a ese juego hipotético se hace posible imaginar ficciones donde la convergencia de situaciones o personajes aparentemente distantes entre si, se revelan como la 'realización' de un arquetipo insospechado que trasciende la historia concreta: un arquetipo que no siempre tolera ser asimilado al concepto de sustrato psicológico interhumano o memoria inconsciente de la especie, a la manera de Jung, como quiere Rest (pienso en "Historia del guerrero y de la cautiva”, “El tango”, “La Trama”, entre otros). Pero de todos modos estamos ante una literatura cuya única certeza sobre el mundo es, excluyente y devastadoramente, la propia literatura, ya que el hombre vive desterrado en el universo de palabras que él mismo ha creado, y ya que las palabras configuran un sistema autosuficiente y por lo tanto desigual, o ajeno, a la realidad que pretenden designar y describir.

Un lenguaje hasta ese punto emancipado, y con él una escritura cuya única certeza son las construcciones que ella misma inventa, es natural que tienda a revelar la precariedad de sus designaciones al mismo tiempo que las utiliza o las crea; y que junto con ese desamparo designativo, toda entidad sentida como tal, es decir toda aparente unidad o aparente coherencia, se vaya mostrando en Borges en lo que tiene de postulación provisoria y se resquebraje, deslizándose constantemente hacia otra cosa-otra unidad, otra posible coherencia-, en un ejercicio imaginativo que amenaza con pulverizarla, reduciéndola a relatividad pura. Y ello, tanto en la estructura del mundo en que los personajes se manejan -incluido el propio Borges cuando aparece como personaje-, como en la estructura formal del discurso que cuenta ese mundo. La crítica ha comentado, y Borges también en cuanto crítico de su propia obra, los 
deslizamientos de género literario en aquellos cuentos suyos que se resuelven como semiensayos, o la Historia tratada como criatura de ficción y viceversa, o la sorpresa final de ciertos relatos que hay que leer retrospectivamente para encontrar las pistas que le dan sentido - una especie de lectura policial al revés- hasta descubrir que habíamos estado accediendo, sin saberlo, a otro relato disimulado en la trama del primero. Esta tarea de desplazamiento migratorio a que se somete el estilo de Borges, quisiera yo examinarla en tres modalidades distintas de realización, a través de dos cuentos suyos -“El Aleph”, "Las ruinas circulares"- y de un ensayo -“Borges y yo".

"Arribo, ahora, al inefable centro de mi relato; empieza, aquí, mi desesperación de escritor”, declara Borges personaje-narrador en “El Aleph”, momentos antes de introducirse en la imposible descripción de la visión unánime del universo. Y es ese ‘centro' del relato el que lo justifica como tal y le da nombre, pero gracias a un doble desfasaje temático que lo descentra varias veces, convirtiendo la historia argumental en un lenguaje desorientado ante sí mismo, también el des-esperado de no abarcarse como unidad coherente y cerrada, al descubrirse sometido a un juego de desplazamientos que configuran un mensaje fatalmente difuso. Como además en este cuento el prurito de desvío alcanza también a otros niveles del texto, valdrá la pena encararlo desde el ángulo de sus diversos tipos de desacuerdo con respecto a sí mismo y con respecto a ciertas convenciones prefijadas que el acoge y al mismo tiempo traiciona. Los aportes de Michael Riffaterre y su polémica con Samuel Levin ${ }^{2}$ me han incitado a reformularme el problema teórico del desvío en los textos concretos -más que en un tipo generalizado de discurso, es decir en un 'género', como tiende a plantearlo Sol Saporta-, ${ }^{3}$ y que a mi modo de ver debe plantearse en estos términos:

1. Desvíos con respecto al extratexto:

a. En relación con las normas del corpus general del idioma: casos de agramaticalidad mas abarcadores.

$b$. En relación con sub-normas situacionales tipo: es decir con convenciones de género literario, estatus de personaje o relación entre personajes o ámbito de producción del mensaje, etc.:

$b_{1}$. en lo lingüístico

$b_{2}$. en lo no lingüístico

2. Desvíos con respecto al propio macrocontexto:

c. Contrastes ocasionales con las convenciones que va codificando el mensaje en su decurso: ruptura de su homogeneidad interna:

$c_{1}$. en lo lingüístico

$C_{2}$. en lo no lingüístico

Excluyo con Levin to que Riffaterre caracteriza como desvío en el microcontexto -es decir con respecto al constituyente inmediato de una célula lingüística-, porque cuando se lo reconoce como tal lo que en realidad se registra es una desacomodación 
con las normas habituales del idioma, es decir un desvío del tipo $a$. Por otra parte mi sistematización excede el límite de lo estrictamente idiomático, incluyéndolo como uno de sus posibles niveles, y permite extender el problema del desvío incluso hasta el estrato temático, como puede inferirse de los tipos $b_{2} \mathrm{y}_{2}$ que postulo.

Ahora bien: la historia de "El Aleph" se articula como un peregrinaje temático que nos va derivando de una historia hacia otra, hasta que descubrimos que el verdadero ‘centro’ del relato no estaba allí donde el lector y el protagonista creían que estuviera. ¿Qué función desempeña en este cuento el intento de recuperación sentimental de Beatriz Viterbo muerta, la búsqueda de cuyo recuerdo inaugura el relato y lo cierra? Los encuentros y desencuentros del azar, que en el universo de la novelística cervantina formaban parte de un mensaje optimista y de gozosa entrega a las potencialidades de lo imprevisto, rigen acá como un intrincamiento de aventuras donde cada una no sólo transforma a las anteriores en un pretexto suyo, o en una simple apoyatura, desjerarquizándolas en términos de la economía del relato, sino que posee ocultas claves para descifrar las otras, y a esas claves se accede azarosamente, sin posibilidad de control; hasta que la clave de las claves (la visión del Aleph) queda a su vez relativizada desde la "Postdata”, porque "por increíble que parezca, yo creo que hay (o que hubo) otro Aleph, yo creo que el Aleph de la calle Garay era un falso Aleph”. Empecemos formalizando la estructura argumental de las tres historias escalonadas que lo constituyen, cuyos puntos de convergencia producen un tejido sagaz de derivaciones que nos van despistando de un eje temático a otro, de modo que lo que se plantea como un relato sentimental se resuelve en una narración satíricoliteraria y ésta a su vez en un cuento metafísico (doble desvío interno, temáticoargumental, del tipo $c_{2}$ ). Siguiendo de cerca la teoría de las funciones nucleares de Roland Barthes, vamos a diagramar en forma paralela las tres historias, vinculando con línea punteada las situaciones-puente entre una y otra:

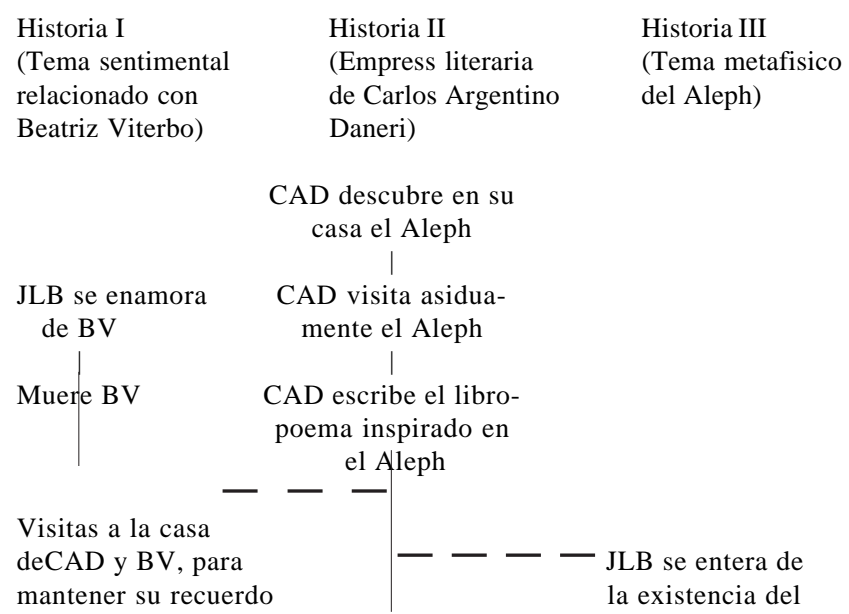




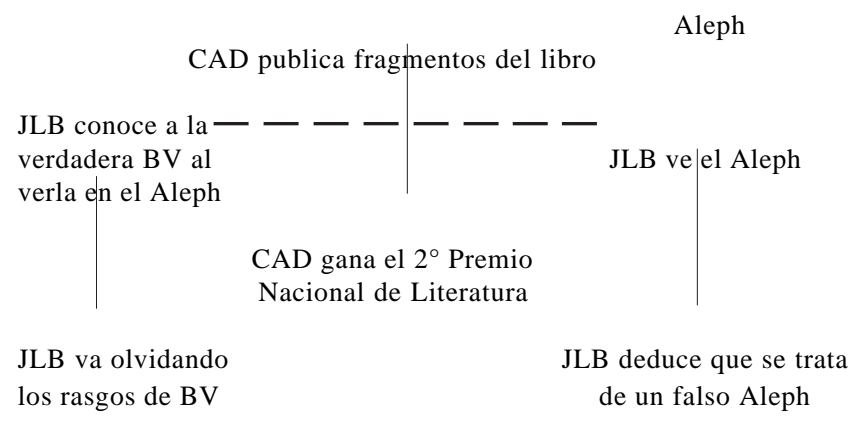

La Historia III implica a II y a I, ya que no hubiera podido suceder sin haber sucedido las otras (recordemos que Carlos Argentino revela a Borges la existencia del Aleph porque necesita conservarlo para continuar su poema). Sin embargo, cada una se vincula con la otra, y aun la desencadena en el último caso, sólo debido a situaciones tangenciales que no hacen a su propia coherencia: pero al realizarse esa vinculación, el relato deriva su ‘centro’ argumental de una secuencia a la otra, hasta que el cuento se consolida en relación con su título sólo después de haber promediado en extensión el discurso que lo narra.

Ese discurso que transmigra de una historia a otra no adopta el procedimiento del relato enmarcado ni del contrapunto temático que culmina en una convergencia unificadora: los tres temas-argumentos se producen mutuamente y también se soslayan buscando cada uno su propio acabamiento; pero al hacerlo, cada nueva historia va desplazando jerárquicamente a la anterior a la busca de una justificación última del relato que la incluye. Esos cambios de jerarquización se realizan de acuerdo con dos instancias: a) debido al distinto interés y valoración con que cada personaje vivencia la misma situación (entrevistas de Borges y Daneri; visión del Aleph); b) debido al proceso de enunciación con que Borges personaje-narrador va articulando, juzgando y enfatizando los hechos que narra. Al principio leemos un relato cuyo tema pertinaz es la persistencia de una nostalgia sentimental: las reflexiones iniciales sobre el tiempo que transcurre postergando a los muertos, la insistencia en referirse a las visitas y a los pretextos para multiplicar esas visitas, el catálogo de retratos de Beatriz, así lo confirman. Pero esas visitas "vanamente eróticas” van desplazando el tema de Beatriz hacia el de su primo Carlos Argentino: primero de un modo subrepticio (mediante alternancias paralelísticas: "Beatriz era alta, frágil, muy ligeramente inclinada...”/ "Carlos Argentino es rosado, considerable, canoso, de rasgos finos...”; o con alguna comparación parentética); hasta que la aventura del libro-poema que está pergeñando este último desplaza al otro tema definitivamente, reduciendo la mención de Beatriz a referencias ocasionales, como si la Historia I estuviera latente para salir de su postergación en algún momento, sin que eso llegue a suceder nunca. Gracias al 
puente episódico de las visitas a la casa de los Viterbo-Daneri, la Historia II totaliza el relato convirtiéndolo en una sátira contra la literatura de los poetastros, y hacia los certámenes oficiales que son capaces de premiarla. La mención del premio aparece mucho después, en la "Postdata del primero de marzo de 1943": pero en el medio está el episodio en primera instancia improcedente de la demolición de la casa donde está el Aleph, y con ello la revelación que nos instala en el tema metafísico de la Historia III. Ahora el puente de enlace es la malhadada enciclopedia rimada que esta produciendo Daneri, versión mostrenca de su contemplación del Aleph. Aquí también el tema de la Historia I vuelve a irrumpir episódicamente, pero sin ahogar ni justificar al otro: primero en las palabras tentadoras de Carlos Argentino previas a la visión del Aleph por Borges: “...Baja; muy en breve podrás entablar un diálogo con todas las imágenes de Beatriz”; después, y como un detalle más del vértigo visionario, la revelación de lo que había sido la vida oculta de Beatriz y su destino actual de cadáver.

Pero el tema metafísico o ‘centro’ del relato no aparece sin antes filtrarse por otro desplazamiento (frustrado) hacia lo que empieza planteándose como episodio enigmático-policial en la mente afiebrada del protagonista: “Cumplí con sus ridículos requisitos; al fin se fue. Cerró cautelosamente la trampa; la oscuridad, pese a la hendija que después distinguí, pudo parecerme total. Súbitamente comprendí el peligro: me había dejado soterrar por un loco, luego de tomar un veneno. Las bravatas de Carlos transparentaban el íntimo terror de que yo no viera el prodigio; Carlos, para defender su delirio, para no saber que estaba loco, tenía que matarme”. Sólo que esta oscilación a que aludimos ahora es de un nuevo carácter: ella no nos aparta de la coherencia interna de la Historia III sino que juega con las convenciones literarias heredadas (caso distinto del de Chesterton, donde lo policial se ahonda hasta el mensaje metafísico, no como aquí donde se abandona el atajo de lo policial para tomar el otro). Se trata de un desvío del tipo $b$, en relación con la estructura de los géneros que condicionan todo texto literario, y cuyo exponente más flagrante es la "Postdata del primero de marzo” y las notas a pie de página que derivan la forma cuento hacia la forma del pseudo-ensayo, al transformarse en una discusión erudita y 'documentada' sobre el asunto mismo que sostiene la ficción y desde su periferia. Pero como el ensayo de la Postdata es también una ficción, y como por otra parte el propio relato-ficción pone en boca de su autor real, con su propio apellido, la anécdota fantástica que cuenta (afantasmando a la vez a ese autor), esos continuos escamoteos quiebran la confianza del lector en toda solidez, y lo dejan atónito ante un continuo desacomodamiento de estructuras, ante una 'norma' fundada precisamente en lo relativo y paradójico de toda norma. Obviamente, los desfasajes formales y temáticos que hemos estudiado se corresponden con lo que llamaríamos 'la paradoja de los hechos' en el mundo representado por el relato: no sólo la visión del Aleph por Borges personaje se produce como un hecho azaroso en relación con situaciones que para nada parecían preanunciarla, como antes hemos visto, sino que el único hombre que alcanzó a disfrutar de esa visión durante una 
larga porción de su vida resultó ser la persona más inepta para poder aprovecharla y, por añadidura, la utiliza para transgredir sistemáticamente la literatura al creer con ello producir literatura; además y sobre todo, alcanzar el conocimiento intuitivo del universo es no haberlo alcanzado, ya que de ponerlo socráticamente en duda se encarga el conocimiento raciocinante de los eruditos, incluido Borges, hacia el final de la narración.

Por su parte los registros de la palabra incurren en procesos de desacomodamiento semejantes. Sintagmáticamente, los apareamientos inesperados y contradictorios marcan la relativización irónica de toda aparente coherencia (agramaticalidad: desvío del tipo $a$, que desarrolla secuencias lingüísticas semánticamente inusitadas): "su actividad mental es continua, apasionada, versátil y del todo insignificante”; "en su escritorio habían colaborado la aplicación, la resignación y el azar”. La enumeración caótica en que se resuelve la indecible presentación del Aleph zigzaguea entre la mención de esencias abarcadoras e ínfimos detalles concretos, encadena lo anónimo y lo autobiográfico, lo visible y lo invisible, la unidad y la multiplicidad.... Y en lo que respecta a la relación lenguaje-situación (desvío del tipo $b_{1}$ ), es revelador el desajuste que se produce en cada intervención de Carlos Argentino, cuya retórica se complace en lo ampuloso y sofisticado precisamente cuando esperaríamos lo contrario (en sus diálogos familiares con Borges); pero desciende a la modalidad cotidiana y vernácula allí donde la solemnidad de la revelación metafísica acaba de experimentarse: “-Tarumba habrás quedado de tanto curiosear donde no te llaman [.... ¡QQué observatorio formidable, che Borges!”, para culminar, en esa misma circunstancia, con una pregunta cuya puerilidad de antesala de cine pone al

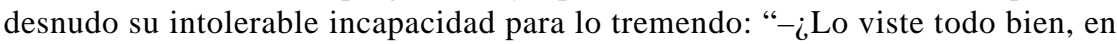
colores?”

Hay un párrafo de "El Aleph" cuya alusividad pasa inadvertida en una primera lectura, ante todo porque el personaje que la pronuncia dice más de lo que cree estar diciendo, en una especie de premonición malgré lui: “... Denostó con amargura a los críticos; luego, más benigno, los equiparó a esas personas 'que no disponen de metales preciosos ni tampoco de prensas de vapor, laminadoras y ácidos sulfúricos para la acuñación de tesoros, pero que pueden indicar a los otros el sitio de un tesoro'. Acto continuo censuró, etc.” (el subrayado es del autor). Esto que dice Daneri con respecto a los críticos literarios lo está diciendo el autor implícito con respecto al propio Daneri, quien precisamente se desempeñará como guía ingenuo en relación con Borges personaje para el descubrimiento de la visión metafísica del Aleph.

La doble lectura de un mismo texto, que en este cuento es excepcional, alimenta en cambio toda la economía del relato en "Las ruinas circulares" y nos obliga a recorrerlo en dos niveles de sentido a la vez. Un nuevo tipo de 
desplazamiento, de escamoteo o de 'transporte', que inmediatamente vamos a examinar.

En "Las ruinas circulares" nos enfrentamos en primera instancia con lo que llamaremos la Historia I, que es la que abarca el relato explícito en casi toda su trayectoria: pero uno de sus episodios (atravesar con inmunidad el fuego) nos ofrece precisamente los elementos para alcanzar el desenlace de otra Historia II, que no se cuenta explícitamente pero que una lectura retrospectiva nos permite rehacer porque estuvo todo el tiempo agazapada en la otra. Esta vez me parece oportuno diagramar la primera historia en los términos de estructuras triádicas que Claude Bremond propone para las microsecuencias narrativas; las líneas de puntos corresponden a algunas catálisis (rellenos) de la acción o a algunos índices (caracterizaciones), que retomaremos más abajo para reconstruir a partir de ellos la historia implícita:

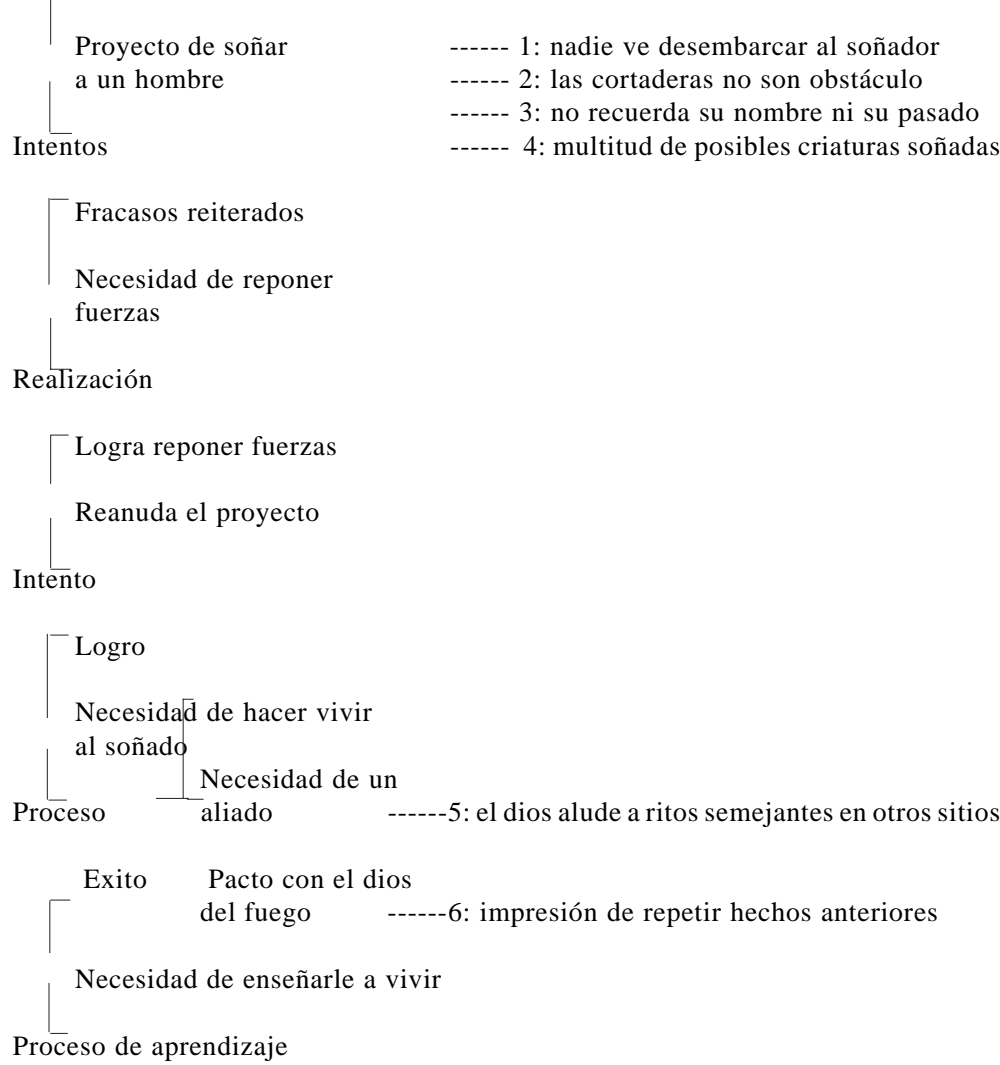

Fracasos reiterados

Necesidad de reponer

fuerzas

Realización

Logra reponer fuerzas

Reanuda el proyecto

Intento

Logro

Necesidad̄ de hacer vivir al soñado

Proceso Necesidad de un aliado ------5: el dios alude a ritos semejantes en otros sitios

Exito Pacto con el dios

del fuego ------6: impresión de repetir hechos anteriores

Necesidad de enseñarle a vivir

Proceso de aprendizaje 


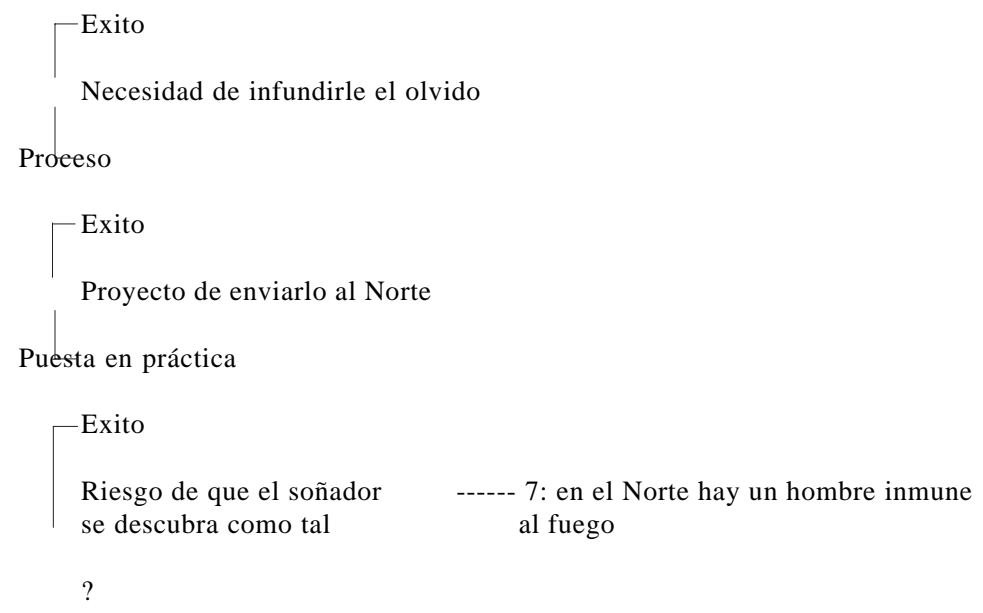

La última microsecuencia no se cierra porque a esa altura del relato nos desinteresamos por el destino del hijo soñado para pasar al desenlace, que pertenece a la Historia II, la que, no ha sido contada: el Soñadar "caminó contra los jirones de fuego. Estos mordieron su carne, éstos lo acariciaron y lo inundaron sin calor y sin combustión. Con alivio, con humillación, con terror, comprendió que él también era una apariencia, que otro estaba soñándolo”. Esta peripecia final (que es a la vez un 'reconocimiento') justifica el resto del relato porque todo lo demás ha servido para posibilitar esa revelación: sin saberlo el Soñador ni el lector, la Historia I ha estado funcionando como replica de lo que a aquél le estaba sucediendo, y escamotea su desenlace en beneficio y al servicio del otro desenlace, que es hacia el cual toda la narración fue conducida.

Recuperando ahora los datos que anotamos arriba en el extremo de la línea de puntos, la relectura del texto valoriza con un nuevo nivel semántico, y sintáticofuncional, cada uno de esos datos. En el último de ellos (7) los remeros "le hablaron de un hombre mágico en un templo del Norte, capaz de hollar el fuego y de no quemarse”, referencia que provoca la apertura de la última secuencia en la Historia I, pero que a la vez permitirá al Soñador descubrirse Soñado cuando atraviese el fuego sin aniquilarse. Ahora entendemos que la referencia 6, aparentemente gratuita 0 difusamente indicial, de que "a veces, lo inquietaba la impresión de que ya todo eso había acontecido", resume toda la Historia II y presenta el proceso explícitamente narrado como su réplica. Ahora percibimos también que los datos 1 y 2, que funcionaban como catálisis más o menos pintorescas de la Historia I, están connotando una función nuclear de la historia implícita: "Nadie lo vio desembarcar en la unánime noche, nadie vio la canoa de bambú sumiéndose en el fango sagrado”, ya que en 
realidad el Soñador Soñado había sido instalado en la ribera desde el sumo del otro, sin canoa ni viaje ni desembarco; y cuando "besó el fango, repechó la ribera sin apartar (probablemente sin sentir) las cortaderas”, era la irrealidad de su cuerpo la que explicaba esos hechos, tanto como estos otros: “cerró los ojos pálidos y durmió, no por flaqueza de la carne sino por determinación de la voluntad” (que era la voluntad del otro). Igualmente, lo que en un nivel se desempeña como acotación indicial de caracterización de personaje, en el otro se corresponde con un núcleo implícito, la infusión del olvido (referencia 3): “Si alguien le hubiera preguntado por su propio nombre o cualquier rasgo de su vida anterior, no habría acertado a responder”. La resemantización del discurso narrativo reconstruye acciones factitivas implícitas tras la textualidad alusiva a procesos simples: 'hacer saber', 'infundir el propósito’, etc., se han transformado en: "Sabía que ese templo era el lugar que requería su invencible propósito; sabía que los árboles no habían logrado estrangular, río abajo, las ruinas de otro templo propicio, también de dioses incendiados y muertos”. Pero esta última cita nos lleva además a inferir la recurrencia infinita de las historias, cosa que queda sugerida en la relectura de la situación 5, con respecto al pasado: "Ese múltiple dios le reveló que su nombre terrenal era Fuego, que en ese templo circular (y en otros iguales) le habían rendido sacrificios y culto”; y en la situación 4 con proyección hacia el futuro, ya que el frustrado intento de infundir 'existencia' a la multitud borrosa de Soñados pareciera implicar su existencia potencial a la espera de futuros sueños de otros sonadores: “...el forastero se soñaba en el centro de un anfiteatro circular que era de algún modo el templo incendiado: nubes de alumnos taciturnos fatigaban las gradas; las caras de los últimos pendían a muchos siglos de distancia y a una altura estelar”.

Por otra parte el discurso narrativo extiende ese destino a toda criatura humana gracias al juego de similes a que se entrega, convirtiéndonos en Adanes meramente pensados por Dios: “En las cosmogonías gnósticas, los demiurgos amasan un rojo Adán que no logra ponerse de pie; tan inhábil y rudo y elemental como ese Adán de polvo era el Adán de sueño que las noches del mago habían fabricado”. La relativización existencial acompaña a la de toda identidad: el Fuego mismo "no era un atroz bastardo de tigre y potro, sino a la vez esas dos criaturas vehementes y también un toro, una rosa, una tempestad”, disolución panteística que conduce a la identificación de los opuestos, puesto que aquí soñar es a la vez ser soñado y la divinidad que crea es la misma que se autodestruye: "Las ruinas del santuario del dios del fuego fueron destruidas por el fuego". De la misma manera, el registro descriptivo del discurso llega a insistir de tal modo en la minuciosidad de los detalles del sueño, que este sueño se impone a la 'realidad' misma invirtiendo los términos de nuestra precaria experiencia al volverse concreto y palpable: “...La noche catorcena rozo la arteria pulmonar con el índice y luego todo el corazón, desde fuera y adentro [...] Antes de un año luego al esqueleto, a los párpados. El pelo innumerable fue tal vez la tarea más difícil”. 
En relación con este universo donde toda entidad se desliza en su contraria y aun llega a identificarse con ella, el proceso de descubrimiento (desde la perspectiva del protagonista) tanto como el de lectura, según hemos visto, se realizan también como una inversión de sentido a la que no se accede sin antes haber consumido con inocencia uno de sus niveles, hasta que este se relativiza desplazándonos hacia otro mensaje, que estaba en el anterior pero al que no habíamos accedido.

La estructura lógica que subyace en todos esos procesos de desplazamiento narrativo, se vuelven reflexión explícita en el ensayo “Borges y yo”, donde la dicotomía del título polifurca esa primera escisión de base hasta atomizar cada uno de esos términos cuestionando todo intento por caracterizar cada identidad, junto con todo intento por asentar sobre alguna base sólida el concepto de realidad. Porque la escisión entre Ia. y 3a. personas, de la cual es la 3a., “el otro”, la que acapara el nombre del escritor que habla en Ia., es sólo el punto de partida desde el cual cada uno de ambos polos emigra a su vez de sí mismo hasta disolverse en una nada conjetural, o en un todo -lo que para Borges es lo mismo-. Aquí un "Yo" privado transmigra hacia un "Borges" escritor en su escritura: pero la precaria realidad del primero es a su vez efímera ("yo estoy destinado a perderme, definitivamente”), y acaso ni siquiera exista como tal ("si es que alguien soy”) al diluirse platónicamente “en el laborioso rasgueo de una guitarra” con la cual, de alguna manera, se iguala. Y el trasvasamiento hacia “el otro" no sólo falsea y magnifica espectacularmente los atributos de la experiencia vivida por el Yo convirtiéndolos “en atributos de un actor”, sino que desde el otro polo por su parte se des-construye porque lo bueno que ha escrito "ya no es de nadie, sino del lenguaje o la tradición”. De esa manera el doble trasvasamiento de la propia individualidad acaba en ambos extremos sumergida en un código compartido, el segundo de los cuales -la 'fuga' del Borges otro- es un código de escritura: no la palabra existencializada sino el verbo a secas, es decir el lenguaje, (mica solidez erigida en un universo conjetural donde el oficio de nombrar no queda respaldado por realidad ni identidad alguna; el imperio de la palabra se sostiene a sí mismo y da cuenta de sí mismo, y allí Borges es lenguaje, nosotros somos, más acá de toda presuntuosa afirmación de existencia, nuestro lenguaje.

Si acaso hay un momento privilegiado en que quizá accedemos a la intuición visionaria de lo real, esa experiencia poco tiene que ver con la palabra según se dice en "Una rosa amarilla": "Marino vio la rosa como Adán pudo verla en el Paraíso, y sintió que ella estaba en su eternidad y no en sus palabras y que podemos mencionar o aludir pero no expresar”. Pero precisamente es el divorcio entre mundo y lenguaje el que privilegia a este último hasta llegar a absolutizarlo, y entonces la literatura se postula a sí misma como modelo de la vida: "a fuerza de apiadarnos de las desdichas de los héroes de las novelas concluimos apiadándonos con exceso de las desdichas propias” (“El fin”). Desde esta última perspectiva la escritura se vuelve más rica que la vida -que la vida como experiencia-, así como 
en "Borges y yo" los códigos en que se resuelve toda escritura asumen la responsabilidad de todo sentido. Para el hombre (para Borges) no cabe otra posibilidad que la soledad de la palabra, vale decir, de la literatura. Y con esto volvemos circularmente a la idea con que iniciamos el presente ensayo.

El constante programa de fugas a que se adscribe la producción de Borges y en el cual la literatura, es decir el lenguaje, es decir la invención, equivalen a la única realidad indiscutible a los ojos del hombre frente a la indefinición de todo lo demás, subvierte de tal modo con su cuestionamiento cualquier esquema cultural al que se enfrente (cualquier esquema de valores y creencias), que no nos explicamos la 'inocencia' que, algunos grupos pensantes de la Argentina actual pretenden asignar a esa escritura. Debido a obvios motivos socio-biográficos, hay ahora quienes promueven, yo diría aún que promocionan, la lectura de Borges en razón misma de esa pretendida inocencia. Sin embargo son los mismos que, para poner un sólo ejemplo, se proclaman detractores del teatro de Sófocles debido precisamente a su 'peligrosidad ideológica'. ${ }^{4}$ Pero la obra de un escritor puede llegar a 'desconocer' a su autor de tal modo -y con éste al público que incurre en el equívoco de confundirlo con su obra-, que se llegue como en el caso presente a recomendar como literatura que se acoge a la conservación de estructuras, precisamente a aquélla que siembra la dispersión de todas ellas (nueva paradoja borgiana que excede los límites de esa misma literatura). Yo creo que el equívoco se debe también a los términos en que la producción de Borges se plantea en cuanto a su relación con el mundo inmediato circundante: cuanto menos 'localizada' y más vastamente alusiva se ha vuelto esa producción, tanto menos se la piensa comprometida con un mundo de hombres. Pero la producci6n de Borges ha resuelto sencillamente comprometerse con la totalidad de lo existente, y aun con el concepto mismo de existencia, poniéndolo en cuarentena: de ahí, absolutamente, su no-inocencia.

Instituto del Profesorado

de CONSUDEC, Buenos Aires

NICOLAS BRATOSEVICH

\section{NOTAS}

1 J. Rest. El laberinto del universo: Borges y el pensamiento nominalista. Buenos Aires, 1976.

2 M. Riffaterre. "Criteria for Style Analysis" (Word, XV, 1960). Id. "Stylistic Context" (Word, XVI, 1960). El comentario y la contrapropuesta a estos planteamientos se hallan en: S. Levin. "Deviation -Statistical and Determinate-in Poetic Language” (Lingua, 12, 1963). A su vez Riffaterre rehace esos mismos artículos y contesta a Levin en dos capítulos de su: Essais de Stylistique structurale. Paris, 1971. (Hay traducción española de este libro.) 
3 S. Saporta. "The Application of Linguistics to the Study of Poetic Language” (en: T. A. Sebeok. Style in Language. Cambridge, Mass., 1960). (Hay traducción española parcial de este libro, que incluye el artículo de Saporta.)

4 Concretamente, al promediar el año 1976 se suspendió la programación de Antigona de Sófocles en un canal de televisión de Buenos Aires, pretextando esas razones. 


\section{Poesía Amorosa de Borges}

El tema del amor no ocupa una posición central en la obra de Borges. Su reticencia no nos permitió entrar en ese mundo emocional privado que ocupara tantas páginas en otros poetas. Sin embargo, por la casi anómala situación de tales composiciones, ellas revelan aspectos de su personalidad. Es cierto que siempre se yerguen ante nosotros imágenes de un tiempo y un espacio vertiginosamente fugitivos, de inaprehensibles formas vagamente discernidas en el sumo, tal vez en la pesadilla, del vivir. Sus poemas son meditaciones penetradas por sus obsesiones cotidianas: realidad y fantasía, ser y apariencia, historia y destino; búsquedas en aquello que está “detrás de los mitos y las máscaras".

No hallamos en Borges esos vuelos cósmico-eróticos que son la nota dominante en algunos poemas de Octavio Paz y en cierta temprana poesía nerudiana. Concretamente pienso en el Neruda de Veinte poemas de amor, en especial en el magnífico poema IX. Tanto en Neruda como en Paz, hay una visión del amor que los comunica con profundas y esenciales fuerzas interiores que, siendo las que gobiernan el ser, los integran con el mundo. La mujer es la posibilidad de una conjunción reveladora. Más modestos, más tímidos, los poemas de contenido amoroso en Borges no dramatizan la pena ni documentan la exaltación gozosa, no celebran esa 'dicha dolorosa'. Son siempre momentos pasajeros que el poeta detiene más por lo que propician que por lo que son en realidad. Es el arabesco de una meditación el que parece justificarlo antes que una intensidad emocional que el poeta siempre sabe algo irreal.

Borges nos quiere hablar menos de sí que de esos temas que siempre lo conmueven. No es el pasajero, alado momento emocional el que más le interesa. No parece ser Borges el centro. Antes bien, es la extrañeza que siente ante ese ser cuya cercanía lo mueve a una reflexión sobre el siempre asombroso oficio de estar en el mundo. En verdad, si toda nuestra existencia, nuestra identidad, adolece de irrealidad es natural que el poeta se busque en el poema, como un ciego que tantea su camino oscuro. Borges sabe que su destino no lo lleva a esos ámbitos de la experiencia que siempre contempla con fascinación, más un tanto desde afuera: 


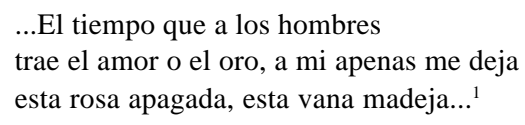

Tal vez por la misma razón que un día viera el universo como una laberíntica biblioteca, o comprendiera el idioma de Tlön en el que no se concibe el sustantivo, en el que el tiempo - ese gran protagonista- diluye en frases adverbiales toda esperanza de concreciones. Consecuentemente, el amor en Borges es siempre lo signado por el tiempo y no la posibilidad de una integración con el ser absoluto y permanente. Su visión contrasta con la noción petrarquesca que hacia del amor la posibilidad de un ingreso hacia realidades esenciales, superando la accidental situación en el mundo. Es cierto que la Laura de Canzoniere es una realidad de carne y hueso, pero esa concreción es la que permite al poeta elevarse hacia un sumo de belleza perdurable. Tampoco se acerca Borges a la visión reveladora que los surrealistas atribuyen al amor. Reveladora en tanto “desrealiza” nuestra convencional vigilia que nos condiciona, y aún más, nos mutila. En verdad, para Desnos o Eluard el ensueño amoroso es una liberación que descubre para el hombre cegado en su cotidianidad nuevos territorios, que hace que todos nosotros -poetas en potencia- participemos de una aventura creadora. Para Borges, igual que los espejos, igual que la memoria, el amor es otra certidumbre de nuestra condición de sombras, de nuestra irredimible precariedad.

Sin embargo, nada más lejos de él que el llanto o la endecha. Una natural parquedad le impide esas formas un tanto histriónicas. Su contenida expresión es parte de un encanto que nos hemos acostumbrado a apreciar y que siempre asociamos con su obra. La persona poética en Borges no asume roles excepcionales, no porta máscaras ni se esconde tras un lenguaje distante. Siempre estamos cerca del hombre que nos habla con la voz que es en verdad la misma que nos narra sus historias o nos comunica sus inquisiciones. No hay símbolos distantes ni asociaciones mitológicas, ni están estos poemas habitados de literatura -como los de Darío, por ejemplo. Conmueven porque casi callan ante una interioridad y nos convidan a un recato que es tal vez lo que les otorga esa frescura y esa permanencia.

Al revisar sus libros notamos que los poemas de tema amoroso van perdiéndose, gradual pero seguramente, entre sus otras preocupaciones: imágenes en un espejo que el tiempo empaña, destellos de una llama que va apagándose.

En Fervor de Buenos Aires (1923) encontramos un poema como “Ausencia” en el que la amada sólo existe como una evocación de lo distante, como la sombra de un recuerdo que ronda al poeta y que llega a él con la fuerza de una presencia agobiadora. El vacío que deja la amada es allí "sol sin ocaso", es "definitivo e inclemente”. Se avecina al poeta y lo atormenta: "cine el alma como cuerda que abarca una garganta”. El sufrimiento, que aquí toma una forma tan física, esta sugerido claramente en su intensidad. Tal vez "Ausencia” sea de los pocos poemas en que Borges nos entrega su dolor tan cándidamente. Es que la naturaleza de la experiencia es tal que quizá sólo esa forma de la desesperación es la que cabe: 


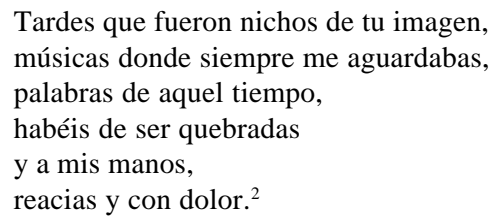

Más controlado, más borgiano, “Sábados” es de las composiciones inolvidables de esta colección. Con una dedicatoria en la primera edición, que luego desaparece: “Para mi novia, C.G.”, es más ficción que alusión concreta a una experiencia. La presencia de la amada es un perfume que lentamente se irá consumiendo "en el recuerdo”. Recuerdo es una forma más íntima de aquello que solemos llamar tiempo. Afuera vive otra raza de "hombres que no lo vieron”, pues la contemplación de esa belleza es transformadora. La música que llega en la tarde, son "anhelos clavados en el piano”. Ansias que se liberan en música. La tarde, la ciudad, se ha tornado en deseo y la belleza de la amada puebla ahora todo el mundo. Esa palpitación ha desplazado toda otra forma de vida. Las miradas del amante llegan hasta un límite allende el cual existe un país misterioso que es "tu vivir", esa realidad existencial inasible al poeta y a todos los hombres. Afuera, en el ocaso, otra imagen de su languidecer, hay otro mundo ciego, nocturnal, al que no llega la luz que el amante percibe y que le inunda el alma. Reaparece en la segunda estrofa una idea que Borges repetirá en otros poemas y en algunos cuentos:

No hay más que una sola tarde

la única tarde de siempre. ${ }^{3}$

Así como juega con la idea de que los hombres, al recitar a Shakespeare son, en tal momento, Shakespeare, podemos decir aquí que el tiempo se ha abolido y que esas tardes de “Sábados” que reviven la misma pasión, el mismo amor, son, en esencia, una sola y única tarde. Es este un momento, una duración que nada altera, que el transcurrir no toca:

$$
\begin{aligned}
& \text {...Las palabras } \\
& \text { no logran arraigarse en su paraje } \\
& \text { Y se escurren como agua. }{ }^{4}
\end{aligned}
$$

Es un mundo transfigurado que el acontecer no penetra, una suerte de duro encantamiento en el que hasta la misma emoción del poeta pareciera una anomalía. De ahí que la estrofa termine:

Te traigo vanamente

mi corazón final para la fiesta. ${ }^{5}$ 
La ofrenda es vana en tanto es un gesto exterior, insalvablemente inútil. La fiesta aquí alude a una suerte de ceremonia sacrificial. Ya antes había equiparado sus “ojos abiertos" a heridas que "hablan de sostener otros lugares”. Es ésta otra alusión a la idea central de “Amanecer”, poema de esta misma colección. El poeta, al no entregarse al sueño, colabora en mantener el mundo en su precaria existencia. Arabesco de la mente que es a la vez irrefutable e indemostrable. Aquí sus ojos darán existencia a otros parajes, a otras realidades. Sugiere así que la amada es también un producto de su mente antes que realidad concreta e independiente del poeta-amante. Y de ese modo la belleza de la amada "prodiga su milagro” aún a pesar de su “desamor”. El yo del poeta se entrega y se disipa en la entrega:

Ya casi no soy nadie, soy tan sólo un anhelo. ${ }^{6}$

Sin duda que en el amante hay una perdida de identidad. Reducir toda esta vibración que llamamos vida a algo que es solamente "un anhelo", aunque apunta a la intensidad de la emoción, es también una forma de anulación, una acentuación de nuestra condición de sombras. Toda la intensidad de la experiencia, deliciosa y dolorosa, está presente en estos versos memorables, que llegan a decirnos tal vez más por lo que callan:

Nuestras dos soledades en la sala severa se buscan como ciegos. ${ }^{7}$

Ellos reaparecen casi intactos en el poema "Susana Bombal” de su colección El oro de los tigres (1972). El lenguaje de Borges triunfa ante la dificultad casi insuperable de resolver en expresión nueva una experiencia frecuentada:

Acallando palabras momentáneas

hablan la angustia y tu pudor y mi anhelo.

Sobrevive a la tarde

la blancura gloriosa de tu carne. ${ }^{8}$

Lo erótico se nos revela aquí como fugitiva visión y como una triste culminación que no alcanza el tono celebratorio, tono que Borges llama, con intención denigratoria, “algazara”. Es más bien la certidumbre de su condición inasible y transitoria la que se patentiza. Así el poema acaba con un adverbio de tiempo que es más presagio de finitud que afirmación de permanencia. Ese “ahora” nos hace más conscientes de la precariedad del momento que el poeta llama, con significativa ambigüedad, "milagroso".

En el poema siguiente del mismo libro, “Caña de ámbar”, el poeta persigue otra idea que a menudo lo visita: la pobreza esencial de la experiencia. Muchos vivimos, 
con ligeros matices diferentes, las mismas módicas aventuras, similares emociones. Queda, es verdad, el heroísmo, el enfrentarse al peligro y a la muerte en gestos que definen nuestra identidad para siempre. De ahí esas presencias insistentes en sus poemas de espadas y cuchillos, éstos empuñados por compadritos del sur y aquéllas por antepasados ilustres. A él le quedaron los libros y algunos juegos con el infinito, como nos lo aclarara. El amor, entonces, también carece de singularidad:

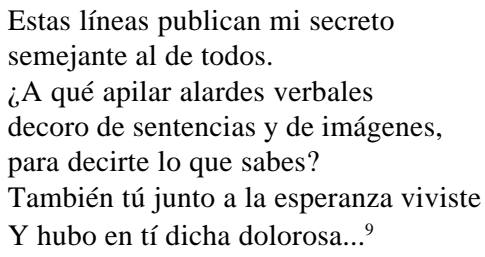

El tema del amor único, intrasferiblemente nuestro, aquí se transforma en pasión de alguna manera compartida, en vivencia casi social. La emoción, en su inevitable pluralidad, lo iguala y acerca a otros seres. Y si tal vibración es así parte de una común intensidad afectiva es natural que en ella nos "reconozcamos iguales, como ante una común música patria”. El amor lejos de tornarnos diferentes nos confunde con una palpitación en última instancia siempre colectiva. Nada más obvio pues que equipararla a esas emociones que nunca concebimos como individualidades. La patria, el himno, tal vez una bandera son afectividades que nos integran con una comunidad. Es importante apreciar que aquí el amante no se eleva a condición de elegido, sino que se involucra en una pluralidad que Borges reitera.

En otro poema, “Trofeo”, la intensidad de la experiencia amorosa paradojalmente testimonia una pobreza. Todo ese ímpetu afectivo que ahora la invade y esa hermosura que al prodigarse le enriquece la vida, eso que lo torna dichoso, "albriciado de luz", dura una jornada. Con el atardecer y la partida ese "noble acopio de memorias" será reducido en el tiempo a unos pocos vestigios. Adornaran el alma "en la inmortalidad de su andanza”. La memoria pertenece al tiempo y el alma es inmortal. Son dos órdenes ontológicos que al unirse evidencian aún más claramente esa situación de transitoriedad. De allí que el título, “Trofeo”, nos revele una suave ironía.

El amor es la motivación central en "Despedida”, que se conforma emocionalmente con pautas ya establecidas, aunque siempre posee la unicidad de la manera borgiana. Ese amor, en un momento tan real y verdadero, se reduce en el recuerdo y se confunde con "las calles”, “el barrio”, se va borrando gradualmente en el tiempo. La imagen de la amada detenida en la memoria, tal vez definitiva, proyectará su sentido de ausencia sobre otras ciudades y otros paisajes y ellos también serán entristecidos.

En Luna de enfrente (1925) se halla “Amorosa anticipación”, memorable poema que resume las actitudes de Borges ante el tema. Una distancia insalvable separa al poeta del objeto amado. La "privanza de tu cuerpo" alude tímidamente a lo sexual, 
pero ese cuerpo es inalcanzable, es “misterioso y tácito”. Su existencia, su vida, llega al poeta a través de palabras o silencios: fragmentarias y frágiles señas de una “realidad” inasible. Tal vez nada ayudará a convocar ideas, nada engendrará poemas, como la contemplación de la amada entregada al sumo. El poema mismo es una meditación en torno a esa contemplación. El sumo, es decir lo opuesto a la vigilia, a lo cotidiano y exterior, devuelve una esencialidad que el tráfago del vivir esconde. Esas provincial del ser que, suponemos, serán las que Dios conoció, conoce y conocerá desde y para siempre. Todo lo demás, el amor, "la ficción del tiempo”, el poeta mismo, son parte de la ilusoria existencia. Ese mirar del sumo de la amada que era en ediciones tempranas "favor tan persuasivo de ideas", más tarde se torna en "favor tan misterioso". Es elocuente el hecho de que Borges haya sustituido, en la edición de 1969, la noción de “ideas” por “favor misterioso”. Asimismo, en la edición más reciente el adjetivo "ávidos" ha desaparecido. El poema se torna de ese modo menos confesional y algo más distante. Sin duda se proyecta fuera del ámbito de lo amoroso hacia una búsqueda esencial. De ahí la referencia a algo misterioso, que posee sin duda una significación polivalente: algo inexplicable tanto en su origen como en lo que otorga. Tal esencialidad, la de Dios, se sitúa más allá de aquello que llamamos Tiempo y por cierto allende tales frágiles y fugitivas expresiones de vida como el amor, el yo. Tal vez pocos poetas en nuestra lengua serían capaces de una reticencia tan perfecta. Este texto, aunque no es abundoso y exuberante, expresa una relación a todos los niveles de la experiencia: "Virgen milagrosamente otra vez por la virtud absolutoria del sumo”. Así visto el poema, la supresión del adjetivo “ávidos” es de la mayor propiedad, ya que mantiene más adecuadamente el tono del discurso.

“Dualidá de una despedida” es tal vez más explícito, más abiertamente dramático que "Despedida” de Fervor de Buenos Aires. Registra esas menudas zozobras que nos involucran en un momento y en un paisaje reconocibles. Otra vez la experiencia coincide con la tarde, que a menudo manifiesta una situación melancólica en Borges, además de ser materialización de esa otra fuerza omnipresente, el tiempo. Es ella quien socava, quien destruye así como otorga su deleite. Su presencia, igual que un ángel oscuro, señalada su dualidad. El ángel que lo imaginamos blanco y venturoso, aquí es oscuro, es decir, heraldo de un advenimiento aciago. Hay también otra “dualidad”. La despedida es una acentuación de la pasión, pues ya sabemos que ella nos será muy pronto negada. Los besos, los labios de la amada, presencias algo desusuales en Borges, están evidenciando esa convicción de temporalidad. A la tarde suceden las sombras de la noche, pero en el alma del poeta ese acontecer indica algo más: "nos rechazó la luz” alude al momento, pero significa también no tocados por la gracia, el amor, pues ella abandonará al poeta y a su amada. Los elegidos podrían tal vez guardar esa dicha para siempre. Ahora, en la memoria de ese tiempo que "noches y singladuras" no han conseguido borrar, esa tarde se eleva "como un sumo". Pertenece ya a un acontecer que es del poeta en perpetuidad. Y en esa remembranza hay una certidumbre de soledad final: 
Prodigábamos pasión juntamente, no para nosotros tal vez sino para la soledad ya cercana.

Nos rechazó la luz; la noche había llegado con urgencia. ${ }^{10}$

La versión más reciente del poema, que prefiero, evita ciertos forzados argentinismos - "intimida”, "praderías”-y se cierra de manera más natural al suprimir los dos versos finales de la primera versión.

"Casas como ángeles" registra una imagen que es espacial antes que temporal. Las casas donde habitan seres queridos y deseados y que en la visión del poeta lucen colores "de aventura", suscitan un entusiasmo aquí sugerido por esa gama viva y activa. Ellos lucen como una promesa de dicha. El amor se identifica con cierta emoción por ese Buenos Aires que el poeta atesora. Detrás de la cancel de hierro está el patio, la sala donde se halla "una clara niña" y en ella -al igual que en "Sábados" de Fervor de Buenos Aires- "los dos callaremos, trémulos como llamas". Otra vez la pasión se sostiene en silencio, en inefable ansiedad. La noción de tiempo se introduce en la última línea: “y la dicha presente se aquietará en pasada.” Es decir, ese estado de exaltación presente había de serenarse y transformarse en otra emoción igualmente bienhechora. No hay un sentido de pérdida, privación, antes bien, la convicción de que la memoria ha de guardar esa felicidad.

En Cuaderno San Martín (1929), “A la doctrina de pasión de tu voz” introduce un elemento nuevo en lo que podemos llamar las figuras recurrentes de su poesía amorosa: la voz de la amada. En composiciones anteriores había un factor diverso: el silencio, el acallamiento. Aquí, por el contrario, la voz "es el sonido de la pasión del amor”. Ella cobra una autonomía que la separa en verdad de las palabras y los significados y se torna una fuerza venturosa capaz de conmover o esclavizar a quienes la escuchan. Lo dicho toma otro sentido pues esa voz "anega las palabras que dice." Ella sueña y vive en el poeta como una promesa de amor en la tierra. Es un mensajero que advierte la vecindad de la belleza. Tal belleza pareciera estar "fuera del destino", es decir de la fatalidad, participando de esa voz casi angélica:

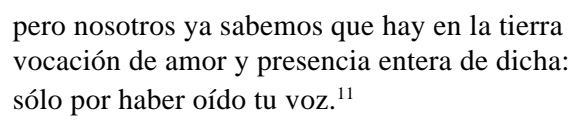

El concepto sería mallarmeano en su condición de presencia etérea, forma no corpórea, idea que una forma sutilísima contiene, si no se sostuviera tan obviamente en lo argumental. De ahí el título que sugiere una conceptualización algo teológica y nos sitúa en un plano de abstracción. Pero si la idea es distante el tono conversacional da al poema un sabor de inmediatez que el título niega.

La edición de Losada de 1943, Poemas (1923-1943), incluye "Prose poems for I.J.” en inglés. Más tarde fueron incorporados en El otro, el mismo (1930-1967) en la edición de volúmenes individuales de su "Obra Poética”. Aunque los elementos que 
componen estos poemas no son sustancialmente diferentes de los que hallamos en poemas anteriores, el tono en inglés nos da una persona poética más abierta y tal vez más confesional que la que conocíamos en su idioma. Es posible que el inglés le prestaba una suerte de parcial anonimato, le daba una libertad que el poeta no sentía antes. Es improbable que Borges escribiera “my hungry heart” en español. A la hora del alba la memoria frecuenta la amada distante. Son algunas palabras que aún viven, es el canto de su risa, su perfil, los sonidos que hacen su nombre, su displicente belleza. Esos fragmentos rescatados de una experiencia lejana son los que el poeta llama “juguetes ilustres”. Pero al igual que en “Amorosa anticipación”, donde se menciona esa “orilla de tu vida” que nadie sino Dios podía poseer, aquí el poeta ansía su escondida imagen, su sonrisa verdadera, reveladora de soledad y de cierta ironía. Es evidente que la amada es en este poema más activa y sugerente que en otros. Nos dice tal vez más de ella que en esos ejercicios donde son las emociones o los pensamientos del poeta la preocupación central. Las alusiones al perfil, a la sonrisa, a su belleza, esbozan un rostro que casi alcanzamos a ver. De modo que cuando llegamos al poema II la pregunta directa con que se inicia nos crea la impresión de diálogo, la sensación de una cercanía desusual: “What can I hold you with?”12 El poeta ofrenda todo aquello que hace de su vida una aventura algo valedera:

I offer you that kernel of myself that I have saved, Somehow -the central heart that deals not in words, traffics not with dreams and is untouched by time, by joy, by adversities. ${ }^{13}$

Hay que aceptar, pues, que de sus poemas surge la clara convicción de una identidad, de una persona esencial y secreta que aunque rara vez se nos revela se hace presente en momentos cruciales de nuestra vida. El amante se nos muestra aquí en actitud de persuadir a la amada, pero hacia el final toca una nota de ironía:

...I am trying to bribe you with uncertainty, with danger, with defeat. ${ }^{14}$

Ya que la posesión no es posible al menos intentemos el soborno; pero la dádiva que se entrega es la negación misma del soborno.

El otro, el mismo incluye otro poema que si bien no tiene como tema específico lo amoroso trae una alusión en la que es útil indagar. De su ciudad dice en "Buenos Aires":

No nos une el amor sino el espanto;

Será por eso que la quiero tanto. ${ }^{15}$

Aquellas casas angélicas, los atardeceres, las rejas y canceles eran como atributos del amor y también parte integral de su visión de la cuidad. Inesperadamente nos 
revela que es "el espanto” lo que lo acerca a esa afección entrañable y no el amor. La certidumbre de que su "sombra” presente se perderá en la "sombra final” pareciera darle esa noción de pertenencia. Esa meditación sobre Buenos Aires nos recuerda su temprano poema "La recoleta", donde se halla el "propio lugar en que han de enterrarme”. Aquí, en “Buenos Aires”, la sombra triunfa sobre el amor y lo entregará a ese abrazo postrero e indisoluble.

El poema “Elegía”, en esta misma colección, lamenta la pobreza de su experiencia a pesar de sus viajes y búsquedas:

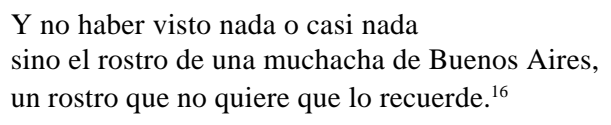

Ese rostro en el que el poeta se encuentra y reconoce, es parte de la ciudad que quiere. Aquí reitera su actitud de amante no correspondido, consciente de la imposibilidad de llegar al ser que constituye tal vez lo único real en su experiencia, al menos según nos lo dice en este poema.

La ciudad, el amor, la muerte se unen activamente en “1964”. El poema llora una partida y la soledad que lo invade, el mundo que ha dejado su encanto, se ve en cada forma o paisaje. “Casas como ángeles” registraba la proyección de la alegría sobre su visión de Buenos Aires. Por el contrario, en "1964” todo es espejo de un pasado venturoso pero ahora perdido. Cualquier nimiedad puede abrir otra vez la herida, reiniciar la agonía. Si la felicidad ya no es posible en ese mundo que no guarda ninguna maravilla, es comprensible gire se vea a la muerte como portadora de una aventura valedera. El poeta no se entrega por entero a su pena. Observa que hay cierto paladear de esa tristeza, cierto goce en la actitud de amante abandonado. Quizás es esa nota irónica la que nos reencuentra con el Borges que conocemos y estimamos. La ciudad -el Sur, una puerta, una esquina- ayer testigo mudo de su dicha, hoy es parte de esa "vana costumbre” que lo lleva a su frecuentación. “1964” comienza con un patetismo que nos extraña, pero la emoción al final ha sido controlada.

Elogio de la sombra no abunda en poemas de inspiración amorosa. Esas meditaciones que el poeta reconoce como parte de un arribo a la vejez, lo llevan a temas en los que se mira y contempla desde esas proximidades a la "sombra”. Nueva Inglaterra es un contraste más a su soledad no compartible. Y el aquí y el ahora existen sólo como proyecciones de otra realidad que “un laberinto de días y de noches” tejiera. El ser está ahora en el recuerdo, en un pasado que nos da una noción -aunque precariade identidad:

Somos nuestra memoria, somos ese quimérico museo de formas inconstantes, ese montón de espejos rotos. ${ }^{17}$ 
La fragmentación de nuestra experiencia y la acumulación desordenada, caótica de rostros, paisajes, lecturas, emociones va formando una continuidad que es nuestro ser. El mundo se ve en esas cambiantes superficies que reflejan otras formas igualmente fugitivas. Cuando el poeta siente que ha llegado a un momento de perfección, de dicha, ella se proyecta sobre ese mundo indiferente y lo transforma. Es lo que nos dice, bellamente, en “Elsa”, composición ejemplar en todo sentido. Como expresión de su visión, de su elocuente reticencia y también de un arribo a un momento de su vida en el que tal vez se halla la justificación de aquello que antes creyera inútil:

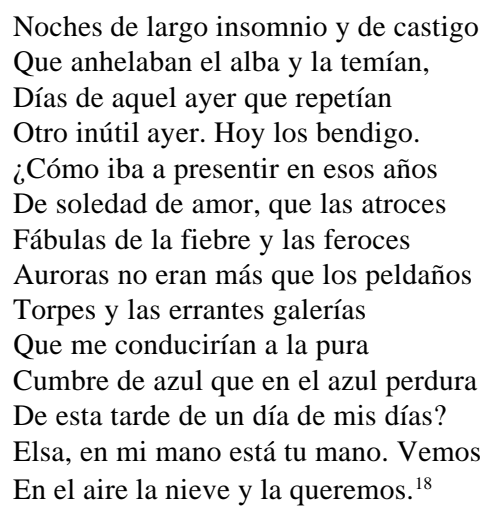

Como en el momento crucial de la muerte, que es cuando al fin se nos revela nuestro destino, "la perfecta forma que supo Dios desde el principio", aquí la dicha ilumina no solamente el instante sino también toda la vida que, ahora lo sabemos, era un largo y doloroso peregrinaje hacia esta felicidad. Desde ella, la contemplación de lo más vacío, la nieve en el aire, refleja esa afectividad que todo lo transforma. "En mi mano está tu mano” nos dice de esa cálida emoción que contrasta con el paisaje invernal. A su vez tal paisaje es una imagen del arribo a la vejez. Así los planos de significación se organizan con ejemplar, irresistible naturalidad.

"Elogio de la sombra”, que cierra esta colección, reitera admirablemente algunos de los temas ya frecuentados y que ahora son vistos desde la posición del que ha dejado el trafago algo inútil de la juventud y mira el vivir en su esencialidad, liberado de otras solicitaciones:

La vejez (tal es el nombre que los otros le dan)

puede ser el tiempo de nuestra dicha.

El animal ha muerto o casi ha muerto. Quedan el hombre y el alma. ${ }^{19}$

Esta división entre animal por un lado y hombre y alma por otro, ¿no nos descubre algo central en su actitud? La razón, por ejemplo, porque su poesía jamás dramatizó 
aquel íntimo territorio de la sensación, esas hondas vibraciones en que se traduce la pasión amorosa y que constituyen la materia original de tantas páginas:

\title{
Mis amigos no tienen cara,
}

las mujeres son lo que fueron hace ya tantas años. ${ }^{20}$

Ese mundo que ya es sólo recuerdo, idea, alma, ha dejado todo lo transitorio, lo accidental. El poeta llega, finalmente, a lo innegable:

$$
\begin{aligned}
& \text {...Llego a mi centro, } \\
& \text { a mi álgebra y mi clave, } \\
& \text { a mi espejo. } \\
& \text { Pronto sabré quien Soy }{ }^{21}
\end{aligned}
$$

Solamente una o dos composiciones de El oro de los tigres poseen la cualidad temática que busca este ensayo. Hay alusiones al amor y a lo amoroso en varios poemas, pero ellas no llegan a constituir lo central de esas composiciones. Son observaciones un tanto tangenciales que contribuyen a darnos una visión total de su personalidad en la que el amor es solo un componente:

\author{
Soy, pero no de las Mil Noches y Una \\ Que abren mares y auroras en mi sombra \\ Ni de Walt Whitman, ese Adán que nombra \\ Las criaturas que son bajo la luna, \\ Ni de los blancos dones del olvido \\ $\mathrm{Ni}$ del amor que espero y que no pido. ${ }^{22}$
}

Esperar el amor es casi invocarlo; al decirnos que no lo pide supongo que el fervor se reduce a cierta resignada apatía.

“H.O.” ostenta todos los elementos de ejercicios más tempranos. Se han conservado el tono, las imágenes, los vocablos. Es evidente que el tratamiento del tema no sufre modificaciones con el tiempo. Por el contrario, hay una cualidad intemporal en esta visión que pareciera cristalizada en una forma que el recuerdo atesora y que es un verdadero desafío al cambio, a las mutaciones, un "trofeo":

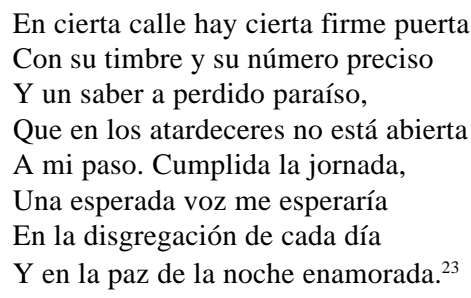


La puerta, la idea de paraísos detrás de ella, los atardeceres melancólicos, la noción de una perdida irreparable en esa voz que presintió una vez suya y que por esos azares no se acercara a él nunca, son elementos que ya conocemos. El milagro del amor correspondido y perfecto no le es concedido y de ahí la invocación que le hace solicitar la piedra sepulcral -“las dos abstractas fechas y el olvido.”-Aquí esta implícita la idea de que el amor puede salvarnos, dar una finalidad permanente a nuestros días.

En todas estas meditaciones sobre su destino hay una interrogación que repite con nostalgia su frustración, se pregunta por lo irredimiblemente perdido. Sin embargo el poeta sugiere a veces la sospecha de que en otro ciclo del tiempo tales destinos en potencia se cumplan. Y, en verdad, en la eternidad todas las combinaciones serian realizables. "Lo perdido" interroga sobre ese laberinto de posibilidades que es la vida en su comienzo, y que en la vejez, todo reducido ya a pasado, se considera con dolor:

Dónde estará mi vida, la que pudo

Haber sido y no fue, la venturosa

O la de triste horror, esa otra cosa

Que pudo ser la espada o el escudo

Y que no fue? ${ }^{24}$

El poema termina con dos líneas que casi sugieren una esperanza, quizás sólo un arabesco de la imaginación, juego que no se aproxima al consuelo:

Pienso también en esa compañera

Que me esperaba, y que tal vez me espera. ${ }^{25}$

Es ésta otra mención de esa latente nostalgia que reaparece en sus poemas. Y es el amor de una mujer lo que a menudo asocia con lo venturoso. En "Al triste” reitera esta idea que una lectura cuidadosa de sus versos nos revela como una insistencia:

Una sola mujer es tu cuidado,

igual a las demás, pero que es ella. ${ }^{26}$

Es así donde en el desdoblamiento que ya señalara en "Borges y yo" y que es el mismo tema de "El centinela", se ve con extrañeza en ese ser cuyo cuerpo comparte. De él nos dice que "Una u otra mujer lo han rechazado y debo compartir su congoja." Es revelador el hecho de que en ese cuestionar de la personalidad sea ese rechazo uno de los aconteceres importantes que signan su destino y que el poeta acepta como una de las notas que tal vez determinan una identidad.

La rosa profunda y La moneda de hierro, sus dos últimos libros de poemas, no recogen una sola composición cuyo tema central sea el amor. Este silencio, en sí mismo significativo, indica una convicción que no necesita reiteración. Tal vez por ello expresa en "El remordimiento": 
He cometido el peor de los pecados

Que un hombre puede cometer. No he sido

Feliz.

No me abandona. Siempre está a mi lado

La sombra de haber sido un desdichado. ${ }^{27}$

Lo que da a estos poemas que me ocupan un sabor de viril intimidad es la voz de Borges que jamás se entrega ni a una retórica excesiva ni a un descabellamiento emocional. Como en sus narraciones, predomina el tono de conversación, si bien con el ocasional paladeo de algunas palabras. Tal vez su temprano poema "Mi vida entera" encierra una verdad que el tiempo y los años no contradicen. Su experiencia -“sus días y sus noches"-

Se igualan en pobreza y riqueza a las de Dios

$\mathrm{Y}$ a la de todos los hombres. ${ }^{28}$

University of Essex, England

E. CARACCIOLO TREJO

\section{NOTAS}

1 Poemas. 1924-1943, Losada, 1943, p. 164.

2 Fervor de Buenos Aires, Imprenta Serrantes, 1923, p. s/n.

3 Op. Cit., p. s/n.

4 Op. Cit., p. s/n.

5 Op. Cit., p. s/n.

6 Op. Cit., p. s/n.

7 Op. Cit., p. s/n.

8 Op. Cit., p. s/n.

9 Op. Cit., p. s/n.

${ }^{10}$ Véase Poemas. 1923-1943, p. 85 y Luna de enfrente y Cuaderno de San Martín. 1925-1929, Emece, 1969, p. 33.

${ }^{11}$ Poemas. 1923-1943, p. 134.

12 Poemas. 1923-1943, p. 159.

${ }^{13}$ Op. Cit., p. 160.

${ }^{14}$ Op. Cit., p. 160.

${ }^{15}$ El otro, el mismo. 1930-1967, Emecé, 1969, p. 123.

${ }^{16}$ Op. Cit., p. 197.

${ }^{17}$ Elogio de la sombra. 1967-1969, Emecé, 1969, p. 24.

${ }^{18}$ Op. Cit., p. 27.

19 Op. Cit., p. 155.

${ }^{20}$ Op. Cit., p. 155

${ }^{21}$ Op. Cit., p. 156.

${ }^{22}$ El oro de los tigres. 1972, Emecé, 1972, p. 33. 


\author{
${ }^{23}$ Op. Cit., p. 45. \\ ${ }^{24}$ Op. Cit., p. 41. \\ ${ }^{25}$ Op. Cit., p. 41. \\ ${ }^{26}$ Op. Cit., p. 87. \\ ${ }^{27}$ La moneda de hierro, Emecé, 1976, p. 89. \\ ${ }^{28}$ Poemas. 1923-1943, p. 111.
}




\title{
"Ser Hombre” (Exploración) del Tema del "Otro" en un Soneto de Jorge Luis Borges
}

\author{
Emerson \\ 1. Ese alto caballero americano \\ 2. Cierra el volumen de Montaigne y sale \\ 3. En busca de otro goce que no vale \\ 4. Menos, la tarde que ya exalta el llano. \\ 5. Hacia el hondo poniente y su declive, \\ 6. Hacia el confín que ese poniente dora, \\ 7. Camina por los campos como ahora \\ 8. Por la memoria de quien esto escribe. \\ 9. Piensa: Leí los libros esenciales \\ 10. Y otros compuse que el oscuro olvido \\ 11. No ha de borrar. Un dios me ha concedido \\ 12. Lo que es dado saber a los mortales. \\ 13. Por todo el continente anda mi nombre; \\ 14. No he vivido. Quisiera ser otro hombre. ${ }^{1}$
}

A diferencia de aquellos escritores para quienes su “otro” puede ser aproximada y tentativamente identificado (el Amadís de Gaula de Cervantes, Balzac para el primer Flaubert, Carlyle en el mismo Emerson), el “otro” literario de Jorge Luis Borges no es una entidad única sino múltiple, cambiante, acumulable a medida que nuevos descubrimientos o nuevos recuerdos agregan nombres y afinidades a su vasto registro. No podría sostenerse legítimamente que Borges, a lo largo de su vida o de buena parte de ella, haya querido “ser más” Macedonio que Lugones o “más” Lugones que Whitman, aunque tampoco podríamos negar la presencia de tales figuras, de un modo insistente, en el conjunto de su obra. Igualmente, si bien en medida menor, no falta en ella la referencia, la mención, la cita de otros escritores: Browning, Blake, Cervantes, Joyce, Keats, Milton, Poe, Quevedo Shakespeare no agotan la larga e incompleta lista, a la que habría aún que agregar el mismo Emerson.

Esta falta de unidad del “otro”, sólo localizable entonces en la Biblioteca, y sólo caracterizable en ella, es, entre otras razones, la que tanto ha potenciado este espacio en la literatura borgeana y, más allá de su fantástica u obsesiva mención, lo ha convertido en uno de los ejes reconocibles de la obra de Borges. ${ }^{2}$ Las afirmaciones que preceden, se ven confirmadas no solamente por el análisis de su obra sino también por sus propias afirmaciones. Escribía Borges en 1969, juzgando retroactivamente los intentos de 1923, en el Prólogo a Fervor de Buenos Aires: “... me propuse demasiados 
fines: remedar ciertas fealdades (que me gustaban) de Miguel de Unamuno, ser un escritor español del siglo diecisiete, ser Macedonio Fernández, descubrir las metáforas que Lugones ya había descubierto....... Más explícitas aún (y más definitorias de ese carácter plural) son aquellas otras palabras de "La flor de Coleridge”: "Quienes minuciosamente copian a un escritor, lo hacen impersonalmente, lo hacen porque confunden a ese escritor con la literatura, lo hacen porque sospechan que apartarse de él en un punto es apartarse de la razón y de la ortodoxia. Durante muchos años, yo creí que la casi infinita literatura estaba en un hombre. Ese hombre fue Carlyle, fue Johanes Becher, fue Whitman, fue Rafael Cansinos-Assens, fue De Quincey.”

La falta de unidad de "el otro" no quita importancia al problema de la identidad en Borges; pienso, por el contrario, que lo profundiza, justamente al convertir la búsqueda en indiferenciable y errática. Su poesía, tan acusada de frialdad y de racionalismo extremo, encontraría en esta dolorosa migración uno de los atributos de "lo humano" ya que, como él mismo escribe en "Cambridge”, mientras las cosas son "monedas de una sola cara”, nosotros "Somos nuestra memoria, / somos ese quimérico museo de formas inconstantes, / ese montón de espejos rotos." ${ }^{\circ}$

Sin entrar a analizar el motivo del espejo (cuya sola mención ocupa un considerable espacio en los 300 poemas estudiados en la obra poética), es evidente que éste abre o habilita temas de honda importancia: la circularidad que de él se deriva abriría un capítulo obvio en la literatura borgeana; la búsqueda de la identidad, otro; el tema del “doble”, un tercero; y así podríamos continuar. Pero preferimos llegar a ellos por otros caminos. Un estudio detenido de su producción específicamente poética -aquella en la que con una mayor libertad el inconsciente del creador se manifiesta- nos demostrará que están presentes en casi todos los poemas, tal vez porque es en el campo de la creación poética donde más se libera el escritor de los controles diurnos, tal vez porque en todo poema "lo escrito" se impone a "lo dicho" o a lo que "quiere decirse".

Las cuestiones que venimos mencionando, aparecen algunas veces explícitamente formuladas en el plano expresivo; en otros casos, se desplazan al inconsciente de la palabra. El objetivo de este trabajo sobre el soneto “Emerson” será intentar la verificación de ese pasaje, y estudiar cómo, en un nivel más profundo que el de la creación consciente del poema, el poeta esta trabajado (y se ve trabajado por) realidades que tienen sus propias leyes: la realidad del lenguaje, la realidad de las lenguas, la realidad de los espacios vacíos - no hablados- de un discurso.

Esos espacios se llenan de manera dificultosa y hasta clandestina; el inconsciente se vale para ello de unidades aún más pequeñas que la de la palabra. Los espacios así completados se incorporan al discurso "visible" y pugnan por imponerse a él. El discurso poético se desarrolla entonces en dos planos; esos planos son simultáneos (espacial y temporalmente superpuestos), son competitivos, son excluyentes (ya que una lengua hablada impide otra), son complementarios (ya que una "dice” lo que la otra no puede “decir”). ${ }^{6}$ 
En el soneto elegido - de apariencia ajena e inocente, y, por que no creerlo, tal vez inocentemente construido desde un punto de vista consciente- se concentran diversos asuntos y motivos habituales en la obra de Borges: las menciones de escritores y filósofos, el cuestionamiento de la fama y de la gloria, la insatisfacción personal por una vida y por una obra. En otro orden las referencias a la lectura y a la escritura como actividades centrales, la oposición creada entre esas actividades y las “vitales” (esa oposición entre el leer, meditar, y el gozar, que recoge la constante oposición semántica de buena parte de su producción entre el “caminar” y el “pensar”). En planos algo más profundos, se destacarían el tema del no vivir (no sólo por la enfática declaración de que no se ha vivido, sino por una perdida de personalidad que trataremos de revelar) y el tema del deseo de ser otro.

El soneto pertenece al libro El otro, el mismo ${ }^{7}$, el más dilatado de los poemarios de Borges, que recoge toda su producción poética a lo largo de casi 35 años. Su sugestivo título es de por sí, naturalmente, todo un incentivo para estudiar el tema que estamos tratando.

“Emerson” es un soneto que, como la mayoría de los de ese libro, está dibujado en una sola unidad. Son, no obstante, suficientemente diferenciables los cuartetos y los tercetos entre sí, aunque la segunda gran particularidad del poema en relación a la categoría "soneto" es que los dos versos finales riman, contradiciendo la tradición de las rimas combinadas entre los seis versos finales. Estas particularidades convertirían al poema en una composición con tres cuartetos y dos versos pareados, pero ello no impediría que algunas de las leyes de correspondencia y de contradicción entre las estrofas del soneto conserven, como se verá, toda su validez. ${ }^{8}$

Así, por ejemplo, la comparación entre lo que llamaríamos estrofas pares e impares del poema brinda algunas concordancias sintácticas, rítmicas y aún semánticas. Entre las primeras, cabe señalar que las estrofas impares contienen las frases más largas del poema: tres versos más una palabra en la primera estrofa, y dos versos y medio en la tercera; obviamente, es en las pares donde encontramos la mayor acumulación de frases. Asimismo encontraríamos cierta correspondencia entre las construcciones relativas de los versos finales de la primera estrofa con la de la tercera. La concordancia rítmica más notable es que la rima del verso 9 retoma -con el agregado del plural- la de los versos 2 y 3 . Ello desde el punto de vista del ritmo acústico; desde un punto de vista visual, habría que destacar el espaciamiento que a la mirada del lector convoca el amplísimo campo presentado por los tres primeros versos de la segunda estrofa, concordantes en ello con el verso 13, o sea, en ambos casos, versos pertenecientes a las estrofas pares. Finalmente, las concordancias semánticas son numerosas: "volumen” del verso 2 se encuentra repetido por vía del sinónimo "libros" en el verso 9; entre las estrofas pares observamos que “camina” del verso 7 se repite en “anda” del verso 13 . Sin forzar demasiado las correspondencias, debe admitirse dentro de este capítulo la semejanza entre “caminar” por la memoria de otro (versos 7 y 8) y querer "ser otro" (verso 14), 
así como la existente entre el "declive” y la "mortalidad” ("mortales”, para ser exactos). Ratifica esta última semejanza, y la carga de significado, el hecho de que con estas palabras finalizan los versos 5 y 12 respectivamente, o sea los versos iniciales de las estrofas pares. Del mismo modo, “confín” y “continente”, ubicadas en las estrofas que acabamos de señalar, se hallan en el centro del segundo verso de cada una de ellas, mientras que, como se habrá advertido, tanto "confín” como la repetición de "poniente” con “continente” contribuyen a reforzar las ya marcadas concordancias acústicas de estas estrofas. Todo ello sin omitir las repeticiones preposicionales, de las que el “por” de los versos 7, 8 y 13 parece tener más interés. No consideramos interesante, en cambio, detenernos por ahora en el hecho de que “otro” (v. 3), pluralizado en el verso 10 y nuevamente repetido en el verso 14, esté presente tantas veces en un soneto, ya que, como se verá más adelante, constituye justamente uno de los ejes semánticos del mismo.

Si examinamos las relaciones entre los relativos cuartetos y tercetos, lo primero que se nota es que el locutor se transforma al finalizar el segundo cuarteto, y que a partir del verso 9 es el personaje Emerson quien cobra voz y habla en primera persona. Este solo dato nos autorizaría a establecer una neta marcación entre cuartetos y tercetos (siempre, insistamos, relativos, por el dibujo que el soneto ofrece), ya que estos últimos cuentan con una sola palabra de la locución de los primeros. El cambio es aún más matizado ya que hasta entonces nadie había asumido ciertamente la primera persona; había dos personas en tercera; si se quiere, una un tanto más cercana del hablante lírico (“esto” opuesto a “ese”), pero es indudable que nadie asumía como suya la locución. Al comenzar el verso 9, los dos puntos abren la locución del personaje; esta habilitación, donada por el que “escribe” no se cerrará sino con el poema. ${ }^{9}$

A estos datos habría que agregar que por primera vez se presentan en el poema otros tiempos verbales que el Presente del Indicativo, el que ahora aparece desplazado de una anterior unanimidad a una sola mención efectiva (“anda”, v. 14) y a formas compuestas con él, la más importante de las cuales, en el verso 11, compone una interesante forma perifrástica de futuro ("ha de borrar”) que acaso tenga mas proyecciones que las inmediatas.

Como en el mismo poema está escrito, el presente, el “ahora”, es el tiempo de la escritura. Este factor hace que asignemos especial importancia al problema verbal, y dentro de et, al presente, en el que, a la vez que se consagra el tiempo de la escritura, se manifiesta la totalidad de una actuación del personaje. También aquí es necesario matizar: aparentemente, Emerson pertenecería al pasado (el tiempo de su "realidad” actual y además el de "su” locución en el poema); en esta situación pretérita le corresponderían las actividades de leer y de escribir (componer), no las de caminar y andar, tan claramente señaladas por el presente. Sin embargo, y siempre dentro del mismo sector del análisis, es útil destacar que el que está acá caminando es Emerson, mientras que el que está acá escribiendo es otro; no es Emerson, en ningún momento, 
el que asume figuradamente la actividad de la escritura. Esta comprobación nos lleva a adelantar uno de nuestros primeros interrogantes: ¿es que "quien esto escribe" ("ahora", en el presente, pero alimentado por su "memoria" que no puede ser sino pasado) querría “otro” presente? ¿Un presente en el que pueda ser por fin yo, es decir, tenga mi lugar, me recupere, signifique de una vez la persona que enuncia la presente instancia del discurso que me contiene? ${ }^{10}$

Con relación al mismo tema del presente verbal hay que señalar todavía que aquel tiempo de "realidad" actual, el pasado, esta formulado en presente, mientras que el presente figurado, su locución, se caracteriza por un predominio de los pretéritos.

Es necesario destacar también que en este poema hay dos presentes: uno, ese presente simulado, dispuesto, convencional, que abarca los primeros ocho versos, y que es el presente de la ficción poética, ya que la simple lectura del título del poema nos da la pauta de que cualquier presente será, en este caso, "no real”. El otro, en cambio, es el presente real de la escritura del poema; a partir de su aparición, aquel presente ficticio vuelve a ser pasado real, y ahora también ficticio: hay, por una parte, una expresa declaración de que su espacio es el de la "memoria"; por otra parte, en el inicio del verso 9, el último de los presentes de la ininterrumpida cadena es seguido de dos puntos a partir de los cuales ese presente "habla" (o "piensa”), como para marcar que es la escritura, y sólo ella, la que concede el verdadero tiempo del discurso literario. No cabe duda, pues, que este pensar sucede “ahora”, en un presente que está más acá que el de los ocho primeros versos, en un presente real de escritura a partir del cual se piensa; poco importa en que tiempo se piense: la escritura vuelve presente cualquiera de los tiempos que sucedan a partir de los dos puntos, así como ha vuelto al pasado aquel presente ficticio de los primeros ocho versos. No tenemos hasta aquí suficientes elementos como para defender la hipótesis, pero ella ya comienza a aparecer: tal vez todo lo que siga a estos ocho versos sea una forma perifrástica y sumamente complicada de decir un presente. Ya la propia formulación del verso 8 lo exhibe: ¿qué es, si no, caminar por un espacio que no es más que pasado y hacerlo en presente (o hacerlo presente)?

Ese verso 8 parece así contener algunos elementos particularmente significativos para la comprensión del poema. No solamente finaliza con él el segundo cuarteto y, con este, prácticamente una locución; también es é1 el que divide aquellos dos mundos de que hablábamos más arriba: el mundo del caminar y el mundo del pensar, el del hacer (cerrar, salir, caminar) y el del meditar. Como para ratificar su papel, el verso 8 aleja de manera simétrica ambos verbos, cuyas posiciones se ubican en el inicio de los versos vecinos ( 7 y 9) y lo hacen, además, en el mismo tiempo verbal, lo que resalta la antinomia.

Para terminar con las relaciones formales, habría que destacar ciertas similitudes entre los versos que dan fin a los tercetos (v. 11 y v. 14). Observamos que ambos están construidos con dos frases, que ambos contienen formas compuestas y negativas (aunque diferentes) de verbos, y que en esa composición incluyen los dos únicos 
infinitivos del poema. Entre esos dos versos se da una rima interna que a la vez rompe la esperada lexía (compleja-variable) "Un dios me ha concedido" (...la vida) con la declaración opuesta: "No he vivido".

Hemos ya mencionado diversas repeticiones gramaticales y lexicales, algunas más relevantes que otras. Queremos destacar ahora las que consideramos más significativas: la triple repetición de "otro" (v. 3, v. 10 y v. 14, aunque en plural en el segundo caso), y las agrupaciones que se observan en el verso 6, donde "ese”, "hacia", "poniente", son, junto a "el” y "que", repeticiones de versos anteriores, con lo que se comprueba que ese verso 6 constituye, a nivel sintagmático, una interesante condensación o resumen de lo que el poema ha ido elaborando hasta llegar a él, ya que 5 de sus 7 palabras son conocidas. Es un elemento a tener en cuenta para cuando nos refiramos al papel que la memoria repetitiva juega en este poema.

De un superficial recuento fonemático surge que las consonantes mas utilizadas son la $m$ y la $n$ (entre ambas suman 43), y entre las vocales la $e$ (60 veces), la o (54 veces) y la a (40 veces). Este neto predominio de la $e$ y de la $o$ señala ya una tendencia, puesto que basta recordar el apellido del personaje que da título al poema, cuyas tres vocales se dividen entre dos $e$ y una $o$. No obstante, hay algo tal vez más útil para señalar en este campo, y es la existencia de segmentos vocálicos insistentes, de secuencias fónicas sumamente semejantes, y de fragmentos paranomásicos a lo largo de todo el poema.

$\mathrm{Si}$, como hemos adelantado, el verso 8 tiene una particular importancia en este soneto, y si, como esperamos, conseguimos demostrar que lo que él dice de la "memoria" es lo que el poema, en otro nivel, exhibe (o escribe), habremos encontrado una vinculación entre estos dos niveles o, lo que es también probable, que el proceso de constitución de este poema este implícito en el verso 6 antes señalado y enunciado en este verso 8 , es decir, que este último sea algo así como el modelo explícito de lo que en diferentes planos implícitos el poema desenvuelve. En fin, que sea la "memoria”, y lo que ella permite, o sea, la repetición, quien genere y construya el poema. ${ }^{11}$

Volveré a reproducir el soneto, pero no destacaré en él (de las numerosas secuencias fónicas mencionadas) sino aquellas que muestran más notoriamente los segmentos vocálicos predominantes, es decir, los segmentos $M E R$ y $M E N$, los que, con $E R, E N, M E$ más $O N$ u $O M$ se distinguen claramente. Veámoslo:

\section{EMERSON}

Ese alto caballERo amERicano

ciERra el voluMEN de MONtaigne (MontEN) y sale

$E N$ busca de otro goce que no vale

$M E N o s$, la tarde que ya exalta el llano.

Hacia el hONdo pONiENte y su declive,

Hacia el cONfín que ese pONiENte dora, 


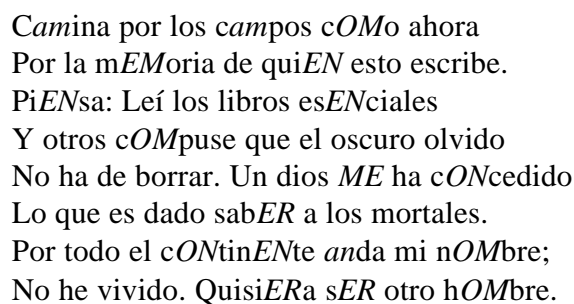

De la observación subrayada de los segmentos repetitivos, y en rápido recuento, surge que: a) el segmento $E R$ está repetido seis veces en el poema; b) los segmentos $O M$ u $O N$, sumados, están repetidos once veces; c) el segmento $M E N$, como tal, está dos veces; $E N$ solo está ocho veces; $E M$ y $M E$ están una vez cada uno. O sea que, en conjunto, $M E N-E N-E M-M E$ suman doce veces a lo largo del poema. (En ningún caso se ha contado el título.) A ello habría que agregar dos $A M$ (v. 7), dos $A N$ (v. 4 y v. 13), y aun otro EN que, por ser estricto y respetar la separación, no he contabilizado. (v. 3)

Aquella discriminación y estos cómputos me permiten ir sacando algunas conclusiones que a primera vista podrían parecer solamente anagramáticas, pero que supongo pueden abrir posibilidades interpretativas en otros campos. La primera conclusión, ya un tanto obvia, es la de que el apellido del personaje elegido, Emerson, ha sido compuesto varias veces a lo largo de las repeticiones y de las combinaciones fónicas del poema. A pesar de su obviedad, es, sin embargo, justo señalarlo, ya que este hecho demuestra como Emerson esta sostenido no sólo por el título, sino también por las numerosas oportunidades en que, por la insistencia vocálica, se vuelve a reconstruir y recordar su nombre. En este sentido, también acá podría pensarse que el poema ofrece, en un nivel de expresión un tanto soterrado, indicios para determinar el origen de su constitución como texto. Por otra parte, y antes de finalizar provisionalmente con este aspecto del análisis, conjeturo que esa insistencia en la repetición de un nombre da también un sentido a lo que más aparentemente el poema expresa: que el personaje esta atado, que no puede escapar de su nombre (y aún de su no-hombre), que su deseo de ser otro será vano. Nuestra memoria seguirá reconstruyéndolo y repitiéndolo porque para eso nos han dispuesto los diferentes tramos interiores del poema.

Antes de pasar al segundo aspecto del análisis, me parece necesario señalar algunos problemas de género en el poema. Todos los finales de verso, salvo los neutros, son masculinos (y todos ellos, salvo en dos casos, son singulares); hay un neto predominio de artículos determinantes masculinos; todos los sustantivos empleados son masculinos, a excepción de "tarde” y "memoria”. Ya que la idea que preside el poema, en un nivel más notorio, es la de querer ser otro "hombre", no me parece indiferente señalar las anteriores particularidades. Más aún si tenemos en cuenta que 
el campo de las hipótesis que me propongo abrir ahora tiene que ver estrechamente con el marcado deseo de ser "hombre".

En efecto, pienso que el poema ha venido diciendo en el inconsciente de la palabra algo a la vez semejante y distinto a lo que manifestaba en su nivel expresivo. Así, al hecho de que en él predominen sustantivos, artículos y finales de verso en masculino; al hecho de que la palabra con que el poema termina sea "hombre”, y aún el hecho de que en los segmentos arriba señalados haya una destacada presencia de la silaba inicial de la palabra "hombre" $(O M u O N)$, agregaremos otras comprobaciones que surgirán mucho más claras luego de un pequeño paréntesis biográfico.

Tan sólo para dar algunos elementos de juicio que hacen al caso, recordaremos que Ralph Waldo Emerson nació en Boston en 1803 y murió en Concord en 1882. Realizó estudios eclesiásticos y posteriormente llegó a ejercer como Predicador, pero a raíz de sus diferencias con la Doctrina (especialmente en lo concerniente a la Cena) se alejó de la práctica del Culto. Viajó luego a Europa donde conoció a Carlyle, quien desde ese momento fue su maestro y su guía. Emerson es el fundador de una doctrina con pretensiones universalistas, cuyo nombre es el Trascendentalismo, y cuya base ideológica es el idealismo individualista. Ella pone en el espíritu del hombre la razón de ser y el fundamento del mundo material, y propone la posibilidad de que todo hombre pueda (y aún deba) crear el mundo por su sola y libre concepción. Emerson fue también periodista y poeta. Escritores vastamente conocidos, como Whitman, Eliot y Nietzsche, lo consideraron y elogiaron. Este último expresó alguna vez: “De ningún libro me he sentido tan cerca como de los libros de Emerson; no tengo derecho a alabarlos”. Entre sus libros figuran Ensayos (1841, y una segunda serie en 1844), Poemas (1846), Misceláneas (1849). Uno de sus libros más importantes es el publicado en 1849, Hombres representativos. Cien años después, en 1949, Jorge Luis Borges tradujo y prologó este libro, junto a De los héroes, de Thomas Carlyle, para la Colección Clásicos Jackson, de la Editorial W. M. Jackson.

No vamos a abundar aquí en detalles biográficos de Jorge Luis Borges; sólo recordaremos un dato que tiene que ver con nuestro tema de estudio: su relación con el idioma inglés. Es sabido que ella es tanto o más antigua que la que tiene con el español; que antes leyó Las mil y una noches en la versión de Burton y Los primeros hombres en la luna, de H. G. Wells, en su lengua original, que a Cervantes, y que, como el mismo escribe en "Una oración”, su boca "ha pronunciado y pronunciada, miles de veces y en los dos idiomas que me son íntimos, al padre nuestro,... ${ }^{12}$ Creo que podemos ya defender la hipótesis de que también en el caso del poema que venimos estudiando, el poeta está pronunciando (o pronunciándose), en dos idiomas que le son íntimos, dos textos simultáneos. Y que uno de ellos, el inglés, está, posiblemente, determinando el texto visible, el español. ${ }^{13}$

A los datos ya adelantados (predominio de masculinos, segmentos iniciales de hombre, palabra "hombre” final, etc.) tendríamos que sumar ahora la presencia en la “memoria” del poeta del libro más célebre del que Emerson es autor (y Borges, 
traductor), Hombres representativos (Representative Men), y recordar a nuestra vez que los segmentos $M E N-E N-E M-M E$ suman en conjunto doce veces a lo largo del poema.

A ello debemos agregar algo que nos ha llamado particularmente la atención. Es el tipo de calificativos que Borges atribuye, también repetitivamente, a Emerson, tanto en el poema que examinamos como en el "Prólogo" a su traducción de Hombres..., mientras que en el "Prólogo" a Cuaderno San Martín lo caracteriza como "poeta intelectual". ${ }^{14}$ La elección del poema, que repite la de aquel "Prólogo" ("Emerson [fue] un caballero y un clásico"), ${ }^{15}$ es nuevamente la de "caballero”. Lo interesante es que en inglés la palabra que corresponde es gentleman, es decir, gentil "hombre", con lo que volvemos a encontrar el tan reiterado vocablo, con la llamativa coincidencia de que en la versión inglesa (que tan probablemente haya manejado el inconsciente del poeta) esta palabra iría al final del primer verso. En efecto, el mismo se compondría, en mi modesta versión personal, del siguiente modo: “That great American gentleman", lo que nos estaría dando no un final a la rima pero si una exacta coincidencia con el final del último verso del soneto, lo que de algún modo completaría un sistema. ${ }^{16}$

A partir de esta última comprobación, sería tal vez una facilidad deducir que aquí el poema está tendiendo a trazar una estructura de espejo, aunque no podemos omitir la importancia que toda la Obra Poética de Borges confiere a este motivo, lo que aparece ya claro en el mero hecho de que esta palabra sea escrita más de veinte veces en 75 poemas que componen el libro al que pertenece el soneto que examinamos. Ya hemos dicho, empero, páginas atrás, que preferíamos abordar los temas en estudio por otros caminos, aunque ello no impide que marquemos éste como una posibilidad más, no explorada por nosotros, pero sin duda presente.

La circunstancia de que en el poema haya un verso en el que se mencione la escritura de ese mismo poema, sumada al hecho de que esa mención se efectúe en presente, y a otras circunstancias que ponían al verso 8 en el centro de interés de un aspecto de nuestros análisis, nos ha llevado a afirmar, acaso exageradamente, que se trataría de un verso “modelo” o, para ser más precisos, del verso en que de algún modo se resumiría el proceso de constitución del poema. Si es sostenible que no hay texto literario que no entregue uno o más modelos velados de su propia constitución como tal, pienso que en el caso de este soneto el paradigma que se esta trazando es el de la "memoria”, y ello en sus dos vertientes: repetitiva y productiva. La "memoria”, como el verso expresa, es facultad fundamental para recrear la existencia del personaje invocado. Eso, en el plano expresivo, en lo que el poema elementalmente “dice”. En el plano de los significantes, creo haber demostrado que la memoria (visual, auditiva) recoge las anáforas que el texto va entregando en sus múltiples niveles. Pero aquí la memoria es también productiva: por un lado, porque el recuerdo inconsciente de una lengua produce un texto en otra lengua que aquella en la que el poema se "expresa" (o, si se quiere, trozos de un texto); por el otro, porque la "memoria” de esa lengua 
cubre los espacios vacantes de un discurso que no sabe que "dice" lo que el inconsciente de la palabra, en sus mínimos fragmentos relacionales, le entrega. En este aspecto, podríamos afirmar que el discurso poético va diciendo no sólo lo que dice sino todo lo que el inconsciente escribe.

Finalmente, la memoria constituiría el núcleo sobre el que giran los diversos presentes a que aludimos páginas atrás. La memoria facilitaría aquella complicada y perifrástica forma del presente que el poema realiza en su conjunto, justamente de manera indirecta, perifrástica, oculta. En efecto, ya no quedan dudas de que el inconsciente de la palabra pronuncia "hombre" (u "hombres") durante todo el poema, y ello en los dos idiomas que a Borges le son “íntimos”. Emerson y "hombre” quedan así indisolublemente unidos a lo largo de este soneto. ¿Quién, nos preguntamos entonces, quisiera ser "otro hombre”?

Hay que notar que la aparición del poeta tiene lugar en 3era. persona, o sea que tenemos la misma distancia entre él y Emerson. No hay diferencia ni contradicciones (por lo menos lingüísticas), a menos que se tome como tal, y ello en desmedro del poeta, el hecho de que la lera. persona sea “alejada”, si se quiere “despersonalizada”, en una 3era., como se sabe, la menos "personal” de las personas. No hay aquí un yo que diferencie, en un poema en el que, por otro lado, hay menciones directas o indirectas a tres personas concretas. Es legitimo suponer que así como toda la actividad del personaje Emerson se pierde al entrar a la memoria del que escribe, así se pierde él mismo o se confunde con quien, por primera vez y paradójicamente, le hace asumir la primera persona, "lo hace hablar”, es decir, habla por él. Llegados a este punto, un tanto avanzado de la interpretación, vale la pena preguntarse si no es ésa, en otros aspectos, toda la mecánica de la “repetición”. Si “repetir” no es estar diciendo lo mismo de un modo diferente, de un modo-otro, estar manejando, sirviéndose de otros, para decir “lo mismo”. Más lejos todavía, si hacer "lo mismo” de "lo otro”, al hacer mío lo que no me pertenece, lo que es mi-ajeno, no es eliminar (¿matar?) "lo otro".

Claro está que un interrogante un tanto más banal ha quedado en el camino. Es el que se formularía más o menos así: ¿es posible que sea el poeta quien expresa, en este presente, el deseo de ser otro hombre? Dicho interrogante se podría responder con algunos ejemplos que lo confirmarían pero que, con ese procedimiento, cerrarían ricas vetas para el análisis borgeano. Simplemente, habría que recordar lo que justamente al prologar al mismo Emerson escribió Borges: “Nuestro destino es trágico porque somos, irreparablemente, individuos, cortados por el tiempo y por el espacio; nada, por consiguiente, hay más lisonjero que una fe que elimina las circunstancias y que declara que todo hombre es todos los hombres y que no hay nadie que no sea el universo. Quienes profesan tal doctrina suelen ser hombres desdichados o indiferentes, ávidos de anularse en el cosmos; Emerson era, pese a una afección pulmonar, instintivamente feliz.” 17 
Cualquier lector de Borges puede certificar la autorreferencia del planteo transcripto, así como la constancia con que recorre la obra de Borges la avidez de anularse en el universo, de “ser nada” y “ser nadie.” Pero no es tal avidez, ni tampoco su felicidad o su desdicha al proseguir una búsqueda sin identidad precisa, la que hemos pretendido examinar hasta acá, sino como la expresión de un deseo puede estar más allá del dominio y control del poeta, y manifestarse de un modo clandestino y hasta en cierta medida secreto. Como escribía Tinianov, "la palabra es un elemento divisible en elementos literarios mucho más pequeños”. ${ }^{18}$ Es en estas más pequeñas unidades donde encontramos núcleos significantes dejados por ese lenguaje que estamos leyendo, y también por otro que compite y colabora con él para formar lo que hemos caracterizado como el inconsciente de esta palabra poética. Si la "memoria" puede ocupar un sitio tan importante como el que hemos visto en páginas precedentes para tratar de explicarnos en un aspecto la constitución del poema, en otro aspecto podemos pensar que es también la “memoria”, la memoria del lenguaje (no el recuerdo de uno o más lenguajes, sino los lenguajes que se recuerdan), la que llene los vacíos que ninguna palabra voluntaria puede cubrir.

Université de Toulouse-Le Mirail

GERARDO MARIO GOLOBOFF

\section{NOTAS}

1 Jorge Luis Borges, "Emerson”, El otro, el mismo, en Obras Completas, Buenos Aires, Emecé, 1974, p. 911.

2 Refiriéndose a Flaubert, escribe Foucault: “...el siglo XIX ha descubierto un espacio de la imaginación cuyo poder sin duda alguna no había sido intuido por el periodo precedente. Este nuevo lugar de los fantasmas no es ya la noche, el sueño de la razón, el incierto vacío abierto ante el deseo: es por el contrario la vigilia, la aplicación infatigable, el celo erudito, la atención acechante. Lo fantástico puede nacer de la superficie negra y blanca de los signos impresos, del volumen cerrado y polvoriento que se abre con un revuelo de palabras olvidadas; se despliega cuidadosamente en la biblioteca enmudecida, con sus columnas de libros, sus títulos alineados y sus estantes que la limitan por todas partes pero que se abren, por el otro lado, sobre mundos imposibles. Lo imaginario se aloja entre el libro y la lámpara.” (Prólogo a La tentación de San Antonio, París, Gallimard, 1967; reproducido en ECO, Bogotá, Setiembre 1974, no. 167, p. 492). *En el siglo XX, pocas obras como la de Borges se desarrollan en tan estrecha vinculación con los libros y con ese espacio que los reúne y sacraliza, la Biblioteca. Las meditaciones de Foucault ayudan a entender esa vinculación; nosotros tratamos, además, de darle una explicación específica, en la que confluya la problemática de una época con la problemática personal del escritor estudiado. * ${ }^{*} \mathrm{La}$ publicación de ECO: Michel Foucault, "La biblioteca fantástica”.

3 Jorge Luis Borges, "Prólogo", en Fervor de Buenos Aires, en ob. cit., p. 13.

4 Jorge Luis Borges, “La flor de Coleridge”, en Otras Inquisiciones, en ob. cit., p. 641.

5 Jorge Luis Borges, “Cambridge”, en Elogio de la sombra, en ob. cit., p. 981. 
6 No sólo metafóricamente podemos asimilar aquí lo que Laplanche y Leclaire recuerdan de Freud explicando la presencia del inconsciente en la experiencia psicoanalítica: "lee données de la conscience sont 'lacunaires' ('lückenhaft'); l'inconscient est ce qui permet de rétablir une suite cohérente, une relation intelligible 'lorsque nous interpolons des actes inconsciente auxquels nous avons conclu'” (Jean Laplanche et Serge Leclaire, "L'inconscient”, en Les temps modernes, Paris, Julio 1961, no. 183, p. 88).

7 En ob. cit., pp. 855-949.

8 Cf. Roman Jakobson, “Vocabulorum constructio dans le sonnet de Dante 'Se vedi li occhi miei'”, en Questions de poetique, Paris, Du Seuil, 1973, pp. 299-318.

9 Mucho habría para decir acá si hablásemos en término de narración. Lo mínimo que no podemos omitir es que el "narrador" omnisciente (tanto que puede contamos lo que su personaje "piensa") desaparece, es plenamente sustituído por su personaje. La falta de comillas agrega un detalle sugestivo a la figura.

Pero habría más: así como se hace decir en 1era. persona lo que a nivel expresivo no puede ser más que una 3era. (“piensa”), así también podría ser que lo que se está diciendo en 3era. ("ese”) no sea más que un ocultamiento bajo el demostrativo de una 1era. La pista, casualmente, nos la podría brindar el varias veces mencionado verso 8 ("esto escribe”). La ausencia de pronombres, la doble locución, el hecho de que se hace "propia” la palabra del otro, agregarían material para el análisis.

${ }^{10}$ Cf. Emile Benveniste, "La nature des pronoms", en Problèmes de linguistique générale, Paris, Gallimard, 1966, pp. 251-257. (Tomo 1).

${ }^{11}$ Con las limitaciones que la advertencia de Macherey nos señala: "Connâitre les conditions d'une production, ce n'est pas ramener le processus de cette production à n'être que le déploiement d'une germe en lequel tout le mouvement du possible serait une foil pour routes anticipé, dans une genèse qui n'est que l'image renversée d'une analyse. C'est au contraire mettre en évidence le processus rée1 de sa constitution: montrer comment une diversité réelle d'éléments compose l'oeuvre, et lui donne sa consistance.” Pierre Macherey, Pour une theorie de la production littéraire, Paris, Maspero, 1971, p. 62.

12 Jorge Luis Borges, “Una oración”, en Elogio de la sombra, en ob. cit., p. 1014.

${ }^{13} \mathrm{Si}$, como pensamos, el bilingüismo de Borges se acomoda a lo que Ervin y Osgood denominan "sistema lingüístico coordinado", le es aplicable al presente análisis esta consideración: “...el conjunto de signos lingüísticos y respuestas apropiados para una lengua se asocian con un conjunto de procesos representacionales mediadores (...) pero el conjunto de signos lingüísticos y respuestas apropiados para la otra lengua se asocian con un conjunto de procesos representacionales algo distinto...” (Susan M. Ervin y Charles E. Osgood, “Aprendizaje de una segunda lengua y bilingüismo”, en: Osgood, Sebeok y Diebold, Psicolingüística Barcelona, Editorial Planeta, 1974, pp. 197-198.

14 Jorge Luis Borges, "Prólogo”, en Cuaderno San Martín, en ob. cit., p. 79.

15 Jorge Luis Borges, Prólogos, Buenos Aires, Torres Agüero Editor, 1975, p. 38.

${ }^{16}$ Afirma Greimas refiriéndose a los fenómenos de adecuación estructural de "la expresión" y "el contenido": "Lo que todos estos fenómenos tienen en común es la reducción de la distancia entre el significante y el significado: diríase que el lenguaje poético, aunque sin dejar de ser lenguaje, trata de recuperar el grito original y se sitúa a mitad de camino entre la articulación simple y la articulación lingüística doble. El resultado es un 'efecto de sentido', común a los diferentes ejemplos citados, que es el de una 'verdad redescubierta', originaria u original, según los casos. En esta significación ilusoria de 'sentido profundo', 
oculto e inherente al plano de las expresiones, es donde podría situarse, particularmente, el problema de los anagramas”. A. J. Greimas, "Las relaciones entre la lingüística estructural y la poética”, en: A. J. Greimas y otros, Lingüística y comunicación, Buenos Aires, Ediciones Nueva Visión, 1971, p. 17.

Este trabajo fue leído en una de las sesiones del S.I.L. (Seminario de Investigación Literaria) de la Section d'Espagnol de la Université de Toulouse-Le Mirail, en el que el suscripto viene actuando como Coordinador desde al año 1974. En oportunidad de la discusión que se suscito alrededor del mismo, surgieron aportes y sugerencias que he tenido en cuenta para la elaboración final del presente. Se barajaron también distintas posibilidades anagramáticas en torno a otras lenguas, hasta descubrirse (de un modo para mi algo alucinante, ya que el título del trabajo era anterior a esa lectura) que las letras de Emerson formaban en latín las del título de mi propio trabajo: SER OMNE.

17 Jorge Luis Borges, Prólogos, ed. cit., p. 38.

${ }^{18}$ Iuri Tinianov, "El ritmo como factor constructivo del verso", en El problema de la lengua poética, Buenos Aires, Siglo XXI Argentina, 1972, p. 36. 


\section{Borges Ante Lugones: Divergencias y Convergencias}

La literatura argentina cuenta, en lo que va del siglo, con dos escritores cuyo genio creador les ha ganado amplia resonancia internacional. Pertenecientes a generaciones sucesivas, Leopoldo Lugones (1874-1938) y Jorge Luis Borges (n. 1899) iluminan en sus relaciones mutuas un capítulo importante de las letras nacionales e ilustran las alternativas del clásico conflicto generacional.

Al avanzar en Buenos Aires la década del veinte, los anhelos de superar la órbita modernista se polarizan en dos tendencias complementarias. Esta nueva generación a la que se le ha asignado diversas fechas clave -1922, 1924, 1925- presenta por una parte un sector preocupado por los problemas sociopolíticos del país, solidario con el obrero y dedicado a un arte comprometido; por otra, un grupo más numeroso consagrado a una literatura estetizante, innovadora y casi sin compromisos ideológicos. Conocidas respectivamente con los nombres de Boedo y Florida, ${ }^{1}$ estas dos alas de la vanguardia argentina tuvieron además sus modelos europeos -Tolstoy, Gorki y Dostoievsky frente a Apollinaire, Valéry y Joyce-y sus publicaciones representativas, entre las que sobresalen Claridad y Martín Fierro. ${ }^{2}$ A pesar de las preferencias diversas, las dos modalidades no se excluyeron mutuamente, y hubo casos de intercambio en la colaboración literaria. El hecho es que de entre este conjunto combativo y bullicioso de jóvenes surgieron los autores que ocuparían un lugar destacado en la literatura nacional al promediar el siglo.

Era inevitable que la vanguardia argentina viniera a enfrentarse, por motivos ideológicos y estéticos, con la figura dominante de Lugones. Nacido en el interior del país, donde en su juventud había profesado con fervor ideas sociales de izquierda, y habiendo recibido en Buenos Aires a fines del siglo el espaldarazo de Rubén Darío, Lugones era por 1920 y desde hacia años el escritor de más prestigio e influencia en el país. Una sostenida y polifacética producción literaria había ido apuntalando este renombre desde Las montañas del oro (1897), libro que le había ganado el elogio del jefe modernista. Se suceden así los ensayos históricos El imperio jesuítico (1904) y la Historia de Sarmiento (1911); las fuertes narraciones de La guerra gaucha (1905) y los cuentos fantásticos de Las fuerzas extrañas (1906); los tomos de poesía Los crepúsculos del jardín (1905), Lunario sentimental (1909), Odas seculares (1910), 
El libro fiel (1912) y El libro de los paisajes (1917); varios estudios helénicos; y el análisis del máximo poema gauchesco en El payador (1916). En su segunda visita a Europa, durante la primera guerra mundial, había decidido apoyar la causa de las democracias liberales -como revela en Mi beligerancia (1917)- y al llegar al período que nos interesa reanudaba su labor literaria con las poesías de Las horas doradas (1922) y el Romancero (1924), las ficciones de Cuentos fatales (1924) y sus Estudios helénicos (1924).

Borges, que conocía desde la adolescencia dos de los libros más innovadores de Lugones -Las montanas del oro y Lunario sentimental-, sintió tempranamente la atracción de su arte y a la vez procuró evitar parecerse a él. En un poema de madurez recuerda los días cuando realizaba sus primeros ejercicios políticos en Suiza, tratando de definir la luna:

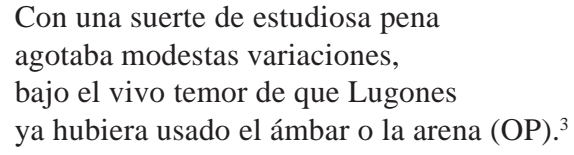

En 1921, a poco de regresar a la Argentina trayendo el evangelio del ultraísmo -en cuya gestación había participado en Sevilla y en Madrid-, Borges rompe lanzas contra los poetas locales que "sólo se ocupan de cambiar de sitio los cachivaches ornamentales que los rubenianos heredaron de Gógora”, y propone "desanquilosar el arte” empleando la metáfora como recurso político fundamental. ${ }^{4}$ También en diciembre de ese año publica en la revista Nosotros un ensayo antológico titulado "Ultraísmo" donde expone con precisión los postulados del movimiento. ${ }^{5}$ No obstante estas declaraciones polémicas, Borges mantiene durante un tiempo una distancia respetuosa frente a Lugones. Cuando a principios de 1923 los directores de Nosotros realizan una encuesta sobre las preferencias de la nueva generación, el poeta novel que a fines de ese año publicaría su primer libro -Fervor de Buenos Aires- responde: "Mis entusiasmos son ortodoxos. Entre los santos de mi devoción cuento a Capdevila, a Banchs y señaladamente a nuestro Quevedo, Lugones”. ${ }^{6}$

La paz, sin embargo, no podía durar mucho. La sombra que proyectaba el escritor y tribuno consagrado era demasiado extensa, sus opiniones políticas y literarias demasiado tajantes, la impaciencia iconoclasta de algunos vanguardistas demasiado impetuosa. Lugones invita el ataque al anunciar públicamente sus nuevas convicciones. Desilusionado ante la situación creada por las democracias liberales tanto en su patria como en Europa, y temeroso del avance izquierdista, expresa en 1923 su admiración por el fascismo italiano y a fines del año siguiente proclama en Ayacucho, Perú: "Нa soñado otra vez, para bien del mundo, la hora de la espada”. Esta definición antidemocrática, que culminaría en su apoyo del golpe militar argentino de 1930, atrae también la condena de varios escritores jóvenes cuyas simpatías tendían hacia la izquierda o hacia el populismo del ex-presidente Hipólito Yrigoyen. 
En el ámbito literario la chispa salta al chocar dos concepciones opuestas sobre el papel que le corresponde a la rima en la poesía. Mientras varios de los nuevos proclamaban su abolición definitiva, cultivando con entusiasmo la versificación totalmente libre -en la línea de los simbolistas y la vanguardia europea-, Lugones venía sosteniendo desde 1909 que la rima era un "elemento esencial” del verso moderno -incluso el irregular- y que los versos sin rima eran "un recurso de impotencia”.7 A partir de 1923 y en artículos dedicados a poetas jóvenes que cultivaban un arte aún al suyo, desarrolla estas ideas para censurar, tanto en el plano estético como en el moral, el versolibrismo sin rima practicado por los ultraístas y otros vanguardistas argentinos. ${ }^{8} \mathrm{~A}$ su juicio el verdadero poeta no se siente trabado por las exigencias del ritmo y la rima; por el contrario, éstas corresponden a su modo natural de expresión. De ahí que la carencia de la rima no sólo reduzca el verso al nivel de la prosa, sino también revele pereza, esterilidad y nihilismo. ${ }^{9}$ Por otra parte la metáfora -santo y será de la "nueva sensibilidad”- tiene por objeto básico expresar con más eficacia las emociones; es un recurso, no un fin.

Leopoldo Marechal, vanguardista y colaborador de la revista Martín Fierro, recoge el guante en nombre de su grupo y contesta a fines de 1925 con un "Retruque a Leopoldo Lugones" en que alternan el razonamiento y la ironía. ${ }^{10}$ "La métrica declara-fue el pantalón corto de la poesía: ahora la poesía es adulta”. Además, la rima favorece el ripio mientras que "el verso libre permite y exige la síntesis”. La réplica de Lugones, aunque tácita, no se hace esperar. "De la rima” se titula el artículo en que a comienzos de 1926 repite con tono magisterial sus argumentos, censurando a los que cometían el error de borrar los límites que a su juicio separan los dos módulos de la expresión literaria: "La prosa -dice- es instrumento de comunicar nociones, principalmente por medio del lenguaje lógico. La poesía es otro de comunicar, principalmente, emociones, por medio del lenguaje musical, que es el rítmico de la referencia”. ${ }^{11}$ Este intercambio se cierra con la "Filípica a Lugones y a otras especies de anteayer”, donde Marechal arremete duramente -”¿Con qué derecho juzga de poesía un hombre que carece de sensibilidad poética?”-, recordándole que después de treinta años ha cambiado la manera de sentir, y concluye en típico desplante martinfierrista desafiando con sus compañeros "a Lugones y a cualquier versificador" a un duelo "en todo metro y forma conocidos". ${ }^{12}$

Hacia 1925 el medido respeto de Borges ante Lugones se convierte en ambivalencia. Por un lado el título de su segundo poemario -Luna de enfrente (1925)sugiere una tácita reverencia hacia el autor de Lunario sentimental. ${ }^{13}$ Por otro, comienza a objetarle su “arduo gongorismo" y su falta de criollismo auténtico (I, 137). Ya por enero de 1926 asume la actitud de varios correligionarios en una demoledora nota bibliográfica sobre el Romancero. Después de declarar que en él Lugones se muestra “muy casi nadie, muy frangollón, muy ripioso”, afirma que la rima consonante conduce inevitablemente a la poesía insustancial y que esta obra es la mejor prueba de ello. El párrafo final sintetiza el tono de esta reseña-ataque: 
El Romancero es muy de su autor. Don Leopoldo se ha pasado los libros entregado a ejercicios de ventriloquia y puede afirmarse que ninguna tarea intelectual le es extraña, salvo la de inventar. [...] Hoy, ya bien arrimado a la gloria y ya en descanso del tesonero ejercicio de ser un genio permanente, ha querido hablar con voz propia y se la hemos escuchado en el Romancero y nos ha dicho su nadería. ¡Qué vergüenza para sus fieles, qué humillación! (TE, 102106). ${ }^{14}$

Por entonces Borges entra también en la polémica poética con un artículo en el que, a partir de un pasaje de Milton, replica a Lugones refutando los tres argumentos tradicionales en favor de la rima. Desde el punto de vista histórico, dice Borges, basta recordar a quienes consideran la rima esencial para la poesía que "literaturas enteras la han ignorado” (TE, 117). Contra el argumento hedónico -basado en el deleite que causa la rima- cita versos blancos “auditivamente perfectos” de Garcilaso (TE, 119), alude a Walt Whitman y sostiene que la habilidad necesaria para "ligar las rimas, es actividad del ingenio, no del sentir”. En cuanto al argumento intelectual, afirma que los rimadores, al no seguir "la correlación y la natural simpatía de las palabras, sino la contingencia del consonante”, se convierten en "parásitos del retruécano” (TE, 120). En otro artículo crítica lo que considera falta de originalidad de Lugones -es uno de los que "hacen bien lo que otros hicieron ya" (TE, 7)-, censurándole también la carencia de hondura y el empleo de adjetivos rebuscados e imprecisos. ${ }^{15} \mathrm{Y}$ al asumir paulatinamente una fervorosa postura criollista, le achaca un presunto extranjerismo, llamándolo “forastero grecizante, verseador de vagos paisajes hechos a puro arbitrio de rimas y donde basta que sea azul el aire en un verso para que al subsiguiente le salga un abedul en la punta”. ${ }^{16}$

Lugones, por su parte, no pierde la calma ni cede terreno. En 1927 publica sus Poemas solariegos que marcan -contrariamente a lo que opinaba Borges- un maduro ahondamiento en lo vernáculo y familiar. Y cuando ese año dos de los nuevos -Pedro Juan Vignale y César Tiempo- le piden una nota introductoria para la antología de poetas jóvenes que preparan, Lugones reitera su parecer con un tono de sorna dirigido precisamente a varios de los autores incluidos:

Esta antigualla lamentable y antiestética [el verso libre sin rima] es el descubrimiento instrumental más importante de la actual vanguardia poética, o nueva sensibilidad, o ultraísmo, como se denomina el grupo de prosistas jóvenes, para quienes resulta verso todo párrafo de prosa dispuesto en renglones verticales separados; mientras su invención psicológica, dominante hasta lo exclusivo, es la metáfora, de no menos venerable historia. Amontonar imágenes inconexas en parrafitos tropezados como la tos, y desde luego sin rima: he ahí toda la poesía y todo el arte. ${ }^{17}$ 
Borges mantiene el fuego graneado, subrayando su desacuerdo ideológico y estético. En una pintoresca carta abierta publicada en Nosotros, califica de absurdos los “cargos de fascismo y lugonería” que un escritor había lanzado contra los directores de la revista Proa. Agradece al autor del "Nulario [sic] sentimental" el deleite de poesías como “El solterón” o “Quimera lunar” y algunas estrofas sueltas, pero -agrega- "ni sufro sus rimas ni me acuerdo del tétrico enlutado ni pretendo que sus imágenes, divagadoras siempre y nunca ayudadoras del pensar” puedan equipararse a las de Ramón Gómez de la Serna o Rafael Cansinos-Asséns. Con respecto “al solemnismo patriotero de fascistas e imperialistas -concluye-, yo jamás he incurrido en semejantes tropezones intelectuales”. ${ }^{18}$

Al sarcasmo de estos ataques sigue una década de asordinamiento y luego de silencio. En varios ensayos publicados alrededor de 1930 Borges replica indirectamente a la tesis épica de Lugones -que exaltaba a José Hernández muy por encima de los demás poetas gauchescos-, destacando el valor de otros cultivadores del género en ambas riberas del Río de la Plata. ${ }^{19}$ Pero el tono ya no es polémico. Y antes de que Lugones se quitara la vida en 1938, Borges había iniciado una retractación que con el tiempo cobraría un énfasis tan vehemente como el de la diatriba anterior. En un artículo de 1937 echa una mirada retrospectiva a las actividades de su grupo político durante la década del veinte $y$, confesando cuanto había de pose en los gestos desaforados de aquellos años, reconoce su inequívoca filiación lugoniana. Eramos, afirma, “involuntarios y fatales alumnos - sin duda la palabra 'continuadores' queda mejor- del abjurado Lunario sentimental”. E insiste:

Yo afirmo que la obra de los poetas de Martín Fierro y Proa -toda la obra anterior a la dispersión que nos dejó ensayar o ejecutar obra personal- está prefigurada, absolutamente, en algunas páginas del Lunario. [...] Lugones exigía, en el prólogo, riqueza de metáforas y de rimas. Nosotros, doce y catorce años después, acumulamos con fervor las primeras y rechazamos ostentosamente las últimas. Fuimos los herederos tardíos de un sólo perfil de Lugones. Nadie lo señaló, parece mentira (LL, 78). ${ }^{20}$

Al combatirlo, explica, no hacíamos sino defendernos de él para poder ser otros. Por 1941 declara con más énfasis que el ultraísmo “durante quince años se dedicó a reconstruir los borradores del Lunario sentimental”. ${ }^{21}$

Para desazón de algunos ex-correligionarios, Borges ha venido repitiendo con escasas variaciones este parecer que, si bien es excesivo, contiene una dosis considerable de verdad. ${ }^{22}$ Lugones era más innovador y estaba mucho más atento a la evolución de la poesía europea de lo que hubieran querido admitir en su tiempo los vanguardistas argentinos. Aquel revolucionario libro -con sus metáforas audaces, sus libertades métricas, sus rimas extravagantes, su irónica irreverencia ante las convenciones literarias, su prosaísmo y asentimentalismo intencionales- se había adelantado a varias de las novedades que después se propondría el ultraísmo. 
Entretanto, Borges se ha dado cuenta de que la caza de metáforas inéditas no basta para hacer poesía. Se convence de que las verdaderas metáforas "han existido siempre" y que "las que aún podemos inventar son las falsas, las que no vale la pena inventar" (OI, 71). El poeta novel que en 1927 repudiaba por extravagante la versificación regular y condenaba "los estrafalarios rigores numéricos del soneto", ${ }^{23}$ termina empleando con frecuencia -desde "La noche cíclica" (1941)- la tradicional estrofa rimada, y en "Un poeta del siglo XIII" (1957) escribe un soneto en homenaje de su anónimo inventor. Además, la ceguera que avanza le ha hecho comprobar la virtud mnemónica de la rima y el carácter "portátil” del soneto, cualidades que le permiten componer y retocar una poesía mentalmente, mientras camina. ${ }^{24}$

Paralelamente, y a partir de un tímido comienzo, ${ }^{25}$ Borges elabora las ficciones que le darían fama internacional. Pero aun en este campo el autor de Las fuerzas extrañas y los Cuentos fatales había anticipado temas y procedimientos de la narración fantástica en la Argentina. Como Lugones, también Borges narra desapasionadamente, alejándose en el tiempo y en el espacio, empleando frecuentes alusiones históricas o filosóficas, e insertando personajes reales en el relato, con lo que ambos logran efectos de gran verosimilitud. Sin embargo, mientras Lugones sobresale en la ficción de apoyo científico y legendario -con predominio de las sensaciones y el desenlace fatal-, Borges alcanza sus logros perdurables en la ficción metafísica estructurada sobre una precisa arquitectura intelectual. La nota predominante en la narrativa del primero es el pavor creciente del hombre afectado por irresistibles fuerzas misteriosas; la del segundo, la perplejidad inquietante o irónica ante un universo laberíntico cuyo designio y destino no se alcanza a descifrar.

En 1955 recoge Borges varios artículos anteriores y los amplia para publicar Leopoldo Lugones, monografía en que traza un retrato matizado de este "hombre solitario, orgulloso y valiente, cuyos libros despertaron la admiración, pero no el afecto, y que murió, tal vez, sin haber escrito la palabra que lo expresara” (LL, 7). Señala allí la labor señera del poeta, cuya influencia marcó la literatura hispánica posterior en autores tan diversos como Ramón María del Valle Inclán, Ramón López Velarde, Ricardo Güiraldes y Ezequiel Martínez Estrada. Menciona su devota consagración a las letras, su vanidad estilística, sus deliberados juegos retóricos, la gravedad y ternura de algunas composiciones de madurez. Explica como producto de un apasionado y sincero patriotismo sus radicales cambios ideológicos. En un balance final lo juzga "el máximo escritor argentino", que "encarnó en grado heroico las cualidades de nuestra literatura, buenas y malas” (LL, 95-96). Años más tarde, al visitar centros universitarios extranjeros, desarrollaría estas ideas dictando cursos y conferencias sobre la obra de Lugones. ${ }^{26}$

Hacia 1957 lo evoca en una sugestiva prosa, situándolo en la tradición mayor de la cultura nacional:

Un hombre que sabía todas las palabras miró con minucioso amor las plantas y los pájaros de esta tierra y los definió, tal vez para siempre, y escribió con 
metáforas de metales la vasta crónica de los tumultuosos ponientes y de las formas de la luna. Estas cosas, ahora, son como si no hubieran sido $(\mathrm{H}, 35){ }^{27}$

La reivindicación de Lugones, a la que Borges se ha dedicado con persistencia, logra su nota más sentida en una prosa con que encabeza El hacedor (1960). Narra allí en primera persona una conversación con él en la oficina de una biblioteca pública. Después de una vivida descripción del ambiente de estudio que impera en el sal6n de lectura, llega a la puerta del despacho del director:

Entro; cambiamos unas cuantas convencionales y cordiales palabras y le doy este libro. Si no me engaño, usted no me malquería, Lugones, y le hubiera gustado que le gustara algún trabajo mío. Ello no ocurrió nunca, pero esta vez usted vuelve las páginas y lee con aprobación algún verso, acaso porque en él ha reconocido su propia voz, acaso porque la práctica deficiente le importa menos que la sana teoría $(H, 7)$.

Aunque tres décadas antes el encuentro había ocurrido varias veces, ${ }^{28}$ esta entrevista ha sido producto de la imaginación: "Mi vanidad y nostalgia han armado una escena imposible” (H, 8). Hace años que Lugones ha muerto; pero al subrayar las coincidencias - ambos fueron directores de bibliotecas estatales en Buenos Aires- y al entregarle su libro preferido, Borges crea un momento de hondo simbolismo. En esa dedicación de El hacedor a Lugones esta claro el propósito de satisfacer un deseo materialmente irrealizable y saldar una antigua deuda. Algunos años después, al reunir su considerable producción poética de 1935 a 1967 con el título de El otro, el mismo, Borges le antepone también esta página, acentuando el gesto expiatorio y filial. "Cada vez que escribo -diría en una entrevista reciente-, siento el temor o la esperanza de haber escrito una página de Lugones. Y cuando mis amigos me dicen que no, me siento un poco aliviado y un poco defraudado". ${ }^{29}$

En perspectiva, las diferencias entre estos dos escritores resultan claras. El contexto literario, la trayectoria vital y el temperamento diverso explican muchas de ellas: extravertido, soberbio y categórico el uno; reservado, modesto y escéptico el otro. A la actividad de tribuno elocuente y a la militancia política del mayor-que se juega entero en cada una de sus sucesivas convicciones-corresponden la conversación dubitativa y la distancia del menor, que procura mantener separados el plano ideológico del estético. La producción vasta y desigual de Lugones se caracteriza por la exuberante riqueza verbal y la propensión a lo épico, a la vez que refleja el influjo de las literaturas francesa e italiana, y el interés por lo helénico. La obra de Borges, en cambio, revela estímulos anglosajones y germanos, y siguiendo un desarrollo más orgánico tiende a la concisión disciplinada e irónica. A la apetencia vital del que capta la naturaleza y el paisaje con aguda sensitividad, se contrapone la ceguera progresiva del que forja fascinantes mundos imaginarios. 
Los paralelos entre los dos escritores no son menos evidentes. En ambos se advierte la imaginación poderosa y la complejidad contradictoria; la asimilación recreadora de lecturas heterogéneas; la falta de interés o capacidad para la novela y el teatro; la pasión por el use preciso del idioma; el humorismo socarrón y -como contrapartida- la melancolía ante el paso del tiempo; el culto al heroísmo y la búsqueda emotiva de la patria a través de la historia, la poesía gauchesca y los antepasados familiares; ${ }^{30}$ el cultivo diestro del cuento fantástico y el ensayo especulativo; la integración equilibrada de lo nacional y lo universal. En los dos puede seguirse una evolución cronológica que va de la izquierda a la derecha - de la innovación al repliegue- en política y en literatura. ${ }^{31}$ Uno logró renombre en el mundo hispánico gracias a su poesía de amplio registro, mientras la proyección del otro traspasa los límites del idioma mediante sus ficciones. Discutidos pero influyentes, Lugones y Borges ocupan una posición de relieve en la tradición literaria de su patria y de la lengua española.

Andrews University

HUMBERTO M. RASI

\section{NOTAS}

1 Los nombres de estas dos calles de Buenos Aires, donde estaban situadas las redacciones de las revistas propulsoras, pasaron a ser sinónimos de las tendencias literarias respectivas. Borges ha rechazado repetidamente esta bipartición, declarando que Boedo y Florida fueron “escuelas inexistentes” (Nosotros, No. 219-220 [agosto-setiembre de 1927], p. 77) y que la polémica entre ambos grupos fue una broma. No todos están de acuerdo, y entre la voluminosa bibliografía sobre el tema merecen destacarse tres libros escritos desde distintas perspectivas por tres participantes: Eduardo González Lanuza, Los martinfierristas (Buenos Aires: Ediciones Culturales Argentinas, 1961); Córdova Iturburu, La revolución martinfierrista (Buenos Aires: Ediciones Culturales Argentinas, 1962); Leónidas Barletta, Boedo y Florida, una version distinta (Buenos Aires: Metrópolis, 1967). Nélida Salvador ofrece un esquema ecuánime en "Mito y realidad de una polémica literaria: 'Boedo Florida'”, Sur, No. 283 (julio-agosto de 1963), pp. 68-72.

2 Claridad se publicó en dos épocas (1924 y 1926-41) y a su sesgo ideológico corresponden otras publicaciones contemporáneas como Extrema Izquierda (1924), Los Pensadores (1922, 1924-26) y La Revista del Pueblo (1926-27). De Martín Fierro interesa su segunda época (1924-27), que acentúa impulsos renovadores que se venían manifestando también en Prisma (1921-22), Proa (1922-23, 1924-26), y Valoraciones (1923-28). Sobre este particular es útil el trabajo de Héctor René Lafleur, Sergio D. Provenzano y Fernando P. Alonso, Las revistas literarias argentinas, 1893-1967 (Buenos Aires: Centro Editor de América Latina, 1968).

3 Inserto en el texto la referencia al libro de Borges y a la página correspondiente según las siguientes siglas: $\mathrm{H}=E l$ hacedor (Emecé, 1960), HUI=Historia universal de la infamia (Emecé, 1954), I=Inquisiciones (Proa, 1925), IA=El idioma de los argentinas (Gleizer, 1928), LL=Leopoldo Lugones, 2a. ed (Pleamar, 1965), OI=Otras Inquisiciones (Emecé, 1960), OP=Obra poética, 1923-1967 (Emecé, 1967), TE=El tamaño de mi esperanza (Proa, 1926). 
4 "Proclama” aparecida en el primer número de Prisma (diciembre de 1921), revista literaria “mural” dirigida por Eduardo González Lanuza, Guillermo de Torre, Guillermo Juan y el autor del manifiesto. El ciclo de la revista se cerró con un segundo y último número en marzo de 1922.

5 Nosotros, No 151 (diciembre de 1921), pp. 466-471.

6 Nosotros, No 168 (mayo de 1923), pp. 16-17.

7 “Prólogo" a Lunario sentimental, Leopoldo Lugones, Obras poéticas completas, 3a. ed. (Madrid: Aguilar, 1959), pp. 194-195, nota. Citaré de esta edición con la sigla OPC. Pedro Luis Barcia ha estudiado con detenimiento aspectos de esta controversia en "Lugones y el ultraísmo”, Estudios literarios, ed. por Raúl H. Castagnino (La Plata: Universidad Nacional, 1966), pp. 149-193).

8 Lugones llama "verso libre" al de metro irregular pero rimado, que él mismo defiende y cultiva a partir del prólogo al Lunario sentimental.

9 Lugones mantendrá esta opinión hasta pocos meses antes de su muerte, extendiendo la relación a lo ideológico: "Comunismo en la política, ateismo en filosofía y prosaísmo en el arte, todo es el mismo círculo vicioso de los extremos que se tocan" ("La rima y el verso", La Nación, 12 de diciembre de 1937, Sección Literaria).

${ }^{10}$ Martín Fierro, No 26 (29 de diciembre de 1925), reproducido por Beatriz Sarlo Sabajanes en Martín Fierro (1924-1927), (Buenos Aires: Carlos Pérez, 1969), pp. 123-125. Véase también William Hardy, "Rhyme and Blank Verse: The Lugones - Marechal Polemic", Romance Notes, 15 (1974), 605-609.

${ }^{11}$ La Nación, 17 de enero de 1926, Sección Literaria.

${ }^{12}$ Martín Fierro, No 32 (4 de agosto de 1926), en Sarlo Sabajanes, op. cit., pp. 140-142. Con frecuencia los ataques de Martín Fierro revistieron un carácter satírico. En el Nº 30-31 (8 de julio de 1926) cuatro colaboradores -que firman con anagrama y entre los que se encuentra Borges- publican un “cuasi romance” sobre el "Roman-cero a la izquierda” de Lugones.

${ }^{13}$ Hasta la explicación del prólogo -donde Borges aclara que la palabra "enfrente” del título no desprestigia la luna, sino que "la urbaniza, la chista, la vuelve aporteñada, de todos" (LE, 7)-recuerda el mecanismo de metaforización ciudadana que Lugones emplea sostenidamente en su libro de 1909. (Véase el estudio de Marta Morello-Frosch, "Metáfora cósmica y ciudadana en el ‘Himno a la luna’ de L. Lugones”, Revista Iberoamericana, 30 [1964], 153161.) Marechal, por su parte, reseña con entusiasmo este nuevo libro de Borges, contrastando "su fuerte voz de hombre" con "la actual garrulería musicante" y con "la oquedad de nuestros poetitas afeminados": "Creo que la lectura de este volumen es el mejor argumento contra las viejas teorías de Lugones” (“Luna de enfrente, por Jorge Luis Borges”, Martín Fierro, No [26] 29 de diciembre de 1925 , en Sarlo Sabajanes, op. cit., p. 126).

14 "Leopoldo Lugones, Romancero" apareció originalmente en Inicial, Buenos Aires, № 9 (enero de 1926), pp. 207-208.

15 En “La adjetivación”, La Prensa, Buenos Aires, 16 de mayo de 1926, 2a. sec., p. 6, Borges hace una exégesis irónica de la primera estrofa del famoso soneto lugoniano "Delectación morosa":

La tarde, con ligera pincelada que iluminó la paz de nuestro asilo, apuntó en su matiz crisoberilo una sutil decoración morada. 
"Estos epítetos - comenta Borges- demandan un esfuerzo de figuración, cansador. Primero, Lugones nos estimula a imaginar un atardecer en un cielo cuya coloración sea precisamente la de los crisoberilos (yo no soy joyero y me voy), y después, una vez agenciado ese difícil cielo crisoberilo, tendremos que pasarle una pincelada (y no de cualquier modo, sino una pincelada ligera y sin apoyar) para añadirle una decoración morada, una de las que son sutiles, no de las otras. [...] ¡Cuanto trabajo! Yo ni lo realizaré, ni creeré nunca que Lugones lo realizó” (TE, 56).

${ }^{16}$ Alberto Hidalgo, Vicente Huidobro y Jorge Luis Borges, Índice de la nueva poesía americana (Buenos Aires: Sociedad de Publicaciones El Inca, 1926), p. 15.

${ }^{17}$ Leopoldo Lugones, “Estética”, en Pedro Juan Vignale y César Tiempo, Exposición de la actual poesía argentina (Buenos Aires: Minerva, 1927), pp. i-ii. Para exasperación de los jóvenes, Lugones rara vez se digna a responder a sus ataques. Barcia (op. cit.) ha señalado unas pocas alusiones irónicas en su poesía:

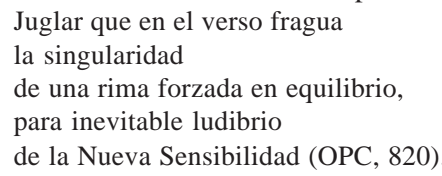

Mas adelante, también en los Poemas solariegos (1927), hay otra referencia: "Prometiendo frituras de sabor inaudito / al anzuelo ultraísta de Simón el Bobito” (OPC, 857). Y en un “Brindis jovial” a Martínez Estrada con motivo de un premio literario de 1932, Lugones alude al "alto imperio de la rima", añadiendo:

¿Cómo quiere usted que me exima

de divertirme así con ella,

cuando al hechizo de la estrella

que nos induce en este oficio,

padece usted del mismo vicio

promotor de tanta querella?

Porque es usted, señor artista,

un ejemplar insoportable

cuya garganta exige un cable

neosensible y ultraísta (OPC, 1243).

18 Nosotros, No 191 (abril de 1925), p. 547.

${ }^{19}$ He estudiado este tema en “Borges frente a la poesía gauchesca: crítica y creación”, Revista Iberoamericana, Vol. XL, Núm. 87-88 (1974), 321-336.

20 “Las 'nuevas generaciones' literarias” apareció originalmente en El Hogar, Buenos Aires, No 1428 (26 de febrero de 1937), p. 5. En rigor, casi una década antes Julio Noé y también Ernesto Palacio - uno de los primeros martinfierristas- ya habían adjudicado a Lugones la paternidad de la vanguardia argentina. Palacio lo hace en una respetuosa y razonada "Carta abierta a Leopoldo Lugones; estética nihilista”, Criterio, Buenos Aires, año 6, No 5 (5 de abril de 1928), pp. 151-152. En 1934 Federico de Onís lo veía asimismo como nexo entre el modernismo y las nuevas promociones poéticas. Véase su Antología de la poesía española e hispanoamericana (1882-1932), (Madrid: Centro de Estudios Históricos, 1934), pp. 370371.

${ }^{21}$ Prólogo a la Antología poética argentina (Buenos Aires: Sudamericana, 1941), p. 8, preparada con la colaboración de Silvina Ocampo y Adolfo Bioy Casares. 
${ }^{22}$ Todavía en 1961 escribía Borges: "Don Lugones, como todo el ultraísmo procedió del Lunario sentimental” (Prólogo a Macedonio Fernández [Buenos Aires: Ediciones Culturales Argentinas, 1961], p. 21). Entre los excorreligionarios que han rechazado esta genealogía se destaca González Lanuza quien, aunque admite la influencia lugoniana sobre Oliverio Girondo y Francisco Luis Bernárdez, afirma no haber conocido el Lunario por aquellos años. Marca además lo que considera una diferencia esencial entre el mecanismo de la metáfora “pintoresca” de Lugones y el de la ultraísta, que buscaba relaciones íntimas entre la realidad exterior y la subjetividad del poeta. Para él sería más lógico considerar a Enrique Banchs como precursor del ultraísmo, ya que si bien Lugones sirvió como punto de referencia fue precisamente para evitar parecerse a él. Véase su artículo "Lugones, la metáfora y mi generación”, El Hogar, №1430 (12 de marzo de 1937), pp. 82, 89. También Guillermo de Torre comenta con perplejidad esta radical tesis borgeana en "Para la prehistoria ultraísta de Borges”, Hispania, 47 (1964), 457-463.

${ }^{23}$ Nosotros, $\mathrm{N}^{\circ} 219-220$ (agosto-setiembre de 1927), p. 76.

${ }^{24}$ Rita Guibert, “Jorge Luis Borges”, Life en Español, 31, 5 (11 de marzo de 1968), p. 49.

${ }^{25}$ Su “Leyenda policial”, Martín Fierro, Nº 38 (26 de febrero de 1927), p. 4 -reproducida con el título de "Hombres pelearon" (IA, 151-153)- contiene el germen de su primer cuento, "Hombre de las orillas", Crítica, revista multicolor de los sábados, Buenos Aires, 1, 6 (16 de setiembre de 1933), p. 7, conocido más tarde con el nombre definitivo de "Hombre de la esquina rosada” (HUI, 91-107).

${ }^{26}$ En 1967, durante un curso sobre literatura argentina dictado en La Universidad de Harvard, Borges se refirió a la poesía y la narrativa de Lugones, recordando que a principios de siglo éste "había publicado un libro de cuentos fantásticos, Las fuerzas extrañas, y que tenía dos cuentos -escritos desde luego con el influjo de Wells y de Poe-, que se adelantan a lo que ahora se llama ficción científica y que, además, son muy buenos” (Guibert, "Jorge Luis Borges”, p. 50).

${ }^{27}$ Publicada originalmente con el título de "Prosas (El testigo; Martín Fierro)”, Sur, No 247 (julio-agosto de 1957), pp. 16-17.

${ }^{28}$ Recuerda Borges: "Lugones tenía una estima personal por mi y creo que se sentía algo triste por no poder admirar lo que yo había. Nos encontrábamos en una situación incómoda porque cada vez que yo publicaba un libro, iba a visitarlo. Lugones era el director de la biblioteca [del Consejo Nacional de Educación] en ese tiempo. Miraba mi libro, lo hojeaba un poco y después muy cortés, hablaba de otra cosa” “"Conversación con Napoleon Murat”, en James Irby et al., Encuentro con Borges [Buenos Aires: Galerna, 1968] , p. 67.

${ }^{29}$ María Esther Vázquez, “Diálogo: El amor por Buenos Aires”, La Nación, 30 de abril de 1977, 3a. seccion, p. 2.

${ }^{30}$ Me he referido a este tema en “The final creole: Borges' view of Argentine history”, TriQuarterly, № 25 (Fall, 1972), pp. 149-171.

${ }^{31}$ Recuerda Borges: "Mi primer libro se publicó en 1923, pero antes había escrito otros dos. Uno, Los ritmos rojos, tan malo como el título, que era de poemas sobre la Revolución Rusa, sobre el comunismo. En aquel tiempo el comunismo tenía un sentido distinto del que tiene ahora; significaba más bien una idea de fraternidad universal. Luego escribí otro libro titulado Los naipes del tahúr, en el que trataba de parecerme a Pío Baroja. Me di cuenta de que esos dos libros eran malos y los he destruido en mi memoria" (Guibert, "Jorge Luis Borges”, p. 54). 


\section{NOTAS}

\section{Borges y los Símbolos}

Borges suele confesar modestamente su pobreza y su "esencial monotonía” $(H$, $109),{ }^{1}$ pero recordarnos también que la poesía “es inmortal y es pobre” $(P, 225)$. Además al hablar del lenguaje, las metáforas o las fábulas, ha condenado como vana la búsqueda de la originalidad y la minuciosa invención de nuevas fórmulas.

Sobre el lenguaje, basta citar las frases de su prólogo a El informe de Brodie:

Cada lenguaje es una tradición, cada palabra, un símbolo compartido, es baladí lo que un innovador puede alterar; recordemos la obra esplendida pero no pocas veces ilegible de un Mallarmé o de un Joyce. $(B, 10)$

Para hacer mas convincentes sus opiniones, las ejemplifica con el nombre de estos dos escritores insignes, cuya extrema maestría torna más patético su fracaso. Borges los conoce bien, los admira y ha comentado su obra, pero rechaza seguir su camino.

Sobre las metáforas y las fábulas esenciales, ha afirmado insistentemente que sólo unas pocas son capaces de traducir los eternos anhelos del hombre:

...es quizá un error suponer que puedan inventarse metáforas. Las verdaderas, las que formulan íntimas conexiones entre una imagen y otra, han existido siempre; las que aún podemos inventar son las falsas, las que no vale la pena inventar. $(O I, 59)$

Toda la poesía debiera consistir en volver a decir esas fórmulas imperecederas; sin embargo su pensamiento no se detiene aquí, y en otras ocasiones agrega un grado más sutil de complejidad. El ensayo “La esfera de Pascal”, que se había iniciado con la postulación consabida:

Quizá la historia universal es la historia de unas cuantas metáforas. (OI, 16) 
concluye retomando la frase con leve variación:

Quizá la historia universal es la historia de la diversa entonación de algunas metáforas. $(O I, 16)$ (El subrayado es mío)

Esa diversa entonación, “algebra y fuego” ( $P, 160$ y E, 152), “fuego y cristal” ( $L a$ Nación, 2 de noviembre de 1975) es la que habría que captar en Borges. ${ }^{2}$

Entre los símbolos que reaparecen una y otra vez en sus textos hay que señalar como uno de los más significativos -quizás el más significativo- el hecho mismo de la simbolización. Borges se ha nombrado en "El muerto" como "el hombre que entreteje estos símbolos” ( $A, 31)$, es decir que, Cuando ha adoptado la mascara del escritor, ha querido mostrarse esclavizado o justificado por esa tarea. Palabras, signos, figuras, cifras, simbolizan los actos humanos y la entera creación; el universo entero y los actos de los hombres son, a su vez, figuras, letras, palabras o símbolos de nuestro destino.

Borges, pues, como teorizador de la literatura o como juez de su obra, y junto a él otros críticos, han destacado la importancia del símbolo en sus textos. En mis primeros trabajos me ocupe de algunos de los más significativos, también de las palabras que constituyen su código del valor simbólico en si y de la creación de ficciones centradas en la revelación de un destino por un acontecimiento que es su cifra. ${ }^{3}$ Luego, posteriormente, he analizado su modo narrativo que propone la lectura en distintos niveles, desde los hechos concretos a las formas arquetípicas. a Pero hay algo que entonces no vi y ahora se me aparece claramente. Mi nueva propuesta es que no sólo debe atenderse a la variedad de estratos para una comprensión más rica de sus ficciones, sino que constituye un hecho esencial en su estructura el conformar un "artefacto" con diversos niveles en tensión.

Se argumentará que decir de una obra que es un acontecer humano capaz de conmovernos y un modelo del universo, es casi una tautología, puesto que toda gran creación lo es. Sin embargo, lo propio de Borges es ofrecer una compleja construcción que se complace en mostrar en filigrana las líneas primordiales del modelo que propone. Y este modelo reside en la tensión entre los diversos estratos, y no en uno o más de los valores simbólicos que podrían descifrarse.

En cuanto a los distintos niveles de abstracción que proponen sus ficciones, basta situarse ya, para percibirlos, en el primer estrato, el de la historia personal que les da un soporte. Borges dice de sus relatos en el prólogo de El informe de Brodie: “...abundan en la requerida invención de hechos circunstanciales.” $(B, 9)$. Junto a la invención de detalles significativos, ha señalado la simulación de olvidos y también de dudas en el conocimiento de los hechos supuestamente reales. Cuando habla de lo que califica sus “astucias” de escritor, enumera las tres características apuntadas antes: “...intercalar en un relato rasgos circunstanciales, exigidos ahora por el lector; simular pequeñas incertidumbres, ya que si la realidad es precisa la memoria no lo es; 
narrar los hechos (esto lo aprendí en Kipling y en las sagas de Islandia) como si no los entendiera del todo...” $(P, 340)$.

Estas y otras técnicas que Borges no menciona caracterizan su desarrollo narrativo, que he llamado lacunar (implícita o explícitamente atribuido por el relator a omisión selectiva o a fallas de la memoria). ${ }^{5}$ Sus rasgos simuladores de empobrecimiento aluden a la rica realidad que se quiere postular detrás del texto, pero al mismo tiempo ya están apuntando a la presencia de otros niveles de abstracción. Saber que no se ha dicho todo, invita a inferir la existencia de hechos callados $u$ olvidados; saber que hay una selección consciente o inconsciente impulsa a continuar esa línea de despojamiento. Por otra parte el "no entender del todo" hace suponer que hay un sentido aun no captado e incita también al desciframiento. Muchos cuentos agregan explícitas manifestaciones de la voz narrativa para advertir sobre la existencia de un núcleo semántica que el lector no debe perder.

Tomemos uno de los relatos de su última época, por ejemplo “El duelo”. El nivel de la supuesta realidad, la historia contada, es la emulación de dos mujeres de alta sociedad, amigas íntimas, diletantes de la pintura, constantemente enfrentadas en veladas rivalidades artísticas. Los incidentes se encadenan y remiten a la existencia de otros niveles de comprensión, hecho hacia el cual el narrador se encarga de llamar la atención desde el comienzo. Estas distintas capas de interpretación o lecturas no son siempre claras y definidas, ni en número ni en significado. Como en todo hecho estético, y especialmente en la obra de Borges, los símbolos mantienen su alusión plurivalente y ambigua. El lector va recibiendo señales intermitentes y dispersas que apuntan a una existencia de desciframiento, hacia una meta cada vez más abstracta, y cada vez más lejana y elusiva.

Desde el comienzo se inserta el primer índice de despojamiento de los detalles concretos de la fábula, al observar que un cambio de los escenarios, Londres o Boston, no habría variado lo esencial del relato. Líneas después se incluye otra llamada a una intepretación selectiva de las señales textuales: "Debo prevenir al lector que los episodios importan menos que la situación que los causa y los caracteres.” $(B, 89)$. Aquí la ambigüedad en la formulación de la advertencia puede tentarnos con la lectura supuestamente psicológica. ${ }^{6}$

La delicada y fragmentaria versión de esa vida de rivalidades concluye con el vacío de la muerte de una de las amigas, el vacío en la inutilidad de la existencia de la segunda, que le rinde homenaje con un retrato, símbolo de la vanidad de sus envidias y emulaciones. Su hipotética reconciliación post mortem en la mente de Dios es un eco apagado del final de "Los teólogos", donde los enemigos que se han perseguido hasta aniquilarse quedan explícitamente unificados por la divinidad.

Un pen-último ${ }^{7}$ nivel de abstracción sería pues la forma de la lucha, lucha en la que las diferencias de los contrarios concluyen por anularse. Borges ha repetido que le gusta repetir los mismos asuntos: "Unos pocos argumentos me han hostigado a lo largo del tiempo; soy decididamente monótono.” $(B, 9)$. La metáfora narrativa de la 
lucha ${ }^{8}$ vuelve insistentemente con varios protagonistas: dos conspiradores irlandeses, dos gauchos, dos guerreros sajones, dos teólogos, dos historiadores que copian a dos héroes de la Independencia, dos pintoras, dos compadritos. La lucha puede figurar bajo la forma del sacrificio ritual. Así el sacrificador y la víctima serán el traidor y el héroe, el perseguidor y el perseguido, o las figuras más individualizadas de Judas y Cristo, César y Bruto, Martín Fierro y el moreno, el nazi y el judío, el compadrito y el adolescente que lo traiciona, el jefe revolucionario irlandés y el partidario cobarde. Y aun quedará subrayada esta forma central en algunos cuentos donde los personajes -sin saberlo-repiten esquemas canónicos inmortalizados por entidades más conspicuas: "El evangelio según San Marcos”, donde unos paisanos ferales reactualizan el drama de la Pasión, y "Guayaquil”, donde dos historiadores contemporáneos duplican el enfrentamiento de San Martín y Bolívar (B, 125 y 109).

Junto a la forma simbólica de la lucha o el sacrificio, encontramos en otros relatos la forma de la búsqueda, siempre en ese pen-último nivel de abstracción, según he convenido en llamarlo. Recuérdese que a uno de los héroes de Borges:

También se le ocurrió que los hombres, a lo largo del tiempo, han repetido siempre dos historias: la de un bajel perdido que busca por los mares mediterráneos una isla querida, y la de un dios que se hace crucificar en el Gólgota. $(B, 133)^{9}$

Metáforas narrativas de la búsqueda las encontramos en el héroe que recorre la inmensa geografía de la India en pos de Almotásim, en el tribuno romano que atraviesa las fiebres y los desiertos para encontrar la Ciudad de los Inmortales, en el desconocido de las ruinas circulares que consume los días y las noches en la ensoñación de un hijo, en la imposible empresa de Funes, el memorioso, o en la de Averroes, intérprete de Aristóteles, o en la de quien recorre eternamente la biblioteca de Babel, para hallar el libro que lo justifique. ${ }^{10}$

Sin embargo podría pensarse que ambas fórmulas (búsqueda y lucha-sacrificio) y quizás otras, son en un nivel ulterior metáforas narrativas, o mejor símbolos, de la pluralidad que se resuelve en unidad o del hombre que alcanza la comunión con el absoluto. Tales serían los antagonistas que se identifican con su contrario o con su víctima, los héroes lanzados en pos de un absoluto (la inmortalidad, la divinidad, la captación del universo). El inmortal, después de ser Homero, Rufo, Cartaphilus, es todos y es nadie; Shakespeare es sus múltiples criaturas de ficción pero enfrenta la nada; al mago de Qaholom le llega con la revelación del nombre de Dios, el poder sobre el universo y la simultánea dilución de su yo. Con las fábulas citadas se enlazan también las que conceden el éxtasis bajo la imagen de la unidad que oblitera la diversidad o de la multiplicidad que entrega el infinito liberado de los límites de tiempo y espacio. Basta recordar al hombre a quien se le ofrece el Zahir y el Aleph, la inabarcable empresa de "El Congreso", la vertiginosa memoria de Funes, la biblioteca infinita de Babel o el infinito libro de arena; y además toda la literatura que 
se resume en una palabra según lo proponen “Undr” o “El espejo y la máscara” (LA, 109 y 99$)$.

Lo múltiple y lo uno sería el arquetipo tentador de lo que se vislumbra como otro paso más en el camino de abstracción aludido. Estamos así casi en el límite de unas figuras que, a fuerza de metamorfosearse en los espejos repetidos de incontables relatos, siempre distintos y en esencia los mismos, aspiran a una forma pura y al mismo tiempo están jugando y amenazando con la fascinación de la nada.

Pero no son la nada -me apresuro a aclarar-porque todas ellas existen como formas en la sustancia de una patética aventura humana, con la complejidad que puede tener una aventura del hombre en el universo. Y además porque existen no como una sola y nítida forma, sino como un camino que tiende hacia una forma a través de niveles de abstracción que configuran varios y a menudo elusivos diseños superpuestos. Recordemos que Borges ha dicho de los cuentos de su última época: "No me atrevo a afirmar que son sencillos; no hay en la tierra una sola página, una sola palabra, que lo sea, ya que todas postulan el universo, cuyo notorio atributo es la complejidad" ( $B$, 7-8).

Antes dije que sus ficciones son al mismo tiempo un acontecer humano capaz de conmovernos y un modelo del universo (en realidad del hombre en su intento de entender el universo). Y que el modelo residía en la tensión entre los diversos estratos (incluso el de la historia concreta), y no en uno o mas de los valores simbólicos que podían descifrarse. ¿Y cuál sería el modelo, en sí? Me atrevo a sugerir que es la empresa eterna, siempre fracasada y siempre renovada, de la búsqueda de un modelo. Recuérdese que en “Otro poema de los dones” se dan gracias por la existencia de “...la razón que no cesará de soñar con un plano del laberinto” $(P, 285)$.

Detengámonos por un momento en su memorable definición del hecho estético:

Generalizando el caso anterior, podríamos inferir que todas las formas tienen su virtud en si mismas y no en su "contenido" conjetural. (...] ya Pater, ${ }^{11}$ en 1877 , afirmó que todas las artes aspiran a la condición de la música, que no es otra cosa que forma. La música, los estrados de felicidad, las caras trabajadas por el tiempo, ciertos crepúsculos y ciertos lugares, quieren decirnos algo, o algo dijeron que no hubiéramos debido perder, o están por decir algo; esta inminencia de una revelación, que no se produce, es, quizá, el hecho estético. (OI, 11-12).

Sabemos que la música ${ }^{12}$ no es un arte que sea fundamental en la vida del Borges de carne y hueso. También sabemos que en cambio le ha servido en su obra como metáfora esencial de la temporalidad y de la eterización lograda en la temporalidad. "La música, -ha dicho- la más dócil de las formas del tiempo" $(P, 159)$. Cuando ha querido presentar este símbolo bajo el diseño de un hecho individualizado ha elegido el rasgueo de una guitarra (una milonga, también un tango) y la música de Brahms. Uno de sus últimos poemas aun no recogido en volumen (“A Johannes Brahms”, $L a$ Nación, 2 de noviembre de 1975) le esta dedicado. Lo cierra esta estrofa: 


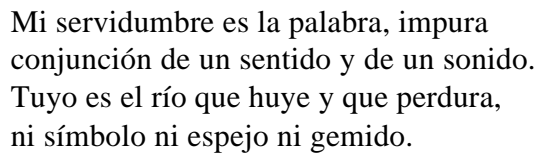

Como dije al principio, el "símbolo" es uno de los símbolos recurrentes en Borges, y alude a la ambigua naturaleza del hombre: su servidumbre y su grandeza. Proclama su miseria, la certidumbre de la imposibilidad de la empresa emprendida por el poeta; porque ni el espejo, ni el gemido, ni el símbolo podrán alcanzar a conformar el misterio del universo y de nuestro destino (traduciendo: ni el arte como mimesis, como expresión, como lenguaje). ${ }^{13}$ Pero no sólo proclama su servidumbre sino también su grandeza: porque el arte construirá otras formas (otros sueños, otros palacios) que tiendan incesantemente, eternamente, a la revelación de ese misterio.

La música es una de las metáforas borgeanas de ese anhelo de absoluto. En los primeros ensayos podía soñar con el lenguaje de Dios o de los ángeles, siguiendo a Santo Tomás, noción que en realidad es la negación del concepto de lenguaje y de signo pues propone la comunicación directa sin intermediarios. ${ }^{14}$ Luego pudo encontrar en la música lo más cercano a esa utopía del lenguaje angélico, liberada de la servidumbre de los signos biplánicos (sonido-sentido). ${ }^{15}$

Las metáforas eternas que establecen relaciones esenciales (rosa, círculo, espejo, río, sueño, ocaso...) renovadas en su “entonación” son una de sus respuestas a esa tiranía. Las ficciones son otra respuesta: en las complejas líneas de una metáfora narrativa dicen otra vez fábulas esenciales con una voz nueva. En ellas atrae la capacidad del artista que repitiendo formas opositivas (los límites del hombre frente a los anhelos del hombre) en constante tensión, A frente a no A, está dando una fórmula más compleja de su destino en una disyunción que es una conjunción: A o no $A=A$ y no A. Permítaseme decirlo así con algebra que le parece a Borges "palacio de precisos cristales" y que en su obra nunca deja de ir unida al fuego, "cuyo fulgor nadie puede mirar sin un asombro antiguo” $(P, 285)$.

Columbia University

ANA MARIA BARRENECHEA

\section{NOTAS}

1 Citamos las otras de Borges por las siguientes ediciones, todas de Buenos Aires, con las siglas indicadas entre paréntesis: El idioma de los argentinos, M. Gleizer, 1928 (Id); El Aleph, Losada, 1949 (A); Otras inquisiciones, Sur, 1952 (OI); y el resto por la colección de Otras completas, Emecé: El hacedor, $1960(H)$; Historia de la eternidad, $1953(E)$; Discusión, 1957 (D); Obra poética ${ }^{9}, 1972$ (P); El informe de Brodie, 1970 (B); El libro de arena, $1975(L A)$.

2 En "La metáfora" ( $E, 69$ ss.) ya insistió sobre la vanidad de la invención de novedades, y también entonces destacó que los modos de variación de las fórmulas esenciales son infinitos: "El primer monumento de las literaturas occidentales, la Ilíada, fue compuesto 
hará tres mil años; es verosímil conjeturar que en ese enorme plazo todas las afinidades íntimas, necesarias (sueño-vida, sueño-muerte, ríos y vidas que trascurren, etc.) fueron advertidas y escritas alguna vez. Ello no significa, naturalmente, que se haya agotado el número de metáforas; los modos de indicar o insinuar estas secretas simpatías de los conceptos resultan, de hecho, ilimitados. Su virtud o flaqueza está en las palabras...” (E, 7374).

3 Véase Ana María Barrenechea, La expresión de la irrealidad en la obra de J. L. B., Buenos Aires, 2da. ed. Paidós, 1967, para algunos símbolos privilegiados: laberintos, espejos, sueños, ocasos, esfera, libro, teatro; para los otros dos puntos; léase esp. el parágrafo "El lenguaje del sentido secreto”, 82-93 y “Actos y vidas simbólicas”, 93-99.

4 Véase A. M. Barrenechea, "Borges y la narración que se autoanaliza”, NRFH. XXIV, 2 (1975), 515-527.

5 Op. cit., 522-526, donde hago un análisis más circunstanciado de su retórica.

${ }_{6}$ En esta aclaración no deja de haber cierto juego de humor muy propio de Borges, como también lo hay en la alusión a Henry James, cercana a las líneas citadas. Pero ello no anula su validez de señal hacia otros estratos de lectura. No deja de ser oportuno recordar que para Borges, H. James esta también asociado a la noción del dibujo oculto en la obra, como autor de The Pattern on the Carpet, aunque no se mencione este relato en "El duelo".

7 Empleo pen-último en el sentido etimológico de 'casi-último', sin postular que deba ser el paso inmediatamente anterior al último, puesto que en la estructura propuesta no existe un nivel definitivo. Hay un camino de abstracciones, pero no una meta fija.

8 Pueden verse otros ejemplos del arquetipo de la lucha, con explícita referencia a la lectura simbólica, en “El indigno” (31), “La intrusa” (15), “Juan Muraña” (72), “Guayaquil” (121), todos tornados de un solo libro (B). Véase tb. el artículo citado en nota 4.

9 Nótese que esta observación sobre las fábulas esenciales no figura en un ensayo sino en una ficción, "El evangelio según San Marcus", y no como opinión del narrador sino como pensamiento interno del héroe que en la historia repite el papel de Cristo, es Cristo, y como tal será sacrificado. Este incidente reitera la situación del personaje de "La espera", entre otros relatos. No sólo produce efectos de espejos enfrentados ("en abismo") sino que tiende a anular distinciones entre simbolizante y simbolizado al intercambiar los elementos constitutivos y la dirección en el hecho semiótico. Desde un punto de vista antropológico todo el que reactúa en un ritual un acontecimiento mítico se identifica con el héroe. Lo característico de Borges es que sus relatos, aunque incorporan arquetipos, se diferencian de la actitud mítica por la conciencia de la distancia que establecen en lector y personajes entre paradigma mítico y acto ritual, entre significado y significante.

10 Téngase bien en claro que no postulo una jerarquía precisa de símbolos y una posición relativa determinada para todos los que figuran en cada uno de los relatos citados. Por ejemplo, no afirmo que en "La biblioteca de Babel” la búsqueda sea el esquema más importante antes de esa elusiva y última meta, y que otros no tratados ahora como el caos, el infinito, etc., sean inferiores a él.

${ }^{11}$ No deja de llamar la atención que Borges, tan alejado de la estética del simbolismo, cite a Walter Pater. También lo recuerda en otro ensayo: "Como Pater, [Mallarmé] sintió que todas las artes propenden a la música, el arte en que la forma es el fondo...” (OI, 81). Quizás lo atrajo su propio interés por los problemas del lenguaje y del signo: es decir, por la relación interna del significante y del significado, y la externa del signo con el referente (bajo los nexos de literatura-realidad, palabra-objeto). La concepción de la música como semiosis 
replantea los problemas del referente y de la biplanidad del signo, aunque ni Pater ni Borges los hayan formulado con esos nombres sino con los tradicionales de fondo y forma, contenido y forma, a los que se agrega en Pater un use no siempre muy preciso de sustancia y forma, y de terra o asunto, al tratar las distintas artes. Pater estuvo influido por ideas de Baudelaire (que luego retomó Mallarmé) y también por el problema de la clasificacién de las artes en Lessing, Laocoonte, IV y XVI. Lessing las dividió en artes del espacio y del tiempo o sea de la simultaneidad y de la sucesión, y sus propuestas fueron reelaboradas por Herbart y Schasler. Para Pater la música era el arte suprema porque cumplía el ideal de suprimir la dualidad sustancia-forma, fondo-forma, mientras las otros artes tendían a ese ideal sin alcanzar por completo la fusión. Cfr. W. Pater, “The School of Giorgione”, en The Renaissance, London, Mac Millan, 1914, esp. 135, 137-139, 149, tb. 150 donde se ve la valoracion del arte por su poder de eternizar el instante fugitivo.

${ }^{12}$ Borges ha citado también la opinión de Schopenhauer sobre las diversas artes, la cual se distingue por poner a la música fuera de la jerarquía de las demás, pues no expresa la idea platónica sino la voluntad misma. No se le aplican las formas del espacio ni del tiempo, sino la sola forma general de la representación. Borges lo recuerda en $D, 44$, por afirmar que la música es “...una tan inmediata objetivación de la voluntad, como el universo...” (subrayado en el original) y concluye que eso "Es postular que la música no precisa del mundo.”

${ }^{13} \mathrm{Si}$ en lugar de estos conceptos tradicionales en crítica literaria, se quiere emplear otros de uso bastante extendido actualmente en semiótica, podría traducirse con los de Peirce: ni el arte como ícono, como índice, o como símbolo. Aunque no figuren en Borges, parecen útiles para establecer y precisar ciertas categorías. Quiero recordar, sin embargo, que en la nomenclatura de Peirce símbolo tiene otro significado que el tradicional en la crítica literaria, utilizado en mi exposición. En la clasificación de los signos que establece según la relación del vehiculo señal con su objeto, ícono es el signo que tiene alguna similaridad con el objeto pero no presupone su existencia (un plano, una foto), índice es el que tiene alguna conexión existencial con el objeto y eso lo hace apropiado para llamar la atención sobre él (el humo con respecto al fuego) y símbolo es el que está relacionado convencionalmente por hábito con su objeto (la mayor parte del léxico en las lenguas naturales). En realidad para Peirce la música es un ícono.

${ }^{14}$ Para el lenguaje de Dios o de los ángeles por comunicación directa, recuérdese: “Como se ve, ni éste [Spinoza] con su metafísica geometrizada, ni aquél [Lulio] con su alfabeto traducible en palabras y éstas en oraciones, consiguió eludir el lenguaje. Ambos alimentaron de él sus sistemas. Solo pueden soslayarlo los ángeles, que conversan por especies inteligibles; es decir por representaciones directas y sin misterio alguno verbal. ¿Y nosotros, los nunca ángeles, los verbales, los que en este bajo, relativo suelo escribimos, los que sotopensamos que ascender a letras de molde es la máxima realidad de las experiencias?” (Id, 26-27). Para el concepto del lenguaje divino como idioma de infinitos signos: OI, 122 y "Funes el memorioso"; para la noción opuesta de que consta de una sola palabra: "Mateo, XXV, 30” ( $P, 159)$, “La escritura del Dios” $(A)$ y “Undr” o “El espejo y la máscara” $(L A)$. Cfr. tb. A. M. Barrenechea libro citado, capítulo sobre el lenguaje, 103-115, esp. 109-111, para los ángeles.

15 En términos precisos, la música no se libera de las convenciones, porque trabaja con códigos (escalas, claves, tonos, intervalos, etc.). Lo que querría indicar Borges en su poema no es sólo la liberación de los signos biplánicos (significante sometido a la existencia del significado) sino también del referente. La música como signo no apuntaría a nada externo a ella misma. 


\section{Borges en Nuestra Biblioteca}

Borges publica un nuevo libro que sugiere un gesto de autodisolución en otro. Se dirá que esto es ya familiar, que la noción de lector-reescritor impregna toda la obra de Borges. Pero el libro de arena supone una repetición acaso distinta. No es -y me refiero, por ahora, al relato que da nombre al volumen de trece cuentos publicado este año ${ }^{1}$ - un testimonio de sumisión a una biblioteca virtual, sino que intuye un libro infinito, un libro atado a su propia discontinuidad de modo que la paginación se metamorfosea para impedir la fijación de un momento de iniciación y otro de final. Un libro que desdice la individualidad de volumen y quiere confundirse con el continuo lingüístico que propone como su soporte; un libro que rehuye su propia materialidad. Este es el Borges que leemos hoy en nuestra biblioteca artificial junto con el Macedonio de Museo de la novela de la Eterna y el Cortázar de Rayuela. El diálogo entre ellos nos permite entrever una multiplicación que, como todas las prolijamente realizadas, acaso culmine en desdecir la impostación de la voz de narradores individuales que impone el texto aislado.

Macedonio veía su novela como la disolución de la diferencia entre autor y lector para alcanzar un estado de vacío privilegiado; las ausencias fundamentales serían la historia (que el radicalmente llamaba tiempo) y sus complementos causales y espaciales. Los libros de Macedonio sin excepción eran, todos, libros de arena. Sin principio, sin final, sin hilación, con páginas intercambiables que sólo en un instante dictatorial y probablemente humorístico, (ver “Al lector salteado”) sugirió férreamente organizado. Pero si Macedonio veía al Museo... como una estructura que en la totalidad de sus efectos y en el análisis de cada una de sus partes debía dar el resultado de vacío, Borges se propone la creación de una imagen que explicita esa condición de infinitud en un juego sutil dentro de un discurso que parece contradecirlo. La imagen de un libro de arena surge dentro de un relato perfectamente lineal. Un vendedor, un intercambio de libros, un escenario y el descubrimiento, por cierto sobrecogedor, de la infinitud del libro.

El lector no se marea leyendo el relato. Por el contrario, el ritmo oral que se ha acentuado cada vez más en la prosa de Borges, lo refiere como quien cuenta un hecho 
cotidiano. El discurso dentro del cual aparece ese libro de arena es su doble antitético. Ordenado. Con principio, medio y fin. Si bien plantea la existencia "real” del libro de arena, su aparición es redefinida por el contexto que lo nombra; su lectura es un hecho "maravilloso" que le sucede a un narrador clasicista. El libro de arena permanece, así, en un nivel hipotético. Pero es precisamente el carácter virtual de su existencia lo que preserva a Borges de los peligros e ingenuidades del vanguardismo literario.

Macedonio, con sus planes y proyectos de una literatura constantemente multiplicada en lectores ayoicos, cae a veces en las trampas de su propia artesanía. El Museo de la novela de la Eterna quiere ser el objeto acabado que exprese la materialidad de la corriente entre lector y autor. ${ }^{2}$ Quiere ser el espacio increado. Y en ese gesto de concreción de la nada llega, a veces, a agotar posibilidades que se pensaban como infinitas. Un libro que efectivamente logre ser siempre promesa, inminencia que lo convierta en su doble, se agota en la formulación de sus condiciones. ${ }^{3}$ Es que Macedonio era un purista. Sus textos sugieren que cada momento de la narración debe ser la nada. La nada no surge necesariamente de un juego intertextual, se produce en cada uno de los fragmentos y el juego que existe entre ellos es de carácter acumulativo. Es una escritura en perpetua desconfianza de los momentos en que puede llegar a convertirse en sus opuestos realistas y naturalistas. $Y$ en ese gesto produce una nada curiosa, naturalistamente descripta, una nada pormenorizada en sus detalles, acumulada y materializada en cada uno de los personajes, en cada uno de los instantes narrativos. Macedonio, por supuesto, pensó en la estructura narrativa como efecto de un juego intertextual y, por eso, escribió esas páginas de "novela en estados”4. Pero es necesario ver que esas páginas operan entre sí y, simultáneamente, dentro de cada uno de los fragmentos. La estructura novelística de Macedonio no admite la heterogeneidad. Es, acaso, el efecto de un discurso novelístico defensivo, cuidadoso de errores de articulación que lo precipiten hacia el arte realista que niega. Su movimiento de descentración (porque el rechazo del argumento no es otra cosa que un intento de dejar de lado la formación de núcleos narrativos que se propongan como centros creadores de ilusiones que permitan la proyección del lector en algo que pueda confundirse con "la vida") puede ser descubierto en un ejercicio analítico de cada una de sus partes. Se trata de una escritura atomística. El humor del absurdo de Macedonio, presente sobre todo en sus Papeles de Recienvenido y teorizado a lo largo de toda su obras, propone un juego que se haga visible en cada frase y es, en ese sentido, el desplazamiento de la concepción ultraísta de la imagen poética a la prosa narrativa.

El Cortázar morelliano de Rayuela participa de esa tendencia macedónica a la descentración. Pero su intención es bien distinta ${ }^{6}$. No pretende crear una estructura narrativa que se contraponga al mundo "real" sino una novela que en el gesto de duplicación que implica la existencia de un "autor” hipotético, con una teoría distinta de la que parece soportar el texto completo reproduzca la calidad de mosaico y dispersión que se ve en la "vida”. No es, como Macedonio, la creación de un universo fantástico que separa del mundo para brindar acceso a otro; es un puente entre los 
referentes extraliterarios y la novela. Pero lo más importante para nuestra lectura en este momento es el punto en que confluyen Macedonio y Cortázar y que esperamos entretejer con Borges.

La descentración de la novela para Rayuela es efecto de una trama cuidadosamente armada. Rayuela es un libro heterogéneo que impide la lectura atomística. Parece brindarse en algún momento como una novela realista y acaso lineal. Sus personajes transcurren en espacios que, tornados individualmente, pueden ser leídos como “realistas". El entretejido que los hace posibles arma un juego en el cual esto se desdice. Las morellianas proponen una estética que en algunos momentos parecen rechazar y, en verdad, terminan planteando otro libro dentro del mismo libro, probablemente realizado en 62, Modelo para armar. En ese sentido son doble antitético de la novela de la cual forman parte. Presentan la inminencia de lo otro, aquello que funciona como agente disolvente de lo que plantea el resto del texto, la condición de su inexistencia, la puesta entre paréntesis de sus presupuestos. Es una escritura desrrealizadora.

La sombra de Macedonio reaparece aquí y probablemente pensaba en esto cuando escribió acerca de la "novela en estados", cuando se refirió a distintas partes de la novela que se leyeran entre sí. Este texto de Cortázar realiza la heterogeneidad que pedía esa teoría de una manera más acentuada que la concreción que Macedonio brindó como realización tentativa de su estética. Porque para que cada una de las partes de la novela mantenga una relación de oblicua lectura con respecto a las otras es necesario ese momento de tensión en el cual se advierte la fisura que separa textos lectores y textos leídos. Los textos atomísticos de Macedonio se han convertido aquí en una trama fiel a las necesidades de la estética, en una novela cuyo efecto final es esa indecisión que ha dado en llamarse hace un tiempo "apertura"”. Como Macedonio, Cortázar trata de construir un trabajo que se mantenga en una relación de aceptación de la estética vanguardista. Hay una violencia contra la forma tradicional de la novela (aunque rechacemos el nombre de "antinovela" que de manera algo sensacionalista se usa para Rayuela) y la intención de crear un objeto que efectúe materialmente el espacio que se propone. El libro mismo con su lectura zigzagueante, sus tableros, sus propuestas que se contradicen propone constantemente momentos que lo duplican, critican y, finalmente, anulan. Es el resultado de una artesanía vanguardista. De algún modo, un objeto sorprendente efecto de una estética de la lucidez pero, también y probablemente de modo más acentuado, de la originalidad. En eso coinciden Macedonio y Cortázar. El autor que pretenden borrar es el perteneciente a la tradición humanista y burguesa que funda la novela realista; la sustitución consiste en la creación de otro supremo jugador que esta vez es capaz de crear universos lúdicos de apariencia sorprendente y original. Se anula el "autor” para quedar metamorfoseado en un juego que lo presenta como término de la corriente entre lector y narrador. Aparente falta de identidades. Máscaras que ocultan a un “autor” constructor de su individualidad por medio del mismo juego que lo descubre. Macedonio rechazó muchas (la idea de que 
sus textos eran "propios”) pero la originalidad que rechazaba lo llevaba a pensar en un continuo literario cuya creación lo devolvía, incesante, a esa componente romántica que existió en tantos ultraístas.

Después de finalizar el trato con el vendedor, el narrador y personaje del "Libro de arena” examina el libro y advierte que es verdaderamente infinito. Su vida se transforma ante el asombro y sobrecogimiento que provoca el volumen:

Prisionero del Libro, casi no me asomaba a la calle. Examiné con una lupa el gastado lomo y las tapas, y rechace la posibilidad de algún artificio. Comprobé que las pequeñas ilustraciones distaban dos mil páginas una de otra. Las fui anotando en una libreta alfabética, que no tarde en llenar. Nunca se repitieron. De noche, en los escasos intervalos que me concedía el insomnio, soñaba con el libro. ${ }^{8}$ (p. 175)

Se trata de un libro único, original. Acaso el logro de una fantasía vanguardista. Y el narrador, al leerlo, realiza ese tropezón conciencial que requería Macedonio, advierte que él mismo puede ser un reflejo especular del volumen:

Declinaba el verano, y comprendí que el libro era monstruoso. De nada me sirvió considerar que no menos monstruoso era yo, que lo percibía con ojos y lo palpaba con diez dedos de uñas. (p. 175)

La primera decisión del narrador es quemar el libro, suprimirlo. Pero lo detiene el miedo de que el fuego de un libro infinito acabe con el universo. Queda perderlo. Y eso hace el narrador,

Antes de jubilarme trabajaba en la Biblioteca Nacional, que guarda novecientos mil libros; se que a mano derecha del vestíbulo una escalera curva se hunde en el sótano, donde están los periódicos y los mapas. Aproveche un descuido de los empleados para perder El Libro de Arena en uno de los húmedos anaqueles. Traté de no fijarme a qué altura ni a que distancia de la puerta.

Siento un poco de alivio, pero no quiero ni pasar por la calle México. (p. 176)

Como aquella carta de Poe, el libro queda escondido en la superficie, reprimido por la Biblioteca, perdido, pero guardado y existente. El discurso del narrador es doble antitético de la imagen de ese libro; la reprime como la historia que culmina con su abandono en un estante de la biblioteca. Es un acto de violencia contra la imagen que plantea como el soporte para la circulación que construye su discurso. Esa represión conserva la posibilidad del libro de arena al mismo tiempo que la define críticamente.

No es demasiado aventurado conjeturar que la literatura de Borges guarda una relación similarmente oblicua con el vanguardismo de Macedonio y Cortázar. Su clasicismo adquiere densidad por la resistencia de ese tipo de textos. Pero, sin 
embargo, los contiene. Es como si reapareciera el proyecto, esta vez con mayor nivel de complejidad, en un discurso que lo asume como uno solo de sus niveles, en coexistencia con otro que prolijamente lo niega.

La aparente simplicidad y linealidad del discurso oculta la relectura de otras posibilidades, la promesa de la realización de un libro infinito, mosaico, inagotable. A diferencia de Macedonio y sus seguidores más obvios que intentan la construcción artesanal de tal libro, Borges lo señala como inminencia, lo apunta como virtual pero también lo sacraliza al negarse otra ejemplificación que la de describirlo en un relato armado linealmente.

Muchas veces se han leído con cierta perplejidad los manifiestos ultraístas de Borges y se ha pensado que esa imagen a la vez inédita y reveladora que prometían había sido abandonada en la literatura posterior del autor. Sin embargo, Borges tiene una voz en el diálogo que surge de esa problemática. Su rechazo de la mera experimentación lo lleva a un clasicismo y a un ritmo oral que lo salva de algunas ingenuidades. Pero sus narraciones adquieren mayor densidad cuando se advierte lo que reprimen, cuando notamos que su discurso ocurre en una biblioteca que le presenta, constantemente, la posibilidad de sus dobles fieles y antitéticos a la vez. La negativa de quemar el libro en "El libro de Arena" debe originar una lectura igualmente no deseosa de olvidarlo, curiosa de los modos en los cuales los textos de Borges se reintegran al contexto que niegan. El ritmo contenido de los otras relatos del libro sugiere posibilidades de leer sus aparentes silencios. "El espejo y la máscara” revela una construcción igualmente pecaminosa de una Belleza que debe ser “olvidada.” El poeta que descubre las palabras del poema conocedor de la Belleza debe matarse. Pero el Rey que se lo ordenó sigue vivo, aunque convertido en mendigo. El disco de Odín en el relato "El disco”, igualmente sorprendente por ser el único objeto de la Tierra que tiene un sólo lado, es igualmente “perdido”. La inminencia de un descubrimiento de algo maravilloso y único que al realizarse debe olvidarse es ubicua en este último libro de Borges. Los relatos piden una lectura de sus discursos que indique el entretejido en el cual la imagen es reprimida. Las limitaciones de esta exposición sólo han permitido señalarla para “El libro de arena” que es, tal vez, un modelo reducido de las duplicaciones que existen en los demás.

\section{NOTAS}

1 Jorge Luis Borges, El libro de arena (Buenos Aires: Emecé, 1975).

2 La literatura de Macedonio se piensa a sí misma como, infinita, pero existe en ella la tensión por lograr un objeto acabado que tenga una relación especular con el infinito.

3 El carácter inacabado de un libro que se brinda sólo como promesa queda como, una propuesta virtual en muchos de los escritos de Macedonio, redefinida por esa realidad implacable del volumen encerrado en tapas. 
4 Ver su Museo de la Novela de la Eterna.

5 Ver su "Para una teoría de la humorística", en Papeles de Recienvenido (Buenos Aires: Losada, 1944).

6 No me refiero a la intención del autor, sino a la tensión que existe en el texto mismo por alcanzar cierto nivel de significación; una tensión que surge de un juego intertextual.

7 Lucille Kerr ha mostrado el carácter ilusorio del carácter de "apertura".

8 La numeración pertenece a la edición citada. 


\section{Borges y la "Palabra” del Universo}

Desde principios del siglo XIX (a raíz del surgimiento y auge de las teorías románticas de la imaginación creadora) hasta nuestros días (Seferis, Cernuda, el “ojo pineal” de Cortázar incluso) pocas metáforas habrán quizá alcanzado en su significación diversa la fortuna de aquélla, de tradición neoplatónica y que conviene a la mente perceptora, del ojo proyectando luz como una lámpara para penetrar la realidad". "Si viéramos realmente el universo, tal vez lo entenderíamos”2. Porque no se ve nada sin que esté constituido como objeto de conocimiento. Para hacerse perceptible de verdad, el universo tiene que dejar de ser el agregado de "formas insensatas", de "cosas incompatibles que sólo por razón de coexistir"3llevan su nombre, y convertirse en un todo orgánico. Percibir ese todo orgánico exige penetrar los esquemas que lo ordenan, las íntimas leyes que lo rigen, la teleología que lo sostiene y da cohesión; en otras palabras, el sentido último que nos lo haga aparecer como un cosmos y no como un caos o un laberinto: “Al principio se creyó que Tlön era un mero caos, una irresponsable licencia de la imaginación; ahora se sabe que es un cosmos y las íntimas leyes que lo rigen han sido formuladas"4. Sin ser capaces de descifrar su secreta morfología, nunca podremos "ver" el universo; “ver” y "entender” se implican mutuamente: "Para ver una cosa hay que comprenderla" 5 . El universo es todavía en rigor inconcebible, sigue siendo "ese objeto secreto y conjetural”6 porque ningún hombre ha aprendido a mirarlo en plenitud, lo cual equivaldría a entenderlo, es decir, a saberlo descifrar; y esto a su vez supondría estar en posesión de la cifra que lo explica y nos lo abre y en virtud de la cual también fue constituido, exigiendo del hombre una inteligencia absoluta, análoga a la de su creador: "falta conjeturar las palabras, las definiciones, las etimologías, las sinonimias, del secreto diccionario de Dios”7. Empresa que parece de antemano condenada al fracaso porque encierra una petición de principio: es imposible aplicar métodos adecuados al objeto de conocimiento cuando éste (el universo que los determinaría) no existe sino como término del acto cognitivo. Para dar con la cifra que nos permitiese descifrar el universo tendríamos que deducir previamente de él (todavía informe) y como mera hipótesis de trabajo esa 
misma cifra; tendríamos que cifrarlo, por tanto. El medio y el fin se identifican: "no hay clasificación del universo que no sea arbitraria y conjetural. La razón es muy simple: no sabemos que cosa es el universo" ". Con todo, "la imposibilidad de penetrar el esquema divino del universo no puede, sin embargo, disuadirnos de planear esquemas humanos, aunque nos conste que éstos son provisorios" ${ }^{\text {. }}$. En la búsqueda de un mapa del laberinto o modelo homológico que nos haga inteligible (visible) el universo hay que correr el riesgo de fracasar y quedarse en simples esquemas aproximativos o extrínsecos a la medida de nuestras fuerzas que, al ser aplicados, nos lo sigan ocultando, nos devuelvan su sinsentido aparente volviéndonoslo definitivamente incomprensible: quizá el universo que conformamos como objeto no sea más que "un error o una ficción de nuestro conocimiento parcial” ${ }^{10}$ : Borges, ha escrito Matamoro, es "un racionalista ortodoxo, un convencido de que el pensamiento humano es incompatible con la sustancia de lo real, y de que el pensamiento sólo puede conocer al pensamiento, y lo real es incognoscible" ${ }^{11}$.

A lo largo de toda la obra de Borges no dejan de oponerse dos modos de conocimiento: el conocimiento mediante las formas del tiempo, el espacio y la causalidad (es decir, las formas que vienen dadas por lo que Schopenhauer llama el “principio de razón suficiente”), y el conocimiento mediante las ideas eternas. El conocimiento mediante las formas sujetas al principio de razón suficiente corresponde al individuo. Este modo de conocimiento resulta limitado e inferior respecto al conocimiento por medio de las ideas eternas, que dejan de ser pura objetividad al diversificarse a través de las determinaciones del principio de razón suficiente dando así lugar a las cosas individuales o particulares. Al individuo no le es dado percibir las ideas eternas u objetos en sí, sino en sus aspectos parciales tal como se le manifiestan en los objetos individuales, que poseen tan sólo una existencia relativa: su existir se reduce al hecho de ocupar una determinada posición en el espacio, el tiempo y la cadena causal. En el prólogo de 1953 a Historia de la eternidad Borges rectifica su anterior (1936) caracterización de las ideas platónicas: "No se como pude comparar a ‘inmóviles piezas de museo’ las formas de Platón y como no sentí, leyendo a Escoto Erigena y a Schopenhauer, que éstas son vivas, poderosas y orgánicas” ${ }^{12}$. Las nuevas lecturas le han llevado a desplazar las ideas eternas del "cielo anterior de la doctrina/del griego"13. Platón y Plotino conciben un “cielo anterior”, realidad puramente inteligible compuesta de formas eternas en contraste con el mundo material y sucesivo que es copia degradada de aquel; Borges llega a superar tal dualidad. Y sigue a Schopenhauer en la manera de entender las ideas eternas o platónicas: su modo de existencia es el de una figura inmortal que se mantuviera mediante la infinita reposición de los individuas o de las cosas cuya generación y muerte (de ahí que Borges matice y prefiera el adjetivo “inmortales” a “eternas”) la constituyen:

$\mathrm{Y}$ ya que las ideas

no son eternas como el mármol

sino inmortales como un bosque o un río. ${ }^{14}$ 
La figura sería el puro objeto en sí, la realidad permanente e inexhaustible por participación de la cual los objetos particulares, que componen su despliegue en las tres formas determinadas por el principio de razón suficiente, alcanzan existencia. Los objetos particulares, reducidos a un "status" puramente relacional, montan, sostenidos por los "instrumentos mágicos del alma” (espacio, tiempo y causalidad) la ilusión de la realidad visible:

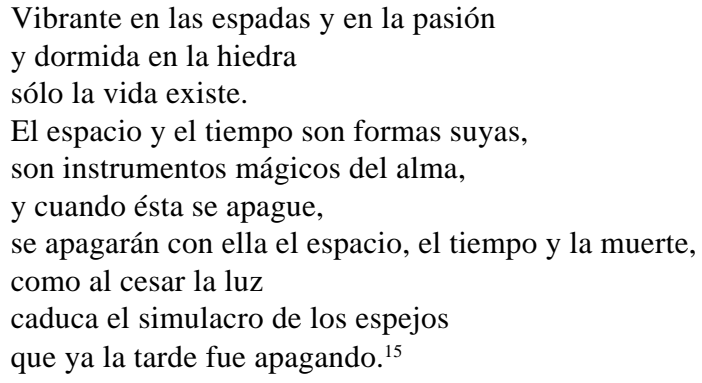

De estas formas propias del conocimiento individual el tiempo puede pasar por el prototipo: "todo lo que es en el tiempo es también no-ser, pues tiempo es sólo aquello mediante lo cual determinaciones encontradas pueden pertenecer a la misma cosa; así que todo fenómeno situado en el tiempo en parte no es, ya que lo que separa su principio de su fin es sólo tiempo, que es por esencia algo huidizo, inconstante y relativo que aquí llamamos duración”"16. La duración o tiempo sucesivo, atributo de lo fenoménico, sirve a Borges para denunciar la existencia fantasmal de los objetos individuales, de las cosas concretas. "El universo ideal a que nos convida Plotino es menos estudioso de variedad que de plenitud; es un repertorio selecto, que no tolera la repetición y el pleonasmo" ${ }^{17}$. En ser consciente de la identidad de los momentos sólo en apariencia repetidos (y de lo percibido en esos mismos momentos, por tanto) consiste la intuición decisiva que le basta a Borges "para desbaratar y confundir la serie del tiempo" ${ }^{18}$. Las relaciones de tipo ascendente que ligan a sus repetidos y sucesivas manifestaciones fenoménicas con los arquetipos de los que son revelaciones parciales permiten deslindar a unas cuantas formas esenciales de lo que constituye su residuo: la múltiple "prolijidad de lo real”, abocada al cambio y la desintegración, que el simulacro del tiempo monta en su seno al discurrir horizontal. Para dar cuenta de la presión que la multiplicidad de lo real ejerce sobre el individuo perceptor Borges extiende la metáfora de la llegada de la noche, que en Fervor de Buenos Aires era liberadora con sus tinieblas de la ficción de lo visible. Es ahora el insomnio quien en "Funes el memorioso" y en el poema del mismo nombre de El otro, el mismo obliga a pesar de la falta de luz a seguir percibiendo "en espantosa vigilia” la realidad esencial alterada en la infinita diversificación que le imponen las formas imperfectas de 
conocimiento del tiempo y del espacio. Por eso en Elogio de la sombra Borges canta a la ceguera, el Demócrito que le ha arrancado los ojos que con las "demasiadas cosas" le distraían de las pocas y esenciales que una vez y otra han regresado en su vida y que ahora sin ellos, al borde de la autorrevelación, en una penumbra "que se parece a la eternidad" por fin puede ver: "la vida es demasiado pobre para no ser también inmortal" 19 . Antes que de "pobreza" convendría hablar de "esencialidad", "ausencia de pleonasmo", el atributo que conviene a la quididad del objeto independiente de las formas del principio de razón suficiente, las cuales, al desplegarlo en la relatividad de un antes y un después, un aquí y un allá, de antecedentes y consecuentes, rompen su compacidad, confiriéndole una existencia fenoménica. De ahí que a Borges le obsesione la compresión. La falacia del conocimiento individual puede cegamos hasta el punto de hacer concebir una eternidad a su modelo: pura agregación mecánica de todos los momentos del pasado, el presente y el porvenir en concatenación causal que, junto con las circunstancias espaciales en que están imbricados, formasen una red infinita de conexiones de naturaleza puramente relacional, sin términos positivos:

Creo esta noche en la terrible inmortalidad: ningún hombre ha muerto en el tiempo, ninguna mujer, ningún muerto, porque esta inevitable realidad de fierro y barro tiene que atravesar la indiferencia de cuantos están dormidos o muertos -aunque se oculten en la corrupción y en los siglosy condenarlos a vigilia espantosa. ${ }^{20}$

Inmortalidad, o bien, eternidad por acumulación sucesiva que correspondería al contenido de una memoria perfecta (no selectiva) porque precisamente la memoria es uno de esos modelos (el absurdo mapa de Royce o la memoria de Funes, "vaciadero de basuras”, por ejemplo) que empleamos para apresar la realidad esencial, pero que jamás nos la revelan, nos la hacen "ver" tal como es, sino que nos devuelven reflejada la inteligibilidad de la apariencia fenoménica que compone su residuo:

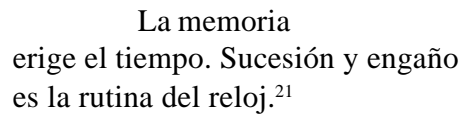

El verdadero e "inconcebible" universo, "ese objeto secreto y conjetural" que integran las ideas eternas o formas esenciales podría describirse negativamente como el resultado de comprimir el infinito tiempo sucesivo en un Nunc-stans, el infinito espacio en un Hic-stans y la infinita concatenación de hechos en uno sólo sin que ello supusiese empobrecimiento ${ }^{22}$ : paradójicamente la unidad y compacidad dejarían de 
ser incompatibles con la multiplicidad y la expansión; la inmediatez y la simultaneidad con la progresión, y la implicación con el despliegue.

En “Undr”, el relato (más bien parábola) de El libro de arena, el islandés Ulf Sigurdarsson, de estirpe de “skalds”, peregrina a la tierra de los urnos sólo para saber que la poesía de éstos consta de una sóla palabra. Una composición laudatoria en la que luce una maestría heredada a través de generaciones le abre las puertas de la corte, y en presencia del rey logra oir de boca de su poeta Bjorni Thorkelsson el ansiado canto de una sola palabra, el cual le parece una incomprensible sucesión de acordes monótonos “o, mejor dicho, infinitos”. Ante su extrañeza y desilusión, alguien le consuela: “Ahora no quiere decir nada”. El cantor real declara: “Ahora no definimos cada hecho que enciende nuestro canto; lo ciframos en una sola palabra que es la Palabra”. En la obra de Borges recurre este tipo de parábolas ("El espejo y la máscara" en El libro de arena; "Parábola del palacio" en El hacedor) protagonizadas por un monarca que pone su reino laberíntico con todas sus maravillas a disposición de un poeta con el encargo de que lo encierre en un poema (el Poema) que constara generalmente de una sola línea o una sola palabra.

Quizá se pudieran aplicar al mismo Borges las palabras que en el ensayo "Del culto de los libros” dedica a Francis Bacon y su empleo de la metáfora de la escritura: "Bacon se proponía mucho más que hacer una metáfora; opinaba que el mundo era reducible a formas esenciales (temperaturas, densidades, pesos, colores), que integraban, en número limitado, un 'abecedarium naturae’ o serie de las letras con que se escribe el texto universal”23. El problema justamente estriba en poder articular el universo por medio de esquemas lingüísticos que correspondan a las unidades con que está escrito; de lo contrario nuestra escritura no pasará de ser una mera metáfora aproximativa. Como ha señalado Didier Anzieu, la adquisición de una cifra que nos permita apresar el sentido último de la biblioteca de Babel (el universo) queda de antemano condenada al fracaso porque "la loi combinatoire qui préside à la composition des livres est celle du code phonologique: les livres réalisent toutes les combinations possibles des vingt-cinq signes verbaux fondamentaux"24, combinaciones que son prácticamente infinitas. El código fonológico está privado de dimensión semántica: los fonemas, unidades de la segunda articulación del lenguaje, por sí mismos nada significan y esto les faculta a combinarse sin trabas y producir significados ilimitadamente; al igual que la memoria de Funes, el mapa de Royce o el monstruoso poema de Danieri en “El Aleph”, el código fonológico no entrega la clave sino la incoherencia del universo fenoménico. No mucho más felices resultan los intentos de John Wilkins o el mismo Francis Bacon de analizar el universo por medio del lenguaje. Borges ha escrito que, según Coleridge, “todos los hombres nacen aristotélicos o platónicos. Los últimos sienten que las clases, los órdenes y los géneros son realidades; los primeros, que son generalizaciones; para estos, el lenguaje no es otra cosa que un aproximativo juego de símbolos; para aquéllos es el mapa del universo”25. Ni Wilkins ni Bacon consiguen articular la realidad como estructura semántica. Las 
clasificaciones que Wilkins se ha impuesto para analizar lingüísticamente el universo no son menos arbitrarias que las naturales "(temperaturas, densidades, pesos, colores)" que Bacon adopta. Según Schopenhauer, conocer mediante las formas esenciales del universo o ideas eternas implica por parte del sujeto cognoscente independizarse de las formas del alma (sujetas al principio de razón suficiente) que constituyen el modo de conocimiento propio del individuo; implica, por tanto, dejar de ser un individuo para adecuarse a la naturaleza absoluta del objeto, confundiéndose en él, haciéndose "sujeto puro de conocimiento" libre de determinaciones temporales, espaciales y causales: pura objetividad perceptora. Escribir el universo es tarea que postula una mente absoluta: “¿Qué tipo de sentencia (me pregunté) construirá una mente absoluta?”26. Dicha escritura tendría que estar en consonancia con la paradoja del universo, cuya infinita plenitud no está reñida con la parvedad propia de la compresión y compacidad máximas que lo erigen en absoluto: “Consideré que en el lenguaje de un dios toda palabra enunciaría esa infinita concatenación de los hechos, y no de un modo implícito, sino explícito, y no de un modo progresivo, sino inmediato. Con el tiempo, la noción de una sentencia divina me pareció pueril o blasfematoria. Un dios, reflexioné, sólo debe decir una palabra y en esa palabra la plenitud. Ninguna voz articulada por él puede ser inferior al universo o menos que la suma del tiempo. Sombras o simulacros de esa voz que equivale a un lenguaje y a cuanto puede comprender un lenguaje son las ambiciosas y pobres voces humanas, 'todo', 'mundo universo'”27. Borges ha apuntado que quizá el mundo visible se dé entero en cada representación: cualquier cosa puede hacer de microcosmos y reflejar el universo entero a la manera de un espejo simbólico. Por encerrar (y confundirse con) el universo, esa escritura de una palabra única sería su cifra: la palabra del universo, realidad absoluta donde la cifra y lo cifrado se confunden.

Escribir el universo implica marcarse una meta inalcanzable. Su texto es un absoluto que postula una mente absoluta, pero ha de ser necesariamente abordado en el tiempo mediante aproximaciones sucesivas por individuos que se valen de un lenguaje también sucesivo: "la historia universal es una Escritura sagrada que desciframos y escribimos inciertamente" ${ }^{28} \mathrm{o}$, en palabras de Shelley (A Defence of Poetry, 1821) que Borges cita: "todos los poemas del pasado, del presente y del porvenir, son episodios o fragmentos de un sólo poema infinito, erigido por todos los poetas del orbe" 29 . Ante la desproporción entre la magnitud de la tarea y las limitaciones inherentes a su condición de individuo, el poeta trata de articular ese objeto absoluto en subdivisiones parciales que se lo hagan accesible. En el Cratilo se define al nombre como instrumento que desentraña y revela la realidad. Platón, a diferencia del bibliotecario de Babel, concibe a las unidades mínimas correspondientes a la segunda articulación del lenguaje (que él denomina "sonidos elementales” y "letras") dotadas de valor significativo. Cada fonema responde a alguna cualidad sensible $\mathrm{o}$ aspecto de la realidad; al articularse en silabas, confieren a los nombres la propiedad de ser adecuados a las cosas: 


\begin{abstract}
Si (como el griego afirma en el Cratilo el nombre es arquetipo de la cosa, en las letras de "rosa" esta la rosa y todo el Nilo en la palabra "Nilo", ${ }^{30}$
\end{abstract}

Pero el nombre a través del significado o concepto genérico (el "lekton” de los estoicos) no retiene la cosa particular o individual sino su idea eterna: "el nombre es arquetipo de la cosa”. El nombre no está motivado del lado de la superficie ilusoria de la apariencia fenoménica que monta el conocimiento individual con la ayuda de las formas del principio de razón suficiente, sino del lado de las ideas eternas, de los arquetipos. Por eso, nombrar, enunciar, enumerar equivale a hacer uso del nombre con el fin de sacar a luz la realidad gracias a la "rectitud de denominación” que lo adecúa a la idea o arquetipo que en él se manifiesta; el lenguaje, garantía de verdad, adquiere (como ha señalado Cassirer ${ }^{31}$ ) un valor metafísico: funciona como instrumento de conocimiento enseñándonos a ver el universo.

De acuerdo con la caracterización anterior de Coleridge que divide a los hombres en platónicos o aristotélicos según su diferente manera de relacionar el lenguaje con la realidad, habría que situar a Borges entre los primeros, los que conciben el lenguaje como mapa del universo. Los platónicos "sienten que las clases, los órdenes y los géneros son realidades”. Si una mente absoluta podría articular el universo por medio de la escritura de una sola palabra absoluta, el individuo que es el poeta cuenta con los nombres que, al manifestar la realidad de las ideas eternas, le ordenan el universo paradigmáticamente, a contrapelo de la relatividad temporal en que se presenta el mundo fenoménico determinado por las formas del principio de razón suficiente: “Consideré que aun en los lenguajes humanos no hay proposición que no implique el universo entero; decir 'el tigre’ es decir los tigres que lo engendraron, los ciervos y tortugas que devoró, el pasto de que se alimentaron los ciervos, la tierra que fue madre del pasto, el cielo que dio luz a la tierra" ${ }^{2}$. Dibujar el mapa del universo es la "aventura indefinida" que aguarda a todo poeta y que hace peregrinar interminablemente a Ulf Sigurdarsson en busca del universo o, mejor dicho, de la palabra que lo cifre. Este arquetipo del universo hay que imaginarlo en el sentido schopenhaueriano en que Borges interpreta a las ideas eternas: no "inmóviles piezas de museo", sino "vivas, poderosas y orgánicas”. Al contar la historia de sus diversas maneras de afrontar como poeta el oficio de cambiar la luna en palabras, escribe:

Sé que entre todas las palabras, una hay para recordarla o figurarla.

El secreto, a mi ver, está en usarla

con humildad. Es la palabra "luna”. ${ }^{33}$

La enumeración (el simple acto de usar el nombre que a cada cosa le corresponde como arquetipo) tiende a anular la cadena sintagmática, que se desenvuelve en el 
tiempo: "Es verosímil que en la insinuación de lo eterno esté la causa del agrado especial que las enumeraciones procuran" ${ }^{34}$. Borges complementa con la ayuda de puntos de vista tornados de Whitehead su lectura schopenhaueriana de las ideas platónicas: "Sé que [el todo armónico de la obra de Whitehead] de algún modo comprende las formas universales de Platón, lo que siempre es grave. Esas formas (que Whitehead denomina 'objetos eternos') van entrando en el tiempo y en el espacio; sus combinados y continuos ingresos determinan la realidad"35. El mapa del universo es una figura intemporal e infinita dibujada mediante la repetición sucesiva de infinitos actos de nominación que nunca la agotan; cuenta como su "reino de la posibilidad" (Whitehead) porque a través de ellos los objetos eternos fluyen desde el futuro a ingresar en el espacio y el tiempo:

\author{
Acaso le ha llegado \\ del porvenir y de su horror sagrado \\ un rumor de remotos ruiseñores. \\ -Habrá sentido que no estaba solo \\ y que el arcano, el increíble Apolo \\ le había revelado un arquetipo, \\ un ávido cristal que apresaría \\ cuanto la noche cierra o abre el día ...?36
}

Así, cada poeta (y cada lector también) contribuye al dibujo de una figura posible que le parece a él por muy poco no puede ver acabada y que es el término siempre aplazado de la "aventura indefinida": el hecho estético reside para Borges en la inminencia de esa revelación que, al no producirse nunca, sigue desencadenando el infinito proceso de desciframiento (escrituras y lecturas) del universo. En la palabraarquetipo del universo (la "palabra") se darían las condiciones que, según Borges, Croce (defensor de la identidad de lo estético y lo expresivo) atribuye a las formas: ser pura expresión de sí mismas y no de un "contenido conjetural”37. La palabra del universo (igual que los nombres-arquetipo no doblan a las cosas) no sería un símbolo arbitrario o doble agregado al universo por imitación (el símbolo aproximativo que el nombre era para los aristotélicos), sino el propio universo en cuanto símbolo motivado de sí mismo, es decir, "un symbole où le signifiant coinciderait exactement avec le signifie" ${ }^{38}$. Sería la autorrevelación del universo que se expresase a si mismo dejándosenos "ver".

El arte del poeta es eterno porque la tarea infinita de nombrar una y otra vez aniquila en virtud de la identidad de lo repetido la serie sucesiva del tiempo en que se lleva a cabo:

El arte es esa Itaca

de verde eternidad, no de prodigios.

También es como el río interminable

que pasa y queda ... ${ }^{39}$ 
Borges repudia los "laboriosas nombres" (todo tipo de figuras o artificios retóricos, pero, sobre todo, la metáfora) como un mal uso del lenguaje, porque el poeta que las emplea toma la "palabra esencial” (los nombres que convienen a las cosas por motivación o ese puñado de "metáforas eternas” que, al responder a semejanzas verificables en la realidad, funcionan como verdaderos nombres) y en ella desliga al significante del arquetipo correspondiente del paradigma (que constituye su significado) para vincularlo de manera convencional (respondiendo quizá a la tradición, a una moda literaria o a simple prurito personal de innovar o asombrar) al significante de una nueva palabra previo abandono del significado de ésta. El poeta (es de lo que Borges acusa a los ultraístas) cree haberse portado como un primer Adán que diese nombre a las cosas, cuando lo que ha hecho en realidad ha sido convertir a una palabra motivada, pura expresión, donde significado y significante coinciden por completo, en un mero objeto verbal compuesto arbitrariamente de dos significantes distintos, sin ascendiente, pues, alguno, sobre la realidad: doble o símbolo aproximativo, definición innecesaria que suplanta a la palabra esencial y verdadera: tautología. Por eso Bjorni Thorkelsson le dice a Ulf Sigurdarsson que ya no se trata de definir las cosas, sino de cifrarlas.

En su autonomización del significante, las “palabras laboriosas" tienden a montar la ilusión del tiempo sucesivo en el arte de la poesía porque su uso contribuye a crear un sistema de referencias de significante a significante que va conformando una fantasmal cadena sintagmática constituida por “dobles” de las ideas eternas los cuales enmascaran su verdadera condición de "variaciones circunstanciales” respecto de ellas. Sólo entre “escaldos”, poetas barrocos, simbolistas o ultraístas, que a los ojos de Borges representan toda una concepción de la poesía que descansa en el goce de la palabra "liberada", tiene sentido hablar de cuestiones de historia literaria tales como “metáforas nuevas”, “arte de prodigios”, “asombrar”, “escuelas”, “tradición”, “oficio”, “innovación”, “vanguardia” o “retaguardia”. Presos en esa engañosa y vana red verbal de significantes, ninguno de ellos supo hacer uso del arte de verde eternidad que, igual que un mapa, les revelara el verdadero rostro (también el suyo propio) de algo muy viejo, como la Itaca de “Arte Poética”, pero nunca visto:

¿Qué habrá sentido al contemplar de frente los Arquetipos y los Esplendores? Quizá lloró y se dijo: Vanamente busqué alimento en sombras y en errores.

¿Qué sucedió cuando el inexorable sol de Dios, la Verdad, mostró su fuego? ¿Quizá la luz de Dios lo dejó ciego en mitad de la gloria interminable. ${ }^{40}$ 
Ulf Sigurdasson se olvida de su heredada maestría en "kennigar" y se pone a recorrer el universo; sólo entonces, cuando reconoce en ellos su propia experiencia y cada una de las cosas que ha visto, los “monótonos e infinitos” acordes que componen la poesía de una sola palabra de los urnos le dicen algo.

\section{JOSE MUNOZ MILLANES}

\section{NOTAS}

1 M. H. Abrams, The Mirror and the Lamp (New York: Oxford University Press, 1953), pp. 58-63.

2 Jorge Luis Borges, El libro de arena (Buenos Aires- Madrid: Ultramar- Emecé, 1975), p. 76.

3 Borges, El libro de arena, pp. 68-69.

4 Jorge Luis Borges, Obras completas (Buenos Aires: Emecé Editores, 1974), p. 435.

5 Borges, El libro de arena, p. 75.

6 Borges, Obras completas, p. 626.

7 Borges, OC, p. 708.

8 Borges, OC, p. 708.

9 OC, p. 708.

10 OC, p. 442.

${ }^{11}$ Blas Matamoro, Jorge Luis Borges o el juego transcendente (Buenos Aires: A. Peña Lilloo editor, 1971), p. 87.

${ }^{12}$ OC, p. 351.

${ }^{13}$ OC, p. 818.

14 OC, p. 38.

15 OC, p. 18.

${ }^{16}$ Traducido de Schopenhauer, Selections of The World as Will and Idea (New York: Charles Scribner's Sons, 1928), p. 97.

${ }_{17}$ OC, p. 355.

${ }^{18}$ OC, p. 763.

${ }^{19}$ OC, p. 367.

${ }^{20}$ OC, p. 860.

${ }^{21}$ OC, p. 917.

${ }^{22}$ OC, pp. 597-8, 617, 625.

${ }^{23}$ OC, pp. 715-6.

${ }^{24}$ Didier Anzieu, "Le corps et le code dans les contes de Borges”, Nouveile Revue de Psychanalyse, No. 3 (Lieux du corps). Printemps, 1971.

${ }^{25}$ OC, p. 718.

${ }^{26}$ OC, p. 597.

${ }^{27}$ OC, pp. 597-98.

${ }^{28}$ OC, p. 716.

${ }^{29}$ OC, p. 639.

${ }^{30}$ Platon, Oeuvres complètes, traduction nouvelle et notes par Léon Robin (Paris: Bibliothèque de la Pléiade, 1959), p. 619, 387b. Borges, OC, p. 885. 


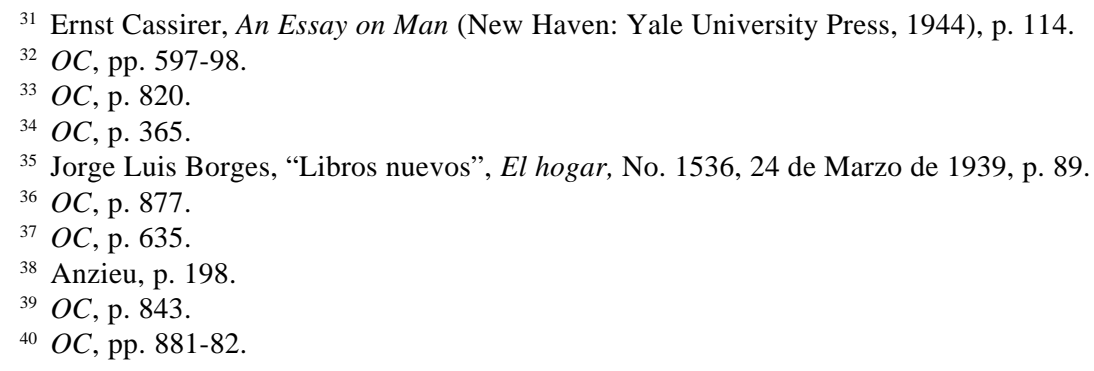




\section{“Everness”: Una Clave para el Mundo Borgiano}

El aspecto más comentado de la obra de Borges quizás haya sido el que se refiere a su naturaleza metafísica. La noción de que la vida es un sueño, axiomática en el mundo ficticio de Borges, y sus corolarios del tiempo cíclico y la vida arquetípica, ya son observaciones por demás obvias en la crítica borgiana. La base de estas nociones es, por supuesto, el idealismo filosófico, y, más precisamente, la aserción de Berkeley sobre la naturaleza de la realidad objetiva: su esse es percipi (OI, 238). ${ }^{1}$ Ya en 1922 (en “La naderia de la personalidad”, I, 84) Borges había declarado que esta filosofía formaría la base de su literatura. Aunque la fuente y las generalidades de la metafísica borgiana no son nada misteriosas, hay sin embargo detalles que deben ser aclarados, como, por ejemplo, la relación entre la metafísica de Borges y su sistema de símbolos.

Entre los símbolos más conocidos de Borges se encuentran el laberinto y el espejo. Emir Rodríguez Monegal, quien ha señalado su frecuencia e importancia, también muestra algo de la extensión de su interpretación. ${ }^{2}$ En cuanto al laberinto simbólico de Borges, cita una multitud de valores tradicionales, entre ellos los de “prisión”, “un caos ordenado por la inteligencia humana”, “el destino humano o la voluntad inescrutable de Dios" y "el misterio de la obra de arte.” Añade las posibilidades mitológicas - “pasaje de la vida a través de la muerte,” el centro sagrado, “el Omphalos” y la mandala- y concluye así: “De todas esas posibilidades me parece indudable que Borges ha elegido consistentemente sobre todo las que aluden al laberinto como símbolo de la prisión (real o imaginaria) en que está encerrado el espíritu humano, el lugar en donde se encuentra la muerte, o la aniquilación final, y tal vez la liberación en la nada.” Menos expansivo en su examen del espejo simbólico, Rodríguez Monegal menciona, sin embargo, “el terror de los espejos” que sufría Borges en su niñez, la idea del doppelgänger que comunican sus espejos, y también su sentido de "una revelación del propio ser” tal vez “dolorosa”, “trágica” o “totalmente aniquiladora.” Una tentativa comprensiva para definir más estrechamente cualquiera de los dos símbolos exigiría un estudio mucho más extenso, desde luego, pero el presente ensayo pretende sugerir un valor para los dos símbolos que se relaciona específica e íntegramente con la metafísica borgiana. 
Para poder proceder con este propósito, se necesita otro elemento: el ejemplo de Schopenhauer. Borges, un “lector apasionado de Schopenhauer” (OI, 133), lo cita muchísimas veces a través de toda su obra y por poco no le concede el merito de la verdad absoluta: "me atrevo a asegurar que sólo en la [filosofía] que formuló Schopenhauer he reconocido algún rasgo del universo” $(O I, 156)$. En otro lugar afirma que "Today, were I to choose a single philosopher, I would choose [Schopenhauer]. If the riddle of the universe can be stated in words, I think these words would be in his writings" (AOS, 216-217). Sólo si se tiene presente la influencia de Schopenhauer se puede desenmarañar la complejidad del mundo ficcionario de Borges.

Que Borges sienta tal afinidad por Schopenhauer no es nada sorprendente, ya que también en el fundamento del pensamiento de éste se encuentra el idealismo de Berkeley (WWR I, 3). ${ }^{3}$ Schopenhauer concibe el mundo como sujeto (el percibidor) y objeto (lo percibido). Llama al sujeto la voluntad universal e indivisible, y llama al objeto -manifestación objetiva del sujeto- el “espejo” de la voluntad. ${ }^{4}$ Así, el mundo es una eterna voluntad cósmica que se contempla: "According to our view, the whole of the visible world is only the objectification, the mirror, of the will, accompanying it to knowledge of itself...” (WWR I, 266). Para Schopenhauer, el objeto, el mundo percibido (cuya substancia, claro, es sólo percepciones), es un mundo platónico de arquetipos tan eternos como el sujeto. La noción borgiana del mundo percibido es idéntica a la de Schopenhauer, excepto que Borges no habla específicamente de arquetipos platónicos sino más bien de unos momentos eternos o arquetípicos que finge descubrir en un temprano relato seudo-autobiográfico ("Sentirse en muerte", 1928). ${ }^{5}$ Schopenhauer arguye que todos los percibidores individuales son iguales el uno al otro, y que son la voluntad indivisible. Borges expresa esta misma estructura como una teoría del mundo de Tlön: "Esa conjetura feliz afirma que hay un sólo sujeto, que ese sujeto indivisible es cada uno de los seres del universo y que estos son los órganos y máscaras de la divinidad. X es Y y es Z. [...] Schopenhauer (el apasionado y lucido Schopenhauer) formula una doctrina muy parecida en el primer volumen de Parerga and Paralipomena" $(F, 26)$. Según Schopenhauer el yo de los individuos es lo que impide que se den cuenta de su unidad, y hace que vean un mundo laberíntico de tiempo cronológico y mutabilidad interminable en vez del arquetípico mundo platónico. Borges también pudo descubrir sus momentos arquetípicos sólo después de la muerte de su yo. Solamente entonces, en su experiencia “autobiográfica” de la eternidad ("Sentirse en muerte”), pudo llegar al estado del "percibidor abstracto del mundo” (IA, 150).

Teniendo presentes estas similaridades, pues, examinemos el soneto “Everness”, porque el espejo simbólico y la imagen del mundo como laberinto (profusos en las obras de Borges), en ningún otro lugar revelan tan concisamente su sistema metafísico. Aquí las imágenes del mundo como lo percibe el individuo -un laberinto-y el mundo como es -un espejo estático de momentos arquetípicos- se incorporan en una sola exposición poética. Una explicación de este soneto revela la unidad esencial de estas 
visiones aparentemente contradictorias, descubre la complejidad de la metafísica borgiana, y aun sugiere el patrón básico de su narrativa:

Everness

Só1o una cosa no hay. Es el olvido.

Dios, que salva el metal, salva la escoria

Y cifra en Su profética memoria

Las lunas que serán y las que han sido.

$5 \quad$ Ya todo está. Los miles de reflejos

Que entre los dos crepúsculos del día

Tu rostro fue dejando en los espejos

Y los que irá dejando todavía.

Y todo es una parte del diverso

10 Cristal de esa memoria, el universo;

No tienen fin sus arduos corredores

Y las puertas se cierran a tu paso;

Sólo del otro lado del ocaso

Verás los Arquetipos y Esplendores. $(O P, 251)$

Dentro de la estructura del idealismo de Borges, sólo existen los objetos percibidos. Ser un objeto de la conciencia confiere la realidad; ser olvidado confiere un olvido absoluto y ontológico. Así el primer verso de "Everness”, una negación categórica del “olvido”, propone simultáneamente una conciencia eterna y constante y la presencia correlativa de toda realidad. Ya que los objetos abarcados por una conciencia eterna tienen que ser eternos, “Dios” (v. 2), como la voluntad cósmica de Schopenhauer, es el correlativo subjetivo de percepciones eternamente presentes. Este mismo concepto estaba presente cuando Borges formuló su arte posterior al ultraísmo en 1924 (“Después de las imágenes”). Exhibiendo su nacionalismo germinante dice, "Ignoro si una voluntad divina se realiza en el mundo, pero si existe fueron pensados en Ella el almacén rosado y esta primavera tupida y el gasómetro rojo” ( $I, 28$, el subrayado es nuestro). El segundo verso, por medio de dos sinécdoques, acentúa lo inclusivo de la conciencia eterna: todo objeto imaginarse, tanto el más importante ("el metal”) como el menos significativo ("la escoria”), queda como una percepción igualmente constante dentro de ella.

El tercer verso de “Everness” introduce la repetición aparentemente cíclica de la realidad. La figura oximorónica "profética memoria” une el futuro y el pasado dentro de la conciencia eterna. El que la "memoria”, la facultad que retiene el pasado, también prediga el futuro, reduce el futuro y el pasado a una identidad. La inversión del orden cronológico de los términos del oxímoron -el poner "profética” (con su sugerencia del futuro) anterior a "memoria"- intensifica la idea de que "futuro" y “pasado" son conceptos sin sentido, iguales e intercambiables. El tiempo como 
sucesión llega a ser tiempo como una repetición cíclica, y un sólo tiempo inmutable dentro de la conciencia eterna.

La periodicidad cíclica de la realidad implícita en el tercer verso se revela por completo en el cuarto. Su estructura, al poner las "lunas" futuras antes de las "lunas" pasadas, y unidas como el objeto compuesto de cifrar, repite la sucesión estructural cronológicamente invertida de la unidad "profética memoria.” El paralelismo estructural dentro del objeto compuesto sugiere visualmente la identidad de las "lunas" pasadas y las futuras: "Las lunas que serán y las que han sido." La palabra "lunas" es un símbolo polivalente. Medida primordial del tiempo sucesivo, la luna es una expresión metonímica por el tiempo mismo, y “meses” o “tiempos” fácilmente podrían haber reemplazado "lunas". No obstante, la luna también muestra el tiempo como un solo ciclo eternamente repetido, y el elemento de la realidad manifestado en los ciclos, las "lunas" aparentemente múltiples y mudables, es de hecho una sola luna inalterable. Debajo de la connotación del tiempo sucesivo que comunica "lunas" en el cuarto verso, pues, hay una sugerencia de que el tiempo es un ciclo periódico, y que el objeto manifestado como múltiple y mudable por todo el ciclo es en realidad uno y eternamente el mismo. Además, la imagen de la luna es luz reflejada, y luna, por supuesto, quiere decir "espejo". Con este significado, "lunas" anticipa los "reflejos" y "espejos" del segundo cuarteto. Como un solo elemento de la realidad, cifrado dentro de la conciencia eterna, la luna es sinecdótica de todos los elementos de la realidad. Representados colectivamente por la luna, todos los objetos de la realidad se desprenden de su multiplicidad ilusoria en el tiempo sucesivo para adquirir la periodicidad cíclica aparente de la luna y su existencia realmente eterna y arquetípica. De igual manera, sus imágenes también adquieren metafóricamente la calidad de la reflexión de un espejo.

El primer cuarteto de "Everness" propone una conciencia eterna que sostiene una realidad eterna y arquetípica. Los objetos que componen esta realidad son espejos (lunas) y la substancia de sus imágenes es la reflexión de un espejo. Aunque las imágenes de los espejos individuales parezcan multiplicarse y cambiar en el tiempo, las imágenes múltiples y variables son en realidad un sólo ciclo periódico. Cifrada dentro de la conciencia eterna que nunca olvida, donde las ilusiones de tiempo, multiplicidad y cambio se desvanecen, cada imagen permaneceúnica y sempiternamente sin mudanza. Semejante al espejo arquetípico de la voluntad auto-contemplativa de Schopenhauer, la memoria de Dios es un espejo compuesto que unifica las imágenes de cada espejo arquetípico que su conciencia eterna sostiene.

El segundo cuarteto de "Everness", una exposición más directa, recapitula y amplia el primero, al enfocar la conciencia del individuo. El primer verso del segundo cuarteto destila el sentido del primero en tres palabras: "Ya todo está." Esta aserción es la contraparte positiva de la negación de "olvido" en el primer verso, equivalente en su naturaleza categórica y paralela a ella dentro de la estructura del soneto. Los significados del primer y quinto versos son idénticos: Toda realidad posible, la pasada y la futura, ya es. 
El resto del segundo cuarteto define el "todo" que la conciencia eterna sostiene. La substancia de toda realidad -la reflexión de espejo de una conciencia sustentadora, implícita en las "lunas” sinecdóticas del primer cuarteto- llega a ser explícita; “todo" es “miles de reflejos” (v. 5). Aunque todos los “reflejos” son percibidos para siempre por la conciencia eterna, y por eso están siempre presentes, en relación con el percibidor individual parecen ser manifestados en un tiempo sucesivo: "Los ... reflejos/ Que .../ Tu rostro fue dejando en los espejos/ Y los que irá dejando todavía.” El orden cronológico usual en estos versos, donde el pasado precede al futuro, contrasta directamente con el tiempo en relación con la conciencia eterna del primer cuarteto (vv. 3-4), donde el futuro, al preceder al pasado, se confunde con él. El que el tiempo parezca existir para la conciencia individual, pero no para la conciencia eterna, es consonante con el sistema de Schopenhauer. Este arguye que la realidad es la objetivización arquetípica y eternamente sin cambio (el espejo) de la voluntad autocontemplativa, pero que el percibidor individual tiene que ver esta objetivización en manifestaciones sucesivas. Además, como dice Schopenhauer, es el percibidor (el sujeto) conociéndose por medio de la objetivización (el objeto-espejo) quien crea las formas de la realidad: el percibidor individual ("Tu rostro"), en conjunción con la objetivización del sujeto ("los espejos”) crea (“fue dejando ... [e] irá dejando") la realidad ("Los miles de reflejos”) (vv. 5-8). Este cuarteto recuerda la definición metafórica de la realidad en el segundo ensayo idealista de Borges ("La encrucijada de Berkeley”, 1923): “La Realidad es como esa imagen nuestra que surge en todos los espejos, simulacro que por nosotros existe, que con nosotros viene, gesticula y se va, pero en cuya busca basta ir, para dar siempre con él” $(I, 119)$.

Además de ampliar las relaciones implícitas en el primer cuarteto, el segundo sutilmente introduce tres hechos nuevos: (1) que la identidad aparente del percibidor individual no es una continuidad ontol6gica; (2) que el ciclo de la vida del individuo se repite eternamente; y (3) que todos los percibidores individuales son uno. El sexto verso revela la discontinuidad del ser del percibidor individual al limitar la realidad ("los reflejos") que el individuo percibe a solo las horas de luz de la percepci6n visual: “Los ... reflejos/ Que entre los dos crepusculos del dia/ Tu rostro fue dejando .../ (vv. 5-7). Si las percepciones (la realidad) implican la existencia de un percibidor, la eliminaci6n de las percepciones, la noche, implica la aniquilaci6n correlativa del percibidor. En los términos del poema, los “reflejos” requieren la conjunción del "rostro" y el "espejo"; y la desaparición de los "reflejos” del espejo indica la desaparición del "rostro” también. Así la obscuridad (la inconsciencia, el tiempo sin percepciones) de cada noche ontológicamente aniquila al percibidor. Pero al estar el “olvido" negado para la conciencia eterna, con el amanecer el percibidor individual y sus percepciones existen otra vez. Esta destrucción de la continuidad del ser del individuo, una ilustración de “la nadería de la personalidad”, recuerda el ejemplo del propósito de su arte futuro formulado por Borges en “Después de la imágenes” (1924), cuando dijo que era necesario "mostrar un individuo que se introduce en el cristal ... 
y que siente el bochorno de no ser más que un simulacro que obliteran las noches y que las vislumbres permiten” $(I, 29)$. Borges introdujo lacónicamente este concepto con las mismas imágenes en su primer cuento fantástico, "El acercamiento a Almotásim” (1936), al comentar el sumo del protagonista: "El estudiante, aniquilado, se duerme; cuando despierta, ya con el sol bien alto, ha desaparecido el ladrón” (F, 37, el subrayado es nuestro).

El hecho de que el ciclo de la vida del percibidor individual se repite eternamente, y el que todos los individuos poseen una identidad en común, también se revelan en el sexto verso. Borges se refiere de nuevo a uno de los límites del ser, "los dos crepúsculos del día” (v. 6), en el verso trece, donde funciona aparentemente como un símbolo tradicional de la muerte: "Sólo del otro lado del ocaso/ Verás los Arquetipos y Esplendores” (vv. 13-14). El uso del segundo crepúsculo del día, “ocaso”, como un símbolo de la muerte, simultáneamente dota al otro crepúsculo, el alba, de un valor simbólico (nacimiento), y “día” llega a ser una sinécdoque de vida. Así los límites del ser en el sexto verso se extienden a los de la conciencia humana comúnmente aceptados, la aparente -aunque ilusoria- continuidad de la vida humana. Leídos dentro de este contexto metafórico, los versos siete y ocho indican que el individuo ya ha percibido la realidad en una vida pasada, y que la percibirá otra vez. Así el individuo a quien el soneto se dirige, cualquier individuo, asume una eterna existencia ilusoriamente continua que se repite cíclicamente. El quinto verso ya ha limitado y fijado para siempre la realidad que este individuo cíclico puede percibir: "Ya todo está”. Desde que cada individuo puede percibir sólo la realidad arquetípica ya fijada dentro de la memoria de Dios, sus vicisitudes sólo pueden ser idénticas a las de cualquier otro. Volviendo a las imágenes borgianas, la variedad de los reflejos dentro del espejo es limitada, y por eso la variedad de los rostros que se miran en él debe ser limitada también. Cuando los individuos comparten los limitados reflejos posibles, comparten el mismo rostro. En otro lugar Borges ha hecho notar que en la tierra idealista de Tlön, “Todos los hombres, en el vertiginoso instante del coito, son el mismo hombre. Todos los hombres que repiten una línea de Shakespeare, son William Shakespeare" (F, 25).

En el séptimo verso Borges personaliza su soneto e individualiza a su lector al tutearlo. Irónicamente, el "tu” distingue la conciencia individual de la conciencia eterna ("Su”, v. 3), y al hacerlo, destruye la continuidad del ser del individuo, le otorga una inmortalidad ignominiosa $y$, al probar que su identidad es común a todos los individuos, lo homogeiniza.

Los últimos seis versos de "Everness" son una sola unidad sintáctica, una frase compuesta tripartita, en la cual cada parte consta de dos versos. Sin embargo, estos versos están organizados por su rima en dos unidades separadas, un pareado y un cuarteto final.

El pareado es el corazón del poema; junta los tres cuartetos en un soneto mientras unifica su tenor metafísico. Unido sintácticamente al cuarteto final, el pareado repite 
palabras importantes de los primeros dos cuartetos, “todo” (vv. 5, 9) y “memoria” (vv. $3,10)$, y establece explícitamente la unidad metafísica de las polaridades aparentes que dominan los primeros dos cuartetos, las conciencias eterna e individual. Los eslabones entre estas conciencias son sus imágenes compartidas. “Todo”, los reflejos diversos que el individuo percibe en múltiples espejos aparentemente sucesivos (vv. 5-8), son reflejos que la conciencia eterna está percibiendo en un sólo espejo: "Y todo es una parte del diverso/ Cristal de esa memoria, el universo ...” (vv. 9-10). El espejo celestial es un “diverso cristal” porque abarca los múltiples espejos (v. 7) del percibidor individual. Las imágenes de espejo compartidas -diversas, múltiples y sucesivas para la conciencia individual, unificadas, arquetípicas y eternamente coexistentes para la conciencia eterna- son el universo.

El último cuarteto de "Everness" vuelve a la separación esencial entre el mundo que el individuo percibe y el que "Dios” percibe. Para el individuo este mundo es un ineludible laberinto interminable y sin sentido que lo aprisiona: "No tienen fin sus arduos corredores/ Y las puertas se cierran a tu paso” (vv. 11-12). El individuo nunca percibirá el orden cósmico; tiene que continuar para siempre en su progreso ilusorio hacia un futuro ilusorio y nunca puede regresar para descubrir que revive lo ya vivido. Queda, sin embargo, la sugerencia de que después de la muerte la conciencia individual percibirá el mundo como lo percibe “Dios”, como reflejos arquetípicos en el espejo celestial: "Sólo del otro lado del ocaso/ Veras los Arquetipos y Esplendores" (vv. 13-14). La muerte del individuo es el único puente que conduce a la unidad de visión de la conciencia individual y la eterna.

Como ya se explicó, “ocaso”, el segundo crepúsculo del día, es el límite del ser del individuo. Cuando el día desaparece, y con él las percepciones, el percibidor individual también se extingue. Traspasar este límite del ser, ir "al otro lado del ocaso”, es para la conciencia individual alcanzar el día sempiterno, la prerrogativa de la conciencia eterna para la que, negado el "olvido", queda también negada la obscuridad. La conciencia individual no puede exceder este límite y quedar individualizada, pero como ha mostrado Borges en su propia experiencia crepuscular, "Sentirse en muerte", una transición al punto de vista de la conciencia eterna es posible. En su epifanía Borges experimentó la muerte de su yo cuando superó lo que Schopenhauer llama el principium individuationis y se fusionó con la conciencia eterna para percibir directamente los eternos momentos arquetípicos. Su visión fue, en un sentido metafísico, una experiencia póstuma. Primero se exigió la muerte de su yo, la conciencia individual: "Me sentí muerto, me sentí percibidor abstracto del mundo...” $(I A, 150)$. Es la muerte en este sentido metafísico, la muerte del yo, que tiene que preceder a la visión celestial de los arquetipos y esplendores.

La muerte de la conciencia individual que la persona literaria de Borges ha sobrevivido para narrar, es obviamente rara, y según Schopenhauer, usualmente se reserva sólo al verdadero artista (WWR I, 235). ${ }^{6}$ "Everness" se dirige a cualquier individuo, y la sugerencia de una revelación culminante dentro de sus últimos dos 
versos es más ecuménica. Como ya se ha dicho, “ocaso” asume el valor simbólico del momento coincidente con el fallecimiento, y así, la muerte física llega a ser el requisito para ver el espejo celestial. Schopenhauer, quien le proporciona a Borges el medio para superar su conciencia individualizada en "Sentirse en muerte”, también suministra la base para una trascendencia idéntica en el momento del fallecimiento. Lo describe, como lo hace "Everness", con imagines solares:

... however much my individual existence, like that sun, outshines everything for me, at bottom it appears only as an obstacle which stands between me and the knowledge of the true extent of my being. And because in his knowledge every individual succumbs to this obstacle, it is simply individuation that keeps the will-to-live in error as to its own true nature; it is the Maya of Brahmanism. Death is a refutation of this error and abolishes it. I believe that, at the moment of dying, we become aware that a mere illusion has limited our existence to our person. (WWR II, 601)

“Ocaso” (v. 13) simboliza el límite de la conciencia individual y del ser del individuo, pero simboliza especialmente el eclipse del yo. Cuando “ocaso” corresponde al momento final de la vida humana, como en el verso trece, simboliza la trascendencia del principium individuationis, el único requisito para la percepción del espejo celestial. Con la puesta del sol de la conciencia individualizada sea antes de la muerte física como en la experiencia crepuscular "Sentirse en muerte”, o coincidente con ella, como es mas usual, la conciencia antes individualizada se escapa del laberinto para percibir los esplendores centelleantes del espejo arquetípico, el cosmos.

El último cuarteto de "Everness" subraya la alternativa agridulce que el mundo de ficción de Borges presenta ante el caos del tiempo sucesivo, la contingencia infinita, la multiplicidad y la substancia material. Borges ofrece un orden, y cada individuo tiene la promesa de verlo, pero sólo a expensas de su propia individualidad. Para escaparse del laberinto, primero hay que anular el propio yo, con lo cual se logra la visión trascendente, visión tan horrorosa en sus implicaciones metafísicas como el propio laberinto. Y tal visión es de muy breve duración. Hay dos “crepúsculos”, y el alba, el nacimiento de la conciencia individual que se repite eternamente, se muestra tan ineludible y ecuménica como la muerte. Como recalca otro poema de Borges mas reciente (“El laberinto”), el individuo está destinado a continuar sin saberlo una jornada de laberinto que se repite para siempre:

ZEUS NO PODRÍA desatar las redes de piedra que me cercan. He olvidado los hombres que antes fui; sigo el odiado camino de monótonas paredes que es mi destino. Rectas galerías que se curvan en círculos secretos al cabo de los años. $(E S, 43)$ 
“Everness” ilustra la unidad básica del espejo y laberinto simbólicos, y en su conjunción revela toda la metafísica compleja del mundo borgiano. Además sugiere la narrativa básica de Borges. La perecedera conciencia individualizada oculta el universo esencialmente platónico, el espejo, con un espejismo laberíntico que inevitablemente tiene que desvanecerse. El hombre, que percibe el universo por esta conciencia individualizada, habita el laberinto, y su vida consiste en un vagar por e1 sin objeto. A pesar de sus vicisitudes, sin embargo, su vida tiene una sola dirección secreta e inevitable. Se acerca constantemente al momento en que la conciencia individualizada perecerá, y el orden, el plano platónico del ser, se revelará. Esta jornada por el laberinto hasta una culminante revelación platónica -o a través de este umbral para entrar en la morada de los arquetipos mismos, “al otro lado del ocaso"forma la narrativa básica de Borges.

Dalhousie University

JAMES E. HOLLOWAY, JR.

\section{NOTAS}

1 Las obras de Borges se citan con las abreviaturas acostumbradas: Otras inquisiciones (Buenos Aires: Emecé, 1960), OI; Inquisiciones (Buenos Aires: Editorial Proa, 1925), I; The Aleph and Other Stories, 1933-1969 (Ed. y trad. por Norman Thomas di Giovanni [New York: E.P. Dutton, 1970], AOS; Obra poética, 1923-1964 (Buenos Aires: Emecé, 1964), OP; El idioma de los argentinos (Buenos Aires: M. Gleizer, 1928), IA; Ficciones (Buenos Aires: Emecé, 1956), F; Elogio de la sombra (Buenos Aires: Emecé, 1969), ES.

2 Emir Rodríguez Monegal, “Símbolos en la obra de Jorge Luis Borges,” SSF, 8 (1971), 6477.

3 Las obras de Schopenhauer (The World As Will and Representation, tomo I, trad. E.F.J. Payne [Indian Hills, Colorado: Falcon's Wing Press, 1958]; The World as Will and Representation, tomo II, trad. E.F.J. Payne [Clinton, Massachusetts: Colonial Press, 1958]) se citan con las abreviaturas WWR I y WWR II.

4 Entre los varios críticos de Borges que mencionan brevemente a Schopenhauer, Jaime Alazraki parece comprender mejor la importancia posible de su influencia: "El estudio de la presencia de Schopenhauer en Borges sería tan revelador como fructífero: ayudaría a comprender no pocos de los resortes de sus ficciones. Tal empresa, lamentablemente, rebasa los límites de nuestro trabajo" (La prosa narrativa de Jorge Luis Borges: temas-estilo (Madrid: Gredos, 1968), págs. 29-30, nota 13. Más recientemente, en una ponencia ("Inside and Outside the Mirror in Borges' Poetry”, Symposium [on] Borges and [with] Borges, Universidad de Maine, el 16 de abril de 1976), Alazraki ha comentado el espejo simbólico de Borges, pero sin acentuar su significado metafísico ni relacionarlo con el "espejo de la voluntad" de Schopenhauer.

5 Habrá los que consideren la alegación de la naturaleza apócrifa de "Sentirse en muerte" tan disputable como la alegación de que la metafísica borgiana es casi idéntica a la de Schopenhauer. Nuestra tesis doctoral inédita, “Borges’ Epiphany: Formulation, Incarnation, Transmutation” (Duke Univeristy, 1975), explora ambas cuestiones detenidamente. Dicha tesis forma parte de un estudio más amplio que poco a poco va realizándose, y cuyo propósito 
es desarrollar la metafísica y la mitología borgianas desde sus principios y clarificar algunos de sus símbolos (como las imágenes solares), para explicar de una manera nueva su obra y su trayectoria literaria. Se espera también comentar la estética de Borges y las implicaciones de su relación con el idealismo. El énfasis del estudio queda siempre en lo consciente que es la obra de Borges -aun premeditada- desde sus principios.

6 La relación entre la epifanía de Borges (“Sentirse en muerte”), la estética de Schopenhauer y la trayectoria premeditada (tal vez) de Borges forma parte de ese estudio más amplio que se menciona en la quinta nota. 


\section{Lenguaje y Estética en Inquisiciones}

La idea de un Borges “desconocido” parece irrisoria hoy en día cuando el nombre de Borges ha llegado a reemplazar al de Kafka en conversaciones literarias. A pesar de su renombre, Borges es un escritor desconocido porque muchos libros suyos, los que publicó durante la década de los veinte, no existen fuera de algunas bibliotecas de investigación.* Borges no sólo decidió no republicar libros como Inquisiciones (1925), El tamaño de mi esperanza (1926) y El idioma de los argentinos (1925), sino que modificó radicalmente textos como Evaristo Carriego (1930) y Discusión (1932), de manera que aunque forman parte de sus llamadas obras completas -como los libros de poemas Fervor de Buenos Aires (1923) y Luna de enfrente (1925)- no son los libros publicados originalmente. Más allá de estos libros condenados o modificados hay los ensayos y artículos publicados en La Nación, Nosotros, y otros periódicos y revistas que todavía no han sido recopilados.

El Borges que emerge del estudio de los ensayos publicados entre 1925 y 1932 resulta extraño para el lector convencido de que Borges es un cuentista que también publica ensayos: en estos libros vemos al Borges polémico, al Borges criollo, al Borges lingüista, al Borges biógrafo, y al Borges filósofo. La palabra “filósofo” puede parecer una exageración: conviene señalar que Borges es filósofo en cuanto a su afán de ubicarse en la historia cultural y en la medida en que emplea para alcanzar aquella meta las ideas que derive de su vocación profesional, las letras. Aclaremos: muy joven, Borges decide que el sector de la cultura que se suele designar "las letras" abarca todas aquellas disciplines en que el lenguaje es el verdadero asunto de investigación. El lenguaje, hablado y escrito, es la gran fijación de Borges durante los años veinte, y es desde la perspectiva del lenguaje que él postula una estética.

Si tratamos de situar la estética de Borges dentro de las corrientes filosóficas del siglo veinte, encontramos que esté en desacuerdo con todas. Por ejemplo, para un

* Naturalmente, la crítica borgiana, y sólo conviene mencionar los nombres de Emir Rodríguez Monegal, Ana María Barrenechea y James E. Irby, no ha ignorado estos textos. Aquí me refiero a la accesibilidad general de los textos. 
existencialista, esta estética resultarla una filosofía de la angustia, pues no orienta la vida humana más que a la producción de textos muertos; para los filósofos del lenguaje, que tratan de diferenciar entre lo que se puede decir lógicamente y lo que es nonsense, las actitudes de Borges serían nonsense: Borges no quiere enunciar verdades sino emplear el lenguaje como un arquitecto emplea sus materiales. Para un positivista, lo que hace Borges es absurdo. Pero si vemos en Borges a un hombre cuya vida es inseparable del lenguaje, el lenguaje empleado como medio de expresión, empezaremos a entender su filosofía. Desde la perspectiva de la lógica, la filosofía de Borges, su manera de explicar su vida, resulta insatisfactoria porque no es una filosofía vital sino una filosofía elegiaca, una filosofía, en último término, para lectores. Lo que hace Borges es desvalorizar la vida, trivializarla subrayando su carencia total de valor intrínseco. La vida, la experiencia vital, ya que es común a todos, no puede ser importante, no puede ser la esencia del ser humano.

Las ideas que Borges deriva de su contemptus vitae, las que aparecen en sus ensayos publicados entre 1925 y 1932, son éstas: el hombre, en cuanto existe, no es más que una máquina perceptiva; ideas tradicionalmente importantes como el yo, la memoria, el tiempo y el espacio no existen en realidad porque no son más que ficciones, metáforas que han llegado a ser tomadas como realidades. ${ }^{1}$ El lenguaje en si no es más que un conjunto de metáforas, pero tiene una importancia suprema en la vida humana porque condiciona al hombre, obligándolo a ver las cosas desde una perspectiva particular. La pluralidad de idiomas humanos implica una pluralidad de puntos de vista no obstante el hecho de que haya un parentesco entre lenguajes. La tarea del escritor, y aquí convergen el filósofo y el esteta, es manipular el lenguaje de manera que surja de él algo nuevo, de influir en el código recibido en vez de seguir siendo manipulado por él. Producir impacto en el lenguaje parece la justificación vital borgiana, justificación que se vuelve irónica cuando reaparece en cuentos como “Tlön, Uqbar, Orbis Tertius,” “Pierre Menard, autor del Quijote,” y el relato “Borges y yo.” En estos textos la creación estética que justifica la existencia biológica del autor, se transforma en su creación monstruosa, espejo que caricaturiza al creador, espejo que será recreado por cada lector.

Pero conviene reconstruir el proceso por el cual el lenguaje se transforma primero en materia para la salvación (justificación en la terminología borgiana) del individuo y luego en tumba del artista. Para hacerlo examinaremos Inquisiciones, la primera colección de ensayos publicada por Borges.

Desde el prefacio, Borges muestra una actitud ambivalente hacia lo que ha escrito, actitud que será característica en su madurez, pero que aquí está apenas enunciada. Primero, su actitud hacia el libro que publica y el acto de redactar un prefacio: "La prefación es aquel rato del libro en que el autor es menos autor. Es ya casi un leyente y goza de los derechos de tal: alejamiento, sorna y elogio. La prefación está en la entrada del libro, pero su tiempo es de posdata y es como un descartarse de 
los pliegos y un decirles adiós” (p. 5). El empleo del participio activo “leyente” en vez del sustantivo "lector" es significativo: implica, al contrario de lo que dice la frase que sigue, que la relación entre el autor y su creación dura más allá de la publicación, y que, posiblemente, cada nuevo texto puede considerarse una revisión del texto que lo procede. Aquí vemos un deseo de borrar orígenes, de crear la ilusión de un proceso continuo de repetición y diferencia, como si el autor tratara de escribir las mismas cosas en distintas maneras. Como dice Jacques Derrida, en una frase que puede ser un eco del cuento "Pierre Menard, autor del Quijote," “La pure répétition, ne changeâtelle ni une chose ni un signe, porte puissance illimitée de perversion et de subversion.”2 El leyente lo repite todo, hasta lo que él mismo ha escrito, pero su identidad de participio activo sugiere, paradójicamente, una falta de identidad, un ser siempre en trance de llegar a ser lo que nunca será. ${ }^{3}$

Esta definición resulta menos enigmática si la situamos dentro de una lectura del ensayo “La nadería de la personalidad,” también de Inquisiciones, donde Borges, sumamente anti-proustiano, dice: "Ocurrióseme que nunca justificaría mi vida un instante pleno, absoluto, contenedor de los demás, que todos ellos serían etapas provisorias, aniquiladoras del pasado y encaradas al porvenir, y que fuera de lo episódico, de lo presente, de lo circunstancial, no éramos nadie. Y abomine todo misteriosismo” (p. 90). El reducirse Borges a un proceso, que en su caso se traduce por la palabra leyente, no significa un empobrecimiento; significa una autodefinición que rechaza conceptos como orígenes, originalidad, precursor, y paternidad (en todos los sentidos, pues el leyente es su propio padre y su propio hijo).

Junto con esta negación del concepto de un yo constante, herencia embarazosa del Romanticismo, según Borges (pp. 61-2, 84, 90), él afirma su vocación literaria: "Yo no sé si hay literatura, pero yo sé que el barajar esa disciplina posible es una urgencia de mi ser” (p. 5). ¿Cómo efectuar la fusión del leyente con el escritor? Si leemos la obra de Borges, como lo hemos hecho todos, en orden anticronológico, resulta fácil imponer la imagen del lector-escritor que se encuentra en Ficciones sobre estas dos imágenes independientes, el leyente y el escritor. La inversión cronológica puede ser metodológicamente satisfactoria (si bien irreal) porque el Borges de Inquisiciones no puede ser sino la teoría de una persona. Es decir, a Borges le importa mucho desvalorizar su existencia personal (su yo) para enfatizar su existencia literaria, su existir como una serie de textos. Los lectores borgianos reconocerán en esa dicotomía el Borges de “Borges y yo,” aunque aquí la ironía todavía no ha entrado en el programa. Durante la década de los veinte entonces, Borges quiere desaparecer como ser humano, para construir sobre esa ausencia "una estética, hostil al psicologismo que nos dejó el siglo pasado, afecta a los clásicos y empero alentadora de las más díscolas tendencias de hoy” (p. 84).

Las consecuencias de la estética de Borges para el escritor son transformarlo en un creador de metáforas. Y habría que recordar que para Borges el lenguaje es básicamente un conjunto de metáforas: 
El mundo aparencial es un tropel de percepciones baraustadas. Una visión de cielo agreste, ese olor como de resignación que alientan los campos, la gustosa acrimonia del tabaco enardeciendo la garganta, el viento largo flagelando nuestro camino y la sumisa rectitud de un bastón ofreciéndose a nuestros dedos, caben aunados en cualquier conciencia, casi de golpe. El idioma es un ordenamiento eficaz de esa enigmática abundancia del mundo. Lo que nombramos sustantivo no es sino abreviatura de adjetivos y su falaz probabilidad, muchas veces. En lugar de contar frío, filoso, hiriente, inquebrantable, brillador, puntiagudo, enunciamos puñal, en sustitución de ausencia de sol y progresión de sombra, decimos que anochece. Nadie negará que esa nomenclatura es un grandioso alivio de nuestra cotidianidad. Pero su fin es tercamente práctico: es un prolijo mapa que nos orienta por las apariencias, es un santo y será utilísimo que nuestra fantasía merecerá olvidar alguna vez. (pp. 65-6)

En este pasaje vemos elementos de la estética que Borges atribuirá a otros pensadores (reales o imaginados) en sus cuentos: la idea de que existe la posibilidad de inventar un lenguaje literario (que habría que diferenciar del lenguaje artificial de muchos textos literarios, el lenguaje criticado por Wordsworth como "poetic diction" en el prefacio a Lyrical Ballads) que será distinto del lenguaje que usamos para la comunicación, concepto que aparece en “Tlön, Uqbar, Orbis Tertius” y "Pierre Menard, autor del Quijote”; y la idea de que el escritor, como creador lingüístico, debe crear nuevas metáforas y no limitarse a barajar lo que le es proporcionado por el lenguaje cotidiano. Aquí, además de su odio contra el "psicologismo,” vemos uno de los argumentos borgianos contra la novela: al reproducir el lenguaje de todos los días, se condena a la trivialidad, y resulta así estéticamente absurda.

Estas ideas de Borges sobre el lenguaje se parecen a las de Ezra Pound durante el período del Imagism. Los dos enfatizan la metáfora (o imagen) como el núcleo del lenguaje literario, pero en ambos casos el núcleo parece más importante para la expresión poética que para la narración en prosa. En la obra de Pound encontramos una técnica para construir un texto basado en metáforas conectadas: los monólogos dramáticos de Browning; en Eliot, The Wasteland, encontramos imágenes yuxtapuestas que constituyen una narrativa discontinua cuyo impacto se deriva de la acumulación y repetición. Para Borges, Poe (en particular el Poe creador de Auguste Dupin) puede representar lo que representa Browning para Pound: le muestra la manera de transformar metáforas en narración sin recaer necesariamente en el lenguaje de todos los días. La conciencia de estar escribiendo un texto impuro o hibrido también se nota en Ficciones, donde hay muchos textos que fingen ser reseñas, ensayos, o notas necrológicas.

Pero más importante que el paso que lleva a Borges desde las metáforas a las narraciones es la manera en que especula sobre el hecho de que el es lingüísticamente “criollo.” Si nos limitamos a analizar las teorías lingüísticas de Borges, lo representamos, 
como se ha hecho tantas veces, como un pensador abstracto, desnacionalizado. El ensayo “Queja de todo criollo” define al criollo en términos de la relación entre un ser humano y su lenguaje. Primero Borges postula una hipótesis de trabajo: "Muestran las naciones dos índoles: una la obligatoria, de convención, hecha de acuerdo con los requerimientos del siglo y las más de las veces con el prejuicio de algún definidor famoso; otra la verdadera, entrañable, que la pausada historia va declarando y que se trasluce también por el lenguaje y las costumbres” (p. 131). De acuerdo con su hipótesis, Borges emprende una investigación de lo verdaderamente criollo:

El criollo, a mi entender, es burlón, suspicaz, desengañado de antemano de todo y tan mal sufridor de la grandiosidad verbal que en poquísimos la perdona y en ninguno la ensalza. El silencio arrimado al fatalismo tiene eficaz encarnación en dos caudillos mayores que abrazaron el alma de Buenos Aires: en Rosas e Irigoyen. Don Juan Manuel, pese a sus fechorías e inútil sangre derramada, fue queridísimo del pueblo. Irigoyen, pese a las mojigangas oficiales, nos está siempre gobernando. La significación que el pueblo apreció en Rosas, entendió en Roca y admira en Irigoyen, es el escarnio de la teatralidad, o el ejercerla con sentido burlesco. En pueblos de mayor avidez en el vivir, los caudillos famosos se muestran botarates y gesteros, mientras aquí son taciturnos y casi desganados. (p. 132)

Estas afirmaciones estimulan, naturalmente, comparaciones y ataques, sociológicos y literarios: a diferencia, según Borges, de los españoles, los criollos carecen de intensidad y mientras que el fatalismo español se atenuó en España, aumentó en el criollo hasta llegar a ser uno de sus rasgos esenciales. El efecto del fatalismo taciturno en la literatura hace que "la tristura, la inmóvil burlería, la insinuación irónica," sean "los únicos sentires que un arte criollo puede pronunciar sin dejo forastero” (p. 136).

Los forasteros a que se refiere Borges son los inmigrantes por un lado y por otro los modernistas (cualquiera que sea su origen étnico) que han tratado de escribir poesía de acuerdo con cánones extranjeros. La xenofobia borgiana (conviene recordar que no todos los argentinos son criollos) aparece raras veces después de 1932, pero en Inquisiciones, en El tamaño de mi esperanza y en Evaristo Carriego se puede notar la angustia de una persona que ve que su cultura y su idioma están a punto de desaparecer bajo una inundación de inmigrantes. En "Funes el memorioso," en esta frase, vemos el resultado de ese miedo: "Recuerdo claramente su voz; la voz pausada, resentida y nasal del orillero antiguo, sin los silbidos italianos de ahora.” Pero es la primera época peronista la que para Borges representa la total transformación de Buenos Aires en Babel: Borges, en colaboración con Adolfo Bioy Casares, parodia aquella lengua bastarda en los textos publicados bajo el seudónimo H. Bustos Domecq. ${ }^{4}$ 
El paralelo entre Borges y Eliot o Pound no es exclusivamente literario. Borges es un conservador iconoclasta, uno que se ve obligado a derribar muchos idola fori, como Rubén Darío o Góngora, para “purificar” la tradición y fijar sus propios orígenes literarios. Y es en este acto de buscar la "buena" tradición donde vemos un elemento de la mente borgiana en conflicto con la idea del "leyente." Si el proceso de autocreación es constante, ¿por qué buscar, en Quevedo o Evaristo Carriego, por ejemplo, modelos? Esta postulación de ideales culturales tiene su doble en la argentinidad de Borges: ¿por qué le importa tanto ser criollo? Obviamente, lo que Borges llama "la nadería de la personalidad” tiene defectos como teoría, y él mismo lo admite: "Yerran también quienes suponen que la negación de la personalidad que con ahínco tan pertinaz voy urgiendo, desmiente que cada cual siente en las honduras de su alma. Yo no niego esa conciencia de ser, ni esa seguridad inmediata del “aquí estoy yo” que alienta en nosotros. Lo que sí niego es que las demás convicciones deban ajustarse a la consabida antítesis entre el yo y el no yo, y que ésta sea constante” (p. 87).

Lo que está diciendo Borges en este pasaje es que queda con él la definición o la postulación de su ser. Como Torres Villarroel (p. 9) o como Agrippa de Nettesheim (p. 88), Borges ha experimentado todas las emociones humanas, pero asevera que estas experiencias no garantizan su existencia individual. Somos anónimos en cuanto a nuestras experiencias comunes, idea claramente enunciada en Evaristo Carriego (pp. 45-6), y alcanzamos una individualidad provisional en la medida en que efectuamos algún cambio en el mundo. Para Borges los únicos cambios que pudieran justificar su existencia se relacionaban con el lenguaje: crear un texto que alterara el código lingüístico es el único acto que puede dar significado a la vida humana.

¿Cuándo sería, entonces, que la ironía entró en el pensamiento borgiano para quebrar este postulado? No sería absurdo ofrecer el cuanto “Tlön, Uqbar, Orbis Tertius” como una vasta metáfora para el desengaño de Borges, como un autorretrato del artista agonizante. "Debo a la conjunción de un espejo y de una enciclopedia el descubrimiento de Uqbar.” Aquí, en la primera frase del relato, Borges se burla, como había hecho en "La nadería de la personalidad,” de la “primera persona,” del yo. Aquí el yo está agrupado con el espejo y la enciclopedia: el primero devuelve al espectador su imagen efímera mientras que la enciclopedia le devuelve una imagen del conocimiento humano, imagen, es claro, parcial y verbal. En ambos espejos, el objeto y el verbal, la imagen es fragmentaria, condenada a cambiar, y ajena al observador. El “descubrimiento de Uqbar,” otra ironía, es el desengaño, porque lo que se descubre, si tomamos el mundo inventado, Uqbar, como metáfora para el lenguaje, es que por mucho que el individuo trate de influir en el código, este fatalmente lo absorbe. El hombre es inventor del lenguaje pero está sujeto a sus leyes, encarcelado en ellas.

Es de notar que “Tlön, Uqbar, Orbis Tertius” es un cuento disfrazado de ensayo (el narrador Borges lo llama “artículo”) o de anécdota. El significado de esta postura autobiográfica es grande si leemos el cuento como el epílogo irónico a la labor filosófica de Borges durante los años veinte y treinta: todo sistema de pensamiento, 
todo sistema verbal, es el doble de quien lo urde y de quien lo trate de analizar (leer). Tanto el creador como el lector pierden su identidad en el lenguaje que, como la imagen en el espejo, es y no es el que lo utiliza. Al final del cuento, Borges se describe así:

Entonces desaparecerán del planeta el inglés y el francés y el mero español. El mundo será Tlön. Yo no hago caso, yo sigo revisando en los quietos días del hotel de Adrogué una indecisa traducción quevediana (que no pienso dar a la imprenta) del Urn Burial de Browne. (p. 37)

El pronombre “yo” aquí lleva una carga de patetismo que nos devuelve al “leyente” de 1925. El círculo se cierra aquí porque la filosofía que buscaba Borges en el lenguaje se subleva en contra de su descubridor. El puede modificar el lenguaje, pero sus modificaciones en poco tiempo adquieren la misma textura que el resto del código: la identidad del modificador se funde con el lenguaje mismo.

El texto, tan monstruoso como el mundo inventado por los inventores de Uqbar, mata a su creador; el artista que quiso combinar los papeles de padre e hijo se encuentra encerrado en la paternidad, y el hijo, el texto hecho del lenguaje supuestamente dominado, destroza la pobre individualidad del padre transformándolo en palabras, en propiedad pública. El único espacio que le queda al Borges moribundo del cuento es el del traductor, creador efímero de metáforas, alcahuete casto entre dos idiomas que ya no existen (el de Browne, el de Quevedo) pero que de alguna manera irónica le justifican la vida.

University of Virginia

ALFRED J. MAC ADAM

\section{NOTAS}

1 Borges vuelve a postular estas ideas en otro ensayo de Inquisiciones, "La encrucijada de Berkeley,”: “Berkeley afirma: Sólo existen las cosas en cuanto se fija en ellas la mente. Lícito es responderle: $\mathrm{Si}$, pero sólo existe la mente como perceptiva y meditadora de cosas. De esta manera queda desbaratada, no sólo la unidad del mundo externo, sino la espiritual. El objeto caduca, y juntamente el sujeto. Ambos enormes sustantivos, espíritu y materia, se desvanecen a un tiempo y la vida se vuelve un enmarañado tropel de situaciones de ánimo, un ensueño sin soñador. No hay que dolerse de la confusión que trae consigo esta doctrina, pues ella únicamente atañe al imaginario conjunto de todos los instantes del vivir, dejando en paz el orden y el rigor de cada uno de ellos y aún de pequeños agrupamientos parciales. Lo que sí vuélvese humo son las grandes continuidades metafísicas: el yo, el espacio, el tiempo...” (p. 115) Todas las citas de Inquisiciones son de la única edición de la Editorial Proa, Buenos Aires, 1925.

2 Jacques Derrida, “Ellipse, “L’Ecriture et la différence (Paris: Editions du Seuil), p. 431. 
3 El ensayo de Roland Barthes, "Ecrivains et écrivants," (Essais critiques) también estudia la diferencia entre el participio activo y el sustantivo, pero su intención es diferente de la de Borges.

4 Véase mi “El espejo y la mentira: dos cuentos de Borges y Bioy Casares," Revista Iberoamericana (Abril-Junio de 1971), pp. 357-374.

5 Jorge Luis Borges, “Tlön, Uqbar, Orbis Tertius,” Ficciones (1935-1944) (Buenos Aires: Sur, 1944), p. 11. Todas las citas son de esta edición. 


\section{"La Escritura del Dios": Laberinto Literario de Jorge Luis Borges}

El Aleph de Jorge Luis Borges se publicó por primera vez en 1949, y a los catorce textos originales se han agregado cinco cuentos y una Posdata en las siguientes ediciones. "La escritura del Dios”, cuento que fue incorporado en la primera edición, ha sido objeto de un reciente estudio de Lida Aronne Amestoy, donde se aplica un método antropofilosófico en el análisis de lo mítico-religioso de esta composición. ${ }^{1}$ En otro estudio, Jaime Giordano analiza algunos aspectos de este cuento con el propósito de demostrar el "carácter pionero de Borges en la literatura de Hispanoamérica” y “algunas de sus limitaciones”, ${ }^{2}$ mientras que otro estudio anterior, de Alberto C. Pérez, coloca el cuento dentro de la tradición de literatura "fantásticocerebral". ${ }^{3}$

Es mi intención ofrecer con este trabajo una nueva interpretación de "La escritura del Dios”, que aunque coincide en algunos puntos con las interpretaciones de otros críticos, la considero desde otro punto de vista. Además, este estudio abarcara más completamente la unidad de forma y estilo, destacando algunos de los recursos técnicos más importantes a que recurre Borges para lograr una ficción temática y estilísticamente unificada. Mientras algunas de las técnicas son características de toda la obra borgiana, no pretendo hacer un estudio englobador que se enfoque en la relación de este cuento con toda la prosa de Borges (ni mucho menos uno que trate de toda esa prosa), sino uno que destaque la reconocida agudeza del escritor tal como se manifiesta en este cuento. ${ }^{4}$

I. Temática y tema. "La escritura del Dios" está construído a base de un marco histórico -la llegada de los españoles al Nuevo Mundo y el subsiguiente saqueo y destrucción de la civilización indígena. La trama ficticia trata del encarcelamiento de Tzinacán, el último “mago” (o sea, sacerdote) de la raza azteca, por los españoles, quienes quisieron sacarle donde escondían el tesoro de su nación. Tzinacán nos narra sus tentativas de averiguar la "escritura del dios" (el secreto del universo, motivo principal del cuento); es una búsqueda que se opera siempre desde la caverna (el laberinto borgianos) que les sirve de cárcel a él y a un jaguar (indicio que parece esconder el Plan Universal). Por fin, según nos cuenta el “mago”, descubre esa 
“escritura”, y se le revela el secreto sagrado. Reproduzco la descripción de esa revelación, por ser esta visión el eje del cuento:

Entonces ocurrió lo que no puedo olvidar ni comunicar. Ocurrió la unión con la divinidad, con el universo (no sé si estas palabras difieren). El éxtasis no repite sus símbolos; hay quien ha visto a Dios en su resplandor, hay quien lo ha percibido en una espada o en los círculos de una rosa. Yo vi una Rueda altísima, que no estaba delante de mis ojos, ni detrás, ni a los lados, sino en todas partes, a un tiempo. Esa Rueda estaba hecha de agua, pero también de fuego, y era (aunque se veía el borde) infinita. Entretejidas, la formaban todas las cosas que serán, que son y que fueron, y yo era una de las hebras de esa trama total, y Pedro de Alvarado, que me dio tormento, era otra. Ahí estaban las causas y los efectos y me bastaba ver esa Rueda para entenderlo todo, sin fin. ¡Oh dicha de entender, mayor que la de imaginar o la de sentir! Vi el universo y vi los íntimos designios del universo. Vi los orígenes que narra el Libro del Común. Vi las montañas que surgieron del agua, vi los primeros hombres de palo, vi las tinajas que se volvieron contra los hombres, vi los perros que les destrozaron las caras. Vi el dios sin cara que hay detrás de los dioses. Vi infinitos procesos que formaban una sola felicidad y, entendiéndolo todo, alcance también a entender la escritura del tigre. ${ }^{6}$

Giordano niega la realidad de esta revelación. Afirma (107-08) que si hubiera acontecido, en primer lugar a Tzinacán no le interesaría narrarla; y luego, que el sacerdote habría usado, durante su descripción de las tentativas de buscar la “escritura”, un tiempo verbal del pasado para hablar de la posibilidad de presenciar y entenderla, ya que esta descripción se narra retrospectivamente. El “mago” nos había dicho:

Horas después, empecé a avistar el recuerdo; era una de las tradiciones del dios. Este, previendo que en el fin de los tiempos ocurrirían muchas desventuras y ruinas, escribió el primer día de la Creación una sentencia mágica, apta para conjurar esos males. La escribió de manera que llegara a las más apartadas generaciones y que no lo tocara el azar. Nadie sabe en que punto la escribió ni con qué caracteres, pero nos consta que perdura, secreta, y que la leerá un elegido. Consideré que estábamos, como siempre, en el fin de los tiempos y que mi destino de último sacerdote del dios me daría acceso al privilegio de intuir esa escritura. (118-19)

Giordano objeta que el usó del presente y del futuro en la frase que comienza “Nadie sabe ...” niega la veracidad de la revelación. Sin embargo, este crítico no explica cómo el cuento en su totalidad -temática y estilísticamente- gira en torno de su interpretación de la visión como sueño irreal. Aunque puede que tenga razón, también puede ser que esa visión podría haber ocurrido; estoy de acuerdo con Pérez 
en que la revelación no era un sueño y que Tzinacán de veras la vió.7 Se puede explicar el uso del tiempo verbal en términos del "presente histórico”, una técnica literaria cuyo uso, en pleno medio de una narración en el pasado, presagia la visión contada al final del cuento. Este recurso también hace resaltar el tema del cuento, un tema fundamental en la obra borgiana: el interés por la posición del hombre en el universo, la creencia en un plan secreto y en una inteligencia sobrehumana, la tentativa de descifrar el sentido oculto del universo y el poco éxito alcanzado. ${ }^{8}$

Este tema existencial se desarrolla en el cuento a base de varias advertencias. El hombre se distingue de la divinidad en perspectiva, en expresión, en existencia, en momento histórico. Dios representa todo el universo, en todos los momentos temporales, con una sola manera de expresión:

Un dios ... sólo debe decir una palabra y en esa palabra la plenitud (121); ocurrió la unión con la divinidad. ... Yo vi una Rueda ... en todas partes, a un tiempo. ... la formaban todas las cosas que serán, que son y que fueron (122);

Dios y su Rueda se ubican en el Aleph, lugar donde se reúnen todos los momentos temporales (y símbolo que da título a la colección en que se encuentra este cuento). El hombre, en cambio, es nada más que una pequeña parte del universo:

Sombras o simulacros de esa voz ... son las ambiciosas y pobres voces humanas (121);

yo era una de las hebras de esa trama total (122);

el hombre común no puede entender el mundo desde la perspectiva de Dios:

acaso yo había visto miles de veces la inscripción de Quaholom y sólo me faltaba entenderla (119).

El que ha percibido este plan no puede volver a su antigua perspectiva:

Quien ha entrevisto el universo ... nunca podrá pensar desde la perspectiva anterior (123).

Así que una vez presenciada la “escritura del dios”, Tzinacán, en vez de usar su conocimiento para liberarse y seguir su vida mortal, prefiere contentarse esperando su destino, ya que su vida anterior, la del hombre que "ha sido el” (123), ya no tiene importancia. Una vez vislumbrado el Plan Universal, su circunstancia humana, tan insignificante dentro de la totalidad del infinito, pierde todo significado. ${ }^{9}$

Giordano acierta cuando percibe una reducción de Tzinacán, pero por razones erróneas, concibiendo esta reducción como resultado de las limitaciones físicas 
impuestas al sacerdote por los españoles y concluyendo que Tzinacán pierde conciencia de sí mismo como individuo (109). Afirmo que la reducción resulta precisamente de la revelación sagrada. Todavía mantiene conciencia de su “yo”, asegurando que

yo, Tzinacán, regiría las tierras que rigió Moctezuma. Pero yo sé que nunca diré esas palabras (123).

Lo que pierde es su importancia ante el sistema universal; es un "nadie” sólo en relación a este ordenamiento:

ya no me acuerdo de Tzinacán.

... Quien ha entrevisto el universo ... no puede pensar en un hombre ... [que] ha sido él.... qué le importa la nación de aquel otro, si él, ahora es nadie (123).

El cambio a la terminología impersonal para referirse a sí mismo refleja un concepto prevalente en la obra de Borges: el narrador es representante de la sociedad humana. ${ }^{10}$ Es precisamente por eso que Tzinacán nos narra lo acontecido: le interesa contarlo, a pesar de lo que afirma Giordano, porque el es nosotros.

El hombre existencial “es, a la larga, sus circunstancias” (122), admite Tzinacán, y debe aceptarlas. Podemos concluir del informe del mismo protagonista que sólo este autoconocimiento y una aceptación de lo que uno es resultara en su unión con Dios y en su entendimiento del secreto divino:

Más que un descifrador o un vengador, más que un sacerdote del dios, yo era un encarcelado. Del incansable laberinto de sueños yo regrese como a mi casa a la dura prisión. Bendije su humedad, bendije su tigre, bendije al agujero de luz, bendije mi viejo cuerpo doliente, bendije la tiniebla y la piedra.

Entonces ocurrió ... la unión con la divinidad, con el universo. (122)

Tzinacán presencia la revelación justamente en el momento de reconocerse a sí mismo, ${ }^{11}$ un autoconocimiento que llega después de mucho tiempo de estudiarse, como nota Pérez. ${ }^{12}$ Pero también resulta de mucho tiempo dedicado a la búsqueda de Dios, representado por el jaguar: "Dediqué largos años a aprender el orden y la configuración de las manchas [del jaguar]" (120). El jaguar no simboliza el universo visible, como afirma Pérez, ${ }^{11}$ sino los dioses de las razas indígenas de México.

II. Lo intemporal. El tiempo divino (lo intemporal), uno de los dos aspectos principales de este tema existencial, se refuerza a través de la estructura y el estilo del cuento. El cuento se estructura en forma circular, narrándose en primera persona desde un punto de vista retrospectivo, después de la revelación divina. La fabula comienza con una introducción: una descripción de los alrededores del "mago" encarcelado, narrada en el tiempo verbal del presente. Después sigue lo que forma la 
exposición -como llegó a estar preso, como eran los días de su encarcelamiento y sus tentativas de descifrar la escritura sagrada. Estos acontecimientos, anteriores a la visión, se narran en el tiempo verbal del pasado. El punto culminante es la revelación del texto divino, el cual -nos cuenta Tzinacán-consta de catorce palabras. Volviendo al tiempo presente en el desenlace, nos relata su decisión de no usar el secreto en el mundo de los humanos. La circularidad de estructura y de tiempo verbal refleja el mundo infinito, continuo, sin fin, del tiempo divino -la eternidad.

El estado y destino del narrador también destacan lo intemporal. Tzinacán, que había servido de puente entre los mortales y los dioses en su papel de sacerdote, y que por eso había representado a todos los hombres, nunca había sido un hombre común. Tampoco ahora lo puede ser, ya que ha visto el Plan Universal. Por eso su destino no puede ser el de los demás. En vez de la muerte le queda, como él mismo parece entrever, una especie de limbo, que ahora también será su cárcel (junto con la caverna). Aquí no existe el tiempo de los hombres:

dejo que me olviden los días (123);

entre mis días y noches, ¿qué diferencia cabe? (121);

no hago otra cosa que aguardar, en la postura de mi muerte, el fin que me destinan los dioses (118). ${ }^{14}$

Como indican las palabras del propio narrador -“olvidarme”, “aguardar”- el destino del protagonista es ahora, después de la visión (y no en el momento de encarcelamiento, como dice Pérez 15), una interminable espera. Será una existencia fuera de los límites temporales, en la cual aguardará un fin que nunca le puede llegar. La “postura de mi muerte” no se refiere, como implica Giordano (108), a una posición de reclinación, sino a su estado personal, un limbo permanente, siempre dentro de la cárcel-laberinto; el laberinto es, como nota Rodríguez Monegal, “un círculo; es decir: un espacio místico que simboliza la duración suspendida ... el lugar inmóvil del tiempo y del espacio." 16

El estado de este encarcelado es estático y de permanente aislamiento. Lo rodean la oscuridad y el silencio (este último resultado de la falta de diálogo e imágenes auditivas). La narración trata de un pasado caracterizado por una actividad mental, y no física, y un presente y un futuro a los cuales se alude con expresiones verbales estáticas: “ser”, “me olviden”, “acostado”. El único contacto personal -que es ni verbal ni físico- es con el jaguar y con el carcelero, quien les baja comida (agua y carne) una vez por día. ${ }^{17}$ Además, aunque se supone que el protagonista dirige su historia a alguien, nunca aparece explícitamente el oyente, ni hay ninguna alusión a él.

Muchas de las imágenes que se encuentran en este cuento también reflejan la circularidad, o cierta multiplicidad, y así refuerzan lo eterno. La forma en que se revela el secreto del universo es una Rueda; la cárcel es “un hemisferio casi perfecto ... algo 
menor que un círculo máximo” (117); los puntos del jaguar son círculos. El narrador describe “círculos de luz” (121) y “círculos de una rosa” (122), y habla de la cartel que le "rodeara” (119). Se crea la multiplicidad con la ordenación de una cosa tras otra: el sumo "esta dentro de otro, y así hasta lo infinito" (121); hay una "infinita concatenación de los hechos” (120) y existe un dios “detrás de los dioses” (123). Esta multiplicidad de los dioses refleja la herencia religiosa americana, como señala Giordano (110-11). En conclusión, la multiplicidad también se refleja en la sintaxis de la narración. Muchas veces las extensas frases combinan series de tres:

Me laceraron, me rompieron, me deformaron (118);

o un río o el imperio o la configuración de los astros (119);

en cavernas, en cañaverales, en islas (119-120);

no estaba delante de mis ojos, ni detrás, ni a los lados” (122);

otras veces las series son aún más extendidas:

generaciones de los cereales, de los pastos, de los pájaros, de los hombres (119); decir el tigre es decir los tigres que lo engendraron, los ciervos y tortugas que devoró, el pasto de que se alimentaron los ciervos, la tierra que fue madre del pasto, el cielo que dio luz a la tierra (120).

III. Dios-hombre. El otro aspecto principal del tema existencial de este cuento es la contraposición Dios-hombre, que se refuerza a través de la combinación de varios elementos de sentido opuesto. Estructuralmente, la trama se basa en el choque de dos civilizaciones (la española y la azteca), un choque que no logra la dominación espiritual que intentan imponer los españoles. Dentro del protagonista se mezclan el ser humano y Dios, y el marco histórico -las referencias al mundo hispanoamericano, a la llegada de los españoles y a Pedro de Alvarado- forma una realidad terrestre que se contrapone a la irrealidad divina, compuesta por los sueños, el laberinto y el oficio del narrador (“mago").

Estilísticamente, las imágenes principales son la luz, que puede simbolizar el conocimiento (del secreto divino) o Dios (que lo sabe todo), y la sombra, símbolo del hombre ignorante con su perspectiva incompleta del mundo. Esta oscuridad se construye a base de la siguiente terminología: “tinieblas”, "sombra”, “noches”, "negras”, "oscuridad”, “muerte”; la luz radica en "incendio”, "la hora sin sombra”, “ardientes”, “el cielo que dio luz a la tierra”, “Dios en un resplandor”, “luz”, “fuego”.

Otra oposición se encuentra entre la vaguedad y lo concreto. Este último, representante del ser humano y de su realidad, se establece en las descripciones detalladas del encarcelamiento y en las enumeraciones exhaustivas de las tentativas de descifrar el secreto. La vaguedad, símbolo de la divinidad desconocida, se crea a través de las imágenes tenues-“luz”, "sombra”, “infinito”, “mutaciones”, “simulacros”, 
“varia”-, el léxico verbal- “sentí”, “empecé a avistar”, “ocurrió lo que no puedo ... comunicar” -y la pregunta retórica ¿Qué tipo de sentencia (me pregunté) construirá una mente absoluta?” (120), “que diferencia cabe?” (121). La vaguedad se establece también a través de la incertidumbre (por parte del protagonista) sobre dónde se encuentra el secreto y en que consiste, y la resultante consideración de múltiples posibilidades. Tal vacilación puede necesitar el tiempo verbal del subjuntivo, otro indicio vago: “Quizá en mi cara estuviera escrita la magia, quizá yo mismo fuera el fin de mi busca” (119). La desintegración también forma parte de esta vaguedad: los años "han ido borrando" al carcelero, se ha partido la cifra de los años, se ha olvidado a Tzinacán-hombre y ahora no hay distinción entre día y noche. El uso de expresiones parentéticas, las cuales echan duda sobre lo que acaba de expresarse, también establece la vaguedad; por ejemplo,

Ocurrió la unión con la divinidad, con el universo (no sé si estas palabras difieren) (122);

catorce palabras casuales (que parecen casuales) (123).

Otra contraposición es el cenit (lo divino) y el nadir (lo humano), establecidos con imágenes visuales que sugieren lo alto o lo bajo: “altísimo”, "parte superior de la bóveda”, "pirámide”, “en lo alto”, “astros”; "nos baja”.

Se utilizan también el oxímoron y la paradoja, para destacar esta oposición temática y además las mencionados combinaciones contrapuestas. Las palabras que contienen el secreto tan buscado consisten en "catorce palabras casuales"; esa casualidad es muy opuesta al número catorce (símbolo divino) y a la importancia que contienen las palabras, siendo expresión del ser divino. La Rueda esta hecha de agua y de fuego, elementos mutuamente exclusivos. Para la contraposición luz-oscuridad, leemos: "Cada ciega jornada me concedía un instante de luz” (120); “para que el día entrara en mi noche” (123). Respecto a la oposición vaguedad-concreto, nos cuenta Tzinacán que la Rueda “era (aunque se veía el borde) infinita” (122) y que

En el ámbito de la tierra hay formas antiguas, formas incorruptibles y eternas ... Una montaña ... o un río o el imperio o la configuración de los astros. Pero en el curso de los siglos las montanas se allanan y el camino de un río suele desviarse y los imperios conocen mutaciones y estragos y la figura de los astros varia. En el firmamento hay mudanza. La montaña y la estrella son individuos y los individuos caducan. (119)

Así, no hay nada definitivo; existe una constante transfiguración de lo permanente. Del mismo modo convergen lo alto y lo bajo: "hombres que bajaron de altos caballos" (118); “montañas que surgieron del agua” (122). 
En conclusión, además de los recursos estilísticos mencionados en los párrafos anteriores, se emplean combinaciones sintácticas para resaltar esta oposición hombreDios. Algunas veces se unen expresiones con conjunciones:

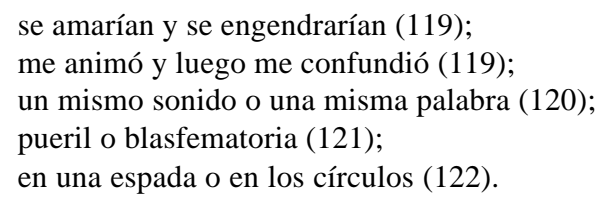

Otras veces se utilizan construcciones paralelísticas:

Así fui debelando los años, así fui entrando en posesión (118); formas antiguas, formas incorruptibles (119); más tenaz, más vulnerable (119);

esa red de tigres, ese caliente laberinto de tigres (120).

En un caso hasta se combinan estos dos trucos sintácticos:

y no de un modo implícito, sino explícito, y no de un modo progresivo, sino inmediato (120-21).

IV. Interpretación. ¿Qué es este mundo, o universo, que se revela en "La escritura del Dios”? Si rechazamos la “visión divina” que experimenta Tzinacán, llamándola un sueño nada más, tendremos que interpretar el cuento como un ejemplo más del tema realidad-irrealidad que es tan prevalente en la obra borgiana. ${ }^{18}$ El laberinto, el sueño que precede a la revelación, lo intemporal, la oposición y la transfiguración de elementos mutuamente exclusivos, el cambio de personalidad -todos contribuyen a la creación de un mundo onírico que simboliza la naturaleza del mundo que ocupa el ser humano, o que refleja la otra cara de la naturaleza racional del hombre. Empero, si aceptamos la "visión” como verdadera, se nos abren muchas más posibilidades de interpretaciones.

En un nivel personal, el cuento puede representar la búsqueda por parte de un individuo de su propio ser. Considerando el cuento dentro de la tradición arquetípica de iniciación, o de renacimiento, ${ }^{19}$ se ve que muchos de los elementos que pertenecen a ese patrón están presentes aquí: el descenso a una caverna laberíntica, el agua (en forma de alimento), la revelación brillante en las alturas de la caverna, la creación de un nuevo hombre. Tzinacán sólo renace después de mucho dolor espiritual, comenzando su personalidad y su vida nuevas en el momento de la “visión” iluminadora que es el autoconocimiento. El laberinto y las oposiciones-transformaciones sirven como la ruta que él sigue en su búsqueda. 
Desarrollando las ideas de Aronne Amestoy, el cuento puede representar, en un nivel social, el esfuerzo exitoso de un pueblo o de una sociedad para resistir la represión y su dominación por otra cultura. El encarcelamiento laberíntico y las oposiciones simbolizan la lucha de los dos grupos; la unión con la divinidad y lo intemporal, la superación espiritual por parte de la sociedad físicamente vencida. Se podría interpretar este cuento como representativo de una sociedad específica -la indígena de las Américas- o de cualquier grupo social cuya libertad se encuentra amenazada.

Se ha visto que en un nivel metafísico, el cuento puede representar la búsqueda del significado del universo, el cual se revela en la "escritura”, símbolo del "Plan Universal”. Lo intemporal y los mencionados símbolos de lo divino, así como varias imágenes de la Creación -ríos, montañas, estrellas- y de la tentativa del hombre de glorificar al Creador -la pirámide, el ídolo del dios- que aparecen en el cuento, refuerzan el concepto de un orden decidido en un nivel más alto que el del ser humano. El encarcelamiento y los símbolos del hombre destacan el hecho de que son pocos los que llegan a entender el significado trascendental, y a ellos les es casi imposible comunicarse en términos reconocibles a los demás hombres.

En un nivel religioso, este cuento puede representar una búsqueda de la unión del hombre con Dios. Como los místicos de siglos pasados, hay que pasar por las tres vías -la purgativa, la iluminativa y la unitiva- para experimentar la presencia divina. ${ }^{20}$ En este cuento, el encarcelamiento en un laberinto simboliza la primera; el autoconocimiento, la segunda. Son pocos los que llegan a experimentar la vía unitiva y, de nuevo, el que pasa por ella no manipula términos capaces de comunicarnos esta experiencia; de ahí la antítesis, que se usa, como nota Emilio Carilla, para expresar lo humanamente inexpresable. ${ }^{21}$ Por su parte, imágenes como "luz" y "altura”, juntas con el léxico ("bendije”) y la sintaxis (las formas exclamatorias), también ayudan a que el cuento se interprete de esta manera. Las oposiciones-transformaciones destacan la separación entre el ser humano y su Dios, y lo intemporal simboliza la forma eterna que parece tomar la rara vía unitiva.

Finalmente, en un nivel literario, el cuento puede representar la tentativa del escritor de comunicarse con el lector a través de palabras exactas. Se procura una "escritura” que refleje con exactitud la realidad que el escritor trata de comunicar y que sea inteligible para el lector. Si se encuentra, será en el momento “cuando la Palabra o el Símbolo coincida con el secreto de lo que es”, ${ }^{22}$ y durará eternamente. Su búsqueda se lleva a cabo en el laberinto donde, como nota Rosa, "la literatura puede mostrarse y desarrollar sus propias contradicciones”. ${ }^{23}$ La dificultad que Tzinacán, representativo del escritor, tiene en comunicarse y en crear un reflejo de su realidad muestra los problemas que tiene un autor en lograr sus intenciones. Su Dios es la “musa” literaria que le inspira a escribir, apareciendo ante él raras veces y sólo después de mucho esfuerzo mental. 
Como se ve, forma y estilo se unen en "La escritura del Dios” para crear una composición bien unida en cuanto a su tema, estructura y estilo. Rumbeando por el laberinto físico (la cárcel de la fábula) y metafórico (la fábula misma), Borges logra crear múltiples universos posibles, cada uno sostenido por la misma temática, la misma estructura, la misma estilística. Por un lado se refleja el mundo onírico y caótico en que vive el hombre, o que existe bajo la superficie racional del ser humano. Por otro lado, en un nivel personal se crea la búsqueda y el encuentro del hombre con su propio ser, mientras que en un nivel humano más amplio se describe la constante búsqueda, por la sociedad en conjunto, de la libertad espiritual. También se construyen niveles más teóricos - uno metafísico, donde se encuentra el significado del universo, otro religioso, donde se unen hombre y Dios. Y finalmente, en esta narración se trata, en un nivel literario, el problema de la propia creación literaria. Con este cuento tan intrincado es obvio que la "musa” le ha inspirado a Borges una vez más en la construcción del laberinto literario.

\section{NOTAS}

1 Lida Aronne Amestoy, “Argentina. Jorge Luis Borges: La escritura del Dios”, en su América en la encrucijada de mito y razón (Buenos Aires: Fernando García Cambeiro, 1976), pp. 158-68.

2 Jaime Giordano, “Forma y Sentido de 'La escritura del Dios' de Jorge Luis Borges”, Revista Iberoamericana, Núm. 78 (ene-mar 1972), 105-15 (p. 106). En adelante, la paginación indicada en paréntesis referente a Giordano se refiere a este artículo.

3 Alberto C. Pérez, Realidad y suprarrealidad en los cuentos de Jorge Luis Borges (Miami: Ediciones Universales, 1971), pp. 143-57.

4 Para estudios más completos referimos al lector a Jaime Alazraki, La prosa narrativa de Jorge Luis Borges (Madrid: Gredos, 1968); Ana María Barrenechea, La expresión de la irrealidad en la obra de Jorge Luis Borges (Buenos Aires: Paidós, 1967); Horacio Jorge Becco, Jorge Luis Borges: Bibliografía total 1923-1973 (Buenos Aires: Casa Pardo, 1973); Manuel Blanco González, Jorge Luis Borges; anotaciones sobre el tiempo en su obra (México: Studium, 1963); David William Foster, “Borges' 'El Aleph' -Some Thematic Considerations", Hispania, 47 (1964), 56-59. James Irby, "The Structure of the Stories of Jorge Luis Borges”, Tesis doctoral inédita (U. de Michigan, 1962); L’Herne (Primer Trimestre, 1964); Emir Rodríguez Monegal, “Símbolos en la obra de Borges” en El cuento hispanoamericano ante la crítica, Direc. y pró1. de Enrique Pupo-Walker (Madrid: Ed. Castalia, 1973).

5 Para una consideración del arquetipo “caverna-celda-laberinto”, véase Rodríguez Monegal, p. 100, y a Nicolás Rosa, "Borges y la ficción laberíntica”, en Nueva novela latinoamericana II: La narrativa Arentina actual, Comp. de Jorge Lafforgue (Buenos Aires: Paidós, 1972), pp. 140-73. No concuerdo con Rosa que el laberinto tiene que conducir siempre a la muerte, como explicare más adelante. 
6 Jorge Luis Borges, “La escritura del Dios”, en El Aleph (Buenos Aires: Emecé; Madrid: Alianza Editorial, 1972), pp. 122-23. En adelante, la paginación indicada en paréntesis se refiere a esta edición.

7 Pérez, p. 152.

8 Véase Martha Paley de Francescato, "Borges y su concepción del universo en Otras Inquisiciones”, Kentucky Romance Quarterly, 20 (1973), 469-81 (pp. 473, 478), у а Rodríguez Monegal, p. 106.

9 Joyce A. E. Loubère, en un artículo sobre Valery y Borges, ofrece la misma interpretación; una vez vista la revelación, “el habrá ido más allá de la condición humana”: “Other Tigers: A Theme in Valery and Borges”, Comparative Literature, 24 (1972). 309-18 (pp. 314-15).

${ }^{10}$ Francescato, por ejemplo, apunta el "deseo de identificarse con todos los hombres" por parte de Borges: Francescato, p. 475; y Pérez escribe: “Ahora [Tzinacán] es nadie porque se ha transformado en todos": Pérez, p. 155.

${ }^{11}$ Lida Aronne Amestoy también llega a esta conclusión: “Con sólo aceptar su condición de hombre prisionero ... Tzinacán accede al misterio máximo del universo”: Aronne Amestoy, p. 167.

12 Pérez, pp. 147-48.

${ }^{13}$ Pérez, p. 145.

${ }^{14}$ Esta última cita, eje de la interpretación que estoy proponiendo, es mal citada por Pérez. El crítico sustituye “dioses” por "hombres” (Pérez, p. 146), y así cambia radicalmente el sentido de la narración.

${ }^{15}$ Pérez, p. 156.

${ }^{16}$ Rodríguez Monegal, p. 104.

${ }^{17}$ Según Aronne Amestoy, la presencia del jaguar y la revelación divina impiden que este aislamiento físico también sea espiritual: Aronne Armestoy, pp. 163-65. Concuerdo con ella que al final no existe un aislamiento espiritual; sin embargo, como ya señale, la unión con la divinidad lo ha dejado en una especie de limbo-encarcelamiento que mantiene el aislamiento físico.

${ }^{18}$ Véase Rodríguez Monegal, pp. 95-99, y a Barrenechea, p. 201.

${ }^{19}$ Para un estudio de este arquetipo dentro de la literatura, véase Maud Bodkin, Archetypal Patterns in Poetry: Psychological Studies of Imagination (London, Oxford, New York: Oxford U. Press, 1934).

${ }^{20}$ No concuerdo con Aronne Amestoy, que ve un misticismo oriental en vez de uno cristiano: Aronne Amestoy, p. 166.

${ }^{21}$ Emilio Carilla, El cuento fantástico (Buenos Aires: Ed. Nova, 1968), p. 66.

${ }^{22}$ Loubère, p. 314.

${ }^{23}$ Rosa, p. 153. 


\section{La Estrategia del Lenguaje en Historia Universal de la Infamia}

En los inicios de Borges narrador se registra su Historia universal de la infamia ${ }^{1}$ y con esta serie de relatos el oxímoron con que inaugura la proclividad de su estilo por las figuras, procedimientos expresivos de persuasión que las actuales investigaciones del discurso literario redimensionan, superando el criterio taxinómico y preceptivo de la antigua Retórica. ${ }^{2}$

Un examen de la estrategia del lenguaje en Historia universal de la infamia a nivel de discurso narrativo en tanto mensaje estético y a la luz de la nueva pertinencia poética que la figura instaura, revela al oxímoron ${ }^{3}$ no solamente como marca estilísticosemántica sino también como modelo semiológico.

Ateniéndome en el presente trabajo a la colección de relatos que focaliza mi atención, evalúo al oxímoron como su constitutivo estructural; la función retórica, ya en estos comienzos de la obra narrativa borgiana, aparece afectando al proceso de enunciación más allá del simple sintagma en una confluencia de los planos de expresión y de contenido. El oxímoron opera en Historia universal de la infamia como procedimiento compositivo y metafórico generador de sentido, toda vez que tal forma expresiva se simbioza con el contenido estético del mensaje narrativo ${ }^{4}$, apelando persuasivamente al receptor como un control de decodificación ${ }^{5}$ y cumpliendo así con criterios estilísticos, semánticos y semiológicos de la comunicación artística.

Los siete relatos, distintos pero solidarios entre sí, se cohesionan en una unidad orgánica sintetizada en el título general otorgado al conjunto. Aunque, desde luego, pueden ser leídos en su sentido literal-entretenidas historias de impostores, bandoleros, asesinos y piratas- configuran en el macrocontexto siete variantes metafóricas de una invariante semántica: la infamia, categoría de no-valor encarnada en personajes y acciones. El papel del oxímoron es capital en el investimiento semántico de las historias narradas, ya que expresa la unión de opuestos en una auto-contradicción significante, tensa de significado. Lejos de equipararse a la antítesis, que es una contradicción lisa y llana, el enunciado oximoronista asimila y asume las oposiciones. El cuadro de opuestos englobados por el oxímoron en Historia universal de la infamia podría esquematizarse así: 


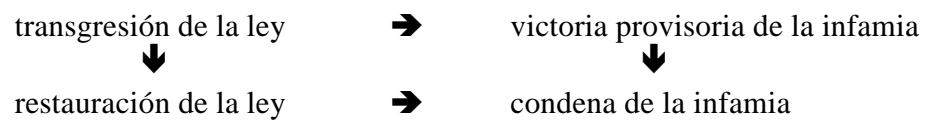

Sintetizadas en sus funciones nucleares las respectivas historias, se obtiene la siguiente sinopsis:

lera.) “El espantoso redentor Lazarus Morell”:

Lazarus Morell no posee riquezas ni poder, pero desea ser rico y poderoso; para obtenerlos se convierte en falso liberador de esclavos en el sur estadounidense. Al comienzo la impostura le reporta beneficios a costa de robos y asesinatos de inocentes a quienes simula redimir. Más tarde uno de sus secuaces lo traiciona y delata la situación ante la Justicia. Morell, perseguido, se refugia enfermo en un hospital donde muere de congestión pulmonar.

2da.) "El impostor inverosímil Tom Castro":

Tom Castro carece de las riquezas que goza la familia Tichborne. Por obra del negro Bogle, su protector, Tom decide apoderarse de esa fortuna y se convierte en impostor gentilhombre suplantando al hijo desaparecido de lady Tichborne, quien no cree en la muerte de este. Logra así su propósito. Sin embargo, los parientes de la dama engañada, celosos de la herencia familiar, acusan de impostura a Tom Castro, finalmente encarcelado por fraude y usurpación.

3era.) "La viuda Ching, pirata”:

Ching, antiguo almirante del Consorcio de escuadras piratas de los mares de Asia, es víctima tanto de la generosidad falaz del emperador chino cuanto de la ingratitud de los consorcistas. A su muerte, la viuda Ching propone a los piratas el abordaje por cuenta propia y es elegida como nuevo almirante. Durante trece años devastan las costas del Imperio hasta que el emperador manda combatir a los piratas quienes, tras noventa días de lucha, deshacen las fuerzas imperiales. Las piraterías de Ching acrecientan los estragos y esta vez el emperador hace armar una escuadra invencible. Las fuerzas de la viuda corsaria se ven perdidas y esta decide rendirse a la nave de comando imperial diciendo: “La zorra busca el ala del dragón”. Esta capitulación le atrae la clemencia del emperador.

4ta.) "El proveedor de iniquidades Monk Eastman”:

Monk Eastman consigue por la fuerza el encargo de vigilar el orden en un salón de baile de Nueva York. Adquiere tal prestigio que es designado caudillo electoral de la zona por los políticos parroquiales. En dicho feudo se beneficia con subsidios, impuestos a garitos, prostíbulos y ladrones. La 
hegemonía en los barrios le es disputada a Monk por Paul Kelly. Monk desea obtenerla a toda costa pero fracasa y es encarcelado. Salido de la cárcel vuelve al hampa y finalmente muere a balazos en su ley.

5ta.) "El asesino desinteresado Bill Harrigan”:

El furtivo pistolero neoyorkino Bill Harrigan anhela la fama. Mata a Belisario Villagran, el hombre más fuerte de Nuevo México y asciende a cacique de la frontera alcanzando la celebridad con el apelativo de Billy the Kid. La Justicia lo persigue como bandido peligroso para el Estado hasta que el sheriff Garret lo aniquila y exhibe su cadáver en público.

6ta.) "El incivil maestro de ceremonias Kotsuké no Suké”:

Kotsuké, insensible al honor, se burla de su amo, el ilustre señor de la Torre del Ako, quien le propina un hachazo por su insolencia. El maestro de ceremonias logra escapar con vida y un tribunal militar sanciona al amo con el suicidio samurai. Kotsuké se fortifica en su casa, se cerca de guardias y espías, mientras Kuranosuké, consejero del señor del Ako, trama la venganza junto a cuarentisiete capitanes. Para ello se aleja de Kioto y hace una vida disoluta hasta que el maestro de ceremonias se persuade de que ya no recaerá venganza sobre él. Así es como Kuranosuke y sus capitanes asedian la casa de Kotsuké, matan sus guardias y lo intiman al suicidio sumarai, que el se niega a ejecutar por carecer de sentido del honor. Finalmente lo degüellan y la Suprema Corte otorga a los vengadores del señor del Ako el privilegio de autoeliminarse.

7ma.) "El tintorero enmascarado Hákim de Merv”:

Hákim el tintorero desaparece de su patria en el Turquestán y al regresar enmascarado por la ruta de Merv pretende ser considerado como enviado de Dios y someter a los hombres. Siempre velado, su apariencia sobrenatural consigue adeptos y victoriosas batallas contra el califa. No obstante, una mujer del harem descubre su falsa condición de Cara Resplandeciente: dos capitanes le quitan la máscara al leproso y lo atraviesan con sus lanzas.

La sintaxis narrativa evidencia una estrategia conforme a la cual una expresión retórica directa como el oxímoron (a nivel de sintagma y del discurso) ${ }^{6}$ crea una tensión semántica extrema entre polos contrastivos; el enunciado autocontradictorio es densamente significativo más allá del sentido literal. Tres secuencias constantes en los relatos permiten deducir un modelo semiológico, a saber:

\section{Deseo}

$\downarrow \quad$ Anhelan fama, dinero, poder o superioridad por vías de la infamia: el espantoso redentor; el impostor inverosímil; la viuda pirata; el proveedor de iniquidades; el asesino desinteresado; el incivil maestro de ceremonial; el tintorero enmascarado. 


\section{Satisfacción}

$\downarrow \quad$ Logran en primera instancia satisfacer su ambición por medios infames.

3. Fracaso y castigo

Fracasan en segunda instancia. En todos la infamia es sancionada, excepto en el caso de la viuda Ching quien alcanza misericordia; excepción que confirma la regla.

Sintagmáticamente los contrarios se implican en la enunciación narrativa; la polaridad es doble, no existe un polo sin el otro:

$\begin{array}{lll}\text { infamia } & \rightarrow & \text { castigo } \\ \text { fuera de la ley } & \rightarrow & \text { vigencia de la ley } \\ \text { injusticia } & \rightarrow & \text { justicia }\end{array}$

Paradigmáticamente, el oxímoron estructurante de los relatos confiere sentido metafórico a las historias de infamia, investidas semánticamente, a partir del título general de la serie, de ejemplaridad ética con sentido irónico y paradojal del tema del destino; precisamente la ironía y la paradoja se emparientan con el oxímoron. La dimensión ética resulta de los oxímoros que recubren los mismos relatos en tanto manifestación de lo contradictorio irónico y paradójico en la historia personal del hombre dentro del contexto de la historia social. Se instaura una nueva pertinencia semántica y poética al metaforizar con la coincidencia de esferas normalmente distanciadas los contrastes de la realidad.

El oxímoron se constituye pues en práctica significante de:

a) La usurpación de identidad en:

"El espantoso redentor Lazarus Morell"

"El impostor inverosímil Tom Castro"

"El tintorero enmascarado Hákim de Merv"

b) La contradictoria personalidad o identidad contradictoria en:

"La viuda Ching, pirata" (o la rendición del coraje)

"El proveedor de iniquidades Monk Eastman" (o triunfos con males en cadena)

“El asesino desinteresado Bill Harrigan” (o la negación de su condición de asesino)

"El incivil maestro de ceremonial Kotsuké no Suké" (o la negación de las virtudes profesionales).

El relato funciona como oxímoron a partir del sintagma ("terribles bienhechores")

y la frase (“el espantoso redentor Lazarus Morell”). Este procedimiento retórico aparece pues desde las primeras incursiones de Borges en el relato breve como figura narrativa; ésta, en la serie conjunta de Historia y en sus piezas individuales, conlleva sentido metafórico por el carácter paradojal de los sucesos narrados y sobre todo de 
los protagonistas que, inspirados por móviles infames, se entregan a una acción desenfrenada y obtienen el triunfo; pero, cuando se encuentran en la cresta de la ola, son desenmascarados y sucumben. Todos son castigados y uno sólo logra misericordia. Sus acciones, con apariencia de bien o de razón, alcanzan una paradójica victoria que a la postre se derrumba con la sanción de la infamia originaria.

En “El espantoso redentor Lazarus Morell”, “El impostor inverosímil Tom Castro” y en “El tintorero enmascarado Hákim de Merv” -por ejemplo-, la intriga gira sobre la falsa personalidad de sus protagonistas: el primero se hace pasar por redentor de esclavos, el segundo por hijo de una madre desconsolada, el tercero por profeta de Dios. La usurpación de identidad logra una primera victoria, pero a la larga se produce el desenmascaramiento y el condigno castigo. El oxímoron se da en la asimilación de dos funciones simétricas: una antilógica -el apogeo de la infamia con apariencia de bien-, y otra compensadora que restituye el orden y la justicia. Este concatenamiento funcional de polos contradictorios es investido semánticamente ya desde el irónico título general de la serie: Historia universal de la infamia donde se subsumen la solemnidad y seriedad académica e historias de bajezas y vulgaridades; a su vez en los títulos de los respectivos relatos los oxímoros asumen de por sí el plano semántico de la narración (espantoso redentor; impostor inverosímil; proveedor de iniquidades; asesino desinteresado; incivil maestro de ceremonias). No obstante corresponder en cada pieza variantes de motivos, intriga y desenlace, el oxímoron es la invariante expresiva de contenido correlativo.

En el primer relato de la serie -“El espantoso redentor Lazarus Morell”integrado por ocho unidades narrativas diferenciadas mediante subtítulo, puede ejemplificarse la autocontradicción significante encarnada en ciertos personajes borgianos oximoronistas. En la primera unidad se hace el prólogo a "la culpable y magnífica existencia del atroz redentor Lazarus Morell” (18); en la segunda se sitúa el teatro de acción del "incomparable canalla” (18); en la tercera se presentan las víctimas, esclavos negros de los algodonales del Mississippi con su "basura venerable” (19). La cuarta pinta al victimario blanco, Lazarus Morell, con "esa peculiar majestad que tienen los canallas encanecidos, los criminales venturosos e impunes”, “caballero del antiguo Sur...que no desconocía las Escrituras y predicaba con singular convicción” (21). En la quinta y la sexta unidad los “terribles bienhechores” (24) ponen en práctica un diabólico plan: bajo promesa de liberación, ayudan a fugar a muchos esclavos para venderlos luego y eliminarlos más tarde en previsión de dificultades futuras. Un día, sin embargo, uno de los sicarios juramentados delata a Morell a la Justicia y éste maquina una sublevación general de los negros, la toma y saqueo de Nueva Orléans y hasta la ocupación territorial. Esta exaltación "redentora”, este "coraje borracho" (27) recubre la séptima unidad narrativa donde el mismo protagonista relata su viaje a Natchez para aunar adictos; toda la ferocidad de Morell queda evidenciada en el modo de asesinar a un jinete para apoderarse de su cabalgadura sin permitirle siquiera 
rezar antes de morir. En la octava y última secuencia acontece el desenlace, siempre con la estrategia semántica de aproximar oposiciones o desarmonías, en este caso con matices irónicos y burlescos que actúan como anticlímax del relato. El mismo acaba con una imagen de quiasmo: "Morell capitaneando puebladas negras que soñaban ahorcarlo, Morell ahorcado por ejércitos negros que soñaba capitanear” (29), y con una distensión de efecto irónicamente contrastivo: "El dos de enero de 1835, Lazarus Morell falleció de una congestión pulmonar en el hospital de Natchez” (29), precisamente cuando la Justicia le pisaba los talones. Este cierre termina de establecer el oxímoron en tanto auto-contradicción metafórica entre dos áreas semánticas distantes entrañadas en la figura narrativa: la oposición entre espantoso y redentor (entre terribles y bienhechores). El fin del protagonista y su cadena de horrores de resultas de una congestión pulmonar, acentúa el desequilibrio fundamental de la historia, clausurada bruscamente con un efecto irónico, antiheroico. Morell muere como un común mortal, ni siquiera a manos de sus enemigos. Como comenta el texto: "Contrariamente a toda justicia poética -o simetría poética- tampoco el río de sus crímenes fue su tumba” (29).

La retórica borgiana repristina al oxímoron en nuestra literatura e incorpora esta figura a su estilo personal; textos posteriores a sus relatos iniciales lo confirman. Borges echa mano del antiguo artificio verbal para renovarlo en la elaboración de personajes y temas, de tramas y sentidos de sus ficciones.

Universidad Nacional de Rosario, Argentina

EDELWEIS SERRA

\section{NOTAS}

1 Jorge Luis Borges, Historia universal de la infamia. Obras completas, Buenos Aires, Emecé Editores, 1958. Las citas y la paginación entre paréntesis corresponden a esta edición. En su prólogo declara el autor: "Son el irresponsable juego de un tímido que no se animó a escribir cuentos y que se distrajo en falsear y tergiversar (sin justificación estética alguna vez) ajenas historias” (10). Cabe recordar que la primera edición se debió a la Editorial Tor, Buenos Aires, 1935.

2 He consultado de J. Dubois, F. Edeline y otros Rhétorique générale, París, Larousse, 1970; de Paul Ricoeur Metaphore vive, París, du Seuil, 1975. Existen otros trabajos de Lausberg, Genette, Todorov, etc.

3 Se han ocupado de esta figura en Historia universal de la infamia: Lisa Blok de Behar: Análisis de un lenguaje en crisis, Montevideo, Nuestra Tierra, 1969, pp. 47-54; Suzanne Jill Levine: El espejo hablado, Caracas, Monte Avila, 1975, pp. 62-63. Jaime Alazraki estudia el oxímoron en textos de Ficciones y El Aleph: La prosa narrativa de Jorge Luis Borges, Madrid, Gredos, 1968, pp. 186-195.

4 Lisa Blok de Behar ha observado que el oxímoron borgiano "adquiere la fuerza de la verdadera visión metafórica porque constituye una demostración de la inextricable coincidencia que se da en la real obra de creación respecto al falso binomio: formacontenido”. Ob. cit., p. 52. 
5 Michael Riffaterre propone la noción de “control de decodificación”, ejercido por el escritor al codificar su mensaje en condiciones diferentes a las del locutor, ya que debe reemplazar los medios lingüísticos y extralingüísticos de la expresión articulada y gestual por otros procedimientos estilísticos o elementos imprevisibles que capten la atención sobre el mensaje para su comprensión. En Essais de stylistique structurale, París, Flammarion, 1971, pp. 3437.

6 Jaime Alazraki estima que: "El consistente empleo del oxímoron en la prosa narrativa de Borges es una forma de expresar en el plano del estilo la paradójica realidad de sus ficciones (...), el oxímoron emerge naturalmente, determinado por la contradictoria realidad de la fáabula; la fábula es, a veces, un gran oxímoron”. Ob. cit., p. 187. 


\section{La Obra Invisible de Pierre Menard}

Lo que nos confunde al mismo tiempo que nos fascina en "Pierre Menard, autor del Quijote”, es que el manuscrito de Menard es idéntico al texto publicado de Cervantes. ¿Cómo es posible que un hombre emplee años para producir unos cuantos fragmentos de un libro que se puede encontrar en cualquier biblioteca? Sin embargo, aclara Borges en su serie de entrevistas con Georges Charbonnier, "Pierre Menard no era imbécil [sino] un hombre que había llegado a un grado tal que no podía hacer más que esto.”1 Mi hipótesis es que Menard hace coincidir su texto con el de Cervantes para que resulte invisible lo que verdaderamente ha logrado.

Los supuestos básicos de la labor de Menard son claros. Su intención no es copiar el Quijote y su tarea tampoco es historicista - no se propone volver a la España de Felipe II, no intenta recrear en su mente el ambiente en el cual se creó el Quijote; es decir, no intenta ser Cervantes para poder re-escribir la novela. De ningún modo. Menard se coloca en la situación de Cervantes de una manera totalmente libre de historicismo:

A los doce o trece años lo leí [Don Quijote], tal vez íntegramente. Después he releído con atención algunos capítulos, aquellos que no intentaré por ahora... Mi recuerdo general del Quijote, simplificado por el olvido y la indiferencia, puede muy bien equivaler a la imprecisa imagen anterior de un libro no escrito. ${ }^{2}$

Lo que Menard ha dicho nos choca porque sugiere que su posición en cuanto lector es parecida a la de Cervantes como escritor: el vago recuerdo de su lectura del Quijote quizá equivale a la imprecisa noción del libro en la mente de Cervantes antes de que empezara a escribirlo. Mas, como son precisamente esos capítulos que recuerda imprecisamente (y no los que ha “releído con atención”) los que acomete, la obra invisible de Menard sugiere que el acto de escribir es parecido al acto de recordar: ambos son un recobrar, una repetición, un revivir en la mente. Pero la metáfora de la escritura como memoria tiene otras implicaciones. Por ejemplo, lo que recordamos ya ha sucedido y el recuerdo sólo puede recobrarlo de una manera parcial e inadecuada. 
El recuerdo retiene algo (¿quién sabe qué?) del original, pero es inevitablemente diferente a este, sea lo que fuere. Haciendo una comparación entre la escritura y el recuerdo, Menard sugiere pues que la obra literaria procura presentar lo que inevitablemente está ausente. De este modo, la diferencia y la ausencia vienen a convertirse en características básicas de la obra literaria.

Que la crítica no agota la obra literaria y en particular la obra maestra, es un lugar común. La declaración de Menard concede a la obra misma una posición tan precaria como la de la crítica. Vista como recuerdo, la obra literaria ya no mantiene su condición original de fuente, sino que se convierte en repetición, lo mismo que la obra crítica. Pero, ¿repetición de que? nos preguntamos. Esta es precisamente la nueva problemática planteada por Menard. El autor pierde su visión privilegiada y el lector ya no procura alzarse a esa visión, sino que los dos se encuentran como hermanos en el intento de recobrarla. En este respecto la obra literaria y la obra crítica permanecen en el mismo terreno: son repeticiones, recuerdos, intentos de recuperar lo que está inevitablemente ausente. De hecho, vale preguntarse si Menard es escritor o crítico. El narrador nos dice que Menard quiso “componer” el Quijote, pero no hay que olvidar el hecho de que esta composición se basa en su lectura infantil de Quijote. ¿Opera como lector o escritor? Es claro que Borges confunde ambos papeles en su protagonista.

Pero queda aún sin respuesta la pregunta inicial: ¿por qué es el texto de Menard idéntico al de Cervantes? Tzvetan Todorov dice que la descripción más meticulosa de la obra literaria resultaría en "una repetición, palabra por palabra, de la misma obra.”3 Será quizá que Menard, actuando como crítico, quiere componer semejante descripciónrepetición? Paul DeMan aclara la cuestión de la siguiente manera:

...la interpretación nunca es mera duplicación. Legítimamente se la puede llamar 'repetición', pero este término es tan rico y tan complejo que suscita una gran cantidad de problemas teóricos. La repetición es un proceso temporal que presupone la diferencia tanto como la semejanza. Funciona como riguroso principio regulativo, mas afirma la imposibilidad de una identidad rigurosa, etc. $^{4}$

Si la tarea de Menard es simular la de la memoria (la cual sólo puede aproximarse a lo que recuerda), si es ese tipo de repetición que presupone la diferencia tanto como la semejanza, según dice DeMan, ¿por qué entonces son idénticos el texto de Menard y el de Cervantes?

Menard describe de la siguiente manera su “método” para escribir el Quijote:

Mi solitario juego está gobernado por dos leyes polares. La primera me permite ensayar variantes de tipo formal o psicológico; la segunda me obliga a sacrificarlas al texto “original” y a razonar de un modo irrefutable esa aniquilación... (p. 52) 
La primera parte del método de Menard -el ensayar variantes-corresponde a la idea de memoria y repetición ya discutida. Es decir, las variantes son los recuerdos que conserva Menard de su lectura infantil del Quijote; repeticiones que no son nunca “mera duplicación” (DeMan). Nótese lo fácil que es olvidar que los fragmentos que coinciden palabra por palabra con el Quijote son creación de Menard. ${ }^{5}$ En realidad, estos fragmentos no se diferencian para nada de las otras variantes que quemó Menard en sus paseos por los alrededores de Nîmes. Pero su identidad con la obra de Cervantes oculta este hecho, nos confunde, nos hace reír incluso, y así olvidamos las circunstancias de su composición.

Si el punto de partida de Menard es de hecho semejante al de Cervantes -su recuerdo infantil de Quijote equivale más o menos a la imagen imprecisa del libro en la mente de Cervantes antes de escribirlo-la tarea de Menard se complica enormemente, pues tendrá que transcribir su recuerdo en innumeras variantes para poder crear la probabilidad de que a1gunas de ellas resulten idénticas al texto impreso del Quijote. Huelga decir que el número de variantes necesario para crear esta probabilidad sería astronómico, y el narrador nos dice que Menard gastó varios años en este trabajo. Ya completadas las variantes, Menard “razona” sobre cuales coinciden en realidad con el Quijote y son estos solamente las que presenta a sus lectores. Pero otra vez surge la pregunta que nos venimos haciendo: ¿por qué hace Menard que su texto coincida con el de Cervantes?

Si la primera parte del método de Menard (el ensayar variantes) está de acuerdo con la metáfora de la escritura como memoria, la segunda parte de ese método (la cual propone “sacrificar” variantes hasta que queden sólo las que coinciden con el Quijote) resulta problemática para el argumento de Menard. ¿Cómo se hace este “sacrificio”? y, sobre todo, por qué? Menard propone "razonar de un modo irrefutable esa aniquilación”, tarea historicista en extremo. ¿Cómo se podría determinar cuales son las variantes idénticas si no es investigando el trasfondo sociológico y hasta psicológico del hombre Cervantes? Es necesario concluir que la segunda parte del método de Menard es un historicismo que choca con su metáfora de la escritura como memoria. Sin embargo, está claro que Menard desde el principio ha rechazado la vía historicista: “Ser, de alguna manera, Cervantes y llegar al Quijote le pareció menos arduo -por consiguiente, menos interesante-que seguir siendo Pierre Menard y llegar al Quijoteéa traves de las experiencias de Pierre Menard” (p. 50). ¿Por qué lo hace entonces?

Mi hipótesis es que Menard presenta sólo aquellos recuerdos (es decir, variantes) de su lectura infantil que coinciden con la obra de Cervantes para ocultar y de este modo proteger las revolucionarias implicaciones de la metáfora de la escritura como memoria. Es quizá a esto a lo que se refiere Menard cuando dice que su "propósito es meramente asombroso” (p. 50). Para determinar cuales son, y en vez de consultar la obra misma, Menard utiliza un historicismo riguroso que contradice abiertamente el espíritu en que fueron escritas las variantes, y con estupenda ironía nos dice entonces que su tarea esta gobernada por “dos leyes polares”. Ese historicismo lleva consigo 
una concepción de la literatura opuesta a la que implica la metáfora de la escritura como memoria, pues la metodología historicista presupone que el objeto de su estudio es fijo y determinable, en tanto que la concepción de la literatura según Borges y Menard implica la ausencia del objeto de estudio: sólo cabe el recuerdo impreciso de ese objeto.

No es fortuita por lo tanto la selección del ya famosísimo fragmento sobre la historia para contraponer el método de Menard al de Cervantes. Dice allí el narrador que "Las cláusulas finales [del pasaje] -ejemplo y aviso de lo presente, advertencia de lo por venir- son descaradamente pragmáticas" (p. 55). Este pragmatismo se relaciona con el historicismo que ya hemos discutido en cuanto a su creencia en la habilidad de fijar el pasado -sólo un pasado que es determinable podría actuar de ejemplo y aviso al futuro. No obstante, en el mismo párrafo el narrador nota una concepción opuesta de la historia:

La historia, madre de la verdad: la idea es asombrosa. Menard ... no define la historia como una indagación de la realidad sino como su origen. La verdad histórica, para él, no es lo que sucedió; es lo que juzgamos que sucedió. (p. 55)

Lo que fue para Cervantes un elogio retórico, es para Menard una declaración del carácter temporal de la verdad. No se trata ya de la correspondencia entre el mundo exterior y nuestra percepción de ese mundo. La nueva noción de la verdad, lo mismo que la de la memoria, tiene que ver con una repetición de algo que se encuentra dentro de nosotros mismos. El ser desaparece como sujeto que percibe la presencia del objeto, del mundo externo, pues sólo podemos “recordar”, es decir, repetir de un modo imperfecto. Para Menard, la verdad viene a ser este recuerdo imperfecto -o, si la perseguimos con la dedicación y la perseverencia con que se aplicó él a recordar el Quijote, podremos decir, como dijo él mismo, que "Todo hombre debe ser capaz de todas las ideas y entiendo que en el porvenir lo será” (p. 56).

Aunque brevemente discutida, la metáfora de la escritura como memoria se puede usar como base para una lectura más completa de los cuentos de Borges. En "El jardín de senderos que se bifurcan”, encontramos otro ejemplo de la obra literaria como repetición: la novela-laberinto de Ts'ui Pên sugiere las infinitas posibilidades de la repetición:

En todas las ficciones, cada vez que un hombre se enfrenta con diversas alternativas, opta por una y elimina las otras; en la del casi inextricable Ts'ui Pên, opta-simultáneamente-por todas. Crea, así, diversos porvenires, diversos tiempos, que también proliferan y se bifurcan. (p. 107)

La metáfora del laberinto es muy parecida a la metáfora de la escritura como memoria. No hay un "centro" u origen desde el que se pueda ver la totalidad: los 
senderos del laberinto, igual que la repetición imprecisa del recuerdo, conducen por direcciones infinitamente diferentes. En “La lotería de Babilonia”, las posibilidades de la repetición se aplican a la vida cotidiana a través de un sorteo que concluye afectando todos los acontecimientos que tienen lugar en la ciudad:

Imaginemos un primer sorteo, que dicta la muerte de un hombre. Para su cumplimiento se procede a un otro sorteo, que propone (digamos) nueve ejecutores posibles. De esos ejecutores, cuatro pueden iniciar un tercer sorteo que dirá el nombre del verdugo, dos pueden reemplazar la orden adversa por una orden feliz (el encuentro de un tesoro, digamos), otro exacerbará la muerte (es decir, la hará infame o la enriquecerá de torturas), otros pueden negarse a cumplirla... Ta1 es el esquema simbólico. En la realidad el número de sorteos es infinito. Ninguna decisión es final, todas se ramifican en otras. (p. 73)

Detrás de cualquier serie de acontecimientos yace una infinitud de posibles ocurrencias. La causalidad da paso a la casualidad.

Análisis de este tipo se podrían hacer respecto a muchos de los cuentos de Ficciones: April March, por ejemplo, la novela “ramificada” del "Examen de la obra de Herbert Quain”, o los infinitos tomos de “La biblioteca de Babel”, etc. Aludir así a estos ricos cuentos sugiere las posibilidades de la metáfora de la escritura como memoria.

Borges y Menard anuncian, en fin, una nueva era, en la que, destruido el ego romántico, el poeta pierde su visión privilegiada. Estamos en la era del lector.

SUNY, Binghamton

JOHN INCLEDON

\section{NOTAS}

1 El escritor y su obra: entrevistas de Georges Charbonnier con Jorge Luis Borges, trad. Marti Soler, (México: Siglo XXI, 1967), p. 75.

2 Jorge Luis Borges, Ficciones, (Buenos Aires: Emecé, 1965), p. 52. Todas las referencias a los cuentos de Borges provienen de esta edición.

3 Tzvetan Todorov, Qu'est-ce que le structuralisme?, (París: Editions du Seuil, 1968), p. 100. Citado por Paul DeMan, Blindness and Insight, (Nueva York: Oxford Univ. Press, 1971), p. 108. La traducción es mía.

4 DeMan, ibid., p. 108. El "etc.” de DeMan indicará que discute materia bien conocida. El término "repetición" se desarrolla en la obra de Kierkegaard, Nietzsche y Heidegger. Recientemente lo podemos encontrar en la obra de Deleuze, Foucault y Derrida.

5 Georges Charbonnier comete precisamente ese error en su entrevista con Borges: GC: La primera idea nos hace reír; un hombre copia un capítulo y lo da por suyo.

JLB: No copia, en realidad. Lo olvida y lo reencuentra en sí mismo. Ahí habría un poco la idea de que no inventamos nada, de que se trabaja con la memoria o, para hablar en una forma más precisa, de que se trabaja con el olvido (op. cit., p. 77). 


\section{Apuntes para una Lectura del Quijote de Pierre Menard}

En "Pierre Menard, autor del Quijote”, un reseñador -narrador pedante y desconfiable- comenta la invisible, subterránea, obra de un inexistente escritor del simbolismo francés. Pierre Menard -nos dice- se había propuesto reescribir textualmente el Quijote, para lo cual debía aprender un idioma extranjero de una época lejana y perder su identidad para ser Cervantes. Luego descartó ese procedimiento por fácil y escogió un camino mucho más arduo: llegar al Quijote a través de sus propias experiencias.

Menard logra generar algunos fragmentos del Quijote. Se nos aconseja que leamos un trozo transcrito dos veces y se nos persuade de que hay diferencias enormes entre ambos, según a quien se le atribuya.

La crítica que ha estudiado "Pierre Menard” se ha ocupado principalmente de la problemática-céntrica a la obra borgiana en general-de la literatura como repetición. En un trabajo reciente, Alicia Borinsky muestra hasta que punto Borges ha complicado en "Pierre Menard" esta problemática. Al enfocar sobre la clave del relato -el fragmento del Quijote textualmente reproducido, que habla del tiempo y la HistoriaBorinsky explica que leerlo dos veces significa "descubrir aquello que lo hace plural, no un texto, sino varios, por lo menos dos.” Más que en ningún otro cuento, Borges logra expresar nítidamente en "Pierre Menard” la idea de que la literatura es siempre anterior a sí misma, que "una literatura difiere de otra, ulterior o anterior, menos por el texto que por la manera de ser leída.”2 Pierre Menard es el autor del Quijote por la razón suficiente de que todo lector lo es.

La crítica también ha explorado otras ramificaciones importantes de esta misma problemática, como la cuestión de autoría y de la literatura como traducción. El título del cuento es, en si, alusión a la primera. Pierre Menard es un autor que trata de ser él y el otro simultáneamente. Pero “Los autores no son los 'dueños' de su discurso; Menard no puede ser Cervantes porque Cervantes no era él mismo, del mismo modo que Menard no es el mismo.”3 Al fenómeno de la traducción se alude por primera vez en la bibliografía de Menard. ${ }^{4}$ Se entiende, desde luego, que la ardua tarea del autor 
francés no consiste en traducir de un idioma a otro, sino en crear otra obra con la misma identidad lingüística. La milagrosa exactitud que logra con el fragmento que leemos dos veces no es sino un juego de espejos sobre la duplicidad de los posibles.

George Steiner, que en After Babel estudia el fenómeno de la traducción como problema humano y literario, dedica algunas agudas observaciones a su función en "Pierre Menard". Curiosamente, Steiner, en un aparte, se pregunta acerca de la significación de los tres capítulos del Quijote mencionados en el texto borgiano:

(How many readers of Borges have observed that Chapter IX turns on a translation from Arabic into Castilian, that there is a labyrinth in XXXVIII, and that Chapter XXII contains a literalist equivocation in the purest kabbalistic vein, on the fact that the word "no" has the same number of letters as the word "sí"? $)^{5}$

Es verdad que la crítica no ha tratado de indagar el porque de esos determinados capítulos y fragmentos del Quijote. Apenas sugerencia inconclusa, la observación parentética de Steiner nos sirve de estímulo para examinar más detenidamente esos tres capítulos de la obra cervantina y su relación con "Pierre Menard”.

El porque de los tres capítulos esta prefigurado por otra duda que merece inicialmente atención: ¿Por qué el Quijote? No es sin cierto alivio que el lector se halla, a mitad del texto, con que el propio reseñador, como si hubiera adivinado su pensamiento, le hace eco: “por qué precisamente el Quijote?, dirá el lector.” ${ }^{6}$ Como respuesta, el reseñador cita directamente un largo trozo de una carta del apócrifo Menard. Es un corto ensayo sobre el Quijote en que Menard alude a ciertas ideas del propio Borges (la literatura como repetición de ciertas metáforas predilectas, el escritor como creador de sus precursores), cuyo comienzo nos proporciona una explicación parcial:

El Quijote, aclara Menard, me interesa profundamente, pero no me parece, ¿cómo lo diré? inevitable ... El Quijote es un libro contingente, el Quijote es innecesario. Puedo premeditar su escritura, puedo escribirlo, sin incurrir en una tautología. (pp. 447-448)

La selección del Quijote descansa, pues, sobre el hecho de que no es obra obligada, necesaria, inevitable; sino todo lo contrario: accidental e innecesaria. Esto la hace susceptible a ser re-pensada sin que ese proceso sea, efectivamente, tautológico. El ejemplo de Pierre Menard prueba que sin tener que copiar el Quijote, se puede reproducir en el siglo XX; es decir, leer el Quijote como no pudo ser leído en la época de Cervantes. 
Pero el porqué del Quijote queda de nuevo ofuscado en la conclusión de la misma carta: “Componer el Quijote a principios del siglo diecisiete era una empresa razonable, necesaria, acaso fatal.” (p. 448) Pues lo que difícilmente puede ser el Quijote es obra a la vez fortuita e innecesaria y necesaria e inevitable. La paradoja que encierra esta cita de Menard nos deja perplejos. La explicación original de la criatura borgiana se desvanece ante nuestros ojos y nos conduce, con la interrogación intacta, ante el propio autor-creador, ya desenmascarado. El laberinto de las sucesivas razones, la misma artificiosidad, nos ha conducido hasta el propio Borges.

En estas circunstancias, lo primero que se le va a ocurrir a un lector cómplice también lector de Cervantes- es algo obvio: ¿Cómo no va a sentirse atraído por el Quijote un escritor como Borges, cuyos proyectos literarios tan perfectamente cuadran con los de Cervantes? ¿Cómo no, si el mismo Borges reconoce a Cervantes como uno de los dos escritores españoles que valen por literaturas enteras? ${ }^{7}$ Resulta casi tautológico tratar de justificar el Quijote respecto a Borges, pues con poco esfuerzo se podrían enumerar teóricamente varios aspectos axiomátios del arte borgiano que -si no nacen al mundo de las letras con el Quijote- en ningún otro libro se hallan tan fraternalmente reunidos: 1) la necesidad de hacer literatura de literatura y la inevitable parodia que encierra este proceso; 2) el escamoteo del autor y la mixtificación de su identidad; 3) la fusión de la realidad y la ficción; 4) el recurso de la inserción consciente de una obra en otra; 5) la atracción por la aventura; 6) la predilección por fundir opuestos, quijotizar a los Sanchos, sanchificar a los Quijotes; 7) la postura auto-contemplativa del autor. Esperamos que nuestra indagación concreta del porque de los trazos cervantinos destacados en "Pierre Menard” confirme en términos reales lo anotado teóricamente.

Pasamos, pues, a la intrigante cuestión: ¿por qué esos capítulos precisamente? En el texto se hace mención explícita de tres:

Esta obra, tal vez la más significativa de nuestro tiempo, consta de los capítulos noveno y trigésimo octavo de la primera parte del don Quijote y de un fragmento del capítulo veintidós. (p. 446)

De hecho, la ambigüedad que encierra el texto borgiano acerca de lo que efectivamente escribió Menard no se resuelve pese al tono definitivo de esta cita. ${ }^{8}$ Basta indicar la duda suscitada con relación al capítulo XXII, que lo mismo puede ser el de la primera parte como el de la segunda parte del Quijote. Pues Menard -nos dice claramente el narrador en otro lugar-trabajó también con la segunda parte del Quijote (p. 447). Todo esto parece estar pensado adrede para despistar al lector. Pero como el propio narrador borgiano nos asegura que "la ambigüedad es una riqueza” (p. 449) no nos limitaremos a escoger una de las dos posibilidades, sino que optaremos por proceder teniendo en cuenta que uno de los laberintos borgianos consiste en senderos que se bifurcan. 
Que la selección de los tres capítulos no es arbitraria ha sido ya establecido por algunos críticos que han comentado uno de ellos, el noveno. En el caso de este capítulo, Borges exige, en cierto modo, la consulta textual del lector, ya que el único fragmento visible del Quijote de Menard procede del capítulo IX. Al consultarlo, la crítica ha dado con el hecho de que este capítulo de la primera parte del Quijote es una especie de espejo del cuento borgiano. Presenta, por ejemplo, "precisamente el momento de don Quijote en el cual su autorazgo parece cuestionable.” ${ }^{\text {El }}$ capítulo comenta una obra, no la continúa; es decir, que es literatura cuyo tema es la literatura. Finalmente, trata, como han visto Steiner y otros, de la traducción. Para destacar ambas cuestiones, tanto la de la autoría como la de la traducción, la selección del capítulo IX no podría ser más acertada. El Quijote, que llega hasta nosotros a través de un autor enigmático, Cide Hamete Benengeli, un traductor moro con ribetes de mentiroso, y un editor lego, el propio Cervantes, alcanza en "Pierre Menard” otro nivel más de re-elaboración creativa. El tratamiento de la traducción en "Pierre Menard” resulta la tesis borgiana de la imposibilidad de reconocer un solo autor para un texto.

Con su inserción de un trozo del capítulo IX del Quijote en "Pierre Menard,” Borges llega a otro extremo en lo relativo a la traducción. Lo que tenemos normalmente en una traducción es una misma obra en dos idiomas; en Borges se amplia el proceso: la obra se duplica dentro de un mismo idioma. ${ }^{10}$ Paradójicamente, ese instante ejemplar de máxima sujeción de la creatividad a la imitación, es asimismo el instante de máxima liberación del arte como inesquivable imitación. Los trozos idénticos son diferentes, sus conceptos casi antagónicos, debido, como ha visto Rodríguez Monegal, a que "Toda historia, todo texto, es definitivamente original porque el acto de creación no está en la escritura sino en la lectura."11 Esta paradoja de "Pierre Menard” es libertadora, y da lugar a la apertura hacia el futuro de la creación artística borgiana. ${ }^{12}$

El capítulo XXXVIII de la primera parte, el siguiente que Borges cita, está incluído en "Pierre Menard”, según Steiner, por la palabra "laberinto”. Entiéndase, no por elaborar Cervantes un laberinto, sino por el empleo de la palabra meramente. Puesto que en los siglos XVI y XVII, tan elaboradores de la mitología clásica, abundan referencias al laberinto minoano, no nos parece ser esa la justificación primaria para la selección menardiana del capítulo XXXVIII. Su incorporación del archi-famoso discurso de las Armas y las Letras, sin embargo, si que nos ofrece una explicación bastante más convincente. Este discurso representa uno de los grandes dilemas del pensamiento renacentista $\mathrm{y}$, asimismo, el gran dilema valorativo de la vida de Cervantes, que lo es también del propio Borges. Una cita de Rodríguez Monegal lo certifica perfectamente:

The two sides of the Borges household will represent as in an allegorical tableau, the famous contrast between arms and letters, a topic to which Don Quijote had something to add. ${ }^{13}$ 
Este tema conflictivo, espina inseparable de su propio existir, se repite a través de la obra de Borges. El Quijote encierra, pues, más que una afinidad filosóficoestética. Cervantes vivió también, hermandad trascendente, algo del terrible dilema vocacional y valorativo del escritor argentino.

Siguiendo la pauta de Steiner, examinaremos primero el capítulo XXII de la primera parte del Quijote. Se trata del famoso capítulo de los galeotes, cuya inclusión en "Pierre Menard" Steiner justifica por existir una posible paradoja cabalística en la sátira del galeote que "cantó". Es tan fácil decir "no" como "si”, puesto que las dos palabras tienen el mismo número de letras. Tal mención compone, sin embargo, una parte minúscula del importante capítulo, y, tratándose del de los galeotes, tan rico en elementos borgianos, es forzoso ir más allá del equívoco cabalístico.

En el capítulo XXII se trata, a nivel filosófico, por ejemplo, de la tensión precaria entre libertad y sociabilidad, entre lo que el hombre occidental exige como individuo y lo que se le concede como miembro necesario de un grupo. En el siglo XX, Borges lleva este conflicto a su límite extremo con su crítica radical del yo, negándole toda identificación individual al ser humano.

A nivel de caracterización literaria, se trata en este capítulo de la fusión de opuestos humanos, fusión de orden paradójico que tan germinal es en la obra de Borges. ${ }^{14}$ Don Quijote libertador se transforma, ante nuestros ojos y sin dejar de ser él, en Don Quijote despota, eclipsando la libertad que acaba de otorgar gratuitamente.

Y finalmente, el capítulo XXII de la primera parte del Quijote contiene a Gines de Pasamonte, autor de La vida de Gines de Pasamonte. No sólo es literatura que trata de literatura, obra comentada dentro de otra obra, sino que se trata de una novela picaresca, una creación literaria cuya condición esencial es confundir y fundir la realidad y la ficción. Con el Quijote mismo como fondo, resulta hasta mareante calcular la complejidad borgiana, de caja chinesca, que ello supone.

No menos borgiano resulta ser el capítulo XXII de la segunda parte del Quijote, pues trata del Primo y de la bajada a la cueva de Montesinos. Comienza el capítulo resumiendo lo acontecido en las bodas de Camacho (que no lo fueron, naturalmente) y sigue con la explicación del "engaño" de Basilio -quien se finge morir para efectuar el desenlace feliz- y con la pontificación definitiva de don Quijote: "No se pueden ni deben llamar engaños los que ponen la mira en virtuosos fines." ${ }^{15}$ Don Quijote propone también el auto-engaño, respecto a la mujer propia, para el contentamiento del que escoge ser marido. En fin, entre lo uno y lo otro, todo el principio del capítulo XXII de la segunda parte -quizá por apuntar ya hacia la aventura de la cueva de Montesinos-resulta ser una justificación del engaño, o sea, del artificio de la realidad, por parte de un ser fictivo alterativo que vive su propia ficción alterativa.

La conversación que sigue entre don Quijote y el Primo, cuya "profesión era ser humanista; sus ejercicios y estudios, componer libros para dar a la estampa, todos de gran provecho y no menos entretenimiento para la república..., ${ }^{16}$ encierra una aguda 
sátira de la huera erudición libresca. La futilidad implícita en el “componer libros para dar a la estampa” del Primo encaja perfectamente con la visión nihilista de Borges respecto al ejercicio literario. ${ }^{17}$ Sus comentarios y análisis de libros verdaderos e inventados -como esta jugosa conversación entre los personajes cervantinos-resultan, no pocas veces, como en "Pierre Menard”, paródica burla de la empresa literaria y de quien la emprende. Crítica y creación, pues, son los polos antagónicos del discurso literario de uno y otro escritor.

El último trozo de este segundo capítulo XXII recoge la aventura quijotesca de más rancio abolengo mítico, el descenso a la cueva de Montesinos, parodia, entre otras cosas, de todos los descenos de la literatura universal. Téngase en cuenta todo lo que ello representa respecto a la noción borgiana de la literatura como re-elaboración. No hay tema máximo más repetido por el hombre. Téngase en cuenta, asimismo, lo que encierra de fusión perspectivesca de realidad y ficción ese viaje subterráneo del héroe cervantino... Y es precisamente en este punto, ante la extraordinaria complejidad que representa el descenso quijotesco, que el lector empieza a darse cuenta de que Borges, al implantar esa ambivalencia respecto al capítulo XXII, le induce, sonriente, a una inacabable búsqueda. Hay en juego tal complejo de ironías, parodias y reflexiones que es imposible tratar de hacerles justicia en un breve comentario.

En conclusión, creemos haber aportado en las páginas que preceden algunas justificaciones de los tres (¿tres?) capítulos cervantinos que Borges cita concretamente en "Pierre Menard”. Descubrimos, como el lector de estas líneas habrá advertido por cuenta propia, que la justificación de los tres capítulos determinados resumen, inmejorablemente, la justificación del Quijote en el mundo borgiano. No es accidente. El propio Borges nos lleva -en esta primera de sus creaciones- al Quijote, al mismo texto, y por la razón general que Goytisolo capta al comentar el sentido esencial que la lectura cervantina tiene para la literatura contemporánea:

La novela de Cervantes es en puridad un relato de diferentes relatos, un discurso sobre discursos literarios anteriores que en ningún momento disimula el proceso de enunciación; antes bien, claramente lo manifiesta. La historia del personaje enloquecido por los libros de caballería se trueca así, de modo insidioso, en la historia de un escritor enloquecido con el poder fantasmal de la literatura. Si el juego constante del enlace entre las partes y el todo por un lado, y las palabras y la estructura por otro se presenta en forma de una espiral en la que el número de vueltas es proporcional a la plenitud y complejidad del sistema, en el caso del Quijote el movimiento helicoidal es prácticamente infinito. Cervantes ha tocado todas las teclas y registros del juego. Por eso, cuando abandonando el “realismo” de corto vuelo predominante en los últimos siglos, la vanguardia de hoy intenta devolver a la novela sus posibilidades de expresión perdidas o mantenidas en barbecho, deliberadamente o no, huella el ámbito cervantino. ${ }^{18}$ 
El análisis de "Pierre Menard" nos suministra un excelente ejemplo de este proceso deliberado en Borges de renovación narrativa.

\section{NOTAS}

1 Alicia Borinsky, "Re-escribir y escribir: Arenas, Menard, Borges, Cervantes, Fray Servando”, Revista Iberoamericana, Nos. 92-93 (julio-diciembre de 1975), p. 606.

2 Jorge Luis Borges, Otras Inquisiciones en Obras completas (Buenos Aires: Emecé Editores, 1974), p. 747.

3 Borinsky, p. 607.

4 Entre los libros citados en la bibliografía de Menard se entreve claramente "una preoccupazione unitaria: quella della traduzione, da una lingua in un'altra, dal lenguaggio naturale nelle formule delle logica formale, da un sistema metrico en altro.” Gerard Genot, Borges, (Firenze: La Nuova Italia, 1969), p. 28.

5 George Steiner, After Babel (London: Oxford University Press, 1975), p. 70.

6 Jorge Luis Borges, "Pierre Menard, autor del Quijote", en Obras completas, p. 447. Todas las citas subsiguientes en el texto se hacen por esta edici6n.

7 Citado por Zunilda Gertel, Borges y su retorno a la poesía (New York: Las Americas Publishing Co., 1967), p. 67.

8 Esto, naturalmente, sin tener en cuenta toda la problemática de que tales capítulos son, efectivamente, "invisibles", porque la obra menardiana -en cuanto de papel y tinta se trataba- fue pasto de las llamas.

9 Borinsky, p. 608.

${ }^{10}$ Ya en 1938, introduce Borges la problemática -que Steiner trata exhaustivamente en su libro citado- de la traducción en su sentido más amplio: i.e. la lectura de Shakespeare en el siglo XX.

${ }^{11}$ Emir Rodríguez Monegal, “Borges y Paz, un diálogo de textos críticos”, Revista Iberoamericana, No. 89 (octubre-diciembre de 1974), p. 590.

12 "Pero donde está más cabalmente expuesta [la estética de la lectura] es en uno de sus más famosos cuentos, "Pierre Menard, autor del Quijote", precisamente el primero que escribe al recuperarse del accidente de 1938... a partir de esta noción del lector como autor, toda una estética nueva puede edificarse.” Ibid., pp. 590-591.

${ }^{13}$ Emir Rodríguez Monegal, "Borges, the Reader”, Diacritics (Winter 1974), p. 48.

${ }^{14}$ Excelentes ejemplos, entre otros, de la fusión de los opuestos son "Tema del traidor y del héroe", "Los teólogos”, y "La forma de la espada”.

${ }^{15}$ Miguel de Cervantes, Don Quijote de la Mancha, ed. de Francisco Rodríguez Marín (Madrid: Ediciones Atlas, 1948), V. 144.

${ }^{16}$ Ibid., pp. 148-149.

${ }^{17}$ Ver A. M. Barrenechea, Borges the Labyrinth Maker (New York: New York Univ. Press, 1965), pp. 46-47.

18 Juan Goytisolo, “Lectura cervantina de Tres tristes tigres”, Revista Iberoamericana, No. 94 (enero-marzo de 1976), p. 10. 


\section{Borges...Derrida... \\ Sollers...Borges}

Si aceptamos las premisas platónicas (enunciadas en el Fedro) y adoptadas por representantes de la "Nouvelle critique”, según las cuales la escritura no puede sino repetirse, significar siempre lo mismo y no ser sino juego ${ }^{1}$, podemos, con toda libertad, saltar por encima del tema de las influencias y abordar el estudio de un texto dado utilizando para su análisis los comentarios nacidos de la lectura de otro texto. En este caso, y para el mejor entendimiento de una de las constantes de la obra de Borges, a saber el empleo de números y cifras, hemos utilizado el análisis que Jacques Derrida hace en La Dissémination de una obra de P. Sollers: Nombres. Debido a los límites de este estudio hemos seleccionado como paradigma "El milagro secreto" de Borges.

En La Dissémination, Derrida explora, dada la imposibilidad existencial y lingüística de apresar, o de intuir, el presente (salvo como inasible ilusión), algunos de los artificios literarios que nos ayudan a enmarcar esa ficción del tiempo. Ante el fracaso de la palabra surge el número (o la cifra), único símbolo en el que pactan significado y significante, libre de referentes exteriores, contextuales. Derrida sugiere que:

Nous écrirons donc-simultanément- dans les angles des Nombres, en eux et hors d'eux, sur la pierre qui vous attend, les questions touchant ce texte "ci," le statut de son rapport aux Nombres, ce qu'il feint d'y ajouter pour en mimer la representation, la représentation et le compte rendu. Car si les Nombres rendent compte d'eux mêmes, ce texte-“ci”- comme tout ce qui le touche-est déjà ou encore ce texte "là". ${ }^{2}$

“El milagro secreto” de Borges concluye de la siguiente manera:

Inició un grito enloquecido, movió la cara, la cuádruple descarga lo derribó. Jaromir Hladík murió el veintinueve de marzo, a las nueve y dos minutos de la mañana. ${ }^{3}$ 
El desdoblamiento 2/2 y 29/92 es obvio, así como el reflejo de la imagen-espejo que contribuye a crear, como en tantos otros de sus cuentos, notablemente en "La muerte y la brújula”, una ilusión de simetría, de idéntica otredad, de repetición llamada a anular el tiempo: “Arguye que no es infinita la cifra de las posibles experiencias del hombre y que basta una sola 'repetición' para demostrar que el tiempo es una falacia." embargo que la misma repetición hace al texto, pero que una repetición "at infinitum” crea la ilusión de un presente perpetuo, o sea de la eternidad.

El “ángulo” formado por el número 29 y su reflejo 9(0)2 finge, pues, presentarle al lector un texto que, en realidad se presenta a sí mismo:

Comme la contrainte de cet angle, cette accumulation sera le seul moyen, non pas de présenter, mais de feindre de présenter le texte qui, plus que tout autre, s'écrit et se lit, présente lui-même sa propre lecture, présente sa propre présentation et fait le décompte de cette opération incéssante. ${ }^{5}$

Todo forma parte de un mismo simulacro en el cual los números inscriben su presencia en un juego que tiende a crear la ilusión de un texto "presente” y totalizador cuando "este” texto (como diría Derrida) no es sino:

cette écriture qui circule “ici” dans l'entre-texte et son soi-disant premier texte et son soi-disant commentaire, chimère comme l'eût nommée l'auteur disparaissant de cette Mimique dont l“idee” n’est certainement pas celle qu’on croit, ni son illustration: ... ${ }^{6}$

Como ya lo notó Jaime Alazraki:

El milagro, como el drama, sólo tienen realidad en la mente de Hladík. La irrealidad del drama es también la irrealidad del milagro: drama y milagro no existen en el plano histórico sino en ese mundo -el arte, los sueños- que opera con signos irreconocibles... ${ }^{7}$

Es precisamente para darle cuerpo a esta quimera por lo que Borges utiliza uno de los artificios del mimo anotados por Derrida:

'(...) Tel opère le Mime, dont le jeu se borne à une allusion perpétuelle sans briser la glase: il installe, ainsi, un milieu pur, de fiction., ${ }^{8}$

Este es el “milagro” o “suspensión” cinematográfica de la acción en "El milagro secreto": 
El universo físico se detuvo. Las armas convergían sobre Hladík, pero los hombres que iban a matarlo estaban inmóviles. El brazo del sargento eternizaba un ademán inconcluso. En una baldosa del patio una abeja proyectaba una sombra fija. El viento había cesado, como en un cuadro. ${ }^{9}$

Evidentemente, la operación del mimo es diametralmente opuesta a la del "still” cinematográfico, verso y anverso de una misma realidad, ya que en ambos casos no hay desplazamiento. El movimiento y la secuencia temporal quedan, pues, anulados. El mimo crea una impresión de movimiento, y el “still”, la ilusión de su petrificación. Derrida añade:

'La scène n'illustre que l'idée, pas une action effective, dans un hymen (d'où procède le Rêve), vicieux mais sacré, entre le désir et l’accomplissement, la pérpétration et son souvenir: içi devançant, là remémorant, au futur, au passé, sous une apparence fausse de présent.' ${ }^{10}$

En efecto, esta parálisis de la acción le permite a Hladík realizar su sueño, terminar su obra. La cuádruple descarga romperá el espejo, pero lo hará, como dice Derrida, reflejando una rotura en la ficción intacta e ininterrumpida que es la del cuento en su totalidad.

Los números (las fechas y las horas) en "El milagro secreto” representan, pues, nodos, ángulos que se cierran al texto anterior de la narración para abrirse al nuevo “sueño”-el sueño del "largo ajedrez”- tiene lugar el 14 de marzo de 1939, y es a partir de esta fecha que Borges elabora un sistema de convergencias y divergencias en el tiempo, multiplicadas por los “centenares de muertes” que Hladík imagina como un último recurso de eliminar las peores variantes de su inevitable muerte por medio de la imaginación, que le permite "vivir” por adelantado cada una de ellas.

El "error" que contribuye a crear la "ilusión” de la lectura y que forma parte de la estructura de Nombres de P. Sollers, según Derrida, aparece también en el "juego" literario de Borges y cumple una función similar a la del azar en el universo. Le permite también a Borges -como a Sollers- asegurar la horizontalidad cuadrada de la página, del “damier figurant le temps" del invisible tablero de ajedrez. ${ }^{11}$ El "error" que Borges introduce en "El milagro secreto”, es el de los dos minutos que transcurren entre la hora designada para el fusilamiento de Hladík y la cuádruple descarga que lo derriba y que en la mente de Hladík se traducen en un “día” y un “año” (el “día” pudiendo ser parte del año). En realidad, si el tiempo se hubiera detenido para solo existir en la mente de Hladík, este debería haber muerto a las nueve en punto. El narrador dice:

Un año entero había solicitado de Dios para terminar su labor: un año le otorgaba su omnipotencia. Dios operaba para el un milagro secreto: lo mataría el plomo 
germánico en la hora determinada, pero en su mente un año transcurriría entre la orden y la ejecución de la orden. ${ }^{12}$

Los dos minutos también le permiten a Borges concluir simétricamente el relato y enmarcar así el triple drama de Hladík, autor de un drama circular al final del cual las manecillas del reloj siguen señalando las siete como al comienzo del mismo, y soñador de un drama, el del "largo ajedrez", que es la tragedia de su raza perseguida y que eventualmente desemboca en su drama personal. Este último necesita de ese “error” de dos minutos para parecer más humano y, paradójicamente, más real, sin dejar por ello de ser una "ficción”.

El "error" al introducir el azar en el cuento también introduce la teatralidad, o sea la ilusión, el arte, al mismo tiempo que el lector puede “imaginar” un "año” reducido a dos minutos cuando difícilmente podría intuir un año, aun mental, que discurriera de las 9 AM a las 9 AM.

Tufts University

MONIQUE J. LEMAITRE

\section{NOTAS}

1 Jacques Derrida, La Dissémination (París: Seuil, 1972), p. 73.

2 La Dissémination, p. 326.

3 Jorge Luis Borges: Ficciones (Buenos Aires: Emecé Editores, 1963), p. 167.

4 Ibid., p. 162.

5 Jacques Derrida, p. 326.

6 Ibid., p. 327.

7 Jaime Alazraki: La prosa narrativa de Jorge Luis Borges, (Madrid: Editorial Gredos, 1974), p. 352.

8 Jacques Derrida, p. 327.

9 Borges, p. 165.

${ }^{10}$ Derrida, p. 327.

11 Jacques Derrida, p. 330.

${ }^{12}$ Borges, p. 166. 


\section{Asterión, o el Divino Narciso}

0. - El espacio del mundo ficticio en los cuentos de Borges suele estar iluminado con una luz ambigua e incierta, crepuscular, si no con sombras o tinieblas: "el último sol”, "el alba”, "la sombra”, "la tarde”, "la penumbra”, son palabras e imágenes frecuentes en los textos de sus cuentos. ${ }^{1}$ Luz propicia (quizá porque "el fervor del día es intolerable" ${ }^{2}$ ) para otra lucidez, la intelectiva, y para los usuales artificios de inversiones (o trans-versiones) de términos, por las que Borges consigue despojar súbitamente de realidad todo el mundo que nos ha propuesto.

1.0. -SOMBRAS, Y LUZ

El Aleph ${ }^{3}$ atiene sin embargo varios cuentos en los que la penumbra del espacio ficticio se ilumina de pronto con un contraste de luz intensa.

1.1 - En "El inmortal”, el romano Flaminio Rufo transita por siglos y generaciones en un mundo de sombra; cuando pierde a sus soldados, por ejemplo, el escenario es "la vasta noche”: "En el desierto los perdí, entre los remolinos de arena y la vasta noche”. ${ }^{4}$ Pero en seguida aparece el contraste, paroxismo de luz que inicia en el cuento el paroxismo temporal: "Varios días erré sin encontrar agua, o un solo día multiplicado por el sol, por la sed, y por el temor de la sed”. ${ }^{5}$

1.2 - En otro cuento, también de El Aleph, "La escritura del dios”, el personajenarrador, “yo, Tzinacán, mago de la pirámide de Qaholom”, ha “perdido la cifra de los años que yazgo en la tiniebla” . ${ }^{6}$ Pero hay en esa tiniebla un agujero de luz, en contraste simultáneo y ya no sucesivo como el anterior:

En la hora sin sombra [el mediodía], se abre una trampa en lo alto y un carcelero que han ido borrando los años maniobra una roldana de hierro, y nos baja, en la punta de un cordel, cántaros de agua y trozos de carne. La luz entra en la bóveda; en ese instante puedo ver el jaguar. ${ }^{7}$

Durante los largos años de su cautiverio, Tzinacán trata de encontrar y de descifrar la sentencia mágica que el dios “Nadie sabe en qué punto la escribió ni con qué caracteres, pero nos consta que perdura, secreta, y que la leerá un elegido”. 
Al final del cuento, después del sueño revelador de su circunstancia ineludible ("Más que un descifrador o un vengador, más que un sacerdote del dios, yo era un encarcelado”), Tzinacán despierta en la tiniebla y el resplandor: "Un resplandor me despertó. En la tiniebla superior se cernía un circulo de luz”. ${ }^{9}$ Su resignación dice entonces: "Bendije su humedad, bendije su tigre, bendije el agujero de luz, bendije mi viejo cuerpo doliente, bendije la tiniebla y la piedra" ${ }^{10}$

1.3. - En “La casa de Asterión” el contraste de sombra y luz es sucesivo en la estructura textual, pues contribuye a separar distintamente las dos partes del cuento; también es, aparentemente, en el mundo ficticio del cuento, cronológicamente sucesivo. Pero en la visión totalizadora, al final de la lectura, luz y sombra coexisten, simultáneas, como se verá: es esta coexistencia la que me propongo interpretar, como reflejo especular la sombra de la luz.

\section{0. - SOMBRAS Y LUZ, EN "LA CASA DE ASTERION"}

2.1 - Mientras habla yo-Asterión, en la primera parte, las imágenes propuestas por el texto (“algún atardecer”, “antes de la noche”, “ya se había puesto el sol’, “una visión de la noche”) confieren a ese mundo ficticio aquella luz incierta tan propia del espacio imaginario de Borges. El único color nombrado es el gris: yo-Asterión pasa infinitas veces, o ha pasado, por "polvorientas galerías de piedra gris” (69).

2.2 - La imagen de luz inunda la segunda parte, brevísima, que con sólo cuatro líneas escasas contrarresta, por su intensidad, el aparente desequilibrio textual con la anterior:

El sol de la mañana reverberó en la espada de bronce. Ya no quedaba ni un vestigio de sangre.

—¿Lo creerás, Ariadna? -dijo Teseo- . El minotauro apenas se defendió.

Aunque fugaz, la imagen tiene una gravitación fundamental en el texto, sobre todo porque coincide con el momento de la revelación, para el lector, de la identidad del minotauro. Pero quisiera subrayar aun más la trascendencia de ese momento de luz, y postularlo como centro donde se condensa, y desde donde, aunque textualmente anterior, se genera en un reflejo especular (o por lo menos se vuelve a generar con un nuevo sentido) todo el mundo ficticio del cuento: otro ejemplo de la técnica de sorpresiva inversión (o transversión) que Borges tan asiduamente hace transitar aun a sus más prevenidos lectores.

3.0. -EL MUNDO ESPECULAR DE ASTERION

3.1 - A medida que el texto se desenvuelve en un monólogo en primera persona ("yo, Asterión”), el espacio ficticio se va desplegando a partir de un centro, el yo, o mejor dicho, la convicción de un yo incluido en la expresión de su convicción: "Sé”, la primera palabra del texto. ${ }^{11}$

El espacio ficticio se extiende progresivamente, en un mismo sentido horizontal aunque con dos dimensiones: “mi casa”, y afuera de ella, más allá, el mundo (la calle, 
el templo de las Hachas, el mar, Egipto), otro mundo, todo el mundo posible fuera de los límites inciertos de la casa pues no hay puertas cerradas que los marquen.

Hay entonces en "La casa de Asterión" tres categorías de espacio ficticio, incluidos e incluyentes, a partir del centro, sé (con el yo incluido en la desinencia verbal): 1) yo, 2) el mundo (la casa, mi casa), y 3) el otro mundo, el trasmundo, desvaído, extraño y ajeno, de límites totalmente inciertos:

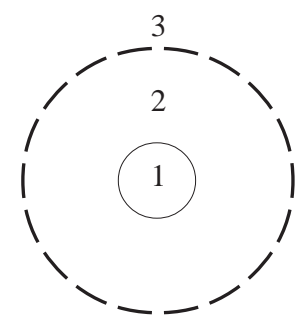

Las líneas de puntos que separan en el diagrama la casa del mundo exterior son infinitas, aunque, cito, “el original dice catorce”. ${ }^{12}$

En cualquier mención de los tres ámbitos, la misma ausencia de luz. Incidentalmente, la oposición entre la casa y el mundo está dada por la ausencia o presencia de ruidos.

Pero el centro de este espacio parece desdoblarse, o repetirse, en otro centro, ficción en la ficción: el otro Asterión, fingido en los juegos de yo-Asterión:

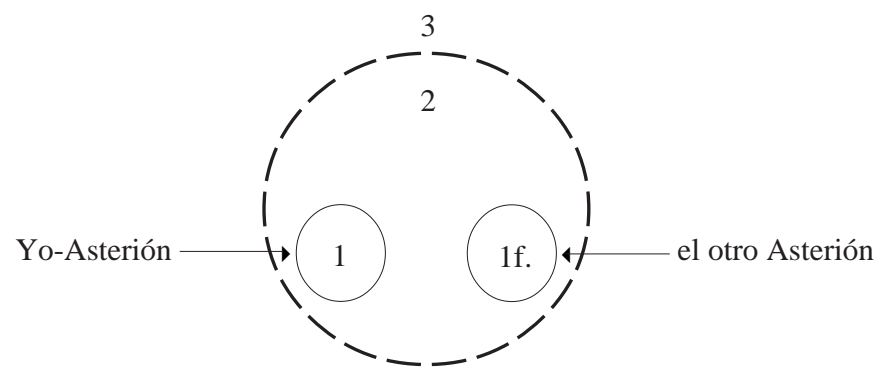

También en la casa se repiten los lugares (“cualquier lugar es otro lugar”); y en el trasmundo también son catorce, infinitos, los mares y los templos.

El espacio ficticio así creado se multiplica en sí mismo, como una esfera de espejos, a la vez en su lado cóncavo y en el convexo, semejante a la descripción del Zahir, el objeto que, en otro cuento también de El Aleph ${ }^{13}$ puede ser cualquier objeto, inolvidable con insistencia que lleva a la locura: 
El tiempo, que atenúa los recuerdos, agrava el del Zahir. Antes, yo me figuraba el anverso y después el reverso; ahora, veo simultáneamente los dos. Ello no ocurre como si fuera de cristal el Zahir, pues una cara no se superpone a la otra; más bien ocurre como si la visión fuera esférica y el Zahir campeara en el centro. ${ }^{14}$

O bien, en “El Aleph”, la descripción del Aleph, “uno de los puntos del espacio que contienen todos los puntos": ${ }^{15}$

El diámetro del Aleph sería de dos o tres centímetros, pero el espacio cósmico estaba ahí, sin disminución de tamaño. Cada cosa (la luna del espejo, digamos) era infinitas cosas, porque yo claramente la veía desde todos los puntos del universo. ${ }^{16}$

También en el mismo cuento se describe el espejo universal de Merlín, otro posible Aleph verdadero, "redondo y hueco y semejante a un mundo de vidrio". ${ }^{17}$

Vale decir, en el espacio ficticio de "La casa de Asterión” cada lugar es otro lugar, cada cosa infinitas cosas, porque se las mira desde diferentes puntos de vista simultáneos (el espejo esférico), o, y, porque cada cosa (y cada lugar) se multiplica en sí misma por ser a la vez la luna de un espejo autoenvolvente, otro espejo esférico:

3

2

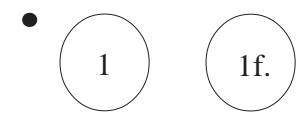

En resumen, el espacio ficticio es aquí un mundo especular: espejo el espacio, espejo las cosas y los lugares que constituyen el espacio.

Pero además del eje horizontal, hay también, en "La casa de Asterión”, otra dimensión espacial, el eje vertical: “Todo está muchas veces, catorce veces, pero dos cosas hay en el mundo que parecen estar una sola vez: arriba, el intrincado sol; abajo, Asterión”. ${ }^{18}$ Asterión sabe (o cree saber), que el otro Asterión es un juego fingido.

Se podría entonces completar el diagrama: 


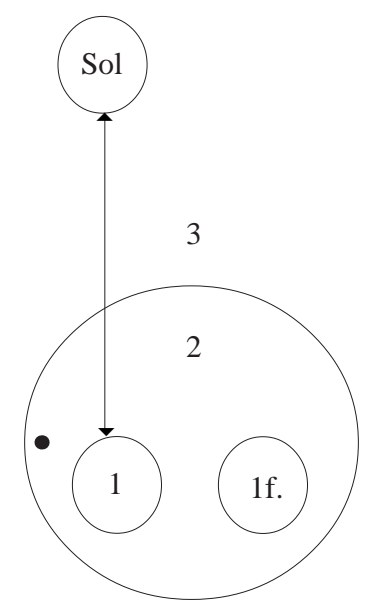

En este mundo multiplicado hasta el delirio, hay sin embargo, como dice Asterión, dos cosas que están una sola vez: Asterión (el otro Asterión es fingido), y el sol. Pero “Asterión” es también el nombre, o uno de los nombres (porque el lenguaje también especula), del sol. ${ }^{19}$ ¿Quién es entonces el verdadero Asterión? ¿O Asterión está no una sola vez, y abajo, como dice Asterión-yo, sino dos veces, una “arriba” y otra “abajo’T O solamente “arriba”, y entonces “abajo” no está Asterión? ¿Quién es, qué es, entonces, Asterión-yo? Quizá, sugiero, una imagen (¿especular?) del verdadero Asterión-sol.

3.2 - La segunda parte, brevísimo deslumbramiento del texto, trasciende a otro espacio (también hay un hiato gráfico que señala esa trascendencia) o al otro polo, en el eje vertical, del espacio ficticio. El punto de referencia es ahora el sol: "El sol de la mañana reverberó en la espada de bronce”.

La espada actúa aquí entonces como un espejo, pues en ella se refleja, reverbera, el sol; y la imagen reflejada surge en el mismo instante en que muere Asteriónminotauro y su mundo.

En la descripción mencionada anteriormente (nota 17), de otros Aleph posibles verdaderos, uno de ellos es precisamente "la lanza especular que el primer libro del Satyricon de Capella atribuye a Júpiter”. Al reverberar o reflejarse en la espada especular de Teseo, el solAsterión sugiere la imagen de un divino Narciso (y digo “divino" no tanto por dios, sino por “día”, o luz), sobre todo si se tiene en cuenta que una de las explicaciones para el mito de Narciso es la de que se trata de un mito solar, aunque generalmente asociado con el sol poniente, que muere reflejándose, como en un gran espejo cósmico, en el mar. ${ }^{20}$ Sólo que aquí la luna en la que Narciso se refleja ha transfigurado la connotación de muerte en la forma de una espada; muerte que es ahora también vida, pues en la misma espada que mata al minotauro el reflejo del sol 
finge, o genera, al verdaderamente otro Asterión, mera reverberación solar, que es el minotauro. Las palabras de Teseo a una tácita Ariadna, “el minotauro apenas se defendió”, son una afirmación de esa irrealidad: cómo podría defenderse un simple reflejo. ${ }^{21}$

Toman ahora también un nuevo sentido las palabras del minotauro: “Quizá yo he creado las estrellas y el sol y la enorme casa, pero ya no me acuerdo” (69): casi como si, a través del olvido, la conciencia del solAsterión hubiese traspasado a su reflejo, el minotauro-Asterión.

3.3 - El salto trascendental no ha sido meramente un salto espacial: ha sido la revelación del sol-Asterión verdadero-Narciso reflejándose en la espada, generando el reverbero que configura, o configuró, el mundo ilusorio, vano juego especular o vana especulación, de Asterión-yominotauro; de él, “ya no quedaba ni un vestigio de sangre”, sino el espejeo del sol en la espada especular, Aleph y Zahir a la vez.

Asterión-yo no sabía, o no sabrá (y el "Sé” inicial cobra ahora un sentido de ironía trágica) que “el otro Asterión” era, es, será, un juego, pero de espejos, y que ese juego es él mismo.

University of California, Santa Barbara

MARTA GALLO

\section{NOTAS}

1 No creo necesario identificar los ejemplos de estas ocurrencias: cualquier cuento suyo presenta, o bien una sola tonalidad (la crepuscular, anterior o posterior a la luz), o si no las sombras de la noche, o bien una gama completa entre esos dos extremos, sin pasar casi nunca por el brillo de una luz clara; como dice Ana María Barrenechea, "matices pálidos que aluden por su misma tenuidad a la disolución” (Barrenechea, 1957, p. 100).

2 "El inmortal", El Aleph, p. 9.

3 El Aleph, 1957.

4 “El inmortal”, p. 10.

5 Ibid.

6 "La escritura del dios", p. 115.

7 Ibid.

8 "La escritura..., p. 116

9 "La escritura..., p. 119.

${ }^{10}$ Ibid.

11 Anderson Imbert llama ya la atención sobre ese "sé" (Anderson Imbert, 1960).

12 Maimónides (Moise Ben Maimun, 1964), hablando del libro de Isaías, XXX, 19 y 26 (sobre todo 26), observa: "Quant á ces mots: comme la lumiére des sept jours, les commentateurs disent gdil veut indiquer par lá la grande quantité (de lumiére); car les Hébreux mettent sept pour un grand nombre” (Moise Ben Maimun, 1964, Deuxiéme partie, chap. XXIX, p. 215). Catorce, duplicación de siete, podría ser un juego especular de números. Hastings (1928) s.v. Numbers, señala el origen semítico del siete como número sagrado; razones astronómicas y astrológicas señalan el siete (siete planetas, mes lunar formado por cuatro periodos de siete 
días, etc.). El tres y el nueve son en cambio números sagrados arios. Hastings señala que el siete, por influencia semítica, ha remplazado a veces al nueve. Borges hace el remplazo inverso cuando cambia el número de víctimas sacrificadas al minotauro, de siete (según las fuentes clásicas del mito), a nueve.

13 "El Zahir", El Aleph, pp. 103-114.

14 "El Zahir", p. 113.

15 “El Aleph”, p. 160. Sobre el aleph dice Scholem (1965), en p. 30: "For in Hebrew the consonant aleph represents nothing more than the position taken by the larynx when a word begins with a vowel. Thus the aleph may be said to denote the source of all articulate sound, and indeed the Kabbalists always regarded it as the spiritual root of all other letters, encompassing in its essence the whole alphabet and hence all other elements of human discourse.” Todo lo que sea posible Aleph en Borges toma así el sentido de principio generador.

16 "El Aleph", p. 164.

17 "El Aleph”, p. 168. El pasaje de Spenser al que se refiere Borges es el siguiente: "For thy it round and hollow shaped was,/Like the world it selfe, and seem'd a world of glass." (Spenser (1909), III, 2, 19).

18 “La casa de Asterión”, p. 69.

${ }^{19}$ Apollodorus, 1921, dice en III, 4, “nace Asterios, que se llamó Minotauro.” Ana María Barrenechea señala el cambio del texto en el epígrafe de "La casa de Asterión”. (Barrenechea, 1957, p. 73) Anderson Imbert da el resumen de los pasajes pertinentes de La biblioteca. (Anderson Imbert, 1960). Apolodoro da el número de víctimas del minotauro: siete muchachos y siete muchachas. (Apollodorus, 1921, III, XV, 8). En 7-11, se cuenta cómo Teseo mató al minotauro con los puños: otra alteración hecha por Borges. Además, en nota a pie de página se señala que según los escoliastas, Teseo encuentra al minotauro dormido. La primera parte de "La casa de Asterión” podría ser entonces, además, un sueño del minotauro en el preciso instante de su muerte.

${ }^{20}$ Bachelard, 1942, passim.

${ }^{21}$ Debo esta última observación a un comentario del profesor Jorge de Sena. Hay otros ejemplos de trans-versiones que el texto plantea, como el de la redención que es muerte también; o el de la redención del minotauro (quizá un dios) por el hombre: en fin, reflexiones sobre los personajes. En todos estos aspectos, vemos, como dice Jaime Alazraki, “el lenguaje usado como instrumento de un juego que, como todo juego, genera una realidad ficticia que cancela o reemplaza la histórica” (y yo agregaría, la histórica también ficticia) (Alazraki, 1974, p. 278).

\section{BIBLIOGRAFIA CITADA}

Alazraki, Jaime, 1974. La prosa narrativa de Jorge Luis Borges. Madrid: Gredos. Anderson Imbert, Enrique, 1960. "Un cuento de Borges: 'La casa de Asterión””. Revista Iberoamericana, 25 (1960), 33-43.

Apollodorus, 1961(1921). The Library. Cambridge, Massachusetts: Harvard University Press, London: William Heinemann Ltd. Traducción inglesa de Sir James George Frazer, 1921. 
Barrenechea, Ana María, 1957. La expresión de la irrealidad en la obra de Jorge Luis Borges. México: El Colegio de México.

Bachelard, Gastón, 1942. L'eau et les rêves. Paris: Librairie José Corti.

Hastings, James, 1928. Encyclopaedia of Religion and Ethics. New York: Charles Scribner's Sons.

Moise Ben Maimun, dit Maïmonides, 1964. Dalalat Al Hairin, Le guide des égarés. [Edición crítica, S. Munk, reimpresión fotomecánica de la edición de 185618661 Osnabrück: Otto Zeller. T. II.

Scholem, Gershom G., 1964. On the Kabbalah and its Symbolism. New York: Schocken Books [Trad. de la edición alemana de Zurich, 1960].

Spenser's Faerie Queene, Edited by J.C. Smith, vol. 1. Oxford: Clarendon Press, 1909. 


\section{Borges y el Arte de la Dedicatoria}

A Borges debemos la elevación del prologo y del auto-prologo a la categoría de obras de arte. A esta deuda hay que agregar otra: el aporte de una pieza maestra al incipiente género de la dedicatoria en letra impresa. Existe una recopilación de prólogos de Borges, a los que el escritor argentino ha puesto un "Prólogo de prólogos”. ${ }^{1}$ No sería extraño que se publicara un libro constituido solamente por dedicatorias memorables, apócrifas o no, destinadas a personajes reales o inexistentes. Como ese hipotético libro aún no ve la luz, analizaremos una de las dedicatorias dignas de figurar en él. La que Borges puso al frente de El hacedor. ${ }^{2}$

Toda dedicatoria es una estructura morfológica, una Forma en la que entran en juego cuatro elementos: el que ofrece la dedicatoria (dedicante), el que la recibe (dedicatario), el objeto dedicado y la razón que la motiva. Estos elementos pueden estar in praesentia o in absentia, pero siempre existen virtualmente. La concreción más elemental del género tiene un mínimo de palabras: las preposiciones "a” o "para” y el nombre del dedicatario. A partir de esa fórmula, infinidad de variaciones y amplificaciones son posibles, desde el epigrama hasta el cuento, el poema o el ensayo breve. Teóricarnente es concebible una Forma mayor cuya estructura básica fuera la de la dedicatoria.

Aunque la forma elemental del género es también empleada por Borges en El hacedor, lo cierto es que la dedicatoria no acaba allí: la formulación funciona como el título de un texto que se despliega en seguida. Lo primero que llama la atención en ese texto es el hecho de que todo lo que en una dedicatoria corriente suele ser virtual o figurado, en la de Borges se transforma en acontecimiento, por actualización de lo virtual y por lateralización de lo figurado. El dedicante, que en la mayoría de las dedicatorias o queda sobreentendido o se explicita mediante la sola mención de su nombre, adquiere aquí corporeidad: se vuelve personaje. Lo mismo ocurre con el dedicatario: ya no es un mero nombre propio sino la figura sensible de Leopoldo Lugones. En cuanto a la acción de dedicar, que tiene el sentido figurado de "dirigirse a” o de "tomar la dirección de", deviene literal: Borges se dirige al despacho de Lugones y le entrega, imaginariamente, un ejemplar de El hacedor. La razón que 
motiva la dedicatoria no es explicitada: el hecho mismo de dedicar implica un tributo, un homenaje. (No excluyo la posibilidad de que se escriban anti-dedicatorias; pero no es éste el caso).

En el plano de la composición del texto se distinguen tres unidades de sentido. La primera se inicia con el verbo “entrar”, en tiempo presente: “Los rumores de la plaza quedan atrás y entro en la Biblioteca”; la segunda empieza con la misma forma de ese verbo: "Estas reflexiones me dejan en la puerta de su despacho. Entro;...”, y se prolonga hasta que el hablante “despierta”. ${ }^{3}$ Desde aquí hasta la última línea de la dedicatoria se extiende la tercera unidad.

Al empezar la narración, el hablante ha abandonado el espacio abierto, ruidoso, anárquico, profano de una plaza y ha ingresado en el espacio cerrado, silencioso, simétrico, sagrado de la Biblioteca donde esta el escritorio de Lugones. Y es como si entrara en un templo. Su avance, flanqueado por lectores que más que leer parecen meditar, es también una travesía hacia el sitio del ofertorio. Recordemos que el verbo “dedicar” tiene connotaciones religiosas que lo ligan al acto de la consagración. Sólo en el "ámbito sereno de un orden” encuentra el hablante la tranquilidad espiritual para la ejecución de su empresa.

En medio de los dos hitos verbales ya mencionados se desarrollan las reflexiones del hablante, que tienen la función de presentar el paso del tiempo, desde su entrada a la Biblioteca hasta el final de la travesía, temporalidad que el lector experimenta como vivencia. Las reflexiones están distribuidas en dos series. La primera puede desglosarse así: "De una manera casi física siento”: a) "la gravitación de los libros”, b) “el ámbito sereno de un orden”, c) “el tiempo disecado y conservado mágicamente”. Como refuerzo del significado mismo de esas frases, la construcción paralelística y la bien proporcionada enumeración de complementos directos, ejercen el rol de significantes que, desde otro ángulo, denotan la cosmovisión que preside el texto: la de un espacio y un tiempo sujetos a la simetría, al equilibrio, al orden, cuyo modelo ideal es la Biblioteca con sus estantes alineados, sus fichas y clasificaciones, y cuya forma de expresión es una prosa que también se caracteriza por la simetría, el equilibrio y el orden. Estas cualidades son perceptibles en todos los niveles de la escritura.

En el plano del enunciado hay pares simétricos en los participios referidos al vocablo "tiempo": “disecado y conservado"; en los adjetivos que determinan al sustantivo "palabras”: “convencionales y cordiales” (en los dos casos hay igualdad morfológica y fónica de los morfemas); y en las paronomasias "Recuerdo haber recordado" y "le habría gustado que le gustara”, donde la acción representada por el verbo principal se duplica en la frase sustantiva. Algo análogo sucede con la comparación “como el agua en el agua”. En todas estas frases el eje de simetría es un elemento de valor gramatical.

Los personajes que flanquean al hablante comparten también la misma condición: ser absortos lectores. Se podría argüir que si son iguales y múltiples no es adecuado 
hablar de pares simétricos, porque esa idea implica la de eje que separa en dos partes análogas. La respuesta es simple: el hablante, al atravesar por el pasillo central, actúa como eje y “corta” la Biblioteca en mitades que tienen rasgos recíprocos. Así lo deja ver la perspectiva desde la que se refiere al contorno: “A izquierda y a derecha, absortos en su lúcido sueño, se perfilan los rostros momentáneos de los lectores”.

Después del hermoso oxímoron por el que llama a la enajenación producto de la lectura un "lúcido sueño", empieza la segunda serie de reflexiones, que se origina en la frase “se perfilan los rostros momentáneos de los lectores”. En lenguaje no figurado diríamos: "se perfilan momentáneamente los rostros de los lectores”. El desplazamiento de la momentaneidad, desde "se perfilan" hasta "rostros" indica que se trata de la figura literaria denominada hipálage. Y lo notable es esto: inmediatamente después, por una especie de asociación mental, señala que los rostros se perfilaban "a la luz de las lámparas estudiosas”; y agrega: “como en la hipálage de Milton”. La mención de esa figura retórica lo lleva a citar otras dos hipálages memorables: el "árido camello” del Lunario sentimental, de Lugones, donde el adjetivo “árido” ha sido desplazado desde la idea de “desierto”, y el hexámetro de la Eneida: Ibant obscuri sola sub nocte per umbras ( $\mathrm{Sic}$ ), en el que se producen dos hipálages cruzadas: obscuri, que debería corresponder a nocte (obscura nocte) es aplicado a los caminantes, y sola, que debería corresponder a los caminantes (Ibant soli) es aplicado a nocte ${ }^{4}$

Las de la segunda serie son entonces reflexiones en el sentido etimológico de la palabra. El lenguaje, después de exhibir sus procedimientos, se vuelve sobre sí mismo: el pensamiento del hablante se centra en el pensamiento del hablante. Desde otra perspectiva, la distancia entre la obra de creación y la exégesis de esa obra queda anulada: el crítico es el creador y el creador es el crítico. Círculo literal y figuradamente vicioso, análogo al acto de Onán, en el que el gozador y lo gozado son uno. El sujeto es el objeto; el otro es él mismo. Simetría en movimiento.

La segunda unidad de la composición presenta el acto material de entrega del libro a Lugones. La mayor parte de esta unidad es una especie de -valga el oxímorondiálogo unilateral, en el que la muda y casi fantasmal figura del dedicatario es fundada por un vocativo, por los respetuosos "usted” y por las particular morfemáticas de los verbos; síntomas todos de un lenguaje en función conativa; conación meramente retórica, que se presta para ser combinada con fragmentos de narración en segunda persona: “pero esta vez usted vuelve las páginas y lee con aprobación algún verso...”. La primera unidad de la composición, en cambio, se configuraba a partir del discurso del hablante puesto en función referencial. El parlamento del diálogo unilateral es instalado en el cauce del discurso con tal habilidad, que el paso desde una función lingüística a otra, sin previo anuncio, es casi imperceptible. ${ }^{5}$

A través de la narración en segunda persona se nos informa que el dedicatario no sólo recibe el libro, sino que lo hojea “y lee con aprobación algún verso”; porque lo que Borges le ha entregado a Lugones no es, claro esta, "un volumen, un prisma de seis caras rectangulares”, sino un libro, es decir “una expresión o una concatenación de 
expresiones”. ${ }^{6}$ De los motivos que Borges atribuye a la aprobación de su libro por el poeta del Lunario, nos interesa subrayar uno: la hipótesis de que (acaso) Lugones “en él ha reconocido su propia voz”. Este reconocimiento se inserta en el proceso de igualación que avanza hacia la simetría absoluta de los rasgos relevantes de Borges y Lugones. En Lugones esos rasgos son: su condición de escritor, de bibliotecario y de persona muerta. Borges comparte con él los dos primeros rasgos, dibujando así una figura parcialmente simétrica, incompleta en relación con la de Lugones. La simetría total sólo puede producirse con la muerte de Borges. Entonces sus aguas habrán alcanzado el mismo nivel y se mezclaran. Estas ideas se vinculan con la noción del "yo plural" expresada en el "Poema de los dones". La pluralidad de ese yo admite la posibilidad de que los contrarios, como Aureliano y Juan de Panonia (cuyas diferencias no interesan en el reino de los cielos), y los análogos, como Groussac y Borges, o como éste y Lugones, no sean sino versiones del mismo Ser. ${ }^{7}$

En la última unidad de la dedicatoria se desmorona todo lo que se ha edificado hasta ese momento: las dos primeras unidades son desmanteladas por el hablante al equipararlas a lo ilusorio: "En este punto se deshace mi sueño como el agua en el agua” ${ }^{8}$ El espacio de la irrealidad había sido el lugar en el que la biblioteca de Borges y la de Lugones, ubicadas en las calles México y Rodríguez Peña, respectivamente, coincidían para dar origen a la Biblioteca. La labor de desmantelamiento se basa en la des-irrealización de los factores claves: el ámbito deja de ser la Biblioteca irreal y vuelve a ser la biblioteca "real” de la calle México. Pero de la des-irralización de Lugones sólo puede surgir su vacío, su ausencia definitiva, “porque se mató a principios del treinta y ocho” y el encuentro con Borges se imagina verificado muchos años después. A su nostalgia y a su vanidad achaca Borges el haber armado esta “escena imposible”. ¿Por qué a su vanidad? En la obra de Borges es frecuente que todo lo que está hecho con la materia de los sueños -el mundo, la literatura, los hombres, las imaginaciones- aparezca ligado al tópico de vanitas vanitatum. La conciencia de la vanidad se hace presente cuando aquello que el hablante creía sólido, consistente, capaz de enfrentarse a las pobrezas de la realidad cotidiana como otra realidad mucho más rica, resulta ser, en rigor, efímero, evanescente, mero simulacro. La consecuencia de esa comprobación es el repliegue del hablante hacia la humildad del mundo real, hacia la biblioteca de la calle México, donde esos encuentros anacrónicos no son posibles. En este punto literalmente desilusionante, Borges da otra vuelta de tuerca.

Desestimadas la irrealidad, por su condición derivativa y fugaz, y la realidad cotidiana, por su inadmisión de lo imposible, Borges recurre al único sitio de encuentro que se levanta por encima de esas limitaciones: el espacio de la muerte. Es la muerte el ámbito infinito donde lo contradictorio deja de existir como tal y los tiempos individuales se disuelven en el Tiempo de "los Arquetipos y Esplendores". 9

En este texto biblio-maníaco en el que un escritor y bibliotecario, rodeado de libros y de lectores, entrega un libro a otro escritor y bibliotecario, en el recinto de una Biblioteca, el autor de Ficciones vuelve a abrumarnos con el sentimiento de lo 
infinito. A medida que leemos su dedicatoria, vamos poniendo en movimiento las acciones representadas y colaborando en la fundación del mundo ficticio. Entre los varios objetos mentados en él se incluye el libro cuya dedicatoria estamos leyendo. En ese cosmos Borges cumple con las sucesivas instancias que culminan con la entrega del libro a Lugones. En la dedicatoria de ese libro están impresas las sucesivas instancias que culminan con la entrega de ese libro a Lugones. ${ }^{10}$ En este punto el vértigo ya se ha desencadenado. Existe primero el volumen de El hacedor en el que leemos la dedicatoria de Borges; en ella aparece Borges con un ejemplar de El hacedor; una dedicatoria en la que figura El hacedor, y así ad infinitum. Infinitos Borges dedican infinitos libros a infinitos Lugones. Non plus ultra: la primera obra maestra del género de la dedicatoria puede ser también la última.

University of Maryland

OSCAR A. HAHN

\section{NOTAS}

1 Véase: Jorge Luis Borges, Prólogos, Buenos Aires, Torres Agüero, 1975.

2 El hacedor, Buenos Aires, Emecé, 1960, pp. 7-8. Como “A Leopoldo Lugones” ocupa sólo una página y media, me abstengo de repetir en cada cita de la dedicatoria el número de la página pertinente. Sólo cuando cito de otras fuentes indico la procedencia mediante una nota. La dedicatoria a Lugones ha aparecido posteriormente en El otro, el mismo, libro incluido en Obra poética, Buenos Aires, Emecé, 1966, pp. 131-289. En El hacedor la dedicatoria está fechada en Buenos Aires, 9 de agosto de 1960. En El otro, el mismo la fecha ha sido omitida.

3 Todos los subrayados son míos.

4 Con la ayuda del "Verbal Index" que aparece en Milton's Poetical Works, New York: Amss Press, 1970, he buscado sin éxito en la obra de Milton la frase en inglés equivalente a "lámparas estudiosas". La más cercana es la hipálage "officious Lamps", Paradise Lost (Book IX), verso 104. Es posible que no se trate de una cita textual y que la referencia sólo aluda al empleo de la hipálage a partir del elemento "lámpara”, a la manera de Milton. La hipálage de Lugones surge del siguiente contexto: "Y el corazón marcha con su pena oscura / como árido camello con su carga”. Véase el poema “Luna marina” de Lunario sentimental, libro incluido en Obras poéticas completas, Madrid, Aguilar, 1959, pp. 280-283. En todas las ediciones de El hacedor y de El otro, el mismo que he revisado, la cita del verso 268 de la Eneida, repite la misma errata: umbras, en lugar de umbram. Véase el texto latino en: Virgil, Aeneid VI, edited with introduction and commentary by Sir Frank Fletcher, London, Oxford University Press, 1951, p. 8.

5 Me refiero a las funciones del lenguaje según las distinciones que hace Roman Jakobson en "La lingüística y la poética”, en Thomas A. Sebeok et. al., Estilo del lenguaje, Madrid, Cátedra, 1974, pp. 125-173. Jakobson describe seis funciones: referencial, emotiva, poética, conativa, fática y metalingüística, según predomine en el discurso, respectivamente, el contexto, el hablante, el mensaje, el oyente, el contacto o el código.

${ }_{6}$ Las dos citas corresponden a J. L. Borges, Evaristo Carriego, Buenos Aires, Emecé, 1965, p. 53. 
7 Véanse las tres últimas estrofas del "Poema de los dones” en Obra poética, pp. 174-175, y "Los teólogos” en El aleph, Buenos Aires, Emecé, 1966, pp. 35-52.

8 En el soneto "Lectores" de Obra poética, p. 225, Borges conjetura, paralelamente, que don Quijote "no salió nunca de su biblioteca” y que la crónica que narra sus aventuras fue soñada por el ingenioso hidalgo.

9 Estas palabras proceden de J. L. Borges, “Baltazar Gracian”, en Obra poética, p. 164.

10 Se trata del mismo procedimiento que Borges denomina "elevaciones a potencia del sumo" cuando se refiere al cuento dentro del cuento, a propósito de la noche 602 de Las mil y una noches, y a la escena dentro de la escena, a propósito de Hamlet, en "Los traductores de las 1001 noches”, Historia de la eternidad, Buenos Aires, Emecé, 1966, p. 133. 


\section{Borges, Carpentier y Ortega: Dos Textos Olvidados}

De los escritores modernos en lengua española, Borges, Carpentier y Ortega son de los que más se han preocupado por la relación entre la literatura hispánica y la de Occidente, y de los que más han servido de “traductores” de lo escrito en otras lenguas. Leer a Ortega hoy en su contexto, como ha hecho con admirable minuciosidad Ciriaco Morón Arroyo, es dibujar el mapa del pensamiento europeo contemporáneo. ${ }^{1} \mathrm{La}$ importancia de la labor de Ortega estriba sobre todo en haber diseminado y re-escrito la filosofía alemana en términos hispánicos, poniéndola al alcance de literatos españoles e hispanoamericanos; de ahí el interés de los textos de Borges y Carpentier sobre Ortega que reproducimos en esta nota.

El artículo de Carpentier da amplia noticia del impacto que tuvo Ortega en América en la época de las vanguardias, no sólo con su propia obra, sino con las que inspiró a otros a escribir o traducir. En muchos sentidos el periodismo de Carpentier, del que procede el artículo en cuestión, está determinado por el de Ortega. Erudito como pocos, Carpentier practica un periodismo culto, refinado, al estilo del de Ortega, sobre todo en las crónicas “Desde París,” que publicó por espacio de más de diez años en el semanario ilustrado habanero Carteles. ${ }^{2}$ El parecido no reside simplemente en el tono sino en el método mismo: como Ortega, Carpentier quiere sorprender, en las minucias de lo cotidiano, de lo efímero, temas de vasto alcance estético, histórico y filosófico. Ambos cultivan un cierto diletantismo, pasando de lo efímero a lo trascendental con una superficialidad muchas veces ilusoria. Borges es muy distinto en el estilo, aunque también ha practicado a veces ese mismo tipo de periodismo. Pero tanto Ortega como Carpentier y Borges desempeñan labores similares: insertar en la lengua española diálogos iniciados en otras. La referencia a “diálogo español” en el texto de Borges que aquí se reproduce no hay que tomarla al pie de la letra; el diálogo que Ortega inició fue hispánico.

La boga existencialista que promovió el propio Ortega en un momento dado de su carrera, hace difícil hoy calibrar la importancia de ese diálogo, y mucho más difícil situarlo históricamente. ${ }^{3}$ El esfuerzo por destacar la debatible primacía de Ortega en 
esa tendencia filosófica conduce a una lectura anacrónica de la obra total del filósofo: se lee a todo Ortega en función del tan (mal) llevado y traído concepto del “yo y mi circunstancia.” Pero el Ortega existencialista no es el importante para el diálogo hispánico de que hablamos al referirnos a Borges y Carpentier. El Ortega crucial para ese diálogo es el de los años veinte, que enfrenta, en español, a Hegel y Spengler, y reinicia así la polémica sobre la universalidad o particularidad de la cultura hispánica. Ya en otra ocasión me he ocupado de este tema con más espacio. Baste añadir a lo dicho que uno de los primeros libros de Borges, Historia universal de la infamia, moviliza en su título tres términos de claras resonancias hegelianas. ${ }^{5}$ ¿No es Historia universal de la infamia una parodia de la Filosofía de la historia?

La diferencia fundamental entre Borges, Ortega y Carpentier es, pues, la manera en que se insertan en el diálogo con la cultura occidental. En Ortega bulle siempre el deseo de hacer universal la cultura hispánica, aunque el cómo hacerlo varía en diversos momentos de su obra. El estilo de Ortega, que Borges crítica en su nota y Carpentier alaba en la suya, es el signo más evidente de ese deseo de universalidad. Ortega hispaniza con éxito notable todo un lenguaje filosófico de ascendencia alemana. Pero Ortega escribe como si el español no fuese, desde el siglo XVIII, una lengua marginada de esa tradición filosófica, por eso el tono artificial que a veces tiene su prosa. El cosmopolitismo estilístico de Ortega flota en el vacío filosófico hispánico de más de dos siglos; es una flor de invernadero, toda una metáfora que encubre precisamente la falta de tradición filosófica en español.

Borges acepta la marginalidad. Su estrategia en ese diálogo que mencionamos es escribir como si lo hiciera desde dentro de la tradición occidental, pero sólo para minarla, reduciéndola a fragmentos dispersos. En español, parece decirnos Borges, sólo podemos escribir comentarios, glosas, notas; pero tal vez la cultura occidental misma no sea otra cosa, si ésta es reductible a fichas de un diccionario o una enciclopedia. El modelo estilístico de Borges -la parquedad antirretórica inglesa- es de por sí un indicio de cómo se inscribe el argentino en la tradición occidental. Inglaterra representa la marginalidad dentro de Occidente, un escepticismo casi programático ante los vastos sistemas de pensamiento continentales, moldeados en la horma de la retórica clásica.

Carpentier pasa por varias etapas: una en que opone lo nativo americano a lo europeo, otra en que intenta rescatar toda una conciencia americana autóctona que es producto de las fusiones de culturas que se dan en el Nuevo Mundo, y por último, otra en que esa fusión no es origen, sino condición permanente, nunca sintética, amalgama de jirones y retazos. ${ }^{6}$ Lo más interesante de Carpentier en este respecto es su "lucha amorosa” con la tradición occidental, particularmente la francesa. El estilo arcaizante y recargado de Carpentier es un rechazo de la Modernidad, motivado paradójicamente por el pensamiento moderno. Hay una simetría inversa entre la austeridad estilística de Borges y el derroche verbal de Carpentier: en Borges hay una metonimia sistemática de toda la cultura, en Carpentier un esfuerzo por crear una metáfora total 
de ésta. En Borges los elementos de la cultura son fragmentos, partículas enlazadas por una contigüidad arbitraria y delirante que alude a un todo cuya existencia niega. En Carpentier el todo existe por acumulación de elementos que son cada uno como los otros hasta converter la totalidad en conglomerado, en amalgama. La pretensión de sistema en Carpentier y el carácter metafórico de su escritura lo hace más aún a Ortega; sólo que la escritura orteguiana es Neoclásica, con giros de academia, mientras que la de Carpentier pretende ser pre-académica, es decir, barroca.

Los dos textos que reproducimos aquí fueron escritos a raíz de la muerte de Ortega en 1955. El de Carpentier apareció en “Letra y Solfa,” columna que publicó case diariamente en El Nacional de Caracas entre 1950 y $1960 .{ }^{7}$ Carpentier se había referido a Ortega y a la Revista de Occidente en otras ocasiones en su columna, en términos similares. Más recientemente, dada su propia evolución política, y recordando tal vez la del filósofo, Carpentier ha negado case todo lo escrito en 1955. Pero ese texto (y otros de los años veinte) es terminante. ${ }^{8}$ La nota de Borges fue escrita en respuesta a la petición de José Rodríguez Feo, director de la revista Ciclón, y fue incluida en el número dedicado al filósofo en ocasión de su muerte. Es probable que la postura tan negativa de Borges ante Ortega obedezca, además de a los factores que él confiesa, a las polémicas que suscitó este con su viaje a la Argentina y las opiniones que luego expresó sobre la vida intelectual en ese país. ${ }^{9}$ La preferencia de Borges por Unamuno, por otra parte, parece ser típica de los escritores hispanoamericanos. Vasco, Unamuno exhibía una marginalidad problemática con respecto a lo español, a la que no podían ser insensibles los hispanoamericanos; no se permitía, además, el paternalismo de que a veces adolecía Ortega, y su interés por lo hispanoamericano era más genuino. Aún así, pese a las divergencias y los rechazos, la influencia de Ortega fue de mayor alcance que la de Unamuno. 


\section{ORTEGA Y GASSET}

Con motivo de la muerte de José Ortega y Gasset, otros, más especializados en el estudio de su pensamiento - tal Juan David García Bacca, que ya le consagró un enjundioso estudio en su libro Nueve Grandes Filósofos contemporáneos y sus temas- hablarán del filósofo y también del escritor que manejó la prosa castellana con señera maestría. "Inagotable” -como decía Novalis que es todo hombre granderesultará Ortega y Gasset para quienes, en estos días, emprendan el análisis de su obra múltiple -obra “a la que nada humano fuera ajena,” parafraseándose, en tal caso, la noble frase renacentista [La frase es de Terencio]. Por lo mismo, permaneciendo en el terreno personal de mis recuerdos, creo oportuno evocar hoy lo que significó Ortega y Gasset para los hombres de mi generación, en América Latina, y no sólo por sus libros, sino también por sus actividades de animador y de informador -por sus tareas de maestro, en suma, cuyo relumbre los alcanzaba en esta orilla del Océanohaciéndoles cobrar conciencia de la época en que vivían, con el conocimiento de las modernas corrientes de ideas y de las inquietudes nuevas que surgían en el campo de la literatura y de la política.

Algo provinciana era nuestra cultura, hacia los años 25, cuando los escritos de Ortega y Gasset comenzaron a circular en América. Nos habíamos quedado un tanto rezagados, en cuando (a) la vida intelectual francesa, demorando en un terreno muy dominado por autores que los hombres de la post-guerra desechaban. En lo que se refería al pensamiento filosófico alemán, permanecíamos en los días anteriores a la contienda de 1914. De la nueva literatura rusa, nada sabíamos. Y en lo que se refería a España, no eran los escritores más representativos de una generación nueva -que mucho habría de darnos- los que llegaban a las librerías de América, sino más bien aquellos que mejor podían contribuir a darnos una falsa idea de lo que entonces ocurría en Madrid ...Primero descubrimos los ensayos recogidos en los tomos de El Espectador, antes de pasar a La España Invertebrada, La Rebelión de las masas, y otros libros que ejercieron pronto, sobre nosotros, una suerte de fascinación. Algunos advertían, acaso, que ciertos conceptos fijados en La Deshumanización del Arte, cierta teoría (“concentración hacia (a)fuera, concentración hacia (a)dentro”) expuesta en Musicalia, eran contrariados a veces por el rápido desarrollo de las tendencias artísticas del momento, siempre modificadas por algún viraje imprevisto. Pero, en esos libros, en esos ensayos, se nos hablaba de lo que queríamos saber; eran "temas de nuestro tiempo," los que eran tratados por Ortega y Gasset. Lo que equivalía a decir: los que más nos apasionaban, los que más contribuían a que cobráramos conciencia de los problemas destinados a afectarnos directamente. Nada de lo que nos concernía era soslayado, y aún cuando comenzáramos a discutir ciertas ideas del maestro acerca del arte, la discusión nos dejaba enriquecidos, situados en un terreno de entendimiento común, por cuanto eran esos los problemas y no otros los que caracterizaban la época que nos tocara vivir. 
La [sic] Revista de Occidente, fue, durante años, nuestro faro y guía. Estableció un nuevo orden de relaciones intelectuales entre España y América Latina-relaciones de las que surgieron empresas tan fecundas como la "Institución Hispano-Cubana de Cultura,” que presidía Don Fernando Ortiz. Sus páginas eran ventanas abiertas sobre todo un pensamiento, ayer ignorado de quienes no fuesen lectores especializados, que se nos mostraba por vez primera. ¿Cuántos autores alemanes, ingleses, franceses; cuantos filósofos; cuantos historiadores del arte, no conocimos gracias a $\mathrm{La}$ [sic] Revista de Occidente, cuyas entregas nos revelaban, además, los nombres de Lord Dunsany, de Georg Kaiser, de Franz Kafka, del Cocteau de Orfeo -toda una dramática, toda una cuentística-, sin olvidar, para quienes se interesaban en los problemas de la música, los primeros ensayos de Adolfo Salazar? ¿Y en cuanto a las ediciones de la revista? Fueron las primeras en presentarnos novelas de Vsevolod Ivanov; de Leonoff; de Babel, sin olvidar ciertos escritos fundamentales de Worringer y Vossler...Recuerdo que algunos de nuestros mayores se alarmaban ante lo que consideraban como una "germanización” de nuestra cultura, cada vez más afecta al ensayo, al estudio detenido, a la reflexión en torno a un tema cotidiano -tema tan simple, a veces, como el de la utilidad del marco en la pintura, que había sugerido a Ortega una de sus más interesantes meditaciones. El filósofo hubiera podido responder a nuestros mayores en aquellos días, con una frase suya: “¿La oscuridad alemana? ¿La claridad latina? ¡Mitos! Cuando habláis de claridad latina, decid más bien espíritu superficial."

La influencia de Ortega y Gasset en el pensamiento, las orientaciones artísticas y literarias, de los hombres de mi generación, fue inmensa. Nos hizo razonar, nos planteó problemas, nos hizo discutir. Y en cuanto al animador: tómese una colección de La [sic] Revista de Occidente. Sigue siendo la mejor revista literaria y filosófica en lengua española que haya existido. ¿Y en cuanto a la biblioteca? Aún nos atenemos a ella cuando necesitamos de ciertos textos que presentó a los lectores de nuestro idioma, sentando normas de edición que siguen en pie, por inmejorables.

ALEJO CARPENTIER

“Letra y Solfa,” El Nacional (Caracas), 20 de octubre, 1955, p. 16. 


\section{NOTA DE UN MAL LECTOR}

Ortega continuo la labor iniciada por Unamuno, que fue de enriquecer, ahondar y ensanchar el diálogo español. Este, durante el siglo pasado, casi no se aplicaba a otra cosa que a la reivindicación colérica o lastimera; su tarea habitual era probar que algún español ya había hecho lo que después hizo un francés con aplauso. A la mediocridad de la materia correspondía la mediocridad de la forma; se afirmaba la primacía del castellano y al mismo tiempo se quería reducirlo a los idiotismos recopilados en el Cuento de cuentos y al fatigoso refranero de Sancho. Así, de paradójico modo, los literatos españoles buscaron la grandeza del español en las aldeanerías y fruslerías rechazadas por Cervantes y por Quevedo...Unamuno y Ortega trajeron otros temas y otro lenguaje. Miraron con sincera curiosidad el ayer y el hoy y los problemas o perplejidades eternos de la filosofía. ¿Cómo no agradecer esta obra benéfica, útil a España y a cuantos compartimos su idioma?

A lo largo de los años, he frecuentado los libros de Unamuno y con ellos he acabado por establecer, pese a las “imperfectas simpatías” de que Charles Lamb habló, una relación parecida a la amistad. No he merecido esa relación con los libros de Ortega. Algo me apartó siempre de su lectura, algo me impidió superar los índices y los párrafos iniciales. Sospecho que el obstáculo era su estilo. Ortega, hombre de lecturas abstractas y de disciplina dialéctica, se dejaba embelesar por los artificios más triviales de la literatura que evidentemente conocía poco, y los prodigaba en su obra. Hay mentes que proceden por imágenes (Chesterton, Hugo) y otras por vía silogística y lógica (Spinoza, Bradley). Ortega no se resignó a no salir de esta segunda categoría, y algo -modestia o vanidad o afán de aventura- lo movió a exornar sus razones con inconvincentes y superficiales metáforas. En Unamuno no incomoda el mal gusto, porque está justificado y como arrebatado por la pasión; el de Ortega, como el de Baltasar Gracián, es menos tolerable, porque ha sido fabricado en frío.

Los estoicos declararon que el universo forma un solo organismo; es harto posible que yo, por obra de la secreta simpatía que une a todas sus partes, deba algo o mucho a Ortega y Gasset, cuyos volúmenes apenas he hojeado.

Cuarenta años de experiencia me han enseñado que, en general, los otros tienen razón. Alguna vez juzgue inexplicable que las generaciones de los hombres veneraran a Cervantes y no a Quevedo; hoy no veo nada misterioso en tal preferencia. Quizá algún día no me parecerá misteriosa la fama que hoy consagra a Ortega y Gasset. 


\section{NOTAS}

1 El sistema de Ortega y Gasset (Madrid: Ediciones Alcalá, 1968)

2 La colaboración de Carpentier en Carteles duró, strictu senso, de 1923 a 1948. Pero fue durante sus años en París que Carpentier colaboró de forma más asidua a la revista: es decir, entre 1928 y 1939.

3 El por otra parte utilísimo libro de Barbara Bockus Aponte, Alfonso Reyes and Spain: His Dialogue with Unamuno, Valle-Inclán, Ortega y Gasset, Jiménez and Gómez de la Serna (Austin: University of Texas Press, 1972), adolece de este defecto en el capítulo sobre Ortega. Para un panorama claro de la evolucón del pensamiento de Ortega y sus relaciones con el europeo, ver Ciriaco Morón Arroyo, op. cit.

4 Roberto González Echevarría, Alejo Carpentier: The Pilgrim at Home (Ithaca: Cornell University Press, 1977).

5 La Filosofía de la historia apareció en 1928 en traducción de José Gaos, editada por la editorial de la Revista de Occidente. Me reservo para otro trabajo la confrontación de los textos de Hegel y Borges.

6 Para más detalles ver mi Alejo Carpentier: The Pilgrim at Home, op. cit.

7 Hay una recopilación muy deficiente de textos de la columna de Carpentier hecha por Alexis Márquez Rodríguez: Letra y Solfa (Caracas: Síntesis Dosmil, 1975). El recopilador no incluye el texto sobre Ortega que se reproduce aquí, ni muchos otros sobre Borges, Asturias y otros escritores hispanoamericanos, agrupa los textos que sí incluye según vagas categorías temáticas, y las pocas notas que pone no son esclarecedoras. El libro es útil, sin embargo, dado que El Nacional de Caracas está en pocas bibliotecas. En una Guía bibliográfica a Carpentier que preparamos Klaus Mtiller-Bergh y yo aparecerán registrados los títulos de todos los textos de "Letra y Solfa."

8 Dice Carpentier en 1975: "Y como hablábase mucho, entonces, de un problema de deshumanización del arte, planteado por Ortega y Gasset, advertí de pronto que, equivocándose en este como se había equivocado ya en muchas otras cosas, Ortega había planteado el problema en falso. Tonto y vano era hablar de deshumanización del arte, cuando el verdadero problema planteado por las voliciones históricas de la época era de la Humanización o Deshumanización del artista." "Han terminado para el escritor cubano los tiempos de soledad, para él han comenzado los tiempos de solidaridad” [Palabras de agradecimiento al Comité Central del P(artido) C(omunista de) C(uba)), Revista de la Biblioteca Nacional José Martí, 3ra época, vol. 17 no. 1 (enero-abril 1975), p. 20. Pero en 1928 Carpentier había escrito una defensa de La deshumanización del arte que estaba muy a tono con sus actividades de promotor del arte nuevo, en particular la música nueva: "Para el buen burgués, los artistas de mi generación resultan iconoclastas por juego: parecen individuos peligrosamente incrédulos para los cuales la vida carece de un sentido profundo (...) Sin embargo quien haya observado, siquiera ligeramente, los resortes que mueven el orden de ideas impuesto por las mentalidades de post-guerra, verá que deben su lozana flexibilidad a una fe intensa, a un concepto casi religioso de las actividades intelectuales. (...) Todo el esfuerzo de los intelectuales contemporáneos, tiende a dar mayor dignidad a la concepción estética. En el fondo, quienes acusan a los nuevos de deshumanizar el arte, protestan contra la extracción de una broza humana -sensibilería, intriguillas hogareñas, psicología de cocido familiar- que lo inutilizaba para batir verdaderos records de altura." "En la extrema avanzada: algunas actitudes del 'Surrealismo',” Social (La Habana), diciembre de 1928, p. 
38. En "Letra y Solfa" Carpentier había elogiado a Ortega y la Revista de Occidente en “Fiebres de primavera," "Letra y Solfa,” El Nacional, 18 de julio, 1951, p. 12, y "El por qué de cierta añoranza,” Ibid., 26 de septiembre, 1953, p. 34.

9 Para detalles sobre este tema ver Aponte, op. cit. Desde luego, el desacuerdo más importante entre Borges y Ortega es el relativo a la novela. Borges polemiza contra las conocidas ideas de Ortega sobre la novela en su prólogo a La invención de Morel, de Adolfo Bioy Casares (1940), texto que ha sido comentado por mí en Alejo Carpentier: The Pilgrim at Home, op. cit., Emir Rodríguez Monegal en "Borges and la nouvelle critique," Diacritics, 2, no. 1 (1972), 57-60 y Alfred J. Mac Adam, en "Narrativa y metáfora: una lectura de La invención de Morel," Otros mundos otros fuegos: fantasía y realismo mágico en Iberoamérica. Memoria del XVI Congreso Internacional de Literatura Iberoamericana, ed. Donald A. Yates (Pittsburgh: A Publication of the Latin American Studies Center of Michigan State University, 1975), pp. 309-13. Significativamente, Carpentier y Borges coinciden en sus críticas de las ideas de Ortega sobre la novela. Escribe Borges: "La novela característica, 'psicológica,' propende a ser informe. Los rusos y los discípulos de los rusos han demostrado hasta el hastió que nadie es imposible: suicidas por felicidad, asesinos por benevolencia, personas que se adoran hasta el punto de separarse para siempre, delatores por fervor o por humildad...Esa libertad plena acaba por equivaler al pleno desorden. Por otra parte, la novela 'psicológica' quiere ser también novela 'realista': prefiere que olvidemos su carácter de artificio verbal y hace de toda vana precisión (o de toda lánguida vaguedad) un nuevo toque verosímil. Hay páginas, hay capítulos de Marcel Proust que son inaceptables como invenciones: a los que, sin saberlo, nos resignamos como a lo insípido y ocioso de cada día. La novela de aventuras, en cambio, no se propone como una transcripción de la realidad: es un objeto artificial que no sufre ninguna parte injustificada." Cito por la edición de 1953 (Buenos Aires: Emecé) de La invención de Morel, p. 12. En un artículo de "Letra y Solfa," precisamente sobre "Carácter y conflicto," Carpentier declara: "De ahí que la novela actual se haya vuelto una novela de 'conflictos,' más que una novela de 'caracteres.' La ciudad donde vive el hombre ha cobrado tanta importancia como el hombre mismo. El escenario ha tomado proporciones considerables, tendiendo a ampliarse cada vez más. El individuo vive en función de cuanto le rodea y los actos que en determinado momento comete un desconocido pueden tener una influencia tremenda en su futuro. De ahí que el 'conflicto' interese más al novelista moderno que la psicología particular de sus personajes. Y que, como decía lean Malaquais, el dolor de mil hombres recluidos en un campo de concentración de la Alemania nazi, haya quitado, para nosotros, mucho del interés que pudo tener otrora el asesinato de la usurera de Dostoyewsky.” El Nacional, 26 de mayo de 1954, p. 28. Carpentier ha repetido estas opiniones en otros trabajos y entrevistas. 


\title{
Borges Marginal
}

\begin{abstract}
Dóciles medias los halagan de día y zapatos de cuero claveteados los fortifican, pero los dedos de mi pie no quieren saberlo. No les interesa otra cosa que emitir unas: láminas córneas, semitransparentes y elásticas, para defenderse ¿de quién? Brutos y desconfiados como ellos solos, no dejan un segundo de preparar ese tenue armamento. Rehusan el universo y el éxtasis para seguir elaborando sin fin unas vanas puntas, que cercenan y vuelven a cercenar los bruscos tijeretazos Solingen. A los noventa días crepusculares de encierro prenatal establecieron esa única industria. Cuando yo esté guardado en la Recoleta, en una casa de color ceniciento provista de flores secas y de talismanes, continuarán su terco trabajo, hasta que los modere la corrupción. Ellos y la barba de mi cara. Borges, "Las unas”
\end{abstract}

There is a finished feeling

Experienced at graves -

A leisure of the future,

A wilderness of size,

By death's bold exhibition

Preciser what we are

And the eternal function

Enabled to infer.

Emily Dickinson

Restituir, delineándolos, cualesquiera de sus textos, desprendiéndolos de sí, devolverlos a los márgenes por ellos eficazmente poblados, retirarlos del ámbito industrioso en que llegaron a sugerir cierta constitución borgiana; buscar a Borges en su patria marginal, y no tomarle como antídoto que fijase los remedios buscados en obras, plenas, convergentes, que él nunca tuvo la ocurrencia de intentar. ¿Por qué no esta lectura disolvente, ciega a los crecientes poderes de la posliteratura; en lugar de esa otra, divulgadora y espiral, con que se añaden a los textos de Borges (con 
proliferante empeño) pedazos de teología menor, lucubraciones de sectas tardías (por él mismo anticipadas) más los parciales designios de frustrados sacerdocios? Me parece difícil que seamos capaces de lograr semejante reposo ocular. Nos agita otra fe en lo visto y su retorno. $\mathrm{O}$, acaso, puede que creamos todavía que al leerle vemos, cuando lo apropiado sería tasar el incipiente poder con que, al ver, le releemos.

He aquí a los sacerdotes; y aunque sean ellos mis enemigos, pasemos por su lado en silencio y con espadas dormidas. Entre ellos también los hay héroes; algunos han sufrido mucho, de aquí que quieran que otros sufran.

Nietzsche, Así habló Zaratustra

Ahora bien, ¿qué es, qué sería, captar a Borges, o regresar a el desde la posliteratura, y qué es esta última agencia descontructora?

¿Y esta lenta araña que camina a la luz de la luna, y esa luz misma, y yo y tú en el umbral, susurrando juntos, murmurando sobre cosas eternas -habríamos todos de haber estado allí antes? Y regresar, y caminar por la otra senda, allá, por delante nuestro, por esta larga y aciaga senda- ¿no habremos todos de regresar eternamente?

Nietzsche, Así habló Zaratustra

La posliteratura comienza por no tener lugar, por no caber. Además, desde la perspectiva obrante de lo escrito, leído, intercambiado, no deja de ser un término irrisorio, un lema descartable. Pero no es este el único corte del asunto: llámeselo como se le llame, algo ha resultado de recientes relecturas (pienso en las efectuadas por Derrida); algo que se libra, que se juega, a través de los márgenes del discurso literario y del filosófico, que los contamina mediante la productiva extensión de sus errores, afectando, anulando, las distinciones entre uno y otro discurso y haciendo imposible un salirse-de con respecto al otro.

... if truth is the recognition of the systematic character of a certain kind of error, then it would be fully dependent on the prior existence of this error. Philosophers of science like Bachelard or Wittgenstein are notoriously dependent on the aberrations of the poets ... Poetic writing is the most advanced and refined mode of deconstruction; it may differ from critical or discursive writing in the economy of its articulation, but not in kind.

Paul de Man, "Semiology and Rhetoric"

Borges vacila, con impecable y modesta economía de recursos y temas, entre las estrategias que se reparten tales tareas aberrantes. Por eso, regresar hasta él desde la posliteratura, equivaldría a diseminarlo, bajo la ilusión de estarle restituyendo (a 
través de discursos técnicos que le serían adyacentes) cierta pluralidad que se fundaría en la dimensión autoritaria del saber analógico. La importación de ese otro discurso equivale hoy en día a lo que en la obra de Dante, par ejemplo, resultaba inmanente con respecto a la pluralidad significante del poema, mediante su riguroso desdoblamiento alegórico. Sólo que ahora la alegoría instituye una temporalidad heterogénea, extraña, con relación al discurso que explicará alienándolo; dicho discurso, el literario, pierde, entonces, la propiedad central que le ha permitido hasta ahora automistificarse, la de ser ambiguo. Ambos discursos contienden por ser excipientes con relación al otro, por recoger y precipitar contenidos. La aporia radica en que la transposición alegórica del discurso literario hacia aquel que venga a poner en juego determinados modelos explicativos, representa sólo un momento de este encuentro dialéctico; pues la exterioridad, el carácter excipiente del segundo, no puede librarse de las mediaciones, de los errores que el primero le ha propuesto, y a los cuales ha tenido acceso por medio de la intertextualidad. Lo que posibilita la transposición momentáneamente esclarecedora, situando errores y certidumbres, encuentra, al final de la operación misma que lo ha hecho factible, el mismo juego de posibilidades, la misma jugada, las mismas instancias de una suerte de errancia abierta al azar: todos los f(j)uegos el f(j)uego.

Es íntimo, en el sentido fuerte, lo que tiene el arrebato de una ausencia de individualidad, la sonoridad inaprehensible de un río, la vacía limpidez del cielo...

Georges Bataille, Teoría de la religión

La posliteratura se definiría no en cuanto a su posición cronológica o histórica, sino por la medida, por la escansión suspensiva, que difiere el emplazamiento y el libre juego de sus errores hasta aquel momento (que es a la vez antecedente y consecuente) en el cual todo ello se repita bajo el signo constativo (único momento de verdad, del preciso error) de lo que se ha(ya) prestado, de lo que es-habiendo-sido(ya)-allá. Borges ha fijado este carácter a la vez posterior y fundador de la literatura al situar la relación alegoría-novela en conjunción con la de realismo-nominalismo (anticipando, entre otras cosas, las tajantes distinciones de Kristeva en Le texte du roman). La literatura alegórica es "fábula de abstracciones, como la novela lo es de individuos. Las abstracciones están personificadas; por eso, en toda alegoría hay algo novelístico. Los individuos que los novelistas proponen aspiran a genéricos” ("De las alegorías a las novelas”).

El proceder contaminante se desdobla: tener acceso a lo genérico constituye el regreso (regreso, ya que al hablar se habla tiempo) de la diferencia obrante en ese imposible lugar del cual el individuo, por así decirlo, ha partido, deviniendo desde entonces como por sucesivas fracturas: fallando. 
Este era entonces el objeto de la ley ceremonial, que los hombres no hicieran nada por libre albedrío, sino que actuaran según la autoridad externa, y que tuvieran que confesar con sus acciones y pensamientos que no eran ellos sus propios amos, sino que eran regidos por otros.

Spinoza, Tratado teológico-político

De aquí que algunos cuentos de Borges (“El sur” por ejemplo, o “El jardín de senderos que se bifurcan”) afirmen simultáneamente una fluctuante antecedencia y una postrera gestión, equivalentes ambas al lugar del origen desvirtuado por repetición fracturante. Ambas instancias configuran el intervalo entre la cosa y los medios, entre el objeto perdido y las infinitas mediaciones que lo ponen en juego, precisamente al retirarlo de circulación; mediaciones que (del lado del pretérito) constituyen el objeto y (del lado del futuro) lo logran. Tanto la cosa como los medios se incorporan a lo que podría denominarse el triunfo del Significante o, de una manera mas propiamente alienada, (siempre bajo el signo de lo-que-se-ha-prestado) como el acceso a una segunda muerte; acceso y cancelación de ésta.

No queda más remedio que poner en circulación un concepto tan extraño como este porque abundan todavía los esfuerzos por explicar algunos de los cuentos de Borges como si estos fuesen en si organismos autónomos y totales. La segunda muerte anuncia el sentido de cada cuento como escansión suspensiva, o como su obligación de prestarse-a, de lograrse-para.

UÑA... Del lat. ‘ungula’ íd, diminutivo de ‘unguis’ id. Corominas, Breve Diccionario Etimológico

UNGULA... A morbid growth in the eye

UNGULA... 'Blancard's Phys. Dict' (ed. 2), a sort of hooked instrument to draw a dead Foetus out of the womb.

\section{Oxford English Dictionary}

“El sur” presta a "El jardín de senderos que se bifurcan” su doble muerte, como repetición de aquella alcanzada por el secular narrador de este último. En ambos cuentos el conocimiento (en su deslizamiento analógico) se define como un encuentro. El Significante sería en los dos un hecho (quehacer o cosa) mayúsculo, o la radical anterioridad de la Ley, del pacto instaurador de diferencias que hubieron de ser borradas (dar tiempo a este fenómeno y a su aspecto verbal es, por supuesto, errar) antes que existieran marcas para significar sus huellas.

El Significante se erige, entonces, como una especie de muerte anterior a la vida (y al crecimiento de ésta como trabajo de la muerte), una muerte doblemente muda, análoga, tal vez, en su definitivo silencio, a la prohibición de la palabra tiempo (diferida hasta la instancia comunicante del crimen) en "El jardín de senderos que se bifurcan”; análoga, también, a esa juntura, imposible de situar, en la cual las dos 
muertes de Juan Dahlmann coincidirían para anular el ignoto intervalo que las separa y condena a la paralela inercia que el texto configura, plegándose hasta el punto de querer propiciar la coincidencia de sus dos mitades.

El progresivo adelgazamiento del remoto laberinto, y su ejecución en "El jardín de senderos que se bifurcan”, llegará a concretarse en mensaje, en un solo acontecimiento comunicante, en átomo final de aquella inicial proliferación de tramas, o en ese logro de la comunicación ejecutado por el gesto asesino dirigido a un distante burócrata. Tal concreción no hace sino trasladar la muerte anterior a la vida, la muerte no significante, (la primera muerte de Dahlmann, que la segunda colma repitiéndola, prestándole sentido) no hace sino traducir dicha muerte insignificante en futuro (de ahora), porque, otra posible versión de la escansión suspensiva por la cual la literatura retorna a sí misma, desvirtuando su insularidad, sería la de poder esta desenmascarar los desplazamientos de la Ley, los ires y venires del Significante que aguarda, mudo, en lo anterior y lo posterior, en las afueras de la prestación. La literatura, como relato en este caso, insiste en que nos trasladamos hacia el futuro retroactivamente, insiste en que el trabajo de la(s) muerte(s) es análogo al del Significante como mediación, como Ley. La aporia vuelve a traducirse: no podría la literatura activar los resortes que desanuden las ataduras de ese extraño advenimiento retroactivo del futuro, sin, a su vez, abrirse a la obrante extrañeza de los diferentes significantes, de los discursos heterogéneos a los que habrá de prestarse.

El hombre es el ser que ha perdido, e incluso rechazado, lo que es oscuramente, intimidad indistinta. La conciencia no habría podido llegar a ser clara a la larga si no se hubiera apartado de sus contenidos molestos, pero la conciencia clara está por su parte a la búsqueda de lo que ella misma ha perdido, y a medida que se acerca a ello, debe perderlo de nuevo. Entiéndase esto bien, lo que ha perdido no está fuera de ella, es de la oscura intimidad de la conciencia misma de lo que la conciencia clara de los objetos se aparta.

Georges Bataille, Teoría de la religión

Laberíntico, tramado o repartido, usurpador de los “diversos porvenires, diversos tiempos”, aniquilador de la memoria (al vertir sus imágenes hacia un futuro que sólo se consumará retroactivamente), es así como, por todas sus semblanzas, el tramado inmaterial de Ts’ui Pên se nutre, al crecer, de lo que, en cada bifurcación, optaría por un nombre y su correspondiente sentencia, por un territorio sobre el cual poder inscribir el accidentado transcurso de su deseo. Inscripción nominalista, ya que, a la inversa de lo propuesto por Borges en "De las alegorías a las novelas”, es por medio de la infinita excavación del espesor arqueológico del objeto, es adentrándose en el laberinto de su radical extrañeza, (en vano intento por constatar los vestigios que todavía allí profeticen, como lo declara "El arte narrativo y la magia”) que los modernos designios del proceder alegórico buscan sus marcas, ciegos a las confusas 
huellas que, en las cosas, hubieron de trazar el perdido acceso desde su particularidad hasta el amplio reducto de su ser genérico.

'Deseo' es la esencia misma del hombre, en cuanto se le concibe como determinada según una acción por cualquiera de sus modificaciones...

‘Asombro' es la imaginación de un objeto en que la mente permanece fija debido a que dicha particular imaginación carece de conexión con otras...

‘Devoción’ es amor hacia el objeto que nos asombra.

Spinoza, Etica, III, lix.

El laberinto de Ts'ui Pên, imposible don, intransferible rúbrica; nunca hollado (ungido, signado) por el contacto que lo hubiese repetido marcándolo, prestándole las sucesivas escansiones de su terrenal nombre, de su acceso a la verdad diferida por los ecos que la emiten, de nuevo, retroactivamente, ese plural átomo de tiempo vendría a posarse allí, en el vacío que separa las dos muertes de Dahlmann, sus dos inercias incomunicadas-comunicantes. Y, al hacerlo, reclamaría, anulándolo, el territorio de un posible cuerpo creciente, el lugar donde cobraría cuerpo una imposible coincidencia, la de la repetición y la diferencia.

"El sur" se escinde por el vacío en que el texto habría de marcar las simpatías, las apropiantes concordias y discordias de la intensidad territorial. Pero puede que, en dicho lugar, haya "el sur" intentando fijar un don asequible, un dócil laberinto en el cual las caras accidentales que rodean a Dahlmann, asistiéndolo en su última anécdota, más la suya propia, (u otro agregado efímero, quimérico de aquellos cuerpos) quedasen todas vertidas entre las recíprocas incisiones por las que surge el grabado, ese intervalo en que el texto figura sus préstamos a los recursos de la memoria y la ley ceremonial.

Láminas, grabados, comunicaciones ungulantes: ilustraciones, márgenes que repiten el texto y suplen su devenir sensible con las firmes líneas que aun vacilan entre figura y cuerpo; breves y fijas ceremonial del crecer ofrecido al tacto, coagulaciones del creciente gasto de sentir...

I lived in habits of intimacy with him to the end of his life; and, when he died, I, with other of his friends, attended his remains to the grave at 'Ballast Hills.' And what graving on the sacred cliffs of Egypt ever honoured them, as that grassdimmed furrow does the mounds of our Northern Land?

John Ruskin, Ariadne Florentina

El cuerpo es una gran razón, una pluralidad con un solo sentido, guerra y paz, rebaño y pastor. Un instrumento de lo cuerpo también será tu pequeña razón, hermano mío, aquello que llamas espíritu -pequeño instrumento y juguete de lo razón mayor.

Nietzsche, Así habló Zaratustra 
No estorben al sol, no frecuenten los caminos, no estrechen manos con demasiada premura, no mantengan golondrinas bajo techo propio, ni pájaros de uñas curvas, no orinen sobre los restos de sus unas y pelo.

Diógenes Laercio, Vidas de filósofos eminentes VIII, 'Pitágoras'

Ya obtenidos parecían idénticos. Antes, los conjuraba un color unánime más el recuerdo de su perdida destreza animal. Desde entonces han cambiado con pareja y rítmica desigualdad. El de la derecha guarda el trazo de un colmillo (o tal vez de dos) cubierto por un parche de piel extraña, reciente y como arrebatada a una bestia mayor e indivisible. El que le sigue (a la izquierda) se conserva apenas intacto, tardío, resignado y puntual como el eco; antifaz que el otro desdeña, sostenedor del semblante que una vez compartiera con la otra mitad de un orbe feliz e indiferente. Dentro de cada uno la antigua unidad recobra su rigor inicial, grave. Allí, en eficaz y oscuro reposo, yacen dos monarcas pasajeros atentos al exterior piramidal, críptico, que ya no podrán ver, ciegos por voluntad, prisioneros peregrinos de lo íntimo errante. 


\section{Borges Sobre los Pasos de Borges: El Libro de Arena}

I.

Con el tiempo, con la edad, el Borges narrador se ha ido haciendo cada vez más oblicuo y ambiguo en el ejercicio de ese género. Paradójicamente, el cuento, que le dió la mayor parte de su inmensa y merecida fama, siempre le inspiró un inexplicable desdén: en la misma cúspide de su arte, el maestro solía manifestar pudores de principiante. Es celebre un pasaje del prólogo a la edición de 1954 de su Historia universal de la infamia: "Son el irresponsable juego de un tímido que no se animó a escribir cuentos y que se distrajo en falsear y tergiversar (sin justificación estética, alguna vez) ajenas historias”. Para entonces Borges ya había publicado sus libros narrativos más perfectos e influyentes: Ficciones (1944) y El Aleph (1949). Sin embargo, en el prólogo de 1944 a la serie “Artificios” que integra Ficciones, reitera esa escéptica nota autocrítica: “Aunque de ejecución menos torpe, las piezas de este libro no difieren de las que forman el anterior”. Como a esta actitud se sumará después una dolorosa razón personal -la de su ceguera, que le impide literalmente escribir: como todo el mundo sabe, su escritura es, desde hace unos veinte años, el resultado de lo que dicta, su composición es oral-, no resultará extraño que el autor haya sido tan parco en manifestaciones narrativas a partir de la segunda mitad de este siglo. Los lectores de El hacedor (1960). libro que señala la frontera entre la obra madura y la obra tardía de Borges, pudieron pensar que se encontraban ante la manifestación final de su evolución como cuentista: ya no relatos, ni siquiera cuentos cortos o cortísimos, sino digresiones, especulaciones, recuerdos de lecturas, dilemas filosóficos, paradojas, etc., que muchas veces logran una concentración magistral justamente por supresión de sus virtualidades narrativas. Una década más tarde, inesperadamente, Borges volvió al cuento, y no por última vez: ese año publicó El informe de Brodie y ahora, en 1975, El libro de arena*. Lo que quiere decir que, pese a sus propios desgaños y pronósticos, el Borges cuentista no ha muerto. Quizá sea interesante examinar esta reciente parte del proceso y averiguar la relación que guarda con la anterior. 
II.

El melancólico y hermoso prólogo a El informe de Brodie es muy revelador de que el primero en advertir que una etapa de su obra ha quedado definitivamente cerrada, es el propio Borges; estamos ante un nuevo prosista, estamos -nos dice- ante "cuentos directos" o "realistas, para usar la nomenclatura hoy en boga”, que son como la reescritura de los temas que en la primera etapa le permitieron tejer fábulas asombrosas. Ahora ya no pretende tanto: "He renunciado a las sorpresas de un estilo barroco; también a las que quieren deparar un final imprevisto. He preferido, en suma, la preparación de una expectativa a la de un asombro. Durante muchos años creí que me sería dado alcanzar una buena página mediante variaciones o novedades; ahora, cumplidos los setenta, creo haber encontrado mi voz”. Aunque un Borges realista es imposible, es evidente el esfuerzo del autor por contar sus historias del modo más llano, con menos subrayados metafóricos y menos guiños de complicidad intelectual con el lector: las cosas pasan como por segunda vez, desleídas y en un mediotono sin sobresaltos. Para el lector, más que esa búsqueda de sencillez y humildad en la composición, es evidente una distensión general, una opacidad invasora en la prosa del escritor. Borges, en este tramo, vuelve sobre sus huellas (en los temas, en los motivos, en los símbolos) con el ánimo incierto de quien no se decide a borrarlas del todo o hacerlas más profundas en su segunda visita. Esa indecisión dejará un sabor equívoco en quien recorra estas páginas: es como si a1guien, que insistiese en ser Borges, escribiese ahora otra vez las páginas de Borges. De ahí el regusto en contar viejas historias de cuchilleros (“Juan Muraña”, “El otro duelo”), en imaginar otras soluciones para sus propios cuentos ("Historia de Rosendo Suárez”), en agregar anécdotas al margen de episodios históricos (“La señora mayor”, “Guayaquil”). Pero también es muy capaz de escribir un cuento como el que da título a ese volumen, que aparte de ser irrecusablemente fantástico y especulativo (a lo Swift, juega con las posibilidades monstruosas y absurdas de una raza humanoide, los Yahoos, y su cultura), tiene registros verbales que no son demasiado diferentes de los de Tlön, Uqbar, Orbis Tertius o El inmortal; júzguese por este comienzo: “En un ejemplar del primer volumen de las Mil y Una Noches (Londres, 1839) de Lane, que me consiguió mi querido amigo Paulino Keins, descubrimos el manuscrito que ahora traduciré al castellano. La esmerada caligrafía -arte que las máquinas de escribir nos están enseñando a perder-sugiere que fue redactado por esa misma fecha. Lane prodigó, según se sabe, extensas notas explicativas; los márgenes abundan en adiciones, en signos de interrogación y alguna vez en correcciones, cuya letra es la misma del manuscrito. Diríase que a su lector le interesaron menos los prodigiosos cuentos de Shahrazad que los hábitos del Islam”. 
III.

He recordado algunos aspectos de El informe de Brodie, porque algo semejante ocurre con El libro de arena, e inclusive en un grado más agudo tanto para las autoimitaciones y citas internas, como para las súbitas fugas a fantasías dignas del escritor que el nuevo Borges quiere desterrar. El mismo señala esa hermandad en una página que aparece en la tapa posterior del libro: “A mis años -he nacido en 1899, no puedo prometer ni prometerme sino esas pocas variaciones parciales, que son, según se sabe, el recurso clásico de la irreparable monotonía”. "Soy decididamente monótono”, declaraba en el prólogo del libro de 1970: la convicción se ha vuelto una fatalidad, cuya admisión lo ánima a escribir casi sin esperanzas siquiera de entretener: “Escribo para mí, para los amigos y para atenuar el curso del tiempo”, agrega en esa página. La conciencia de estarse repitiendo, la manía de escribir sobre los recuerdos de su propia escritura, llena el volumen de tautologías. Ya el título lo es: el libro se llama El libro de arena, además: el tiempo y la fatiga están allí aludidos.

En el prólogo del libro, Borges presenta algunas fuentes, algunos comentarios e intenciones de sus textos; como de costumbre, esos indicios pueden ser despistadores o callar lo que Borges sabe perfectamente. Por ejemplo, a propósito del primer relato del libro, "El otro", Borges recuerda a Stevenson pero finge no recordar un cuento de él mismo, "Las ruinas circulares". Ambos desarrollan uno de sus motivos favoritos: el del soñador soñado, el del doble ilusorio que irrealiza también al original. Aquí aparece un doble de Borges, lo que remite también al citadísimo "Borges y yo" de El hacedor. Que el Borges “verdadero” se vea como una sombra del doble que lo habita, “cuyo inevitable destino era ser el que soy” (p. 19) y que sus palabras revelen íntimas claves autobiográficas, no hace sino agregar dramaticidad al juego imaginativo: "Mi sueño ha durado ya setenta años. Al fin y al cabo, al recordarse, no hay persona que no se encuentre consigo misma. Es lo que nos está pasando ahora, salvo que somos dos... No sé la cifra de los libros que escribirás, pero sé que son demasiados. Escribirás poesías que te darán un agrado no compartido y cuentos de índole fantástica. Darás clases como tu padre y como tantos otros de nuestra sangre” (pp. 12-14). Pero casi todo en el texto es derivativo de algún otro texto borgiano: la reflexión sobre el engreimiento porteño (p. 14), la idea de que repetir lo que otros han hecho es (por supuesto) mejor que tratar de inventar algo nuevo (p. 17), la referencia a la fantasía de Coleridge (p. 19), etc., contribuyen a crear esa sensación de que la imaginación del autor se ha empozado en los caminos que le son familiares, que sólo da otros inflexiones (no siempre justificadas) a asuntos sobre los que ya escribió páginas definitivas.

"Ulrica” es un breve relato que Borges mismo se encarga de destacar como algo muy especial: su tema es amoroso, "harto común en mis versos; no así en mi prosa, que no guarda otro ejemplo” (p. 180). Contiene, es cierto, una escena erótica que, no por velada, es menos intensa: "El esperado lecho se duplicaba en un vago cristal y la bruñida caoba me recordó el espejo de la Escritura. Ulrica ya se había desvestido. Me 
llamó por mi verdadero nombre, Javier. Sentí que la nieve arreciaba. Ya no quedaban muebles ni espejos. No había una espada entre los dos. Como la arena se iba el tiempo. Secular en la sombra fluyó el amor y poses por primera y última vez la imagen de Ulrica” (p. 30-31). Hay otras confesiones personales y notorias en el relato: el amante reflexiona que "para un hombre célibe entrado en años, el ofrecido amor es un don que ya no se espera” (p. 28); el nombre completo que asume como personaje de su cuento es el de Javier Otálora, que evoca el de Benjamín Otálora, el héroe de “El muerto” (El Aleph), que hace suya una mujer ajena y así decreta su muerte; la pareja adopta luego nuevos nombres (él será Sigurd, ella Brynhild) que provienen de las mismas sagas nórdicas a las que Borges ha dedicado su vejez; hasta el símbolo de la espada en el lecho contiene alusiones que los psicoanalistas interpretaran fácilmente.

\section{IV.}

Aunque en varias partes del libro hay aislados momentos de brillo y sabiduría narrativos, la única pieza que puede considerarse enteramente digna del maestro es "El Congreso”. Se trata de un relato singular por muchos motivos; Borges también lo distingue: "es quizá la más ambiciosa de las fábulas de este libro” (p. 180) e indica las fuentes de la obra: Kafka, Chesterton, Bunyan. En primer término, es el texto más antiguo del conjunto: está fechado “Buenos Aires, 1955” y, aunque esa fecha es parte del juego, como Borges mismo me lo aclaró en el curso de una entrevista (publicado por El Sol de México, marzo 29, 1976), la idea del cuento data de un periodo muy anterior. Es imposible saber si Borges ha usado, en todo o en parte, una redacción de años atrás, pero en todo caso el cuento debe haber sufrido, a partir de la idea primera, muchos cambios e interpolaciones, cuyas señas serán notadas por el lector atento: varias capas estilísticas, desde el primer modelo “barroco” hasta la apacible entonación de hoy se superponen en él. El cuento, de hecho, existió antes como entidad bibliográfica aparte: en 1971 apareció en una edición limitada bajo el improbable sello “El Archibrazo Editor” de Buenos Aires. Eso se justificaba porque, por otro lado, se trata de uno de los relatos más extensos que jamás haya escrito Borges, quizá más largo que "El inmortal” o "El Aleph”: unas 27 páginas. Si uno observa con más cuidado descubrirá por que: más que un cuento, “El Congreso” es como el borrador de una abortada novela breve, ese género que siempre tentó e inhibió a Borges, convencido de que todo lo que podía decirse cabía en un cuento de extensión normal, seguro de que la novela era un género tautológico. Ahora, en el trecho final de su producción, el autor nos muestra el tortuoso fruto que su pudor y su atrevimiento han logrado.

Como dije, “El Congreso” no es un cuento, pero no se anima tampoco a ser una novela: esa incertidumbre no la daña, pero sí la hace más ambigua, más rara y a la vez más típica dentro del mundo borgiano. En tercer lugar, hay que advertir que si los otros cuentos de este libro citan copiosamente textos de libros anteriores, “El Congreso” es, 
agudamente, un texto que existe únicamente porque Borges ya ha escrito antes otros: es una variante, una summa y una reducción de ellos. El tema-la organización de una empresa que es tan vasta que se confunde con el mundo- es el mismo, en mayor o menor grado, que los de “Tlön, Uqbar, Orbis Tertius”, “El Aleph”, “La lotería en Babilonia” (donde el Congreso es la Compañía), “La biblioteca de Babel”, "Funes el memorioso", o sea, los de la producción mayor de Borges. Creo que la diferencia esencial esta, otra vez, en el tono más personal con el que el autor intenta validar su trama imaginativa: bajo el nombre de Alejandro Ferri encontramos inconfundiblemente a Borges: "Por indecisión o por negligencia o por otras razones, no me casé, y ahora estoy sólo. No me duele la soledad; bastante esfuerzo es tolerarse a uno mismo y a sus manías ... Cuando era joven, me atraían los atardeceres, los arrabales y la desdicha; ahora las mañanas del (sic) centro y la serenidad” (pp. 35-36).

Un pasaje crucial en "El Congreso" es aquel en el cual Ferri-Borges, desatendiendo un encargo que los congresistas le han encomendado en Londres, encuentra a Beatriz y se enamora de ella. Las citas literales de otros cuentos ya han aparecido antes en el texto (en la p. 49 se dice de la estancia de Alejandro Glencoe que "el primer sol y el último la golpeaban”, que es la misma frase con la que caracterizó la estancia a la que Otálora, en "El muerto", llega para ser liquidado), pero en dicho pasaje hay como una apoteosis de ese sistema de citas internas. Se nos informa que Beatriz era "alta, esbelta, de rasgos puros", casi como la famosa Beatriz de "El Aleph"; se describe Londres como un "rojo laberinto", lo que remite otra vez a ese mismo cuento; el abrazo carnal de los amantes da origen a una breve exaltación lírica en la que encontramos casi idéntica una imagen que proviene del encuentro erótico de "Ulrica” (“el amor que fluye en la sombra como un río secreto”, p. 55). Que una aventura sexual ponga en peligro la existencia del Congreso, es una afilada ironía de Borges: si el Congreso “abarca el mundo entero” (p. 60) se parece entonces a esa otra empresa por la cual se perpetúa la especie; el anhelado orden de una biblioteca que sintetiza el esfuerzo del Congreso necesariamente incluye también el estallido pasional de los cuerpos. "El Congreso del Mundo comenzó con el primer instante del mundo y proseguirá cuando seamos polvo” (p. 60), dice Glencoe, y esa revelación conecta ahora el cuento con "La secta del Fénix": la secta comparte su secreto (el secreto del acto procreador) con todo el mundo, pues no hay nadie que haya escapado a ese destino fatal. Como relato, "El Congreso” presenta un tejido menos firme que los de 25 años atrás; quizá porque el autor ha comprimido sus márgenes negándose, por pereza o escepticismo, a escribir la novela que podía escribir con este argumento, el lector tiene la impresión de que pasan demasiadas cosas en demasiado poco espacio o tiempo, o de que cada página es como un capítulo reducido a su mínima expresión. 
V.

“There are more things” es un homenaje a Lovecraft que casi lo parodia (lo monstruoso como algo invisible e indecible) de una manera que no hace mucho honor a Borges: el final, más que sorpresivo, es inconsistente, para no hablar del desarrollo innecesariamente truculento. "La secta_de los treinta" trata el tema de la herejía y la traición apenas como un escolio de "Tres versiones de Judas" o de "La forma de la espada”. Para la misericordia divina, nos recuerda otra vez, "no hay un sólo culpable; no hay uno que no sea un ejecutor, a sabiendas o no, del plan que trazó la Sabiduría” (pp. 85-86). "La noche de los dones” aprovecha otro de los temas gauchescos de la literatura argentina: el del Juan Moreira. Sus directos modelos ("Biografía de Tadeo Isidoro Cruz” y “El fin”) pesan excesivamente sobre el texto como para no desmerecerlo por comparación: en lo semejante es inferior, en lo diferente es sólo una versión pálida. Todavía más lo es "El espejo y la máscara”, fantasía decorativa de ambiente escandinavo. El mismo ambiente es el que encontramos en "Undr”, pero su registro es más hondo: es una nueva fábula sobre la posibilidad de dar con una palabra que contenga a todas las otras, que sea la clave que nos salve; el cuento se apoya, con algún mérito, en la idea que utilizó para "La escritura del Dios”. “Utopía de un hombre que esta cansado" presenta un diálogo conjetural, que se desarrolla "en Oklahoma o en Texas o en la región que los literatos llaman la pampa” (p. 123) y que le permite a Borges haber un catálogo de sus aversiones, nostalgias y predicciones; los sarcasmos más ácidos están dirigidos contra los políticos: “Los políticos tuvieron que buscar oficios honestos; algunos fueron buenos cómicos o buenos curanderos” (p. 131). “El soborno” es de una ingenuidad casi inexplicable. Imagina unos Estados Unidos donde hasta los odios y resentimientos profesionales se someten a una ética decorosa. Vaga o involuntariamente, el relato es como una versión rebajada de "Los teólogos”, con la diferencia de que aquí el debate, que pretende ser “real”, es totalmente inverosímil. En cambio, “Avelino Arredondo” es un buen cuento. Trata de un crimen (político, para más detalles) como destino que el protagonista asume con una pureza y rigor casi sacerdotales, y que traen a la memoria la muerte ritual que aguardan (o sueñan que aguardan) los personajes de “El sur” o “La espera”. Las dos últimas piezas del libro tienen que ver con objetos mágicos o imposibles: "El disco" habla de un disco o moneda que tiene una sola cara y que bien puede ser otro zahir, como el que permitía ver simultáneamente sus dos lados; y "El libro de arena” propone otra vez un libro infinito, uno que podría haber salido, literalmente, de "La biblioteca de Babel”.

VI.

Como se habrá podido ver, este volumen de cuentos tiene un carácter paradójico: sólo puede ser convenientemente disfrutado por los lectores más asiduos (y hasta viciosos) de Borges, pero son justamente ellos los que pueden medir la distancia que 
va de los modelos a las copias. Escribir un libro no es lo mismo que dictarlo: los mecanismos de la memoria, que en la composición oral son fundamentales para Borges, lo predisponen a la repetición, al avance tímido sobre terrenos familiares, a la reinvención más que a la invención. Su ceguera física se ha convertido también en una fatalidad literaria: a estas alturas Borges solo puede avanzar, re-conociéndolos, sobre los pasos de Borges.

*Jorge Luis Borges: El libro de arena (Buenos Aires: Emecé Editores), 1975,182 pp. 


\section{Borges y la Primera \\ Hoja de Ulysses}

Que "La última hoja de Ulises" sea la primera hoja de Ulysses publicada en lengua española, ${ }^{1}$ es un oxímoron cuya simetría sería del agrado de Borges. Sepultada en el sexto número de la revista argentina de vanguardia Proa (1925), la traducción ha sido descuidada por los especialistas. Es la finalidad de esta nota rescatar del olvido dicho texto y ofrecer un esbozo de su contexto. La traducción de Borges ofrece también un estudio introductorio, en el cual afirma: "Soy el primer aventurero hispánico que ha arribado al libro de Joyce.”2 El viaje con el escritor irlandés que aquí se inicia, se repetirá en varios momentos de su trayecto literario.

Las diversas opiniones de Borges a lo largo de los años sobre la novela, muestran por un lado su profunda admiración y el reconocimiento de su “catedralicio grandor”. 3 Pero su lectura no es en ningún momento unilateral; años después, al comentar una traducción al español de Ulysses, Borges es vehemente en la ambigua afirmación que “el Ulises, tal vez, incluye las páginas más caóticas y tediosas que registra la historia pero también incluye las más perfectas. Lo repito, esa perfección es verbal.”4 Esta atracción temporaria por la verbalidad joyceana habría de despertar en Borges una fascinación mayor, con la publicación de Finnegans Wake en 1939. Entonces llega a escribir una nota extremamente erudita, donde descifra varios "portemanteau words" creados por Joyce, así como recupera y comenta ejemplos insólitos: desde los casos más remotos en que aparecen estos procesos de yuxtaposición de significantes, hasta una versión latina del Jabberwocky de Lewis Carroll. ${ }^{5}$

Pero la originalidad de Borges no se limita en estos textos a su gesto de “adelantado" de la vanguardia ni a su monstruosa erudición. Son mucho más fecundos sus comentarios sobre los problemas de la traducción, que aparecen en la minuciosa y severa reseña hecha a la versión española de Ulysses, por J. Salas Subirat. ${ }^{6}$ Según Borges, la posibilidad que una traducción tiene de superar al original, coloca al traductor en posición de verdadero recreador: "Joyce dilata y reforma el idioma inglés;

su traductor tiene el deber de ensayar libertades congeneres." A partir de esta idea básica y tan moderna del traductor-recreador, Borges pasa a definir el texto como un objeto provisorio, pasible de una continua re-escritura: 
Presuponer que toda recombinación de elementos es necesariamente inferior a un arreglo previo es presuponer que el borrador 9 es necesariamente inferior al borrador $\mathrm{H}$ ya que no puede haber sino borradores. El concepto de texto definitivo no corresponde sino a la superstición o al cansancio. ${ }^{8}$

Esta definición permite considerar el lenguaje como un gran anagrama (“recombinación de elementos"), donde prevalece lo previsible por sobre lo definitivo, y que se regenera como serie o texto definitivo gracias a la posibilidad de redistribuir (traducir) los elementos básicos (no nos atrevemos a llamarlos “originales”). En fin, para Borges, el texto definitivo constituye una falacia. Y si la escritura y la re-escritura son tareas en principio inconclusas, también lo es la lectura:

Habremos muerto sin haber divisado

la biforme fiera o la rosa

que son el centro de tu dédalo. ${ }^{9}$

Vemos como se perfila una estética del fragmento, en esta concepción borgeana de la emisión y recepción del texto literario. Al hacer la primera presentación de Ulysses, declara: “Confieso no haber desbrozado las setecientas páginas que lo integran, confieso haberlo practicado solamente a retazos.”10 Varios años más tarde, corrobora esta afirmación de modo radical: "Yo (como el resto del universo) no he leído el Ulises, pero leo y releo con felicidad algunas escenas." ${ }^{11}$ Se comprende entonces que Borges, como traductor del Ulysses, se haya limitado en definitiva a la versión de una única página.

Además de las limitaciones impuestas por la novela en su lectura y traducción, Borges apunta serias dificultades en relación a la descodificación del texto joyceano. La primera, es su carácter de ilegibilidad: "la vasta novela de Joyce es indescifrablemente caótica." ${ }^{12}$ Por eso, hay momentos en que parece capitular delante del universo de significación de Ulysses:

quiero hacer mías las decentes palabras que confesó Lope de Vega acerca de Góngora: Sea lo que fuere, yo he de estimar y amar el divino ingenio deste Cavallero, tomando del lo que entendiere con humildad y admirando con veneración lo que no alcanzare a entender. ${ }^{13}$

Mucho más tarde, al tratar específicamente de los problemas de la traducción, afirmara con convicción: “A priori, una versión cabal del Ulises me parece imposible, ${ }^{14}$ y unos veinte años después, al referirse al Ulysses y Finnegans Wake, enuncia categóricamente: "Los libros que he enumerado son intraducibles." ${ }^{15}$ Al comparar ciertas posibilidades sintácticas y morfológicas del español con las del inglés, Borges señala la desventaja del primero, denunciando "la incapacidad para ciertos fines de todos los idiomas neolatinos y, singularmente, del español.”16 
Hemos enumerado hasta ahora una serie de problemas postulados por Borges, que revelan a Ulysses como una imposibilidad: un texto teóricamente incompleto, ilegible e intraducible. Realmente, no son pocos los a prioris borgeanos.

Aun así, y para retomar su metáfora inicial, Borges se embarca en la tarea de su fragmentaria y reducida traducción. Su hazaña será continuada y llevada a cabo por J. Salas Subirat, dos décadas más tarde. Sin pretender entrar en esta nota en los aspectos teóricos de la traducción, creo que vale la pena apuntar el modo como los dos traductores han enfrentado y resuelto ciertos problemas análogos frente al mismo texto joyceano. Más aún, "Borges traductor” es un estudio que merecería toda una tesis.

En la mayor parte de los casos, Borges aprieta y torna el lenguaje más coloquial -siendo este último un rasgo esencial para el tipo de discurso en cuestión: el monólogo interiorizado de Molly Bloom (corriente de la conciencia). Así, cuando ella comenta "they go howling for the priest and they dying", B. ${ }^{17}$ lo transpone simplemente en "piden berreando un cura al morirse"; la solución de SS es barroca: "van lanzando alaridos clamando por un sacerdote cuando se están muriendo.” No en vano el texto integral de SS cuenta con cien páginas más en relación al ya voluminoso original. B. a veces resuelve reducir hasta el propio texto joyceano, aliviándolo de particularidades irlandesas: "And the devil knows who else from all the end of Europe and Duke street”, encuentra por equivalente el sintético "hombres de todos los rincones de Europa”.

La tarea más ardua del traductor es tal vez la necesidad constante de evitar una versión literal del texto original, especialmente cuando se trata de una escritura donde predomina la función poética del lenguaje. De no tener en cuenta este aspecto, es inevitable el peligro de caer en soluciones artificiales de expresión. Así, para expresiones como "all the fine cattle going about”, B. encuentra un equivalente simple y reducido: "ganado pastando”, en tanto que SS lo vierte españolísimamente como "la preciosa hacienda paseándose”. El peligro de una traducción al pie de la letra puede ser fatal para la comprensión del texto traducido; así, cuando Joyce denomina un juego local de los marineros "the sailors playing all birds fly", ${ }^{18}$ el equivalente borgeano es "los marineros en el muelle a los brincos", en tanto que SS lo resuelve de modo incomprensible para el lector hispánico: "los marineros que juegan al todos los pájaros vuelan”.

Es muy distinta la actitud de ambos traductores con respecto a expresiones idiomáticas ya cristalizadas en el repertorio del lenguaje. Es así que al "I wouldn’t give a snap of my two fingers for all their learning”, B. lo reduce acertadamente al "me importa un pito lo que saben”, en tanto que SS repite literalmente "no daría un chasquido de mis dos dedos por toda su ciencia”, ignorando el use cotidiano del lenguaje.

Uno de los grandes problemas de este tipo de traducción, es caer en soluciones artificiales que no encajen dentro de la propuesta del lenguaje original. Por ejemplo, 
cuando Molly Bloom recuerda "the sun shines for you he said”, reproduciendo en su intimidad una forma altamente coloquial, Borges encuentra como equivalente el "Para vos brilla el sol”, y SS recae en "el sol brilla para ti me dijo", que representa una forma literaria escrita, y no dialogada.

Pasemos ahora a las soluciones mas creativas por parte de los traductores. Al "and the fowl market all clucking”, SS encuentra un efecto aún más aliterativoonomatopéyico: “y el mercado de aves todas clocleando”, que se destaca frente al mas literal cloqueando de Borges.

$\mathrm{Al}$ encontrar efectos paronomásticos, las soluciones borgeanas son verdaderas recreaciones textuales. Por ejemplo, "and the poor donkeys slipping and half asleep”, es vertido por B. sin los efectos poéticos del original: “y los pobres burritos cayéndose de sueno” (SS: “y los pobres burros resbalándose medio dormidos”) (!). Pero lo compensa en otro momento: "all sorts of shapes and smells and colours", es traducido por B., “con cuanta forma Dios creo y olores y colours”, en una verdadera equivalencia paronomástica. En este sentido, y de acuerdo a presupuestos básicos de la traducción, ciertos efectos pueden y deben ser dislocados por el traductor, a modo de compensación poética. ${ }^{19}$

Otro proceso análogo, es cuando Borges opta por no repetir la forma anafórica "the sea the sea”, (“el mar”, apenas), pero duplica el sustantivo "las castanuelas y aquella noche en Algeciras cuando perdimos el vapor las castanuelas...”; esta repetición no figura en el original.

De difícil equivalencia en lengua española es la forma sintáctica "the posadas glancing eyes”, la solución borgeana es el logrado "posadas ojos que atisban”, eliminando el elemento de enlace entre los dos sustantivos, y SS opta por "posadas los ojos que espían ocultos”, desmembrando la posibilidad sintética Joyce-Borges.

Otra alteración deliberada la encontramos en el orden impuesto por Joyce al "and pink and blue and yellow houses”, redistribuido por B. en "las casas rosadas y amarillas y azules”, por razones que ya ha elucidado Roman Jakobson al explicar la función poética; en el orden de la secuencia sintagmática hay un motivo importante para el efecto de dicha función, que se proyecta hasta en formas coloquiales (decimos "blanco y negro", y no "negro y blanco"). ${ }^{20}$

Deseamos aún destacar que Borges ha eliminado en su fragmento casi todos los nombres propios del texto original; además de aligerar el texto, esta decisión disimula el desconocimiento por parte del lector de ese fragmento, de los antecedentes que harían significativas la mención de nombres o títulos.

Existen también en la página de Joyce elementos intransponibles, y sin posibles equivalencias, como la omisión de los apóstrofes, en formas como "Id”, “wheres”, “wouldn't”, “don't”, “governors house”, etc.

Sin haber pretendido agotar todos los aspectos que el fragmento de Borges presenta, hemos dejado para el final lo que, nos parece, ha sido una solución que supera el original joyceano, lo que confirmaría la teoría de Borges sobre la traducción. 
En las últimas líneas del texto, rememora Molly Bloom: “and first I put my arms around him yes and drew him down to me"; la frase es transpuesta por B. con vigor erótico:

y primero lo abracé sí y encima mío lo agaché

(SS: “y yo primero lo rodee con mis brazos si y lo atraje hacia mí”).

Una comparación entre estas dos versiones al español de la última pagina de Ulysses puede parecer un acto de crueldad intelectual, ya que realmente Borges cuenta con una ventaja: ser Borges. Sin embargo, en su reseña sobre la traducción de Salas Subirat, el encuentra ocasión de aplauso: “ Muy superiores son aquellos pasajes en que el texto español es no menos neológico que el original. Verbigracia, este, de la página 743: que no era un árbolcielo, no un antrocielo, no un bestiacielo, no un hombrecielo, que recta e inventivamente traduce: that it was not a heaventree, not a heavengrot, not a heavenbeast, not a heavenman." Viniendo de quien viene, no es poco elogio.

Universidade de São Paulo; Yale University

JORGE SCHWARTZ

Nota:

Gracias a la Beinecke Rare Book and Manuscript Library, de la Universidad de Yale, he podido entrar en contacto con los textos de Borges en la colección de Proa, la edición original de 1922 de Ulysses, y la traducción al español de J. Salas Subirat. Deseo aún extender mis agradecimientos a Emir Rodríguez Monegal por las sugerencias, así como por el material bibliográfico cedido.

NOTAS

1 Borges, J. L. - “La última hoja de Ulises”, Proa (segunda época), Año Segundo, Número 6, Enero 1925, Buenos Aires, pp. 8-9.

2 “El 'Ulises' de Joyce”, Ibid., pp. 3-6. (Ensayo posteriormente recogido en Inquisiciones, 1925).

3 Ibid., p. 4.

4 “Nota sobre el Ulises en español”, en Los Anales de Buenos Aires, Año I. Buenos Aires, enero de 1946, no 1, p. 49.

5 “Joyce y los neologismos”, Sur no 62, Noviembre 1939, Buenos Aires, p. 61.

6 Joyce, James - Ulises, trad. por J. Salas Subirat - Santiago Rueda ed., Buenos Aires, 1945, 833 pp.

7 “Nota sobre el Ulises en español”.

8 Ibid.

9 “Invocación a Joyce”, en Elogio de la sombra, OC, Emecé, Buenos Aires, 1974, p. 1004. Hay otro poema de Borges sobre Joyce: “James Joyce”, en Ibid., p. 983.

10 “El 'Ulises' de Joyce”, p. 3. 
11 “Fragmento sobre Joyce”, Sur, no 77, 1941, Buenos Aires, p. 61.

${ }^{12}$ Ibid.

13 “El 'Ulises' de Joyce”, p. 6.

14 “Nota sobre el Ulises en español”.

${ }^{15}$ Introducción a la literatura inglesa, ed. Columba, Buenos Aires, 1965, p. 61

16 "Nota sobre el Ulises en español”.

17 Para efectos de cotejo, use la primera edición de Ulysses, The Egoist Press, London, by John Rodker, Paris, 1922. (pp. 731-2). De ahora en adelante, paso a usar las siguientes siglas: B (Borges) y SS (J. Salas Subirat).

${ }^{18}$ Todos los subrayados, de ahora en adelante, son míos.

${ }^{19}$ Cf. Campos, Haroldo de - "O texto-espelho (Poe, Engenheiro de Avessos)", en A operação do texto, ed. Perspectiva, São Paulo, 1976, p. 39.

20 Jakobson, Roman - "Linguistics and Poetics", en Style in Language, ed. by Thomas A. Sebeok, The M.I.T. Press, Mass., 1960, pp. 356-7. 


\title{
La Ultima Hoja de Ulises
}

\author{
PROA - Año Segundo-Enero - \\ Número 6, Enero 1925, Buenos Aires
}

...usaré una rosa Blanca o esas masas divinas de lo de Lipton me gusta el olor de una tienda rica salen a siete y medio la libra o esas otras que traen cerezas adentro y con azúcar rosadita que salen a once el par de libras claro una linda planta para poner en medio de la mesa yo puedo conseguirla barata dónde fué que las vi hace poco soy loca por las flores yo tendría nadando en rosas toda la casa Dios del Cielo no hay como la naturaleza las montañas después el mar y las olas que se vienen encima después el campo lindísimo con maizales trigales y toda clase de cosas y el ganado pastando te alegraría el corazón ver ríos bañados y flores con cuanta forma Dios creó y olores y colores saltando hasta de los charcos y los que dicen que no hay Dios me importa un pito lo que saben por que no van y crean algo yo siempre le decía libre-pensadores o como quieran llamarse que se quiten las telarañas después piden berreando un cura al morirse y a qué santos es porque temen el infierno por su mala conciencia si ya los conozco bien cual fué la primer persona en el universo antes que hubiera alguien que lo hizo todo ah eso no lo saben ni yo tampoco están embromados eso es como atajarlo al sol de salir Para vos brilla el sol me dijo el día que estábamos tirados en el pasto de traje gris y de sombrero de paja cuando yo lo hice declarárseme sí primero le di a comer de mi boca el trozito de torta con almendras y era año bisiesto como este si ya pasaron 16 años Dios mío después de ese largo beso casi pierdo el aliento si me dijo que yo era una flor serrana si somos flores todo el cuerpo de una mujer si por una vez estuvo en lo cierto y para vos hoy brilla el sol si por eso me gustó pues vi que él comprendía lo que es una mujer y yo sabía que lograría engatusarlo siempre y le di todo el gusto que pude llevándolo despacito hasta que me pidió que le contestara que sí y yo no quise contestarle en seguida sólo mirando el mar y el cielo pensando en tantas cosas que él no sabía de fulano y zutano y de papa y de Ester y del capitán y de los marineros en el muelle a los brincos y el centinela frente a la casa del gobernador con la cosa en el salacot pobre hombre medio achicharrado y las chicas españolas riéndose con sus mantones y peinas y los remates de mañana los griegos y los judíos y los árabes y hombres de todos los rincones de Europa y el mercado cloqueando y los pobres 
burritos cayéndose de sumo y los tipos cualquiera dormidos en la sombra de los portales y las ruedas grandotas de las carretas de bueyes y el castillo de miles de años si y esos moros buenos mozos todos de blanco y con turbantes como reyes haciéndola sentar a uno en su tendencia y Ronda con las ventanas de las posadas ojos que atisban y una reja escondida para que bese los barrotes su novio y los bodegones a medio abrir toda la noche y las castañuelas y aquella noche en Algeciras cuando perdimos el vapor las castañuelas y el sereno pasando quietamente con su farol y Oh ese torrente atroz y de golpe Oh y el mar carmesí a veces como fuego y los ocasos brillantes y las higueras en la Alameda sí y las callecitas rarísimas y las casas rosadas y amarillas y azules, y los rosales y jazmines y geranios y tunas y Gibraltar de jovencita cuando yo era una Flor de la Montaña si cuando me ate la rosa en el pelo como las chicas andaluzas o me pondré una colorada sí y como me beso junto al paredón morisco y pensé lo mismo me da él que otro cualquiera y entonces le pedí con los ojos que me pidiera otra vez y entonces me pidió si quería sí para decirle sí mi flor serrana y primero lo abrazé sí y encima mío lo agache para que sintiera mis pechos toda fragancia sí y su corazón como enloquecido y sí yo dije sí quiero Sí.

Versión de J.L.B.

JAIME JOYCE 


\section{Publicaciones Recientes Sobre Borges}

Hace unos siete años escribí una nota en que me referí a una serie de libros dedicados a la obra de Jorge Luis Borges, reseñando y comentando lo que era entonces una muestra de la reciente crítica sobre los inagotables escritos del autor argentino. ${ }^{1}$ Los años han corrido desde 1970, y tanto Borges como sus interpretes y comentaristas han seguido escribiendo, incansablemente. De modo que hoy nos encontramos con un nuevo y extenso conjunto de obras y de obras sobre obras. Puesto que aquéllas en su mayoría ya han sido comentadas en las páginas de esta revista, son éstas las que más nos interesan aquí.

Huelga decir que no hay espacio disponible para comentar todo lo que se ha publicado en siete años sobre la obra de Borges. Ni siquiera una simple lista de las publicaciones cabría aquí. Por eso, hay que ser algo arbitrario en la selección de obras representativas y bien conciso en el comentario de las mismas.

Hemos dividido las obras a comentar en tres categorías: 1) libros que consisten en transcripciones de diálogos entre Borges y un interlocutor; 2) libros que recogen ensayos sobre distintos aspectos de su obra; y 3) libros dedicados a análisis críticos más extensos.

En lo que se refiere a la primera categoría, ya hemos visto varios libros que reproducen diálogos con Borges. Ahora se agregan tres más a la lista y, ya que Borges parece estar dispuesto a conceder esta clase de entrevista estilo maratón, veremos sin duda otros. Siete conversaciones con Jorge Luis Borges, ${ }^{2}$ de Fernando Sorrentino, tal vez resulte el mejor de los libros de esta índole. Se trata de siete diálogos entre Borges y Sorrentino grabados en 1972. Hay, como es de suponer, muchos datos y juicios que repiten otros momentos de otras charlas públicas de Borges, pero considero que es, sin embargo, un testimonio importante. Sorrentino conoce bien la obra borgeana y Borges le facilita amplias y sinceras respuestas a sus preguntas. La imagen de Borges que surge de estas páginas es, creo, lo más fidedigno de todas las versiones que hemos visto hasta ahora en libros de este tipo. Rita Guibert consiguió una excelente entrevista en 1968, pero percibimos en el Borges que conversa con Sorrentino un tono más 
abierto e íntimo. Sorrentino, evidentemente más literato que periodista, ha sabido guiar a Borges por senderos bastante bien definidos y así se puede apreciar no sólo la originalidad de sus juicios sino también la profundidad de que es capaz Borges en el diálogo -a diferencia de lo que han logrado otros interlocutores (Burgin, por ejemplo), que parecen entusiasmarse con la cantidad de temas que consiguen que toque el escritor. Cabe señalar, además, que Borges aquí ofrece declaraciones políticas de tanta franqueza que la distribución en la Argentina de este libro, publicado en 1974, tuvo que ser postergada hasta 1976, después del movimiento militar que puso fin a la presidencia de Isabel Perón.

Un libro más artificial, más “confeccionado”, es Diálogos ${ }^{3}$-siete conversaciones grabadas entre diciembre del '74 y marzo del '75 en las que participan Borges y su compatriota- que también ha sido en algún momento su adversario -Ernesto Sábato. Estas páginas surgieron de la iniciativa de Orlando Borlone, que tuvo la idea de “reunir a los dos escritores y de hacerlos dialogar.” En estas páginas tanto Borges como Sábato tienen territorio que vigilar y juicios que establecer. (Para formarse una idea de las diferencias políticas que los dos han discutido en el foro público, recomiendo el libro de Sábato, Claves polítical, ${ }^{4}$ donde el dedica unas veinte páginas a las varios declaraciones de ambos sobre el peronismo.) En Diálogos, Borges y Sábato son como dos barcos que se cruzan en la noche. Sábato, característicamente, es brillante en su despliegue de conceptos, ideas, conocimientos. Borges, por su lado, deslumbra con su mezcla de sorprendentes opiniones y conmovedoras alusiones a ciertos aspectos personales de su carrera de escritor. Parece emplear la desnuda intimidad como una especie de arma contra las observaciones agresivamente intelectuales de Sábato. Al fin de cuentas, todo parece un match de "shadow boxing." Los dos apenas se tocan, se lanzan contra sombras, y todo se reduce a dos actuaciones individuales y casi independientes. Lo esperado, dadas las circunstancias del origen del libro. Borges y Sábato, al parecer, se conformaron con los resultados: el texto que leemos fue repasado y aprobado por los dos.

El más reciente de estos libros dialogados es Reportaje a Borges, ${ }^{5}$ por M. P. Montecchia, autor y estudioso de considerable formación filosófica. Es precisamente por su conocimiento del temario que le presenta a Borges que cobra valor este testimonio-grabado. Indudablemente, lo más valioso son las páginas que tratan de aspectos del conocimiento filosófico de Borges y, sobre todo, de la forma en que tales conceptos se han expresado en su obra. De sumo interés son los comentarios de Borges sobre varios aspectos de su pensamiento y sobre la manera en que él concibe su oficio literario. Es cierto que en 1976 Borges inevitablemente va a reiterar muchos juicios que ya conocemos; pero, a pesar de que este libro carece de notas inteligentes y útiles como las que Sorrentino incluye en Siete conversaciones, su saldo es favorable. Un diálogo más que nos parece interesante mencionar es la audición de televisión, “Borges: South America’s Titan,” televisada en la Public Broadcasting System en Estados Unidos el 18 de febrero de 1977 en el programa "Firing Line” de William 
Buckley, Jr. Es una conversación entre Buckley y Borges en la que aquél, que por costumbre controla, con mano de hierro cubierta por guante de terciopelo, los diálogos de esta audición, se ve en el papel de perseguidor de fantasmas. Borges se le desliza por entre las manos por no conformarse con la condición de respondiente ante las salidas y preguntas “cargadas” de Buckley. Es un texto bastante interesante que puede conseguirse en Firing Line, P.O. Box 5966, Columbia, S. Carolina 29250.

En materia de recopilaciones de ensayos sobre Borges, tenemos a la vista seis volúmenes. El primero, cronológicamente, es The Cardinal Points of Borges, ${ }^{6}$ que refine los textos de los siete trabajos críticos presentados en el simposio sobre Borges organizado en 1969 por la Universidad de Oklahoma. Los siete "especialistas borgeanos”, invitados a participar después de haber sido sugeridos por Borges mismo son: Jaime Aiazraki, Ronald Christ, Norman Thomas di Giovanni, James Irby, John Murchison, Emir Rodríguez Monegal y Donald Yates. Son todos trabajos sólidos que destacan con autoridad y soltura múltiples facetas de la prosa de Borges. Se incluye también una actualización de la bibliografía crítica sobre Borges de Robert L. Fiore.

Borges: hacia una interpretación, ${ }^{7}$ de Emir Rodríguez Monegal, refine tres artículos del crítico uruguayo aparecidos anteriormente en revistas norteamericanas (dos de ellos en esta revista). “Borges y Paz: Un diálogo de textos críticos” ofrece un enfoque personal que, aunque no tiene el propósito de establecer una relación básica o significativa entre estos dos escritores (el autor prefiere considerar "lo que separa la obra crítica de uno de la del otro”), termina señalando una profunda afinidad intelectual entre Borges y Octavio Paz. "El lector como escritor”, que tiene otros méritos con respecto a la elaboración de una “poética de la lectura”, me parece la mejor interpretación de la relación entre Borges y su padre que se ha publicado hasta ahora. Es un texto indispensable para la comprensión de cómo el joven Borges iba percibiendo su “destino” de escritor. "Borges y la nouvelle critique” ofrece un estudio muy valioso para la apreciación de la forma en que la obra de Borges ha contribuido a definir la nueva orientación de la crítica literaria en Europa, sobre todo en Francia.

Otro libro, que no se dedica íntegramente a ensayos sobre Borges, pero que vale la pena destacar, es El realismo mágico y otros ensayos ${ }^{8}$ de Enrique Anderson Imbert. Anderson recoge aquí, entre los nueve ensayos que integran el volumen, tres que versan sobre Borges. Son: "El éxito de Borges,” que incluye singulares observaciones sobre el carácter de la consagración del escritor; “Chesterton y Borges,” estudio meticuloso que trata de la (posible) influencia del autor inglés sobre la prosa del cuentista argentino; y "El punto de vista en Borges,” trabajo más bien formal sobre la perspectiva narrativa en los relatos borgeanos. En resumidas cuentas, son tres artículos sumamente interesantes por un crítico que tal vez con más insistencia que nadie ha ido analizando e interpretando la obra de su célebre compatriota.

La más admirable de las colecciones de ensayos críticos sobre Borges es, sin lugar a dudas, Jorge Luis Borges, ${ }^{9}$ edición de Jaime Alazraki, que forma parte de la serie “El escritor y la crítica” de la editorial española Taurus. Se trata de una impecable 
colección de textos sobre: 1) Primeros textos críticos; 2) Poesía; 3) Ficción; 4) Ensayo y prosa de varia invención; y 5) La crítica de la crítica. Alazraki incluye también un artículo sobre la amistad epistolar entre Borges y Alfonso Reyes y la antes citada entrevista con Borges de Rita Guibert, amén de compilaciones bibliográficas de la obra del escritor y de la crítica sobre la misma. Para estudiosos del tema, es un libro indispensable.

Como primer volumen de su colección “Letra Abierta,” la editorial El Mangrullo de Buenos Aires ofrece Borges, ${ }^{10}$ una miscelánea de breves textos de Borges junto con una serie de notas y artículos -algunos nuevos, otros reproducidos- que integran un dossier que "con el ánimo de equilibrar el fervor con la lucidez, intenta rescatar nuevos o desconocidos aspectos del escritor.” Hay, en efecto, cosas novedosas aquí. Entre ellas tal vez interese más la nota de Jorge B. Rivera sobre la colaboración de Borges (como director del suplemento literario) en el diario porteño Crítica de 1933 hasta 1934. Se reproducen también algunos testimonios de amigos y familiares de Borges, una entrevista que data de 1973 con María Esther Gilio, y fragmentos de varias otras; $y$, finalmente, una breve cronología. Es un libro preparado con evidente seriedad que, efectivamente, redondea la imagen del escritor.

Antes de pasar a la última categoría, conviene mencionar tres números especiales de publicaciones periódicas que han sido dedicados a estudios críticos sobre Borges y su obra. Son: TriQuarterly 25; Prose for Borges, Evanston, Illinois, Northwestern University, Fall 1972, 467 pp.; Modern Fiction Studies, “Jorge Luis Borges Number,” West Lafayette, Indiana, Purdue University, Vol. 19, No. 3, Autumn 1973, 165 pp.; e Iberoromania, Erlangen, Alemania, Universität Erlangen-Nürenberg, núm. 3, mayo de 1975, 284 pp. El primero tiene sus altibajos; los otros dos traen casi todos estudios serios y bien documentados.

Ahora pasamos a cinco libros recientes dedicados a estudios extensos de la obra de Borges. Pero, primero quisiera reafirmar que, a mi juicio, el mejor estudio de mayores dimensiones sobre un aspecto amplio de la obra borgeana es La prosa narrativa de Jorges Luis Borges ${ }^{11}$ de Jaime Alazraki, publicado en 1968. Hay ahora una segunda edición, aumentada (1974) de este libro fundamental.

Marcos Ricardo Barrnatán publicó en 1972 dos libros sobre Borges. El primero es Borges, ${ }^{12}$ que en unas cien páginas presenta una versión esquemática de la carrera de Borges y después agrega una pequeña antología, una cronología (donde no faltan errores), y una modesta bibliografía de “algunos libros y articulos sobre Borges.” El segundo es Jorge Luis Borges, ${ }^{13}$ volumen que forma parte de una colección de libros sobre poetas. Los dos libros se parecen mucho en lo que se refiere al formato, con la diferencia de que en el segundo el autor se propone perfilar más bien al Borges poeta. No hay mucho que alabar ni criticar en estos volúmenes. Agregan poco a nuestro conocimiento de Borges, pero tal vez se justifican -como homenajes-por el evidente respeto y admiración que demuestra Barnatán por el autor argentino. 
Borges ante la crítica argentina, 1923-1960, ${ }^{14}$ de María Luisa Bastos, es un examen detallado de los textos críticos que provocaron las obras de Borges entre los argentinos, desde Fervor de Buenos Aires en 1923 hasta El hacedor en 1960. Constituye un valioso estudio realizado sobre la base de una impresionante labor de investigación y síntesis. La autora, razonablemente, se ha dedicado más a la descripción y la documentación que a la interpretación y la conjetura sobre las mismas. Que esto quede por hacerse no le quita méritos a este libro inteligente y bien organizado.

Estudio mas abstracto es El laberinto del universo, ${ }^{15}$ en que el crítico Jaime Rest, que ha publicado ya una serie de meditados estudios sobre la obra de Borges, emprende un análisis del modo en que se han expresado en los escritos borgeanos las perplejidades del pensamiento nominalista -sistema filosófico que viene a poner en tela de juicio la validez del lenguaje mismo como medio para interpretar y expresar la realidad. En sus ensayos Borges ha discutido este concepto, mientras que en algunos cuentos (“La escritura del dios,” “El etnógrafo,”etc.) parece insinuar otra forma de conocimiento -la mística. Rest indaga en los ejercicios de Borges que para él representan su aporte a esta cuestión enigmática y luego presenta sus conclusiones. Este es un aspecto fascinante de la obra de Borges que merece un análisis detenido. El de Rest está lúcidamente desarrollado; sus argumentos son coherentes. Hay que señalar, sin embargo, que el intento del epílogo sobre "El silencio privado” parece estar en conflicto con las conclusiones que Rest va articulando a lo largo de los tres densos capítulos de su estudio.

Hemos reservado para el final el comentario sobre Borges y la nada ${ }^{16}$ de Manuel Ferrer. Es un libro que requiere atención especial por una teoría que el autor toma como presupuesto básico de su estudio. No hay lugar aquí para describir en todos sus detalles el propósito del libro de Ferrer. Pero, esencialmente, el autor quiere sugerir que llegó un momento en la vida de Borges cuando "la única realidad [era] la irrealidad.” A partir de ese momento, según su tesis, Borges se puso a suprimir casi todo lo que había escrito anteriormente-es decir, durante la década de los años veintey a armar e interrelacionar deliberadamente una nueva obra sobre la base de un concepto estético distinto -el de no-ser. Debo confesar que nada de esto me convence -ni lo que teoriza acerca de la minuciosa aniquilación de sus obras tempranas, ni lo que propone como la motivación de lo que escribió posteriormente. Diré más: jamás he leído un libro que tanto necesitaba una refutación. Ferrer teje una compleja telaraña de supuestos indicios, pistas y claves que, según él, forman una especie de mensaje secreto que Borges nos viene insinuando desde hace casi medio siglo. Ferrer quiere convencer al lector de que ese mensaje cifrado, articulado en un sutilísimo código por Borges, está presente en su obra y puede descifrarse.

Todo esto está muy bien como juego. En fin, en las páginas de Borges, se puede encontrar lo que se quiera. Pero estas lucubraciones ingeniosas no sostienen un estudio serio. Y creo que Ferrer quiere que se tome su libro seriamente. Sin embargo, esta obra, con su entusiasmado y cuidadosamente documentado rastreo del mensaje 
fantasma no carece totalmente de mérito. Podríamos decir que es un libro que tenía que escribirse, porque era inevitable que a alguien se le iba a ocurrir desentrañar claves y pistas escondidas en la obra de Borges. Ahora que dicha ambición ha sido realizada, ya no ofrece atractivos esa vana empresa.

La última palabra, apropiadamente, puede ser la de Borges. Yo discutí con él en 1972 la posibilidad de que pudiera existir indicios secretos esparcidos por sus páginas. El observó que sus obras fueron escritas a través de may de cincuenta años, y que cada texto suyo había surgido como consecuencia de estímulos inconscientes e individuales. Claro está que si uno lee durante un periodo relativamente corto la obra total de un escritor, es muy probable que halle ciertos temas reiterados, ciertas repeticiones que el autor mismo sinceramente desconoce. Yo insistí en la idea y le pregunté a Borges en inglés: "Have you consciously used echoes, affinities, reflections -not within just a single piece but between individual pieces [la teoría de Ferrer]- for some special purpose or effect?” Borges respondió con una expresión de sorpresa y una rotunda negativa, como si yo le hubiera acusado de algún delito. “Never!” dijo.

Michigan State University

DONALD YATES

\section{NOTAS}

1 “Borges in Books” Books Abroad, Vol, XLIV, No. 1, Winter 1970, pp. 404-411. Este artículo, en versión española, ha sido recogido en Jorge Luis Borges (Edición de Jaime Alazraki), Madrid, Taurus, pp. 293-301.

2 Sorrentino, Fernando, Siete conversaciones con Jorge Luis Borges, Buenos Aires, Pardo, 1974, 162 pp.

3 Borges, Jorge Luis y Ernesto Sábato, Diálogos, Buenos Aires, Emecé, 1976, 198 pp.

4 Sábato, Ernesto, Claves políticas, Buenos Aires, Rodolfo Alonso Editor, 1971, pp. 57-58.

5 Montecchia, M. P., Reportaje a Borges, Buenos Aires, Crisol, 1977, 123 pp.

6 Dunham, Lowell and Ivar Ivask, The Cardinal Points of Borges, Norman, Oklahoma, University of Oklahoma Press, 1970, 113 pp.

7 Rodríguez Monegal, Emir, Borges: hacia una interpretación, Madrid, Guadarrama, 1976, 125 pp.

8 Anderson Imbert, Enrique, El realismo mágico y otros ensayos, Caracas, Monte Avila, 1976, 175 pp.

9 Alazraki, Jaime, Jorge Luis Borges, Madrid, Taurus, 1976, 364 pp.

${ }^{10}$ Borges, Buenos Aires, El Mangrullo, 1976, 94 pp.

${ }_{11}$ Alazraki, Jaime, La prosa narrativa de Jorge Luis Borges, Madrid, Gredos, 1968, 246 pp.

${ }^{12}$ Barnatán, Marcos R., Borges, Madrid, E.P.E.S.A., 1972, 203 pp.

${ }^{13}$ Barnatán, Marcos R., Jorge Luis Borges, Madrid, Júcar, 1972, 210 pp.

14 Bastos, María Luisa, Borges ante la crítica argentina, 1923-1960, Buenos Aires, Hispamérica, 1964, 356 pp. 
${ }^{15}$ Rest, Jaime, El laberinto del universo: Borges y el pensamiento nominalista, Buenos Aires, Librerías Fausto, 1976, 201 pp.

${ }^{16}$ Ferrer, Manuel, Borges y la nada, London, Tamesis Books Limited, 1971, 201 pp. 


\section{Dante en la Lectura de Borges}

Aunque Borges haya declarado varias veces su admiración por la Divina Comedia $^{1}$ hasta ahora no se había estudiado seriamente la influencia de Dante en la obra del escritor argentino. ${ }^{2}$

En un libro reciente Borges, Percorsi di significato ${ }^{3}$, Roberto Paoli hizo un análisis excelente de algunos cuentos fundamentales de Borges, y aplicando un amplio material crítico estructuralista, puso en evidencia los aspectos más sobresalientes de la obra borgiana en lo que se refiere a la estrecha relación con Dante.

Lástima que por falta de conocimiento directo de algunos textos críticos de Borges -como el prólogo a la Divina Comedia, publicado en $1949^{4}$ y que Paoli cita sin analizar-, en su trabajo se encuentran algunas imprecisiones que trataremos de corregir.

Leyendo el ensayo sobre “El Aleph”, que es el primero del libro, asombra no hallar ninguna cita del artículo de Borges "Encuentro en un sumo" ${ }^{5}$ que, como subraya correctamente Cro, ha dejado la huella más profunda en la elaboración de este cuento. Entre los personajes clave del mismo aparece también una Beatriz que, aún resultando desde distintos puntos de vista una evidente alusión a la Beatrice dantesca, llegará a ser exactamente su antítesis. ${ }^{6}$

En el artículo mencionado Borges describe y analiza el encuentro de Dante con Beatrice en el Paraíso Terrenal. Observa que Dante idolatró tanto a Beatrice (a pesar de que ella lo despreciara y hasta se mofara públicamente de él) que, después de muerta, en la ficción del encuentro evocado en la Divina Comedia, no pudo evitar representarla muy severa, inaccesible, dispuesta a humillarlo de nuevo.

La humillación misma es el elemento de conjunción entre las dos Beatrices.

En la Divina Comedia la humillación impuesta al personaje Dante tiene una doble finalidad positiva, es decir el logro de la salvación y la visión final de Dios. En "El Aleph” la incesante humillación a que somete Beatriz Viterbo al personaje Borges, llega a su límite cuando éste, en la visión multiforme del Aleph, tiene la revelación de las cartas obscenas enviadas por ella a su primo Carlos Argentino Daneri, revelación que termina por descalificarla totalmente ante sus ojos. 
El ensayo, "Encuentro en un sumo", que Paoli ni siquiera menciona, es imprescindible para la comprensión perfecta de “El Aleph”, porque ilumina su núcleo y permite el acceso a su sentido más profundo. O para decirlo con palabras de Cro, esta relación de las dos Beatrices ilumina "l’intensa analogía simbólica con il poema dantesco, per quanto riguarda la rappresentazione, e con il significato onirico dell'evocazione di Beatrice"7.

Analizando el personaje de Carlos Argentino Daneri, Paoli con razón destaca la semejanza fonética con el nombre de Dante Alighieri, signo de un "mensaje paródico y antifrástico” y en varias ocasiones subraya el elemento paródico presente a menudo en la obra borgiana, pero nunca hace una interpretación de conjunto de este recurso, que el autor utiliza para acentuar y destacar situaciones y personajes como "proyecciones invertidas" de otros muy conocidos, en este caso los dantescos.

En este ensayo sobre "El Aleph" Paoli incurre en excesos de interpretación textual. Así, por ejemplo, le parecen “piuttosto improbabili” (p. 29) los apellidos Zunino y Zungri que identifican a los dueños de la casa donde vive Carlos Argentino. Sin embargo, en Montevideo existió una empresa de demoliciones con el nombre “improbable” pero verdadero de Zunino. En otra ocasión Paoli adelanta una hipótesis bastante exagerada sobre el coñac nacional que Borges regala a Carlos Argentino y que éste a su vez le hará tomar antes de llevarlo al sótano para mostrarle el Aleph.

Paoli sostiene que: "non è assolutamente possibile escludere che si tratti di una bevanda allucinogena introdotta da Borges in quella casa per ragioni inconsapevolmente ritorsionistiche” (p. 37).

Más adelante hasta emite la sospecha que pueda ser veneno disfrazado de coñac (p. 38), aunque dos páginas más adelante se contradiga afirmando que puede “anch'essere che il cognac, sebbene di modesta qualità (coñac del país) sia innocentissimo” (p. 40).

Por perseguir una superflua motivación realista, Paoli no advierte la evidente referencia paródica al conocido cuento de E. A. Poe, "The Cask of Amontillado" donde, contra todas las expectativas del lector, el vino amontillado no es otra cosa que el anzuelo inocente que usa el asesino para atraer a su víctima al sótano y matarla de una manera mucho más atroz que un simple envenenamiento.

Por lo que se refiere a la concepción borgiana del Aleph, como visión inefable, punto que incluye a todos los puntos del universo, Paoli muy agudamente destaca los pasajes análogos del "Paradiso" (XXX, 22-23 y XXXIII, 85-89), donde Dante proclama la insuficiencia de su lenguaje poético para expresar la belleza de Beatrice, y donde logra la visión sublime del Absoluto; pero al mismo tiempo subraya cómo en Borges no hay nada de sobrenatural, “... il suo dantismo è senza al di là. Per lui il divino è al di fuori di questo mondo” (p. 44).

Sin embargo, analizando la enumeración ca6tica por medio de la cual Borges describe al Aleph, Paoli no se da cuenta, por ejemplo, que "vi un laberinto roto (era Londres)" es una alusión a una frase de De Quincey y la estudia como si fuera una 
invención del mismo autor argentino. Por otra parte parece atribuir seriamente al Capitán Burton una cita que aparece al final del cuento sobre la existencia del Aleph, porque así la refiere Borges, sin advertir que en realidad ha sido inventada por él mismo.

En el segundo ensayo de su libro, Paoli continúa con profundo sentido crítico el estudio de otros dos importantes cuentos de Borges: "El Sur” y "La muerte y la brújula”, de la colección Ficciones.

En "El Sur”, "racconto di una morte sognata come rinascita”, destaca en seguida el aspecto más relevante, o sea el onírico, y subraya cómo la posibilidad de una doble lectura (experiencia real y experiencia soñada) sugiere y confirma "la nota indistinzione borgesiana fra vivere e sognare, fra universo reale e universo mentale” (p. 47).

En "La muerte y la brújula", Paoli subraya la novedad más auténtica, la contaminación del cuento por la doctrina y el sistema de la Cábala hebrea que constituye un código

che con le sue divaricazioni simboliche tra il tre e il quattro, con le sue oscurità, polivalenze e ambiguità, col suo verbo ignoto che nasconde la chiave dell'universo è un sistema di segni che opera a livello paradigmatico, suggerendo le possibili scelte semiologiche in base alle quali si determina l'intreccio (p. 55).

Paoli analiza con cuidado la profusión de signos y de símbolos “ai limiti della ridondanza” que abundan en este cuento,

testo proteiforme costituito da una continua emissione di nuovi segni the giocano a contraddirsi fra di loro, in una delirante e insieme lucidissima altalena (p. 68).

Tal vez la única observación que podría hacerse a este brillante ensayo sobre la numerología borgiana de "La muerte y la brújula” es la de no haber intentado una vinculación con la numerología dantesca de los cap. 28-29 de la Vita Nuova, donde Dante explica la razón de su insistencia en los números 3 y 9.

El capítulo tal vez más interesante de este estudio crítico es el tercero, sobre Dante en Borges, y es este donde nos detendremos más tiempo.

Paoli regresa de nuevo a "La muerte y la brújula” y a "El Sur”, para reducir su trama a dos funciones esenciales (según el método de Propp): “infracción seguida de castigo”, “elección de un fin seguida de fracaso”, y también para establecer la analogía con el último viaje de Ulises. Es curioso que Borges, en el mismo Estudio Preliminar a la Divina Comedia se detenga largo rato en el personaje de Ulises, sobre el que adelanta una tesis bastante interesante. ${ }^{9}$

Paoli cita esta tesis pero sin analizarla y sin referirse críticamente a ella. Las analogías que subraya con el Ulises dantesco son esencialmente estas: 
También Lonnrot y Dahlmann, en los respectivos cuentos, pagan con la vida su propia temeridad.

Lönnrot ha decifrato (o crede di averlo fatto) la trama profonda che si cela sotto il disegno superficiale, ma la scoperta del segreto ha un suo prezzo che egli non aveva forse preventivato. Varcato il limite (la convalescenza? il sogno?), Dahlmann entra in una sfera che solo in apparenza è di gioiosa libertà ... Il visitatore viola un mondo che non è suo, ambiguo kafkianamente estraneo ed ostile (p. 87).

Si para el Ulises dantesco lo ignoto está vagamente situado en el "occidente”, en el "lato mancino", bajo "le stelle... dello altro polo", en Borges se encuentra del otro lado de Buenos Aires, la capital que representa la civilización, o sea en el interior, en la pampa, al "Sur”, que representa el desierto, la barbarie. Con razón Paoli observa que:

con un po' di esagerazione mitologica, si può affermare che in ogni bonaerense che s'avventuri nell'interno del suo paese s'annida un ulisside europeo che affronti l'ignoto di un continente diverso (ma lo stesso si può dire anche di un abitante di Lima e forse con minore esagerazione) (p. 90).

En “La muerte y la brújula”, el Sur está indicado por el cuarto punto que hay que agregar al triángulo equilátero dibujado en un mapa de la ciudad y enviado a la policía, y que Lönnrot situará con la ayuda de una brújula determinando así un rombo perfecto. El punto que falta es lo opuesto al Norte que significa orientación, por consiguiente "il Sud viene a significare all'inverso, disorientamento, perdita della bussola, propria perdizione” (p. 91). Por eso en ambos cuentos el Sur torna a ser lugar de encuentro con la muerte y de cumplimiento del destino secreto.

La obsesión del Sur como frontera -continúa Paoli- se encuentra también en la poesía de Borges, en especial en el conocido "Poema conjetural"10, donde el escritor imagina las reflexiones y sensaciones de su antepasado Francisco Laprida, mientras huye hacia el Sur, antes de morir en manos de sus perseguidores.

Uno de los aspectos más interesantes de este poema lo constituye la precipitada narración de la derrota, relatada en primera persona por el mismo Laprida, que llega a ser:

bilancio lapidario della propria vita, ... condensazione di una biografia in un'ultima carrellata di coscienza ..., che richiama gli inserimenti "mimetici" delle anime dei tre regni nella narrazione dantesca, col racconto compendiario e selettivo the fanno della propria vita ... Il discorso interiore di Laprida è poi avvicinabile alle confessioni the le anime fanno a Dante anche in ragione del suo 
carattere "conjetural”, cioè in quanto ipotesi fondate, riferimento di una versione sconosciuta e segreta ma realmente o idealmente autentica e verace, la quale ristabilisce un ordine di verità infranto dalle false versioni (p. 97).

La referencia a Dante, en este poema, es evidente en particular en los versos en que Borges compara la huida de Laprida con la de Bonconte da Montefeltro:

\author{
Como aquel capitán de Purgatorio \\ que, huyendo a pie y ensangrentando el llano, \\ fue cegado y tumbado por la muerte \\ donde un oscuro río pierde el nombre, \\ así habré de caer. Hoy es el término. \\ La noche lateral de los pantanos \\ me acecha y me demora. Oigo los cascos \\ de mi caliente muerte que me busca \\ con jinetes, con belfos y con lanzas. ${ }^{11}$
}

que corresponde bastante fielmente, como ya Cro había notado, a la imagen del canto V del "Purgatorio”. Con mucho acierto Paoli ha subrayado, además de la clara referencia a Bonconte, la relación, tal vez por “inconsciente contaminación”, con otro episodio del mismo canto del "Purgatorio”: la persecución a que es sometido Jacopo del Cassero, la primera de las tres almas que se dirigen a Dante en ese canto V. Aclara, Paoli, esta comparación destacando cómo los pantanos y el lodo del Sur, que detienen la huída de Laprida, encuentran su equivalencia en "la palude”, "le cannucce”, "il braco” que atrapan a Jacopo del Cassero.

Infine l'errore fatale compiuto da Jacopo durante la fuga, l'essersi messo in trappola praticamente da sè, dirigendosi verso la palude della foce dove è stato raggiunto, anzichè verso l'interno dove si sarebbe salvato, suona come un richiamo misterioso della morte, una manifestazione subdola del destino che è perfettamente in chiave con le formule borgesiane, mentre l'episodio di Bonconte, al pari di quello di Ulisse, è viceversa esemplare piuttosto per quanto riguarda il resoconto della "versione segreta” della morte (p. 99).

En la segunda parte de este ensayo Paoli evidencia el aspecto tal vez más notable de la mayoría de los cuentos de Borges, que consiste en una gran intensidad, condensación narrativa de acontecimientos relatados con aceleración, para detenerse en un momento particular, "istante privilegiato verso il quale tutto il resto converge, preparandolo e subordinandovisi: momento cruciale o culminante in cui il destino si compie e si rivela” (p. 103).

Para entender este proceso, hay que remitirse, como hace Paoli, a la famosa cita de Borges, donde este último se refiere a su técnica estructurante del cuento: 
"Cualquier destino, por largo y complicado que sea, consta en realidad de un sólo momento: el momento en que el hombre sabe para siempre quien es". ${ }^{12}$

Este momento culminante, que en muchos cuentos coincide con una iluminación en vísperas de la muerte, o con un momento crucial de la vida, Paoli lo relaciona con las historias particulares que las almas de los tres reinos refieren a Dante. También los relatos de estos difuntos "si riducono a un solo episodio estremamente condensato, si che fra l'uomo e il suo atto (o abito) fondamentale si stabilisce un'equazione che è anche una condanna immutabile" (p. 107).

Muchas veces el cuento se concentra en su fin, como ocurre en los ejemplos dantescos de Pier della Vigna, Ulisse, Ugolino, Manfredi, Jacopo del Cassero; fin que casi siempre ha sido causado por una muerte violenta. Este es otro aspecto más que asemeja los personajes de Borges a los de Dante.

Paoli reconoce una última analogía entre los textos de Borges y el poema dantesco, comparando "la versión secreta y la versión conjetural" de muchos cuentos borgianos. Considera, según la conocida clasificación de Genette, los niveles narrativos de la Divina Comedia, estableciendo como nivel diegético aquel constituido por "las peripecias del viaje, la relación de Dante con Virgilio y luego con Beatrice, por el encuentro o choque entre los viajeros y las almas de ultratumba.” Por otra parte Paoli coloca a nivel metadiegético "le varie narrazioni incastrate entro la narrazione omnicomprensiva del viaggio" (p. 109).

Regresa luego a Borges para establecer los respectivos universos diegético y metadiegético. Reconoce el primero en el ambiente casi siempre autobiográfico del autor, poblado de amistades, lecturas, relaciones, sean reales o ficticias: "È un universo che può apparire un po' monotono e grigio, statico e libresco, ma è anche imbevuto di una sua serena pacatezza e anche percorso da una vena ironica e bizzarra che lo rendono piacevole" (p. 109). Mientras que considera universo metadiegético: “i racconti tradizionalmente definiti 'in prima' o 'in terza persona', che hanno come tratto tematico comune un segreto, o una o più congetture sulla base di dati controversi” (p. 110). Ejemplos de textos en posición metadiegética son -según Paoli- los impresos y los manuscritos apócrifos en que se basan textualmente "El jardín de senderos que se bifurcan” y "El inmortal” ...; los resúmenes de fingidas obras ajenas (“El acercamiento a Almotásim”), falsos esbozos de libros propios (“Tema del traidor y del héroe”).

Ma soprattutto -continúa Paoli- lo sono nella maniera più classica e ortodossa, i racconti orali inseriti nella cornice dei racconti di primo grado ("La forma de la espada”, "El indigno”) ... Tutti questi racconti di secondo grado ... hanno come abbiamo già detto- la funzione di riferire una storia sconosciuta o di rivelare una versione che è, di solito, "segreta” e/o "congetturale”. È "segreta" nel rapporto the unisce il narratore del metaracconto (assente $o$, perlopiù, presente nella storia narrata) al destinatario (che può essere il narratore del 
racconto primo o, semplicemente, un personaggio del primo livello narrativo). È, invece, “congetturale” sul piano del messaggio che il narratore extradiegetico (che ribadiamo, non coincide neppure in questo caso con fautore, anche se ne porta il nome, come di solito in Borges) intende comunicare a un "narratario" che a questo livello si confonde con il lettore virtuale (pp. 110-111).

En el último capítulo, “Il muro e l’infinito”, que concluye su libro Paoli sintetiza la situación presente en tres cuentos de Borges, "La casa de Asterión”, "La escritura del Dios” y “La espera”, de la colección El Aleph, que tienen “per storia (per tempo) una reclusione e per spazio una prigione”, lo que sin embargo, no limita la capacidad perceptiva y alucinatoria del espacio exterior.

Con este ensayo termina el valiosísimo estudio de Paoli, contribución fundamental a la nueva crítica borgiana. La novedad principal de este trabajo es, sin duda, el análisis sutil de la influencia dantesca en la narrativa del escritor argentino. Las únicas reservas que se le pueden hacer conciernen a algunas imprecisiones críticas debidas al desconocimiento de textos o declaraciones de Borges. Por ejemplo, las declaraciones contenidas en An Autobiographical Essay, que está incluído en la traducción norteamericana de El Aleph. Allí Borges cuenta (p. 242) su primera experiencia como lector de la Divina Comedia, realizada por primera vez, bastante tarde en su carrera, a fines de los años '30. Este material, como también el Prólogo a la Divina Comedia, ya mencionado, habría sin duda constituído una ayuda ulterior y complementaria para Paoli en su minucioso estudio de la narrativa borgiana. ${ }^{13}$

Yale University

MARIA BONATTI

\section{NOTAS}

1 Este ha sido también el tema de una conferencia dictada por Borges el $1^{\circ}$ de Julio de 1977 en el Teatro Coliseo de Buenos Aires, la cuarta de un ciclo que incluía variados temas: La ceguera, El budismo, Los sueños, La Cábala. Fue recogida en el diario La Opinión, Buenos Aires, 10 de agosto de 1977.

2 Stelio Cro, en su libro Jorge Luis Borges, poeta, saggista, narratore, (Milano, Mursia, 1971), ha dedicado un capítulo a las lecturas dantescas del escritor argentino.

3 Paoli, R., Borges: Percorsi di significato. (Firenze: D’Anna, 1977).

4 J. L. Borges, “Estudio Preliminar” a La Divina Comedia (Buenos Aires: “Clásicos Jackson”, 1949).

5 Borges, "El encuentro en un sueño", La Nación, Buenos Aires, 3 de octubre de 1948, recogido en Otras Inquisiciones, (Buenos Aires, Sur, 1952), pp. 116-120. También forma parte del Prólogo a la Divina Comedia, ya citado, pp. XXIV-XXVII.

6 Cro, op. cit., p. 118.

7 Cro, ibid.

8 Borges, “El Aleph”, en Obras Completas (Buenos Aires: Emecé, 1957), p. 165. 
9 Stelio Cro en su estudio sobre Borges resume esta tesis: "La premessa è data dalle ipotesi di alcuni studiosi” (Hugo, Friederich, Carlo Steiner), secondo i quali Ulisse è vittima della sua superbia, che provoca la tragedia del naufragio, mentre Dante, illuminato dalla grazia e dalla fede, porta a felice compimento il suo viaggio ultraterreno. La tesi di Borges è che il problema non va impostato in termini cosi contrapposti. Dopo aver esaminato i passi del poema in cui Dante confessa la sua incapacità e impossibilità di portare a termine l'alta impresa, Borges osserva che il personaggio di Ulisse è la personificazione di uno stato d'animo dello stesso Dante, che temeva di aver osato troppo". Cfr. "Estudio Preliminar" pp. XVII-XXI.

${ }^{10}$ Borges, “Poema Conjetural”, Obra Poética 1923-1964, (Buenos Aires: Emecé, 1964), p. 148.

11 Op. cit., p. 115.

12 Borges, “Biografía de Tadeo Isidoro Cruz (1829-1874)”, El Aleph, p. 55.

${ }^{13}$ Para este trabajo he aprovechado indicaciones del Profesor Emir Rodríguez Monegal en un curso sobre Borges, dictado en la Universidad de Yale. 


\title{
RESEÑAS
}

\author{
PARA UN MAPA DE BORGES
}

JAIME ALAZRAKI. Jorge Luis Borges. Madrid: Taurus, 1976.

EMIR RODRIGUEZ MONEGAL. Borges: hacia una lectura poética. Madrid: Ediciones Guadarrama, 1976.

SAUL SOSNOWSKI. Borges y la Cábala. La búsqueda del verbo. Buenos Aires: Ediciones Hispamérica, 1976.

Como ocurre con Mallarmé y con Joyce, y también con Vallejo y Neruda, la crítica sobre Borges forma parte ya de la misma obra de Borges: no porque sea su paciente tributo, sino porque desarrolla su existencia intelectual, diseña el ámbito de su aventura creadora y, en fin, da cuenta de su radical renovación del acto literario. Por eso, para discriminar en la sobreproducción crítica que hace eco al éxito internacional de esta obra, para reconocer las lecturas pertinentes, sin duda que es necesario efectuar algunos balances de esa crítica, y precisar también el espacio generado por Borges, distinguiendo en él las lecturas que lo constituyen de aquéllas que simplemente lo duplican.

Precisamente, tres libros recientes se proponen este mapa del espacio borgiano. Ellos son Jorge Luis Borges, antología crítica editada por Jaime Alazraki ${ }^{1 ;}$ Borges, hacia una lectura poética, de Emir Rodríguez Monega1², y Borges y la Cábala. La búsqueda del verbo, de Saúl Sosnowski³. Los tres plantean distintas lecturas de la obra de Borges, y lo hacen desde la perspectiva crítica suscitada por ella: desde el recuento de un buen número de ensayos y testimonios (Alazraki), desde una poética de la lectura crítica (Rodríguez Monegal), y desde la interpretación cabalística del lenguaje (Sosnowski). Conviene, pues, que discutamos con algún detalle el convergente diseño del espacio borgiano que postulan.

En la valiosa serie "El escritor y la crítica”, que dirige Ricardo Gullón, el tomo antológico de Alazraki da cuenta, en primer lugar, de la diversidad y de la diseminación de la obra borgiana en su plural crítica. Como otra paradoja borgiana, esta selección ilustra más el estado de la crítica misma, que el proceso o el ámbito de una lectura sistemática. No quiero decir que estos textos, valiosos de por sí, no nos aproximen a una mejor lectura de Borges; sino que, aun haciéndolo, en buena parte testimonian más que la secuencia del análisis sistemático, que nos entregaría una topografía del espacio borgiano, el recomienzo mismo de la lectura crítica: de hecho, la mayoría de los textos recogidos siguen la pauta de la sección inicial del tomo, "Primeros testimonios críticos"; o sea, la pauta del descubrimiento de Borges, desde su irrupción en el ámbito internacional de las letras, y en la actualidad de su insólita aventura creadora. Así, este recuento paga tributo a la situación internacional de la obra del autor: a la suma crítica que lo vuelve a descubrir, que lo sitúa en el ámbito de su renombre. De allí el carácter de este tomo: la crítica se refiere aquí a sí misma, en una operación no menos borgiana, que nos remite a una nueva "primera lectura” de Borges. "Tan cosmopolita como la obra de Borges es la extensa bibliografía que la glosa, comenta o estudia”, escribe Alazraki en su "Introducción”; y, en efecto, su selección ilustra este principio común a una obra moderna y mayor.

Podemos deducir las dificultades de la empresa de Alazraki si por un momento imaginamos a un improbable compilador que decidiese testimoniar la resonancia internacional de Baudelaire: por un lado, su antología coincidiría, en parte al menos, con la poesía moderna; y terminaría dando fe de una disolución. Pero, por otro lado, seguramente nos entregaría, más acá de las resonancias de 
una “carrera poética”, textos válidos y testimonios disímiles. Corriendo, pues, el riesgo primero, que podría duplicar su selección, Alazraki, finalmente, cumple el segundo propósito, que es el que en definitiva importa. Justamente, el "espacio intelectual” de un diálogo de textos sobre Borges, que Alazraki busca manifestar, se da en este segundo nivel. Solo que, una vez más, se da como el debate de distintas perspectivas que, todavía, reflejan más el espacio de una crítica que vuelve a leer cada vez, que el mismo espacio objetivado del universo borgiano.

Naturalmente, sólo podemos responder críticamente a las lecturas que suscita la obra de Borges en un contexto literario internacional. Lo contrario nos conduciría a un acolitismo bastante poco provechoso, y a la perdida de ese "espacio intelectual” de la crítica que reclamó Octavio Paz. O, lo que sería más lamentable, a limitarnos al reconocimiento de una obra según los términos de su mayor o menor éxito. En este sentido, el tomo de Alazraki también es útil para probarnos que la distinta crítica francesa o norteamericana sobre Borges, siendo no pocas veces brillante, suele estar determinada par dos situaciones: por una lectura un tanto literal, en unos casos, y por una reducción a las pautas literarias de la respectiva tradición moderna del crítico, en otros. Así, un texto tan coherente como el de Paul de Man ("Un maestro moderno: J. L. B.”) asume literalmente los mecanismos borgianos como un "estilo"; lo que le lleva a concluir que "El estilo es un espejo, pero diferente al espejo de los realistas que no nos permite olvidar ni por un momento su irrealidad: es un espejo que crea lo que imita”; siendo claro más bien, que este "espejo” es, en Borges, la misma literatura revelándose en sus mecanismos, en los espejos de sus duplicaciones, y, así, el "estilo" es una instancia de su lenguaje.

Con ser una valiosa primera lectura, la de John Updike ("El autor bibliotecario") suele ser también más candida. Sorprende, por ejemplo, su versión de Otras Inquisiciones, que es también literal pero que, además, no percibe en el contexto crítico moderno generado por Valery y Pound, cuyos debates estéticos evocan estos ensayos de Borges. Dice Updike de este libro: "Pero la totalidad de sus textos no se abre al exterior. Mientras, digamos, un Eliot renueva una tradición continua de criticismo literario a través de relativos tanteos, los ceñidos ordenamientos de Borges semejan una extraña especialización de la tradición. Sus ensayos guardan una cualidad que sólo puedo definir con el adjetivo sellados.” Esta opinión confirma plenamente la paradójica tradición anglosajona de Borges: un autor norteamericano la encuentra insólita, y no puede evitar que se le escurra de entre las manos. De allí esta dramática conclusión del novelista: "todos sus ensayos tienden a abrirse hacia el interior, poniendo al descubierto una imaginación obsedida y una personalidad arrogante, estoica, casi cruelmente masculina."

Naturalmente, tan frívolo como aceptar esta crítica como medida de la importancia de Borges, sería el coleccionar sus dislates. Lejos de mí esa fácil tentación. Prefiero, en cambio, observar hasta que punto en Updike se extravía la lección de una tradición moderna practicada por Pound, cuyos ensayos, por lo menos desde la década del 10, son una lectura crítica de la tradición establecida y, por eso, una desconstrucción poética de la cultura literaria. Los paralelos con la crítica de Borges, la revelan precisamente como postulaciones abiertas, que especulan sobre la naturaleza del hecho literario; a diferencia de Eliot, que más bien busca reconstruir las fuentes de la tradición, la que asume como repertorio estable y probatorio. Menos extraño es que Updike no pueda percibir la naturaleza hispanoamericana de los mecanismos desconstructores de la prosa borgiana; aunque su conclusión cultural es ambigua: "Es europeo en todo (Borges), excepto en la objetividad con que examina la civilización europea, como algo intrínsicamente extraño -un montón de reliquías, un universo de libros sin una clave central.” O sea: es muy poco europeo y, más bien, la clave de esa perspectiva es su origen americano. La conclusión final de Updike no es menos digresiva: “Tal vez América Latina, que nos ha dado ya el escepticismo absoluto de Machado de Assís, está destinada a reconstruir los modelos intelectuales de la antigua Grecia." Se refiere a una "inversión” de lo que llama "atributos estoicos". Pero es claro que América Latina sólo está destinada a construir sus propios modelos intelectuales: la descodificación cultural practicada por Borges es una de ellos. 
Mientras que para Paul de Man el estilo de Borges es barroco, para John Barth, ("Literatura del agotamiento"), en cambio, no lo es; y mientras que para Maurice Blanchot ("El infinito literario: 'El Aleph”'), esta obra refiere la infinitud del hecho literario, para el mismo Barth refiere el agotamiento de la literatura. Por lo demás, si Updike encuentra que en su tratamiento de la tradición Borges difiere de Eliot; Barth, en buena cuenta, sitúa a Borges dentro de esa literatura que Eliot llamó "mito crítica": aquélla que rehusa la originalidad y reitera la tradición. No obstante, este ensayo de Barth, que no en vano tiene un eco de la iconoclastia de Pound, es tal vez el más brillante del tomo. Es cierto que su tesis sobre una literatura de la extenuación -aquella que en lugar de la originalidad de índole romántica opta por los mecanismos de su reconstrucción, siendo en ello una operación también de ruptura y no solamente clásica- no deja de ser una postulación de su propia poética narrativa; pero es así mismo cierto que el análisis interpretativo de Barth tiene la virtud de devolver la obra borgiana a su práctica: a su centro desconstructor. Sólo habría que añadir que la literatura de Borges, siempre más compleja, provee sus propias respuestas: porque a la imagen simbólica del laberinto (“un lugar en el que, idealmente, todas las posibilidades de elección ... están dadas"), que para Barth resume la versión del "agotamiento", cabría oponer otro símbolo polar: el del aleph, precisamente. O sea, un lugar donde la simultaneidad libera a la totalidad. La oposición de una teoría literaria no se plantea así, sólo entre Menelao y Teseo, como deduce Barth, sino también, e irónicamente, entre Carlos Argentino Daneri y Jorge Luis Borges: entre la escritura prolija y reiterativa del mundo, y la escritura que da cuenta del asombro de su propio instrumento. Ya se ve que "el aleph”, la literatura, deduce sus propios caminos: su extenuación puede ser, también, su recomienzo.

La noción de una totalidad parece haber cautivado a no pocos lectores de Borges. Y algunos han tomado las figuras, los símbolos y los temas que la refieren, literalmente como una postulación filosófica o, por lo menos, como una cosmovisión borgiana. Sin embargo, en este tema convendría empezar por un análisis que no sólo fuese el recuento de las afirmaciones y recuperaciones idealistas y panteístas de Borges, sino que también las situase en su función textual, en su ámbito de realización especular y en sus operaciones críticas; o sea, en el proceso de ficcionalización que las remite a su noción imaginaría. Gerard Genette (“La Utopía literaria”) sostiene, por ejemplo, que la totalización del mundo y de la historia en su universalización se produce y equivale a la literatura: al final, la utopía borgiana sería de una notoria sencillez: los autores y los libros, todos ellos, se equivalen en la lectura. Genette dice bien que Borges trasciende tanto la explicación panteísta ("un espíritu habita la aparente pluralidad de los autores") como la explicación clásica ("la pluralidad de autores, simplemente, no merece ninguna consideración”); con ser penetrante su lectura de Borges, la conclusión a que arriba está amenazada por la indistinción. La utopía literaria estaría, más bien, en una operación más aventurada: que la totalidad coincida en la escritura con su rendición simultánea e instantánea; y esta tensión polar es también un comentario permanente que en Borges equivale a la misma literatura. Por lo demás, no podemos olvidar que las proposiciones borgianas panteístas, clásicas o utópicas, actúan, desde las reducciones textuales, como formas críticas de la naturaleza imaginaria que, en la escritura, dramatizan el sentido y las explicaciones fijadas en su nombre. Si una cosmovisión es, pues, deducida desde esta literatura, ella sería otra instancia de la práctica de esta escritura, y su sentido estaría dado por la dinámica de los mecanismos que la producen como hecho imaginario. Lo ha visto bien la inteligencia crítica de Maurice Blanchot: “....si el libro es la posibilidad del mundo, debemos concluir que en él actúan no solamente el poder de acción, sino además ese gran poder de fingir, de falsificar, de engañar que proviene de toda obra de ficción, y esto de modo más evidente cuanto más oculto está ese poder.” Y añade: "Borges comprende que la peligrosa dignidad de la literatura no reside en hacernos suponer que en el mundo hay un gran autor, absorto en mistificadores ensueños, sino en hacernos sentir la proximidad de un poder extraño, neutro e impersonal.” Ese poder actúa desde la imaginación. Y la utopía literaria de Borges es su diseño. Antes y después de las culturas, al comienzo de las palabras y en el ámbito de otra realización cultural. 
En la crítica hispanoamericana, Emir Rodríguez Monegal hace ya buen tiempo que viene desarrollando una lectura analítica de la naturaleza imaginaria del universo borgiano. Borges, hacia una lectura poética (evidentemente el título es un desliz de la editorial, pues es claro que debería ser: hacia una poética de la lectura, lo que anuncia su verdadero carácter) reúne tres ensayos: "Borges y Paz: Un diálogo de textos críticos”, “El lector como escritor” y "Borges y la 'nouvelle critique”, el cual también está incluido en la compilación de Alazraki. Estos textos promueven una interesante discusión, desde su perspectiva de la lectura como crítica; una perspectiva, pues, eminentemente borgiana y, por cierto, contemporánea a la especulación crítica misma. Así, la poética de la lectura, que Rodríguez Monegal busca manifestar en la práctica borgiana, se postula y realiza también en estos análisis.

Frente a los textos que hemos comentado, estos poseen una ventaja evidente: su autor conoce el corpus integral de la obra, y se maneja dentro de él con soltura y eficacia. Pero su virtud mayor es menos explícita: desde una lectura de Borges que privilegia la noción creadora de la lectura, Rodríguez Monegal, en verdad, se propone plantear la realización de la obra borgiana en el ámbito crítico que ella promueve. Esto es, Rodríguez Monegal asume esta obra como una aventura intelectual cuyo horizonte imaginario es también una actividad crítica; y cuya función literaria se cumple en la formación de un nuevo espacio crítico. Espacio que es uno y doble: tanto el diálogo de textos que fundan una crítica, según el reclamo de Octavio Paz, como el cotejo de los textos que universaliza una literatura. O sea: el ámbito crítico que se construye en la cultura hispanoamericana desde la convergencia de autores como Borges y Paz; y el otro ámbito en que la obra borgiana se refleja al centro de la especulación crítica francesa, en un rasgo de su función contemporánea. Al centro de este espacio textual, la operación misma de la escritura borgiana como una lectura desconstructora, sustenta lo que, finalmente, es la raíz de este debate: una poética de la lectura en la cual la creación y la crítica son una misma literatura.

Un paralelismo entre las obras de Paz y Borges no es sólo un atractivo ejercicio intelectual, y hasta una probable autobiografía de la lectura: es, también, una buena manera de ingresar a algunos de los dilemas y problemas de la cultura hispanoamericana y, asimismo, a una zona realizada de su productividad. Rodríguez Monegal establece con precisión las correspondencias, semejanzas y desemejanzas entre la experiencia intelectual y la obra literaria de ambos; pero, además, el establecer esta rica confluencia lo conduce a la problematización que habita en su tema. Esta no es otra que la existencia dramatizada del propio discurso de cultura hispanoamericana en que pueda sustentarse el cotejo de ambas obras. Si, en efecto, tanto Paz como Borges asumen libremente distintas tradiciones culturales y si, además, su trabajo es una ruptura, no menos americana, de los nacionalismos restrictivos, la misma lectura reclama por el espacio mayor de una realización cultural en la que los textos den cuenta de su existencia más plena. Es, pues, esta línea de reflexión, lo que conduce a Rodríguez Monegal al famoso reclamo de Octavio Paz por una crítica capaz de crear un espacio intelectual (reclamo que el crítico documenta desde El arco y la lira hasta Corriente alterna). Y es revelador que esta misma postulación sea central al propósito que desarrolla Jaime Alazraki en la "Introducción” a su repertorio borgiano. Esto es: la obra de Borges, su convocación crítica, nos remite al reclamo de Paz, y, a su vez, el planteamiento central de Paz nos devuelve a Borges. Rodríguez Monegal asume la tarea de apuntalar el plano convergente entre ambos autores, y en esta misma operación, resulta evidente que ese espacio (que es, dice Paz, "el lugar de encuentro con las otras obras, la posibilidad del diálogo entre ellas”) se constituye como el discurso de una cultura; y la actividad crítica requiere manifestar en ella la realización de los textos, su diálogo y su debate. Como sostiene Rodríguez Monegal: “la crítica no consiste solamente en la formación de un ámbito intelectual, por importante que este sea. Implica, también, la producción de un 'doble' de la obra misma: doble que prolonga en el campo del discurso lo que la obra 'dice' en el campo de la poesía.” De allí que sea válida su conclusión: "Y diría más: el diálogo se ha iniciado hace un tiempo ya. Son muchos los que han aprendido en Reyes y en aquel su amigo, don Pedro Henríquez Ureña, 
muchos los que han aprendido en Mariátegui y en Martínez Estrada, en Lezama Lima y en Borges, en Octavio Paz, a leer y a escribir, a pensar e inventar, a soñar un poco más críticamente a nuestra América.” Los paralelos, pues, entre Borges y Lezama aluden, finalmente, a la misma aventura intelectual hispanoamericana: ambas obras realizan ese espacio intelectual nuestro; y nos hacen leer de un modo más exacto y complejo el diálogo de otros textos que, en la imaginación crítica, dan razón de nuestro origen cultural y de las realizaciones de nuestra escritura.

Es, pues, en la perspectiva del espacio crítico que ella abre, donde Rodríguez Monegal sitúa su análisis de la obra: desde la teoría literaria que está implícita en "Pierre Menard, autor del Quijote”, el crítico sigue las metamorfosis literarias de esta obra, sus recurrencias y paradigmas, para arribar a una interpretación no planteada hasta ahora: la posibilidad de una lectura psicoanalítica de las opciones borgianas. Esta interpretación, con ser probable, no redunda, sin embargo, en cualquier tipo de psicologismo, ya que se apoya en el plano mismo de los textos, al cual finalmente vuelve. Se trata, en todo caso, de una intrigante interpretación, que habrá que ver desarrollada en la biografía literaria de Borges, que Emir Rodríguez Monegal anuncia. El último trabajo, es una paciente y, en general tolerante, lectura de la crítica francesa sobre Borges. Da cuenta, en detalle, de las aportaciones y algunas omisiones de seis textos interpretativos; y, con ello, ilustra bien ese otro debate crítico que Borges ha suscitado. Tratándose, además, de una exposición, hubiese convenido beneficiar al lector con la traducción de las numerosas citas.

Cuando George Steiner ("Los tigres en el espejo”, incluido en el tomo de Alazraki) razona que Borges cultiva la metáfora cabalística del mundo como una escritura, reincide en una lectura literal del texto borgiano, ya que la Cábala no supone una cosmovisión asumida por Borges sino, más bien, un repertorio no menos fantástico que la metafísica. Saúl Sosnowski ha dado forma en su libro a una de las correlaciones instrumentales, más que fuente en su sentido lato, de la obra borgiana: a su recurso cabalístico, a su manejo de esa rica y compleja tradición de una lectura trascendentalista. Borges y la Cábala. La búsqueda del verbo es, en primer término, un revelador recuento de las coincidencias cabalísticas en los textos de Borges, algunas de ellas, como la búsqueda del Nombre, centrales a esos textos; otras, demostrativas de la dinámica desconstructora de la escritura borgiana, como las imágenes y paralelismos sobre el papel fundador del lenguaje. El trabajo de Sosnowski se beneficia de su conocimiento del hebreo, pero sobre todo de la inteligencia con que vincula y deslinda un texto religioso y un texto literario. La eficacia de su prolija investigación radica, justamente, en haber sabido establecer las equivalencias y divergencias, y, lo que no es menos importante, en devolver el análisis al conjunto de la obra borgiana, de modo de superar el plano comparativista. Así, las relaciones de Borges y la Cábala se sitúan en la naturaleza misma de una escritura.

Naturalmente, este libro también prueba que nuestra lectura de la Cábala no puede ser sino borgiana: y ello porque el papel de la lectura, y de su exteriorización en una "escritura divina", poseen una codificación cuyo sentido está, por cierto, en la religión; pero cuya lectura literaria, desde Borges, deduce ya una descodificación. Sosnowski debe, por eso, sostener el análisis en la perspectiva literaria; si bien el ámbito de una lectura y una escritura con significaciones polares lo inducen, finalmente, a situar la obra de Borges en un proceso indagatorio por el Verbo. Tiene razón cuando observa en la escritura borgiana "una relación primigenia entre el Verbo y el que lo enuncia (como si fuera) por primera vez"; pero creo que lo ganan las significaciones de su tema cuando al hablar del aleph, afirma: "El poder de este signo surge aún fuera del contexto teológico en el que se debe colocar la obra de Borges.” No es que Sosnowski se haya propuesto una lectura cabalística de Borges, ni tampoco una lectura borgiana de la Cábala, pero al situarse en la perspectiva crítica del lenguaje como mediador de la obra borgiana, le ocurre lo que a Alazraki al situarse en la mediación crítica internacional sobre Borges, o lo que a Rodríguez Monegal al leer la convocación borgiana desde el reclamo mediador de Paz: al diseñar un espacio crítico característico del texto borgiano, no 
deja de testimoniar la ocurrencia de su lectura, el recomienzo crítico del texto en la lectura. Y, en este caso, esa lectura siendo erudita y probatoria, es también conjetural. Es, finalmente, no menos borgiana que las otras dos: de allí que de razón del espacio que esa obra apertura, al ilustrar una de sus dimensiones justamente más conjeturales.

Por lo demás, las nociones sobre un lenguaje fundador y un alfabeto del mundo, remiten desde Borges también a lo que es ya una tradición occidental, desde Boehme hasta Novalis; $y$, no en vano, una íntima recuperación de la literatura hispanoamericana. Con su trabajo, Sosnowski ha levantado el terreno necesario para diseñar ese espacio de correspondencias, que suponen a la Cábala pero que así mismo la trascienden; no sólo porque son sus metáforas y mecanismos los que son recuperados, sino también porque la interrogación por una escritura del mundo nos devuelve a una pregunta por la naturaleza del lenguaje, y, al final, por la razón imaginaria que lo transmuta en literatura. Sin olvidar que tal indagación supone la práctica descodificadora de la tradición; su recomienzo en el espacio crítico de la imaginación, que trabaja su propia tierra firme más allá de las fórmulas fijadas por las culturas.

El útil tomo de Alazraki, que promueve una sugestiva discusión; la razonada crítica de Rodríguez Monegal, que postula un debate central; y la novedosa monografía de Sosnowski, que recorre aspectos decisivos de la poética borgiana, son, pues, tres modos convergentes en que la obra de Borges testimonia el privilegiado espacio crítico que suscita en la naturaleza de su aventura intelectual. Estos libros, en la indagación que formulan, nos demuestran, por último, que esa aventura es también la de nuestra literatura, la de su imaginación crítica.

University of Maryland

JULIO ORTEGA

1 Jaime Alazraki, Jorge Luis Borges, Madrid, Taurus, 1976. Serie El Escritor y la Crítica, Colección Persiles, 88, 364 pp.

2 Emir Rodríguez Monegal, Borges: hacia una lectura poética, Madrid, Ediciones Guadarrama, 1976, 125 pp.

3 Saúl Sosnowski, Borges y la Cábala. La búsqueda del verbo, Buenos Aires, Ediciones Hispamérica, 1976, 118 pp.

\section{DE BORGES, SOBRE BORGES}

EDGARDO COZARINSKY. Borges y el cine. Buenos Aires: Sur, 1974.

J. M. COHEN. Jorge Luis Borges. New York \& London: Harper \& Row; Cox \& Wyman: 1973. JORGE LUIS BORGES. Prólogos. Buenos Aires: Torres Agüero Editor, 1975.

Dos libros aparecidos casi simultáneamente -escritos supuestamente circunstanciales: notas de cine; prólogos- proveen un repertorio de tópicos de Borges que, aunque simplificados, muestran intacto (o latente, en algunos textos muy tempranos) su potencial de mutaciones. En Borges y el cine, Edgardo Cozarinsky coleccionó catorce notas de Borges publicadas en Sur entre 1931 y 1945, que habían sido parcialmente recogidas en Discusión. Prólogos consta de treinta y ocho prólogos que Borges escribió para libros ajenos entre 1925 y 1974.

El libro de Cozarinsky es resultado de un interés doble: de lector idóneo y perspicaz de la literatura de Borges y de inteligente director y crítico de cine. Las notas de Borges forman parte de la primera sección del volumen, titulada "Borges y el cine”; están precedidas por una "Introducción" 
de Cozarinsky y seguidas por el "Prólogo" de Borges y Bioy Casares para dos argumentos escritos en colaboración y nunca filmados - Los orilleros. El paraíso de los creyentes (Buenos Aires: Losada, 1955)-, fechado en 1951. La sección se cierra con una brevísima sinopsis -poco más de una páginaque Borges “aceptó componer” para los argumentos de “Invasión” y “Los otros”, también producto de la colaboración con Bioy, que Hugo Santiago contribuyó a transformar en libro cinematográfico y dirigió. La segunda sección del libro -“Cine sobre Borges”- está íntegramente compuesta por Cozarinsky. El primer trabajo -articulado en dos apartados- tiene como título general "Las aventuras del texto”. En algo más de veinte páginas se traza una petite histoire de la mención del nombre de Borges en películas, crítica de cine y entrevistas fuera de la Argentina. He subrayado mención porque de los apretados datos que se dan no se pueden deducir "aventuras" -influencia o lectura- (aunque de hecho las ha habido) de textos borgeanos en la crítica cinematográfica o en las películas europeas o norteamericanas. Falta una interpretación de ese despliegue de datos, de esas referencias a veces del todo opacas para el lector no especializado en el mundo del cine. "Versiones, perversiones" es el título con que Cozarinsky ha agrupado, al final del libro, seis reseñas suyas sobre películas relacionadas más o menos directamente con textos de Borges: "Días de odio" (1953-54); “Hombre de la esquina rosada” (1961-62); “Invasión” (1968-69); “Emma Zunz” (1969); "Strategia del ragno” (1969-70); "Les autres” (1973-1974).

El atractivo proyecto de Cozarinsky habría podido resultar en un diálogo intertextual entre literatura y cine o -más bien- entre el approach literario del cine (las notas de Borges) y el approach cinematográfico de la literatura (los textos de Cozarinsky, sobre todo las seis notas finales. Pero el diálogo no llega a estructurarse, y el libro resulta una yuxtaposición de elementos atrayentes en sí pero desarticulados entre sí. La desarticulación ya se advierte en la "Introducción” de Cozarinsky. Las puntualizaciones prometedoras (pp. 10-13) -Cozarinsky afirma que "una idea del cine” aparece no sólo asociada a las narraciones de Historia universal de la infamia sino a las hipótesis de Borges sobre "el funcionamiento de todo relato". Y añade que "el cine era un hábito para el joven Borges, un accesible repertorio de referencias, tan visitado como la Encyclopaedia Britannica o la no impresa realidad” (p. 11)- se disuelven inesperadamente en una recapitulación de rasgos generales de la narración en Borges. Esos rasgos, vistos con acierto (pp. 16-18), se alejan de la idea del cine de que se habla al principio. Como si Cozarinsky, atraído y distraído por la pura literatura, hubiese olvidado el motivo explícito del libro y el planteo de las primeras páginas de la "Introducción”. Y, así, menciona ciertas técnicas cinematográficas (ya reconocidas por Borges, según Cozarinsky mismo recuerda), obvias en Evaristo Carriego, Historia universal de la infamia y otros textos de Borges pero nada dice de como se consiguen ese montaje, esa deliberada unidimensionalidad, ese interjuego entre continuidad y discontinuidad.

Por otra parte, los defectos y aciertos que Cozarinsky ve en las "versiones" y "perversiones" cinematográficas de los textos de Borges habrían podido servir como puntos de partida para establecer las similitudes entre la operación narrativa por excelencia: post hoc, ergo propter hoc, "la lengua del Destino" (Cozarinsky citando a Barthes, p. 22) y la idea del montaje -cinematográfico o verbal-, meramente expuesta como elemento de pregunta retórica (ibid.). Sin duda no escaparon a Cozarinsky estas objeciones, y en la "Presentación” concede que su libro "respeta la alteridad” de sus materiales, "permitiéndoles que irradien en direcciones dispares a partir de un centro común" (p. 8).

Las catorce notas de Borges, rescatadas de otros tantos números de la época de oro de Sur, constituyen una sección peculiar del libro único que está escribiendo desde hace cincuenta y tantos años. La calidad especial de estas notas -la dimensión que han adquirido con el tiempo- se debe a su inmediatez. En ellas, liberadas de encuadres más ambiciosos - poema, ensayo, ficción- y ya inevitablemente desconectadas (por lo menos para el lector no especializado en cine) de las películas que les dieron motivo, funcionan ciertas ideas borgeanas como ' contrafuertes o puntales, desprovistos de casi todo aditamento. La ineficacia del excesivo color local, por ejemplo; "Sternberg, para 
significar Marruecos, no ha imaginado un medio, menos brutal que la trabajosa falsificación de una ciudad mora en suburbios de Hollywood, con lujo de albornoces y piletas y altos muecines guturales que preceden el alba y camellos con sol” (29). La nota, sobre "Marruecos”, es de 1931. Borges aún no había publicado ficciones. En 1937, ya aparecido "Hombre de la esquina rosada" y ya quizás arrepentido de "esos ejercicios de excesivo y apócrifo color local” ("Prólogo”, Antología personal), comenta a propósito de "uno de los mejores films argentinos que he visto: vale decir, uno de los peores del mundo" (p. 52) -“Los muchachos de antes no usaban gomina”-: "Los personajes doctores, patoteros y compadrones de 1906-[...] no existen fuera del color local y del color temporal” (ibid.).

Las flaquezas de "El delator" muestran la inoperancia del realismo: "La realidad no es vaga, pero si nuestra percepción de la realidad; de ahí el peligro de justificar demasiado los actos o de inventar muchos detalles” (p. 35). Esas flaquezas también exponen la necesidad de cierto desapego, fundamental para la eficacia de toda obra: "Que los espectadores se conmuevan con el espantoso destino del delator, me parece bien; que el director de la película se conmueva y le otorgue una muerte sentimental con vitrales católicos y música de órgano me parece menos admirable” (p. 36). Compárese la declaración con la de "El primer Wells” (Otras inquisiciones): "El autor debe aparecer ignorante de todo simbolismo".

La posible interpretación alegórica de "El bosque petrificado" (1936) suscita una primera versión de la idea de Borges sobre las alegorías, "tolerables en razón directa de su inconsistencia y de su vaguedad; lo cual [...] significa [...] que el género alegórico es un error” (p. 41), (Cf. "De las alegorías a las novelas”, en Otras inquisiciones.)

Las enumeraciones caóticas clásicas en ciertos textos de Borges ("El espantoso redentor Lazarus Morell”, “El Aleph”, “Mateo XXV, 30”) están esbozadas, en una sola dimensión -irónica, en la caracterización de la utilería de von Sternberg, "devoto de la Musa inexorable del Bric-àBrac": "yo aguardaba una vasta inundación de barbas postizas, de mitras, de samovares, de máscaras, de espejos, de caras bruscas, de enrejados, de viñedos, de piezas de ajedrez, de balalaikas, de pómulos salientes y de caballos” (p. 38).

Citizen Kane dice Borges en 1941, se presta a más de una lectura, ya que tiene por lo menos dos argumentos. "El tema (a la vez metafísico y policial, a la vez psicológico y alegórico) es la investigación secreta del alma de un hombre, a través de las obras que ha construido, de las palabras que ha pronunciado, de los muchos destinos que ha roto" (p. 64). El paréntesis encierra una caracterización tan apta para el film de Orson Welles como para "La muerte y la brújula”; la segunda parte de la enunciación es, obviamente, el programa de muchos de las ficciones de Borges.

Un libro titulado Film and Theatre, de Allardyce Nicoll, "cuya ignorancia no sólo es increíble, o inverosímil: también es real” (p. 47) da pie para el típico sarcasmo borgeano frente a la erudición como mero acopio de datos.

El doblaje, que "propone monstruos que combinan las ilustres ficciones de Greta Garbo con la voz de Aldonsa Lorenzo" (p. 72), es el tema de la última de las notas, donde Borges hace alarde de su gracia entre irrefutable y arbitraria.

La capacidad de sugerencias insospechadas en acotaciones hechas, en apariencia al pasar, linda con lo inquietante. Así, es difícil no experimentar una suerte de sobresalto al advertir como el Mr. Memory de "Los treinta y nueve escalones" de Hitchcock fue para Borges en 1936 una especie de esbozo de Funes: "Hitchcock ha intercalado un personaje agradabilísimo-Mr. Memory-hombre infinitamente ajeno de las otras dos potencias del alma, hombre que revela un grave secreto, simplemente porque alguien se lo pregunta y porque contestar es, en ese momento, su rol” (p. 39). "Funes el Memorioso" es, íntegramente, la confirmación de la ausencia de "las otras dos facultades del alma” del personaje; pero esa carencia se hace del todo explícita en uno de los últimos párrafos del cuento: "Sospecho, sin embargo, que no era muy capaz de pensar. Pensar es olvidar diferencias, es generalizar, abstraer” (Ficciones). 
El problema de las trasposiciones de textos, de los anatropismos y anacronismos está planteado con claridad didáctica a propósito de "Verdes praderas", de 1937. Ya Historia universal de la infamia había quedado atrás y, sin duda, Borges pensaba en otros ensambles para organizar la ficción.

Es imposible recopilar en estas anotaciones todos los elementos de la literatura borgeana presentes en las notas sobre películas: habría que trascribirlas, tarea que ya cumplió Cozarinsky. Por otra parte, comparar esos textos con los poemas, ensayos y ficciones coetáneos exigiría un cotejo minucioso, que esta reseña sólo aspira a estimular. Citemos, sin embargo, otros pasajes significativos. Con motivo de "La extraña pasajera" (1942) hace Borges una apretada enumeración de clichés cinematográficos -proto-Manuel Puig-: "hace muchos años que Hollywood (a semejanza de los trágicos griegos) se atiene a diez o doce argumentos: el aviador que, mediante una conveniente catástrofe, muere para salvar al compañero de quien su mujer está enamorada; la falaz mecanógrafa que no rehusa donaciones de pieles, departamentos, diademas y vehículos, pero que abofetea o mata al dador cuando éste 'se propasa'; el inefable y alabado repórter que busca la amistad de un gangster con el puro propósito de traicionarlo y de hacerlo morir en la horca...” (p. 69).

Al reseñar, en 1936, "Lo que vendrá”, Borges disintió del optimismo de Wells, fundado en una admiración de la técnica que no compartía: "el cielo de Alexander Korda y de Wells, como el de tantos otros escatólogos y escenógrafos, no difiere muchísimo de su infierno y es todavía menos encantador" (p. 44). La dicotomía del novelista inglés se entiende porque "le desagradan los tiranos pero los laboratorios le gustan; de ahí su previsión de que los hombres de laboratorio se juntaran para zurcir el mundo destrozado por los tiranos. [...] Wells venera los chauffeurs y los aviadores; la ocupación tiránica de Abisinia fue obra de los aviadores y de los chauffeurs -y del terror, tal vez un poco mitológico, de los perversos laboratorios de Hitler” (pp. 44-45). Huelga acotar, melancólicamente, que el mismo Borges habría de caer en las redes de temores tal vez un poco mitológicos que desviaron su intelección de ese aspecto de la realidad que se llama política.

Una recorrida de las páginas de Jorge Luis Borges de J. M. Cohen refuerza la opinión sobre la posible utilidad monitoria tanto de las notas sobre cine como de los prólogos compilados en el volumen editado por Torres Agüero.

En efecto, Cohen no sólo confunde o distorsiona hechos de la historia literaria:

Borges no refounded (p. 23) Proa al volver de Europa después de su primer viaje, sino que participó en la creación de la primera Proa, de la cual sólo aparecieron dos números. La segunda Proa -que además tuvo una empresa editorial- también contó con la participación de Borges, gracias a una estratagema de Brandán Caraffa, referida en numerosos trabajos (ver, por ejemplo: Ivonne Bordelois, Genio y figura de Ricardo Güiraldes, p. 123; Victoria Ocampo, Testimonios, VIIa serie, p. 112);

José Bianco renunció como secretario de redacción de Sur -no en 1955 como parece implicar Cohen, sino en 1961-; aunque su renuncia se debió a diferencias con Victoria Ocampo con respecto a una visita que hizo a Cuba en cuanto crítico literario, la directora de Sur no dismissed a Bianco (p. 107).

Pero más graves que esas y otras inexactitudes son las lecturas -o más bien paráfrasis-, de una literalidad extrema, de los textos que Cohen elige comentar; o los términos de su desacuerdo con Carlos Fuentes respecto a la prosa borgeana: “Fuentes' accents on linguistics, on the need for new sic language, is exaggerated [...] the young men who learned from Borges returned to myth, the quality that united them with the Indians and consequently with a land that was still steeped in myth" (p. 105). O: "in a poet and storyteller, linguistic mastery is not enough" (p. 110).

La nota sobre "El bosque petrificado" (Borges y el cine, pp. 41-42), agregada al ensayo "De las alegorías a las novelas” (Otras inquisiciones), sería útil para rectificar esta apreciación: "Indeed, in Borges' sense, Cien años de soledad may be described as an allegory, and would therefore be exempted from his general condemnation of the naturalistic novel” (p. 106). No es improbable que 
Borges considerara Cien años como una alegoría, y por lo tanto la condenara como "un error estético”. Lo cual, desde luego, no significa que la escritura de García Márquez, por divergente que sea de la de Borges, no la tenga como fundamento.

Las erratas, se sabe, se deben a toda suerte de imponderables y también a descuido. Las numerosísimas de este libro le dan inesperados toques irónicos, y es imposible dejar de anotar unas pocas: p. 9: "Ramón Gómez de la Soma”; p. 29: “Fundición mítica de Buenos Aires”; p. 85: “Poema conyectural”. Pierre Menard es Pierre Mesnard para Cohen: el nombre nunca está escrito correctamente, y la versión Mesnard se repite por lo menos once veces entre las páginas 43 y 45.

Aunque Borges atribuye al editor Torres Agüero la selección de los Prólogos (p. 7), los textos recolectados parecerían responder a un orden de "simpatías y diferencias" equivalente al que rigió la compilación de la Antología personal.

Sea como fuera, el azar de la organización alfabética por nombre de autor prologado ${ }^{1}$ reitera esas simpatías y diferencias, y el libro se presenta una y otra vez como índice y refuerzo de coincidencias -o de complicidades en lo diverso- dentro mismo de sus límites o proyectadas hacia otros lugares de la obra de Borges.

Las caracterizaciones de la obra de Kafka -del prólogo para La metamorfosis, de 1938- hoy aparece, mutatis las diferencias notorias entre la literatura de Kafka y la de Borges, como el programa esquematizado de las ficciones que sucederían a Historia universal de la infamia: "Hombres, no hay más que uno en su obra: [...] ganoso de un lugar, siquiera humildísimo en un Orden cualquiera” (p. 105). La justificación de la superioridad del cuento sobre la novela que sigue -"El argumento y el ambiente son lo esencial; no las evoluciones de la fábula ni la penetración psicológica” (ibid.)-, paradójicamente, reproduce las excelencias de que también la novela no realista puede alcanzar: véase el difundido prólogo de La invención de Morel (pp. 22-24).

Hay convergencias entre autores prologados, tan distantes en el tiempo y en la geografía como Cervantes y Sarmiento: los dos, escritores geniales cuyo estilo es deficiente retóricamente y, a la vez, de una suprema eficacia (p. 45 y p. 129).

Abundan vinculaciones -obvias, tangenciales o secretas- entre los autores prologados y el prologuista. A Cervantes -como a Borges- "lo atraían el azar, los dibujos mágicos del destino" (p. 44); pero -a diferencia de Borges- "profundamente lo atrae el hombre, ya como tipo [...], ya como individuo" (ibid.). Las contradicciones de Quevedo -"hombre de apetitos vehementes, no dejó nunca de aspirar al ascetismo estoico” (p. 122. Este prólogo, de 1948, a Prosa y verso de Quevedo fue incorporado en Otras inquisiciones)- son como el reverso del culto profesado por el reprimido Borges al coraje. Es ilustrativa, en este sentido, la mise au point del prólogo de 1943 para Recuerdos de provincia, en que atribuye Borges el culto literario de la violencia a la situación aparentemente segura del mundo "insípido” de la década de 1920 (p. 130). Más tarde en su vida concederá que esa fascinación también reconocía raíces personales.

Como Borges, como tantos personajes de Borges, Macedonio Fernández "quería comprender el universo y saber quién era o saber si era alguien” (p. 59). Como el Borges que en 1953 todavía no había escrito el poema ("Mateo, XXV, 30”), José Hernández, a los cuarenta años estaba cargado de "experiencia múltiple"; aunque, comparada con la de Borges, esa experiencia se revele tan módica: "mañanas, amaneceres perdidos, noches de la llanura, caras y entonaciones de gauchos muertos, memorias de caballos y de tormentas, lo entrevisto, lo soñado y lo ya olvidado” (p. 95. Prólogo para Martín Fierro, 1962).

Pero no sólo las correspondencias en la letra -que, aquí, es el espíritu- se pliegan en combinaciones múltiples en estos prólogos. Por lo que Almafuerte y Whitman han significado para Borges, importa que el azar de la distribución alfabética haya hecho que el volumen se abra con el prólogo de 1962 para la Prosa y Poesía de Almafuerte y se clausure con el texto de 1969 en que Borges presentó su traducción de Hojas de hierba. Del primer prólogo interesa por cierto la circunstancia biográfica. Para Borges adolescente, los versos de Almafuerte -recitados en casa de 
sus padres por Carriego-significaron la primera demarcación entre prosa y poesía, le revelaron que el lenguaje "podía ser también una música, una pasión y un sueño. [...] Otros poetas y otras lenguas lo oscurecieron o lo desdibujaron después; Hugo fue borrado por Whitman y Liliencron por Yeats, pero yo he recordado a Almafuerte a orillas del Guadalquivir y del Ródano” (p. 11). Más allá de ese primer contacto con la poesía, los versos - generalmente defectuosos-de Almafuerte atraen a Borges porque "presentan una paradoja o problema de una íntima virtud que se abre camino a través de una forma a veces vulgar" (ibid.). Acaso este interés ayude a explicar cierta sorprendente prodigalidad de Borges, manifiesta en algunos prólogos de otros libros de poesía deficientes. Pero sin duda también se podría aducir lo que el mismo Borges recuerda al hablar de Swedenborg y sus Mystical Works: "no hay libro que sea inútil. Ya Plinio el Joven había escrito que no hay libro tan malo que no encierre algo bueno, dictamen que Cervantes recordaría” (p. 155). Entre las notorias cualidades de Whitman, sintetizadas con certera precisión en algo más de cuatro páginas, se desliza una reserva, que vale la pena consignar. El poeta norteamericano, dice Borges, llevó a cabo "el experimento más audaz y más vasto que la historia de la literatura registra. Hablar de experimentos literarios es hablar de ejercicios que han fracasado de una manera más o menos brillante, como las Soledades de Góngora o la obra de Joyce. El experimento de Whitman salió tan bien que propendemos a olvidar que fue un experimento" (p. 171).

Sería posible aproximar entre sí muchos otros textos, e incluso mostrar como formas eminentemente borgeanas de organizar el discurso y de aproximar elementos en locuciones que hacen pensar en el lenguaje ideal de Tlön se reiteran y se adaptan para denotar, connotar y juzgar certeramente aspectos diversos de la literatura. Pero en vez de ceder a esa tentación, señalemos que también en este libro de Prólogos la letra borgeana subraya más de una vez la preeminencia del texto sobre el referente: la famosa décima de Fausto, de Estanislao del Campo, condenada por Rafael Hernández y por Lugones, en nombre de "la erudición de los hombres versados en el pelo de los caballos", es "un tremolante y bizarro objeto verbal; inútil cotejarla con la realidad, con otras realidades” (p. 30). La eficacia de un dístico de Quevedo ("Su Tumba son de Flandes las Campañas/ y su Epitaphio la sangrienta Luna”) “es anterior a toda interpretación y no depende de ella” (p. 123).

Terminemos con el principio, con el texto más temprano de los recogidos por Torres Agüero. En 1925, ve Borges entre las cualidades de los versos de Nora Lange -"versos de chica de quince años” (p. 107)-: "la noble prodigalidad de metáforas que ilustra las estancias y cuyo encuentro de afinidades imprevisibles justifica la evocación de las grandes fiestas de imágenes que hay en la prosa de Cansinos-Asséns y las de los escaldas medievales - ¿no es Nora, acaso, de raigambre noruega?que apodaban a los navíos potros del mar y a la sangre, agua de la espada" (ibid.) "El decurso del tiempo cambia los libros" (p. 130, a propósito de Recuerdos de provincia). Hoy, de estas y otras declaraciones más ostentosas sobre Calle de la tarde sólo sobrevive el esbozo de "Las kenningar" (Historia de la eternidad). Pero el trazo es tan leve que el resto del texto predomina, y lo que fue pensado como celebración se lee como elegía. El ultraísmo fue una juventud, de la que no emergieron quienes carecían del don de la intuición lúcida.

H. H. Lehman College (CUNY)

MARIA LUISA BASTOS

\section{NOTA}

1 Con dos excepciones. Los prólogos de una colección de fotografías con texto de José Luis Lanuza -El gaucho Muchnik Editores: Buenos Aires, 1968)- y de una colección de textos seleccionada por Borges -El matrero, Buenos Aires: Edicom, S.A.: 1970- están alfabetizados según su título. 
ROBERTO PAOLI. Borges. Percorsi di significato. Messina-Firenze: Casa Editrice D’Anna, 1977.

El justo renombre que el Profesor Paoli adquirió por sus contribuciones interpretativas y sus traducciones de la obra de Vallejo, se extiende con este trabajo a un lugar privilegiado en la nutrida bibliografía sobre los textos de Borges.

Limitándose a un número reducido de cuentos, Paoli se desplaza a través de varias coordenadas para elaborar una lectura de los recursos literarios utilizados por Borges y para señalar sus referentes en la cultura occidental y en los planteos esotéricos de la Cábala. Como era de esperar, el crítico se centra en la presencia de Dante. Este aspecto no se da sólo en las obvias referencias a su obra, sino también en lecturas que apuntan a los inveterados juegos que desenmascaran otras presencias en las transformaciones textuales. Es así, por ejemplo, que las evocaciones del personaje Borges de su amor por BEATRIZ Elena Viterbo se centran -siguiendo la ironización del texto que lo potencia- en la antinómica figura de Carlos Argentino DAN(te Alighi)ERI-. De este modo, lo que algunos ya hemos practicado en la minuciosa y desmenuzadora lectura de estas páginas, adquiere nuevos significados mediante los aportes de textos que señalan fuentes y que, a la vez, subrayan el concepto de clase que sostiene la ridiculización del personaje y de los nombres que provienen de las masas inmigratorias que transformaron los esquemas argentinos y su estructura social. El capítulo que se refiere a "El aleph”, lleva como subtítulo "Biforcazioni di lectura”: esto y algo más: superposición de estratos de significación que se cancelan mutuamente en la lectura total que los integra.

La ambigüedad y multiplicidad de sentidos potenciales también es estudiada en "La muerte y la brújula" y en "El sur”, que Paoli ve como re-escritura del primero. Lo correspondiente a esta sección -“Autobiografia esteriore e autobiografia interiore: le lettere e le armi”- es, posiblemente, uno de los mayores aciertos del libro ya que amplia lo propuesto por múltiples cuentos y poemas en una versión sucinta y clarificadora en cuanto a la unión de las obsesiones evidentes desde la más temprana producción de Borges.

El ya mencionado interés en Dante se centra en el tercer ensayo -“Dante in Borges”- que parte de las aptamente demostradas coincidencias en los proyectos de "La muerte y la brújula” y "El sur" para pasar revista a "Historia del guerrero y de la cautiva”, "El evangelio según Marcos” y otros, antes de subrayar la presencia de motivos dantescos. Estos no se limitan a aspectos "contenidistas" sino, y con razón, a aspectos composicionales de su producción cuentística (véanse en especial "Le biografie compendiose" y "Versione segreta e versione congeturale", pp. 101-20 y, como ejemplo, el análisis de "Historia de Rosendo Juárez").

El cuarto ensayo, "Il muro e l'infinito", se centra en tres cuentos "che hanno per storia (per tempo) una reclusione e per spazio una prigione”: "La casa de Asterión”, "La escritura del dios” y "La espera".

Más que el amplio despliegue de conocimientos de la bibliografía sobre Borges -que Paoli elabora con sus comentarios críticos-, interesa el manejo de la teoría que sustenta estas lecturas. Apelando con igual destreza y amplitud a los tempranos aportes formalistas de Tomashevski, Shklovski y Eichenbaum, a las nociones derivadas del análisis de Dostoievski hecho por Backtine, y recurriendo con mayor frecuencia a Umberto Eco, T. Todorov y, especialmente, Gérard Genette, Paoli logra sustentar sus consideraciones filosóficas y literarias con un sólido armazón crítico que le reservará un lugar privilegiado entre las serias lecturas de los textos de Borges. 